\title{
CORES DA TRADIÇÃO: Uma história do debate racial na Universidade de São Paulo (USP) e a Configuração Racial do seu Corpo Docente
}

Tese apresentada ao Programa de Pós-Graduação em Educação da Faculdade Educação da Universidade de São Paulo (USP) como parte dos requisitos para obtenção do título de doutor em Educação.

Área de Concentração: Sociologia da Educação

Orientadora: Profa. Dra. Marília Pinto de Carvalho. 


\section{CORES DA TRADIÇÃO: Uma história do debate racial na Universidade de São Paulo (USP) e a Configuração Racial do seu Corpo Docente}

Tese apresentada ao Programa de Pós-Graduação em Sociologia da Faculdade Educação da Universidade de São Paulo (USP) como parte dos requisitos para obtenção do título de doutor em Educação.

Área de Concentração: Sociologia da Educação

Orientadora: Profa. Dra. Marília Pinto de Carvalho. 
378

S586c
Silva, Viviane Angélica

Cores da tradição: uma história do debate racial na Universidade de São Paulo (USP) e a configuração racial do seu corpo docente / Viviane Angélica Silva; orientação Marília Pinto de Carvalho. São Paulo: s.n., 2015.

305 p.; grafs.; tabs.

Tese (Doutorado - Programa de Pós-Graduação em Educação. Área de Concentração: Sociologia da Educação) - - Faculdade de Educação da Universidade de São Paulo.

1. Universidade 2. Professores 3. Negros 4. Desigualdades 5. Ensino Superior 6. Universidade de São Paulo I. Carvalho, Marília Pinto de, orient. 


\section{FOLHA DE APROVAÇÃO}

Viviane Angélica Silva

Cores da tradição: uma história do debate racial na Universidade de São Paulo (USP) e a configuração racial do seu corpo docente

Aprovado em:

Banca Examinadora

Prof. Dr.

Instituição:

Assinatura:

Prof. Dr.

Instituição: Assinatura:

Prof. Dr.

Instituição: Assinatura:

Prof. Dr.

Instituição: Assinatura:

Prof. Dr.

Instituição: Assinatura: 
É nesta encruzilhada que os estudos sobre o negro brasileiro se situam. Há encontros e desencontros entre as tendências: de um lado a acadêmica, universitária, que postula uma ciência neutra, equilibrada, sem interferência de uma consciência crítica e/ou revolucionária, e, de outro, o pensamento elaborado pela intelectualidade negra ou outros setores étnicos discriminados e/ou conscientizados, também interessados na reformulação radical da nossa realidade racial e social. (Clóvis Moura, 1988, p.32) 


\section{Agradecimentos}

Verão de 1988. Ela me conduziu ao jardim onde as flores comentavam os fatos da temporada. Paramos no quarteirão das Cristas de Galo, macias, aveludadas, mal cabendo em si de tanta semente, pequenas, pretas, infinitas. Colheu um buquê generoso, envolveu em papel de pão e me entregou com uma recomendação: amanhã é seu primeiro dia de escola, você é minha neta e na sala de aula, nunca se esqueça de manter a crista sempre alta. Sigo pelejando desde então. Não tem sido fácil, mas as sementes prevalecem a germinar em flores longevas e raízes que teimam procurando terras desconhecidas. De onde a senhora estiver, obrigada vó Naná! Gostaria de agradecer a meu pai Eli Antônio e minha mãe Sílvia Maria que cotidianamente fofaram e regaram meu projeto escolar e arrancaram muitas ervas daninhas que ameaçaram meu percurso. Agradeço às minhas irmãs Érica Cristina e Camila Margarida e ao meu irmão Guilherme Henrique por tanto apoio e torcida, por cada palavra de ânimo nos momentos mais difíceis dessa caminhada. Gostaria também de agradecer à segunda família que a vida me deu: As florzinhas da Casa da Pretas (Amandinha Pretita Mon amour Nzinga! Comadres Romenia, Kelly, Eliana, Izabela, Sônia, Denise, Andreia, Glauciele, Ana Maria, Angélica, Poliana, Rosiane, Divina, Daniela e Kátia). Deus me livre de um coração que não coubesse todas/os vocês!

O caminho da UFMG à USP só foi possível porque contei com o apoio de muita gente amiga pra não precisar capinar no asfalto: Gostaria de agradecer à Elias Evangelista por ter sinalizado a USP como possível paragem. Num piscar se foram cinco anos de CRUSP. O lado bom é se sentir em casa e lado ruim é que as pessoas se vão mais rápido do que a gente gostaria: Obrigada Milessa (Tchura!) e Toninho por terem aberto a porta do 611 do bloco $\mathrm{G}$ pra mim, obrigada a você também Lília, que passou como um beija-flor pelo apê. Obrigada Bruno Martins (Vó!) por tudo, pelo grande amigo que você é. Que saudade de acordar te ouvindo cantar Madonna, volta pra casa! Ao quilombo que conheci no CRUSP, que também se tornou a extensão das disciplinas que cursei e grupos de pesquisas que participei, com profícuos debates regados a afeto, apoio, café, pizza e cachacinhas, porque ninguém é de ferro. Obrigada de coração à grande família negra cruspiana: Flávia Rios, Matheus Gato, Jorginho Gato, Thiago Molina, Fernanda Miranda, Elis Regina, Erenay, Niyi, Tago, Jaqueline Romio, Priscila Romio, Allyne Andrade, Migh Danae, Cláudia Simões, Valéria Alves, Adriana Alves, Mbuta, Amarildes, Isadora, Roberto, Pedro, Marciano Ventura, André Miguel, Diógenes Foguinho, Lucas Bento, Débora, Fran, Célia Regina, André James, Egas. Quase tão bom quanto o sofá de casa, foi o da vizinha: obrigada, Edilza Sotero, a pertinente vizinha polishop e soteropolitana de alma, a Ozzy Magia, pelas boas risadas, ser 
divertido é um dom! A Tânia Borges pela disposição pra um bom papo sempre! Ao Felipe Moraes, à Fernanda Aires, pelas doses adicionais de Belém que sempre me caíram tão bem! À Mary, Crisnael, Josilãna, valeu também! Aida Binze, minha linda, ainda te ouço pelos corredores, amiga querida de Moz. Francamente, você faz tanta falta! A vizinhas memoráveis como Binta, Laura; Marina, Angela Grillo e Kelin e muitas outras: se o CRUSP ficou sem capulanas e flores de chita, pelo menos nos restou a poesia da vida virtual. Ah, Deisson Figueiredo, foi muito bom morar perto da sua risada! Enfim... O CRUSP é uma grande constelação e certamente várias estrelas repousam nos becos da minha memória. Ainda assim, gostaria de deixar registrada a minha gratidão a quem nas encruzilhadas dos blocos e apartamentos trouxe delícia ao meu cotidiano. Gostaria ainda de agradecer à quase cruspiana Jaqueline Lima pela amizade e pelo apoio fundamental. Jaquelinda sempre! A Tiago Gualberto (Titi!) por me cobrir de azul ensolarado. Na sua casa algodão doce tem gosto de nuvem. Ao todo o pessoal do bandejão da USP, e em especial a Iolanda, Cleusa, Ivonete, Francisca, Gorete, Maurício, Renato e Diamantino: obrigada pelas generosas porções de afeto e prosa que me alimentaram esses anos. Aos porteiros do CRUSP em especial Ailton, Joice e Robson.

Essa pesquisa não seria a mesma sem o sorriso e a boa vontade das secretarias do Departamento de Sociologia da Educação, Solange, Raquel, Eloisa, Luci e Cristina; bem como do pessoal da Secretaria de Pós-Graduação da FEUSP, Marcelo de Souza Ribeiro, Antônio Carlos, Bruna Pozzi, Cláudia Regina, Diana de Oliveira: com vocês minha vida ficou muito mais fácil! À professora Maurilane Biccas, pela porta aberta aos mineiros na FEUSP. Aos professores César Minto, Dóris Accioly, Elie Ghanem, Kimi Tomikazi, Cláudia Vianna, Shirley Silva, Ocimar Munoz pelos diálogos e simpatia cotidianos. Gostaria de agradecer aos colegas do Grupo de Estudo de Gênero, Educação e Cultura Sexual (EDGEs), Luciana Alves, Alan Augusto, Adriano Senkevics, Fábio Hoffman, Ana Capitânio, Cíntia Toledo, Marla Santos, Juliana, Divimary Borges, Amélia Cristina, Camila Lisboa, Tatiana Lages, Maria Clara Saboya pelos encontros e possibilidades de trocas acadêmicas. Muito importante para os rumos desse trabalho foi também a minha participação no Grupo Raça e Desigualdades Políticas coordenado pela professora Márcia Lima, a quem agradeço juntamente com os colegas pela leitura ao meu trabalho e a possibilidade de aprender com as pesquisas do grupo: Márcio Macedo, Denise Carvalho, Uvanderson Vitor, Valéria Alves, Danilo França, Paulo Ramos, Renata Braga, Edilza Sotero, Mateus Gato. Unbutu, Somos Um! Agradeço a possibilidade de aprendizado e trabalho com parte importante da jovem intelectualidade negra que conheci no Projeto a A Cor da Cultura a partir das equipes do Geledés e Ação Educativa. Gostaria de agradecer também à Vilma Bokany e Lílian Breschigliaro colegas paulistas da pesquisa SOS Corpo. Valeu a pena, aprendi bastante com vocês, bem como a equipe pernanbucana do projeto Betania e Verônica, obrigada pelas portas abertas. Gostaria ainda de agradecer à professora KeishaKhan Perry e ao professor Anani Dzidzienyo por terem me recebido com muito afeto e 
disponibilidade na Brown University e pela leitura enriquecedora ao meu trabalho. Minha passagem pela Brown não seria a mesma sem a colega de departamento e vizinha Katsí Yarí, com quem seguimos descolonizando o amor e subvertendo fronteiras, Adi Gold que irradiou tanta beleza e boas energias na nossa vida, a Flora pela incandescente perspicácia, a Benjamim Legg, pela mais divertida Providence que eu poderia desejar, com você em EUA, com você em Sampa, com você everywhere forever! ao Ramon Stern, você é lindo fofo, incrível, sensível, amigo amado, estou te esperando! A Jacinta Lomba pela simpatia e pela cachupa divina! Aos colegas brazucas do Portuguese Brazilian Studies, Marcelo Português, Sílvia, Danilo, Felipe, Luiza, a malta! A família negra e brasileira que a vida permitiu que eu conhecesse em Connecticut: Deivison Nkosi, Kairu Nkosi e Leila Maria, obrigada pelas portas abertas.

Gostaria ainda de agradecer à Flávia Rios, Janaína Damaceno e Alan Augusto, que na reta final da escrita dessa tese leram meu trabalho com a urgência do meu desespero. Gostaria de agradecer especialmente ao Philipe Pessoa, que segurou minha mão para que o capítulo VI viesse ao mundo.

Gostaria de agradecer ao conjunto de sujeitos da minha pesquisa, pois ter contato com as experiências de docentes negros/as na USP foi uma possibilidade ímpar de aprendizado e desse modo minha postura como pesquisadora não poderia ser outra além de ética e respeito pelos dados que me foram confiados.

Gostaria de agradecer à minha orientadora Marília Carvalho por ter aceitado o desafio da parceria durante toda essa jornada, a você meu respeito e carinho. Gostaria de agradecer ao apoio finaceiro do CNPq sem o qual essa pesquisa não seria possível.

A você Alan Augusto, a lã que me aquece a vida, companheiro que topa minhas viagens e embarca comigo em tantas aventuras: Te amo!

Dedico essa tese à Melissa Silva, minha afilhada do coração, a Melzinha que me adoça a existência. Te desejo um mundo onde você possa ser o que quiser, inclusive intelectual negra! 


\section{RESUMO:}

Embora a fundação da Universidade de São Paulo (USP) tenha sido em 1934, os primórdios da instituição remonta a 1827, ano em que foi criada a Faculdade de Direito. Desde então a USP tem produzido conhecimento sobre o campo das relações raciais brasileiras. Esta tese propõe analisar como o debate racial atravessa a história da universidade, buscando compreender qual tem sido a participação docente negra e não-negra nesse processo. Assim, a história do debate racial na USP é apresentada em quatro momentos: O primeiro compreende as discussões sobre a questão racial no Brasil empreendidas por duas instituições, as Faculdades de Direito e Medicina, incorporadas à universidade em 1934. O segundo momento é considerado a partir da história da Faculdade de Filosofia Ciências, sobretudo no que diz respeito aos debates empreendidos pela chamada "Escola Paulista de Sociologia", sob a batuta de Florestan Fernandes. Para entender o terceiro momento é preciso ter em conta uma lacuna no debate racial coincidente com a Ditadura Militar que trouxe tempos difíceis para a Faculdade de Filosofia Ciências e Letras. Assim, a discussão racial esteve em estado de latência na Sociologia da USP por quase duas décadas, apesar de timidamente abrigada na Antropologia. Destaca-se a importância da trajetória do professor Kabengele Munanga para este momento da história do debate racial na instituição, na condição de herdeiro bastardo da Escola Paulista de Sociologia. O quarto momento da discussão racial na universidade ainda é corrente, e começa nos anos 90 com a recém instituída constituição de 1988. Esta década foi marcada por um incipiente, porém importante conjunto de medidas sensíveis às desigualdades raciais na universidade. Destaca-se novamente a figura do Kabengele Munanga, importante elo com o momento anterior do debate e a figura do professor Edson Moreira da USP São Carlos, em função de sua presença no Conselho de Cultura e Extensão. Por sua vez, os anos 2000 tem sido marcados por retrocessos na implementação de políticas que democratizassem o acesso da população negra na USP. Após a leitura sobre a história do debate racial na USP a tese centra-se na consideração da presença negra no corpo docente da instituição. Para tanto, apresenta-se dados sobre a configuração racial da universidade entre os anos de 2008 a 2015; bem como análises sobre um conjunto de dez trajetórias de docentes negros/as, no sentido de conhecer as estratégias, recursos, discursos e práticas de que acadêmicos/as negros/as da USP lançaram mão para tentar driblar as (im)possibilidades de acesso a um universo que tem sido cerceado à população negra: a docência da maior universidade do país.

Palavras-Chave: USP, docentes negro/as, desigualdades raciais, ensino superior 


\begin{abstract}
Although the University of Sao Paulo (USP) was officially founded in 1934, the institutions deepest origins lie in the establishment of the Faculty of Law in 1827. Since then USP has been producing knowledge in the field of race relations in Brazil. This thesis proposes to analyze the way that racial debate passes through the history of the university, looking to understand the participation of both black and non-black faculty in this process. The history of racial debate at USP is presented in four moments: The first consists of discussions of the question of race within the Faculties of Law and Medicine, incorporated into the university in 1934. The second moment concerns the Faculty of Philosophy, Sciences and Literature, particularly in relation to the debates fueled by the so-called "Paulista School" of sociologists under the direction of Florestan Fernandes. To understand the third moment it is necessary to take into account the gap in racial debate that coincided with the military dictatorship which brought difficult times to the Faculty of Philosophy, Sciences and Literature. Due to this, racial discussions stayed in a state of latency in the field of Sociology at USP, although they were timidly sheltered by Anthropology. During this period, the trajectory of professor Kabengele Munanga stands out in the history of racial debate at the institution, as he took on the role of bastard heir of the "Paulista School." The fourth moment of racial discussion at the university continues today, dating from the 1990s and the influence of the recently implemented Constitution of 1988. This decade was marked by an incipient though important group of measures sensitive to racial inequality taken at the university. Once again, Kabengele Munanga, an important link to earlier moments in these debates, stands out during this phase, along with Edson Moreira of USP Sao Carlos, due to his presence on the Council for Culture and Extension. Since the year 2000, these debates have been marked by certain regressions in the implementation of policies that would have democratized access to USP for the black population. After a reading of the history of racial debate at USP the thesis will focus on the black presence in the teaching faculty of the institution. To this end, this research will present data about the racial configuration of the university between 2008 and 2015. Furthermore it will include an analysis of the trajectories of a group of ten black professors to better understand the strategies, resources, discourses and practices that black academics at USP have used to negociate the (im)possibilities of access to a universe that has long limited itself from the black population: a teaching career at the nation's largest university.
\end{abstract}

Keywords: USP, black faculty, racial injustice, higher education. 


\section{LISTA DE SIGLAS}

ABA - Associação Brasileira de Antropologia

ABPN - Associação Brasileira de Pesquisadores Negros

ADUSP - Associação de Docentes da Universidade de São Paulo

ANPED - Associação Nacional de Pós-Graduação e Pesquisa em Educação

ANPOCS - Associação Nacional de Pós-Graduação e Pesquisa em Ciências Sociais

ANPOLL Associação Nacional de Pós-Graduação e Pesquisa em Letras e Linguística

CEA - Centro de Estudos Africanos

CNPQ - Conselho Nacional de Desenvolvimento Científico e Tecnológico

$\mathrm{CO}$ - Conselho Universitário

COCEX - Conselho de Cultura e Extensão

CPPPN - Comissão de Políticas Para População Negra

CRUESP- Conselho de Reitores das Universidades do Estado de São Paulo

CRUSP - Conjunto Residencial da Universidade de São Paulo

EMPLASA: Empresa de Planejamento da Grande São Paulo

ENEM - Exame Nacional do Ensino Médio

FFCL - Faculdade de Filosofia Ciência e Letras

FFLCH - Faculdade de Filosofia Letras Ciências e Letras

ICES- Instituto Comunitário de Ensino Superior

ICMS- Imposto sobre Circulação de Mercadorias Prestações de Serviços

ICMSC - Instituto de Ciências Matemáticas de São Carlos

ICMC- Instituto de Ciências Matemáticas e de Computação

INCLUSP- Programa de Inclusão Social da USP

INEP- Instituto Nacional de Estudos e Pesquisas Educacionais Anísio Teixeira

MAC - Museu de Arte Contemporânea

MAE - Museu de Arqueologia e Etnologia

MNU - Movimento Negro Universitário

NEINB - Núcleo de Estudos Interdisciplinares do Negro Brasileiro

PASUSP - Programa de Avaliação Seriada da USP

PIMESP- Programa de Inclusão com Mérito no Ensino Superior Público Paulista

PNAD - Pesquisa Nacional por Amostra de Domicílios

PVNS - Programa Professor Visitante Nacional Sênior

RFDSP - Revista da Faculdade de Direito de São Paulo

SEPPIR - Secretaria de Promoção de Política da Igualdade Racial

UFSCAR- Universidade Federal de São Carlos

UFRB - Universidade Federal do Recôncavo Baiano

UNIVESP - Universidade Virtual do Estado de São Paulo

USP - Universidade de São Paulo 


\section{Sumário}

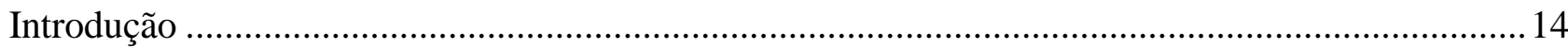

Capítulo I- História de um debate - primeira parte: uma leitura étnico-racial do longo antecedente da universidade de São Paulo

I- 1. O Longo Antecedente da USP: o debate sobre raça e relações raciais na Faculdade de

Direito, na Escola de Medicina e a Missão Bandeirante da Universidade

I-2. Uma nota de rodapé estendida: o desafio de pensar o triângulo racial na USP para além da alegoria.

I.3. A presença negra no corpo discente e docente da Faculdade de Medicina da USP

I-4. A presença negra no corpo discente e docente nas arcadas do Largo São Francisco.....

I-5. Ser docente e mulher negra nas Arcadas: Professora Eunice Prudente, uma trajetória pioneira

Capítulo II- História de um debate - segunda parte: uma leitura étnico-racial da universidade de São Paulo a partir do projeto de fundação e da criação da Faculdade de Filosofia, Ciências e Letras. ...60

II-1. De mentores a clientes e vice-versa: Redefinições do Projeto USP e Reconfigurações intelectuais e acadêmicas

II-2. (Re) Configurações intelectuais e acadêmicas: notas sobre a sociologia paulista e a

importância dos estudos sobre relações raciais.

Capítulo III - História de um debate - terceira parte: Um Herdeiro bastardo? Notas sobre a Antropologia na USP e a emergência de novos estudos sobre relações raciais e a herança do Professor Kabengele Munanga

Capítulo IV- História de um debate - quarta parte: a participação de docentes negros/as na construção da agenda do debate racial na USP a partir da década de 1990

IV-1. Milton Santos: um cidadão do mundo na docência da USP.....

IV-2. Trajetória de um professor negro nas ciências exatas da USP: Edson dos Santos Moreira 116 Capítulo V - Gênero e raça do corpo docente da USP: horizontes que se ampliam, outras vozes em cena.

V.1- Sobre gênero, raça e docência na USP: outras vozes em cena.......................................... 140

Capítulo VI- Configuração racial do corpo docente da USP: uma tentativa de dar cor aos pares... 165

VI-1. Sobre o processo de classificação racial no Brasil e na academia: algumas considerações

VI-2. Trilhas abertas no processo de sondagem da configuração racial do corpo docente na

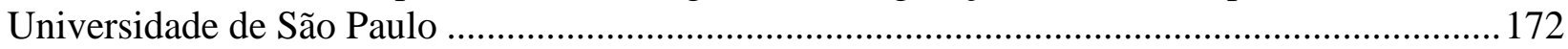

VI-3. Retrato em preto e branco: raça/cor na docência da USP: ............................................. 178

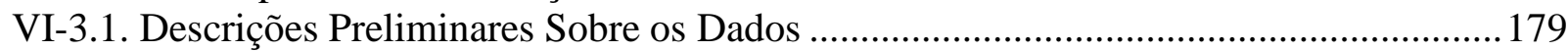

VI-3.2. Configuração racial corpo docente da USP dos/as Aposentados/as: ...........................181

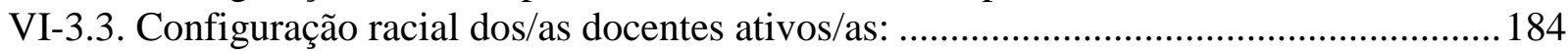

VI-4. Algumas considerações sobre raça/cor, sexo \& categoria docente ................................. 187

Capítulo VII- Docente Negro/a na USP hoje: Outras Trajetórias e Significados ............................ 194

VII. 1 Perfil dos/as docentes ingressantes a partir dos anos 2000: .......................................... 196

VII. 2- Origens Sócio-Econômicas e Auto-Classificação Étnico-Racial:................................... 199

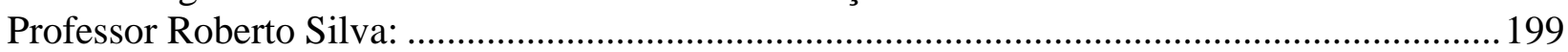

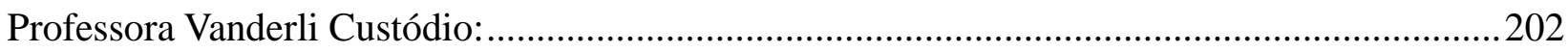

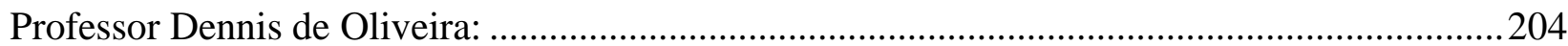

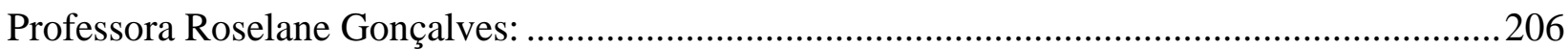

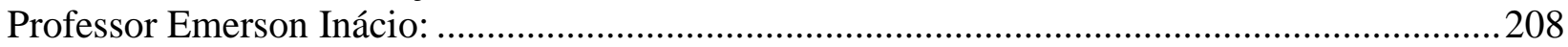

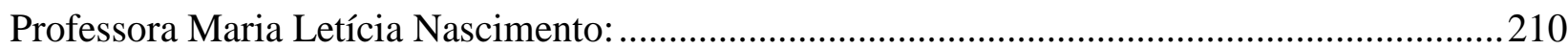

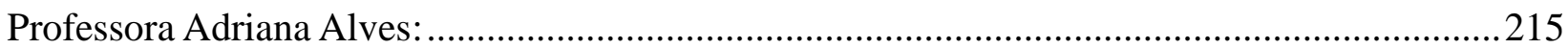

VII. 3- Estrada para a Docência: Vivências Acadêmicas na Graduação e Pós-Graduação, e o

Concurso de Entrada na USP .............................................................................................219 
VII. 4- Ser Docente Negro/a na USP: Faces (In)Visíveis 252 Considerações Finais 


\section{Introdução}

Esta pesquisa começou com uma questão: qual a importância das categorias gênero e raça para pensar o corpo docente da USP? O foco era as professoras negras desta universidade e interessava compreender como essas intelectuais subvertem algumas noções pré-concebidas sobre o corpo da mulher negra como a subserviência e a erotização; e vivem o desafio de lecionar e produzir conhecimento na maior universidade do país. O projeto era informado sobretudo pela noção de Donna Haraway (1995) segundo a qual o corpo é importante posição de conhecimento, de saberes localizados; e por Sardenberg (2000) quando discute o corpo gendrado, pensado não como algo dado "naturalmente", mas historicamente construído, seja como objeto, seja como práticas e representações sociais diversas. Desse modo, concepções historicamente definidas como gênero, raça, etnia, classe, idade e gerações, diferenciam, classificam, categorizam e demarcam corpos a determinadas posições e relações sociais. O objetivo era compreender se as docentes negras explicitariam ou não significados atribuídos socialmente ao corpo da mulher negra e se apontariam os mesmos com alguma relação com seu processo de escolarização, pertencimento ao corpo docente do ensino superior, sua carreia acadêmica e o reconhecimento da sua produção científica.

O primeiro passo foi tentar localizá-las e, portanto comecei perguntando a diversos/as alunos/as e professores/as indicações de nomes de professoras negras na USP. A surpresa diante da insólita questão "você conhece alguma docente negra da USP?" me revelou que estava diante de um universo tão pequeno que poderia tornar a pesquisa praticamente inviável. Além disso, as respostas invariavelmente indicavam professores negros, sobretudo um nome bastante conhecido no segmento que pesquisa relações raciais brasileiras: o professor Kabengele Munanga. Vale destacar que a emergência dos nomes masculinos não foi muito mais abundante do que a dos nomes femininos, mas sensivelmente maior, confirmando uma tendência já apontada por bell hooks (1995) quando analisou sua experiência em sala de aula de propor o mesmo exercício: levantar nomes de docentes negras nas universidades norte-americanas pelas quais passou. A autora aponta que apesar da raridade da presença negra nas academias norte-americanas, os docentes negros eram frequentemente mais lembrados do que as docentes negras. Em minha pesquisa, depois de muito garimpar, cheguei a sete nomes de professoras negras e vinte nomes de professores negros na USP. ${ }^{1}$

As reformulações no projeto de pesquisa tornaram-se inevitáveis e acabei chegando a

\footnotetext{
${ }^{1}$ Desse conjunto de indicações entrevistei cinco das sete docentes negras e cinco professores negros, usando como critério de escolha aqueles/as com os/as quais consegui estabelecer efetivo contato. Seria importante registrar também que emergiu nessa busca o nome da professora Lígia Ferreira, da Faculdade de Letras. Porém, a professora foi submetida a um controverso processo de exoneração e atualmente leciona na UNIFESP
} 
uma encruzilhada: manter a questão inicial e tentar uma comparação entre as trajetórias das professoras negras e brancas da USP; ou empreender um trabalho de investigação sobre a presença de mulheres e homens negros/as na docência da USP. A primeira opção é sem dúvida muito interessante, mas diante da rara porém consistente e robusta bibliografia existente sobre as trajetórias de algumas docentes brancas, sobretudo da Faculdade de Filosofia Ciências e Letras (FFCL),2 me inclinei para a segunda possibilidade, utilizando o conhecimento já acumulado sobre as experiências dessas docentes da FFCL para melhor compreender a história de duas docentes negras: a professora Eunice Prudente da Faculdade de Direito, entrevistada para este trabalho; e a professora Virgínia Leone Bicudo, cuja trajetória é analisada por Damaceno (2013) e que apesar da rápida carreira na USP, foi um importante nome na institucionalização de cursos no campo da psicologia no Instituto de Psicologia da USP e na Faculdade de Saúde Pública. No processo de redefinição da proposta de pesquisa, a categoria corpo ficou pelo caminho, e busquei trazer até aqui as noções de raça e gênero no processo de investigação da presença negra na docência da USP. A busca pelos/as docentes negros/as tomou novos caminhos metodológicos, pois além das indicações de colegas discentes e de docentes, enviei também e-mails para 42 assistentes técnicoadministrativos indagando sobre a presença em suas unidades de professores e professoras negros/as. Esse conjunto de e-mails gerou respostas muito interessantes também para se pensar o constrangimento causado quando se solicita a alguém que aponte a cor de outra pessoa.

Para melhor compreender esse conjunto de respostas dos assistentes acadêmicos, que serão apresentadas no penúltimo capítulo dessa tese, é interessante trazer considerações sobre o processo de classificação racial no Brasil, com sua história e implicações conceituais. Tal procedimento se faz necessário em função do quão complexo é atribuir cor/raça a alguém neste país. Complexidade da qual a comunidade acadêmica não está isenta. Há quem considere que a elite acadêmica brasileira se recusa a ter cor, pois a comunidade de pares evita se considerar a partir de critérios raciais. Neste sentido a ideologia da democracia racial aparece como argumento eficiente (considerando que Gilberto Freyre sequer cunhou a expressão), que de um lado desviou a atenção da discriminação e das péssimas condições de vida da população negra e de outro, implicou na desautorização do uso de identidade racial:

(...) quando Gilberto Freyre defendeu a morenidade e repudiou a presença no Brasil de ideologias de negritude, ele, branco, utilizou-se de sua grande influência para impedir que os negros afirmassem sua identidade de negros. E por que o fez? Porque o discurso da negritude deslocaria a discussão de uma celebração abstrata da interpenetração das culturas

\footnotetext{
2A Faculdade de Filosofia, Ciências e Letras (FFCL), fundada em 1934 foi reestruturada com a Reforma do Ensino Superior de 1968 que aconteceu em todo o ensino universitário brasileiro. Dentre outras mudanças, houve a extinção do sistema de cátedras e a instituição de Departamentos. Nesse processo, a FFCL muda de nome, passando a ser a Faculdade de Filosofia e Ciências Humanas (FFLCH), pois deixou de abranger os cursos de os cursos de Física, Química, Matemática e Estatística, Biociências, Geociências, Psicologia e Educação, que passaram a ser Institutos e/ou Faculdades autônomas. Cf.: <http://fflch.usp.br/historico>
} 
para uma denúncia veemente das condições de vida precárias e sempre desiguais, enfrentadas pela população negra no país da suposta democracia racial. (Carvalho, 2003, p.175).

Mesmo diante de dados que exibem a desigualdade racial na sociedade brasileira, os acadêmicos das nossas principais universidades públicas se cercariam ainda de outros argumentos para rebater as propostas de discussões sobre políticas reparadoras de desigualdades raciais, como as ações afirmativas. Um deles é tratar a discussão racial no âmbito da biologia, onde o debate racial não se sustenta, deslocando a atenção do que de fato está em jogo: "a racialização construída como uma representação social que gera desigualdades crônicas e sistemáticas" (Carvalho, 2003, p.177).

Assim, face à complexidade que envolve os parâmetros de classificação racial no Brasil, algumas tendências analíticas tornaram-se clássicas e evidenciam posicionamentos conflitantes. Por exemplo, Fry (2006) com base nas discussões de Oracy Nogueira - para quem o brasileiro se classifica pela aparência (marca) e os norte-americanos a partir da descendência (origem) - sugere que a primeira forma enseja múltiplas possibilidades de classificações raciais, enquanto a segunda possibilitaria basicamente duas formas, a negra e a branca. As duas formas, tanto a multipolar, quanto a bipolar coexistem no Brasil. A bipolar teria sido inserida a partir das discussões do movimento negro brasileiro, com evidente inspiração norte-americana. Considerando o caráter classe média e acadêmico do movimento negro brasileiro, a classificação bipolar circularia mais nesse meio, enquanto a classificação multipolar seria mais frequente nas camadas populares. Enquanto Carvalho (2003) entende que segmentos brancos da academia brasileira manejam as classificações bipolar e multipolar conforme lhes convém; Fry (2006) advoga que a classificação bipolar é arbitrária, abrindo uma via conflituosa na resolução das desigualdades raciais no Brasil. Para Fry (1996), ainda que sejam ideologias contraditórias, na sociedade brasileira a democracia racial e o racismo convivem e são plenamente reais e presentes na orientação das ações sociais. Nas brechas abertas por ambas está a possibilidade de ocorrência do (im) previsível.

É justamente em função dessa (im)previsibilidade que configura as relações raciais no Brasil, que se deve ressaltar o desafio metodológico que subjaz às pesquisas sobre relações raciais no país. Há grande necessidade de cautela e de crítica sobre o legado acumulado, bem como de ampliar e refinar definições e preocupações de pesquisa. Segundo Mayorga (2010), em pesquisas sobre desigualdades no ensino superior, as escolhas metodológicas não são casuais, e são reveladoras das ideologias implícitas no ato da pesquisa. Considerando a invisibilidade um traço característico do ensino superior brasileiro no seu processo de dissimular hegemonias, desigualdades e ausências, estudar a presença das minorias na universidade é se comprometer com 
“o problema que não tem nome"3 (Mayorga, 2010, p.151).

A ambiguidade do racismo à brasileira, que é ao mesmo tempo negado e reconhecido, impõe problemas metodológicos, pois "como nomear problemas sobre os quais não há consenso público ou ainda como propor e realizar enfrentamentos a problemas que não são reconhecidos como problemas?” (Mayorga, 2010, p.153).

Este trabalho adota a classificação racial sugerida pelo Instituto Brasileiro de Geografia e Estatística (IBGE) que utiliza cinco categorias: branco, amarelo, indígena, preto e pardo; agregando analiticamente pretos e pardos como negros, em função das semelhanças que apresentam em termos de história do processo de classificação racial e de condições de vida. Conforme indica Osório (2003) a proposta de classificação racial do IBGE, apesar das polêmicas, possui origem centenária e se mostra bastante acertada e útil para entender a sociedade brasileira, conforme se verá mais detidamente no penúltimo capítulo deste trabalho.

Seguindo as trilhas da classificação racial proposta pelo IBGE na busca por nomes de docente negros/as na USP, vieram indicações de 27 nomes, num universo de mais de 6000 docentes. Parecia-me, porém uma safra generosa até a entrevista realizada com o professor (negro) Edson Moreira da USP São Carlos, do Instituto de Ciências Matemáticas e de Computação, que me alertou para o fato de que esse número poderia ser na verdade bem maior. Este professor me sugeriu consultar o Departamento de Recursos Humanos da Universidade de São Paulo em busca dos dados do Recadastramento Anual, um procedimento obrigatório a todo servidor público do estado de São Paulo, (conforme o decreto de No. 52.691, de $1^{\circ}$. Fevereiro de 2008) que dentre outras questões, deve informar seu pertencimento racial. Tomando como base o Departamento de Ciências da Computação, seu endereço profissional, onde verificara pelo menos quatro docentes negros num conjunto de 120 professores/as uma proporção de 3,3\% de negros; o professor Edson Moreira arriscou o palpite de que o número de docentes negros na USP poderia superar a ordem de uma centena. Conforme se verá no capítulo referente à consideração desses dados, de fato, o palpite do professor Edson Moreira se mostrou certeiro.

Além dos dados que revelaram quantos e onde estão os/as docentes negros/as; procurouse conhecer o que significa ser parte do corpo docente da USP na condição de negro/a. Para tanto, foram feitas dez entrevistas com cinco professoras negras e cinco professores negros. As narrativas docentes possibilitaram entender de que modo a categoria raça amplia os desafios da carreira acadêmica na maior universidade brasileira. De imediato percebeu-se que apresentar apenas um instantâneo da atual configuração racial do corpo docente da USP e os significados de

3Mayorga (2010) toma de empréstimo a expressão "problema que não tem nome" da psicóloga social e feminista Betty Friedan (1963), nas suas análises sobre a persistência de desigualdades de gênero, apesar das importantes conquistas ao longo do século XX. 
ser docente negro nesta instituição abriria algumas possibilidades de compreensão dessa subrepresentação quantitativa, mas não seria suficiente para entender porque de fato a população negra não foi integrada à Universidade de São Paulo. Fez-se necessário portanto, realizar um debate sobre a situação anterior e, para isso, voltar aos primórdios da USP e reler a história da instituição destacando como se deu a participação negra na docência, na construção da universidade e, sobretudo, no debate racial dentro da instituição. Voltar às origens da USP, rever as concepções de universidade reinventadas aqui e recapitular a história do debate racial construído na instituição, mesmo antes do seu decreto de fundação, foram tarefas necessárias para a efetivação dessa pesquisa.

Só então foi possível delinear a pergunta que orienta esse trabalho: por que passados mais de oitenta anos de fundação da Universidade de São Paulo, a população negra ainda não foi efetivamente integrada à USP, mais especificamente na composição do corpo docente? Vale ressaltar que a USP figura como instituição de fundamental importância na construção de importantes capítulos do debate racial no cenário paulista e nacional, mesmo antes do seu decreto de fundação em 1934, se considerarmos que a história desse debate na universidade remonta à Faculdade de Direito no Largo São Francisco criada em 1827 e à Faculdade de Medicina inaugurada em 1912, ambas posteriormente integradas à nova Universidade, que nascia para ser um marco na história dos 380 anos da cidade de São Paulo, para traduzir em termos científicos a missão bandeirante do estado. Diante disso, emerge outra questão igualmente necessária: qual foi a participação de intelectuais negros/as na construção dos debates raciais que tiveram lugar no seio dessa universidade que já surgiu imponente e se propondo como imprescindível à nação brasileira? A história da USP revela que mesmo rara, a presença negra no corpo docente e discente sempre foi uma realidade, apesar do silêncio das fontes históricas. Mas a efetiva integração da população negra nesta instituição ainda é um desafio a ser perseguido. Sendo assim, a hipótese aventada nesse trabalho é que a pequena presença negra na USP se deve ao fato de que esta instituição se ergueu sobre concepções de universidade fundamentalmente europeias, voltando os holofotes para noções como universalidade, excelência e mérito, que também poderiam ser facilmente entendidas ou traduzidas como eurocêntricas.

Assim, a USP se assenta nas experiências universitárias europeias, sobretudo a alemã e a francesa, mas também bebeu do modelo norte-americano. Drèze e Debelle (1983) em considerações sobre os modelos de universidade na Inglaterra, Alemanha e França, apontam essas concepções como paradigmáticas. Assim, a tradição acadêmica inglesa é compreendida como expoente de uma perspectiva que enfatiza a conservação e transmissão do conhecimento mais do que o seu progresso; a universalidade do saber em detrimento da especialização, a autonomia universitária ante a prestação de serviço (Drèze e Debelle, 1983, p.33). Voltada para uma elite, o 
resultado de uma educação liberal seria o gentleman, importando ter uma inteligência cultivada, com gostos refinados, lealdade de espírito e nobreza de conduta. Por sua vez, os alemães teriam estabelecido a melhor formulação da "Ideia de Universidade", que prima pela pesquisa científica a partir de dois princípios: Unidade do saber e Unidade da pesquisa e do ensino. Nessa perspectiva, a iniciação científica, ou seja, a "educação universitária" é um privilégio de elite, da "aristocracia intelectual". (Drèze e Debelle, 1983, p.52). Além disso, a universidade deve apresentar como princípio de organização a liberdade acadêmica, que significa "autonomia administrativa, liberdade para a ‘corporação’ de se administrar ela mesma” (Drèze e Debelle, 1983, p.57).

No modelo norte-americano a universidade busca servir aos interesses de uma sociedade que aspira ao progresso; considerando que a aspiração de todos só possa se realizar por meio de alguns. O princípio de educação deve se pautar por princípios de utilidade, onde o saber deve servir a um fim, conjugando prática e teoria. $\mathrm{O}$ aspecto original da universidade norteamericana é a capacidade "de conceber tarefas tradicionais e prolongá-las, amanhã, no plano de novas tarefas" (Drèze e Debelle, 1983, p.66). Assim, nos Estados Unidos, a universidade esteve mais engajada num ensino de massa, ainda que preservando e desenvolvendo seu caráter aristocrático. Pensando a universidade americana, é interessante retomar também as considerações de Kerr (1982) sobre a Multiversidade que concebe a universidade como sendo fragmentada, um corpo com vários enxertos e funções diversas. É "um mecanismo interligado por normas administradas e cujo poder deriva do dinheiro" (Kerr, 1982, p.31). Por fim, há a universidade francesa, versada como uma instituição que presta serviço público, de caráter napoleônico, onde a autonomia é um desafio permanente (Drèze e Debelle, 1983, p.97).

Estas concepções acompanham a história da USP desde o projeto de fundação que a alicerça e tem como pedra angular uma orientação desde sempre liberal. Essa preocupação está presente, por exemplo, na obra "Política e Cultura", na qual Júlio de Mesquita Filho concebe uma universidade para a pesquisa, que focaliza a alta cultura, com rigorosos critérios de seleção, que tem por finalidade fomentar a ciência, pura e aplicada e que prima pela autonomia. Essas ideias soam românticas, mas tinham a preocupação de preservar a USP de alguns "perigos" que se avizinhavam como a massificação, limitação doutrinária ou de campo, engajamentos políticos, ou mesmo a subordinação da universidade a interesses exteriores a ela, seja de ordem econômica, social ou política (Antunha, 1974, p.15). Embora não seja tarefa fácil apontar de forma conclusiva a filosofia universitária da USP, é possível delimitar algumas ideias e princípios básicos: o princípio da universalidade, pelo qual a USP defende uma universidade autêntica que cultiva a totalidade ou universalidade do conhecimento e a ideia de autonomia universitária, que diz respeito à possibilidade de realização dos objetivos específicos e inalienáveis da instituição. Essa autonomia pode ser técnico-administrativa, como pode dizer respeito à liberdade de expressão e pensamento. A 
construção da autonomia na USP passa em grande parte pela busca por um projeto universitário de orientação liberal (Antunha, 1974).

As conciliações entre universidade e desenvolvimento estão marcadas pela assimilação da civilização ocidental moderna. Embora o processo de absorção e expansão dessa civilização tenha tido êxito em todos os países latino-americanos, os efeitos do passado colonial e da dependência econômica geraram dilemas educacionais e problemas universitários análogos. Embora possuam universidades mais antigas que as brasileiras, nossos vizinhos latino-americanos adotaram regras bastante semelhantes nas concepções de universidade, que também foram formuladas num primeiro momento sob moldes ibéricos, e posteriormente reformuladas tendo em vistas os paradigmas universitário europeus, mais especificamente francês, alemão e inglês (Fernandes, 1976). A influência mais recente é norte-americana, em consonância com as políticas científicas e muitas vezes de cunho imperialistas no continente.

As universidades reinventadas na América Latina selecionaram algumas concepções essenciais, sobretudo aquelas que fossem compatíveis com "o estilo social de vida predominante" (Fernandes, 1976, p.207) e restringiram o alcance das suas possibilidades de contribuição para o desenvolvimento econômico e sócio-cultural. Assim, até os anos de 1930 prevaleceu no continente a antiga universidade, caracterizada em termos de filosofia pedagógica, pelo apego "às necessidades intelectuais do ambiente" (Fernandes, 1976, p.213), operando como uma ponte com o "mundo civilizado europeu" (Ibidem) e exercendo as funções de "colonizadora, civilizadora, elitista e aristocratizante" (Fernandes, 1976, p.215). Assim, a crítica a esse modelo aconteceu em torno da ideia de nova universidade que,

(...) não pretendia destruir uma herança, mas superar um passado tão cheio de
contingências. A contribuição positiva dos movimentos de autonomia e de reforma
universitárias dizia respeito, portanto, ao que se devia fazer para criar-se uma universidade
capaz de preencher todas as funções normais, que ela precisaria satisfazer à luz dos
requisitos da civilização baseada na ciência e na tecnologia científica (Fernandes, 1976,
p.221)

Não coincidentemente a fundação da Universidade de São Paulo, a USP, em 1934, exigiu a criação da Faculdade de Filosofia Ciências e Letras (FFCL), concomitante ao decreto inaugural da universidade com o propósito de ser sua célula mater, o elo de integração científica e cultural da nova universidade. A primeira configuração do corpo docente da USP foi essencialmente europeia devido à contratação da missão estrangeira composta por professores oriundos da França, Alemanha e Itália. Esta foi a política anunciada como garantia de que a universidade cultivasse todos os ramos do saber, a implantação de múltiplos pontos de vista e uma mentalidade pesquisadora (Antunha 1974). Se essa contratação trouxe a possibilidade de modernizar o ensino superior para melhor adequá-lo ao pensamento científico ocidental corrente, favoreceu também 
um processo de colonização acadêmica, uma vez que o caráter universal da ciência trouxe historicamente em seu cerne o vício colonizatório. Para Quijano (2000), o conhecimento tem sido historicamente eurocêntrico; pois auto-proclamado racional, foi imposto ao mundo capitalista como a única racionalidade válida e como signo da modernidade. O eurocentrismo se espraia e cria raízes de modo que deixa de ser uma perspectiva cognitiva exclusiva dos europeus e/ou dos dominantes do capitalismo mundial e passa a ser também do conjunto dos educados sob sua hegemonia. (Quijano, 2000, p. 343.

A criação da USP foi deliberadamente um projeto político cultural para São Paulo e para o país, com intenções de renovar a vocação bandeirante do estado, que teria na universidade nova via de avanço para o progresso (Witter, 2006). Oferecendo "uma crônica das origens" da universidade, Bosi (1982) ressalta a importância, em São Paulo, de um grupo que reunia "intelectuais orgânicos da oligarquia cafeeira e uma brilhante ala dissidente cujas posições se afirmavam então democráticas e modernizadoras". (Bosi, 1982, p.11). Setores da "classe média, alta e baixa" todos aqueles que direta ou indiretamente foram afetados pela crise do café, são conclamados a pensar soluções, sendo desde então batizados de "Comunhão Paulista Ilustrada" (Bosi, 1982, p.12). O principal problema diagnosticado foi referente à educação, mais especificamente à necessidade de formação de elites intelectuais aptas a orientar os projetos da oligarquia em crise. Apesar da herança colonial, a criação de uma universidade em São Paulo foi tida como uma proposta inovadora, prometendo colocar o Brasil no mapa internacional da produção científica. A noção de universidade proposta em São Paulo começou elitista, mas com a criação da Faculdade de Filosofia Ciências e Letras, percebeu-se que a universidade deveria abrir suas portas, ampliar-se para tornar-se viável. De fato os anos pós 1934 são marcados pela entrada de segmentos que até então haviam estado tradicionalmente fora da universidade, a saber: mulheres e descendentes de imigrantes. (Miceli, 2001)

Diante disso, este trabalho propõe pensar porque estes processos não contemplaram a população negra e nem reverberam numa composição racial mais diversa e democrática da USP. Articular as discussões sobre relações raciais e docência no ensino superior é interpelar algumas (in)visibilidades. Onde estão os professores negros e as professoras negras na USP, é uma pergunta que esse trabalho faz, diante da ausência de um censo étnico-racial do corpo docente das universidades públicas brasileiras e da escassez de bibliografia a respeito. Se a vocação primeira da Universidade de São Paulo é formar uma elite intelectual capaz de elaborar conhecimentos, políticas e tecnologias para setores estratégicos tanto no estado como no país, a universidade permitiu readaptações nessa vocação permitindo a entrada de filhos de imigrantes europeus e mulheres. E permanece a questão: por que não negros/as? Considerando que a história da Universidade de São Paulo também foi tecida com fios de desigualdades de raça, gênero e classe, 
esse trabalho propõe pensar que, em compasso com a dinâmica histórica da instituição, a discussão racial na universidade viveu diferentes momentos. A proposta dessa pesquisa é trazer historicamente como a discussão racial se caracterizou em quatro diferentes momentos e indicar se e como aconteceu a participação de intelectuais negros/as em cada um deles.

O primeiro momento é analisado no capítulo de abertura da tese e compreenderia as discussões sobre a questão racial no Brasil e em São Paulo, empreendidas por duas instituições, as Faculdades de Direito e Medicina, incorporadas à universidade em 1934. Interessa aqui ressaltar que embora o decreto de fundação da Universidade de São Paulo date de 1934, houve um longo antecedente. O século XIX é fundamental para a história do ensino superior em São Paulo, quando também é lançada a pedra fundamental para o projeto da universidade, criada quase um século depois. Com a fundação da Faculdade de Direito de São Paulo em 1827, o estado assenta as bases acadêmicas para a confecção de teorias raciais defendidas por homens de ciência. Os novos bacharéis, preocupados em aplainar os terrenos para melhor erguer o futuro do país, enfrentam a mais flagrante ameaça de então, que era o enorme contingente de negros, que maculava o corpo da nação. A Faculdade de Direito e a Faculdade de Medicina em São Paulo talharam em seus primórdios algumas propostas teóricas e políticas, de modo que os debates sobre raça, ciência e nação, atravessam a história da universidade de São Paulo e imprimiram sua marca na missão dessa universidade bandeirante. Nesta sessão do trabalho, há um especial destaque para a análise da entrevista concedida pela professora Eunice Prudente, da Faculdade de Direito, que traz em sua trajetória elementos para a compreensão dos significados de ser negra e mulher na mais antiga instituição de ensino superior de São Paulo, possibilitando também um importante elo de ligação com o professor José Rubino de Oliveira, que no século XIX, em pleno período escravocrata, foi o primeiro docente negro das Arcadas do Largo São Francisco, outro nome pelo qual a Faculdade é conhecida. A análise da trajetória da professora Eunice Prudente permite verificar que para além da presença ideológica, houve de fato negros/as na universidade e na Faculdade Direito.

O segundo momento do debate racial na USP é considerado nesta pesquisa a partir da história da Faculdade de Filosofia, Ciências e Letras, sobretudo no que diz respeito aos debates empreendidos pela chamada "Escola Paulista de Sociologia", que aninhou a construção da Sociologia como disciplina na USP, sob a regência de Florestan Fernandes, intelectual branco, cuja tese A Integração do Negro na Sociedade Brasileira tornou-se um marco no pensamento social brasileiro, ao desvelar como operava o preconceito racial no Brasil. Igualmente importante para a história do debate racial na USP, foi o fato de que Florestan Fernandes estabeleceu relações com acadêmicos negros/as que precisam ser melhor interpeladas; como por exemplo, a história de disputas no campo da institucionalização da Sociologia entre Florestan Fernandes e o intelectual negro Guerreiro Ramos, bem como os silêncios que cercam os trabalhos da socióloga e psicanalista 
negra Virginia Leone Bicudo. Atento a estes aspectos da história do debate racial na USP, este trabalho indica como somente após duas décadas da publicação da tese de Florestan na Cadeira I de Sociologia da USP, é que a FFCL vê pela primeira vez a entrada de um docente negro, o antropólogo africano Kabengele Munanga, cuja presença na instituição acontece no contexto do terceiro momento do debate racial na USP.

Para entender este terceiro momento é preciso ter em conta a lacuna no debate racial coincidente com a ditadura militar que trouxe tempos difíceis para a Faculdade de Filosofia Ciências e Letras e dentre tantas agruras, culminou na aposentadoria compulsória de Florestan Fernandes. Foi também o momento da implementação da Reforma de 1968, que instituiu os departamentos e extinguiu o sistema de cátedras. Assim, neste contexto a discussão racial esteve em estado de latência na Sociologia da USP por quase duas décadas, apesar de timidamente abrigada na Antropologia. Além disso, o terceiro momento do debate racial na USP coincide com o crescimento e consolidação da pós-graduação nas ciências humanas e sociais; a emergência de associações científicas, como a ANPOCS, e seus grupos de trabalho sobre o tema; e por fim, a disponibilidade de dados oficiais do IBGE sobre cor/raça da população. Em termos políticos, há também o ressurgimento do Movimento Negro na década de 1970 e a partir da década de 1990, a configuração de novos padrões de reivindicações pautadas na adoção de medidas anti-discriminatórias e formulação de políticas de ação afirmativa (Hasenbalg, 2005). Esta pesquisa destaca a importância da trajetória do professor Kabengele Munanga para este período da história do debate racial na USP.

O quarto momento ainda é corrente, começa nos anos 1990 e está vinculado mesmo que indiretamente a uma série de eventos importantes no cenário nacional concernente à agenda antirracista brasileira: a recém instituída constituição de 1988 que tornou o racismo crime inafiançável e imprescritível; o fato de o governo do então presidente Fernando Henrique Cardoso, importante nome da Escola Paulista de Sociologia da USP, ter reconhecido oficialmente a existência do racismo e discriminação racial no Brasil. E na USP, mais especificamente, em 1995, ocasião em que aconteceu a rememoração do tricentenário da morte de Zumbi dos Palmares, e que teve importantes desdobramentos, como o seminário internacional "Estratégias e Políticas de Combate às Práticas Discriminatórias", ocorrido em novembro de 1995, do qual resultou a publicação do livro "Estratégias e Políticas de Combate à Discriminação Racial", organizado pelo professor Kabengele Munanga. Além disso, a criação em 1999 da CPPPN, a Comissão de Políticas Para a População Negra da USP, que fez o primeiro censo sobre a cor dos candidatos ao vestibular da USP e a cor dos ingressantes. Esta tese principia as considerações desse momento destacando a importância das figuras de Kabengele Munanga, importante elo com o momento anterior do debate; e do professor Edson Moreira, da USP de São Carlos, cuja presença no Conselho de Cultura e Extensão foi de suma importância para a introdução da categoria raça/cor no questionário de 
candidatos e ingressantes da FUVEST, o vestibular da USP.

Apesar da assunção de um horizonte promissor nos anos 1990 na USP, a década seguinte é marcada por resistências e retrocessos no que diz respeito às políticas de cunho racial na universidade, mesmo diante dos avanços no cenário nacional: fruto direto dos compromissos assumidos pelo Brasil em 2001 na Conferência de Durban contra o racismo, em 2002 a Universidade do Estado do Rio de Janeiro (UERJ) adota o critério de reservas de vagas para negros no vestibular, desencadeando na sociedade brasileira o acalorado debate sobre cotas raciais. Em 2003, já no governo Lula, é criada a SEPPIR (Secretaria Especial de Promoção de Políticas de Igualdade Racial). Neste mesmo ano é promulgada a Lei 10.639 que institui a obrigatoriedade do ensino da história e cultura afro-brasileira na educação básica. Assim, nos anos 2000, a questão racial foi incorporada de maneira definitiva na agenda pública brasileira. Apesar do cenário nacional, o debate racial, sobretudo no que concerne à adoção de políticas de ações afirmativas, não foi nada fácil na USP. Docentes da universidade, que produzem ou não conhecimento no campo das relações raciais, manifestaram posicionamentos sobre o assunto, que podem ser verificados, por exemplo, nas assinaturas do "Manifesto a Favor das Cotas" ou do "Manifesto Contra as Cotas". Os manifestos, que mobilizaram a comunidade acadêmica de todo o território brasileiro, tiveram também a participação de docentes da USP, sobretudo nos manifestos contra as cotas. A CPPPN foi extinta em 2010 no calor das discussões no Congresso sobre a constitucionalidade das cotas e foi substituída pelo INCLUSP, o atual programa de inclusão social na USP, que descarta a categoria raça e adota a categoria "estudante de escola pública", que pode ou não ser pobre ou negro, mas que em linhas gerais favorece a classe em detrimento da raça. Apesar destes retrocessos na implementação de políticas de ampliação do acesso da população negra na USP, ao longo dos anos 2000 aconteceu o ingresso de alguns/mas docentes negros/as na universidade. Do conjunto de dez docentes negros/as entrevistados/as para esta pesquisa, sete ingressaram na carreira docente da USP a partir dos anos 2000 .

Esta tese dedica o quinto capítulo à releitura da história da presença feminina no corpo docente da USP, a qual já foi analisada em outros trabalhos, mas trazendo como novidade a intersecção com a categoria raça. Mais uma vez a trajetória da professora Eunice Prudente é retomada em função da sua relevância para o importante capítulo do movimento feminista em São Paulo nos anos 1980. A clássica bibliografia referente à trajetória de algumas gerações de docentes na FFCL é evocada com o propósito de tecer algumas comparações com as carreiras acadêmicas das docentes negras Eunice Prudente e Virgínea Bicudo. Conforme propõe Brah (1996) não se trata de considerar as lutas e dilemas das mulheres brancas e negras em campos opostos, mas tentar compreender como acontece o processo de racialização da categoria gênero. Além disso, interessa a essa pesquisa interpelar a perspectiva historicamente masculina de pensar e construir conhecimento 
na universidade brasileira e na USP em particular e apontar suas reverberações nas trajetórias acadêmicas de mulheres brancas e negras.

No sexto capítulo apresenta-se a configuração racial do corpo docente da USP, a partir de dados do Departamento de Recursos Humanos da universidade referente aos docentes aposentados/as e ativos/as entre anos de 2008 a 2015, trazendo também a discussão sobre classificação racial na sociedade brasileira e na universidade. A sub-representatividade da população negra constatada na configuração do corpo docente da USP atualiza a questão sobre a não integração desse segmento da população ao ensino superior brasileiro e na USP particularmente. A possibilidade de resposta, manutenção ou mudança desse quadro passa pela mãos dos professores, mesmo que se considere o quão problemática é a noção de autonomia para a USP em função do modo como se configura a estrutura de poder na universidade. Ou conforme indica Bourdieu (2011) quando disseca a vida universitária em Homo Academicus, há na universidade mecanismos de seleções e hierarquias que classificam os sujeitos acadêmicos entre eleitos e não eleitos; a partir de critérios cuja objetividade é bastante questionável, caracterizando assim, o campo científico como espaço de disputas e relações de poder. Analisando como se dá a reprodução do corpo universitário, o autor aponta a importância do "capital universitário" no processo de acesso, ocupação de posições, que permite dominar outras posições e seus ocupantes. De modo que "esse poder sobre as instâncias de reprodução do corpo universitário assegura a seus detentores uma autoridade estatutária, espécie de atributo de função que está muito mais ligado à posição hierárquica que a propriedades extraordinárias da obra ou da pessoa”. (Bourdieu, 2011, p. 116).

Por fim, o sétimo e último capítulo deste trabalho propõe conhecer as estratégias, recursos, discursos e práticas que acadêmicos/as negros/as da USP lançaram mão para tentar driblar as (im)possibilidades de acesso a um universo que tem sido cerceado à população negra: a docência da maior universidade do país. As dez entrevistas que compõem a maior parte do material empírico analisado neste capítulo foram realizadas no primeiro semestre de 2011, sendo cinco professoras negras e cinco professores negros. Foram entrevistadas semi-estruturadas, gravadas e duraram entre uma a três horas, gerando mais 300 páginas de transcrições. Foram realizadas em local escolhido pelos/as entrevistados/as, nas unidades da USP a qual pertencem. A partir da consulta por e-mail a cada docente entrevistado/a e com a resposta de consentimento, optou-se aqui pelo uso do nome verdadeiro de cada docente nos depoimentos publicados. Além do conjunto de entrevistas concedidas para esta pesquisa, fez-se também uso de outras fontes, como o currículo Lattes, memorial de concurso, palestras, entrevistas concedidas para veículos acadêmicos e midiáticos, e textos publicados em redes sociais.

A leitura das narrativas dos/as docente negra/as contempla a história da população negra brasileira em tempos diversos de classificação e segregação sócio-racial, desvelando suas 
persistências e avanços. Nesse sentido empreende-se também o esforço de trazer para o plano analítico a solidão, a solidariedade, a realização pessoal e coletiva que marcam as travessias de sucesso acadêmico protagonizado por esses sujeitos. Assim, busca considerar as narrativas docentes “desde a condição de negro" (Arroyo, 2009, p.176). Ou seja, considerar que avançar na escolarização não é garantia de supressão da origem racial, aliás, a condição racial é uma companhia constante que delineou a trajetória escolar e acadêmica de modo perene.

Em suma, este trabalho tem especial interesse em compreender como algumas tradições reinventadas nesta universidade permeiam seu cotidiano acadêmico e interpelam seus posicionamentos frente à realidade brasileira, particularmente os debates sobre relações raciais. Considerando as concepções de universidade que a USP concilia ao longo de sua história, este trabalho pergunta qual é a configuração racial do seu corpo docente, e quais são os significados dessa questão para a parcela negra do professorado da USP, que vive no cotidiano a dor e delícia de construir uma carreira acadêmica na maior instituição pública de ensino superior brasileira e latinoamericana. No esforço de responder às questões levantadas, esse trabalho se debruça sobre aspectos da história da USP que apontem quando suas concepções de universidade informaram os posicionamentos do seu corpo docente, branco ou não, frente aos debates sobre relações raciais.

Considerando que este trabalho tem abrigo na Sociologia da Educação, entendida aqui como "a análise científica dos processos e regularidades sociais inerentes ao sistema educacional" (Brookover, 1977:19), pretende-se considerar o sistema de ensino superior público brasileiro, a partir do caso da Universidade de São Paulo, para compreender "o funcionamento do sistema de educação formal em suas vinculações com os grupos raciais" e sua função "no processo de mudança social" e "manutenção do status quo", tal como sugere Brookover (1977, p.20.). Na interface entre a Sociologia da Educação e a História da Educação, este trabalho propõe analisar sociologicamente os "sinais raciais" mais ou menos implícitos nos discursos de diferentes atores da universidade que possam contribuir para uma leitura marcadamente racial da história desta instituição, que celebra sua oitava década de fundação mergulhada em crise financeira e políticoadministrativa, mas orgulhosa de sua história, tradição, elitismo e de sua tão propalada excelência acadêmica. 


\section{Capítulo I- História de um debate - primeira parte: uma leitura étnico-racial do longo} antecedente da universidade de São Paulo

\section{I- 1. O Longo Antecedente da USP: o debate sobre raça e relações raciais na Faculdade de Direito, na Escola de Medicina e a Missão Bandeirante da Universidade}

No dia 25 de janeiro do ano de 1954, a cidade de São Paulo celebrava seu aniversário de quatrocentos anos. Na mesma data, a Universidade de São Paulo (USP) completava vinte anos de fundação. Como parte das comemorações promovidas pela universidade, foi lançada a obra "História da Universidade de São Paulo", escrita pelo professor Ernesto de Souza Campos. Sua monumentalidade é atestada pelo seu caráter enciclopédico e pelo pioneirismo da escrita da história da instituição. O autor apresenta com riqueza de documentos, as raízes da universidade, buscando em Portugal e nas figuras dos jesuítas no Brasil, os fundamentos do projeto USP. Aos jesuítas é creditada a primazia do ensino no Brasil, missão que teriam cumprido com exclusividade durante os dois primeiros séculos da América Portuguesa, com destaque para a ação daqueles que foram os “(...) dois grandes semeadores da civilização nacional” (Campos, 1954, p. 38), a saber, os jesuítas Manoel da Nóbrega, fundador de São Paulo de Piratininga, e José de Anchieta, seu braço direito. Assim,

\footnotetext{
Nóbrega foi o Fundador; Anchieta o Apóstolo (...). Nóbrega foi a espada habilmente manejada que recortou a fundo o molde da primeira civilização brasileira; Anchieta foi o florete leve e macio que se frustrava ao "tocato", para esgrimir mais além e contra a incultura do gentio (Campos, 1954, p. 38).
}

Ao discorrer sobre "as raízes das primeiras fundações universitárias brasileiras" (Campos, 1954, p. 25), nota-se que as tentativas de criação de uma primeira universidade brasileira são numerosas, que se alongaram por mais de três séculos e meio. O Brasil foi o último país da América a instituir o ensino superior universitário, apesar de inúmeras tentativas de homens interessados. O dia 11 de agosto de 1827 marca a história do ensino superior no estado de São Paulo com a criação do curso de Direito, que, assentado no convento de São Francisco, alicerçou a futura Universidade de São Paulo. Quase um século depois, a Lei Rodrigues Alves, de 19 de dezembro 1912, criou a então chamada Faculdade de Medicina e Cirurgia, regulamentada em janeiro do ano seguinte, tendo sido nomeado o Dr. Arnaldo Vieira de Carvalho como diretor, cargo que ocupou até a data de sua morte, em 5 de junho de 1920.

Interessa destacar que tanto a história da Faculdade de Direito quanto da Faculdade de Medicina são atravessadas por importantes aspectos das teorias raciais correntes no país desde a segunda metade do século XIX. Na virada para o século XX, estava em pauta no Brasil o seu 
avançado estado de miscigenação, ainda que as teorias raciais europeias tenham chegado tardiamente no Brasil, num contexto de desmontagem da escravidão, de entrada de um ideário positivo-evolucionista e de estruturação de centros de ensino nacionais. Assim, a consideração das teorias raciais no Brasil é contemporânea "aos modelos liberais de atuação política e de concepção de Estado" (Schwarcz, 1993, p.14). Coube aos "homens de sciencia" definidos como "misto de cientistas e políticos, pesquisadores, literatos, acadêmicos e missionários” (Schwarcz, 1993, p.14), a tarefa de oferecer dentro dos limites conflitivos dos modelos, novas recombinações interpretativas, apontando caminhos para o projeto de nação que então se constituía. Assim é que:

Do darwinismo social adotou-se o suposto da diferença entre as raças e sua natural hierarquia, sem que se problematizassem as implicações negativas da miscigenação. Das máximas do evolucionismo social sublinhou-se a noção de que as raças humanas não permaneciam estacionadas, mas em constante evolução e "aperfeiçoamento", obliterandose a ideia de que a humanidade era uma. (Schwarcz, 1993, p.18).

O impulso na história das instituições educacionais no Brasil acontece com a vinda de D. João VI para a colônia no início do século XIX. E, se até meados do século, o perfil dos intelectuais era bastante homogêneo, o mesmo não poderia mais ser dito nos anos seguintes. Os motivos eram, dentre outros, o fortalecimento da cafeicultura, que deslocou o eixo econômico do nordeste para o sudeste brasileiro, assim como a campanha republicana, no bojo da qual estava não apenas o estabelecimento de um novo regime político, como a preservação de uma arraigada hierarquia social que polarizava de um lado a elite rural e de outro, escravos e a pequena classe média urbana. $\mathrm{O}$ desmantelamento do sistema escravista trouxe a preocupação referente à mão de obra e os primeiros debates sobre a imigração de trabalhadores estrangeiros, de preferência europeus. Esses eram alguns dos impasses vividos pela jovem nação brasileira, no esforço de se libertar "das amarras do Império" (Schwarcz, 1993, p.27).

As primeiras faculdades de medicina do país, entre os anos 1870 a 1930, localizadas na Bahia e Rio de Janeiro, tiveram nesse período, importantes diferenças de abordagem. Se para os médicos cariocas o foco era o combate às doenças, para os baianos o doente era quem estava em questão. De todo modo, o debate racial tem centralidade nas duas propostas. A principal contribuição da escola baiana está nos estudos sobre medicina legal, alienação e doenças mentais; já a escola carioca se destacou nos estudos sobre "higiene pública" para combater as doenças que infectavam o corpo da nação (Schwarcz , 1993, p.199). Um dos grandes expoentes da escola baiana de medicina foi Raimundo de Nina Rodrigues com suas análises sobre as diferenças entre as raças e a condenação da mestiçagem. Nina Rodrigues e seus colegas, numa perspectiva social-darwinista, apontam a mestiçagem e a degeneração decorrente, como o maior mal nacional. No conjunto dessas discussões não estava em questão a inferioridade biológica e cultural dos negros, pois não havia 
espaço para contestá-la, porém havia divergência entre os que indicavam essa inferioridade como transitória e aqueles que a postulavam irremediável, orgânica. Em 1923, pela primeira vez, a escola baiana publica artigos de apoio à eugenia, num movimento em direção à regeneração da raça.

A escola carioca começa a delinear a sua identidade por volta dos anos 1900, a partir da configuração de uma "medicina tropical” (Schwarcz, 1993, p.223), com campanhas de saneamento e higiene pública. As epidemias são tratadas por duas vias, a cura e a profilaxia. Surge a figura do "médico pesquisador" que apostava na cura, enquanto a função dos higienistas e saneadores era impedir a proliferação de doenças e surtos, atuando junto às populações para educar e prevenir. Desse esforço despontam alguns expoentes, como Oswaldo Cruz e Carlos Chagas. A sociedade era entendida como um "imenso hospital" da qual "esperava-se a passividade absoluta" (Schwarcz, 1993, p.227). É nesse contexto que acontecem as grandes campanhas de vacinação e suas controvérsias decorrentes das posturas autoritárias dos profissionais da saúde. A doença era tida como a grande explicação do fracasso da nação, ao passo que seu diagnóstico e tratamento eram as vias de solução. É só a partir dos anos 1920 que a escola carioca passa a considerar a questão racial com maior ênfase, aproximando-se da escola baiana. As doenças são interpretadas como oriundas da África, com os escravos, ou da Europa e Ásia com as imigrações de mão de obra no início do século XX. O enfraquecimento biológico passa a ser explicado pela miscigenação. A higiene passa a abranger a pobreza e a condição negra ou mestiça da população.

Considerando especificamente a Faculdade de Medicina de São Paulo, a história dessa instituição se cruza com aspectos importantes das teorias raciais estabelecidas nas faculdades de medicina do Rio de Janeiro e da Bahia. A leitura do prefácio escrito em 1932 por Homero Pires para a obra Os africanos no Brasil, do médico Nina Rodrigues oferece indícios, por exemplo, da proximidade entre a medicina legal proposta na Bahia e em São Paulo. Oscar Freire, que exerceu a função de médico legista na Faculdade de Medicina e Cirurgia de São Paulo, foi discípulo de Nina Rodrigues; e teve sob sua guarda parte importante da produção bibliográfica do mestre da escola baiana após sua morte.

Outro fator relevante detalhado por Campos (1954), que foi aluno da Faculdade de Medicina, é a obra empreendida por Dr. Arnaldo de Carvalho, o primeiro diretor da instituição. Para a consolidação da faculdade, uma das iniciativas do diretor amplamente destacada por Campos (1954), consistiu no acordo que promoveu entre o Estado de São Paulo e a Fundação Rockefeller, assinado no dia 9 de fevereiro de 1918, que possibilitou o pontapé inicial para a construção de todo o conjunto de laboratórios no Centro Médico do Araçá, outra designação para a Faculdade de Medicina de São Paulo.Tal acordo também é informado pelas discussões raciais que aconteciam na ocasião, como se verá mais a seguir.

A importância da escola paulista de medicina no debate racial pode ser considerada a partir 
das análises sobre o movimento sanitarista e eugenista no Brasil. São Paulo marcou a institucionalização da eugenia no Brasil a partir da criação da Sociedade Eugênica de São Paulo em 1918, a qual sistematizou todos os trabalhos sobre eugenia feitos até então no país. A escolha da cidade de São Paulo aconteceu, sobretudo, pela importância política e econômica que o estado assumia no cenário nacional, embora desde o princípio estivesse prevista a expansão da Sociedade para outros estados. Para compor a presidência da sociedade paulista foi nomeado Dr. Arnaldo Vieira de Carvalho, médico e diretor da recém-criada Faculdade de Medicina e Cirurgia de São Paulo (Kobayashi et ali, 2009).

O movimento eugenista no Brasil, na década de 1920, tinha significativo caráter de "eugenia preventiva" (Kobayashi et ali, 2009, p.329). E, em 1915 quando começam as primeiras negociações entre o Brasil e a Fundação Rockefeller, no contexto da primeira guerra mundial pois viu no país possibilidades estratégicas de ação. Essa parceria acabou gerando também outros "efeitos colaterais" (Kobayashi et ali, 2009, p.330) tais como:

(...) reorganização das instituições de saúde pública locais, a extensão dos serviços sanitários às áreas rurais, além da substituição gradual do modelo acadêmico e técnico francês pelo norte-americano, que privilegiava o trabalho de pesquisa e a dedicação integral dos professores ao ensino. (Kobayashi et ali, 2009, p. 330)

A influência norte-americana no ensino superior brasileiro é usualmente associada aos acordos de 1966, conhecidos como MEC-USAID, fundamentais para o processo de Reforma ocorrido em 1968. Apesar da grande resistência gerada pela atuação dos técnicos norte-americanos, estes imprimiram ao ensino superior brasileiro uma concepção mais utilitarista de ciência, com preocupações mais mercadológicas, em contraste com a herança mais humanista, traço marcante na concepção europeia de universidade. No entanto, a presença norte-americana na USP é bem anterior, tendo começado em 1915, numa parceria que durou trinta anos entre a Faculdade de Medicina e Cirurgia, que veio a ser integrada em 1934 à USP, e a Fundação Rockfeller, que configurou importantes aspectos da filantropia científica norte-americana no Brasil (Marinho, 2001). Ao que parece, a USP quis a parceria europeia, sobretudo francesa, enquanto a presença norte-americana aconteceu, porque estava alinhada aos interesses e estratégias das políticas de filantropia ianque:

(...) a presença francesa na USP advinha de convites formalizados pelos dirigentes acadêmicos das instituições brasileiras, ao passo que a Fundação Rockefeller instalava-se nos diferentes países em que atuou em decorrência de decisões estratégicas tomadas por seus administradores, o que coloca uma importante questão sobre o controle destas trocas. [grifo da autora] (Marinho, 2001, p. 48-49).

A agenda desta vertente filantrópica e científica focalizou num primeiro momento as áreas 
da saúde pública e ensino médico. A Faculdade de Medicina e Cirurgia de São Paulo reunia as condições necessárias para se tornar uma "Rockefeller's School” (Marinho, Op. cit, p.63). Durante as articulações acadêmicas, membros da fundação visitavam o Brasil para conhecer e produzir relatórios sobre diversos aspectos da realidade brasileira. O médico Arnaldo Vieira de Carvalho, que como vimos foi o primeiro diretor da Faculdade de Medicina e Cirurgia de São Paulo e o presidente da Sociedade Eugênica de São Paulo, foi o nome escolhido pela Fundação para estabelecer as negociações. O tom das observações da Fundação sobre a composição racial do Brasil pode ser vislumbrado recorrendo-se a trechos que Marinho (2005) traz de um dos documentos elaborados, datado de 25 de outubro de 1920, no qual o país era descrito da seguinte maneira:

\begin{abstract}
Presentemente a população se compõe de negros incapazes, brancos parasitas de origem portuguesa e uma grande porcentagem de seus descendentes híbridos, com traços aqui e ali de características indígenas. (...) O Brasil Sul, começando no Estado de São Paulo, foi colonizado por portugueses destemidos e autoconfiantes que desde o começo cruzaram com índios nativos, desenvolveram uma estirpe brasileira resistente, estabeleceram-se nas estreitas margens costeiras de Santos e logo passaram a explorar e conquistar o interior. Esta população tem sido revigorada por uma onda de imigrantes europeus que continua a trazer para os estados sulistas tipos vigorosos de colonos - italianos, alemães, austríacos e poloneses. Os japoneses também estão chegando em grande número. Tais imigrantes fincam raízes no solo e tendem, na segunda geração, a tornar-se uma raça de brasileiros fortes e brancos. (...) Tais Estados do Sul, tendo a vantagem de um clima mais frio e mais variável e uma população muito mais viril, têm sob sua conta o futuro do Brasil. É o homem branco autoconfiante que está expandindo a fronteira e deitando as fundações de uma civilização mais progressista. O Estado de São Paulo é o centro e a alma deste movimento, com Rio Grande do Sul prometendo se tornar um importante segundo lugar. A esperança do Norte reside na liderança do Sul e no sangue destes Estados e da Europa. (...) Os brasileiros são um povo latino, de origem portuguesa, e há gerações vêm sendo ardentes imitadores dos franceses ${ }^{4}$. (...) (Rose, 1920 apud Marinho, 2005, p. 65).
\end{abstract}

A discussão racial apresentada no documento da Fundação Rockefeller é também contemporânea a outras travadas no país, que embora não dispusesse de um ensino superior estabelecido sob o regime de universidade, possuía intelectuais que perseguiam o rigor metodológico e acadêmico na tentativa de construção de teorias científicas que ajudassem a entender e orientar o Brasil como um projeto de nação, ainda que muitas dessas teorias tivessem o caráter de "sociologias de encomenda" (Ventura, 1991, p. 62).

Trazendo essas discussões para o campo do Direito, ao analisar as faculdades de Recife e São Paulo, Schwarcz (1993) indica que a última posicionou-se a favor de um Estado centralizador durante a República Velha, combinando liberalismo elitista e evolucionismo, tendo sido ainda grande provedora dos quadros políticos e burocratas do Estado. Apesar de criticarem o modelo "germânico e racial de Recife" (Schwarcz, 1993, p.180) e de aparentemente não se ocuparem da

\footnotetext{
4Interessante destacar neste texto como se opera de modo flagrante a associação das características desejáveis brancura, autoconfiança, capacidade, conquista, vigor, força - com a virilidade, revelando não apenas aspectos eurocêntricos, como também androcêntricos das concepções de ciência que subjaz a história de nossas instituições acadêmicas.
} 
mestiçagem tal qual os colegas pernambucanos, durante as discussões realizadas pela Sociedade Central de Imigração, São Paulo, que se proclamava "a mais avançada das províncias", posicionouse radicalmente contra a vinda de mão de obra asiática e africana, em nome de "um projeto liberal e modernizante". A justificativa para a restrição a esses grupos foi tomada de empréstimo dos “modelos eugenistas de intervenção" (Schwarcz, 1993, p.185) defendidos em Recife.

A escola de São Paulo oferecia um "liberalismo de fachada" (Schwarcz, 1993, p.186) para posicionamentos de "cunho oficial" acionando de pronto discursos raciais, sempre que fosse necessário "defender hierarquias" e "explicar desigualdades" (Ibidem). Apesar disso, nas publicações da Faculdade não é possível “encontrar os ataques mais rasteiros às populações asiáticas e africanas, ou a reprodução fiel dos debates travados em outros fóruns. Nesse espaço figura apenas a teoria que ilumina o intelectual” (p.186). “distante das paixões e das intempéries do mundo de fora" (RFDSP 5 , 1922, p. 103, apud Schwarcz, 1993, p. 186). Portanto, a Faculdade de Direito de São Paulo posicionou-se a favor de um Estado centralizador durante a República Velha, combinando liberalismo elitista e evolucionismo. Desse modo, o modelo paulista de liberalismo era elitista, conservador e anti-popular, perfeitamente conciliável com a escravidão e o latifúndio durante o império, e com a hipertrofia estatal e o autoritarismo republicano. O liberalismo revela claramente seu lado antidemocrático no Brasil. Apesar disso, São Paulo, advogava um estado liberal harmonioso, acima das diferenças sociais e raciais. (Schwarcz, 1993, p.181).

Importante considerar ainda que em São Paulo a política de imigração foi um tema complementar à política da abolição, promovendo debates com participação efetiva da Academia de Direito de São Paulo. A imigração aparecera como tema em meados do século XIX como alternativa ao trabalho escravo. Um exemplo de experiência com o intuito de substituir mão de obra cativa pela imigrante foi a da fazenda de Ibicaba na região de Rio Claro, proposta em 1840 por Nicolau de Campos Vergueiro, que além de ser senador do Império, dirigiu a Academia de Direito de São Paulo entre os anos de 1837 a 1842. A fazenda foi um sistema de parceria com imigrantes suíços e embora não tenha tido sucesso, "a ideia de imigração continuou forte no imaginário dos fazendeiros e intelectuais" (Motoyama, 2006, p. 80). Houve também conciliações entre o interesse econômico e os de cunho racial, sobretudo a ideologia do branqueamento, tornando a imigração europeia uma política de destaque desde a segunda metade do século XIX. A Faculdade de Direito proveu importantes figuras desse processo, tais como Aureliano Cândido Tavares, abolicionista e adepto do branqueamento, que além de diversas publicações, fundou o Vale do Amazonas, Sociedade Internacional de Imigração, que obteve grande repercussão e adesão (Motoyama, 2006).

O avanço da imigração continuava a envolver egressos da Faculdade tais como José Maria 
da Silva Paranhos Júnior, mais conhecido como Barão de Rio Branco, que promulgou a Lei do Ventre Livre em 1871. O Barão cursou os quatro primeiros anos do curso de Direito em São Paulo e concluiu o último ano da sua formação em Recife. Outros egressos da Academia também figuram como nomes importantes no avanço das políticas de imigração, como Martinho Prado Júnior, que presidiu a Sociedade Promotora de Imigração fundada em 1886 e Francisco de Paula Rodrigues Alves, que tornou possível a imigração japonesa, conforme indica Motoyma (2006):

Todavia, esse processo só começa realmente a acelerar-se com o governo (1886-1887) de Antônio Queiroz Teles, Visconde de Parnaíba, em São Paulo. Entusiasta da nova forma de recrutar trabalhadores, o Visconde construiu a Hospedaria de Imigrantes, em São Paulo, com dormitórios, refeitórios e enfermaria. Aumentou a subvenção provincial de São Paulo destinada a essa finalidade para 3.203:000\$000, em 1887, quantia quase 70 vezes maior comparada a de 1881. Ao mesmo tempo ajudou a formar uma Sociedade Promotora de Imigração (1886), que teve como primeiro presidente um bacharel das Arcadas, Martinho Prado Júnior. Talvez fosse bom assinalar o curioso papel de outro ilustre personagem originário da Academia, Francisco de Paula Rodrigues Alves, então presidente da província de São Paulo, abrindo a possibilidade (1900) da entrada de imigrantes japoneses, que vinha obstada, sobretudo, por adeptos do branqueamento. (Motoyama, 2006, p. 81)[Grifos meus].

Importa lembrar que a efetivação do processo de imigração europeia no início do século foi favorecida pelas políticas sanitaristas que justificaram a criação da Faculdade de Medicina em São Paulo, nos termos da parceria financeira com a Fundação Rockefeller:

A falta de condições sanitárias adequadas constituía uma ameaça efetiva ao fluxo migratório, necessário para substituir a mão-de-obra da escravidão recém-abolida, Entre os anos de 1890 e 1899, cerca de 120 mil imigrantes chegaram ao Brasil anualmente. Entre 1900 e 1904 esse índice baixou para 50 mil. Além de comprometer a imigração, a precariedade sanitária colocava internamente em risco as estruturas de produção do café principal produto de exportação do país no período - devido a um número crescente de óbitos. (Marinho, 2001, p. 51)

Tais políticas pensadas na virada e começo do século passado no âmbito da Faculdade de Direito num primeiro momento, e posteriormente também na Faculdade de Medicina, fortaleceram a construção do racismo científico, exemplificado pela defesa da imigração branca e por conseguinte, da eugenia ${ }^{6}$. No entanto, percebe-se também um movimento de defesa de novas ideias, o que fica mais evidente sobretudo ao longo dos anos 1930, com notável tendência de

6Conforme já dito nesse trabalho, a USP é fundada em 1934 congregando escolas já existentes no estado de São Paulo e dentre elas a Escola Politécnica (1893); Escola Livre de Farmácia de São Paulo (1898); Escola Agrícola Prática de Piracicaba - atual Escola Superior de Agricultura "Luiz de Queiroz"(ESALQ) - (1901); Faculdade de Medicina (1912); Fundação do Laboratório de Higiene de São Paulo - que daria origem à atual Faculdade de Saúde Pública (1918); Instituto de Veterinária - atual Faculdade de Medicina Veterinária e Zootecnia - (1919). Embora esta pesquisa não tenha investigado a importância das teorias eugenistas nestas outras escolas, vale registrar aqui que a ESALQ também esteve comprometida com esse debate, numa perspectiva diferente da Faculdade de Medicina. Conforme indica Stepan (1985), enquanto Renato Ferraz Kehl, professor da Faculdade de Medicina e fundador da Sociedade Eugênica de São Paulo condenava a mistura de raças porque ameaçaria o futuro da humanidade; o professor Octávio Domingues da ESALQ foi um importante nome na defesa da miscigenação, por acreditar que favoreceria o melhoramento genético e, por conseguinte, o desaparecimento da população negra. 
apostar em soluções para o país, agregando novas teorias. A eugenia apresenta outras nuances e passa a ser defendida não apenas como regeneração da raça, mas também de valorização do homem pela cultura. Além de um estado liberal, há ainda a defesa da democracia, entendida como resultado da evolução humana, restando, porém, a noção de desigualdade entre as raças. Assim, ao longo da década de 1930 não é possível desconsiderar que concomitante a ideologias preocupadas com a catástrofe racial brasileira, já havia a defesa neste momento, de um Brasil mais aberto à mestiçagem, propondo outras interpretações para os problemas raciais brasileiros. Conforme indica Dantas (2008), a preocupação com a ideia de nação motivava o mergulho de intelectuais no que seriam as ditas coisas brasileiras.

Num contexto de diversificação do debate racial, a Universidade de São Paulo na ocasião de sua fundação, já estava comprometida com tradicionais e novas interpretações para a questão racial brasileira, o que acabou reverberando na "missão bandeirante". Antes, porém de analisar qual seria essa vocação, é interessante trazer um panorama sobre as novas interpretações raciais em emergência. A mestiçagem como síntese das três raças na definição da cultura nacional foi sucessivamente ocupando o espaço do racismo científico. Se como dito anteriormente, o debate racial esteve preocupado com a degeneração causada pela mestiçagem, a cena seguinte indica significativas transformações no debate. Nesse sentido, a novidade da ideia de um Brasil mestiço sintetizada por Gilberto Freyre tem história anterior às suas formulações. ${ }^{7}$ As teses freyrianas traduziram significativos reajustes interpretativos. A miscigenação passa a equalizar culturalmente as raças e suprimir antagonismos, tornando mais promissor o futuro da nação. O Brasil torna-se peculiar no seu desenvolvimento pacífico. A produção de riquezas no país passa a ser entendida como resultado da participação equânime das três raças. (Ventura, 1991).

Boa parte das análises das relações raciais no Brasil tem se dedicado a compreender o impacto causado pela chamada teoria da democracia racial, um desdobramento da obra de Gilberto Freyre. Uma crítica importante ao legado freyriano é proposta por DaMatta (1990) e consiste na análise da chamada fábula das três raças, que constitui uma poderosa força ideológica no Brasil e que tem no mito da democracia racial as bases de um projeto político e social para o país. A suposta democracia de uma triangulação étnica se tornou uma arma poderosa na autoimagem do país em todas as suas instituições, uma vez que:

(...) tornou-se uma ideologia dominante, abrangente, capaz de permear a visão do povo, dos intelectuais, dos políticos e dos acadêmicos de esquerda e de direita, uns e outros gritando pela mestiçagem e se utilizando do branco, do negro e do índio como unidades

7Para Azevedo (1996) é no abolicionismo transatlântico que se encontra o delineamento do discurso do Brasil como paraíso tropical, e que "o mito da democracia racial brasileira tem raízes tão longínquas quanto as lutas dos abolicionistas contra a escravidão e contra o racismo" (Azevedo, 1996, p.159). 
básicas através das quais se realiza a exploração ou redenção das massas. (DaMatta, 1990, p. 63).

A solução na "forma da fábula das três raças cunha um racismo à brasileira, uma ideologia capaz de conciliar uma série de impulsos contraditórios" (DaMatta, 1990, p.68). O racismo à brasileira contou com a justificativa católica para a colonização portuguesa no seu processo de exploração de negros e índios. À explicação de Gilberto Freyre sobre uma suposta disposição portuguesa à mestiçagem, DaMatta contrapõe ressaltando que um traço distintivo de Portugal seria a importância histórica das ideias de hierarquias nas quais tudo e todos têm lugar social específico. Assim, se numa sociedade fortemente hierarquizada, como a brasileira, há possibilidade de brancos, negros e índios interagirem, não é porque a colonização portuguesa tenha sido mais humanitária, mas porque negros e índios ocupavam lugares específicos na sociedade hierarquizada, com o mestiço ocupando espaços intermediários, de modo que as gradações e nuances tornam-se pontos chave. Desse modo, o triângulo em que cada vértice é ocupado por um grupo racial permite novas triangulações que indicam conciliações e sincretismos das posições polares nas quais o mestiço funciona como "válvula de escape" (Degler, 1976 apud DaMatta, 1990, p. 83).

O debate sobre democracia racial ofereceu ingredientes para a noção de "missão bandeirante" da Universidade de São Paulo e informou os posicionamentos do grupo de políticos, intelectuais e empresários culturais que também foram os mentores da universidade. Este conjunto de pensadores se autonominava A Comunhão Paulista Ilustrada e era representado por figuras como Armando Salles de Oliveira, Júlio de Mesquita Filho e Fernando de Azevedo. Mais adiante este trabalho traz considerações sobre o grupo com mais vagar, porém antes disso, é interessante compreender como a ideia de democracia racial é entendida e apresenta singularidades no Estado de São Paulo.

Ampliando a compreensão histórica da concepção de democracia racial, um aspecto fundamental foi o chamado Movimento Bandeira, apoiado por Armando de Salles Oliveira, com participação ativa de Cassiano Ricardo, que sistematizou o avanço do movimento bandeirante de São Paulo para todo o Brasil, entre os anos 1935 a 1940 na obra Marcha para o Oeste. Nesta obra Cassiano Ricardo defende uma "democracia tipicamente brasileira" cujo argumento fundamental era a necessidade de harmonia racial (Campos, 2006, p.144). Cassiano Ricardo teria apontado São Paulo como eixo da construção de uma nacionalidade original para o Brasil, exaltando a missão bandeirante, na qual os três grupos raciais teriam colaborado "hierarquicamente dispostos pela função que cada cor adquiriu na organização de cada grupo" (Ricardo, 1937, p.97; apud Campos, 2006, p.145). Assim, no pensamento de Cassiano Ricardo, a reunião das três raças na bandeira 
aconteceu de forma hierárquica, com aproveitamento de todos os elementos, mesmo os inferiores, sem utopias igualitárias, de modo que democracia significa também hierarquia. A hierarquização não seria impedimento para a mobilidade social, pois com a mestiçagem, uma raça se fundia à outra e uma classe passava à outra. A Bandeira teria cumprido a função de mediadora contra manifestações que ameaçassem a unidade nacional. Dessa forma, ao combater os quistos étnicos (como o quisto negro dos Palmares e o quisto vermelho do Recôncavo), a bandeira teria sido um agente integrador. (Campos, 2006, p.149)

As considerações sobre a fábula das três raças e a vocação bandeirante do estado de São Paulo indicam interpretações do passado brasileiro ancoradas em possíveis qualidades do colonizador português. Duas dessas grandes interpretações seriam: 1) a que ressalta o "espírito aventureiro" do português, uma "ética da aventura" oposta à "ética do trabalho" presente em Sérgio Buarque de Holanda e 2) o "patriarcalismo polígamo" proposto por Gilberto Freyre. (Bosi, 1992, p.27). Assim:

\begin{abstract}
Os vários modos da chamada assimilação luso-africana e luso-tupi adquirem, vistos por essa ótica, um relevo tal que acabam deixando em discreto ou subentendido segundo plano os aspectos estruturais e constantes de assenhoreamento e violência que marcaram a história da colonização tanto no Nordeste dos engenhos e quilombos quanto no Sul das bandeiras e missões. (Bosi, 1992, p.27)
\end{abstract}

Interpretações como a de Buarque e Freyre abrem espaços para certa idealização do vencedor, como "uma sutil sublimação do bandeirantismo" no pensamento de Buarque, que "relativiza o contexto de agressão e defesa que definiu objetivamente as incursões dos paulistas" (Bosi, 1992, p.29). Próximo de questões referentes ao projeto intelectual paulista, Buarque também teria endossado a "apologia que Júlio de Mesquita faz da colonização portuguesa" (Ibidem). Júlio de Mesquita, um dos intelectuais do grupo "A Comunhão Paulista Ilustrada", também não estava sozinho numa literatura ufanista sobre São Paulo. Esse era o tom que matizava a historiografia ${ }^{8}$ do estado nos anos 20, 30 e 40 do século XX, empenhada na construção de um passado glorioso de São Paulo e da saga bandeirante. Para Souza (2000) há, de um lado, uma vasta historiografia que tem creditado ao movimento bandeirante a conquista e expansão de fronteiras políticas e econômicas da nação e, reversamente, há outra que denuncia a devastação de povos indígenas e negros. A autora apresenta a chamada "Lenda Negra" da história paulista como decorrente de uma historiografia

8Schwarcz (1993) analisando os institutos históricos e geográficos, aponta-os como "guardiões da história oficial" (Schwarcz , 1993, p.99). Criados após a independência política, tinham a tarefa de "construir uma história da nação, recriar um passado, solidificar mitos de fundação, ordenar fatos buscando homogeneidades em personagens e eventos até então dispersos." (Schwarcz, 1993, p.99). Esse passado recriado era marcado pelo perfil dos principais grupos econômicos e políticos na capital e nas demais regiões do país. O Instituto Historico e Geographico de São Paulo foi criado no ano de 1894 com duas intenções distintas: seguir o modelo do IHGB [Instituto Geographico Brasileiro, localizado no Rio de Janeiro] e delimitar uma especificidade regional. Desse amálgama resultou a máxima "a história de São Paulo é a própria história do Brasil” (Schwarcz, 199, p.125). 
elaborada por padres jesuítas nos séculos XVI e XVII na qual bandeirantes figuram como cruéis assassinos de índios e negros em oposição a uma outra, chamada "Lenda Áurea", elaborada por descendentes de conquistadores. Nesta segunda versão, os bandeirantes aparecem como aqueles que efetivaram a obra colonizadora e integraram as populações indígenas ao povo brasileiro.

Schwarcz (1993) também indica que a figura do bandeirante é valorizada e popularizada numa imagem mitológica de garra e busca de aventuras e oportunidades. Desse modo, o bandeirante, destemido desbravador do sertão, é eleito como marca original que podia assegurar a competição dos paulistas com a capital federal. O bandeirante personificaria também o tipo local que respaldava a defesa do branqueamento racial. Por sua vez, Bosi (1992) visualiza duas retóricas que correram em paralelo, mas que por vezes se tangenciaram: a primeira que serviu ao sistema agro mercantil por meio dos seus porta-vozes intelectuais, com uma escrita firmemente amarrada à máquina econômica. A segunda, chamada "retórica humanista-cristã", teve a função de aproximar cultura e culto, utopia e tradição (Bosi, 1992, p.37). Embora critique o fascínio dos ufanistas paulistas, Souza (2000) considera importante delimitar as especificidades regionais das escritas jactanciosas. No caso de São Paulo, considera que:

O regionalismo ufanista foi a resposta ideológica à generalização das detrações ou, quando muito, às ambiguidades. Como boa ideologia, desbastou as contradições inerentes ao papel histórico dos paulistas e sublinhou isolando as virtudes que, até então, nunca haviam se mostrado em separado dos vícios. (Souza, 2000, p.275)

Estes aspectos da vida nacional e do estado de São Paulo conciliam-se com a história da Universidade de São Paulo. Nota-se um indisfarçável ufanismo, por exemplo, na escrita da primeira historiografia da Universidade de São Paulo feita por Souza Campos em 1954 e nos posicionamentos de Júlio Mesquita, importante intelectual dos primórdios da USP. Estes são dois exemplos da tendência que se verificava de endossar um projeto de universidade que efetuasse a expansão das fronteiras acadêmicas do país, no qual a Universidade de São Paulo é apontada como a única capaz de levar adiante a vocação bandeirante do estado para o campo da investigação científica, os altos estudos e a cultura livre e desinteressada. Neste sentido, a missão da universidade bandeirante indicada no projeto de criação da USP era, além de assegurar a formação das elites dirigentes,

(...) criar, especialmente através da Faculdade de Filosofia, a "mística nacional" a ser irradiada para todo o país; e de se constituir em "luz inconfundível", "guia para os brasileiros", "ponto de partida para onde eles se voltarão esperançados e consolados, nas vicissitudes de nossa pátria". (Cardoso, 1982, p. 177)

Analisando os cinquenta anos de história da USP, Witter (2006) reforça a tese de que a criação da universidade era deliberadamente um projeto político cultural para São Paulo e para o 
país, com intenções de renovar a vocação bandeirante do estado, que teria na universidade nova via de avanço para o progresso. Nas palavras de Júlio de Mesquita Filho:

\begin{abstract}
Vencidos pelas armas, sabíamos que só pela ciência e pela perseverança no esforço voltaríamos a exercer a hegemonia que durante longas décadas desfrutáramos no seio da Federação. Paulistas até a medula, herdáramos de nossa ascendência bandeirante o gosto pelos planos arrojados e a paciência necessária à execução dos grandes empreendimentos. Ora, que maior monumento poderíamos erguer aos que haviam consentido no sacrifício supremo para preservar contra o vandalismo que acabava de aviltar a obra de nossos maiores, das bandeiras à independência e da Regência à República, do que a Universidade? (Mesquita Filho, apud Witter, 2006, p. 25).
\end{abstract}

Interessa aqui retomar que embora o decreto de fundação da Universidade de São Paulo date de 1934, houve um longo antecedente. O século XIX marca a história do ensino superior em São Paulo, posteriormente da USP e conhece uma profusão de teorias raciais defendidas por homens de ciência, preocupados em aplainar os terrenos para melhor erguer o futuro do país. A mais flagrante ameaça era o enorme contingente de negros, que maculava o corpo da nação. Neste sentido a Faculdade de Direito e a Faculdade de Medicina em São Paulo também ofereceram seus préstimos na busca por soluções. Serra \& Scarcelli (2014) indicam como pouco antes da fundação da USP o ensino superior de São Paulo esteve comprometido em assegurar o puro sangue bandeirante. As autoras analisam o legado de Antonio Carlos Pacheco e Silva, que teve grande trânsito no ensino superior paulista, pois acumulou as funções de médico e professor da Faculdade de Medicina de São Paulo, tendo lecionado também na Faculdade de Direito de São Paulo e na Escola de Sociologia de São Paulo. Importante sucessor do professor Renato Ferraz Kehl, Pacheco e Silva figura como personagem que bem articulou os conceitos de eugenia e vocação bandeirante do estado de São Paulo:

Para Pacheco e Silva, havia um projeto de nação que se pautava no enaltecimento da linhagem genética e que poderia ter como alvo a ossada de um bandeirante. Em seus pressupostos, os paulistas deveriam se vangloriar de estar à frente do país, com um padrão de "raça" mais elevado. (Serra \& Scarcelli, 2014, p. 90)

Esta discussão foi muito pertinente à concepção da USP, de modo que os debates sobre raça, ciência e nação atravessam a história da universidade de São Paulo e imprimiram sua marca na missão dessa universidade bandeirante. 


\section{I-2. Uma nota de rodapé estendida: o desafio de pensar o triângulo racial na USP para além da alegoria.}

A missão bandeirante da USP se metamorfoseia em outros debates, tais como aqueles que exaltam a sólida tradição da universidade que a define como protagonista da produção acadêmica nacional. Certamente tal interpretação não se fundamenta apenas em um sentimento ufanista, mas se apoia no orçamento de que a universidade dispõe, em dados estatísticos referentes à produção acadêmica nacional, e nos rankings internacionais que posicionam a USP como a mais relevante universidade brasileira. Fomentar no cotidiano da vida acadêmica essa missão requer diversas abordagens. Para ilustrar essa discussão, abre-se aqui um parêntese para uma pequena "licença etnográfica". Na vida acadêmica a divulgação é um elemento fundamental, seja na forma de periódicos, artigos, livros, teses, dissertações, pôsteres, editais, portarias, ofícios, boletins, anuários, enfim, cartazes de eventos como congressos, seminários, simpósios, colóquios, debates, palestras, minicursos e inclusive festas. Em 2011 foi divulgado na universidade o banner de uma festa reproduzido a seguir:

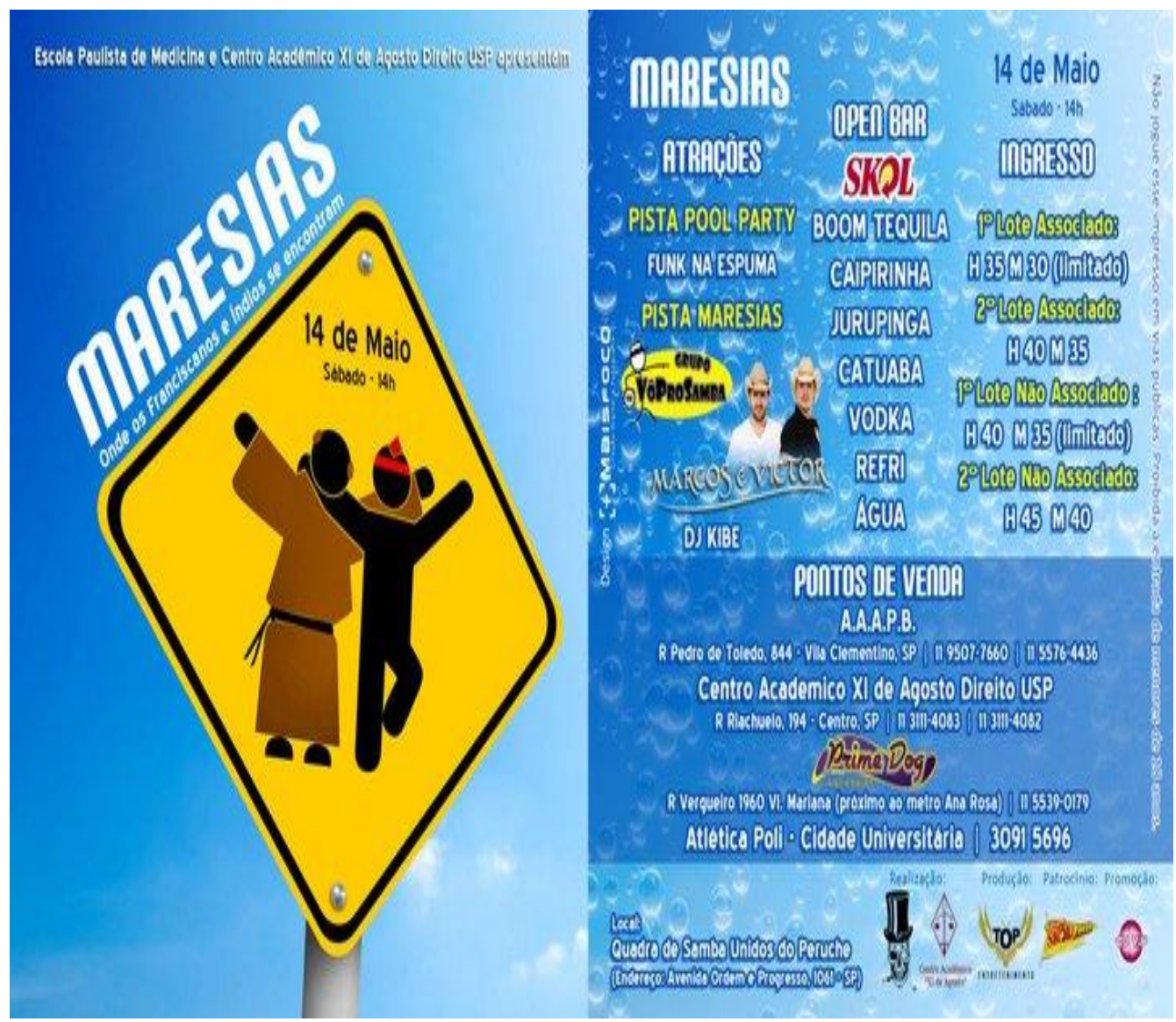

Este panfleto foi material de propaganda da festa "Cervejada Maresias" divulgada 
também no Facebook. O banner traz os dizeres "Escola Paulista de Medicina e Centro Acadêmico XI de Agosto da USP apresentam: MARESIAS Onde os Franciscanos e Índios Se Encontram". A Escola Paulista de Medicina integra a Universidade Federal do Estado de São Paulo (UNIFESP), portanto não é a Faculdade de Medicina da USP (FMUSP)9. O banner traz algumas referências à Faculdade de Direito da USP, seja através do Centro Acadêmico XI de Agosto, a associação dos estudantes da Faculdade de Direito da USP, fundada no dia 11 de agosto de 1903, no aniversário de setenta e seis anos das Arcadas; seja na figura do franciscano, já que a faculdade tem o cognome Largo de São Francisco, onde está localizada. Já as referências à Faculdade de Medicina e Cirurgia da USP não são evidentes, mas são possíveis. Em vários momentos da obra de Ernesto de Souza Campos escrita em 1954 para comemoração dos vintes anos da USP, o conjunto de obras e edifícios do complexo médico que integra a Faculdade de Medicina da USP era designado como "Campus Médico do Araçá" (p.152), "Centro Médico do Araçá" (p. 405), "Faculdade de Medicina, no planalto do Araçá"10 (p.117), etc. O cognome da Faculdade de Medicina e Cirurgia da USP tem origem num vocábulo indígena, trazendo um pouco de sentido para a figura do índio no banner da festa. Mas talvez o abraço do franciscano e do índio remeta apenas à relação que se construiu historicamente entre jesuítas e indígenas, tão fundamental na memória de São Paulo desde o marco zero da cidade no Pátio do Colégio. Enfim...

Conforme considerado anteriormente, os intelectuais que escreveram o projeto de fundação da USP visavam à expansão das fronteiras acadêmicas do país e indicavam a Universidade de São Paulo como a única capaz de levar adiante a vocação bandeirante do estado para o campo da investigação científica, os altos estudos e a cultura livre e desinteressada. $\mathrm{O}$ propósito inicial parece ter se efetivado. Para comemorar os setenta anos da universidade, a obra organizada por Motoyama (2006) trouxe dados que indicavam o sucesso das concepções iniciais, que mantém a USP na liderança em vários campos acadêmicos desde a sua fundação. Uma possibilidade de explicação para essa conquista foi dada por Setúbal ${ }^{11}$ no prefácio da obra:

Pode-se chorar por aqueles que foram massacrados pelo avanço da tecnologia. Mas isso jamais detém o progresso nem, muito menos, altera seu resultado final (...). O conhecido

9Mas conforme página eletrônica da UNIFESP, dentre os fatores que deram origem à criação da escola de medicina em 1933, está o elevado número de alunos excedentes que não entraram no curso da Faculdade de Medicina e Cirurgia, integrada à USP em 1934. Um professor de nome Octávio de Carvalho convidou os alunos excedentes a comporem o corpo discente de uma nova faculdade, que veio então a ser a Escola Paulista de Medicina, cuja história fica de algum modo associada à da Faculdade de Medicina e Cirurgia da USP.

10 O site da prefeitura de um município do interior de São Paulo chamado "Araçatuba" indica na seção "História", que o nome "Araçatuba" "provém do vocábulo indígena que significa: "terra do Araçá", espécie de fruto abundante na região. Pesquisando sobre o significado da palavra "Araçá", no dicionário de guarani - espanhol, tem-se que 'Arasa' significa "guayabo, guayaba, árbol frutal”. Diccionario Guaraní - Espanhol e Espanhol - Guaraní. Natalia Krivoshein de Canese e Feliciano Acosta Alcatraz. Colecion Nemitỹ. Instituto Superior de Línguas. Universidade Nacional de Asunción. Paraguay, 1997.

11Olavo Egydio Setúbal foi aluno do curso da Politécnica da USP e criador do Grupo Financeiro Itaú (Motoyama, 2006, p.19) 
processo de "destruição criadora" é uma das chaves interpretativas, entre tantas outras possíveis, para se avaliar os sucessivos êxitos alcançados pela Universidade de São Paulo e os efeitos modernizadores que provocaram na sociedade brasileira. (Motoyama, 2006, p.13)

Um processo de conquistas dessa monta requer a participação de muitas pessoas em vários tempos. Assim, parece razoável considerar também qual tem sido a participação empírica do triângulo étnico no processo de fortalecimento do ensino superior no Brasil desejado por esta universidade. Nesse sentido, essa pesquisa considera que narrativas raciais, tais como a "fábula das três raças" ou a "ética da aventura" que remonta à força de um passado europeu marcadamente branco e masculino, possuem profundidade histórica e dão liga a uma memória social viscosa que lubrifica de forma (in)consciente muitas engrenagens da vida acadêmica. As fábulas podem ser consistentes a ponto de impermeabilizarem as tentativas de mostrar a distância significativa entre a presença empírica dos três elementos raciais e seu uso como recursos apenas ideológicos. Dessa forma, parece plausível perguntar como essas fábulas engrossam o curso histórico da USP. De início, pode-se dizer que são escorregadias e ambíguas, às vezes deixando rastros, como no panfleto citado, que cumpre aqui não a função de dado empírico, mas a de metáfora provocativa.

“Onde os franciscanos e índios se encontram”, na USP, é uma boa pergunta a ser feita. A presença simbólica dos três elementos não é difícil de encontrar, mas, onde estariam, no campo efetivo de construção e participação do projeto USP? Souza Campos (1954) trouxe as raízes além e aquém mar da presença portuguesa nesta universidade. Porém, seria possível sustentar que a Faculdade de Medicina, também conhecida como Campus do Araçá, sugeriria a presença (ou o massacre) indígena? Para completar o triângulo racial, seria necessário localizar também a presença negra. Estaria na quadra de samba "Unidos do Peruche", na Avenida Ordem e Progresso, onde aconteceu a referida festa no dia 14 de maio de 2011 (conforme informações do panfleto) e passados 123 anos da abolição no Brasil? Fica a provocação.

A presença simbólica de brancos, negros e índios numa mesma cena tem sido enredo de muitos outros carnavais, num país que se proclama democraticamente mestiço. Schwarcz (1995) analisa como a tradição possibilita certas persistências cujas lógicas devem ser recuperadas. Valendo-se da noção "estrutura da conjuntura" de M. Sahlins ${ }^{12}$, a autora repensa a "antiga fábula das três raças" (p.9), apontada como "curinga para a representação da mestiçagem nacional" (p.9), na qual cada elemento traria contribuições específicas para o "cadinho de raças" (p.5). Em face disso, no caso da Universidade de São Paulo, importa considerar também que:

(...) para além da necessária referência ao contexto e às dimensões políticas (que revelam como a história é o estudo dos processos com os quais se constrói sentido), seria preciso pensar como, desmontados os "mitos de fundação", desconstruídas as categorias culturais - 
cujo significado é correlato à ação, restam valores não redutíveis ao seu significado imediato (Schwarcz,1995, p.11).

Esta nota de cunho etnográfico sugere a necessidade de verificar, para além da presença ideológica, onde de fato estariam os/as negros/as na universidade e nas faculdades de Medicina e Direito. É preciso desde já pontuar que não se trata de uma presença meramente alegórica, foi e é real, apesar de sempre ínfima.

\section{I.3. A presença negra no corpo discente e docente da Faculdade de Medicina da USP}

Esta seção traz considerações sobre o registro de acadêmicos/as negros/as na Faculdade de Medicina, no corpo discente e docente. A proposta é contribuir para visibilizar a presença empírica de negros/as na USP e na FMUSP em particular, considerando que a história da educação da população negra tem sido alvo de um eficiente processo de invisibilização, que felizmente tem sido interpelado por novas historiografias bem representadas em trabalhos como os de Fonseca (2007) e D'Avila (2006), dentre outros, que já se tornaram referências no campo da história da educação do negro. Assim, esta pesquisa está atenta à necessidade de tratar de modo mais atualizado a configuração racial do corpo docente da USP no que diz respeito à área da Saúde, que viveu grande expansão no último século, nos diversos campi da universidade. Por isso traz mais adiante, no último capítulo, dados quantitativos e análises sobre a configuração racial do corpo docente nas diversas unidades e áreas do saber que compõem essa universidade. Neste item, recuperamos informações nem sempre completas, atendendo ao objetivo central de dar visibilidade aos alunos/as e docentes negros/a da USP.

De imediato uma questão: a formação de negros/as na FMUSP pode ser entendida como um processo de democratização do acesso à Faculdade ou decorreria de alguma "super seleção"? Este foi um questionamento proposto por Almeida (2009) que analisou o ingresso e a trajetória escolar de nove alunos negros que passaram pela FMUSP entre os anos de 1935 e 1964. A consulta a documentos aconteceu em duas etapas. A primeira selecionou documentos da primeira turma de formandos em 1918, até a turma de 1970 no acervo da Faculdade de Medicina da Universidade de São Paulo. Nestes documentos constava o histórico da vida escolar anterior à graduação, documentos pessoais dos alunos e fichas de rendimento acadêmico. Os prontuários variavam conforme os anos, mas invariavelmente continham:

(...) certidão de nascimento, ficha de identificação com fotografia, estado civil, profissão, marcas cicatrizes, sinais, cor, estatura, peso, tipo sanguíneo etc.; certificados de conduta moral, de saúde, taxas de matrícula e anuidades e históricos escolares, que informam nome, local e data de nascimento, filiação; curso secundário (onde e quando cursou, notas, 
disciplinas, nome do inspetor federal); curso complementar (onde e quando cursou, exame de admissão, notas, disciplinas); curso superior $\left(1^{\circ}\right.$ ao $6^{\circ}$ ano $)$ - notas, disciplinas, datas, colação de grau, diploma, se defendeu tese de doutoramento. (Almeida, 2009, p. 14).

O critério do autor para a seleção dos sujeitos baseou-se em fotos e documentos escritos, caracterizando como negros o conjunto de pardos, morenos e mulatos. Em função dos limites de informações disponíveis no arquivo, que segundo Almeida (2009) não dispõe de prontuários recentes, estabeleceu-se o ano de 1970 como teto histórico da pesquisa documental neste arquivo. Assim, entre 1918 e 1970 num conjunto de aproximadamente 2.500 fichas de alunos, foram selecionados 11 sujeitos.

A segunda etapa de pesquisa documental aconteceu no arquivo permanente do Campus Pacaembu, onde estão os prontuários completos com diversas fontes relativas aos alunos e instituição. Assim o autor encontrou um conjunto de fichas de identificação dos alunos elaboradas pelo Instituto Oscar Freire, que é o Departamento de Medicina Legal da FMUSP. Considerando os sujeitos que interessavam a aquela pesquisa, nas fichas elaboradas pelo Instituto a classificação racial utilizada era "pardo" enquanto as classificações "moreno" e "mulato" constavam apenas nas certidões de nascimento anexadas aos prontuários. Assim, o autor preferiu adotar a classificação racial realizada pelo Instituto Oscar Freire, delimitando o universo de sua pesquisa a nove sujeitos, oito homens e uma mulher, cujos registros estão situados, vale ressaltar, entre os anos de 1935 e 1964. Desse modo o autor optou por não trabalhar com os dois sujeitos registrados em documentos pessoais como "moreno" em função da ambivalência dessa categoria. A partir das informações referentes a local de nascimento, nomes e sobrenomes, para esse período o autor constatou um número expressivo de estrangeiros, como italianos, judeus, espanhóis, japoneses e venezuelanos, com predominância de italianos. Essa constatação vai ao encontro dos trabalhos de Miceli (2001), que analisou os condicionantes do desenvolvimento das Ciências Sociais no Brasil, e de Limongi (2001), que investigou quais seriam os mentores e as clientelas da USP. Os achados desses autores serão considerados mais detidamente no segundo capítulo dessa pesquisa.

Considerando os trabalhos de Biesiegel (1984) e Sposito (1992), que apontavam um processo de expansão e mudanças no sistema escolar de São Paulo entre os anos 1930 e 1960, Almeida (2009) levantou a hipótese de que os nove alunos negros da FMUSP, sujeitos da sua pesquisa, haviam sido contemplados pelo processo político na educação paulista de ampliação de vagas, Mas analisando a trajetória escolar anterior à FMUSP, Almeida (2009) constatou que os nove alunos estudaram em escolas particulares de grande prestígio, concluindo que:

A hipótese da ascensão escolar desses alunos ligada aos processos de ampliação das vagas nos níveis secundários, no chamado "processo de democratização das oportunidades de acesso" mostrou-se insatisfatória, tendo em vista o fato dos nove alunos negros serem 
oriundos de colégios tradicionais e altamente seletivos, o que demonstra que para acessar a FMUSP o capital cultural exigido incompatibilizava o acesso de um aluno qualquer e que as instituições que foram para as classes populares, mantendo em maior número o conjunto dos negros, não obtiveram êxito em criar "oportunidades de acesso" a esse grupo racial às instituições de nível superior. Dessa forma, o único trajeto possível aos negros que objetivavam formarem-se médicos pela FMUSP era o mesmo cuja elite social "naturalmente" percorria, ou seja, estudar no Rio Branco, no Franklin Roosevelt, no Arquidiocesano, no Colégio Universitário ou no que demandava em termos de arbitrário cultural a FMUSP. (Almeida, 2009, p. 69)

No que diz respeito à vida acadêmica desses sujeitos após a graduação, o autor destaca a trajetória de apenas uma mulher do universo da sua pesquisa, que mostrou ser "o único caso comprovado nessa pesquisa de sucesso profissional da carreira". (Almeida, 2009, p. 70). Consultando dados do Conselho Regional de Medicina, encontrou indícios de que seis alunos da amostra haviam falecido, dois remanescentes não foram localizados, encontrando sólidas informações apenas a respeito da carreira da aluna negra, que se fez conhecida junto à Frente Negra Brasileira, entidade pioneira na organização do movimento negro brasileiro no século XX, conforme o relato do seu fundador, José Correia Leite:

\footnotetext{
Chegando a casa de uma família negra, eu vi uma coisa que há muito tempo não via nas famílias de classe média: um sarau musical muito bonito, onde se cantou modinhas brasileiras (...) Naquela visita, depois eu vim saber que estávamos na casa dos pais da moça que se tornou depois conhecida, a Dra. Iracema de Almeida (...) Na época a jovem Iracema era estudante do primeiro ano de medicina, coisa muito importante naqueles tempos (Correia Leite \& Cuti, 1992, pp. 150/151 apud Almeida, 2009, p. 58).
}

Por hora, interessa destacar aqui que a Frente Negra Brasileira esteve mobilizada com a educação (escolarizada ou não) da população negra em São Paulo, constituindo uma das principais bandeiras do movimento. No que diz respeito à trajetória da aluna negra, embora Almeida (2009) não traga informações que identifiquem, como nome ou idade dos sujeitos, a aluna em questão tem alguma chance de ser a Iracema de Almeida, citada na fala de José Correia Leite. E Almeida (2009) traz ainda outras informações fundamentais sobre a trajetória escolar da aluna, que passou por colégios tradicionais como a Escola Normal Padre Anchieta, Colégio Franklin Roosevelt e fez a graduação em Medicina. Continuou sua formação, doutorando-se pela FMUSP e ingressou como docente na instituição no Departamento de Psiquiatria, tendo publicado "entre os anos 1970 e 1980 , três obras de importância na área de psicologia, convertendo-se em referência dessa área". (Almeida, 2009, p. 70). O autor tentou entrevistar a docente, que aos 81 anos foi figura presente e destaque entre ex-alunos e ex-professores nas comemorações de aniversário da FMUSP em 2007. Infelizmente a entrevista não foi possível. No próximo tópico buscamos reler a história da Faculdade de Direito da USP considerando a presença empírica de negros/as no seu corpo discente e docente. 


\section{I-4. A presença negra no corpo discente e docente nas arcadas do Largo São Francisco}

Considerando a história da Faculdade de Direito desde o século XIX, foi possível verificar registros de alguns nomes de docentes considerados negros/as. Cruz (2009) compara a trajetória de dois docentes negros da Faculdade de Direito: José Rubino de Oliveira, que lecionou nas Arcadas no século XIX, em pleno período escravocrata e a professora Eunice Aparecida de Jesus Prudente, docente da USP desde 1985. O autor consultou um vasto conjunto de fontes: as obras de dois memorialistas da Academia: Almeida Nogueira e Spencer Vampré, além do Arquivo e prontuários da Faculdade, livros de matrícula, de colação de grau e de registros de diploma, fotos, periódicos que circulavam então, como O Correio Paulistano, O Clube Acadêmico Político e Literário e o Círculo dos Estudantes Catholicos. No caso da professora Eunice Prudente (que também foi entrevistada para esta pesquisa), foram realizadas algumas entrevistas. Há ainda o trabalho de Barbosa (1997) que analisa a trajetória de Antonio Cesarino Júnior, docente negro na Faculdade de Direito e na Faculdade de Economia, Administração e Ciências Contábeis da USP, a FEA, cuja trajetória se localiza entre as do professor José Rubino e da professora Eunice Prudente.

O professor José Rubino de Oliveira nasceu em Sorocaba no dia 24 de agosto de 1837 e faleceu no dia 04 de agosto de 1891. Vindo de família pobre, órfão de pai, foi alfabetizado pelo padrasto. Trabalhou como seleiro e como jockey em Sorocaba. Muda-se para São Paulo e em 1859 matricula-se no Seminário Episcopal, onde adquiriu conhecimentos fundamentais para sua entrada na Academia de Direito. Assim, José Rubino deixa o Seminário em 1863, presta os exames e ingressa no ano seguinte na Academia Jurídica de São Paulo, aos 27 anos de idade. Devido à estreiteza de seus recursos financeiros, durante a sua graduação José Rubino teve que trabalhar dando aulas particulares de matemática, conseguindo colar grau em 1868, aos 31 anos de idade, e na sequência fez a pós-graduação, com a intenção de seguir a carreira docente na Faculdade. (Nogueira, 1908)

Rubino obtém o grau de doutor em 1869, dando início à sua saga de concursos na tentativa de conquistar um lugar na congregação da Academia Jurídica. José Rubino só foi nomeado professor no nono concurso que prestou. Embora tenha sido aprovado na sexta tentativa em 1874, o concurso foi anulado pelo governo. Quando o novo concurso é aberto em 1875, o candidato vencedor, Joaquim Augusto de Camargo havia participado do concurso anterior e fora reprovado, o que parece indicar, que "os candidatos eram selecionados e indicados mais pelo gosto pessoal do governo, do que pela competência demonstrada nos concursos" (Cruz, 2009, p. 48).

Apesar da demora, José Rubino foi nomeado professor substituto em 1879, cinco anos após a aprovação no concurso e somente três anos depois assume a cadeira de Direito 
Administrativo, tornando-se catedrático aos 45 anos. Sua nomeação foi de fato morosa, conforme parecer do memorialista Nogueira (1908) que chegou a comentar que: "Desta vez não se fez demorar o decreto da sua nomeação. E já era tempo, tanto mais que havia elle chegado áquelle ponto com o exclusivo arrimo do seu talento e inquebrantável energia d'alma" (Nogueira, 1908, p. 239, 4a. Série). O memorialista constata elementos importantes para a trajetória docente de José Rubino e chega a tecer elogios sobre sua habilidade de driblar as dificuldades decorrentes da sua origem humilde:

(...) não hesitamos na divulgação dos dados biographicos, porque são até muito honrosos para o nosso illustrado collega, cujo merecimento cresce na directa proporção do numero de degraus que elle teve de galgar para chegar á posição social que occupou. (Nogueira, 1908, p. 235).

Além disso, reconhece em Rubino um grande talento intelectual desde os tempos de graduação: "Na Academia, segundo nos afirmam os seus colegas de anno, foi elle sempre contado entre os mais notáveis estudantes." (Nogueira, 1908, 236). Nas notas biográficas que traz a respeito do corpo discente da Academia de Direito, desde a primeira turma de 1828, Nogueira (1907 1912) ${ }^{13}$ caracterizou com muita frequência os alunos conforme o tipo físico com epítetos tais como "moreno, tez clara, pállido, loiro, tipo germanico, etc". Ao fazer tais descrições, o autor não justificava a classificação racial atribuída. Interessante observar que ao fazer a descrição física de José Rubino, percebe-se certo cuidado ao chamá-lo de pardo: "De côr parda... sim, elle era pardo. Não tocaríamos neste ponto, se não fosse o próprio Rubino o primeiro a chasquear sobre a coisa." (Nogueira, 1908, p. 230). Acrescenta que José Rubino não tinha a intenção de omitir seu pertencimento racial:

Embora pardo disfarçado, não queria elle aproveitar-se desse disfarce; ao contrario, fazia alarde da sua côr. Nella falava todos os dias, a toda a hora, em tom humoristico, tal qual o fazia Luiz Gama, de quem era amigo e de quem, gracejando, se dizia parente. Demais, Rubino e Luiz Gama, como se sabe, costumavam dar o tratamento de primo a todos os homens de côr, e muito principalmente aos que desejavam ser tidos como brancos. E se a pessoas protestava, quanta caustidade engraçada então se ouvia! (Nogueira, 1908, p. 230).

No prefácio do primeiro volume de sua obra, o memorialista Nogueira (1907) indicou que a intenção da coletânea era reunir crônicas sobre a vida acadêmica nas Arcadas, algumas já publicadas no periódico Correio Paulistano e outras inéditas. Não omitiu o desejo de "proporcionar aos leitores momentos de attrahente diversão" salvando do esquecimento “interessantes pormenores desses que a desdenhosa historia omitte do alto dos seus cothurnos", 
mas que não devem passar despercebidos a um cronista solícito, mesmo que para isso seja necessário o uso da caricatura. (Nogueira, 1907, p. I). Igualmente importante seria também o registro de determinadas questões. Sendo assim, por mais escrupulosa que possa ter sido a sua escrita, não estaria a salvo de incorreções, injustiças e embora não estivesse alheio ao descontentamento de alguém, estava ciente do risco e o assumia; considerando que "de sentenças benignas não há quem se lastime de ser victima; e destas já se vai callejando a nossa consciência de examinador". (Nogueira, 1907, p. II).

De fato, observa-se que as crônicas propostas pelo memorialista não se furtaram da anedota e do tom jocoso na consideração das personagens que teciam o cotidiano da vida acadêmica no Largo São Francisco. Assim, os apelidos e as narrativas anedóticas, os "bestialógicos" são recorrentes indiferentemente à cor ou condição social da personalidade considerada. No entanto, conforme destaca Cruz (2009) o registro da presença de alunos negros na Academia Jurídica no século XIX acontece atrelado a uma anedota, a uma caricatura, ao cômico. Assim estão registrados todos os estudantes negros, com exceção de José Rubino de Oliveira, que veio a ser professor da Faculdade. Cruz (2009) identifica a partir de Nogueira (1908) e dos prontuários cinco estudantes negros no século XIX, que são: Avelino Rodrigues Milagres, Octávio Pereira da Cunha, João Thomas de Araújo, José Fernandes Coelho e José Rubino de Oliveira. No século XX, Cruz (2009) destaca nos prontuários quatros alunos/as negros/as: Antonio Cesarino Júnior, José Sebastião Lima dos Santos, Eunice Aparecida de Jesus Prudente e Oscarino Marçal. Vale considerar ainda que no século XX houve também o Chamado "Grupo dos 21", alunos negros contemporâneos à professora Eunice Prudente e que serão considerados mais adiante nesse tópico. Do conjunto desses/as alunos/as negros/as pelo menos três fizeram carreira docente na Faculdade: José Rubino de Oliveira, Antonio Cesarino Junior e Eunice Prudente.

As lacunas e os silêncios nas fontes impossibilitam afirmar conclusivamente o número de docentes negros que passaram pelas Arcadas até meados do século passado. Há também registro de outro professor negro, livre-docente chamado Pinto Pereira, cuja atuação aconteceu nas primeiras décadas do século XX. Não foi possível encontrar maiores dados sobre sua formação e sua atividade docente, porque seu nome apenas foi citado num depoimento do professor Miguel Reale e publicado na obra organizada por Motoyama (2006) por ocasião dos setenta anos da USP.

Miguel Reale, que por duas vezes foi reitor da USP (1949-1950 e 1969-1973), iniciou a formação em Direito em 1930, e tornou-se Professor Catedrático da Faculdade do Largo São Francisco em 1941. Fazendo uso do tom anedótico, conta que durante a sua formação fora aluno do catedrático Braz Arruda, também conhecido como Arrudinha, que em algum momento fora substituído pelo Pereira Pinto, cuja presença na sala de aula foi assim registrada: 
Certa vez um aluno levou à sala um frango, que dava intermitente sinal de incômoda presença, enquanto Arrudinha pregava em prol da paz. Por fim, a ave acabou esvoaçando pela sala, enquanto o professor bradava indignado: "Não dou aula para galináceos. Os senhores jamais me verão nesta cátedra!" E saiu revoltado. Cumpriu a promessa, pois na aula seguinte, era substituído pelo livre-docente Pinto Pereira, mulato espigado e erudito, que era uma espécie de curinga, chamado a prelecionar qualquer matéria nos impedimentos ou falta de catedráticos. E assim comentou um colega com a sua habitual ironia: "Deu nisso. Desafiamos o Arrudinha com um frango e ele nos confia a um pinto". No fundo saímos perdendo, condenados que fomos a ouvir um curso improvisado de "direito aéreo", que tornava mais evanescente O Direito Internacional Público, o qual para a maioria dos estudantes, habituados à visão positivista e coercitiva das normas jurídicas, não passava de uma grande esperança malograda pelos interesses ou pela violência dos Estados. (Reale apud Motoyama, 2006, p.184)

A trajetória de outro docente negro das Arcadas, Antonio Ferreira Cesarino Júnior, foi investigada por Barbosa (1997), e também aponta um caminho de enfrentamento de preconceitos raciais rumo ao sucesso acadêmico. Sua carreira docente começa com a inovação no ensino de História para os cursos secundários, na década de 1920, aproximando seu nome do movimento de renovação da educação que ficou conhecido como Escola Nova. Tendo feito a graduação em Direito pela Faculdade do Largo São Francisco, é nomeado professor catedrático em 1939 na cadeira de Legislação Social com a defesa da tese "Natureza Jurídica do Contrato Individual do Trabalho". Lecionou na Faculdade de Direito da USP por quase quarenta anos. Em 1952 formou-se médico pela Escola Paulista de Medicina. Em 1948 foi nomeado professor catedrático da Faculdade de Economia, Administração e Ciências Contábeis da USP (FEA), onde lecionou até a sua aposentadoria compulsória.

Ciente da presença desses três docentes negros na faculdade de Direito, a saber: José Rubino, Pinto Pereira e Antônio Cesarino, a presente pesquisa detém-se na consideração da trajetória da docente negra Eunice Aparecida de Jesus Prudente. As considerações sobre a carreira de Eunice Prudente, docente da Faculdade de Direito desde 1985, apresentadas a seguir, fundamentam-se principalmente na entrevista que ela concedeu a essa pesquisadora. 


\section{I-5. Ser docente e mulher negra nas Arcadas: Professora Eunice Prudente, uma trajetória pioneira}

A professora Eunice Aparecida de Jesus Prudente nasceu no dia 10 de setembro de 1946, na cidade de São Paulo, na Vila Maria. Em termos étnico-raciais se define como "negra". Seu pai veio da região de Cajuru, Mococa, interior de São Paulo onde era lavrador e filho de lavradores. Ele cursou até o segundo ano do ensino primário numa escola organizada na fazenda na qual trabalhava e vivia. Sua mãe veio de Jundiaí, interior de São Paulo, cursou o antigo primário e depois de adulta fez o supletivo. A professora Eunice tem ainda um irmão, que fez carreira na Aeronáutica como sargento especialista e chegou a cursar Ciências Sociais e Economia em duas diferentes faculdades privadas da capital paulista. Seus pais se conheceram em São Paulo, na condição de trabalhadores e militantes da Juventude Operária Católica (JOC). Ser trabalhadora, estudar em escola pública e ser filha de militantes foram aspectos fundamentais na trajetória escolar da professora Eunice Prudente, até mesmo na escolha da sua carreira profissional:

Em 1968, entrei em Direito e História. Então durante um ano e meio fiz os dois cursos ao mesmo tempo. Mas era uma loucura porque eu trabalhava de manhã, fazia História à tarde e Direito à noite. E aquela cidade universitária não tinha os transportes coletivos à noite como tem hoje, era uma dificuldade, mas era assim algo como tirar leite da pedra. Então meu pai via aquele sacrifício, "ah, você vai ter que se decidir porque você não vai aguentar”, porque eu não aguentava mesmo, né. Então aí eu deixei História e fiz Direito assim um pouco orientada pelo meu pai principalmente. Meu pai era metalúrgico e sindicalista, minha mãe tecelã e sindicalista, eles eram muito politizados e então eles acharam que em Direito eu teria mais possibilidades de trabalho, como de fato acho que eu tenho mesmo. Mas eu gosto de História até hoje.

Um dos fatos destacados pela professora Eunice Prudente referente à sua graduação, feita no período noturno, foi a excepcionalidade da sua turma na qual havia vinte e um alunos/as negros/as, que ficaram conhecidos como "O Grupo dos 21 ”. Sua explicação para tal fenômeno é a qualidade do ensino público de então, que teria sido posteriormente prejudicado pelas políticas de educação adotadas pelo regime militar:

Minha graduação é do curso de Direito. Eu sou da turma de 1972 desta universidade. Talvez da última turma dessa escola que teve 21 alunos negros, até nós falávamos: "nós do Grupo dos 21". Eram dois do curso da manhã e 19 do curso noturno. Mas era na época aí dos finais de uma escola pública boa, onde muitos filhos ou pessoas oriundas de famílias trabalhadoras ou operárias chegavam à universidade pública, porque os colégios estaduais eram muito bons. Então [era] um ensino de qualidade. Então enfrentávamos os vestibulares e chegávamos aí. Foi uma política né, do governo militar, da ditadura militar que prejudicou muito o ensino público, adotando uma orientação ou, melhor dizendo, uma ação imperialista do governo dos Estados Unidos da América, adotaram o MEC-USAID e aí realmente detonaram com a escola pública no Brasil e aí por toda a América Latina.

A opinião da professora Eunice Prudente vai ao encontro das análises de Romanelli 
(1986) a respeito dos efeitos nefastos dos acordos MEC-USAID sobre a educação brasileira. O pós 1964 é marcado pela redefinição do processo político e econômico que agravou a crise educacional. De um modo geral essa influência se expressa em um modelo de modernização que "teria como função integrar melhor o Brasil na expansão do capitalismo ocidental e mantê-lo, todavia, em sua posição periférica". (Romanelli, 1986, p. 257). Contudo, uma questão a considerar é que, se em algum momento a escola pública chegou a ser tão boa, por que tão poucos negros chegaram à USP mesmo nesse período? Porque poucas pessoas de baixa renda - e poucos negros - chegavam à escola pública, que atingia parcela mínima da população. A qualidade do ensino público era "boa" porque o acesso se dava por meio de um processo extremamente seletivo. Azanha (2004), considerando a expansão do ensino ginasial ocorrida em 1968-70, indica que "os exames de admissão a esse nível, obrigatórios por lei federal, haviam se transformado numa barreira quase intransponível para a grande massa de egressos do primário". (Azanha, 2004, p. 339). Assim, essa expansão é um dos fenômenos que tipifica na história da educação brasileira os conflitos em torno da necessidade de aumento do acesso, o temor da massificação e o dilema sobre qualidade no processo de democratização do ensino.

Diante do exposto, as chances de acesso ao ensino superior pela população negra nos anos 1960 eram bastante reduzidas. Sendo assim, para melhor compreender a trajetória de longevidade escolar da professora Eunice Prudente, faz-se necessário considerar também uma questão abordada por Pinto (1987), que em revisão bibliográfica sobre “educação do negro", aponta para um dado que chama a atenção: na história de diversas entidades de mobilização política organizadas por negros, registra-se a preocupação com a promoção da educação no seio da população negra. Cruz (2009) indica que a professora Eunice Prudente vem de família de militantes: além da militância de seus pais, seu avô materno militou na Frente Negra Brasileira, e até mesmo, Arlindo da Veiga Santos, (que foi presidente desta entidade a qual abriu importantes caminhos para o Movimento Negro Brasileiro), era amigo e algumas vezes hóspede da família. Além disso, sua tia paterna, Ana Florença de Jesus Romão chegou a ser dirigente nacional da Juventude Operária Católica.

Embora não se declare militante de nenhum movimento, a professora Eunice foi uma aluna com preocupações políticas. Participou do referido Grupo dos 21, que apesar de ter existido apenas durante o curso da graduação, assumiu feições de um coletivo organizado em torno do debate étnico-racial na Faculdade, pelo qual a professora Eunice tem se mobilizado desde então. Desse grupo foi a única que seguiu carreira acadêmica, pois a maioria dos colegas acabaram fazendo concursos públicos, conforme relata:

Olha, nós fazíamos reuniões, no Centro Acadêmico XI de Agosto, organizávamos. 
Participamos daquela virada de organizar o 20 de Novembro como uma data que expressasse a africanidade, participamos muito disso. Fazíamos política no Centro Acadêmico XI de Agosto. [...] Então era lá que fazíamos as nossas reuniões pra discutir a questão da discriminação, principalmente no mercado de trabalho. Muita preocupação com os futuros concursos. Aquele Grupo dos 21, nós estávamos todos no mesmo ano, porque naquela época o curso era anual, mas tinha gente já, mais velha, que se tornou um dos maiores advogados daqui de São Paulo. [...] O pessoal, é, foi principalmente para os concursos públicos, poucos ficaram na chamada advocacia e ninguém ficou aqui na área acadêmica, ficou só eu. Porque é muito difícil, até hoje, é difícil até hoje. Mas não impossível, animo muito as pessoas, porque é algo pra ser enfrentado e participado.

A opção de dar sequência à sua formação e ingressar na pós-graduação, cursando duas especializações, mestrado e doutorado, foi de certo modo favorecida pela sensibilidade do professor Dalmo de Abreu Dallari, cuja postura acadêmica era atenta às diversas desigualdades na sociedade brasileira:

Ele formou uma escola de direito dentro da Faculdade de Direito. De desmistificar o Direito, de valorizar a democracia, se opor às formas de discriminação. Ele foi uma pessoa muito importante aqui, fez uma história em torno dos direitos fundamentais. Então acredito que eu e outros professores que atuamos a partir de orientação de mestrado e doutorado com ele, a gente teve toda a liberdade.

Interessante pontuar que a trajetória da professora Eunice Prudente se aproxima das trajetórias dos/as docentes negros/as da Universidade Federal de Minas Gerais, analisadas em Praxedes et.al (2009), em vários aspectos: a humilde origem socioeconômica; a participação e apoio da família que cotidianamente indicou a educação como caminho para alguma ascensão social, apesar das dificuldades; a possibilidade de acesso a uma escola pública de qualidade; o destaque de alguma figura docente que se mostrou solidária e incentivou o prolongamento dessa trajetória escolar; e a presença instigante da militância política. Além de ser filha de militantes operários, da participação no Grupo dos 21 alunos/as negros/as da Faculdade de Direito, preocupado com a temática racial, a professora Eunice, que diz nunca ter sido militante de nenhum movimento social nem filiada a partido político, construiu de maneira muito autônoma, profícuos diálogos com os governos estadual e municipal, com o movimento negro e com o movimento feminista (este último será considerado com mais detalhes no capítulo 5). Sua dissertação de mestrado, defendida em 1982, adiantou discussões sobre a criminalização do racismo, instituída a partir da Constituição de 1988. E apesar de não ter influenciado imediatamente os debates do Movimento Negro Unificado, é uma importante referência bibliográfica sobre o tema ${ }^{14}$ :

Porque como a minha dissertação de mestrado foi voltada para a criminalização da discriminação racial, que na época era contravenção penal. [...]. Eu tive que ir pra criminologia, escrever o que era crime de discriminação racial, porque não o era aqui e é o primeiro trabalho é a primeira tese nesse sentido, embora fosse uma dissertação, defendida

14Sobre a institucionalização do movimento negro contemporâneo, ver Rios (2012). 
em 1982 e publicada em 1989. Então antes de a Constituição dizer que racismo era crime, o único trabalho era o meu. Eu tive a honra então [...] Eu notei pouca atenção do movimento negro com essa questão do meu trabalho. Mas o importante é que tá na Constituição, fechado né, aí a questão.

Por outro lado, algumas singularidades na trajetória da professora Eunice Prudente aparecem, por exemplo, na sua opção por ser apartidária e independente, o que difere significativamente das trajetórias dos/as docentes negros/as da UFMG analisadas por Praxedes et.al (2009). Pois no caso desses/as, a militância aparece associada à filiação a partidos e/ou ao movimento negro. Porém assim como os/as docentes negros/as da UFMG, houve também por parte da professora Eunice Prudente a constatação do limite da discussão racial com a militância da esquerda, questão que ultrapassa o debate sobre experiências docentes, pois também o movimento negro encontrou limites neste diálogo, conforme indica Alberti (2009) quando considera a experiência de docentes negros/as da UFMG com os movimentos de esquerda.

Assim, a construção de certa autonomia política conferiu à professora Eunice Prudente a possibilidade de ser a primeira mulher negra superintendente no Instituto da Previdência Municipal e a primeira secretária de Justiça do Estado de São Paulo:

Porque eu sou muito independente. Eu fui orientanda do professor Dalmo Dallari, sempre trabalhei com ele até ele se aposentar. Mas por exemplo, nunca integrei o PT nem nada. Porque eu venho de um tempo em que a experiência do meu pai, que eu desde pequena acompanhei, o Partido Comunista não discutia questão de gênero e a questão racial, era proibida mesmo. Então eu vi o meu pai aguentar poucas e boas por tentar discutir a questão racial no sindicato dos metalúrgicos. Então eu sou crítica a eles, sei lá como eles me veem. Então eu sou independente mesmo. E nessa minha independência eu fui do Instituto de Previdência Municipal, quando o Jânio Quadros era prefeito. Por que? Porque eu sou da Vila Maria [região que tradicionalmente foi base de apoio de Jânio Quadros] Quando ele retornou à política e foi prefeito da cidade, ele chamou as pessoas, e aí já tinha muitos formados pelos colégios estaduais da região da Vila Maria e de outros. Eu fui uma delas. Então eu acabei sendo superintendente. Quando eu fui superintendente deste instituto de Previdência Municipal, o professor Cláudio Lembo era secretário dos negócios Jurídicos, acabamos estabelecendo uma certa amizade, ele é do Mackenzie também e tal, e quando ele foi vice-governador do Geraldo Alckmim alguns anos atrás, foi que ele me convidou pra ser Secretária da Justiça, fui Secretária da Justiça durante nove meses, durante o tempo que ele foi governador. Então ele estava substituindo o Alckmim que deixou o governo de São Paulo pra ser candidato a presidente.

E no segundo semestre de 2012 a professora Eunice Prudente assumiu também a direção do Departamento de Prevenção e Transparência da Corregedoria Geral da Administração da Casa Civil do Estado de São Paulo. Além da carreira acadêmica na USP, construiu outras paralelamente, no exercício da advocacia, no governo ou mesmo em outras universidades, como será considerado mais adiante. De modo sucinto, a USP passa definitivamente a fazer parte do seu cotidiano a partir de 1968, quando ingressa na graduação em Direito. Desde então, a professora Eunice Prudente nunca mais se desvinculou da Faculdade do Largo São Francisco, mesmo exercendo outras atividades. Concluiu a graduação em 1972, logo na sequência fez duas 
especializações, o mestrado, ingressou na docência, fez doutorado e por fim, o concurso para efetivação. Além das funções de aluna e professora, acumulou também por alguns anos a função de funcionária concursada, chegando ao cargo de Assistente Acadêmico.

Interessante observar que a professora Eunice Prudente já era funcionária da USP antes de assumir a função docente. Enquanto era funcionária concursada da universidade continuava paralelamente a sua formação na graduação e na pós, o que parece ter favorecido também sua carreira administrativa. Mas se esta carreira se beneficiava da formação acadêmica, é possível que o inverso também tenha ocorrido, uma vez que o cargo administrativo permitiria também o acesso a conhecimentos sobre os meandros burocráticos da vida acadêmica. Aqui reside um elemento crucial da trajetória da professora Eunice Prudente, que é a mobilização de conhecimentos que a permitiu cruzar algumas fronteiras dentro do seu departamento (Direito do Estado): ser aluna de graduação/funcionária técnico-administrativo/aluna de pós-graduação/docente. Antes de ser assistente do professor Dalmo de Abreu Dallari, ampliando assim, os caminhos para a docência, foi secretária do departamento ao qual está vinculada toda a sua formação e no qual é docente hoje. Desse modo, depois de terminar o mestrado e quando a docência na universidade se tornava possível, abriu mão da carreira no funcionalismo técnico-administrativo. Ela parece ter sido capaz de suplantar as intensas hierarquias entre funcionários/as administrativos/as e docentes que existem no espaço universitário, utilizando essa dupla inserção a favor de sua ascensão acadêmica.

Além das carreiras dentro da universidade, a professora Eunice construiu outras, em outros espaços de atuação dentro da sua profissão, conforme relata nesse balanço profissional:

\footnotetext{
Eu prestei um concurso em 1979, na época em que a USP fazia concurso para os seus funcionários, uma época boa então. (...) Eu comecei como assistente administrativo no Instituto Oceanográfico. Aí depois eu fui secretária [...] Mas eu já era aluna aqui e era um sacrifício, porque saía da cidade universitária, pra trabalhar aqui, era aquela confusão toda. Já era aluna, tava no segundo ano. Aí o diretor aqui, o professor José Pinto Antunes entrou em contato com o professor Miguel Reale que era o reitor da época. Consegui uma transferência pra cá [Faculdade de Direito]. Aí sim. Eu trabalhava durante o dia e estudava aqui à noite. Ficou mais assentada minha vida, porque até aí era uma tribulação constante de ir pra lá pra cá. Aí sim eu pude fazer carreira. Eu fui secretária de departamento. Então desse departamento aqui de Direito do Estado eu fui secretária. Eu mantinha assim uma formação né, era muito referente. Fui secretária nesse departamento durante alguns anos. Aí quando eu fiz o mestrado eu fui indicada pra ser contratada [como professora] aí eu pedi demissão [do cargo de secretária]. Aí eu fui já tendo atividades na advocacia pública, né. Eu prestei concurso na EMPLASA, Empresa de Planejamento da Grande São Paulo. Depois fui advogada da Companhia do Metrô, lá eu me aposentei na advocacia pública, já como advogada pública eu sou aposentada por tempo de serviço. Então eu fiz paralelamente duas carreiras. Mas enquanto atividade administrativa da USP eu fui até a ser assistente acadêmica, né, aqui da escola mesmo.
}

Sua carreira docente na USP começa em 1985, poucos anos depois do término do mestrado (1982) e de ter sido assistente do professor Dalmo Dallari. Interessante observar que seu concurso para efetivação acontece em 1992, dez anos após o mestrado, porém antes do término do 
doutorado, em 1996, e da universidade começar a exigir o título de doutor nos concursos para novos docentes:

\begin{abstract}
Meu concurso pra efetivação foi antes do doutorado, também fui da última turma de mestres que podiam ser efetivados, parece que foi em 1992, porque de 1985 a 1992 eu fiquei como professora contratada. Aí depois prestei o concurso pra efetivação, parece que foi em 1992.
\end{abstract}

Sobre o processo do concurso, relata que foi um momento tranquilo, considerando que na Faculdade os concursos para professores costumam ser tensos:

Olha, o concurso foi ao meu ver tranquilo. Os concursos aqui na faculdade são dramáticos (risos). $\mathrm{O}$ meu foi tranquilo. Muitas exigências, examinadores assim, exigentes, muito duros com o curso aqui, sabe. Mas enfrentei bem.

Questionada sobre outros/as candidatos/as negros/as em outros concursos para docentes na Faculdade, a professora Eunice Prudente disse não se lembrar deste tipo de situação:

Não, nunca vi. E olha que inclusive fui funcionária da Universidade. [...] Nunca vi um concurso com participação... Não, nunca... Não... Aquele senhor ${ }^{15}$ lá da Bahia, que é tributarista, ele foi vice-prefeito de Salvador e depois veio aqui em São Paulo e foi secretário de assuntos jurídicos na época do Celso Pita, eu sei que ele participou de concursos aqui, mas eu não cheguei assim a assistir. Ele era tributarista, mas participou de concurso acho que era disputando uma titularidade na área de direito civil. Eu soube assim notícias e tal.

A única lembrança de ver candidatos/as negros/as em concursos para docência na USP foi na Escola de Artes e Ciências e Humanidades, EACH, na USP Leste, fundada em 2005, quando integrou uma banca de concurso para efetivação:

A não ser quando eu integrei a banca. Integrei a banca de titulação da professora Gislene Santos, ela é negra né, aí sim. Como eu participei... Acompanhei porque eu participei. Ela é uma filósofa, ela é uma pensadora, ela é brilhante. Um concurso assim inesquecível. Sentime muito orgulhosa de ter integrado aquele concurso e de ter dado nota 10 pra ela. E era para a efetivação dela como professora na chamada USP Leste.

A ausência de candidatos/as negros/as em concursos dentro da universidade, relatada pela professora, concilia-se com a história de acesso da população negra ao ensino superior, marcada por ausências e invisibilidades; e aponta também para uma história de exceções: se por um lado, a professora Eunice integrou durante a graduação uma turma excepcional, o já referido “Grupo dos 21”, apenas ela seguiu carreira docente na Faculdade do Largo São Francisco. Compreendendo-se como parte de uma cadeia de poucos elos, destaca a existência dos dois 
docentes negros na Faculdade, que mencionamos acima. É o que relata, quando questionada se conhecia ou foi aluna de professores negros na Faculdade de Direito:

\begin{abstract}
Sim, e até já viramos história e a história é contada lá no curso de História da PUC. Teve um mestrado sobre os professores negros aqui da escola. Então teve no século XIX o José Rubino de Oliveira que dá nome a uma rua de São Paulo e o estruturador do Direito do Trabalho no Brasil o Antônio Cesarino Júnior, mas ele era um gênio. Era médico, advogado, com uma formação assim, espetacular, um dos maiores juristas brasileiros do século XX e negro. Tem uma sala no prédio velho com o nome dele, com a pintura né, na parede. Então se vê que era um homem negro. Eu não fui aluna dele, porque ele já estava à beira da aposentadoria. Fui da assistente dele, da Marli Cardoni. Mas de vez em quando ele visitava a classe, né. Ele tava passando já pra ela, para outros professores da cátedra de Direito do Trabalho e só. Depois eu fui aluna do Kabengele [Munanga], mas aí eu já tava no mestrado né, lá na Ciências Sociais.
\end{abstract}

De fato, a professora Eunice Prudente "virou história" na análise comparativa que Cruz (2009) fez de sua trajetória com a de José Rubino de Oliveira, docente negro da Faculdade de Direito no século XIX. Outro docente, parte dessa história, é o citado professor Antônio Cesarino Júnior; e desse modo, ao apontar os nomes que configuram algumas referências, a professora Eunice Prudente reconhece que há um processo de invisibilidade do/a negro/a não apenas na Faculdade de Direito, como em toda a Universidade de São Paulo, o que indica a ocorrência do racismo institucional:

\begin{abstract}
Acho que é muito grave o racismo institucional. Não é tanto a nível de pessoas. (...) mas de qualquer forma demonstra sim a existência do racismo institucional. Somos muito poucos. Não se explica, não se explica tão poucos professores. Então a USP precisa democratizar mais os acessos aí para a docência inclusive. Eu por estar aqui desde 1985, foi meu primeiro contrato, depois me efetivei. Eu vi uma certa passagem. Nós temos na Universidade de São Paulo muitos alunos de origem asiática, nisseis, muito agora, muitos coreanos, chineses, vietnamitas, nossa, a USP tem gente do mundo todo. Mas nas ciências humanas eram muito poucos, eles escolhiam mais a área de exatas e biológicas. Eu vi a passagem da chegada dos alunos asiáticos aqui no Direito, na Faculdade de Direito da USP. Como professora, devo dizer que me sinto confortável e contente com o semblante deles na sala de aula, que agora são muitos aqui. Não tem os semblantes negros. Sempre tem um aluno, não tem nenhum, tem classe que não tem nenhum aluno. Nem o chamado pardo não tem, a USP não tem. [...] Mas a verdade é que olhar uma classe no Brasil, da Faculdade de Direito da Universidade de São Paulo e ver a diversidade para mim, professora negra, é um alívio, a despeito de ainda não termos negros. Mas vejo, acho que me senti mais confortável e melhor tratada pelos alunos com a presença dos asiáticos. Eu estou aguardando as políticas de ação afirmativa (...).
\end{abstract}

A professora Eunice Prudente aponta a ausência de docentes e discentes negros/as na USP como reflexo do chamado racismo institucional. Analisando esse conceito, Wiervioka (2007) indica que racismo institucional não diz respeito apenas a doutrinas, ideologias, argumentos, científicos ou não, utilizados para justificar atos racistas, pois o racismo pode ser percebido por meio de outras vias, no funcionamento mesmo da sociedade. O racismo passa a ser entendido como elemento estrutural, inscrito nos processos rotineiros. Está no esqueleto do cotidiano, que assegura um lugar permanente de inferioridade negra, cujo deslocamento é moroso e esbarra em 
impedimentos não declarados. Assim o racismo aparece como um sistema generalizado de discriminações, que se alimenta de outras discriminações.

Esse conceito traz a possibilidade de imaginar que as classes dominantes podem não ter total consciência de suas atitudes de dominação e ao mesmo tempo ter posicionamentos compatíveis com ideias antirracistas. Asseguram assim um racismo camuflado, invisível, despersonalizado, ao passo que tiram vantagem dele. As causas do racismo são camufladas, mas seus efeitos são concretos. A força do conceito é fazer evidente que o declínio das doutrinas científicas não implica o desaparecimento do próprio racismo. O autor aponta a necessidade de contrariar a tendência das instituições, pois do contrário, a população negra continuaria a ocupar lugares subalternos. A fraqueza do conceito é seu paradoxo: o grupo dominante é exterior ao racismo, se beneficiando dele. Se a responsabilidade passa a ser das instituições, exonera-se a todos da suspeita de racismo e ao mesmo tempo, responsabilizam-se todos por sua ocorrência. O racismo institucional é um conceito que desafia a enxergar além da opacidade dos mecanismos das instituições, que favorecem setores restritos da população, os quais se beneficiam do racismo sem que isso lhes afete a consciência.

No que diz respeito às relações estabelecidas com os pares e os alunos, a questão do racismo, como narrada pela professora Eunice Prudente apresenta algumas nuances: embora os alunos nunca a confrontassem diretamente por ser negra, essa é uma questão que aparece, indicando conflitos não tão evidentes nas relações raciais:

\begin{abstract}
Aí quando começam a surgir os rostinhos asiáticos isso deve ter sido em 1995. Porque quando eu me dei conta, já na classe tinham vários, meninos, meninas e tal. Sinto neles um tratamento muito respeitoso comigo, mas muito mesmo. O que mostra que existe o racismo entre os alunos. Pelo jeito que eles tratam. Mas não faço nenhum comentário. Até que um dia fizeram uma bagunça na minha sala, eu tô olhando aquela bagunça, aquela confusão, alguém falando com alguém, não sei o quê. Aí que um aluno asiático levantou e falou que nas outras aulas, dos outros professores, ele não estava vendo aquela bagunça, e que aquilo era um ato de racismo. (...) Aí chamei a atenção da classe, levei pra frente...
\end{abstract}

Quando questionada se tinha conhecimento de alguma situação de discriminação na Faculdade, ela relata que teve conhecimento de alunos que vivenciaram situações de discriminação racial:

$\mathrm{Eu}$ acompanhei aluno dizer que esses seguranças aqui da escola os acompanhavam perguntando se eles eram alunos aqui da escola e quem eles eram. Eles ficam passeando né, pelo prédio. Mas veja que é por parte do terceirizado, etc. Não diretamente dos assim, da casa. Com relação aos professores, discriminação racial assim, ato direto, eu não tenho conhecimento de nenhum. Eu pessoalmente nunca tive, mas volto a dizer que essa invisibilidade de negro é uma forma discriminatória e a questão é política. E isso é grave.

Diante da ausência e/ou invisibilização do negro nas universidades públicas, a 
carreira intelectual da professora Eunice Prudente tem oferecido subsídios para interpelar esses processos, e sua atuação no Núcleo de Apoio à Pesquisa e Estudos Interdisciplinares sobre o Negro Brasileiro (NEINB) é bastante ilustrativa do seu comprometimento:

Então atualmente eu estou na coordenação do Núcleo de Apoio à Pesquisa e Estudos Interdisciplinares sobre o Negro Brasileiro (NEIMB). Então esse núcleo no momento nós estamos prestando serviço à prefeitura de São Bernardo do Campo. [...] E o que estamos fazendo lá? Aplicando ou ensinando, ministrando aula sobre a implementação da lei 10.639 e a 11.645 as duas leis aperfeiçoando a Lei de Diretrizes e Base da Educação.

Interessante destacar que a trajetória da professora Eunice Prudente está conciliada às lutas e interesses da comunidade acadêmica negra, seja na implantação das leis 10.639 e 11.645 , seja na construção de redes de pesquisadores/as (negros/as ou não) que investigam a temática racial brasileira. A professora Eunice Prudente demonstra ainda preocupações com o futuro das políticas de inclusão racial na USP, diante do insuficiente INCLUSP ${ }^{16}$, política da universidade para a ampliação do acesso à universidade que enfoca a inclusão social e de modo implícito, furta-se a discutir a inclusão racial.

Conheço como todo mundo o INCLUSP. Mas o INCLUSP não inclui, essa é que é a verdade. Então não aumentou o número de alunos da escola pública... Isto não ocorreu. Então ela precisa corrigir isto. Ela precisa se dedicar mais aos problemas brasileiros, às questões brasileiras, entre elas a questão racial. Dessa ela não vai poder fugir. (...) Todas [universidades] com cotas para negros ou para afrodescendentes. Então todos aderiram praticamente. Até quando a USP vai ficar fora? Então eu não conheço bem qual é a política de inclusão da USP.

A trajetória da professora Eunice Prudente é marcada por processos de (des)articulações com a USP. Desarticulada no sentido de interpelar as desigualdades raciais que são reais na universidade e na sociedade. Assim, sua trajetória de pesquisadora, desde o mestrado, endossa uma série de questionamentos e cobranças para que a população negra possa de fato ser cidadã de direitos. Porém é também uma trajetória de articulações, pois a professora reconhece que a tradição

16A discussão sobre esses programas será considerada novamente em outros momentos desse trabalho em função da recorrência com que aparece nas narrativas dos/as docentes entrevistados. Para iniciar a discussão a respeito do INCLUSP, a página eletrônica da USP, o define como "Programa de Inclusão Social da USP, inclui uma série de iniciativas para ampliar o acesso do estudante de escola pública à Universidade. O Programa atua na superação das barreiras educacionais que dificultam esse acesso, apoiando a participação antes, durante e após o vestibular. $O$ aluno que fez todo o ensino médio em escola pública pode obter inscrição gratuita para o vestibular; somar até três bônus na nota, dependendo do seu desempenho em outras duas avaliações (o ENEM e o PASUSP [Programa de Avaliação Seriada]); após o ingresso pode contar com bolsas de apoio e incentivo para auxiliar sua permanência durante os estudos." Este trabalho considera no terceiro capítulo como o INCLUSP aponta para um retrocesso nas políticas de acesso da população negra à USP. E face à pressão pela adoção das cotas a USP tem proposto também o PIMESP (Programa de Inclusão com Mérito no Ensino Superior Público Paulista) apresentado pelo Governo Geraldo Alckmin e pelo CRUESP (Conselho de Reitores das Universidades Estaduais de São Paulo), como tentativa de adiar a adoção de políticas de cotas nas universidades do estado de São Paulo. 
da Faculdade de Direito da USP é um elemento formador fundamental que abriu portas para a sua carreira intelectual possibilitando os diálogos que construiu com os governos, militância e sociedade civil:

\begin{abstract}
Olha... A Faculdade de Direito por ela ter sido anterior à própria universidade, bem anterior, ela formou os governantes do Brasil durante muito tempo, antes de virem os economistas com tudo né. O pessoal da área de direito é que comandou esse Brasil grande e muita gente, e muitos dos nossos governantes são dessa escola. Ainda há muito. O próprio Fernando Haddad,[atual Prefeito de São Paulo] lá da [Ministério da] Educação é daqui também, né. Então nós ainda temos, o pessoal aqui os alunos que integravam o centro acadêmico, principalmente, o grupo, a ala petista estão todos trabalhando no governo federal, alguns trabalharam bem juntos do presidente Lula, como assessor direto dele. Então ela ainda forma governantes. Acredito que uma certa participação política que eu tive na OAB e no próprio governo se deu por eu ser formada aqui. Aqui se estuda Direito com profundidade, com seriedade, se prepara mesmo as pessoas com vida política. As pessoas saem aí tinindo.
\end{abstract}

Docente da Faculdade de Direito desde 1985, efetivada em 1992, a professora Eunice Prudente construiu sólida carreira profissional e acadêmica, conforme seu currículo lattes indica. Apesar disso, vê ainda alguns desafios e sonhos na sua carreira docente na USP, como a realização do concurso de Livre Docência, a obtenção desse título que lhe assegurará também a ascensão de Doutor para Associado. De modo geral, a trajetória intelectual da professora Eunice Prudente é exitosa, coroada de prêmios e homenagens ${ }^{17}$. Sua narrativa revela uma prática docente comprometida com o fortalecimento da cidadania e construção de uma realidade de equidade racial e de gênero, numa atuação que vai além da sala de aula, na qual se percebe uma conciliação entre as identidades pessoal e coletiva. Interessante observar que o diálogo com a militância, seja nos movimentos de esquerda, no movimento negro e no movimento feminista é uma importante marca na sua trajetória, embasando suas opções, convicções e ações.

Esta tese, no quinto capítulo, intitulado Um debate necessário: gênero e raça do corpo docente da USP; horizontes que se ampliam, ou, outras vozes em cena, referente à questão de gênero, analisa também o envolvimento da professora Eunice com a história do movimento feminista brasileiro, o que torna ainda mais rica uma trajetória marcada por pioneirismos: primeira mulher negra docente da USP, primeira mulher negra superintendente no Instituto da Previdência Municipal e a primeira secretária de Justiça do Estado de São Paulo,tendo ainda assumido outros cargos importantes como a direção do Departamento de Prevenção e Transparência da Corregedoria Geral da Administração da Casa Civil do Estado de São Paulo. Desse modo, as questões raciais e de

\footnotetext{
17Conforme indica seu currículo lattes, a professora Eunice Prudente acumula alguns prêmios: Em 2010: Dra. Maria Immaculada Xavier da Silveira, Ordem dos Advogados do Brasil, Seção de São Paulo, Comissão da Mulher Advogada da OAB/SP. Em 2008: Luta pela Igualdade Racial, Comissão do Negro e de Assuntos Antidiscriminatórios-Oab/SP. Em 2006, ano que chegou à secretaria da justiça, ela obteve mais três prêmios: 1) Cidadã Prudentina, Câmara Municipal de Presidente Prudente. 2) Amigo dos nordestinos, Folha Paulista. 3) Medalha Regente Feijó, Polícia Militar do Estado de São Paulo. Em 1992 ano em que se doutorou, recebeu a Medalha de Reconhecimento Maçônico, Grande Oriente de São Paulo. Em 1987 recebeu a Medalha Anchieta, Câmara Municipal de São Paulo.
} 
gênero transbordam-se na sua experiência pessoal e tornam-se temas centrais de suas preocupações de pesquisa, processo semelhante ao vivido por outros/as docentes negros/as. Nesse sentido, Gusmão (2009) propõe pensar como se dá esse processo e boa parte dele se deve ao fato de, uma vez na academia, docentes negros/as depararem-se com pelo menos duas situações de escassez: a de pesquisas em torno da temática e a de docentes negros/as nesse universo. Porém os/as docentes negros/as não enfrentam sozinhos/as essa preocupação acadêmica cotidiana, pois há uma rede de apoio que vai além da academia:

(...) uma rede que os conforma na luta que toma a questão racial como centro na sua formação social e acadêmica (...). Tudo em conflito aclarado por um arcabouço científico que, desde sempre, os nega, mas que também permite contrapor outras formas de ver e compreender o mundo e, assim, transcender os limites da academia (Gusmão, 2009, p.194).

Em diversos momentos, esse texto deliberadamente exalta as qualidades da docente Eunice Prudente, sendo assim, desde já reconhece essa postura, não se esquivando da necessidade de evidenciar a existência de negras e negros que têm feito de suas vidas um compromisso com a construção de uma sociedade brasileira mais sensível às desigualdades raciais. Apesar disso, esse trabalho não está alheio ao fato de que a vida acadêmica é feita de conflitos, disputas, dos quais a trajetória da professora Eunice Prudente não passa ilesa. Esse trabalho poderia ter explorado mais algumas tensões? Possivelmente. Mas por enquanto, se dedica principalmente a reconhecer que há docentes negro/as na USP que têm assumido os riscos de interpelar as injustiças raciais na própria universidade e na sociedade brasileira.

$* * * * * * * * * * * * * * * * * * * * * * *$

Tendo em vista a importância da Faculdade de Medicina e da Faculdade de Direito para a tradição da USP, este capítulo propôs uma releitura das histórias dessas instituições enfocando ideias e autores que construíram os posicionamentos raciais nesses espaços, apontando holofotes para discentes e docentes negros/as que descortinam outras histórias dessa universidade. O próximo capítulo propõe o mesmo exercício, mas trazendo o foco para o projeto de fundação da universidade, a antiga Faculdade de Filosofia Ciências e Letras (FFCL) e sua herdeira, a Faculdade de Filosofia, Letras e Ciências Humanas (FFLCH), destacando ideias e docentes negros e brancos, nesse processo. 

São Paulo a partir do projeto de fundação e da criação da Faculdade de Filosofia, Ciências $e$ Letras.

\section{II-1. De mentores a clientes e vice-versa: Redefinições do Projeto USP e Reconfigurações intelectuais e acadêmicas}

Apesar da criação de escolas de ensino superior em alguns estados brasileiros ao longo do século XIX e começo do século XX, vários anos se passaram até o Brasil escrever capítulos decisivos na história deste nível de ensino. Na segunda década do século XX verificou-se intensa propaganda em torno dos problemas do ensino superior, que eram muitos: ausência de universidades, pouquíssimas escolas superiores, muitos alunos e material didático deficiente. Acresce ainda a inexistência propriamente dita de faculdades de filosofia, ciências e letras e a precária situação do ensino secundário.

Oferecendo "uma crônica das origens" da universidade de São Paulo, Bosi (1982) destaca o grupo que reunia "intelectuais orgânicos da oligarquia cafeeira e uma brilhante ala dissidente cujas posições se afirmavam então democráticas e modernizadoras". (Bosi, 1982, p.11). Composto por setores sobretudo das classe média e alta paulistana que haviam sido direta ou indiretamente afetados pela crise do café, reuniram-se para procurar soluções, e foram batizados de "Comunhão Paulista Ilustrada" 18 (Bosi, 1982, p.12). O principal problema diagnosticado foi referente à educação, mais especificamente à necessidade de formação de elites intelectuais aptas a orientar os projetos da oligarquia em crise.

Nesse cenário, foram promovidos dois grandes inquéritos: um em São Paulo pelo jornal O Estado de S. Paulo em 1926 e outro no Rio de Janeiro em 1928 pela ABE (Associação Brasileira de Educação). Em São Paulo, o Inquérito sobre a Instrução Pública de São Paulo, encomendado a Fernando de Azevedo por Júlio de Mesquita Filho para o jornal $O$ Estado de $S$. Paulo, delineia posições bem definidas e aponta princípios doutrinários como "liberalismo orientado" e a formação de uma "elite norteadora" acima dos "interesses partidários". (Ibidem). Nesse sentido:

\footnotetext{
Um renovado humanismo pedagógico alimenta então as posições de Fernando de Azevedo e dão ao seu discurso um ar inequívoco de boa consciência ilustrada. Outro caráter desse discurso (que teoricamente resgata a generalidade incolor das suas premissas) é a preocupação com os mais altos 'interesses nacionais', traço que servirá depois de ponte entre o iluminismo de Fernando de Azevedo e os planos bem mais específicos e práticos do Governo Vargas. (...) No contexto do 'Inquérito' ganha força a ideia de uma Universidade
}

18 A Comunhão Paulista é título de um texto escrito por Júlio de Mesquita Filho e publicado originalmente em $O$ Estado de S. Paulo nos dias 21 e 22.11.1922. (LIMONGI, 2001, P. 143). 
como centro formador de elites políticas. Reconhecemos aqui, quase em estado puro, a crença no papel insubstituível da escola como transformadora real da sociedade e (certeza que vai sobreviver ao 'grupo do Estado') retificadora de desníveis econômicos de classe. (Bosi, 1982, p.13)

Consoante à sua missão bandeirante, a universidade traria as ferramentas para que a nação se conscientizasse de si, das suas potencialidades e destinos a partir do momento que dispusesse de institutos cuja função seria a busca da mais alta e qualificada cultura científica, filosófica e artística. O projeto previa uma universidade, que a partir dos seus institutos, deveria voltar-se para a formação das classes dirigentes, compreendidas como muito necessárias em um país tão diverso como o Brasil. Assim, a campanha a favor da universidade caminhou bem junto de outra, voltada para a regeneração da vida político-partidária brasileira. Quando Getúlio Vargas nomeia Armando Salles de Oliveira como interventor de São Paulo, torna-se possível a "Universidade da Comunhão". A USP é alçada à condição de suprema consagração dos ideais de 9 de Julho de 1932. Assim, conforme analisa Cardoso (1982), a criação da USP se fundamenta sobre um mito, o liberal-democrático. Análises da história da criação da Universidade de São Paulo indicam a importância da atuação da chamada Comunhão Paulista Ilustrada, que orbitava em torno do grupo do Estado (Jornal O Estado de S. Paulo), celeiro político que forneceu os educadores profissionais, responsáveis pelo movimento de reformas educacionais não apenas no estado, como na federação. Este amplo e complexo quadro de atores que assumiram posições nevrálgicas para a educação brasileira constitui também o conjunto de mentores da Universidade de São Paulo.

Analisando quais seriam os "mentores e clientelas da Universidade de São Paulo", Limongi (2001) ressalta a importância dos "educadores profissionais" promotores do movimento de renovação educacional que ficou conhecido como "Escola Nova"19. Considerando a luta desses educadores, o autor traça as principais linhas de continuidade, partindo da Reforma de 1920 regida por Antônio Sampaio Dória, que projetou a Faculdade de Educação; passando pela Reforma Lourenço Filho de 1931, destacando o curso de aperfeiçoamento de professores primários; até a Reforma Fernando de Azevedo, que dentre outros feitos, criou o Instituto de Educação; e chegando por fim ao ponto alto com a criação da Faculdade de Filosofia Ciências e Letras da USP em 1934.

De modo comum, as reformas giravam em torno de dois eixos: submissão dos critérios político-partidários a preceitos técnicos, daí o profissionalismo desses educadores; e prioridade dada à criação e expansão do ensino superior em detrimento dos demais níveis, com a finalidade

19Tal como sugere Limongi (2001), trata-se de um movimento de natureza complexa, o que dificulta a delimitação clara dos seus objetivos. Autores como Nagle (1978) apontam para os princípios pedagógicos professados, outros como Romanelli (1988) apontam os princípios políticos defendidos (Limongi, 2001, p. 155-156) 
de formar novos profissionais para o setor da educação. Segundo o autor, não por acaso, algumas cátedras da Faculdade de Filosofia da USP foram ocupadas por educadores que advogaram por sua criação, ascendendo assim de professores da Escola Normal a professores da Universidade de São Paulo. Sem o concurso desses educadores, a Universidade de São Paulo seria impensável.

A década de 1920 foi marcada pela disputa entre dois grupos de educadores pelo ensino paulista: os "educadores profissionais" também chamados "reformadores" e/ou "renovadores" que ascenderam com a Reforma de 1920; e os "tradicionalistas", grupo responsável pelas Reformas de 1925 e 1927. Antonio Sampaio Dória foi o primeiro líder do movimento renovador, seguido por Fernando de Azevedo e Lourenço Filho, além de outros intelectuais ligados ao grupo tais como Sud Menucci e Almeida Jr. Dentre os tradicionalistas destacam-se as lideranças de Américo Moura, Pedro Voss e Antônio Firmino Proença. De um modo geral, estes eram mais sensíveis aos reclamos da máquina político-partidária, ao clientelismo e, em tese, priorizavam a expansão do ensino básico em detrimento do ensino superior.

A Reforma de 1920 em São Paulo se proclamava como uma tentativa de gestão do sistema de ensino de modo burocratizado, racional, autônomo e protegido das demandas mais imediatas de políticos; e teve como plataforma a expansão do ensino superior paulista por meio da criação de uma Faculdade de Filosofia. Também conhecida como Reforma Dória, lançou as bases que orientam as reformas posteriores promovidas pelos "renovadores", aos quais também se credita: a fundação da Sociedade de Educação, em 1922, cujo primeiro presidente foi o médico legista Oscar Freire, também defensor da criação da universidade; o Inquérito de 1926 promovido pelo jornal $O$ Estado de S. Paulo, sob a coordenação de Fernando de Azevedo; o processo de contratação dos professores da missão estrangeira através do francês George Dumas, que promoveu no seio da sociedade paulista a concepção francesa de universidade, sobretudo a ideia de formação de elites desinteressadas a partir de um ensino calcado no humanismo (Limongi, 2001).

A Reforma Fernando de Azevedo, efetuada no Distrito Federal em 1927, foi a oportunidade do grupo de reformadores experimentar seus princípios educacionais fora das fronteiras do estado de São Paulo, definindo novos campos de atuação, como a disputa pelos postos e orientação do recém-criado Ministério da Educação e Saúde Pública. Segundo Limongi (2001) há uma sólida bibliografia que salienta sucessivas vitórias de grupos católicos que teriam frustrado as linhas mestras das reformas propostas em nível nacional por Fernando de Azevedo e Anísio Teixeira, líderes progressistas cuja atuação estava organizada em torno de três pontos básicos: ensino laico, expansão da escola pública e acesso igualitário aos dois sexos. A representação mais acabada desses preceitos doutrinários está no Manifesto dos Pioneiros da Educação Nacional, elaborado em 1932 por Fernando de Azevedo e assinado por 26 educadores. 
Porém o autor acha sensato "reivindicar uma qualificação mais detida quanto ao caráter progressista do movimento" de renovadores. (Limongi, 2001, p. 181). Além disso, se de fato Fernando de Azevedo e Anísio Teixeira foram cerceados, nem todos os "renovadores" ou as ideias que advogavam sofreram sanções junto ao governo federal. Em São Paulo a situação se mostrava bastante favorável, uma vez que os reformadores se revezam na direção dos principais postos do aparelho de ensino desde a Revolução de 1930 até o golpe de 1937, tendo como ponto alto a Reforma de 1933 dirigida por Fernando de Azevedo, que dentre outros feitos, instituiu o Código de Educação do Estado de São Paulo. Em dezembro do mesmo ano, Júlio de Mesquita Filho solicitou a Fernando de Azevedo a elaboração do projeto do decreto-lei que instituiu a Universidade de São Paulo, aprovado em janeiro do ano seguinte.

Retomando a discussão proposta no primeiro capítulo deste trabalho, é possível rastrear alguns posicionamentos desse conjunto de mentores face às discussões raciais, como a defesa que fizeram da vocação bandeirante da universidade. Além disso, se a Faculdade de Direito e a Faculdade de Medicina ensejaram a discussão sobre racismo científico, há estudos que também aproximam essas teorias raciais pseudo-científicas das propostas dos educadores que reformaram a educação brasileira nas décadas iniciais do século $\mathrm{XX}$, muitos dos quais foram também mentores da Universidade de São Paulo. Sem a intenção de julgar ou minimizar o trabalho desses educadores, a leitura do trabalho de Dávila (2006) oferece a possibilidade de pensar como os discursos raciais de educadores como Afrânio Peixoto, Anísio Teixeira, Fernando de Azevedo, Lourenço Filho, Oscar Freire, dentre outros, orientaram as políticas educacionais implementadas pelo grupo. Segundo o autor, “dotados da incumbência de forjar um Brasil mais europeu e presos a um senso de modernidade vinculado à brancura, esses educadores construíram escolas em que quase toda ação e prática estabelecia normas racializadas e concedia ou negava recompensas com base nelas" (Dávila, 2006, p. 25).

O sistema escolar foi informado por algumas metanarrativas, como a racial, de classe e gênero, em diferentes níveis, desde a construção do "currículo à seleção de alunos, distribuição e promoção; testes e medidas; seleção e treinamento de professores; programas de saúde e higiene; eventos públicos, e até mesmo na construção de escolas.” (Dávila, 2006, p. 363). O conjunto de reformadores educacionais cuja atuação expandiu o sistema educacional brasileiro era composto não apenas por pedagogos, como também médicos e cientistas sociais, que consideravam o sistema escolar um mecanismo difusor de ideias de brancura:

(...) [uma] máquina que de modo tanto deliberado (fornecendo aos brasileiros pobres e nãobrancos a ferramenta da brancura) quanto inconsciente (estabelecendo barreiras ao reificar seus valores estreitos) criou uma hierarquia racial no sistema escolar que espelhava sua própria visão de valor social. Essa hierarquia foi especialmente estável, eficaz e duradoura porque se fundava em valores inquestionáveis da ciência e do mérito. (Dávila, 2006, p.32) 
Os educadores brasileiros e sua geração intelectual concebiam raça não no sentido biológico, mas como metáfora que descrevia o sentido da evolução histórica da sociedade brasileira: o passado negro, o presente mestiço e o futuro inexoravelmente branco:

\begin{abstract}
Mais amplamente, as elites brancas equiparavam negritude à falta de saúde, à preguiça $\mathrm{e}$ criminalidade. A mistura racial simbolizava o processo histórico, visualizado como uma trajetória da negritude à brancura e do passado ao futuro. Na década de 1930, os brasileiros brancos podiam celebrar a salvo a mistura racial porque a viam como um passo inevitável na evolução da nação. A brancura encarnava as virtudes desejadas de saúde, cultura, ciência e modernidade. (Dávila, 2006, p. 25)
\end{abstract}

Para esses educadores, raça era também compreendida como categoria social de modo que um indivíduo estaria mais próximo da brancura se possuísse ou adquirisse virtudes como saúde, cultura, ciência e modernidade. Caso contrário, o indivíduo continuaria atrelado à degeneração da negritude com seus vícios, doenças e pobreza. Uma escola de caráter universal poderia embranquecer a população, livrando-a da degeneração. Assim, as políticas públicas para a educação foram informadas por teorias científicas como a eugenia, uma vez que condutores das reformas educacionais postulavam que a grande maioria dos brasileiros eram pobres e/ou pessoas de cor afetados pela falta de cultura e saúde, mas que podiam ser curados uma vez que fosse mobilizada a ciência na formulação de políticas estatais. O embranquecimento decorreria da educação, cultura, higiene e eventualmente pela cor. Em um período no qual havia divergências sobre o caráter permanente ou temporário da degeneração do negro e do mestiço, resultando em diferentes posicionamentos sobre a eugenia, o valor da brancura era consenso. Assim, as políticas públicas se por um lado possibilitaram o acesso à educação por segmentos historicamente excluídos, de outro, sedimentaram uma percepção pejorativa dos mesmos, na sua maioria "pessoas de cor".

Afinadas com o caráter ambivalente das relações raciais do país “essas políticas não só colocavam novos obstáculos no caminho da integração social e racial no Brasil como deixavam apenas pálidos sinais de seus efeitos, limitando a capacidade dos afro-brasileiros de desafiarem sua justiça inerente" (Dávila, 2006, p. 22). Embora tenham ampliado as oportunidades educacionais, essas políticas não beneficiaram afrodescendentes na mesma proporção que brancos. Ainda que não houvesse a exclusão deliberada de negros do sistema educacional, o mesmo foi refratário à população negra, limitando suas oportunidades educacionais e favorecendo as desigualdades educacionais entre os segmentos brancos e não brancos da população brasileira. Como consequência, "em parte, as persistentes desigualdades raciais resultaram da fusão dos movimentos da reforma educacional e pensamento racial do entre guerras" (Dávila, Op. cit.p. 29).

Fazendo aproximações entre esta discussão e a história da USP, vale lembrar, por exemplo, 
que a Sociedade de Educação fundada em 1922 por obra dos "renovadores" teve como presidente o médico legista da Faculdade de Medicina, Oscar Freire, que também foi discípulo de Nina Rodrigues, o grande mestre da escola baiana de eugenia. Como vimos, a Sociedade Eugênica de São Paulo, organizada em 1918, foi a primeira do país e teve como presidente o médico Arnaldo Vieira, que era também diretor da Faculdade de Medicina e como secretário o sociólogo Fernando Azevedo, que dirigiu as reformas escolares do Rio de Janeiro (1926-1930) e de São Paulo (19331934), redigiu o projeto de fundação da USP, além de ter sido regente da Cadeira II de Sociologia entre 1943 a 1963. Fernando de Azevedo considerava que a "eugenia buscava a eliminação dos venenos e não das pessoas". (Azevedo, apud Dávila, 2006, p. 54).

Sabe-se que a elite intelectual que se ocupou da fundação da universidade estava interessada também na regeneração política do país, saudosa que estava das condições sociais que gozava no Império e cerceadas na República. A participação das elites intelectuais na vida política do Império era plena de condições ideais, situação que mudou com a República. Dois motivos apontados por Júlio de Mesquita Filho foram a abolição e a imigração. A partir da abolição "entrou a circular no sistema arterial do nosso organismo político a massa impura e formidável de milhões de negros, subitamente investidos de prerrogativas constitucionais". (Mesquita Filho apud Limongi, 2001, p.150).20 Por sua vez, o imigrante europeu inicialmente foi visto com resistências, pois "penetrava em nosso meio no propósito inabalável de fazer fortuna, sem preocupação alguma de ordem cívica". (Ibidem).

Analisando as condições de vantagem vividas por imigrantes europeus no processo de integração e ascensão social e as correlatas desvantagens da população negra no período pósabolição, Monsma (2010) aponta duas tradições de estudos nesse sentido. A primeira apoia-se nos argumentos de Florestan Fernandes de que os negros estavam em desvantagem na competição com os imigrantes europeus, por serem inaptos para uma sociedade de classes uma vez que a escravidão deixara-os anômicos e comprometera laços familiares e comunitários, bem como a noção de disciplina interna e de trabalho. Em contraposição à primeira, a literatura mais atual ressalta os processos de discriminação e exclusão dos libertos e outros negros. Assim, além do racismo dos fazendeiros, haveria ainda o monopólio do colonato pelos imigrantes. Disso decorre que comparada à história da imigração mundial no mesmo período, São Paulo e o Brasil como um todo são casos excepcionais "em que imigrantes e seus descendentes rapidamente alcançaram

20Conforme lembra Damaceno (2013) a adesão ao movimento republicano, não equivalia à simpatia com o movimento abolicionista. Mas em algumas situações, era conveniente a alguns republicanos "posarem" de abolicionistas para criarem uma imagem de modernos. Júlio de Mesquita Filho chegou a lançar mão desse artifício, o que ajuda a entender porque Júlio de Mesquita Filho ostentou sua relação com Francisco Glicério, negro, filho de agricultores, importante líder abolicionista e membro do Partido Republicano de quem "Júlio de Mesquita Filho tinha orgulho de mostrar a sua foto aos visitantes do jornal como sinal de que aquele era um espaço democrático.” (Damaceno, 2013, p. 45) 
posições econômicas melhores que a maioria da população já existente no lugar que os recebeu." (Monsma, 2010, p.510).

Embora haja dificuldade de comparações sistemáticas sobre as condições de imigrantes e negros nas primeiras décadas da abolição em função da escassez das fontes, o autor aponta várias áreas em que os negros estavam em nítida desvantagem, tais como a taxa de alfabetização da população negra era muito baixa comparada às taxas de imigrantes e de outros brasileiros, que proporcionalmente cresceram em ritmo muito mais acelerado. Duas décadas após a abolição, os dados apontavam que a Republica pouco fizera pela educação da população negra. Além disso, mesmo que negros e imigrantes tivessem os mesmos níveis de escolaridade e riqueza, a integração dos imigrantes com as elites locais era muito mais fácil.

Voltando ao projeto de educação proposto pelos "renovadores", interessante notar a correspondência entre o nível sócio-político e a escolaridade: a elite teria acesso ao curso primário, secundário e superior; a classe média ao curso primário e preferencialmente ao secundário; às massas o curso primário e assim, a possibilidade de alfabetização. A novidade ficou por conta da definição de elite, que na concepção dos "pedagogos ilustrados" (Bosi, 1982, p.14) deixa de ser definida como classe econômica e passa a ser grupo intelectual. E pela leitura da obra de Dávila (2006) percebe-se que essa elite antes econômica e agora também intelectual seria branca e, por sua vez as massas, o contingente não-branco, que precisaria ser resgatado e regenerado pela educação sanitarista.

No que diz respeito à criação da USP e da FFCL, os reformadores da educação a pensaram como uma universidade destinada primeiramente à nobre tarefa de formação humanista das elites intelectuais aptas a reger o curso histórico e político da nação; e uma segunda tarefa, mais prosaica, porém fundamental, que é a formação de professores secundaristas (Limongi, 2001). Assim as primeiras clientelas da universidade se configuraram em torno desses interesses. A partir de depoimentos dos professores europeus contratados para lecionar na recém-criada FFCL, nas salas de aula figurou a "alta sociedade paulistana" nos primórdios da universidade. O historiador francês Fernand Braudel relata que

\footnotetext{
Minhas primeiras aulas foram em francês, e na sala havia representantes do governador, amigos de Júlio de Mesquita Filho, dono do jornal O Estado de S. Paulo, e diversos grãfinos que deixavam carrões estacionados na porta. Havia também intelectuais autodidatas, como Paulo Prado, um homem de enorme finesse e que possuía uma fantástica coleção de pinturas. Muitos vinham só para se distrair. (Braudel apud Limongi, 2001, p. 188)
}

Rapidamente esse perfil passaria por profundas mudanças, pois uma clientela em busca de ilustração, vida social e novidades, seria pouco afeita às exigências escolares próprias da formação profissional. O grande índice de evasão exigiu ações imediatas que revertessem esse quadro, pois a 
vida da nova faculdade não poderia depender do perfil inicial de alunos que na sua maioria era dispensada do vestibular. Em 1935, segundo ano da Faculdade de Filosofia, a inscrição para o vestibular foi aberta duas vezes, indicando a insistência nesse processo seletivo. Além disso, criouse o comissionamento, política pública voltada para o recrutamento de professores primários, (que nessa época já eram majoritariamente mulheres) e que, dispensados de suas funções didáticas e sem prejuízo de seus vencimentos, poderiam fazer os cursos da FFCL. Como esses professores também foram dispensados do vestibular, esta política constitui mais uma “"liberalidade' do Conselho Universitário na admissão dos alunos.” (Limongi, 2001, p.190). Posteriormente essa política se estendeu também aos professores do secundário.

A alteração no perfil discente da Faculdade foi assim definida por Pierre Monbeig, outro francês da missão estrangeira de docentes:

\begin{abstract}
Quando de sua instalação, a Faculdade atraíra alguns moços já nutridos de boa cultura, alguns dos quais, graças à sua idade, já com soma regular de conhecimentos, ou em todo caso, com inegável maturidade de espírito. O contingente do segundo ano, composto na sua maior parte, de professores comissionados, de moças, sobretudo, mais jovens que os primeiros, ofereceu ao professor um material completamente diferente. De um lado a minoria desejosa, sobretudo de completar a sua cultura geral, tendo o gosto das ideias e das discussões; de outro lado, um grupo de jovens, animado de grande ardor para o trabalho, conhecendo perfeitamente as suas possibilidades, mas sabendo também que, antes de mais nada, são professores e que por esta razão foram enviados à Faculdade. Os desejos são diferentes, e esta situação formula o problema da faculdade. (Monbeig apud Limongi, 2001, p. 191)
\end{abstract}

Considerando minuciosamente o perfil dos alunos que se matricularam e dos que se formaram, referentes às quatro primeiras turmas da FFCL, Limongi (2001) indica que havia quatro modalidades de ingresso: por dispensa do vestibular (para quem já fizera matrícula em algum curso superior anteriormente), admissão pelo vestibular, por comissionamento e por bolsa. A política de bolsa foi uma concessão da Secretaria de Educação, outro incentivo disponível a partir de 1938 a quem não fosse comissionado e que não pudesse se dedicar exclusivamente aos estudos.

Com riqueza de dados o autor mostra que a escolha dos cursos, a taxa de matrícula, a taxa de evasão, o número de concluintes, o rendimento acadêmico, a idade, o sexo, a condição socioeconômica, ser oriundo de escola pública ou particular, ser oriundo da capital ou do interior do estado, foram categorias que variaram conforme a modalidade de ingresso. Considerando que ter bom rendimento acadêmico era requisito para manter o comissionamento e o acesso às bolsas, nos quatro primeiros anos da FFCL, 58,3\% das conclusões de cursos eram de comissionados e bolsistas. Tal dado indica que a própria sobrevivência da FFCL dependeu de demanda e rendimento induzidos. Face ao conjunto de dados apresentados, o autor considera que:

Tais resultados recomendam que desconfiemos das construções grandiosas dos planos e fins da universidade projetados por seus mentores. Não seriam as fraquezas, inconsistências e 
contradições internas deste mesmo 'projeto' que estariam na dificuldade de atrair alunos? (Limongi, 2001, p. 196)

Era a própria finalidade da Universidade e, por conseguinte, da Faculdade, que estava em questão: formação de elites intelectuais, a partir do conhecimento livre e desinteressado, ou a formação de professores para o ensino secundário? Recorrendo novamente a Monbeig, o mestre francês apontava a necessidade de:

(...) dar aos estudos na Faculdade uma finalidade prática: no dia em que os estudantes tiverem a certeza de encontrar uma situação garantida e estável, como conclusão de seus anos de trabalho, tornar-se-ão mais numerosos e será então possível e indispensável fazer uma seleção estrita entre eles. Mas até lá, que valor e importância dar a um título que não consubstancia senão vaidades humanas? (Monbeig apud Limongi, 2001, p. 197)

Embora Monbeig tenha questionado a vocação científica da Faculdade, essa foi a finalidade que se impôs "como prioridade na fase de expansão em detrimento da formação de professores secundários cujo impulso só se daria com a expansão do sistema de ensino médio iniciada nos anos 50." (Limongi, 2001, p.218). Se houve dúvidas quanto à finalidade da Faculdade de Filosofia, o mesmo não acontecia às faculdades profissionais (Faculdade de Direito, Faculdade de Medicina e Escola Politécnica). Eram claramente distintos os perfis discentes da FFCL e das faculdades profissionais. Estas últimas atraíam "os filhos das elites, os possuidores de diplomas secundários obtidos nas melhores escolas, aqueles que saíam diretamente do secundário para a faculdade. Alunos desse tipo são raros na FFCL" (Limongi, 2001, p.197). Se a FFCL, nos seus primeiros anos pretendeu concorrer com as faculdades profissionais pela formação das elites, seu sucesso foi menor. Porém, a FFCL deve ser considerada a partir das duas seções de cursos que oferecia: humanidades (filosofia, história, geografia, ciências sociais e políticas, letras clássicas, português e línguas estrangeiras) e as ciências exatas (matemática, física, química e ciências naturais). Nas exatas o perfil discente era bem mais próximo das faculdades profissionais do que da própria seção de humanidades.

De modo geral, a FFCL ampliou as oportunidades de acesso ao ensino superior para segmentos que antes eram praticamente excluídos, tais como as mulheres e descendentes de imigrantes. Se o recrutamento por sexo nas faculdades profissionais continuou essencialmente favorável aos homens, na FFCL a situação foi diferente. De um modo geral, as faculdades profissionais constituíam universos predominantemente masculinos. A Politécnica não tem até 1946 qualquer registro de formatura de mulher. Na Faculdade de Direito, num universo de 982 bacharéis, apenas 24 eram mulheres. Na Medicina foram quatro mulheres em 341 diplomados. Na FFCL nas primeiras quatro turmas as mulheres corresponderam a $42 \%$ dos formandos. Esse alto índice é decorrência do comissionamento, modalidade pela qual ingressaram $70 \%$ das mulheres que se 
formaram nesse período. Nas humanidades o número de mulheres concluintes é ligeiramente superior ao de homens.

No que concerne aos imigrantes, também há considerações interessantes. Embora as faculdades profissionais não inquirissem a naturalidade dos pais dos alunos e a FFCL só o fizesse esporadicamente, mesmo assim, a partir dos sobrenomes, foi possível a Limongi (2001) verificar que no período considerado, na Faculdade de Direito, que já tinha mais de um século de existência, 15,5 \% dos formandos eram descendentes de imigrantes. Na Faculdade de Filosofia, em quase uma década, "é certo que no mínimo $13,4 \%$ do total de formandos pela FFCL tinham um dos pais estrangeiros". (Limongi, 2001, p.205). Indicando que a faculdade não ofereceu nenhuma restrição aos descendentes de imigrantes; "ao contrário, a FFCL esteve sempre aberta a filhos ou netos de imigrantes, oferecendo novas alternativas para que estes prosseguissem seus estudos e encontrassem condições de, por seu intermédio, percorrer um caminho de ascensão social”. (Limongi, 2001, p.206).

No que diz respeito aos significados dos diplomas concedidos pela FFCL, nota-se algumas tendências: para as normalistas foi a chance de obter um título e ampliar as chances de sucesso nas carreiras intelectuais; para os egressos do secundário, que possuíam ou não outra formação profissional, o diploma otimizava os investimentos anteriores na educação formal, e entre estes havia muitos atraídos e mantidos pela concessão de bolsas. E ainda, a carreira científica se mostrou um canal de mobilidade ascendente por um lado e por outro, refúgio para os setores ameaçados pelas transformações sociais em curso. "Alguns sobrenomes de ex-alunos - Eduardo d'Oliveira França, Ary França, Gilda de Moraes Rocha - que vieram a ser professores da FFCL, ilustram este último ponto (...)”. (Limongi, 2001, p. 204).

As perspectivas profissionais sinalizadas pela FFCL acabaram por ser o preenchimento de seus próprios quadros. Nas primeiras quatro turmas consideradas, até 1950, dos 187 formandos, 46 assumiram funções docentes na própria faculdade. Foi o caso, por exemplo, de João Cruz Costa, Mário Schemberg, Fernando Joaquim de Almeida, contratados um ano após a formatura. Além disso, muitos professores estrangeiros ao se retirarem do país tiveram suas cátedras assumidas por parcela significativa desses alunos, que de clientes, passaram a mentores da universidade e da FFCL. Apesar da grande proximidade entre as elites locais, mentoras do projeto da USP, e os docentes estrangeiros, as funções docentes das novas disciplinas foram parar nas mãos de mulheres e/ou descendentes de famílias de imigrantes. Muitas dessas famílias embora fossem abastadas, não possuíam tradição cultural junto a setores cultos dos grupos dirigentes:

Do total de 150 diplomados em ciências sociais pela Faculdade de Filosofia, Ciências e Letras da Universidade de São Paulo, nas 20 turmas formadas entre 1936 e 1955, 57\% eram mulheres e $38 \%$ eram moças e rapazes com nomes imigrantes, a maioria dos quais de origem italiana afora uns poucos de origem japonesa, espanhola e árabe. (Miceli, 2001, 
Miceli (2001) oferece uma rara descrição do perfil da universidade a partir de alguns sobrenomes. Considerando os estudantes de ciências sociais tanto da FFCL, quanto da Escola Livre de Sociologia e Política (ELSP), apresenta representantes da antiga comunidade judaica paulista: Levy, Schreiner, Loewenberg, Hamburger, Segall, Teperman, Farkas, Berezovsky, Beiguelmann, Feinberg, Lifchitz, Goldberg, Rosenberg, Berezin, que perfaziam cerca de 13 a $15 \%$ do total de licenciados. (Miceli, 2001, p.94). Os "brasileiros" diplomados nesses dois cursos geralmente pertenciam a "setores tradicionais empobrecidos, quase sempre do interior do estado, ou então de famílias ligadas ao magistério secundário, à burocracia estatal e ao desempenho de encargos intelectuais (imprensa, etc.)." (Miceli, 2001, p.95).

Outro era o perfil verificado nas faculdades profissionais. No curso de Direito, entre os anos de 1934 a 1939, havia apenas duas ou três alunas, algo como 1,5\% do total de bacharéis. Nos anos 1940 houve uma elevação, chegando à média de 3,5\% e na década seguinte, entre os anos de 1950 a 1955, à casa dos 8,5\%. Porém, dentre os descendentes de imigrantes, o curso de Direito apresenta uma distribuição semelhante aos dois cursos de ciências sociais: maioria de famílias de italianos, e na sequência árabes, judeus, etc. Nos anos 1930 registrava-se 15,5\% de presença de filhos de imigrantes. Na década seguinte houve um crescimento de dez pontos percentuais e no início dos anos 1950, manteve-se a progressão ascendente nessa direção. A recorrência de certos nomes entre os bacharéis da Faculdade de Direito, aponta o perfil social de sua clientela cativa. Sendo assim, constatou-se:

(...) o suprimento regular de quadros para as elites atuantes nos diversos ramos do judiciário e da magistratura, nos comandos políticos das áreas públicas de justiça, segurança e polícia (Gama e Silva, Alfredo Buzaid, Miguel Reale, Orlando Zancaner, Octávio Gonzaga Jr., Hely Lopes Meirelles, Hélio Bicudo, etc), nos escritórios e bancas de advocacia, e nas posições docentes e de criação intelectual no próprio ensino jurídico (Goffredo da Silva Telles, Rubens Cintra Gomes de Souza, Vicente Marotta Rangel etc.).” (Miceli, 2001, p.97)

Nesse período, a Faculdade de Direito também favoreceu a socialização de líderes políticos e profissionais, tais como: Franco Montoro, Jânio Quadros, Ulysses Guimarães, Abreu Sodré, Severo Gomes, Almino Afonso, Plínio de Arruda Sampaio, Chopin Tavares de Lima, Rogê Ferreira, etc.; outros "em convívio próximo com os herdeiros das elites econômicas": Aloysio Foz, Sebastião Paes de Almeida, Walter Moreira Salles, Gastão Eduardo de Bueno Vidigal, José Carlos de Moraes Abreu, Pedro Conde, Júlio de Mesquita Neto, etc. Entre os que possuem ascendência árabe estão as famílias Maluf, Mafud, Mussa, Ashcar, Eid, Atalla, Temer, Bussamra, Zarif, etc. Dentre as famílias judias: Mindlin, Goldstein, Kauffmann, Schwartzman, Frankental, Cherkasky, Tabacow, Zimmermann, Gorestein, Rotemberg, etc. (Miceli, 2001, p.97). Os bacharéis da 
Faculdade de Direito figuram ainda com louvor nas carreiras intelectuais não-científicas, especialmente as literárias: Domingos Carvalho da Silva, Miroel Silveira, Péricles Eugênio da Silva Ramos, Clóvis Garcia, Hilda Hilst, Renata Pallotini, etc. (p.98).

Comparando os cursos de Direito e Medicina, proporcionalmente o conjunto de judeus licenciados é menor do que nos cursos de ciências sociais da FFCL e da ELSP. O perfil de uma típica turma do curso de Medicina entre os anos de 1934 e 1939 era de 1,8\% de mulheres, ampliando para 5,4\% ao longo da década seguinte. Os descendentes de imigrantes estavam bem representados com média de 37\% (1934-1939) e 43\% entre os anos 1940-1949. Esses índices levam a crer que "a carreira médica constituía uma alavanca muito mais segura e ao alcance de grupos sociais emergentes do que a carreira em direito, estritamente dependente do cacife de relações acionáveis pelo círculo familiar”. (Miceli, 2001, p.98).

A expressiva presença feminina nas ciências sociais pode ser creditada a algumas características do mercado acadêmico em expansão. Muitas mulheres acabaram migrando para cursos como Pedagogia ou Psicologia. Mesmo assim, muitas construíram prestigiadas carreiras como cientistas sociais. Houve ainda uma considerável taxa de casamentos entre cientistas sociais dessa geração pioneira: Fernando Henrique Cardoso e Ruth Corrêa Leite Cardoso; Antonio Candido de Mello e Souza e Gilda de Mello e Souza; Dante Moreira Leite e Miriam Lifchitz Moreira Leite; Oliveiros da Silva Ferreira e Walnice Galvão; Renato Jardim Moreira e Maria Sylvia Carvallho Franco, etc. (Miceli, 2001, p. 100). Em termos gerais, a atração exercida pelas novas carreiras científicas decorria destas profissões:

(...) constituírem a oportunidade quase única, talvez pela primeira vez na história do país, de acesso a uma profissão intelectual cujos integrantes poderiam se lançar no mercado como detentores de uma oferta personalizada, com nome próprio e, por conseguinte, em condições de suscitar sua própria demanda. (Miceli, 2001, p.100)

Em face dessas discussões é interessante destacar que o projeto da USP foi concebido por um grupo de intelectuais em torno do jornal O Estado de S. Paulo, autodenominado "Comunhão Paulista Ilustrada". A consolidação da universidade foi decorrência do desencontro entre o projeto original, concebido por seus mentores e a progressiva profissionalização demandada por setores da sua base social de atendimento. Houve, portanto, "uma colisão entre o 'projeto iluminista' das elites locais e a irresistível profisssionalização de setores médios em ascensão social”. (Miceli, 2001, p.105). Foi justamente o gradativo esvaziamento do projeto inicial por grupos emergentes beneficiados pela expansão da universidade (sobretudo mulheres e imigrantes), que tornou a USP viável. E ao que tudo indica, o processo de integração da população imigrante na USP seguiu a mesma lógica de integração na sociedade de classe paulistana: com grande sucesso e assustadora vantagem sobre a população negra do estado. A novidade fica por conta da população feminina e 
branca, cuja entrada na USP torna-se um importante indicador da democratização da universidade.

Interessante observar que a bibliografia aqui evocada para apresentar os perfis dos mentores e das clientelas na USP esteve atenta a categorias como sexo, ascendência imigrante, origem sócio-econômica, segmentos oriundos de escolas públicas ou particulares, da capital ou interior do estado, modalidades de ingresso assim como à distribuição dessas categorias por curso nas faculdades profissionais ou na FFCL. Por sua vez, um perfil racial, mais próximo das categorias dos censos étnicos, não esteve em pauta. Uma decorrência disso é a dificuldade de encontrar bibliografia que considere a presença da população negra como clientela e quiçá mentora da Universidade de São Paulo. O insuficiente processo de integração da população negra na nova ordem capitalista brasileira foi analisado no âmbito da USP pela chamada Escola Paulista de Sociologia, cujas contribuições serão consideradas no próximo tópico. Apesar da ausência e ou invisibilização empírica de negros e negras, a institucionalização da sociologia na USP se fundamentou nas pesquisas sobre relações raciais no Brasil e ensejou outro momento de teorização e debates nesse campo. Alguns nomes foram fundamentais nesse processo, como o de Florestan Fernandes, que instituiu um fazer científico que se contrapôs em larga medida à proposta de Fernando de Azevedo. Assim, o novo olhar acadêmico e as novas interpretações para as relações raciais, são tema da próxima discussão.

\section{II-2. (Re) Configurações intelectuais e acadêmicas: notas sobre a sociologia paulista e a importância dos estudos sobre relações raciais.}

O legado da chamada Escola Paulista de Sociologia pode ser considerado a partir do grupo de sociólogos organizados em torno de Florestan Fernandes quando este assumiu a Cadeira de Sociologia I em 1954. De modo sucinto, o grupo produziu trabalhos próximos, tanto do ponto de vista temático, quanto teórico. Quando Florestan Fernandes torna-se catedrático, a disciplina assume novas disposições intelectuais e acadêmicas (Arruda, 1995). Comparada à cadeira de Sociologia II essas novidades se traduzem em concepções de universidade divergentes, pois apesar da origem comum, sob a regência de mestres franceses, as duas Cadeiras seguiram tendências bem distintas, segundo a tônica de seus dois regentes brasileiros: Florestan Fernandes (no período de 1954-1963) e Fernando de Azevedo (1943-1963), respectivamente (Pulici, 2008).

A biografia de Fernando de Azevedo por si só sustenta tradições de estudos sobre fatos e ideologias que marcaram a história da educação no Brasil, em São Paulo e na USP especificamente, ao longo de pelo menos cinco décadas de produção política e acadêmica. Cauvilla (1997) o aponta como maior ideólogo do movimento dos "pioneiros da educação nova", ao qual a criação da USP está atrelada. Como vimos, Fernando de Azevedo, como membro do chamado "Grupo do Estado", 
que girava em torno de Júlio Mesquita Filho, um dos donos do jornal O Estado de S. Paulo, foi o principal idealizador da universidade da comunhão paulista. Além de fundamental na concepção da USP, sua obra marca também a institucionalização da Sociologia como disciplina acadêmica no Brasil:

(..) é importante marcar o papel essencial exercido por Fernando Azevedo na construção do espaço acadêmico da Sociologia em São Paulo. (...) Fernando Azevedo foi o primeiro catedrático brasileiro da disciplina na Faculdade de Filosofia e foi responsável pela contratação de figuras proeminentes, tais como Antonio Candido, Aziz Simão, Florestan Fernandes. (Arruda, 1995, p.146).

Fernando de Azevedo esteve mais próximo do padrão intelectual que vigorou na República Velha, embora nos anos de 1950 tenha defendido um humanismo novo em prol de currículos modernos de base técnica e científica. Tradicionalmente esteve associado à imagem de um intelectual de preocupações teóricas, conforme sua formação humanística clássica. Sua orientação acadêmica foi baseada em princípios distantes do modelo de trabalhador intelectual preconizado na Cadeira de Sociologia I por Florestan Fernandes. Por sua vez, Florestan e discípulos se opunham a um ensino livresco, que dispensava investigações empíricas sistemáticas; entendia que um ensino humanístico não favorecia a aceitação plena de valores nacionais e fomentava complexos, ressentimentos e inseguranças diante das ditas nações cultas. Assim, apostava num padrão de trabalho científico competitivo para melhor proveito de méritos próprios. Apesar de Florestan Fernandes ter sido assistente de cátedra de Fernando de Azevedo na Cadeira de Sociologia II, ambos polarizaram tendências que reverberaram nas Cadeiras de Sociologia que regeram:

(...) enquanto o grupo de Florestan inclina-se mais e mais à profissionalização do trabalho acadêmico e aos estudos da Sociologia aplicada, os veteranos da Cadeira de Sociologia II, por seu turno, gostam de ser reconhecidos numa atitude "desinteressada" em todos os sentidos, ou seja, tanto do ponto de vista da progressão na carreira quanto das visões a respeito do ensino universitário. (Pulici, 2008, p. 89)

A Cadeira de Sociologia II tradicionalmente congregou quem já possuía raízes anteriores no mundo das letras e das artes, versados num universo cosmopolita. Relatos de antigos alunos da universidade, que posteriormente construíram carreira como docentes da USP, apontam que ter aulas com os professores europeus, muitas vezes em idioma estrangeiro, era também um indicador de distinção na sociedade paulistana da época ${ }^{21}$. Em suas memórias sobre os tempos de

21Em 1994, por ocasião dos sessenta anos da universidade, a revista Estudos Avançados publicou uma edição especial comemorativa. Nas seções "Depoimentos" e "Perfis de Mestres" pesam consideravelmente as memórias de antigos alunos dos professores da missão estrangeira. Vide por exemplo, os relatos de Fernando Novais sobre Fernand Braudel, Henrique Fleming sobre Gleb Wataghin; Erasmo Garcia Mendes sobre Ernest Marcus, Maria Isaura Pereira de Queiróz sobre Roger Bastide, dentre outros. 
graduação, trazendo críticas sobre as relações que se estabeleciam entre os alunos e os professores estrangeiros, Florestan indica que:

(...) a questão era ter acesso aos professores fora dos contactos formais das salas de aula. Eu não sabia como conseguir isso e, o pior, não era capaz de falar francês ou italiano. Como também não possuía um nome de família, eu desaparecia no pequeno número, como se estivesse perdido em uma massa enorme de estudantes (Fernandes, 1994, p. 131).

A Cadeira de Sociologia I foi a porta que se mostrou mais aberta a grupos marcados pela diferença, como os descendentes de famílias estrangeiras, cuja presença na universidade era indício da sua democratização, mesmo sendo abastadas. É possível encontrar nas duas cadeiras sociólogos de perfis sociais os mais distintos, mas é na Cadeira de Sociologia I que estão “os grandes 'oblatos', ou seja, os intelectuais que devem tudo que são à Faculdade de Filosofia" (Pulici, 2001, p.143). A oposição a um ideal de saber desinteressado presente no projeto inicial, e a aposta na construção de uma carreira a partir da eficiência acadêmica independente da herança cultural anterior à universidade, fez do grupo sob a orientação de Florestan Fernandes, a típica "nova elite" intelectual, reconfigurando o projeto inicial idealizado pelas elites paulistas. (Pulici, 2001, p. 151)

Florestan Fernandes destoava radicalmente dos seus colegas em termos de origem social, pois não teve acesso ao mesmo patrimônio de cultura erudita que eles compartilhavam. Este fato ajuda a explicar porque Florestan elegeu a Sociologia como sua seara, de modo que a biografia do autor informa também suas preocupações analíticas, e a dedicação ao trabalho acadêmico possui raízes em questões de ordem material, de simples sobrevivência (Arruda,1995). Sua aposta na Sociologia o aproxima de Durkheim, que na França desempenhou a mesma função de "assentar as bases da Sociologia acadêmica" (Arruda, 1995, p.144). De modo semelhante à experiência francesa, enfatizou a teoria impondo novos padrões de concepção e transmissão das obras, criando o molde acadêmico de reflexão e rompendo com o passado. De modo diferente dos chamados "intérpretes do Brasil", mais preocupados com os "fundamentos da sociedade" brasileira, os "sociólogos paulistas buscam apreender as relações entre certos fenômenos e o contexto abrangente" (Arruda, 1995, p.132). Os sociólogos paulistas propõem a superação de uma produção ensaística, mais característica dos intérpretes, optando por novas regras e valores do cânone científico.

Para Florestan, nos anos 1940 e 1950, o fundamental era construir a Sociologia como ciência empírica. Mas a Sociologia proposta por Florestan não está alheia a orientações pragmáticas. À medida que consolidava sua trajetória intelectual, acontecia também certa guinada no sentido de buscar foros de ação mais amplos para a disciplina, sem descuidar dos propósitos iniciais. Ele "claramente adere à importância do conhecimento científico para aprimorar a sociedade" (Arruda, 1995, p.163), colocando assim, ao sociólogo, a tarefa de responder aos desafios do mundo moderno, mesmo considerando que os modos de intervenção deveriam acontecer dentro 
da tradição sociológica ${ }^{22}$.

A obra A integração do negro na sociedade de classes, tese apresentada em 1964 para professor titular da cadeira de Sociologia I, é apontada por Arruda (1995) como um marco na trajetória intelectual de Florestan não apenas com relação aos estudos das relações raciais, mas também quanto ao amadurecimento do autor nas suas reflexões sobre a sociedade brasileira. Para Guimarães (2009) Florestan Fernandes teria cristalizado como propriamente brasileira a problemática sociológica das relações raciais. Embora não tenha sido o único na construção dessa nova agenda, chamou a atenção para aspectos discutíveis no campo das relações raciais, o que antes era visto como solucionado em termos de democracia racial. Além disso, foi também muito bem sucedido ao propor uma agenda de pesquisa que considerasse tanto as aspirações dos intelectuais nacionalistas, quanto as reivindicações dos intelectuais negros, as aspirações por igualdade social e desenvolvimento. Dessa maneira, tal agenda transformou o estudo das relações raciais no Brasil nos anos 1950 e 1960.

Sob a batuta de Florestan, a Escola Paulista de Sociologia apresentou outras singularidades no cenário nacional. Num contexto de disputa ideológica sobre a existência ou não de preconceito racial no Brasil, dúvida gerada pela ampla disseminação e aceitação do caráter supostamente democrático das relações raciais no país, a Escola Paulista indicava que para a elite paulista, "a mestiçagem nunca fora um valor" (Guimarães, 2009, p.87). A razão para isso era de ordem demográfica, pois São Paulo foi o estado de maior presença imigrante europeia no começo do século, sinalizando como nenhum outro estado, adesão ao ideal de branqueamento. Este dado empírico não podia ser negado nem pelas elites paulistas, nem pelos sociólogos. Assim, a democracia racial seria mais resultado da "ordem social competitiva e do modo racional burocrático de dominação, próprios do capitalismo burguês" (Guimarães, 2009, p.88). Antes de ser realidade, tal democracia seria uma meta, um ideal. Assim, Florestan Fernandes não teria visto restrição à possibilidade de nomear como preconceito de cor as barreiras impostas aos homens e mulheres de cor, constatadas nas suas pesquisas. Na sua interpretação, tais discriminações só demonstravam o quanto o avanço da ordem social competitiva e a democracia eram obstruídos.

Tal posicionamento o aproximou dos militantes e intelectuais negros, ampliando o reconhecimento da sua obra, pois Florestan Fernandes justificou em termos teóricos a existência do preconceito, apontando qual seria a função que desempenharia. A resposta encontrada, na interpretação de Guimarães (2009), foi enfática na responsabilização das elites brancas por seu papel na ordem social competitiva emergente:

22Conforme indica Arruda (1995) o afastamento compulsório de Florestan da universidade em 1969 atinge seriamente suas convicções sobre as possibilidades da Sociologia em termos de responsabilidades intelectual e política. Cada vez mais assume o perfil do publicista, numa atividade política que lhe exigia, porém, as qualidades de intelectual militante, que teve por consequência um papel atuante e renovado para o intelectual. 
(...) o preconceito no Brasil seria uma reação das elites brancas (e não do povo) às novas relações sociais, próprias à ordem social competitiva. A potencialidade revolucionária dos negros estaria justamente em livrar a sociedade burguesa emergente das amarras e dos privilégios e das desigualdades da ordem patrimonial. (Guimarães, 2009, p.92).

A revolução burguesa posta a cabo pelo "negro revoltado" completaria o serviço inacabado das novas elites brancas. A imperfeição da revolução burguesa seria ainda a explicação para a persistência do passado, da ordem racial negada nas representações burguesas e reafirmada nos seus atos, resultando na transformação do ideal da democracia racial em um mito. (Guimarães, 2009, p. 93).

Além da proposição de novidades no campo de pesquisa e interpretação das relações raciais brasileiras, Florestan Fernandes não era o único sociólogo apontando os limites da revolução burguesa no Brasil, os processos de modernização e industrialização brasileiros e propondo um projeto de Sociologia brasileira. Interessa aqui destacar um outro importante nome que emerge nesse cenário: Alberto Guerreiro Ramos, sociólogo negro, baiano nascido em Santo Amaro da Purificação em 1915, que fez carreira intelectual no Rio de Janeiro e Estados Unidos, também levantou e delineou questões que se desdobraram no seio da Sociologia brasileira. Martins (2009) analisa o debate entre Florestan e Guerreiro nos anos 1950 e 1960, destacando as divergências sobre os fundamentos de uma Sociologia no e do Brasil, bem como as disputas na definição e orientação de um projeto político de desenvolvimento nacional.

A análise da produção sociológica de Guerreiro Ramos é proposta por Oliveira (1995), considerando desde a trajetória do autor, a geração intelectual à qual pertence, suas heranças e renúncias sociológicas, bem como o seu legado. A autora confronta os padrões sociológicos estabelecidos por Florestan e Guerreiro, indicando que, ao contrário de Florestan, Guerreiro ${ }^{23}$ não partilhava da crença no modelo francês de ciência positiva expressa na Sociologia de Durkheim. Mas 'o pomo da discórdia' entre os autores "se encontra na questão referente ao transplante cultural" (Oliveira, 1995, p. 94), acusação que Guerreiro faz ao modo como Florestan se apropria da teoria

23Reconhecendo que a Sociologia como método de pensar os fatos corretamente é uma ciência universal, Guerreiro Ramos (1995) ressalta, porém, a juventude da disciplina no plano realmente científico, pois de início, a Sociologia "estava fortemente afetada de etnocentrismo" (Ramos, 1995, 44). Para o autor, o caráter universal da Sociologia não a impede de se diferenciar nacionalmente, sobretudo no que diz respeito aos temas e problemas que enfrenta. A autenticidade da Sociologia no Brasil passa pela construção da autoconsciência nacional: “A Sociologia, no Brasil, será autêntica na medida que colaborar para a autoconsciência nacional, na medida que ganhar em funcionalidade, intencionalidade e, consequentemente, em organicidade. (...) Em resumo, sem a disposição para empreender a sua autocrítica, a Sociologia no Brasil não poderá realizar a sua tarefa essencial - a de tornar-se uma teoria militante da própria realidade nacional." (Ramos, 1995, p.45). E além de criticar o caráter "enlatado" da Sociologia brasileira, expressa na academia, Guerreiro problematiza também outra versão da disciplina, “"em mangas de camisa', presente no exercício de atividades executivas e de aconselhamento". (Oliveira, 1995, p. 99). Em entrevista a Oliveira (1995) Guerreiro Ramos elege Max Weber " a influência mais poderosa desde os anos 40 até hoje, em termos da minha profissão de homem de ciência social.” (Oliveira, 1995, p. 144) 
sociológica para pensar questões brasileiras. Seria essa a principal via para acompanhar as divergências entre os autores. Guerreiro Ramos credita a Fernando de Azevedo a "conquista da categoria universitária para a Sociologia" no país. E embora admita que Florestan Fernandes seja "bem representativo da experiência universitária paulista, seu símbolo vivo", com uma carreira transcorrida "dentro dos trâmites universitários mais rigorosos", sua contribuição teórica poderia até introduzir o Brasil no "clássico universal", porém no campo da Antropologia ${ }^{24}$. (Ramos, apud Oliveira, 1995, p. 96-97).

A disputa entre os autores se estende aos estudos sobre relações raciais no Brasil, existindo entre eles uma grande e fundamental discordância. Guerreiro não deixou de fazer "críticas contundentes aos estudos produzidos sobre o tema, demarcando diversas vezes o seu descontentamento com o que estava sendo produzido". (Figueiredo \& Grosfogel, 2007, p. 39). Crítico mordaz do fato de a vida do negro ser amplamente analisada por pesquisadores na sua totalidade brancos, na perspectiva do "problema do negro", Guerreiro Ramos faz importante distinção entre "negro tema" e "negro vida". Em texto intitulado O problema do negro, o autor propõe uma "história sincera dos estudos sobre o negro no Brasil", indicando três correntes fundamentais: uma fundada por Sylvio Romero com continuidade em Euclides da Cunha, Alberto Torres e Oliveira Viana, que "se caracteriza pela atitude crítico-assimilativa dos seus epígonos, em face da ciência social estrangeira". A segunda corrente, fundada por Nina Rodrigues teria sequência nas obras de Arthur Ramos, Gilberto Freyre "e de seus imitadores" pode ser chamada "monográfica" e se caracteriza pelo fato de que o "elemento negro se torna 'assunto', tema de especialistas, cujos estudos pormenorizados promoveram, entre nós, movimento de atenção de uma parcela de cidadãos para os chamados afro-brasileiros". A terceira corrente se configura "sob a forma de comportamentos mais que sob a forma de escritos" e "caracteriza-se pelo propósito antes de transformar a condição humana do negro na sociedade brasileira do que descrever ou interpretar aspectos pitorescos e particularíssimos da situação de gente de cor”. (Ramos, 1995, p. 168-169).

Sendo assim, Guerreiro Ramos propõe a distinção entre o negro tema e o negro vida, que seria:

\footnotetext{
O negro-tema é uma coisa examinada, olhada, vista, ora como ser mumificado, ora como ser curioso, ou de qualquer modo como um risco, um traço da nacionalidade que chama a atenção. O negro-vida é, entretanto, algo que não se deixa imobilizar; é despistador, proteico, multiforme, do qual, na verdade, não se pode dar versão definitiva, pois é hoje o que não era ontem e será amanhã o que não é hoje. (Ramos, 1995, p. 215).
}

24Conforme indica Mariza Peirano (1982) Florestan Fernandes teve uma fase marcadamente antropológica exemplificada pelos seus estudos sobre a sociedade Tupinambá. 
Criticando a perspectiva de estudos sob o viés do "problema do negro" Guerreiro Ramos indica que, no âmbito da Sociologia brasileira, o negro tem sido encarado como problema num primeiro momento por portar "traços culturais vinculados a culturas africanas", e posteriormente "porque tende a confundir-se pela cultura com camadas mais claras da população brasileira". O autor lança o seguinte questionamento: "Que é que, no domínio de nossas ciências sociais, faz do negro um problema, ou um assunto? A partir de que norma, de que padrão, de que valor, se define como problemático ou se considera tema o negro no Brasil?" (Ramos, 1995, p. 190). Para responder à questão, Guerreiro Ramos traz para o centro do debate a imposição de normas e ideais de brancura à sociedade brasileira decorrentes da transplantação de um etnocentrismo europeu:

Nestas condições, o que parece justificar a insistência com que se considera como problemática a situação do negro no Brasil é o fato de que ele é portador de pele escura. A cor da pele do negro parece constituir o obstáculo, a anormalidade a sanar. Dir-se-ia que na cultura brasileira o branco é o ideal, a norma, o valor, por excelência. (Ramos, 1995, p. 192).

Disso decorrem processos de patologização da sociedade brasileira em vários níveis: os negros brasileiros, assim como outros negros no mundo que passaram pelo processo de europeização, estão passíveis de desenvolver um “desvio existencial” (Ramos, 1995, p. 195) caracterizado por detestar ou mesmo negar sua condição racial. Quanto ao segmento branco da população, o autor dedica um capítulo à análise da patologia social do "branco" brasileiro, em que ele se admitiria mais branco do que realmente seria. Para Guerreiro Ramos até o fazer científico no Brasil padece de afecções, pois o "'problema' de nossa ciência social é uma alienação, uma forma mórbida de psicologia coletiva.” (Ramos, 1995, p. 196). Assim, a partir do momento em que o negro fosse entendido como normal no seio da população brasileira, não um elemento estranho na demografia, seria possível perceber que de fato, “o negro é o povo, no Brasil”. (Ramos, 1995, p. 200).

A originalidade do pensamento de Guerreiro Ramos no campo de estudos das relações raciais brasileiras pode ser compreendida, segundo Barbosa (2006), a partir de duas tradições filosóficas que marcam sua trajetória: a negritude francófona, sartriana, sobretudo, que lhe foi apresentada no Teatro Experimental do Negro (TEN); e a herança filosófica personalista e existencialista, que marcou também sua visão teórica e política ${ }^{25}$. De fato, a produção de Guerreiro 
Ramos pode afirmá-lo como um dos maiores sociólogos do país, num momento de institucionalização da disciplina no Brasil. Assim, na história da institucionalização da disciplina no país, é possível pensar na possibilidade de apostas que cercam o fazer científico, tal como indica Bourdieu (2011):

Se a cientificidade socialmente reconhecida é uma aposta tão importante é porque, embora não haja uma força intrínseca da verdade, há uma força da crença na verdade, da crença que produz a aparência da verdade: na luta das representações, a representação socialmente reconhecida como científica, isto é, como verdadeira, contém uma força social própria e, quando se trata do mundo social, a ciência dá ao que detém, ou que aparenta detê-la, o monopólio do ponto de vista legítimo, da previsão autoverificadora. (Bourdieu, 2011, p. 53)

Pesquisas como a de Oliveira (1995) e Martins (2008) propõem analisar comparativamente as contribuições de Guerreiro Ramos e Florestan Fernandes para a construção da Sociologia brasileira. E diante da consagração de Florestan Fernandes como um dos fundadores da Sociologia na universidade brasileira, Figueiredo \& Grosfogel (2007) questionam: Por que não Guerreiro Ramos? Tentando compreender este processo de marginalização no meio acadêmico brasileiro, relembram hipóteses levantadas por outros autores como Oliveira (1995) que aponta para o fato de Guerreiro ter problematizado os cânones das ciências sociais brasileiras; e Chor Maio (1997) que destaca o fato de Guerreiro ter sido integralista. Mas conforme apontam os autores, "outros importantes nomes, a exemplo de Dom Helder Câmara e Alceu Amoroso Lima, também foram envolvidos com o integralismo e conseguiram desvincular seus nomes dessas experiências" (Figueiredo \& Grosfogel, 2007, p. 39). A identificação com um posicionamento político de extrema direita permaneceu como estigma na trajetória de Guerreiro, desconsiderando sua formulação de projetos e discursos que o aproximavam da esquerda predominante nos anos 1950 e 1960, conforme analisa Martins (2009). Para a autora esse é um aspecto que aproxima Guerreiro Ramos e Florestan Fernandes:

(...) os próprios autores procuram se situar em relação à esquerda, o que revela a importância dessa perspectiva, sobretudo na passagem para a década de 1960. Guerreiro Ramos associa o projeto de emancipação nacional nos moldes por ele desenvolvidos como legítimo representante dos interesses populares, estabelecendo debates e críticas ao PCB e ao PTB. Florestan Fernandes por sua vez, aproxima sua proposta de Planejamento Democrático de um projeto Socialista na medida em que é entendido como caminho para passagem de uma ordem burguesa para aquele modelo. (Martins, 2009, p. 8)

Aparece ainda como explicação a polêmica e controversa personalidade de Guerreiro Ramos e sua disposição para "embates teóricos e políticos não muito frequentes na academia branca brasileira. Guerreiro tem uma forma de fazer ciência e de produzir conhecimento que vai de encontro aos moldes hegemônicos, que se contrapõe à nossa propalada cordialidade”. (Ibidem).

Ramos se estende também à construção de um pensamento anti-racista, bem como pós-colonial, que o aproxima de autores importantes dessa seara, como Franz Fanon e Homi Bhaba. 
Figueiredo \& Grosfogel (2007) sugerem que a marginalização de Guerreiro Ramos na academia brasileira, por mais plausível que seja este conjunto de explicações, não pode esquivar-se do fato dele ser negro num contexto de poucos negros nas universidades. É nessa chave que os autores compreendem o fato de Guerreiro Ramos não ter sido convidado para participar do Projeto UNESCO, ter sido duas vezes preterido em concurso para docente em universidades públicas e ainda ter assumido o cargo de técnico em administração em 1943, no Departamento do Serviço Público (DASP) quando já tinha formação que o habilitava a ser professor acadêmico.

E Guerreiro Ramos reconhece que o Brasil não lhe deu o devido reconhecimento:

Eu acho que o Brasil não me deu o que eu mereço. Quando fui cassado, a minha ficha na comissão de inquérito do Conselho de Segurança começava assim: "Alberto Guerreiro Ramos: mulato metido a sociólogo". Palavra de honra: "metido a sociólogo". É a minha ficha no exército. Eu olhei para o coronel e disse: "Cadê a ficha do Afonso Arinos?" Ele me deu a ficha do Afonso Arinos e eu disse: "Mas seu coronel, não tem a cor do Afonso Arinos! Por que é que na ficha que o Exército brasileiro fez de mim tem a minha cor? E depois tem esse negócio: metido a sociólogo. Eu não sou metido a sociólogo. Eu sou um dos maiores sociólogos do mundo”. Está lá na minha ficha. (Ramos apud Oliveira, 1995, p.162).

Embora a carreira intelectual de Guerreiro Ramos não tenha sido construída na USP, interessa destacar que foi construída também de forma tangencial à USP. A frequente comparação de sua obra à de Florestan Fernandes dá indícios suficientes disso. Há ainda outra questão que merece ser considerada: Guerreiro Ramos viveu mais de quinze anos nos Estados Unidos, onde faleceu em 1982. Sua carreira de docente universitário aconteceu lá, mas isso não lhe abriu as portas das universidades no Brasil, muito menos o levou a ser incluído na Escola Paulista de Sociologia que se fez na USP, sob a regência de Florestan Fernandes. Segundo Oliveira (1995) os dois estabeleceram discussões públicas a respeito de suas perspectivas analíticas. Embora ciente do não reconhecimento da academia brasileira, Guerreiro Ramos considerava-se um homem realizado, e quando questionado se teve nos Estados Unidos o reconhecimento que não teve no Brasil, compreendia que:

\footnotetext{
Reconhecimento não é o caso. Eu sou uma pessoa considerada no Brasil. Eminente, membro da comunidade acadêmica da minha profissão. Sou uma pessoa de quem as pessoas falam, estou nos compêndios como um inovador, pacificamente. Hoje, a minha ascensão como teórico nos Estados Unidos é uma beleza. (...) Já visitei todas as grandes universidades americanas: Harvard, Berkeley, Stanford... Que universidades eu visitava antes? São Paulo não me deixava entrar... [grifos meus] (Ramos apud Oliveira, 1995, p. 176).
}

Por que retomar Guerreiro Ramos para considerar a trajetória da Sociologia na USP? É necessário pontuar que o sucesso do projeto de Sociologia acadêmica proposto por Florestan Fernandes, do qual intelectuais negros da USP, como por exemplo, Kabengele Munanga, são herdeiros na Antropologia, a partir da década de 1970, foi disputado décadas antes também por 
Guerreiro Ramos, importante intelectual negro e brasileiro. Contemporâneo de Florestan Fernandes no debate da institucionalização da Sociologia no Brasil, Guerreiro Ramos esteve interessado na sociologia de São Paulo. Mas nos anos de 1950 e 1960 aventurar-se nessa seara significou buscar guarida na Faculdade de Filosofia Ciências e Letras ou na Escola Livre de Sociologia e Política, instituições que foram profundamente marcadas pela atuação de Florestan Fernandes. Sendo públicas as desavenças entre Guerreiro Ramos e Florestan Fernandes, a possibilidade de Guerreiro Ramos entrar na FFCL ou na ELSP foi cerceada.

Assim, vale indicar uma consequência problemática dessa disputa: se por um lado o trabalho de Florestan Fernandes na institucionalização da Sociologia foi fundamental para o debate e a pesquisa no campo das relações raciais, abrindo algumas portas para os intelectuais negros, por outro lado, durante o processo, outras portas podem ter sido fechadas para intelectuais negros. Ironicamente, as portas que Florestan Fernandes ajudou a abrir posteriormente para Kabengele Munanga na Antropologia na USP estiveram fechadas na Sociologia para Guerreiro Ramos, seu contemporâneo e importante interlocutor. Obviamente não se trata aqui de desprezar toda a simpatia e solidariedade que Florestan Fernandes endereçou aos oprimidos, excluídos e desprivilegiados de toda ordem. É deveras conhecido que Florestan Fernandes nunca escondeu sua humilde origem social, fator que o fez sensível às desigualdades raciais brasileiras. Mas torna-se necessário encarar alguns dilemas e contradições inerentes ao fazer acadêmico, dos quais nem Florestan Fernandes passou incólume. Seria interessante também considerar qual foi a relação que Florestan Fernandes estabeleceu com a parcela da população negra com quem trabalhou durante suas pesquisas. É fato que reconheceu a importância dos ativistas negros para o conjunto de trabalhos que realizou ao longo da vida sobre a temática, o que está registrado em seus escritos:

\begin{abstract}
A colaboração do negro e do mulato foi maciça: nos seminários contávamos com uma afluência média de 130 ou 150 pessoas. Nessa massa selecionamos intelectuais negros, para entrevistas em grupo focalizadas; mulheres com maior consciência do "problema negro", para seminários e entrevistas focalizadas; e sujeitos para história de vida e entrevistas formais ou informais, de caráter pessoal. A colaboração do branco se deu através da assistência de um grande número de estudantes de sociologia da Universidade de São Paulo, de assistentes e auxiliares de ensino da cadeira de Sociologia I, e de pessoas que ocupavam posições-chaves em diversos tipos de instituições, através das quais as "linhas de cor" definiam sua vitalidade e funções, selecionadas para entrevistas formais e informais. (Fernandes, 2010:98)
\end{abstract}

Florestan Fernandes define os sujeitos que colaboraram com sua pesquisa em termos raciais como negros, mulatos e brancos. No grupo dos negros e mulatos estão os intelectuais negros (homens) e mulheres com consciência do "problema negro". No grupo dos brancos estão sociólogos e pessoas de diversas instituições em posições chave. Apesar de nomear alguns homens negros como intelectuais, Florestan Fernandes estava falando de negros ativistas, literatos, jornalistas e de 
setores médios negros e não de acadêmicos negros. Além disso, as mulheres negras parecem estar fora da classificação de intelectuais. Desse modo, é possível perceber que o diálogo com intelectuais negros que interessava a Florestan Fernandes parece ser mais com aqueles que estavam fora da universidade brasileira, ainda que possuíssem formação superior ${ }^{26}$. No que diz respeito ao intelectual negro da academia, a exemplo de Guerreiro Ramos, com quem Florestan Fernandes poderia dialogar enquanto sociólogo e pesquisador, a relação não se efetivou.

Interessante ressaltar que Guerreiro Ramos não era o único intelectual negro no campo das ciências sociais apto à docência na USP desde os anos 1950 e dela ausente, pois além dele havia, por exemplo, Virgínia Leone Bicudo27, cuja trajetória será considerada com mais detalhes no capítulo cinco. A questão que permanece é por que somente a partir dos anos 1980, com Kabengele Munanga e, posteriormente, Milton Santos, torna-se possível a presença de docentes negros na Faculdade de Filosofia da USP? O próximo tópico desse trabalho analisa a entrada de Kabengele Munanga na Faculdade desde a condição de aluno, considerando o contexto de pesquisas sobre relações raciais na Sociologia e na Antropologia, sobretudo a inflexão da temática na Sociologia.

\footnotetext{
26A natureza das relações estabelecidas entre pesquisadores da academia paulista e setores negros é também analisada por Silva (2011) que aponta para uma "ligação que congrega interesses analíticos e políticos, postura ética, método científico e trajetórias particulares que permite, em São Paulo, o decisivo sucesso da pesquisa sobre as relações sociais racializadas, fazendo dela um marco da Sociologia Brasileira" (Silva, 2011:153). De modo que em São Paulo, o "encontro na encruzilhada social" entre ativistas negros e pesquisadores "foi promissor" (Ibidem), a despeito de algumas distâncias que persistiram, tais como o lugar dos pesquisadores (brancos) e o dos sujeitos (negros). Essa distância chegou a ser questionada por um sujeito da pesquisa, o doutor Edgar Santana, que não queria ser apenas um "pesquisado", pois tinha condições de ser "pesquisador" também. (Leite \& Cuti, 1992, p. 153).
}

27Virginia Leone Bicudo (1915-2003), cuja trajetória será melhor considerada no quinto capítulo foi educadora sanitarista, socióloga e psicanalista, dentre outras profissões. Foi a primeira mulher negra a fazer pós-graduação no Brasil em Sociologia, com pesquisas sobre relações raciais. O que importa destacar aqui, é que se Guerreiro Ramos não conseguiu estabelecer diálogos teóricos no campo da Sociologia com Florestan Fernandes, conseguiu estabelecer com Virginia Bicudo. Damaceno (2013) aponta para o conjunto de proximidades entre ambos: "Virgínia e Guerreiro guardam grandes afinidades: infância, puericultura, questões raciais, psicanálise, sociologia aplicada: para ele "democracia era engenharia social". Mas de um modo distinto de Virgínia, Guerreiro era um sociólogo engajado, tendo participado ativamente da militância negra entre os anos de 1948 a 1955. Pelo Instituto Nacional do Negro montou, em 1949, seminários de grupoterapia - terapêutica emocional de base sociológica - que visava o desenvolvimento da personalidade da "gente de cor". A ideia de intervir na personalidade do negro para combater o complexo de inferioridade era muito afim do trabalho de Virgínia." (Damaceno, 2013, p.118). E do mesmo modo que Guerreiro Ramos, a relação de Virginia Bicudo e Florestan Fernandes (como será discutido no capítulo V) também foi marcada por controvérsias. Virginia Bicudo, que adiantou em dez anos algumas conclusões as quais Florestan Fernandes chegaria nos anos 1950 e 1960, esteve na equipe do Projeto UNESCO, porém seu nome e trabalhos foram retirados da ultima versão publicada do relatório da pesquisa da UNESCO, como se verá mais adiante nesta pesquisa. 


\section{Capítulo III - História de um debate - terceira parte: Um Herdeiro bastardo? Notas sobre a Antropologia na USP e a emergência de novos estudos sobre relações raciais e a herança do Professor Kabengele Munanga}

Na trajetória da pesquisa na Sociologia na USP, no decorrer da década de 1950, prevaleceu uma vertente de investigações focada nos estudos sobre relações raciais, a partir do projeto de Roger Bastide e Florestan Fernandes. Em torno das questões referentes ao negro, Florestan orientou uma série de importantes trabalhos, de autores tais como Fernando Henrique Cardoso, Octávio Ianni, Maria Sylvia de Carvalho Franco, Juarez Rubens Brandão Lopes, trabalhos estes defendidos na primeira metade da década de 1960. No entanto, nesta década já despontavam outras características que marcaram a produção dessa segunda geração de sociólogos na USP, apesar de algumas persistências. O forte registro dessa segunda geração de sociólogos diz respeito à preocupação em torno da mudança social e da estruturação da sociedade de classes (Arruda, 1994).

A segunda metade da década de 1960 é marcada pelo desinteresse de pesquisas que tematizassem a questão racial negra. Dentre os fatores possíveis para explicar o esvaziamento do tema na chamada Escola de Sociologia Paulista, que revolucionara os estudos sobre o assunto, estão:

\footnotetext{
Roger Bastide retornara à França; Florestan Fernandes, o grande líder da escola, após o término de sua tese (que levara vinte anos para ser concluída), não aceitava nem mesmo orientar pesquisas sobre a questão; e seus assistentes - Octavio Ianni e Fernando Henrique Cardoso -, depois de suas respectivas pesquisas sobre a Região Sul do país, também se desinteressaram do tema. Todos pareciam tomados pelos "grandes dilemas e desafios" da sociedade brasileira: classes trabalhadoras, revisão da educação formal, industrialização, urbanização... Dentro dessa perspectiva "macro" o interesse pelo negro (ou acerca do preconceito), quando existia, parecia residual e subsumido a um problema maior explicado pelo conflito social, político e intraclasses. (Schwarcz, 2006, p.171)
}

Verifica-se, sobretudo a partir da década de 1970 um recuo das pesquisas clássicas da Sociologia uspiana referentes à temática, e a emergência de novos interesses de investigação. É nesse contexto que novos estudos ganham vulto fora da sociologia da USP, como os de Carlos Hasenbalg e Nelson do Valle e Silva ou mesmo os de João Batista Borges Pereira na Antropologia da USP, oferecendo releituras das teses da sociologia clássica. De um modo geral, ao final da década de 1970 pouco se escrevia ou publicava sobre relações raciais no país. Segundo Hasenbalg (1998) a sociologia das relações raciais era um tema marginal no cenário das ciências sociais:

Há vinte anos, eram muito poucas as pessoas trabalhando esse tema. Eu tive medo de publicar o meu livro em 1979. Dez anos antes, Florestan Fernandes tinha sido expulso da USP, aposentado compulsoriamente. Durante esse período, não se falou nada no país sobre relações raciais. Depois que Florestan publicou "A integração do negro na sociedade de classes", em 1965, e, em 72, "O negro no mundo dos brancos", a produção na ótica sociológica era ínfima, e as condições políticas não eram propícias. A Antropologia, sim, continuou estudando o candomblé, a umbanda, que não eram coisas tão 'perigosas' (Hasenbalg 1998, p. 36). 
Assim, o recuo das pesquisas sobre a temática racial na Sociologia da USP não significou o desaparecimento do tema na universidade, havendo uma migração para a Antropologia e mudanças de enfoque.

$* * * * * * * * * * * * * * *$

Em termos históricos, a Antropologia na USP existe como disciplina ministrada de modo intermitente desde 1936, e passa a ser lecionada obrigatoriamente nos cursos de Ciências Sociais, Geografia e História a partir de 1941. A história da institucionalização da disciplina destaca o nome de dois professores: Emilio Willems e Egon Shaden. O primeiro era imigrante alemão formado em Economia na Alemanha e que chega à USP pelas mãos de Fernando de Azevedo. A Antropologia sob a condução de Willems tornar-se disciplina obrigatória em 1941 e em 1947 é instituída a especialização em Antropologia, Sociologia e Ciência Política. Em 1948 de disciplina obrigatória a Antropologia passa a ser a Cadeira de número 49. Tendo Florestan Fernandes como um de seus assistentes, Emilio Willems realiza o primeiro estudo de comunidade no Brasil. Mas o primeiro assistente de Emilio Willems foi Egon Shaden, neto de alemães de Santa Catarina, diplomado em Filosofia, e que ao assumir a Cadeira de no. 49 em 1950 a amplia e fortalece institucionalmente (Borges Pereira, 1994).

A existência paralela da Cadeira de Etnografia do Brasil e Língua Tupi-Guarani, sob a regência de Plínio Ayrosa cerceava as possibilidades de afirmação integral da Antropologia como área do saber. Com a morte de Ayrosa, Shaden consegue superar a dualidade institucional, tendo que vencer "a resistência da área da Sociologia, liderada por Florestan Fernandes, que pretendia trazer Herbert Baldus, do Museu Paulista, para reger a cadeira de Etnografia." (Borges Pereira, 1994, p. 252). Em suma, Shaden promoveu a criação da Cadeira de Antropologia ao incorporar definitivamente as disciplinas de Etnografia e Etnologia, concomitante à criação da cadeira de Línguas Indígenas do Brasil no setor de Letras.

Considerando que a natureza do saber antropológico é configurada pela natureza "de seus objetos reais", a qual predomina sobre o recorte teórico, duas vertentes ordenaram a agenda de trabalho da disciplina: "a etnologia indígena e a Antropologia da sociedade nacional, mais conhecida, no caso das populações negras, pela rubrica de 'questão racial'". (Schwarcz, 1999, p. 272). A discussão racial nesse campo do saber do e no Brasil teria seus primórdios associado a Nina Rodrigues, "um de nossos primeiros antropólogos avant la lettre com seu trabalho sobre os Africanos no Brasil" (Schwarcz, 1999, p. 273). Outros importantes autores calçaram a trilha da discussão racial na disciplina, mesmo antes de sua institucionalização. É nessa chave que também 
podem ser compreendidos os trabalhos de Gilberto Freyre, M. Herskovits, Donald Pierson, Charles Wagley, no que diz respeito à discussão sobre democracia racial nos anos 1930 e 1940. O campo da Antropologia era delineado também com os estudos na área de etnologia realizados por pesquisadores do porte de Eduardo Galvão (1949), Darcy Ribeiro (1950), Florestan Fernandes (1949, 1952). (Schwarcz, 1999, p. 279).

Desde meados da década de 1950 é possível perceber certos redirecionamentos nos estudos sobre o negro na Antropologia. As críticas de Sérgio Buarque de Holanda e de Edson Carneiro e a influência dos estudos da UNESCO foram fundamentais para que o negro deixasse "de ser visto como um objeto exótico, como dizia Sérgio Buarque de Holanda, e passou a ser encarado como velho cidadão do país que era, como dizia Édson Carneiro - passando, também da esfera da Antropologia (cultural) para a esfera da Sociologia." (Corrêa, 2011, p. 210).

Como não era possível desconsiderar as evidências das desigualdades nas relações raciais estabelecidas, uma série de pesquisas foi mobilizada no âmbito da $\mathrm{UNESCO}^{28}$, de onde surgiu também a ideia de um Brasil como "modelo de convivência racial" (Schwarcz, 1999, p. 279). O projeto ampliou-se por meio de novas pesquisas na Cadeira de Sociologia I da USP. Assim, assistese a uma guinada na discussão com as proposições da chamada Escola Paulista de Sociologia, cujas bases teóricas sustentavam essa inovação: "em lugar das análises culturalistas, as visadas sociológicas" (Schwarcz, 1999, p. 282). O enfoque sociológico nas relações entre negros e brancos após o regime escravocrata ganha novo estatuto ao passo que há mudanças nas etnografias que privilegiavam até então as análises das influências africanas sobre as populações negras. Desse modo, importantes questões surgem em relação às análises dos cultos afro. Assim:

\begin{abstract}
As críticas à Antropologia, partindo de argumentos de natureza sociológica, surgem já a partir do início dos anos 40, com Sérgio Buarque de Holanda, que problematiza a oportunidade dos estudos afro-brasileiros da assim chamada escola Nina Rodrigues, que nesse contexto tinha em Arthur Ramos sua figura de proa. Além dele, Guerreiro Ramos, no final dos anos 40 (já militante do Teatro Experimental do Negro), retoma o debate que se radicaliza nos anos 50, com as críticas aos estudos de comunidade. Por sua vez, Florestan Fernandes, ainda nos anos 50, questionará o estatuto de ciência social do "folclore", o que significava, de alguma maneira, uma investida contra a própria Antropologia. (Schwarcz, 1999, p. 283-284).
\end{abstract}

A partir dos anos 1960 a Antropologia esteve associada a representações mais conservadoras, em função do enfoque que privilegiava a harmonia e o equilíbrio da seleção dos objetos que pareciam pouco relevantes no debate nacional; ao passo que a Sociologia esteve mais alinhada à ideia de disciplina politicamente mais comprometida, devido à desconstrução da noção

\footnotetext{
28Era um momento no qual o mundo acabava de vivenciar os horrores da segunda guerra mundial e a possibilidade de uma democracia racial soava como alento. Sobre o projeto UNESCO ver Marcos Chor Maio: A História do projeto Unesco: estudos raciais e ciências sociais no Brasil (1997).
} 
de raça e o investimento no conceito de classe. "À Antropologia corresponderia, grosso modo, a estrutura, enquanto à Sociologia, a mudança." (Schwarcz, 1999, p. 284). Apesar disso, aconteceu importante continuidade das pesquisas sobre relações raciais na USP no âmbito da Antropologia.

Borges Pereira (1981b) ao propor um balanço sobre os estudos das populações negras feitos na USP nos cursos de Antropologia, Sociologia e Ciências Políticas, indica que tais investigações eram sistematicamente desenvolvidas na Antropologia. Quando acontecia na Sociologia, era em grande parte obra de pesquisadores ligados à Antropologia, ou que estavam na Sociologia por questões de ordem burocrática. Na Ciência Política naquele momento, não encontra nenhum trabalho preocupado com o tema. O autor agrupa esses estudos sobre o negro na Antropologia da USP em quatro conjuntos: "1) o negro e a comunicação; 2) o negro em contexto religioso; 3) o negro no sistema de relações raciais; 4) o negro em condições de vida rural." (Borges Pereira, 1981b, p. 64). Para o autor, tais trabalhos apesar de pretender leituras críticas, são herdeiros e de alguma maneira dão sequência às pesquisas desenvolvidas pela Sociologia uspiana. Peirano (1999) endossa essa ideia de certa continuidade entre a Sociologia e a Antropologia ao lembrar que o então estudante João Baptista Borges Pereira apresentou um projeto de pesquisa de doutorado sobre a temática do negro a Florestan Fernandes, que não aceitou orientá-lo. Ou nas palavras de Borges Pereira (2003):

Eu mesmo tive um desacordo com Florestan Fernandes que reflete esse instante de transição temática. Quando lhe entreguei meu projeto de doutorado, ele me falou que não orientava mais teses sobre o negro, pois tudo o que tinha de se escrever, já fora escrito. (Borges Pereira, 2003, p. 324).

A recusa de Florestan Fernandes levou João Baptista a buscar a orientação de Egon Shaden, configurando segundo Peirano (2000) a criação de uma sublinhagem, pois João Baptista encontrou na Antropologia um orientador para uma pesquisa, cuja realização na Sociologia era plausível também. No entanto vale ressaltar, que o próprio Egon Shaden, que ocupou a cadeira de Antropologia da USP entre os anos de 1949 e 1967, considerou que "nunca chegou a esboçar-se felizmente, na Universidade de São Paulo, algo que pudesse denominar-se uma 'escola antropológica paulista"' (Shaden 1984, p. 254 apud Peirano, 2000, p. 220 [ênfase da autora]).

Era um momento em que a Antropologia parecia pouco atraente. Borges Pereira conta que fora convidado por Shaden para ser seu assistente e quando Florestan Fernandes ficou sabendo, teve a seguinte reação:

Pois Florestan ficou indignado, disse que era um prejuízo, uma perda desperdiçar meu talento com uma disciplina politicamente alienada. Quer dizer, nesse período da vida nacional, não havia mesmo o menor estímulo para a carreira em Antropologia. (Borges Pereira, 2003, p. 338). 
Com o retorno de Shaden à Alemanha e a morte de Gioconda Mussolini, que era o nome mais cotado para assumir a cadeira, Borges Pereira assume a cátedra de Antropologia por dois anos e meio, e depois da reforma no ensino superior que instituiu os departamentos, continuou como professor livre docente. Considerando que a Antropologia estava em pleno processo de configuração institucional, ${ }^{29}$ Borges Pereira herdou vários desafios impostos à disciplina naquela ocasião: além de assumir os orientandos de Shaden e a Revista de Antropologia, com todas as dificuldades inerentes à manutenção inicial deste periódico, ele e seu pessoal criaram a primeira pós-graduação brasileira em Antropologia (Borges Pereira, 2003, pp. 327-328).

Como era de se esperar, Borges Pereira constituiu também seu próprio conjunto de orientandos. Um deles era o então estudante Kabengele Munanga, que em 1975 chega à universidade para fazer seu doutorado, num contexto de ambiguidades da Antropologia, uma disciplina que era vista como alienada, mas ao mesmo tempo herdava uma tradição de pesquisas sobre relações raciais na USP. Segundo Borges Pereira (1981b), embora os trabalhos pretendessem criticar o legado, são descendentes e de certa forma continuadores das tradições sociológicas paulistas "que propunham ver o negro basicamente como problema social, a partir do diagnóstico científico de suas condições de vida”. (Borges Pereira, 1981b, p. 71). Esses estudos sócioantropológicos procurariam preservar e mesmo cultivar a "denúncia" que foi uma das marcas revolucionárias da escola paulista. (Borges Pereira, 1981b, p. 71-72). No entanto, o autor propõe o seguinte questionamento:

Mas até que ponto um estudioso branco, mesmo treinado para tal, consegue se colocar no lugar do outro, quando o outro é um negro? Esta interrogação traz consigo a certeza de que será altamente frutífera para a compreensão mais justa do problema do negro no Brasil a ascensão do intelectual preto à cena da pesquisa e reflexões críticas. (Borges Pereira, 1981b, p. 72).

No âmbito da Faculdade de Filosofia da USP, Borges Pereira assistiu na década de 1970 à chegada de pelo menos dois pesquisadores negros: Kabengele Munanga, seu orientando e Eduardo de Oliveira e Oliveira, sociólogo. A trajetória do professor Kabengele tem destaque aqui, pois dá ensejo a esse tópico. Contudo, quanto à passagem de Eduardo de Oliveira, o primeiro desafio é a pouca informação biográfica disponível. Eduardo de Oliveira foi aluno da Faculdade nos anos de 1970, tendo sido contemporâneo e amigo de José de Souza Martins na USP e é baseada nas

29Em entrevista publicada em 2003, Borges Pereira conta que o núcleo de Antropologia na USP era bem reduzido: "Na USP, até 1964, só havia o Egon Schaden e a Gioconda Mussolini, que contavam com a colaboração de dois instrutores voluntários: Ruth Cardoso e Eunice Ribeiro Durham. A partir da metade da década de 1960, vindo da UNESP, chegaram Amadeu Lanna e eu. Juntando-se a nós na mesma época, vieram Thekla Hartmann, Renate Viertler e Hunaldo Beiker. Depois vieram Lux Vidal, Renato Queiroz, Carlos Serrano, Aracy Lopes e Sylvia Caiuby Novaes. E assim o grupo foi sendo ampliado até chegar ao que é atualmente." (Borges Pereira, 2003, pp. 320-321) 
informações deste professor do Departamento de Sociologia da USP que Grin (2002) faz breves considerações sobre a vida acadêmica de Eduardo de Oliveira e Oliveira. O sociólogo chegou a ser professor na Universidade Federal de São Carlos (UFSCAR), no interior do estado de São Paulo. Seu trabalho mais relevante é intitulado: $O$ mulato: um obstáculo epistemológico, publicado em 1974. Suicidou-se em 1980.

São Paulo, 1980. O sociólogo Eduardo de Oliveira e Oliveira, "mulato e brasileiro", é encontrado morto em seu apartamento em completo estado de inanição autoinfligida. Reconhecido pelos seus colegas como talentoso e polêmico, Eduardo de Oliveira e Oliveira deixou parco material escrito, uma peça de teatro encenada e morreu praticamente desconhecido. (Grin, 2002, p.204)

O nome do professor Eduardo de Oliveira, que fez sua breve carreira docente na UFSCAR vem à tona apenas para registrar sua passagem como aluno pelo departamento de Sociologia, um negro que conheceu dentro da instituição a importância da Escola Paulista de Sociologia. Apesar disso, ficam alguns questionamentos: embora seja um nome conhecido na militância do movimento negro, por que há pouca informação disponível a seu respeito? Se seu texto supracitado é a sua produção mais divulgada, qual é o conhecimento sobre seu trabalho de pós-graduação? Que projeto de pesquisa empreendeu na Universidade Federal de São Carlos (UFSCAR)30?

Fechando esse parênteses sem respostas satisfatórias para essas indagações, segue-se com considerações mais detalhadas sobre a trajetória do professor Kabengele Munanga, nascido na atual República Democrática do Congo, e que desde os anos 1980 tem sido uma voz negra solitária no Departamento de Antropologia da USP. Trazer a experiência do professor Kabengele na USP e sua história de conflitos com a universidade, tanto como intelectual negro - amplamente reconhecido no país, sobretudo por segmentos que discutem relações raciais - quanto no exercício de acadêmico, na condição de professor de Antropologia na USP, pode ser útil para refletir sobre os dilemas raciais neste contexto universitário.

Kabengele Munanga chegou à USP em 1975, a partir de convênio entre USP e Itamaraty com universidades africanas. Em 1969 graduou-se em Antropologia Cultural Africana, na Université Officielle Du Congo à Lubumbashi. Passados quatro anos do processo de independência do país, começou seu doutorado na Universidade de Louvain, Bélgica, nas Ciências Políticas. Por questões políticas (parte da sua família fazia oposição ao regime político no Congo, num contexto de ditadura militar) teve a sua bolsa suspensa, interrompendo sua formação. Por alguns anos esteve

30No catálogo da produção intelectual sobre escravidão e relações raciais feitas no Brasil entre os anos 1970 a 1990 Barcelos et. al (1991) registram a produção de Eduardo de Oliveira e Oliveira. São listados mais dois textos além do $O$ Mulato: um obstáculo epistemológico, que são: Movimentos Políticos do Início do Século XX no Brasil e nos Estados Unidos e Etnia e Compromisso Cultural. Ambos foram apresentados no Grupo de Trabalhos André Rebouças no âmbito da Semana de Estudos sobre a Contribuição do Negro na Formação Brasileira ocorrida na Universidade Federal Fluminense em 1976. 
na Bélgica como professor assistente auxiliar e foi nessa ocasião que conheceu o professor Fernando Augusto Albuquerque Mourão31, fundador do Centro de Estudos Africanos da USP, que estava em missão oficial para estabelecer relações de cooperação entre a Universidade de São Paulo, o Itamaraty e as universidades africanas. Após aceitar o convite do professor Mourão, conseguiu bolsa de estudos para vir para a USP. Como sua pesquisa estava bastante adiantada, pôde concluir o doutorado em apenas dois anos. Em entrevista ao Jornal İrohìn ${ }^{32}$, o professor Kabengele conta que na sua recepção não teve grandes problemas,

(...) mas era aquela coisa: todo mundo se aproximando, querendo saber se já cacei um leão, se tem televisão na África, se tem estradas. Muitos compreendiam África como se fosse um país ou uma aldeia, ou coisa assim, como sempre. Não mudou grande coisa. Então não tinha nenhum problema. Tinha aquelas ideias pré-concebidas sobre a África. (p.1).

O professor Kabengele Munanga diz que na sua vivência no Brasil não se deparou com o preconceito à primeira vista, mas que aos poucos foi ficando cada vez mais nítido quais os destinos possíveis ao negro no Brasil, conforme indica em entrevista concedida a esse trabalho33:

\begin{abstract}
Não se depara com o preconceito à primeira vista, logo que sai do aeroporto. Essas coisas vêm pouco a pouco, quando se começa a descobrir que você entra em alguns lugares e percebe que é único, que te olham e já sabem que não é daqui, que não é como "nossos negros", é diferente. Poderia dizer que esse estranhamento é por ser estrangeiro, mas essa comparação na verdade é feita em relação aos negros da terra, que não entram em alguns lugares ou não entram de cabeça erguida. Depois, com o tempo, na academia, fiz disciplinas em Antropologia e alguns de meus professores eram especialistas na questão racial. Foi através da academia, da literatura, que comecei a descobrir que havia problemas no país. Uma das primeiras aulas que fiz foi em 1975, 1976, já era uma disciplina sobre a questão racial com meu orientador João Baptista Borges Pereira. Depois, com o tempo, você vai entrar em algum lugar em que está sozinho e se pergunta: onde estão os outros?
\end{abstract}

Em entrevista publicada em 2013 pela Revista de Antropologia da USP, Kabengele Munanga ressalta o fato de que a convivência com negros brasileiros não aconteceu de modo imediato, porque a vida acadêmica na USP era marcadamente branca:

Quem fazia parte do nosso cotidiano, começando pelo desembarque no aeroporto e passando pelo CRUSP [Conjunto Residencial dos Estudantes da USP], pelos professores, pelas salas de aula e bibliotecas não eram negros e mestiços. Daí a primeira dificuldade para observar o tipo de relação que se estabelecia entre colegas brancos e negros brasileiros, porque estes últimos não circulavam na universidade. Nós, enquanto estrangeiros vindos da África e vivendo num meio universitário quase exclusivamente branco, éramos tratados com uma afabilidade curiosa. (Munanga apud Jaime; Lima, 2013, p. 534).

\footnotetext{
31Professor Titular Senior da USP. Formou-se em Ciências Sociais na FFCL em 1965, onde também fez seu mestrado e doutorado sob orientação de Ruy Galvão de Andrada Coelho.

32Entrevista concedida por Kabengele Munanga no dia 10 de setembro de 2006 ao Jornal Ìrohìn: "Sem Paixão a gente não faz nada". Disponível em: <http://br.dir.groups.yahoo.com/group/DemocraciaRacial/message/2524> Acesso em: $06 / 02 / 2011$
}

33Entrevista que realizei com o professor Kabengele Munanga no dia 25/04/2011, para minha pesquisa de doutorado em andamento. 
Para Kabengele Munanga, sua presença suscitava um estranhamento que possuía ares de ignorância e preconceito sobre seu corpo negro e a África e, cuja geografia marcava uma diferença no cotidiano da Faculdade. O estranhamento parece ter sido mútuo. Se por um lado o homem que veio do Zaire ${ }^{34}$ parece ter provocado deslocamentos nas percepções de discentes e/ou docentes na USP, por outro, esse intelectual negro e africano problematiza as expectativas tecidas a respeito do negro no Brasil. Durante a sua formação na USP, Kabengele Munanga descobriu que existia outra África no Brasil e que apesar de tudo o que a universidade já havia pesquisado sobre afrobrasileiros havia um espaço no qual ele poderia trazer contribuições necessárias a partir de um olhar negro e estrangeiro (Jaime; Lima, 2013, p. 532).

O professor Kabengele Munanga ingressou no curso de Ciências Sociais na Universidade Oficial do Congo em 1964, onde dois anos depois são criadas as formações em Antropologia e Linguística Africana sendo que apenas um discente fez opção pela Antropologia; na ocasião, o aluno atendia pelo nome de Kabengele Crispim, hoje conhecido como Kabengele Munanga. Escolher cursar Antropologia no Congo na década de 1960 era também encarar a fama de alienação e conservadorismo que a disciplina carregava. O Kabengele aluno fez a opção pela Antropologia muito ciente da história e dos problemas que a disciplina possuía:

\begin{abstract}
Ninguém, fora eu, queria fazer Antropologia, porque todos os meus colegas da época tinham a informação de que a Antropologia era uma disciplina que se colocou a serviço da colonização para justificar a inferioridade do negro. De que adiantaria uma ciência considerada colonial no contexto das independências? Havia certamente uma confusão entre a antropologia cultural e a antropologia física (cuja participação na construção e disseminação de teorias racialistas era inegável). Eu, um "louco", como alguns de meus colegas e amigos consideravam, encarei o desafio, porque através da disciplina de Introdução à Antropologia, ministrada pelo professor Ferdinand Ngoma, doutor em Sociologia pela Sorbonne e, aliás, o único professor negro (congolês) na Universidade Oficial do Congo, já tinha certo discernimento entre a antropologia física e a antropologia cultural. Fechei os ouvidos às bobagens racistas que eram faladas, tais como "Os cursos de ciências sociais, em especial a antropologia, ajudam os negros a entenderem porque são inferiores aos brancos”, e segui em frente. (Munanga apud Jaime; Lima, 2013, p. 516-517).
\end{abstract}

Um debate que o professor Kabengele Munanga assumiu durante a sua trajetória acadêmica refere-se à problematização da colonização no mundo das ciências. Ele tem ressaltado a importância de situar quem faz ciência e onde o conhecimento acontece. No que diz respeito a quem produz, Kabengele tem refutado a pretensa neutralidade racial no campo científico. No que diz respeito ao onde, ou seja, às instituições acadêmicas, é interessante observar que embora a academia brasileira possa em algum momento ter desqualificado alguns lugares e sujeitos do saber, menos frequentemente problematiza sua posição nesse universo. A trajetória de Kabengele traz

34Título do texto de "boas vindas" que um jornal do MAE (Museu de Arqueologia e Etnologia, da USP) fez em 1977, a respeito do então estudante Kabengele Munanga. 
elementos que também apontam nessa direção: quando escolheu cursar o doutorado no Brasil, foi novamente taxado de louco, mas dessa vez em função das desconfianças a respeito do tipo de Antropologia que era feita num país famoso mais pelo carnaval e futebol e menos pelas credenciais científicas: "Você é louco! Em vez de esperar outra oportunidade para ir para a Europa ou para os Estados Unidos, vai para o Brasil, um país de carnaval, samba e futebol! Que antropologia você vai estudar naquele país?”. (Munanga apud Jaime; Lima, 2013, p. 525). Sem negar que parte da sua formação foi feita no continente europeu, Kabengele admite também que foi positivamente surpreendido quando se deparou com o nível de qualidade da USP.

Outra coisa também foi marcante para mim, o grande desenvolvimento das ciências sociais e da antropologia na USP me deixa sem complexo de inferioridade comparativamente aos colegas que estudaram nas universidades ocidentais. Apresento-me em qualquer lugar do mundo por onde passo, com a cabeça erguida, como Doutor em Antropologia pela Universidade de São Paulo! (Munanga apud Jaime; Lima, 2013, p. 525-526).

A narrativa de Kabengele Munanga permite compreender que ele reconhece a importância que seu orientador, João Baptista Borges Pereira, teve ao apresentar-lhe os clássicos estudos desenvolvidos pela Escola Paulista de Sociologia sobre as relações raciais brasileiras. Além disso, a USP é entendida como fundamental no seu processo de formação antropológica, de mudança epistemológica, e de construção de novos olhares sobre a África e sobre o negro. (Jaime; Lima, 2013, p. 526).

A ambivalente condição de ser estrangeiro e negro pode ser percebida também na trajetória de suas preocupações acadêmicas. Sua tese de doutorado intitulada Os Basanga de Shaba (Zaire) Aspectos socioeconômicos e político-religiosos, defendida em 1977, demonstra vinculação explícita com seu país de origem, fazendo desse Kabengele Munanga um pesquisador africano de passagem pelo Brasil. Após a defesa do doutorado a intenção de Kabengele Munanga era voltar para o Congo e continuar sua vida acadêmica no seu país de origem, porém mais uma vez as condições políticas frustraram seus intentos, conforme relata em entrevista concedida para este trabalho:

[...] quando me formei em 77, voltei para o Congo para integrar minha universidade, para prestar serviço ao meu país, mas como lhe falei a conjuntura política de ditadura militar, questões sérias políticas, eu acabei abandonando meu emprego, fui desertor mesmo e voltei ao Brasil. Tive um contrato como professor visitante na Universidade Federal do Rio Grande do Norte, no programa de mestrado em Ciências Sociais. Então atuei naquela universidade de 79 a 80.

Interessante observar que quando retorna ao Brasil o professor Kabengele Munanga, que no doutorado pesquisou sobre arte africana, apresentou já na Universidade do Rio Grande do Norte projeto de pesquisa sobre a realidade do negro brasileiro. Quando prestou concurso na USP, 
concorreu à vaga do professor José Mariano Carneiro da Cunha, do Museu de Arqueologia e Etnologia, que pesquisava arte africana e brasileira. E mesmo para ingresso como docente na USP, em 1981, apresentou projeto de pesquisa sobre o negro brasileiro. Assim relata sua história de envolvimento com a questão:

Então foi esse o processo, começar a trabalhar sobre a questão do negro desde que entrei na Universidade Federal do Rio Grande do Norte. Então foi o meu primeiro projeto de pesquisa, eu continuei nessa área até agora. [...] Não entrei no meu projeto de engajamento com a USP com um projeto sobre a África. Então essas pessoas não acompanharam, essas pessoas estavam dormindo e quando abriram os olhos eu já estava na USP sentado. Muitos perguntam como eu entrei, então essa análise do que eles esperavam que eu ia porque... Muitos não acompanharam meu processo, estava na Universidade Federal do Rio Grande do Norte, quando faleceu José Mariano Carneiro da Cunha, do Museu de Arqueologia, me ligam dizendo que meu processo já estava correndo para trabalhar no Museu como pesquisador junto com Mariano. Mariano faleceu, você tem que entrar no lugar dele, só que precisa entrar com um projeto de pesquisa. O projeto de pesquisa com o qual entrei, não era um projeto sobre a África, era um projeto sobre o negro no Brasil. [...] Foi um concurso tranquilo, porque naquela época, tinha pouca gente que trabalhava com África [...] eu concorri nessa área e não tinha outra pessoa que tivesse conhecimento sobre a arte africana e então era uma entrada fácil.

Avaliando algumas consequências do seu envolvimento com questões raciais brasileiras, o professor Kabengele Munanga aponta a emergência de conflitos na universidade e no diálogo com alguns pesquisadores negros ou não, que questionam tanto a sua posição de estrangeiro, quanto a de negro que pesquisa a realidade racial brasileira:

[...] porque se eu tivesse simplesmente ficado aqui, calado, estudando a África, sem me meter na questão nacional, não teria nenhum problema. Talvez muita gente não teria, não sei quantas pessoas não gostam de mim, mas eu entrei numa questão, como uma questão nacional, isso deve ter criado problemas, tanto do ponto de vista da instituição (grifos meus) e de algumas pessoas negras que acham que eu estou ocupando um lugar que elas deveriam ocupar, estou falando do negro no lugar deles, com tanta propriedade, eu sou apenas um estrangeiro, como do ponto de vista de brancos, 'mas ele é um estrangeiro que entrou aqui, o que ele tem que se meter nas questões nacionais, para falar do negro com tanta propriedade, com tanto engajamento?'

Assim, Kabengele Munanga volta e se estabelece no Brasil com a intenção de se aprofundar nas relações raciais brasileiras. Porém, a condição de especialista em África é que lhe abriu portas na USP efetivamente. Essa ambiguidade é muito importante para entender como o professor Kabengele está institucionalmente situado, bem como aponta para o fato de que sua escolha por pesquisar as desigualdades raciais no Brasil, não se fez sem conflitos, tornando sua trajetória dentro do departamento menos confortável e mais marginal. Por mais que tenha apresentado um projeto sobre o negro brasileiro no seu concurso de ingresso na USP, Kabengele Munanga era graduado, especialista e doutor em África. Sua contratação no Departamento de Antropologia da USP a princípio, deveria ter atendido à demanda do Departamento de um especialista em África, distante da realidade de desigualdades vivida pela população negra 
brasileira. No entanto, assumir se como herdeiro da Escola Paulista de Sociologia o afastou dos propósitos que justificavam seu concurso e sua contratação. Ao fazer esse desvio de rota, Kabengele Munanga tornou-se assim, um herdeiro bastardo dentro do seu próprio Departamento.

Cabe ressaltar que o interesse do professor Kabengele Munanga pelas relações raciais no Brasil não eliminou suas preocupações de pesquisa sobre o continente africano, conforme atesta sua produção bibliográfica registrada em seu currículo Lattes, que sintetiza sua preocupação de pesquisa da seguinte forma: "Tem experiência na área de Antropologia, com ênfase em Antropologia das Populações Afro-Brasileiras, atuando principalmente nos seguintes temas: racismo, identidade, identidade negra, África e Brasil."(ênfase minha). Interessa destacar que embora Kabengele Munanga seja o único professor negro no seu departamento há mais de trinta anos, não é o único interessado em investigar a temática racial; considerando as dissertações e teses defendidas entre os anos 1970 e 1990 Barcelos et al.(1991) registraram na Faculdade de Filosofia e Ciências Humanas da USP (FFLCH) (entre 1970-1990) 23 trabalhos na Antropologia, cinco nas Ciências Sociais, 41 na História e oito na Sociologia. Nesse catálogo da produção sobre escravidão e relações raciais entre os anos 1970 a 1990 Barcelos et al(1991) levantam cerca de 2500 referências ${ }^{35}$.

Dentre os fatores que ajudam a explicar a retomada das pesquisas sobre a temática neste período estão: a expansão e fortalecimento da pós-graduação nas ciências humanas e sociais; o surgimento de associações científicas, como a ANPOCS, e seus grupos de trabalho sobre o tema; a disponibilidade de dados oficiais do IBGE sobre cor/raça da população. Especial destaque deve ser dado para as novas rearticulações e o ressurgimento do Movimento Negro na década de 1970; e nos anos 1990, a configuração de novos padrões de reivindicações pautadas na adoção de medidas antidiscriminatórias e formulação de políticas de ação afirmativa, conforme indica Hasenbalg (2005).

É pertinente retomar aqui a distinção entre "negro tema" e "negro vida" proposta por Guerreiro Ramos: desde os anos 1950 existe um conjunto de análises sobre os processos de formação, manifestação e efeitos do preconceito de raça no seio da sociedade. A Escola Paulista de Sociologia, orquestrada por Florestan Fernandes, apresentou as diferenças raciais (sejam elas reais ou imaginárias) como causa eficiente dos processos de desigualdade tanto psíquica quanto social e apontou um dilema para a população negra no processo de ascensão social: a qualificação técnica não necessariamente assegura a ascenção social, que passa a ser regida por outros requisitos não racionais de seleção, havendo a presença do critério cor. Considerando as manifestações do

35A frequência dos temas foi de $47 \%$ para escravidão e abolição, 18,4\% para participação política, cultura e identidade, 16,7\% para religião, 10,9\% para relações raciais e desigualdades e 7\% para bibliografia, fontes impressas e estudos gerais sobre o tema. (Barcelos et. al., 1991: , p. 19). 
preconceito racial, perguntou se havia barreiras raciais em São Paulo e constatou que o horizonte de ascensão do negro estaria comprometido pelos efeitos inibidores do preconceito de cor, no processo de competição com os brancos. Nas décadas seguintes percebe-se que o acúmulo de pesquisas e o consequente refinamento do "negro tema" não melhoraram satisfatoriamente as condições de existência do "negro vida", pois são insuficientes as melhorias que diminuíssem os índices de desigualdade historicamente verificados entre brancos e não brancos; e, percebe-se que essas desigualdades são transmitidas através das gerações.

Em entrevistas36 que Kabengele Munanga concedeu, ele, aliado às reivindicações de acadêmicos e militantes negros, recorrentemente apontou para o modo como o racismo à brasileira priva a população negra de acessar direitos básicos que ainda são entendidos como privilégios, tais como saúde, educação, trabalho e redistribuição de renda. Assim, Kabengele Munanga empreendeu uma ampliação de suas preocupações acadêmicas num momento em que a pesquisa sobre questão racial revigora-se concomitante ao fortalecimento do Movimento Negro no Brasil. A produção bibliográfica do professor Kabengele, conforme ele afirma, está em constante movimento de "valsar" com a sociedade e a academia, sendo fundamental na formação de opiniões na sociedade brasileira e na formação de importantes intelectuais e acadêmicos. Além da sua atuação junto ao Conselho Nacional de Políticas de Promoção da Igualdade Racial (CNPIR) na condição de portador de notório saber, desde que começaram os debates sobre cotas no ensino superior, o professor Kabengele Munanga tem feito um sem número de palestras, entrevistas e encontros com movimentos sociais diversos defendendo as políticas de ações afirmativas. É o que atesta, por exemplo, a sua presença nas audiências públicas sobre a constitucionalidade das cotas ocorridas em março de $2010^{37}$, e nos debates a respeito do Estatuto da Igualdade Racial sancionado pelo presidente Lula em meados de 2010.

Esta tese defende a hipótese de que apesar ou mesmo em razão da sua importância como grande intelectual negro que se coloca na condição de porta-voz nesse debate racial na Antropologia brasileira, o professor Kabengele Munanga pagou o preço em importantes fóruns da disciplina devido a seu posicionamento engajado, o que se evidencia quando se toma em consideração alguns episódios de conflito que o professor viveu ao longo de sua trajetória acadêmica. Nesse sentido, ocupou em diferentes momentos lugares de ambiguidade, reconhecimento e marginalidade no

36Cf.: Nosso racismo é um crime perfeito. - Entrevista com Kabengele Munanga para a Revista Fórum, edição 89, de - agosto 2010 e publicada do site sítio da Fundação Perseu Abramo no dia 28/02/2013.

37Nos dias 3, 4 e 5 de março de 2010 aconteceram no Supremo Tribunal Federal audiências públicas a respeito da constitucionalidade das cotas como decorrência da ação movida pelo Partido Democratas (DEM) contra atos administrativos do Conselho de Ensino, Pesquisa e Extensão da Universidade de Brasília (Cepe/UnB). Com a ação, o partido alegava que a adoção do sistema de cotas pela UNB feria preceitos fundamentais da Constituição Federal, como os princípios republicano e da dignidade da pessoa humana; repúdio ao racismo; igualdade e legalidade. As ações foram julgadas ao longo de 2012 e o STF decidiu por unanimidade pela constitucionalidade das cotas. 
Departamento de Antropologia da USP, na Associação Brasileira de Antropologia (ABA) e na Associação Nacional de Pós-Graduação e Pesquisa em Ciências Sociais (ANPOCS). Vale lembrar que instituições como a ABA, ANPOCS e Coordenação de Aperfeiçoamento de Pessoal do Ensino Superior (CAPES) são círculos que fazem intersecções com a USP, e desse modo, debates que Kabengele iniciou dentro do seu Departamento, podem reverberar em outros espaços acadêmicos.

Como único professor negro no departamento de Antropologia da USP há mais de trinta anos, seu isolamento intelectual passa também por uma série de cerceamentos propugnados por muitos de seus pares do campo nacional das ciências sociais, conforme noticia o Jornal Ìrohìn (2006):

\begin{abstract}
Kabengele passou dez anos sem participar das reuniões da Associação Brasileira de Antropologia (ABA). Em 1996, sua proposta de mesa foi recusada pela organização da ABA. Em 2006, a mesa redonda da qual participaria como palestrante só foi aceita depois de um recurso enviado à organização da ABA, que inicialmente havia recusado a proposta.
\end{abstract}

Em entrevista a esse trabalho o professor Kabengele falou sobre seu descontentamento com duas associações de pesquisa de grande prestígio no campo das ciências sociais brasileiras: ANPOCS e a ABA. Embora tenha sido coordenador do grupo de trabalho na ANPOCS "Temas e Problemas da População Negra" em 1987, viu sua relação com as duas associações desmoronarem ao longo dos anos:

Eu participava da ABA, como participava da ANPOCS. Depois deixei de participar, porque você pede uma mesa redonda para discutir a questão do negro, eles te recusam, ou te aceitam para um grupo de trabalho, onde você vê um jovem que foi seu aluno, que faz parte de outra universidade, que está lá com uma mesa enorme, que não te deram. A primeira vez que veio questão de política de Ação Afirmativa, eu pedi uma mesa, não sei se foi na ABA ou foi na ANPOCS, me recusaram. Desde então eu deixei de participar. Não participo nem da ANPOCS, nem da ABA, porque eles oferecem pequeno espaço para você, espaço que nada tem a ver o que você é. Então eu não me contento, então quando eu vejo isso, eu caio fora, eu não me submeto, eu não quero ocupar posição subalterna, não quero ficar na sombra de um ou outro pesquisador, isso não quero. Isso é talvez um dos grandes problemas que eu tenho, porque muitos gostariam que eu ficasse como alguns negros, com apadrinhamento, atrás de um grande professor branco. Como sou independente, isso acaba me criando um pouquinho de dificuldade com essas associações.

A queixa de Kabengele Munanga a respeito dessas associações é um momento singular em que o professor torna públicas algumas dificuldades que enfrenta no seu ofício acadêmico cotidiano. Sua condição de primeiro negro na Antropologia da USP é amplamente destacada em vários fóruns e assim, parece pertinente perguntar: quando a principal associação dessa disciplina no Brasil reconheceu ou reconhecerá esse fato? Em 2006, por ocasião dos cinquenta anos da ABA, foi publicado um livro intitulado Homenagens ${ }^{38}$. O nome de Kabengele Munanga é considerado

38Eckert, Cornelia. \& Godoi, Emilia Pietrafesa de. (org.). Homenagens : Associação Brasileira de Antropologia : 50 anos / - Blumenau : Nova Letra, 2006. 408 pp. 
apenas na seção que rememora a instituição da pós-graduação em Antropologia Social na Universidade Federal do Rio Grande do Norte, onde ele atuou entre os anos de 1979 e 1980. O livro também rememora a história da Antropologia na USP e não há qualquer nota que considere a presença de Kabengele como primeiro e único professor negro do Departamento, embora o documento não tenha se esquecido de destacar a importância das primeiras professoras, "as grandes damas" (brancas) a se aventurar nessa seara. Obviamente não se trata de sacrificar a discussão de gênero na história do fazer antropológico no Brasil, mas de atentar para a necessidade de considerar a importância do pertencimento racial dos grandes nomes que construíram essa disciplina no Brasil.

Após a sua aposentadoria compulsória por idade, Kabengele Munanga intentou alçar novos voos na sua carreira intelectual. Aceitou o convite da professora Georgina Gonçalves dos Santos para atuar na Universidade Federal do Recôncavo Baiano (UFRB). Para tanto, concorreu em 2013 a uma bolsa da CAPES, do programa "Professor Visitante Nacional Sênior" (PVNS). Esta é uma história escrita em alguns importantes capítulos: a candidatura do professor Kabengele Munanga, o parecer da CAPES que não considerou o candidato Kabengele Munanga suficientemente apto à bolsa; a mobilização da comunidade acadêmica, sobretudo negra e o novo parecer da CAPES, agora reconsiderando a primeira decisão. Sendo assim, a proposta do programa de atividades que Kabengele Munanga apresentou teve parecer favorável, mas sem aprovação final:

Pelo parecer da Comissão Julgadora (Edital 28- 2013), nosso programa foi deferido e recomendado à bolsa com certo elogio, classificando-me na Categoria I dos pesquisadores do CNPQ. Foi, se entendi bem, na última instância que fomos preteridos, em comparação com os demais deferidos. Em outros termos, tenhamos a coragem de aceitá-lo, nosso programa [da UFRB] e meu CV foram considerados inferiores para sermos incluídos entre os 59 bolsistas aprovados. (CARTA ABERTA DO PROFESSOR KABENGELE MUNANGA)39.

Esse resultado gerou discussões em círculos acadêmicos que produzem conhecimento no campo das relações raciais no Brasil. Houve a construção de debates, documentos, abaixoassinados que foram amplamente divulgados em fóruns acadêmicos e redes sociais. A UFRB entrou com um recurso contra a decisão da CAPES, o antropólogo José Jorge de Carvalho, professor da Universidade de Brasília construiu um documento em apoio ao professor Kabengele Munanga, que teve muitos signatários. Alguns abaixo-assinados circularam pelas redes sociais, a Associação Brasileira de Pesquisadores Negros (ABPN) também manifestou apoio ao professor

39Carta Aberta do Professor Kabengele Munanga. Disponível emin: <http://www.geledes.org.br/areas-deatuacao/questao-racial/afrobrasileiros-e-suas-lutas/23302-racismo-as-altas-esferas-quem-tem-medo-de-um-negro-quesabe-professor-kabengele-munanga-quebra-o-silencio-academico>. Acesso em: 14/02/ fev. 2014. 
Kabengele, e o Departamento de Antropologia da USP, por intermédio da chefe do departamento, professora Ana Lucia Pastore, enviou carta aberta à CAPES exigindo retratação pública.

Durante esse processo, uma questão levantada pelo professor Kabengele em sua carta aberta, foi que ele não foi o primeiro e nem o único a ter o pedido indeferido. Sem desmerecer os demais candidatos, ele destacou que sua experiência de quarenta e três anos como docente e pesquisador foi considerada comparativamente insuficiente, mas conforme ressaltou, é necessário questionar os critérios de comparação: "Pois bem, é possível comparar propostas diferentes sem antes estabelecer entre elas um denominador comum? Qual foi esse denominador? As regras do jogo de comparação não parecem claramente definidas". Outro ponto importante foi levantado pelo professor José Jorge de Carvalho, quando disse que o professor Kabengele Munanga foi o único ou um dos poucos negros nesse processo seletivo, mas "por coincidência, esse único negro foi o menos qualificado, por comparação. Estranha e triste coincidência!". Mas apesar de a comunidade negra ser ainda pouco representada nas altas esferas da academia brasileira, depois de toda a mobilização e discussão que esse caso gerou a CAPES voltou atrás e no segundo semestre de 2014 o habilitou a obter a bolsa do PVNS. Conforme ressaltou o professor Kabengele, essa "é uma vitória coletiva40".

Esta tese de modo algum está alheia ao fato de que Kabengele Munanga alcançou indiscutível reconhecimento acadêmico, sobretudo fora da USP, atestado por sua premiada trajetória intelectual $^{41}$.

Na USP Kabengele Munanga além de ter chegado ao topo da carreira docente ao tornar-se Professor Titular, foi vice-diretor do Museu de Arte Contemporânea, (MAC), diretor do Museu de Arqueologia e Etnologia (MAE) e do Centro de Estudos Africanos (CEA). Além disso, recebeu também algumas honrarias: a Homenagem como Decano em Estudos Antropológicos e Processos de Produção de Diferenças, etnicidade, raça, sexualidade, gênero e idade, do Departamento de Antropologia da FFLCH-USP (2008); a Homenagem da Associação dos Docentes da USP pela contribuição à superação das desigualdades raciais no Brasil e pela trajetória acadêmica (2012). E ainda foi convidado em 2012 pelos colegas de Departamento para ministrar a aula inaugural do

40Beneficiado fui eu, mas a vitória é coletiva, diz Kabengele Munanga http://www.afropress.com/post.asp?id=17402\#.U_Xxrdf_ajc.facebook: Acesso em 09/09/2014.

41Kabengele conquistou a Comenda da Ordem do Mérito Cultural, Contribuição à Cultura Brasileira, da Presidência da República do Brasil (2002); a Comenda Zumbi dos Palmares, Grau Cavaleiro Mérito da Liberdade, do Governo do Estado de Alagoas (2004); Homenagem pelo conjunto da obra conferido pela Universidade Federal de Santa Catarina (2012); o Prêmio Benedito Galvão da Ordem dos Advogados do Estado de São Paulo (2012) e a Homenagem da Associação Brasileira de Pesquisadores Negros pela dedicação e contribuição à promoção da igualdade e valorização das populações afro-brasileiras (2012). (Jaime \& Lima 2013, p. 509). Dentre outros termômetros que sinalizam o quanto ele é reconhecido estão ainda a sua participação, na condição de notório saber em 2003, quando a SEPPIR foi criada, o fato de que integrou o Conselho Nacional de Políticas de Promoção da Igualdade Racial e, em 2010, também na categoria de notório saber, participou dos debates sobre a constitucionalidade das cotas e na promulgação do Estatuto da Igualdade Racial. 
curso de Ciências Sociais e para o incipiente debate sobre cotas na pós-graduação no Departamento de Antropologia (JAIME; LIMA, op. cit., p. 509 e 549-550). Apesar dessas homenagens, é interessante observar que quando recebeu da Presidência da República, no governo de Fernando Henrique Cardoso, a Comenda da Ordem do Mérito Cultural, em 2002, Kabengele diz que não houve nenhuma repercussão dentro do seu Departamento, o mesmo se repetiu ao longo dos seus concursos de livre docente e titular:

\begin{abstract}
Quando eu recebi o título de comendador da república, pelo governo Fernando Henrique Cardoso, como reconhecimento de mérito cívico ao meu trabalho sobre a cultura do negro no Brasil, sobre a cultura brasileira, eu recebi parabéns de todos os lugares, da própria reitoria, da congregação, menos dos meus colegas do departamento. Foi um silêncio, parece que nada aconteceu. Isso saiu nos jornais, na Folha, mas você não encontra alguém para parabenizar, ignora completamente. Até alguns dos meus concursos, quando eu fiz, você não via pessoa te cumprimentar. [...] Quando eu fiz meu concurso de livre docente, um ou dois me cumprimentaram, no mais, fui ignorado. Quando fiz meu concurso de professor titular, ignorado completamente, como se nada tivesse acontecido. São manifestações de inveja, não há como você transformar isso numa manifestação preconceituosa, mas essas coisas são difíceis de avaliar. Então é difícil você receber aplausos e dizer que o santo de casa não faz milagre, faz milagre fora. Então é mais ou menos isso a minha situação. Mas isso não me incomoda porque tenho consciência disso. Isso me incomodaria se tudo o que escrevi não tivesse servido para o processo de conscientização da população negra.
\end{abstract}

É importante pontuar que, para o concurso de Livre Docente na USP, entre as exigências está a defesa de uma tese. Sendo assim, esse é um processo que depende fundamentalmente do mérito individual. A princípio, é um concurso que pode ser disputado por qualquer Professor Doutor, sem restrições de vagas. A defesa da tese de livre docência para um Professor Doutor da USP assegura a ascensão para o nível de Professor Associado. Por sua vez, o concurso para Professor Titular, que é o topo da carreira acadêmica da USP, depende não apenas da Livre Docência, mas decorre diretamente de configurações políticas internas de cada departamento, uma vez que o número de vagas é limitado, restringindo assim, o número depossíveis aprovações, em geral somente uma. O concurso de livre-docência de Kabengele Munanga, defendido em 1997, com a tese intitulada Rediscutindo a Mestiçagem no Brasil - Identidade Nacional Versus Identidade Negra, é um marco na trajetória de Kabengele no departamento de Antropologia da USP, pois explicita sua preocupação com a questão racial brasileira. Porém, apesar de uma história de ambiguidades e divergências com seu departamento, em 2001 o professor Kabengele Munanga avança na carreira acadêmica, passando pelo concurso de titular e integrando assim a elite docente da USP, ainda que sem o reconhecimento dos seus colegas de departamento.

Com uma produção bibliográfica que possui ampla circulação em outros espaços de discussão, que não apenas os fóruns acadêmicos, e reconhecendo-se como intelectual e não como militante, Kabengele Munanga tem plena consciência do quanto a sua obra dialoga com vários 
outros setores da sociedade, como o movimento negro, professores/as da educação básica, instâncias do governo, etc.

Eu não tenho atuação política, porque não sou político, eu sou intelectual. Minha atuação é o que... Eu percorri esse Brasil, todos os lugares. [...] Então eu tinha um trabalho de penetração para a comunidade muito grande. Eu diria na realidade, que atuei tanto na academia, quanto no movimento negro. Eu costumo dizer que o meu trabalho foi como uma dança de valsa, um para frente, a comunidade, outro atrás na academia. Isso que fez de mim um intelectual diferenciado. As pessoas que me leem acham que eu escrevo coisas diferentes, que sou acessível aos outros, porque quando escrevo sobre a questão do negro, a primeira coisa é: escrevo para eu atender as pessoas da minha comunidade, à qual eu pertenço historicamente, apesar de ter nascido na África. Se eu não entendi o que escrevo, então os outros não vão entender. Então essa é uma maneira de atuar. Quando nasceu a Lei 10.639, uma das pessoas que viajou em vários estados a convite da SECAD, da Educação, para fazer a conferência de abertura sobre a Lei 10.639, fui eu.

Apesar das críticas e certos descontentamentos com a universidade, a USP aparece como fundamental na construção da sua carreira de intelectual engajado, pois abriu-lhe portas importantes conforme admite: "Então é isso, a USP foi significativa na minha trajetória, nos meus processos de conscientização, no meu engajamento, no meu trabalho intelectual engajado”. A produção bibliográfica do professor Kabengele, nesse movimento de "valsar" com a sociedade e a academia, tornou-se fundamental na construção de opiniões na sociedade brasileira e na formação de destacados intelectuais e acadêmicos42. Dentro da USP, o professor Kabengele tem tentado dialogar com importantes intelectuais negros ou não que também são interessados nos debates acadêmicos e políticos sobre as questões raciais brasileiras, na esteira da pesquisa no campo das relações raciais, desde a sua chegada ao doutorado na década de 1970.

Foi assim com o seu orientador João Baptista Borges Pereira, com Carlos Serrano, Fernando Mourão, Renato Queiroz e outros. Considerando a Faculdade de Filosofia, Ciências e Letras (FFLCH), em 1982 viu chegar à USP no curso de Geografia o professor Milton Santos, intelectual negro, "um grande intelectual, talvez um dos maiores intelectuais que o Brasil produziu", nas palavras do professor Kabengele Munanga em entrevista para essa pesquisa. A obra do professor Milton Santos é muito extensa e ele deixou suas contribuições também no debate racial. Em 1988, Munanga viu chegar à universidade outro intelectual negro, Wilson do Nascimento Barbosa, no departamento de História, economista de formação, que tem atuado nas áreas de história econômica, economia, cultura do negro brasileiro, cultura negra no Brasil. Interessante observar que esse trio de professores negros conseguiu chegar ao topo da carreira docente, que é o nível de Professor Titular. Em 1992 viu chegar à Faculdade de Direito da USP a

$42 \mathrm{O}$ professor Kabenguele Munanga orientou um importante conjunto de intelectuais que produzem conhecimento no campo das relações raciais brasileiras, a exemplo de Nilma Lino Gomes, Alecsandro José Prudêncio Ratts, Andreas, Houfbauer, Jacques D'Adesky, Ana Maria Singule Mayer,Neusa Maria Gusmão, etc. 
professora Eunice Prudente. Na Sociologia, em 2004, viu a chegada da professora Márcia Regina de Lima Silva, intelectual negra e referência em pesquisas sobre mercado de trabalho, trajetórias ocupacionais, desigualdades raciais e de gênero e políticas de ação afirmativa no ensino superior.

Ainda em 1988, no seu departamento, o professor Kabengele assiste à chegada de intelectuais brancos, pesquisadores da questão, como a professora Lilia Katri Moritz Schwarcz, consagrada no campo de pesquisas sobre relações raciais. No Departamento de Sociologia viu a chegada em 1994 do professor Antônio Sérgio Alfredo Guimarães, que de certa maneira dá continuidade à tradição de pesquisa sobre relações raciais na Sociologia da USP ao propor uma análise crítica da Escola Paulista de Sociologia, análise que reconhece o legado e traz importantes avanços teóricos. Ainda na Antropologia, o professor Kabengele tem acompanhado o ingresso de gerações mais recentes de outros pesquisadores da temática racial, como Vagner Gonçalves, Laura Moutinho, etc.

Em suma, Kabengele Munanga é o primeiro intelectual negro que pesquisa sobre a temática no departamento de Antropologia da USP e entra para o panteão da Faculdade de Filosofia Ciências e Letras da Universidade de São Paulo como um nome fundamental para o debate racial. Após trinta anos como único docente negro do departamento, sua aposentadoria em 2012 fez emergir ainda outros dilemas institucionais: qual a possibilidade de entrada de outro(a) docente negro(a) na Antropologia da USP? Esse questionamento tornou-se mais aguçado quando foram abertas as inscrições no primeiro semestre de 2013, do concurso para provimento de um cargo de Professor Doutor na área de Antropologia das Populações Africanas e Afro-brasileiras e Teoria Antropológica. O desfecho do processo seletivo revelou que o professor Kabengele Munanga foi o primeiro e até agora único docente negro do departamento, sem que fossem abertas trilhas para algum intelectual negro/a na sucessão. A trajetória acadêmica do professor Kabengele Munanga dentro do Departamento de Antropologia da USP é marcada por conflitos: se por um lado enfrentou resistências e falta de reconhecimento de alguns de seus pares, por outro lado construiu também uma trajetória de êxitos e amplo reconhecimento, porém sem conseguir deixar herdeiros43. O que o situa entre algumas margens: a do reconhecimento acadêmico e a da solidão de ser o único professor negro num renomado Departamento há mais de trinta anos, sem perspectivas de ver outro(a) negro(a) como colega num futuro próximo.

Esta tese aventa a hipótese de que a entrada do professor Kabengele Munanga na docência da USP na década de 1980 é um importante marco na história de docentes negros nesta universidade, embora sua aprovação tenha sido decorrência da sua experiência de pesquisas sobre

430 candidato que foi aprovado em primeiro lugar nesse concurso, Lorenzo Gustavo Macagno, não assumiu a vaga. Dentre os outros candidatos aprovados está o nome de Pedro Jaime de Coelho Júnior, que foi orientando do professor Kabengele Munanga. 
África, e não por sua então incipiente inserção do campo de pesquisas sobre relações raciais na sociedade brasileira. Considerando a história do debate racial na Faculdade de Filosofia, Letras e Ciências Humanas na USP desde a Escola Paulista de Sociologia, é possível situar o professor Kabengele Munanga numa rede de relações de orientação e parcerias acadêmicas, com destaque para a figura do seu orientador, João Baptista Borges Pereira, que herda uma tradição de pesquisas sobre relações raciais da Sociologia, porém efetuando-as na Antropologia. Assim, Kabengele Munanga é também herdeiro, ainda que indiretamente, de uma tradição de pesquisas inauguradas pela Escola de Sociologia Paulista, porém com a grande diferença de ser o primeiro pesquisador negro e africano na história da Faculdade e por ter trazido críticas e avanços ao debate. Embora sua trajetória acadêmica não tenha expandido a possibilidade de entrada de outros docentes negros/as, a presença do professor Kabengele Munanga no departamento de Antropologia foi uma porta que se mostrou aberta à entrada e formação de pós-graduandos negros na USP. A passagem de Kabengele pela Antropologia da USP não se fez sem conflitos. Ele próprio indica que sua carreira no departamento poderia ter sido mais tranquila se tivesse escolhido pesquisar apenas sobre África e não se aventurar a falar de desigualdades raciais no Brasil, na condição de negro e africano. No entanto, apesar do isolamento muitas vezes experimentado ao longo da sua estada no departamento, conseguiu fazer uma carreira amplamente reconhecida em outros espaços acadêmicos, junto à comunidade negra e ao poder público.

E ainda, esta pesquisa não tem a pretensão de esgotar a discussão sobre a importância intelectual do professsor Kabengele Munanga, que embora seja amplamente reconhecido e autor de uma bibliografia já consagrada, poucos trabalhos se propuseram a avaliar sua extensa contribuição teórica e analítica44. A trajetória e a obra de Kabengele Munanga merecem mais pesquisas que façam jus aos mais de quarenta anos de dedicação ao "negro-tema", enfrentando os desafios de ser “negro-vida". No próximo capítulo é apresentada a discussão do quarto momento do debate racial na USP, destacando alguns fatores teóricos e políticos e determinados aspectos das trajetórias de alguns docentes negros envolvidos nesta dinâmica, a saber: o professor Kabengele Munanga, o professor Milton Santos e o professor Edson Moreira. Vale lembrar que estes três docentes são parte fundamental da construção desse momento do debate racial, que conta ainda com a atuação de outros docentes não-negros e negros, sendo que alguns destes terão suas trajetórias consideradas mais detidamente no penúltimo capítulo desse trabalho.

44Em consulta ao banco de dissertações e teses da USP, foi encontrada a tese de doutorado a respeito de Kabengele Munanga: OLIVEIRA, Julvan Moreira de. Africanidades e Educação: ancestralidade, identidade e oralidade no pensamento de Kabengele Munanga., 2010. Faculdade de Educação, da Universidade Sao do Estado de São Paulo, . Ano de obtenção: 2010. No banco de dados do Domínio Público, foi encontrada a dissertação de mestrado: SILVA, Cristiano Pinto da. Educação Brasileira e Identidade Negra em Kabengele Munanga. Faculdade de Educação, da Universaidade Federal do ParáA. Ano de obtenção:, 2009. 


\section{Capítulo IV-História de um debate - quarta parte: a participação de docentes negros/as na construção da agenda do debate racial na USP a partir da década de 1990}

Desde os anos 1980 alguns avanços nas políticas de promoção da igualdade racial ocorreram no cenário nacional e no estado de São Paulo, apesar de estarem bem aquém da demanda: em maio de 1984 o então governador de São Paulo, André Franco Montoro, criou o Conselho de Participação e de Desenvolvimento da Comunidade Negra; a constituição de 1988 tornou o racismo crime inafiançável e imprescritível; em 1995 ocorreu a rememoração do tricentenário da morte de Zumbi, sinalizando um horizonte promissor, pois no governo de Fernando Henrique Cardoso "há o reconhecimento oficial da existência do racismo e discriminação racial no Brasil" (Hasenbalg, 2005, p.30). Ao fazer um balanço sobre essas propostas, o professor Kabengele Munanga se mostrou bastante cético quanto ao seu sucesso:

\footnotetext{
Estamos acostumados a escutar com emoção discursos demagógicos nos momentos de ritos de passagem como este dos 300 anos ou como em 1988 no Centenário da Abolição, depois cruzar os braços e esperar soluções mágicas ou paternalistas do "Pai da Nação". (Munanga, 1996, p. 90)
}

Na USP mais especificamente, para que a questão avançasse além da retórica foi criado em 1996 um grupo de trabalho "encarregado de pensar e elaborar os projetos direcionados na melhoria de vida da população negra”. (Munanga, 1996, p. 90). Esse conjunto de mudanças gerou discussões dentro da universidade, que não se esquivou de posicionamentos sobre o assunto. Nesse sentido foi realizado o seminário internacional "Estratégias e Políticas de Combate às Práticas Discriminatórias", entre os dia 21 e 24 de novembro de 1995, no contexto de rememoração do tricentenário da morte de Zumbi. Um dos frutos do seminário foi a publicação no ano seguinte do livro "Estratégias e Políticas de Combate à Discriminação Racial", organizado pelo professor Kabengele Munanga. No prefácio da obra o então pró-reitor de Cultura e Extensão Universitária, Jacques Marcovitch, considerou que o livro documenta a reflexão ocorrida na USP no transcorrer do ano do tricentenário da morte de Zumbi, indicando o posicionamento da Universidade:

\footnotetext{
Insere-se este livro na dimensão de respeito aos valores humanos que devem estar presentes como premissas de qualquer política cultural, em especial na Universidade. A cidadania negra tornou-se o mote principal da rememoração na USP da morte de Zumbi. Evitou-se, no transcurso da efeméride, qualquer evento de natureza meramente discursiva ou folclorizante. (Marcovitch, 1996, p. 15)
}

Trata-se de um momento crucial na Universidade para a proposição de discursos e práticas 
antirracistas. Alçado a reitor, Jacques Marcovitch (1997-2001) "debruçou-se no campo da cultura, promovendo muitos debates e encontros, dinamizando o cultivo de valores" (Motoyama, 2006, p.47). e assumiu posicionamentos na USP dos anos 1990 com relação à discussão sobre discriminação racial e ensino superior. Reconheceu a gravidade da situação, concordando com Kabengele Munanga, que indicava a exclusão negra como decorrente não apenas de fatores econômicos ou classistas, mas como resquícios de séculos de escravidão e racismo. Ainda como pró-reitor, Marcovitch indicava que "essa questão exige algo mais do que estudos teóricos e vozes eloquentes", sendo um tema que "vem, desde o pioneiro Florestan Fernandes, despertando a consciência solidária da Universidade.” (Marcovitch, 1996, p. 15). Embora reconhecendo a problematização analítica proposta Escola Paulista de Sociologia, e a necessidade de ações efetivas mais que teoria e discursos, a universidade, na figura de Jacques Marcovitch ainda concebia as políticas antirracistas no âmbito genérico das "políticas culturais".

Em 1999, avança-se um passo importante na reflexão e proposição de "políticas raciais" na USP ao instituir a CPPPN (Comissão Permanente de Políticas Para a População Negra). Kabengele Munanga (1996) aponta essa comissão como fruto dos eventos que configuraram na USP a rememoração do tricentenário da morte de Zumbi. A comissão que chegou a ser presidida pelo professor João Baptista Borges Pereira, contou com importantes estudiosos da questão racial, professores da USP, como Antonio Sérgio Guimarães, Lília Schwarcz e de intelectuais negros/as de outras universidades, como a professora Petronilha Beatriz Gonçalves. Outro membro da comissão, o professor negro Édson Moreira, da USP São Carlos, também exerceu papel fundamental tanto no tricentenário da morte de Zumbi quanto na comissão e sua trajetória será considerada atentamente mais adiante nesse trabalho. Em entrevista para essa pesquisa Kabengele analisa o caráter e as atribuições da CPPPN:

Ah! A comissão que foi dirigida pelo professor João Baptista, Comissão de Política Pública para a População Negra. Bom essa comissão tem uma história. Em 1995 quando se comemorou, rememorou os trezentos anos da morte de Zumbi dos Palmares, o reitor da USP, o professor Flávio, o professor Fava de Moraes, criou uma comissão de política pública para os trezentos anos da morte de Zumbi dos Palmares. Era uma comissão ampla. Até o professor Milton Santos foi convidado nessa comissão, mas não atuou. E o professor Marcovitch, que era pró-reitor de cultura foi nomeado um dos coordenadores dessa comissão e junto com o professor João Baptista Borges Pereira, e o professor... me esqueci o nome... falecido, da Faculdade de Direito eram os dois coordenadores. O professor Jacques Marcovitch, era o presidente. Essa comissão começou um trabalho interessante, inclusive com pessoal convidado, que foi a professora Petronilha, Cunha, acho que Hélio Santos, para fazer uma vistoria de todas as questões do negro no Brasil, na educação, meios de comunicação, etc. E a partir desse diagnóstico, propor algumas políticas de mudança pública no âmbito da USP e da sociedade brasileira. Foi um trabalho praticamente de um ano. Quando terminou esse trabalho, houve uma mudança, o Marcovitch se tornou reitor da USP, então ele nomeou essa comissão como uma comissão permanente que pôde continuar a discutir políticas de mudança da questão do negro, no âmbito da USP, etc. 
Assim, na USP, enquanto os anos 1990 foram marcados por algumas tímidas, porém importantes possibilidades de diálogos e proposições, na década seguinte além de não ter se efetivado o fortalecimento das políticas de acesso da população negra na universidade, verifica-se um retrocesso, a despeito da extinção da CPPPN só ter ocorrido em 2010, como se verá adiante, e dos avanços no cenário nacional: no país começava-se a colher alguns frutos da Conferência de Durban $^{45}$ de 2001 contra o racismo, em função dos compromissos assumidos. Assim é que no ano seguinte, a Universidade do Estado do Rio de Janeiro (UERJ) adota o critério de reservas de vagas para negros no vestibular. Este é um importante acontecimento na sociedade brasileira, pois desencadeou o acalorado debate sobre cotas raciais. Na sequência, em 2003, no primeiro mandato do presidente Lula, é criada a SEPPIR (Secretaria Especial de Promoção de Políticas de Igualdade Racial); e sancionada a Lei 10.639, instituindo a obrigatoriedade do ensino da história e cultura afro-brasileira na educação básica. Desse modo, a questão racial foi incorporada à agenda pública brasileira nos anos 2000 .

Apesar do cenário nacional, o debate racial, sobretudo no que concerne à adoção de políticas de ações afirmativas, não foi nada fácil na USP. Conforme relato de Fernando Conceição dado ao Observatório da Imprensa em 2001 o debate sobre cotas nas universidades brasileiras começou na USP em 1993, e apesar do caráter pioneiro, foi sempre marcado por intensa resistência:

\begin{abstract}
Mas o debate sobre a implantação de quotas para afro-descendentes nas universidades públicas brasileiras foi introduzido no Brasil há exatos oito anos. E surgiu dentro da Universidade de São Paulo (USP), não por iniciativa institucional, mas pela ação política de meia dúzia de gatos pingados, alunos da vetusta academia - entre eles, este escrivinhador e outros simpatizantes. Nota-se que agora até mesmo o ex-presidente José Sarney, em sua coluna semanal na Folha de S.Paulo (31/8/01), quer para si a paternidade do tema. Há quase nenhuma menção àquele pequeno grupo abrigado na USP que, contando com o apoio de poucos, embora significativos professores da casa, a exemplo de Milton Santos, Paulo Sérgio Pinheiro, Kabengele Munanga, Solange Couceiro e Antonio Junqueira, enfrentou o racismo ou a arrogância de muitos. Por conta das ações do movimento pró-quotas, o aluno de filosofia Mauro Gopfert Cetrone e o então doutorando Fernando Conceição (eu mesmo!), foram detidos pela guarda interna da USP certa noite, enquanto faziam pichações. No meu caso, no dia seguinte fui novamente detido e levado à delegacia da circunscrição. Fiquei preso por mais sete horas. A delegada plantonista buscou um acordo com a administração da universidade, que recusou-se a ceder, obrigando a policial lavrar o flagrante. Por ser réu primário, fui solto, mediante pagamento de fiança, mas um processo
\end{abstract}

45Segundo a página do IBGE, "de 31 de agosto a 7 de setembro de 2001 ocorreu a III Conferência Mundial contra o Racismo, a Discriminação Racial, a Xenofobia e as Formas Conexas de Intolerância em Durban, na África do Sul. Temas urgentes e polêmicos sacudiram a conferência, da qual fizeram parte 173 países, 4 mil organizações não governamentais (ONGs) e um total de mais de 16 mil participantes. O Brasil estava presente, com 42 delegados e cinco assessores técnicos. Um importante papel coube ao nosso país: Edna Roland, mulher, negra e ativista foi a relatora geral da conferência, representando também as minorias vítimas de discriminação e intolerância. A proposta de um programa de criação de cotas para estudantes negros nas universidades públicas brasileiras foi apresentada e gerou polêmica. Ao fim da Conferência, foram elaboradas uma Declaração e uma Plataforma de Ação, a fim de direcionar esforços e concretizar as intenções da reunião." http://www.ibge.gov.br/ibgeteen/datas/discriminacao/cenferenciadedurban.html. Acesso em 01/05/2012 
criminal foi aberto. A direção da USP - sob o comando do reitor Flavio Fava de Moraes, por sua vez, impetrou processos administrativos contra os dois alunos, que poderiam levar à sua expulsão dos quadros discentes. Somente recuou pela repercussão havida, inclusive com pronunciamentos na Câmara dos Deputados pelo deputado Paulo Paim, (PT/RS) e pressões junto à reitoria daqueles e outros professores acima mencionados. (Conceição, 2001, p.1).

Conforme o relato de Fernando Conceição, aluno negro que se fez doutor em Comunicação pela ECA/USP, o debate sobre cotas mobilizou a comunidade uspiana. Se no corpo discente as manifestações favoráveis às ações afirmativas geraram tal repercussão, no corpo docente da USP os posicionamentos favoráveis e contrários às cotas aconteceram também no bojo dos "manifestos" de intelectuais de todo o país. Em 2006, dois manifestos foram enviados à sociedade e ao congresso nacional. Assim, docentes da universidade, que produzem ou não conhecimento no campo das relações raciais, manifestaram posicionamentos sobre o assunto, que podem ser verificados, por exemplo, nas assinaturas do "Manifesto a Favor das Cotas" ou do "Manifesto Contra as Cotas". O manifesto contrário é intitulado Todos têm direitos iguais na República Democrática e data de 29/06/06. O outro, favorável, Em favor da Lei de Cotas e do Estatuto da Igualdade Racial, data do dia 04/07/06. Em 2008 a história se repete: no dia 13 de maio foi entregue ao Supremo Tribunal Federal um texto intitulado 120 anos da luta pela igualdade racial no Brasil. Manifesto em defesa da justiça e constitucionalidade das cotas, que contou com 740 assinaturas, com 11 signatários da USP. Anteriormente, no mesmo ano, no dia 29/04, o ministro do Supremo recebera outro manifesto intitulado: "113 Cidadãos Anti-Racistas Contra as Cotas Raciais", dos quais 13 signatários eram da USP (Nascimento, 2008).

Dentre os signatários contrários às cotas constam até mesmo membros da CPPPN46 que se declaram anti-racistas, vale ressaltar. Em entrevista para essa pesquisa, Kabengele Munanga relata o processo de resistência que cerceou sua possibilidade de atuação no sentido da implantação das cotas na USP:

Só que nesta comissão tive um problema, não consegui enfrentar a discussão sobre as políticas de cotas. O pessoal do movimento negro, o Núcleo de Consciência, reclamava, fazia manifestações na frente da reitoria, queimando pneus, "cotas já!” para o negro. Nessa comissão não consegui encarar a questão do debate sobre cotas, as questões políticas da USP e ficamos simplesmente discutindo como, por exemplo, indenizar, não é indenizar... a

46Dentre os membros da CPPPN e signatários do manifesto contra as cotas está o professor da Sociologia José de Souza Martins e a professora do Departamento de Antropologia Lilia K. Moritz Schwarcz; esta por sua vez, coincidentemente ou não, depois da promulgação da Lei 12.711 de agosto de 2012, que institui o sistema de cotas nas universidades federais, mudou de posicionamento. Desde então passou a ser comum vê-la defendendo a política de ação afirmativa, por exemplo, nos eventos do Departamento no processo que instituiu a adoção de cotas para a pósgraduação em Antropologia da USP; ou ainda, no texto publicado no dia 12/03/2013 jornal Folha de S. Paulo que ela assina juntamente com a professora Maria Helena Machado e o professor John Monteiro intitulado Tendências/Debates: Cotas em Diálogo, no qual criticam a proposta do PIMESP reconhecendo a insuficiência da proposta e o atraso das universidades paulistas no debate sobre o "estratégico e espinhoso assunto das cotas sociais e étnico-raciais". Disponível em http://www1.folha.uol.com.br/opiniao/2013/03/1244586-tendenciasdebates-cotas-em-dialogo.shtml. Acesso em 14/07/2013. 
matrícula que os alunos pagam para fazer o vestibular. Como dispensar os alunos pobres para não pagar essa matrícula para se fazer o vestibular da USP; como ajudar os poucos alunos da USP a ter acesso ao bandejão, coisas pequenas que ficou se discutindo só sobre isso. Num certo momento não se adiantou muito, ficou nas coisas pequenas, e o próprio presidente de acordo com a política da USP também não foi ele que organizava o debate sobre cotas se não tinha um sinal verde da parte da reitoria da USP e acabou não se fazendo nada. E finalmente alguns membros dessa comissão, da qual eu participei desde o início, o presidente era meu orientador, professor João Baptista Borges Pereira, o José Martins de Souza, (que assinou o manifesto contra cotas), que era desta comissão; Antonio Sérgio Guimarães, a Lílian Schwarcz, o Edson Moreira da USP São Carlos, fazia parte dessa comissão. E finalmente a comissão não funcionou, agora foi substituída, não é mais comissão permanente de política pública, agora é comissão de inclusão social de acordo com a própria proposta da USP, deixou de lado a questão do negro. Na verdade uma comissão, com o trabalho que nós fizemos, de diagnosticar a questão do negro foi complicado, você pegar meu livro, "Estratégia Econômica de Combate à Discriminação", se você vai ver um capítulo sobre os trabalhos dessa comissão está naquele livro ${ }^{47}$.

A CPPPN foi extinta em 2010 no calor das discussões no Congresso sobre a constitucionalidade das cotas, e foi substituída pelo INCLUSP, o atual programa de inclusão social na USP. Importante destacar alguns artigos das portarias que instituíram cada comissão, pois evidenciam as orientações gerais de cada política. A Comissão Permanente de Política Públicas para a População Negra (CPPPN) foi criada em 1999 na gestão do reitor Jacques Marcovitch. Dentre as competências da comissão estavam:

II - criar condições na USP para divulgação, debates, ensino regular e extra-curricular, e pesquisas sistemáticas relacionadas com a vida sócio-cultural e econômico-política da população negra;

III - estimular o ingresso e a permanência dos negros nos quadros discentes da USP, dentro dos padrões acadêmicos e de acordo com as condições financeiras da Instituição;

$\mathrm{V}$ - alertar permanentemente docentes, alunos e funcionários da USP sobre o papel ético que a Universidade deve ter perante o problema do negro na sociedade brasileira; (Portaria GR no. 3156, de 29 de abril de 1999. Artigo $2^{\circ}$ )

No ano de 2010, já na gestão do reitor João Grandino Rodas, essa portaria foi revogada, sendo substituída por outra que criou a Comissão Permanente de Políticas Públicas para a Inclusão Social. Algumas competências dessa nova comissão são:

II. criar condições na Universidade para divulgação, debates, ensino regular e extracurricular, e pesquisas sistemáticas relacionados à ampliação da inclusão social no âmbito da USP;

III. alertar permanentemente docentes, alunos e funcionários técnico-administrativos da USP sobre o papel que a Universidade deve ter perante a sociedade brasileira, com vistas à

47A obra em questão, assim descreve o caráter e as atribuições da CPPPN: "Uma comissão especial com essa finalidade foi nomeada pelo reitor da Universidade e dentro dela um grupo de trabalho incumbido da elaboração das propostas ou pistas de políticas públicas em benefício da população negra, vítima da discriminação racial. Questões espinhosas como o ingresso de negros na Universidade, a introdução das disciplinas de História da África e do Negro Brasileiro no currículo do curso de História foram colocadas com muita força e emoção. Uma cartilha dirigida aos alunos de 1o. e 2o. graus foi editada. Foram promovidos cursos de difusão em algumas faculdades, sobre racismo e a cultura negra, sem esquecer seminários nacionais e internacionais. Com a colaboração da imprensa escrita (Jornal da USP) e audiovisual (Rádio USP, FM Cultura, TV Globo (Bom Dia São Paulo), alguns professores, membros da comissão, deram entrevistas para informar e formar a consciência da população sobre a gravidade da discriminação racial no Brasil, dentro do significado da luta de Zumbi e sua morte.” (Munanga, 1996, p. 89) 


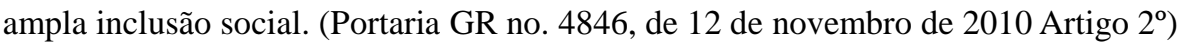

Entre a primeira e a segunda comissão percebe-se o recuo da universidade em assumir a importância de medidas reparadoras das desigualdades raciais, adotando a via geral de "inclusão social". Esse redirecionamento segue o debate no cenário nacional, no qual predomina a tendência a posicionamentos favoráveis à democratização do acesso ao ensino superior, desde que se contemplem alunos da escola pública, indicando o forte viés classista no debate sobre o processo de democratização da universidade. Segundo Mayorga (2010), haveria um consenso de que a inclusão deveria ser social, já que o problema seria a desigualdade sócio-econômica. Por sua vez, o debate sobre as desigualdades raciais é marcado muito mais por divergências, de modo que "o racismo à brasileira é ao mesmo tempo reconhecido e negado" (Mayorga, 2010, p. 152). Nessa direção, o professor Kabengele indicou em entrevista a essa pesquisa, como a USP está conciliada com discursos e práticas antirracistas que efetivamente pouco oferecem para o combate e superação do racismo na universidade e na sociedade brasileira. Além disso, aponta como no cotidiano acadêmico as ideologias e práticas racistas acontecem, mesmo que blindadas de acusações:

\footnotetext{
Não quero dizer que a questão social não exista, mas nós sabemos que numa sociedade que é racista, os negros são duplamente discriminados, porque são pobres e são discriminados porque são negros, porque são mulheres, porque são mulheres negras. Mas a academia fecha a coisa do ponto de vista social.
}

Na Universidade de São Paulo o professor Kabengele tem sido voz ativa dentro do restrito corpo de críticos às políticas do INCLUSP e agora mais recentemente o PIMESP. O INCLUSP, que substituiu a CPPPN, conforme dito anteriormente, tem proposto ser um programa de inclusão social para o aluno do ensino médio oriundo de escola pública que prevê isenção da taxa do vestibular, bônus na nota que depende do desempenho no ENEM e no PASUSP, o Programa de Avaliação Seriada; e bolsas de auxílio permanência após o ingresso na graduação. 48 Face à pressão pela adoção das cotas raciais, a USP, juntamente com as outras duas universidades estaduais, tem proposto o PIMESP (Programa de Inclusão com Mérito no Ensino Superior Público Paulista) apresentado pelo governador Geraldo Alckmin e pelo CRUESP (Conselho de Reitores das Universidades Estaduais de São Paulo), como alternativa à adoção de políticas de cotas raciais nas universidades do estado de São Paulo. O PIMESP objetiva estabelecer um regime de metas para incrementar o número de matrículas de oriundos de escola pública (aí inclusos negros e indígenas) nas universidades públicas de São Paulo. Esta tem sido a resposta proposta pelo

48Informações retiradas da página eletrônica da Pró-reitoria de Graduação da USP. http://www.prg.usp.br/?page_id=365. Acesso em 19/03/2013 
governo do estado após a repercussão da aprovação pelo senado, em agosto de 2012, do sistema de cotas raciais e sociais que reservam $25 \%$ das vagas em universidades federais para negros e indígenas e outros $25 \%$ para estudantes de escola pública oriundos de família com renda per capita de até um salário mínimo e meio, inicialmente com validade de dez anos.

Bem mais do que o INCLUSP, o PIMESP tem sido duramente criticado por setores que defendem a adoção de políticas de ações afirmativas que debatem a necessidade de real inclusão racial nas universidades públicas.49 Dentre as principais críticas ao PIMESP está a proposta do ICES (Instituto Comunitário de Ensino Superior), que seria um curso à distância destinado aos alunos "cotistas" a ser cursado antes do ingresso na universidade, com exigência de desempenho igual ou superior a $70 \%$ para só então começar a graduação de fato. Atrelado à UNIVESP, a Universidade Virtual do Estado de São Paulo, que reúne recursos das três universidades estaduais paulistas, o curso do ICES seria à distância, e denominado "college". E conforme sintetiza o professor Dennis de Oliveira em artigo publicado pelo Revista Fórum50, o PIMESP seria um engodo pois:

\begin{abstract}
A proposta do "college" brasileiro decorre, primeiramente, de uma visão de que o aluno negro e indígena e vindo de escola pública necessita de uma "preparação prévia" para ingressar na universidade e combina isto com um modelo de "profissionalização" estranha que junta disciplinas como "Princípios de Economia", "Profissionalização, Inovação e Empreendedorismo", "Liderança e Trabalho em Equipe", "Matemática Financeira" que sinaliza para uma formação básica na área de gestão e administração. Lembra muito a reforma do ensino realizada pela ditadura militar em 1971, com a Lei 5692, que instituiu a formação profissionalizante básica no ensino médio, com os alunos divididos em "exatas", "humanas" e "biológicas" a partir do segundo ano do ciclo. (...) Em outras palavras, o tal "college" do governo paulista é um tremendo engodo - não recuperará conteúdos e nem tampouco será uma formação profissional de qualidade. Será mais uma demagogia do governo para atender a demanda de jovens pobres, negros e indígenas pela educação superior pública, criando um outro sistema de ensino de segunda mão, dando um alento para a polêmica Univesp e seu ensino à distância e dando uma resposta a reivindicação por cotas. A importação do nome "college" é só para dar um ar de sofisticação ao projeto, mas além do nome, nada tem a ver com a experiência dos community colleges estadunidenses.
\end{abstract}

O professor (negro) Dennis de Oliveira, também entrevistado para essa pesquisa e cuja trajetória será analisada no capítulo sete, e o professor Kabengele Munanga são dois nomes bem recorrentes na construção do quarto momento do debate racial na USP. Em carta aberta e

49Conforme publicação da Associação de Docentes da USP (ADUSP), de autoria da professora Selma Garrido Pimenta e pró-reitora de graduação entre os anos 2006 a 2009, o INCLUSP foi aprovado no CO de maio de 2006 e foi elaborado fundamentalmente por docentes da USP, mas contou com a participação discente e de docentes de outras instituições, Interessante destacar que dois docentes da FFLCH comprometidos com o debate e a pesquisa no campo das relações raciais estão nesta lista: Antonio Sérgio Alfredo Guimarães, do Departamento de Sociologia e João Baptista Borges Pereira, professor aposentado do Departamento de Antropologia. Impacto do Inclusp no ingresso de alunos da escola Pública (análises iniciais). Autoras: Selma Garrido Pimenta Pró-Reitora de Graduação da USP Maria Amélia Campos Oliveira, Maria Isabel de Almeida e Maurício dos Santos Matos Assessores da Pró-Reitoria de Graduação da USP. Revista ADUSP, Julho de 2008.

50Ainda sobre o PIMESP: o que é de fato o "college" proposto pelo governo de São Paulo. Autor: Dennis de Oliveira 08/03/2013. 
publicada em 15/03/2013, o professor Kabengele Munanga arremata a discussão que rejeita a proposta do PIMESP dizendo que se dependesse dele se discutiria apenas a questão das cotas no modelo das universidades federais e estaduais que as adotaram e não do College, seja ele de um ou de dois anos. Quem sou eu para decidir, mas não posso deixar de dizer o que penso a respeito! Tal pronunciamento é bem ilustrativo do que tem sido a sua carreira, pois o debate e a proposição de políticas de acesso ao ensino superior e ações afirmativas tem sido acompanhado de perto pelo professor Kabengele Munanga pelo menos desde os anos 1990, indicando que a sua trajetória intelectual e acadêmica tem sido delineada também por questões dentro e fora da universidade.

\section{IV-1. Milton Santos: um cidadão do mundo na docência da USP}

Este tópico pretende um rápido registro sobre a presença de um dos maiores geógrafos brasileiros na docência da USP, destacando sua negritude. A vida intelectual do professor Milton Santos tem sido amplamente investigada, gerando uma profícua produção ${ }^{51}$. Sendo assim, nossa intenção aqui é pontuar e não exaurir a trajetória acadêmica desse grande intelectual negro que apenas encerrou a sua carreira na USP. E, por mais importante que tenha sido a sua passagem como docente pela Universidade de São Paulo para os propósitos dessa pesquisa, não se pode perder de vista o fato de que a carreira intelectual do professor Milton Santos já era internacionalmente consolidada, de modo que a USP foi uma passagem em sua carreira e não seu ponto alto.

Na página eletrônica ${ }^{52}$ mantida pela família de Milton Santos consta que o mesmo nasceu em 1926 em Brotas de Macaúba, interior da Bahia. A longevidade e o sucesso de sua carreira intelectual podem ser entendidos a partir da singular história de sua família. Em entrevista concedida à GEOSUL e publicada em 1991, Milton Santos aponta que sua família, apesar das estreitas possibilidades de educação para a população negra, teve uma história escolar bastante excepcional:

Minha família pelo lado materno é uma família de professores. Os meus avós maternos eram professores primários - ambos eram professores no Centro Operário de Salvador. Nessa época não havia ainda os sindicatos, mas eles eram professores deste Centro Operário que ocupava um dos solares da velha cidade de Salvador, antes da Abolição. Uma

51 CARDOSO (1996); CONCEIÇÃO (2009), (2002), (2001); PORTO-GONÇALVES (2002); RUFINO DOS SANTOS (2006); SILVA (2002), (1996).

52 Página eletrônica mantida pela família de Milton Santos: http://miltonsantos.com.br/site/ Acesso em 20/04/2013. 
das coisas curiosas na historia de minha família e o fato de que antes mesmo da Abolição esses meus avos puderam terminar um curso regular na Escola Normal, e isto se deve naturalmente as famílias que participaram da velha pequena burguesia negra da Bahia. Já os meus avós paternos eram lavradores urbanos. (Milton Santos, 1991, p. 170).

Milton Santos diz que foi alfabetizado por seus pais, com quem aprendeu também "álgebra, francês e boas maneiras" (p.171). Foi para Salvador aos dez anos para dar sequência à formação. Dos tempos de ginásio guarda a memória do prognóstico de um professor a respeito do seu futuro:

Eu me recordo do meu professor de Português que era um grande poeta e que me disse um dia "Você não chegará nunca a ser Presidente da Republica, mas você será um Teodoro Sampaio". Ele imaginava que eu iria ser um intelectual ou geógrafo, pois Teodoro Sampaio, apesar de ser engenheiro, foi sobretudo um importante geógrafo que escreveu sobre São Francisco, sobre São Paulo e sobre a cidade de Salvador. (Milton Santos, 1991, p. 173).

Conforme destaca Cirqueira (2010), Milton Santos nunca passou despercebido no universo escolar. Sua genialidade se fez notável em várias disciplinas. Coincidentemente ou não, assim como Teodoro Sampaio, a primeira opção de carreira que ocorreu a Milton Santos foi a engenharia, porém foi desmotivado a seguir essa área em função da hostilidade racial que espreitava os alunos negros na Politécnica de Salvador:

\begin{abstract}
Eu imaginava que iria estudar Engenharia, mas havia uma ideia de certo modo corroborada pelo fato de que a Escola Politécnica não gostava de admitir negros. Então como havia um cuidado para evitar decepções na juventude, eu fui orientado a fazer Direito, renunciando a uma vocação que eu imaginava ter quando menino que era a de ir para a Igreja, para ser padre. Um tio meu advogado e que tinha estado no seminário me dissuadiu da ideia de ser padre e com argumentos que vocês imaginam quais. Ele me sugeriu estudar Direito. Então, como eu ia estudar Direito decidi que a Matemática não tinha mais cabimento e passei a estudar Geografia e, logo que deixei o ginásio, com quinze anos, eu comecei a ensinar Geografia. (Milton Santos, 1991, p. 174).
\end{abstract}

Sendo assim, Milton Santos bacharelou-se em 1948 em Ciências Jurídicas e Sociais pela Faculdade de Direito de Salvador. Na referida página eletrônica mantida por seus familiares, a carreira intelectual de Milton Santos é divida em três momentos. O primeiro está compreendido entre os anos de 1948 a 1964: "Um pesquisador implicado na realidade local". Neste período de sua vida Milton Santos foi jornalista e redator do jornal A Tarde por dez anos (1954-1964), professor de geografia humana na Universidade Católica de Salvador (1956-1960), professor catedrático de geografia humana na Universidade Federal da Bahia, criando o Laboratório de Geociências, diretor da Imprensa Oficial da Bahia (1959-1961), presidente da Fundação Comissão de Planejamento Econômico do Estado da Bahia (1962-1964), e representante da Casa Civil do presidente Jânio Quadros na Bahia, em 1961. Em 1958 conclui seu doutorado em Strasbourg com 
a tese intitulada $O$ Centro da Cidade de Salvador, o que atesta sua preocupação analítica com a realidade soteropolitana.

O segundo momento da carreira de Milton Santos, ali intitulado como Um pesquisador viajante, começa em 1964, ano em que deixa o Brasil em decorrência do regime militar, e vai até o ano de 1977. Sua carreira internacional começa na França como professor convidado nas universidades de Toulouse, Bordeaux e Paris-Sorbonne, e no IEDES (Instituto de Estudos do Desenvolvimento Econômico e Social). Os anos de 1971 a 1977 marcam um período itinerante da sua carreira: é convidado como pesquisador pelo MIT (Massachusetts Institute of Technology Boston); e como professor pelas universidades de Toronto (Canadá), Caracas (Venezuela), Dar-esSalam (Tanzânia), Columbia University (New York). É também um momento de profícua produção teórica no campo da Geografia, algumas consideradas referência internacional como a obra L'Espace Partagé: les deux circuits de l'économie des pays sous-développés originalmente publicada em francês em 1975, e posteriormente em inglês e português no ano de 1979.

Por fim, tem-se em Milton Santos Um pesquisador engajado que retorna ao Brasil em 1977. Na entrevista publicada pelo GEOSUL, já considerada neste texto, Milton Santos conta que seu retorno à docência universitária no Brasil, não se deu de modo tranquilo ou rápido.

É verdade que naquele tempo os professores das universidades, mesmo aqueles que fingiam ser de esquerda, corriam dos professores chamados exilados, como o diabo corre da cruz. Tanto que na USP eu fui o convidado da Associação dos Geógrafos, em 1975, e não do Departamento, cujos professores mais importantes não foram me assistir, exceto Araujo Filho. Os professores importantes não foram lá e os que foram, eram exatamente os que estavam despontando, que tinham um certo compromisso. (...) Eu me recordo que em 31/12/76, Armen me telefonou a New York dizendo que era quase certa a minha nomeação e vinda para cá e depois ele me telefonou dizendo que isso não era mais possível, por frouxidão dos colegas, sobretudo, mais do que por qualquer coisa, porque não creio que fosse uma pessoa tão perigosa assim. Quando cheguei no Brasil em 1977, não houve meios de obter emprego em universidades. Vale lembrar que ainda em 1975, quando me candidatei na Universidade da Bahia - que era a minha própria vaga - a minha inscrição foi aceita por engano de um funcionário e depois foi cancelada pela administração da universidade, o que significa que não era tão fácil assim, voltar ao Brasil, como alguns colegas do IPGH afirmaram a Pierre George, que gentilmente me transmitiu essa conversa. $^{53}$ (Milton santos, 1991, p. 195).

Como convidado do Programa Roda Viva exibido em 1997, Milton Santos problematiza o posicionamento da professora da FAU, Maria Irena Szmrecsanyi, uma das pessoas convidadas para entrevistá-lo. Para a socióloga a simples presença do professor Milton Santos seria um indicativo de que a USP seria uma universidade acolhedora e não burocrática. Milton Santos contesta, dizendo que sua entrada na USP foi laboriosa. Na entrevista que concedeu ao GEOSUL, Milton Santos sabia que sua experiência internacional favorecia seu currículo no Brasil, mas tinha

53Em 1995 Milton Santos foi reintegrado oficialmente à Universidade Federal da Bahia, da qual tinha sido demitido por "ausência", eufemismo para sua expulsão que aconteceu com o estourar da ditadura militar. 
ciência de que sua condição de exilado o tornava pouco aceito. Isso acontecia desde 1974 quando começou a vir esporadicamente ao Brasil para oferecer palestras e participar de seminários para plateias esvaziadas.

Assim, apenas em 1979 Milton Santos volta a lecionar no Brasil, primeiro na Universidade Federal do Rio de Janeiro, até 1983. Neste mesmo ano presta concurso e ingressa na USP, primeiro na Faculdade de Arquitetura e Urbanismo (FAU) e posteriormente no Departamento de Geografia, onde chegou a Professor Titular, topo da carreira universitária. Após a sua aposentadoria compulsória por idade recebe o título de Professor Emérito da USP em 1997. Sua carreira na USP como pesquisador e orientador foi interrompida em 2001, quando faleceu em decorrência de um câncer. Sua consagração intelectual é atestada pelos dezenove títulos de Doutor Honoris Causa outorgados por doze universidades brasileiras e sete universidades estrangeiras. Além disso, em 1994 recebeu o equivalente ao Nobel em Geografia, o Prêmio Internacional de Geografia Vautrin Lud, maior premiação existente na área. Milton Santos recebeu mais de vinte outros prêmios, incluindo o Prêmio Jabuti. Sua extensa produção bibliográfica com cerca de cinquenta livros publicados, configurou revoluções epistemológicas na disciplina à qual se dedicou.

Além da vida acadêmica, conforme indica seu currículo completo, publicado no site Milton Santos, o professor também construiu sólida carreira política, sempre cercada de polêmicas. A exemplo de Guerreiro Ramos, também teve o início da sua trajetória associada à direita política e inicialmente não era bem quisto pelas lideranças comunistas. A aproximação de Milton Santos com o marxismo foi gradual: "A gente tinha ideias democráticas, liberais, mas não éramos de esquerda", (...) o marxismo veio lentamente, principalmente depois que fui fazer meu doutorado na França, nos anos 50, com o professor Tricart”. (Santos, apud Conceição, 2001, p. 2).

Na sua vida docente na USP, o marxismo do professor Milton Santos chegou a ser posto à prova, conforme relatou em entrevista para essa tese, a professora Vanderli Custódio, que foi sua aluna na Geografia:

Olha, difícil falar do Milton, porque, as pessoas dizem que... todo mundo se sente viúva de Milton Santos, fica todo mundo falando dele como se tivesse tido uma intimidade profunda com ele e tal. Ele foi meu professor e no departamento ele era visto como alguém que tinha... que era muito conceituado fora e que estava voltando para o Brasil. Eu entrei em 81, era bem quando ele estava voltando e que tinha umas propostas teóricas diferenciadas para a geografia, uma geografia crítica. Mas o que se cobrava dele, e aí era um policiamento mesmo, marxista, de uma esquerda meio dogmática, era "ah ele não tem práxis, ah, falta práxis". Cobravam dele que ele propunha uma geografia crítica, portanto uma geografia de cunho marxista, mas que ele não era envolvido com nenhum sindicato, com nenhuma... não vou dizer ONG, porque naquela época não existia, mas com nenhuma associação de bairro, nenhuma associação religiosa, de ajuda aos pobres, ou alguma coisa assim. $\mathrm{O}$ que eu particularmente acho que era uma ignorância daquela esquerda, por que assim, o Milton sempre participou de todo tipo de... aí falavam que ele cobrava "ah, ele cobra cinco mil reais por palestra, imagina, o que isso, não sei o quê". Coisas que falavam que até hoje eu não sei se é verdade ou se é mentira, se é folclore ou não é. Eu só sei que quando ele era chamado pra falar para os negros, ele ia e ia de graça e não fazia propaganda disso dentro da academia e então muita gente desconhece porque ele não ficava falando "olha, eu participo do movimento negro, quando o movimento negro me chama". 
Outra questão que acompanhou a trajetória de Milton Santos na USP foi seu envolvimento com o debate racial. No texto intitulado Não sou militante de coisa alguma exceto de ideias, publicado na Revista da ADUSP (Revista da Associação de Docentes da USP) em junho de 1999, Milton Santos reconhece a sua condição de intelectual negro preocupado com processos de exclusão, porém crítico em relação a noções tradicionais de militância:

\begin{abstract}
Minha própria biografia pessoal acaba sendo decisiva para o entendimento de minha posição ideológica e política. Quer dizer, o próprio fato de ser negro e a exclusão correspondente acabam por me conduzir a uma condição de permanente vigilância. Não sou militante de coisa nenhuma, possivelmente pela forte influência do estilo francês de ser intelectual, que houve na minha formação, por mais que eu deseje me libertar dessa herança, é tão forte, razão pela qual às vezes eu o faço com certa brutalidade. Essa idéia de intelectual, aprendida com Sartre, de uma independência total, distanciou-me de toda forma de militância, exceto a das idéias. A militância político-partidária me assusta, me faz medo, porque ainda que a considere como indispensável, como também são indispensáveis os políticos, não desejo sê-lo, porque quero ser permanentemente sozinho. Embora separados, os militantes conscientes e convictos, constituem um bloco de resistência. (p.12).
\end{abstract}

Parece haver um consenso entre as pessoas próximas ou que trabalharam com Milton Santos na USP, de que ele pouco falou sobre a temática racial. Mas é importante atentar para alguns fatos: existe muito material midiático, (inclusive disponível na internet), onde é possível verificar Milton Santos se posicionando como um intelectual negro preocupado com desigualdades raciais, de modo que ele "'discutia' tranquilamente o assunto, obviamente que, com todo rigor crítico que lhe era típico" (Cirqueira, 2010, p. 146); Milton Santos também teria reservado maior espaço para a discussão em fóruns externos à universidade. Há uma hipótese interessante apresentada por Cirqueira (2010) de que sua produção final sobre corpo, memória e experiências pode ter sido a via encontrada por Milton Santos para discutir a questão racial:

\begin{abstract}
A despeito das especulações em torno da vida e das discussões de Milton Santos sobre a questão étnico-racial, uma coisa é certa, ele é produtor e produto de suas proposições sobre esse assunto. Sua escrita sobre o assunto, principalmente a que compreende o final de sua vida, envolveu corpo, memória e experiências, e, apesar de toda "racionalidade" que o mesmo tenha tentado imprimir em sua obra, estes fatores desempenharam um papel primordial em suas discussões sobre o tema mencionado. Sua trajetória socioespacial: um menino negro que saiu de Brotas de Macaúbas e se deslocou por vários países no Mundo, deu o tom disso. Ele foi um negro que rompeu com o "lugar de negro" e sofreu as conseqüências disso. Teve a corporeidade esquadrinhada pelo "olhar vesgo" racista, que buscava the impor um "lugar": "fora da nação" e como um não-cidadão. Daí as contradições da vida do grande intelectual: era um "cidadão do mundo", mas, ao mesmo tempo, era um "cidadão mutilado"; era um intelectual brasileiro internacionalmente reconhecido, entretanto, por várias vezes foi identificado genericamente como "africano", "norte-americano" ou "jogador de futebol". (Cirqueira, 2010, p.147).
\end{abstract}

O episódio relatado anteriormente neste trabalho, em que o então doutorando e militante do Núcleo de Consciência Negra da USP, Fernando Conceição, que sofreu processo administrativo movido pela universidade quando reivindicava cotas, atesta o envolvimento do professor Milton 
Santos com o debate dentro da universidade também. A amizade que se estabeleceu entre os dois, foi profunda a ponto de Milton Santos ter autorizado Fernando da Conceição a escrever sua biografia. Mas como destacou Conceição, a resistência de Milton Santos como negro a tratar dessa questão, decorria do fato de que o grande geógrafo considerava que essa é uma questão que deve envolver não apenas negros, mas toda a população brasileira:

Até certo outono de 1992, quando o conheci (membros do Núcleo de Consciência Negra, na USP, do qual fazia parte, o procuraram para solicitar apoio), se dizia que "Milton Santos não se sentia negro". O que naquele primeiro contato ele deixou explícito é que não poderia aceitar a ideia de que a questão racial no Brasil devesse ser deixada apenas para os negros resolverem ou discutirem. Era e é, no seu entendimento, um problema de toda a sociedade, e ele recusava a tratá-lo como uma questão exclusivista. A questão racial passou a fazer parte da agenda de Milton Santos, de forma intensa, nos anos 90. (Conceição, 2001, p.3).

Outra questão que parece consenso entre aqueles/as que conviveram com o professor Milton Santos na USP refere-se ao quanto o intelectual foi subestimado pela universidade. Na entrevista que concedeu para esta pesquisa, a professora Vanderli Custódio indica o processo de constante questionamento das proposições teóricas de Milton Santos, tida como controvertida para muitos no Departamento de Geografia:

Ele sempre foi muito controvertido, as pessoas questionavam os conceitos que ele criava dentro da geografia, mas também ninguém escrevia coisa melhor para se contrapor a ele. Então ele foi uma pessoa controvertida e sempre com um discurso muito provocador, ele tinha um discurso provocador, um discurso geográfico provocador. Então era assim de ter... ou ame-o ou deixe-o, ele era esse tipo de pessoa. Então quem gostava, gostava, quem não gostava não gostava mesmo (risos), tanto da produção geográfica dele, quanto dele.

As polêmicas referentes à sua presença na universidade foram muitas. Em texto publicado pela Revista ADUSP (Revista da Associação de Docentes da USP) em setembro de 2001, a professora titular do Departamento de Geografia da USP, Maria Adélia Aparecida de Souza, denuncia o quanto a USP não considerou com a devida importância a presença de Milton Santos no seu quadro docente: "Milton Santos e sua importante obra foram ignorados pela USP. Como ele mesmo dizia, era apenas lembrado pela instituição quando havia necessidade de exibir um crioulo ilustre. Desnecessário dizer que ele jamais se prestou a tais papéis." (p.83). O descaso da instituição com Milton Santos parece vir desde o desconhecimento de sua obra até omissões no momento de sua enfermidade e morte:

Milton partiu e a USP não tomou conhecimento nem de sua obra, de sua liderança, de sua concepção de Universidade pública, livre e gratuita, nem de sua experiência. Eu mesma inúmeras vezes tentei alertá-lo, quantas vezes... E como ele se zangava comigo quando eu incitava a Universidade a notá-lo... A USP como instituição não se incomodou com sua doença, não deu afeto a ele ou a sua família, não velou seu corpo. (p.83) 
Apesar de negligenciado institucionalmente e pouco compreendido noutras vezes, Milton Santos foi fundamental na trajetória acadêmica de alunas/os negras/os, que tiveram a oportunidade de conhecê-lo como Fernando Conceição e a professora Vanderli Custódio. Estas experiências apontam para a importância da existência de intelectuais negros/as que sejam referências para a população negra, tão sub representada no ensino superior brasileiro. Apesar do número reduzido de docentes negros/as nos diferentes departamentos da USP, a presença deles pode, numa perspectiva otimista, ter um efeito multiplicador. Considerando o currículo do geógrafo Milton Santos, que foi bolsista 1A do CNPQ, professor titular na USP entre os anos de 1983 a 1995 e professor emérito da Faculdade de Filosofia da USP a partir de 1997, percebe-se que estar no topo da carreira docente na USP foi um espaço utilizado por Milton Santos para dar sequência à defesa da cidadania plena dos excluídos, tal qual atesta toda a sua produção bibliográfica.

Considerando a história da pesquisa sobre relações raciais na Faculdade de Filosofia, Letras e Ciências Humanas, somente a partir da década de 1980, é que a Faculdade assiste pela primeira vez a possibilidade de produção teórica de intelectuais negros, com a presença de Kabengele Munanga no Departamento de Antropologia, Milton Santos no Departamento de Geografia e Wilson Barbosa no de Departamento de História. Os anos de 1990 e 2000 foram de intensa produção intelectual e participação de docentes negros/as no sentido de interpelar as desigualdades raciais na sociedade brasileira e na USP em particular.

O próximo tópico desse trabalho apresenta aspectos da atuação de outro docente negro, Edson dos Santos Moreira que, apesar de estar fora das Ciências Humanas, também teve importante visibilidade na luta pela ampliação do acesso da população negra ao ensino superior. Assim, a intenção de reuni-los aqui decorre do fato de que esses nomes foram contemporâneos nos anos 1990 e foram personagens fundamentais na proposição de políticas e debates raciais que mobilizaram a USP nas últimas duas décadas. 


\section{IV-2. Trajetória de um professor negro nas ciências exatas da USP: Edson dos Santos Moreira}

O professor Edson dos Santos Moreira nasceu numa família oriunda de região rural da Bahia, que veio para o interior de São Paulo. É o primeiro filho a nascer em solo paulista, em Pontal, divisa com o Mato Grosso. Em entrevista a essa pesquisa, conta que seu pai foi alfabetizado por sua mãe, que havia cursado o primário. Embora sua mãe não viesse a estudar novamente, o pai após os quarenta anos de idade deu continuidade à formação e chegou a concluir o ginásio, que equivalia à oitava série. Este fato, segundo relata, reforçou na família a importância da formação escolar, de modo que todos os filhos chegaram a ingressar no ensino superior, embora dois irmãos não tenham concluído a graduação.

Vários fatores confluíram para o ingresso do professor Edson Moreira no curso de Engenharia Elétrica da USP São Carlos em 1977. O primeiro deles era que na chácara onde nasceu e viveu parte da vida, havia uma antena de rádio e um transmissor, sendo que metade da casa onde viviam era da família e a outra metade abrigava o aparelho, de modo que a eletrônica faz parte de suas primeiras memórias, tal qual narra em entrevista para esta pesquisa:

\footnotetext{
Bom, eu nasci... esse lugar que a gente morou quando eu era pequeno, era uma chácara que tinha um transmissor e uma antena de rádio da cidade. Tinha a antena da rádio e tinha uma casa, uma casinha, que era... metade da casa era um quarto, metade da minha mãe e metade da casa era onde ficava o transmissor, tanto que eles tiveram que fazer uma cerquinha em volta do transmissor, porque eu engatinhava lá, porque eu queria mexer lá no transmissor e ia ser eletrocutado. E eu sempre gostei desse negócio de eletrônica, brincava com eletrônica, fui trabalhar, eu fui trabalhar numa rádio. Então achava que eletrônica era a coisa mais bonita do mundo, foi por isso.
}

Além da familiaridade com a eletrônica, era um tempo que ele recorda ser bom para essa área profissional, pois "no final dos anos 70, o governo tinha políticas de proteção pra eletrônica e quem fazia eletrônica tinha emprego, era a época da televisão". Outro fator que contou na escolha do curso foi o fato de existir alojamento e bolsas de estudo em São Carlos, o que na sua perspectiva, adiciona também o acaso na escolha da carreira, conforme narra em entrevista para esta pesquisa:

\footnotetext{
Acho que... eu fui para eletrônica assim meio que por acaso, eu fui para São Carlos meio por acaso também, porque eu tinha encontrado alguém, uma namorada do meu irmão, uma coisa desse tipo, que disse "olha, em São Carlos tem alojamento e tem bolsa de estudos". Então eu fiquei com aquele negócio na cabeça e como fiz a opção lá... o... a inscrição pro vestibular, eu coloquei São Carlos por conta disso, (...) eu tive a opção de ir para a UNICAMP ou para São Carlos e eu escolhi São Carlos, por conta disso.
}

A entrada no mestrado partiu do convite de um professor com quem fizera a iniciação científica. Após a defesa começou a dar aulas na Computação, instituto que era então pouco prestigiado. A possibilidade de sair do país para fazer o doutorado surgiu como uma exigência da 
universidade, conforme entrevista concedida para esta pesquisa:

Quando eu me formei, o meu orientador de iniciação científica me convidou para fazer mestrado e ele tinha acabado de fazer o doutorado. (...) Quando eu terminei o mestrado, a Computação que era o patinho pobre do meu Instituto, do que deveria ser o meu Instituto, eles queriam gente para trabalhar com hardware, porque só tinha gente que trabalhava com software e aí eles foram me procurar, se eu não queria ser professor da Computação, naquele tempo contratava-se mestres, só que eles queriam alguém que quisesse fazer doutorado fora do país. Oba! Então veja, eu não queria fazer mestrado, não pensei em fazer mestrado, não pensei em fazer o doutorado, mas aí foi praticamente uma imposição deles, de fazer fora do país... bom, então eu fui fazer doutorado também quase que por acaso em Computação, porque poderia ter sido Física, poderia ter sido em Eletrônica e eu fiz em Computação e em Manchester.

Interessante destacar que desde a graduação o professor Edson Moreira tem refletido sobre a presença de negros no ensino superior. Sua militância no movimento negro Congada, num momento de ditadura militar, foi fundamental nesse processo, conforme entrevista para esta pesquisa.

Então o Congada foi muito importante, porque a gente discutia muito a questão racial, lia muito e tinha muita influência dos negros norte-americanos e por aí que os esportes foram importantes e o atletismo em particular, sabe, porque na época que os americanos, logo depois de 68, dez anos depois os caras tinham uma postura, todos os atletas americanos tinham uma postura política, o cara que no atletismo fazia o Black Power e tudo mais, eram tudo ideias políticas que permeavam muito no meio esportivo. Acho que em 72 eles recusaram a cantar o hino nacional americano, foi um escândalo enorme, o Muhammad Ali se recusou a ir para a guerra do Vietnã, certo? Tinham os Panteras e tudo mais. Então o atletismo, o atletismo e o movimento negro naquela época era muito conectado.

Segundo relata o professor, o Congada envolvia jovens negros na USP São Carlos e na UFSCAR de modo que pensar a configuração da equipe de atletas dentro do Congada, acaba remetendo à história da dinâmica racial da cidade de São Carlos: a produção cafeeira de mão de obra escrava desce de Minas e chega em São Carlos no final do período escravocrata, num momento de extinção do tráfico, gerando um movimento de migração de remanescentes de escravos para a região. No início do período republicano, a população negra, que não era tão grande na cidade, acaba por diminuir em função do fluxo de imigrantes europeus, que vão ocupando as posições dos negros recém libertos. Apesar do tempo transcorrido, essas dinâmicas migratórias se fizeram sentir dentro do Congada: numa cidade de poucos negros, em quantidade ainda menor dentro das universidades, um movimento negro de caráter acadêmico tinha que estar conectado com negros fora da universidade se quisesse alguma representatividade. Assim é que as equipes de atletas eram constituídas em sua quase totalidade, por negros não universitários, o que gerava conflitos dentro da USP São Carlos, conforme entrevista para esta pesquisa:

Olha, a USP não tinha ninguém, então assim, eu era meio que uma pérola rara a assim, 
sabe, então... na Federal [UFSCAR] tinha mais, tem bem mais negros que na USP. E eu assim, dentro do meio acadêmico, a gente não tinha muito problema, digamos assim, tinha certas tensões, sabe, porque obviamente a gente não era fechado dentro da universidade, isso era uma coisa importante. Então, no atletismo, por exemplo, na equipe do atletismo que eram $70 \%$ de negros, tinha $20 \%$ de universitários, o resto eram negros da cidade, entendeu? Então as coisas que a gente fazia na universidade, a gente era uma porta de entrada para a comunidade. Então as tensões aconteciam exatamente aí: enquanto membros da universidade, a gente era sempre muito bem vistos e admirados, que no meu caso, sendo eu atleta, eu era conhecido, na fina flor, eu era querido dentro da universidade, mas quando a gente trabalhava pra ser uma porta de entrada pra comunidade, aí já começava: "esse pessoal aí, quem é?"não sei o que. Aí a gente fazia questão "vamos fazer festa, ou show, sei lá o que, teatro, dentro da universidade." Então aí já tinha algumas tensões, tanto na Federal, quanto na USP. A Federal era... era mais fácil fazer as coisas na Federal, e as razões são simples: a Federal era uma universidade per si, lá. Então tinha cursos na área de humanas, biológicas e nas áreas exatas. Na USP não, era só exatas, São Carlos era, é ainda até hoje só exatas, então pra começar, tinha menos negros, porque você sabe que quanto mais disputado, menos negros você vai achar. $\mathrm{E}$ as pessoas estavam menos acostumadas a conviver com negros, num é isso? Esse é que é o ponto, na verdade, o problema é "não tenho nada contra o negro", mas aí na convivência é que vem... é que as tensões surgem, né? E os preconceitos, assim disfarçados, por exemplo: o que esse pessoal todo tá aqui... quem é esse pessoal que está aqui? Se fosse um monte de italianos que chegassem lá para fazer uma festa, ninguém ia perceber como sendo algo diferente, diferente do normal do ambiente, mas aquele monte de negros aí já... Então, assim, me perguntam muito "você foi discriminado?" Digo "bom, eu como pessoa nunca fui, pelo contrário, até as pessoas me... mas, como membro de um grupo a coisa é... às vezes são nuances e às vezes são explicitas, às vezes..." quer dizer, como a instituição é... a universidade é racista, não tem negro, então porque não tem negro?

Durante a entrevista para essa pesquisa, ocorrida em meados de 2011, com um olhar atento para a quantidade de negros dentro da USP São Carlos, (que é um campus de ciências exatas) o professor Edson contou três docentes negros no seu Instituto, sendo ele o único no seu Departamento. Tanto na entrevista que concedeu a essa pesquisa em 2011, no Memorial que apresentou para o concurso de Titular em 2010, quanto na palestra que proferiu na FFLCH em 2002 (cujo arquivo do texto proferido, ele me enviou por email) destaca-se uma preocupação fundamental nas suas narrativas, a necessidade de existirem negros/as no corpo docente da USP, principalmente nas instâncias de decisão.

A carreira acadêmica do professor Edson Moreira reflete essa perspectiva. Sua vida na USP começa em 1977 como aluno na graduação e a partir de 1984 na docência. Após concluir o doutorado na Inglaterra em 1989, volta com o propósito de estabelecer sólida carreira de pesquisador, conforme relatou em palestra: "Entre 1990 e 1994 trabalhei bastante para me estabelecer como pesquisador numa área que explodia: redes TCP/IP e tecnologia Internet. Ministrei um dos primeiros cursos sobre protocolos de internet no Brasil, em 1991." E conforme indica em seu memorial, Moreira (2010) seu doutorado abriu possibilidades de contribuir com o desenvolvimento inicial da internet no país, de modo que os primeiros cinco anos após o retorno se caracterizam por amplo envolvimento do professor em iniciativas na USP no âmbito da RPN (Rede Nacional de Pesquisas). Dessa forma torna-se professor visitante no CTI (Centro Tecnológico de Informática) em 1993 e consultor da IBM em 1995 e “de várias universidades 
brasileiras, públicas e privadas, em seus projetos de instalação de redes e de conexão com a Internet.”. O reconhecimento não tardaria a aparecer, pois seu nome foi inserido no Directory of Experts in Informatics da UNESCO em 1994.

Em sua carreira acadêmica na USP começa a acumular importantes funções administrativas. Entre 1996 e 1998 foi chefe do então Departamento de Ciência da Computação e Estatística. Durante a sua gestão foi criado o curso de Bacharelado em Informática desencadeando a ampliação do departamento. Houve ainda nesse período a mudança de nome do Instituto que passou de Instituto de Ciências Matemáticas de São Carlos (ICMSC) para Instituto de Ciências Matemáticas e de Computação (ICMC). Considerando que a vida acadêmica se faz com tensões e disputas que geram a necessidade de se organizar e criar estratégias para aumentar a representação de determinados segmentos na docência, na entrevista que concedeu a esse trabalho, o professor Edson indicou que a expansão do departamento fez parte de um processo de fortalecer o curso de Computação institucionalmente, na entrevista que concedeu para esta pesquisa:

(...) um instituto que tenha matemática e computação como o meu, é uma briga entre matemáticas e computação e até uns 15 anos atrás mais ou menos, a computação vivia de migalhas, a computação só conseguiu se impor quando criou massa crítica e aí nós fomos atrás de espaços novos, entendeu? Por exemplo, em 99, 98 a USP decidiu que só aumentaria departamentos que propusessem cursos noturnos, cursos novos noturnos, porque a USP estava sob pressão do ministério público porque tinha poucos cursos noturnos. Aí a gente percebeu "aí há um jeito de crescer". A gente propôs um curso noturno e conseguimos lá, sei lá, dez vagas, 12 vagas, quer dizer, doze novos professores. O número de professores é importante num instituto, que aí você tem a maior representação na congregação, aumenta o número de vagas para titular, entendeu?

Desde 1994 a discussão sobre a representatividade em sítios nevrálgicos da universidade tem interpelado a carreira do professor Edson na condição de membro da comunidade negra uspiana. Portas se abrem para esse debate quando o professor assume como suplente na Comissão de Cultura e Extensão Universitária em 1994, conforme relatou na palestra que realizou na FFLCH em 2002:

Em 1994 fui eleito para a Comissão de Cultura e Extensão do meu Instituto. O presidente da Comissão era o Diretor do Instituto. Como presidente, ele, naturalmente, fazia parte do Conselho de Cultura e Extensão. Como era muito ocupado, começou a solicitar que, como vice-presidente, o representasse nas reuniões do Conselho. Para a minha primeira participação no Conselho, em dezembro de 1994, eu recebera a carta de convocação com a pauta do encontro. Havia também o jornalzinho da Pró-Reitoria que trazia reportagem dizendo que a USP, no ano seguinte, estaria engajada em duas comemorações igualmente importantes: os 50 anos da declaração dos Direitos Humanos e os 100 anos do início da Imigração Japonesa. Numa conversa no dia anterior à viagem a São Paulo, uma colega funcionária negra do Centro Cultural do Campus, Maria de Lourdes Thobias, que também lera o Jornal, comentara com minha esposa a intrigante realidade: a USP se decidira sobre as datas significativas no ano seguinte, ressaltando a imigração japonesa e a Declaração, e se esquecera completamente dos 300 anos da morte de Zumbi. Eu decidi então, durante a reunião, pedir a palavra e falar sobre aquele aviltamento. Acredito que meu discurso tenha 
sido alguma coisa das mais inesperadas já vistas na sala do Conselho Universitário. Um silêncio profundo encheu a sala, como se um ET tivesse descido de paraquedas lá. Percebia-se que este tema não era comum para aquelas pessoas. Só não foi mais incômodo por que o então Pró-Reitor [Jacques Marcovitch], muito habilmente, usou da palavra para dizer que ainda estava em tempo de fazermos algo e que ele estava disposto a inserir o tema na programação de 1995. Ele havia comparecido a um evento promovido pela Fundação Palmares no dia anterior e havia sido questionado sobre o posicionamento da USP na questão. Estava interessado em fazer algo e assim começou um envolvimento mais formal e institucional da USP, em relação à questão racial, que em termos de pesquisa, havia sempre sido bastante profícuo e consolidado (Aliás, como objeto de estudos, o negro foi sempre muito presente nesta universidade; mas a presença pára por ai.)

A narrativa do professor Edson Moreira endossa o curso da historiografia da USP, discutida anteriormente, referente à rememoração do tricentenário da morte de Zumbi dos Palmares, mas também apresenta novos e preocupantes detalhes de bastidores que revelam que, por mais que o então pró-reitor Jacques Marcovicth estivesse informado sobre debate racial, faltava espaço para esta pauta em instâncias decisivas da universidade. Uma vez assegurada na agenda de eventos da universidade, o tricentenário da morte de Zumbi tornou-se um evento fundamental na história da universidade em meados dos anos 1990. Na referida palestra de 2002 o professor Edson assim avalia a importância do evento:

Durante 1995 houve bastante ação por aqui. Todas as unidades foram chamadas a proporem atividades que lembrassem Zumbi dos Palmares e a saga por liberdade, como algo importante para a História do Brasil e não apenas como algo folclórico, como a gente aprende na escola. Eu acho que os 300 Anos foi um marco importante porque ele definiu uma mudança de atitude da Administração da universidade, deixando a questão racial de ser apenas uma área de pesquisa na universidade. Uma Comissão foi formada para organizar as atividades. Esta comissão tinha membros da USP mas também vários de fora dela. No ano seguinte a Comissão continuou operante. Um levantamento sobre a Situação do Negro na sociedade brasileira (política, saúde, mídia, etc) foi elaborado. Uma das preocupações da comissão foi a de fazer propostas de políticas públicas para os órgãos públicos competentes, inclusive a própria USP. O aumento do número de negros nos quadros docente e discente foi colocado como ponto chave. (Palestra FFLCH, 2002)

Apesar de ter sido um ano promissor, as melhorias não foram amplas a ponto de mudar a configuração racial do corpo docente e discente nos anos seguintes. Isso ficou evidente em 1996, com a visita do reverendo Jesse Jackson à USP, conforme narra na palestra realizada em 2002, é possível dimensionar o ocorrido:

Em 1996 o reverendo Jesse Jackson veio ao Brasil e foi convidado a visitar a USP. Vários negros foram convidados; de novo, muito mais convidados externos do que internos, ou seja, para que a exclusão de negros não ficasse por demais vexatória, tratou-se de convidar externos. O reverendo falou com eloquência sobre a ação que sua ONG acabara de ganhar nos Estados Unidos contra a empresa Texaco, por ter, em seu quadro de funcionários, uma sub-representação de negros. No final de sua fala perguntou ao Reitor: qual é a percentagem de negros na USP? O Reitor não soube responder; um ativista do Movimento Negro (Henrique Cunha Jr) foi quem tomou a palavra; disse que não havia estatísticas sobre o assunto mas se estimava que o número fosse menor que $1 \%$. Desde aquele encontro, saber o número de negros na Universidade passou a ser um desafio para a administração da USP. Tanto que uma proposta minha de incluir uma pergunta extra (a 15ª no Questionário Sócio- 
Econômico da FUVEST foi muito bem recebida e encaminhada ao CoG (Conselho de Graduação). Lá, recebeu um parecer negativo e não foi aprovado. No ano anterior, a $14^{\text {a }}$ pergunta (algo sobre computadores e uso de Internet) havia sido inserida no Questionário, sem consulta ao CoG.

Entre 1996 e 2000 conforme indica o seu Lattes, o professor Edson assumiu o cargo de Presidente da Comissão de Cultura e Extensão Universitária e em 1999 foi indicado para o Conselho Superior da FUVEST, onde pôde consolidar importantes ações, conforme indica na referida palestra:

Em 1999 fui indicado para o Conselho Curador da FUVEST. Imagino que minha indicação tenha tido a ver com a minha atuação na Comissão dos 300 anos e seus desdobramentos, inclusive em relação a uma possível política de cotas. Logo aprendi as limitações e as possibilidades de atuação do Conselho Curador. Por exemplo, o Conselho não tem como atuar diretamente em relação à questão das quotas. Isto é atribuição do Conselho de Graduação e do Conselho Universitário. No entanto, pode trabalhar em pesquisas sobre o perfil dos ingressantes e sobre as barreiras impostas. Desde que faço parte do Conselho, o mesmo financiou pesquisas do NUPES, e o Censo Étnico da USP. Trabalhou também na implantação do sistema de isenções de taxa de inscrição e, timidamente, no processo de unificação dos vestibulares das universidades públicas paulistas.

O trabalho na FUVEST foi feito em parceria com os intelectuais que compunham a CPPPN, já discutida nesta tese, que por sua vez é herdeira da comissão criada em função do tricentenário, que reuniu desde então intelectuais comprometidos com o debate racial na USP. Sendo assim, vale lembrar que como membro da CPPPN desde 1999, o professor Edson Moreira trabalhou com nomes fundamentais da discussão racial no Brasil e na USP, como Kabengele Munanga, João Baptista Borges Pereira, Antonio Sérgio Guimaraes, Petronilha Beatriz Gonçalves, dentre outros. Além disso, as proposições no âmbito da FUVEST eram também fruto de diálogos com a comunidade negra externa à USP. Na entrevista que concedeu a essa pesquisa, o professor Edson Moreira citou a interlocução com Frei Davi, militante negro da EDUCAFRO ${ }^{54}$ entidade nacionalmente conhecida, cuja atuação foi importante para pressionar a FUVEST no aumento da isenção de taxas para o vestibular, por exemplo.

Conforme indica seu memorial para professor titular Moreira (2010), sua atuação na CPPPN lhe rendeu uma declaração de apreço, emitida pelo professor João Baptista Borges Pereira, reconhecendo as contribuições do professor Edson Moreira enquanto esteve na CPPPN. Seus esforços na promoção da comunidade negra lhe renderam também o Troféu Consciência, outorgado pelo Centro Municipal Negro de São Carlos.

A convite do professor Sérgio Mascarenhas, o professor Edson Moreira desenvolveu entre 2000 e 2005, no âmbito do Instituto de Estudos Avançados de São Carlos, um grupo de

54Educafro é uma rede nacional de cursinhos populares voltadas para a população negra, criada na década de 1990 pelo Frei Davi no estado do Rio de Janeiro. 
trabalho para debater a questão racial, promovendo ações junto à comunidade. Em 2002 submeteram um projeto à Fundação Ford dentro do programa Cor na Universidade Brasileira, obtendo o financiamento de $\mathrm{R} \$ 70.000,00$ investidos na preparação de alunos das escolas públicas para o vestibular. A iniciativa, que diferiu de um cursinho pré-vestibular tradicional, teve por objetivo preparar o aluno para o vestibular durante dois ou três anos, mas em concomitância promover a autoafirmação da identidade étnico-racial, e uma formação diferenciada que incluía inglês e computação, além de oferecer vale transporte. Foram visitadas todas as salas de aula do ensino médio de São Carlos para selecionar alunos interessados na proposta e foram escolhidos 36 dos 84 inscritos, sendo 18 alunas e 18 alunos. Em entrevista a essa pesquisa, o professor Edson Moreira disse que não houve nenhuma aprovação na USP, mas houve aprovações na UFSCAR e em universidades privadas. Além da aprovação, um dos objetivos da proposta era verificar as razões da não aprovação. $O$ trecho a seguir de entrevista concedida para esta pesquisa, indica algumas razões da (não) aprovação e avaliações sobre o projeto.

\begin{abstract}
E a ideia era verificar as razões que vão fazendo com que eles fiquem no meio da estrada. E são várias as razões. Então alguns não tem ideia, você vai num colégio público, muitos não tem ideia do que seja a USP. Tem muita gente que acha que a USP é paga. Então tem muita gente que nem aspira entrar na USP, que é um negócio mais terrível assim, que é a auto exclusão. Então a pessoa já acha "ah não, a USP, naquele negócio lá, só entra lá se você for muito rico ou se você tem algum conhecido, sabe, é coisa desse tipo." Não tem ideia do que seja a USP, do sistema de entrada. Então a auto exclusão é um negócio importante. Depois, que a gente foi medindo, né, com esse projeto lá. Muitos quando você chega aos 16 anos mais ou menos esses adolescentes acabam ficando muito importantes em prover coisas para casa, tem que trabalhar, aí quando vai trabalhar, não consegue estudar e param. Teve duas mortes durante os três anos. Um foi um acidente de moto, ah! foi um absurdo, não foi acidente de moto, ele não estava na moto, ele foi ver uma corrida de moto e... sabe esse cross, moto cross e tal e o cara voou em cima dele e o matou. E o outro morreu de morte, sei lá, morte natural, quase natural. Ah outra coisa, meninas grávidas, sabe, tinham 18 meninas e 3 ficaram grávidas, então é quase $20 \%$ de gravidez na adolescência e sai também, desiste. Então foi interessante, um projeto que assim, juntou várias unidades de São Carlos, uma deu o laboratório, outra deu professor, foi legal. Ninguém entrou na USP, não, não. Entraram em faculdades... um entrou na Federal de São Carlos, outros entraram em faculdades particulares, mas ninguém entrou na USP
\end{abstract}

Importante destacar que a atuação do professor Edson Moreira na USP não tem visado apenas à comunidade negra. Dentre suas atribuições administrativas houve outra fundamental, que afetou a vida de toda a comunidade uspiana em seu cotidiano: entre os anos 2000-2006, Edson Moreira assumiu a coordenação do CCE (Centro de Computação Eletrônica da USP), atualizando toda a estrutura organizacional do Centro, adequando-a às novas demandas que se impunham; além de oferecer cursos de atualização para toda a comunidade uspiana, redimensionou a infraestrutura administrativa para prover a logística necessária para as atividades-fim do Centro. E para otimizar a performance e economia de recursos financeiros, integrou o sistema de telefonia da universidade, antes ligado à Prefeitura do Campus, à estrutura organizacional do CCE. Por fim, 
executou vários outros projetos de renovação tecnológica na USP. ${ }^{55}$

A trajetória acadêmica do professor Edson Moreira aponta para um fato muito importante: a importância da representação de professores/as negros/as no topo da carreira docente da USP, na condição de Titular (a exemplo dos professores Kabengele Munanga, Milton Santos e Wilson Barbosa); e além disso, a possibilidade de assumir cargos administrativos e a participação em instâncias decisivas de poder dentro da universidade. Apesar do fato de ainda não ser professor Titular na década de 90, o professor Edson Moreira tinha acesso a um dos quatro conselhos centrais, mais especificamente o Conselho de Cultura e Extensão. Apesar das limitações desse conselho no sentido de democratização do acesso da população negra à universidade, a presença do professor Edson Moreira foi fundamental para os debates e proposições de políticas raciais que marcaram a década de 1990 na USP.

O professor Edson Moreira aponta porém para a necessidade da presença de docentes negros/as no principal conselho decisório, que é o Conselho Universitário, onde infelizmente ainda não foi possível a presença de nenhum/a docente negro/a como porta-voz das reivindicações desse segmento da população acadêmica, conforme narra em entrevista para esta pesquisa:

\begin{abstract}
Então se você vai no Conselho Universitário, se não tem negro no Conselho Universitário, o assunto nem é discutido, porque não tem quem coloque lá, aí vai alguém lá falar sobre o negro e vai um outro lá e dá uma paulada, o cara sai... então, porque ele não entende o problema, pode até ser simpático ao problema, mas ele não entende o problema, não sente a ponto de prever que isso é uma coisa importante pra universidade, que diversidade é uma coisa importante. Até que muita gente entende isso, obviamente, mas não sabe como transformar isso numa política, numa estratégia de valor pra universidade "olha, nós vamos fazer um plano, uma estratégia de políticas públicas para a população negra, não porque nós estamos com dó da população negra, não é porque eles merecem porque eles foram maltratados e tal, é porque é bom para a universidade"., Então isso é uma coisa que se você não tem massa crítica nos mecanismos de poder, não passa.
\end{abstract}

Outra questão que merece ser pontuada é que na USP a população negra não é a única que debate a necessidade de estar articulada enquanto coletivo. $\mathrm{O}$ fato ao que parece, é que apesar

55No seu memorial para o concurso de Titular o professor Edson Moreira destaca algumas dessas atividades desenvolvidas como as importantes da sua carreira: Projetos de Implantação de Infraestrutura de TI:- Renovação da USPnet, a rede de comunicação da USP. Projeto orçado em cerca de US\$ 7.500.000,00 tratou da especificação, projeto, aquisição e implantação do backbone avançado da USPnet, com características singulares de segurança, disponibilidade e qualidade de serviço. Vários resultados de pesquisa, notadamente os referentes ao transporte de multimídia interativa, foram utilizados neste projeto. Alguns ex orientandos se juntaram à equipe deste projeto;- Malha de Rede de Acesso Sem Fio. Projeto em parceria entre a Coordenadoria de Tecnologia da Informação e a Pró-Reitoria de Pesquisa da USP para instalar uma rede de acesso sem fio na universidade. Todo o serviço de acesso foi alvo do projeto, desde a campanha de divulgação até o sistema distribuído de autenticação, inovador àquela época, que permitia ao usuário fazer login com username/password únicos em qualquer campus da USP;- Renovação do CPD. No início de 2002, o CPD da USP tinha uma estrutura de pessoal, de procedimentos, ambiental (eletricidade e ar-condicionado) em moldes do fim dos anos 80, quando foi instrumentado para receber grandes mainframes. O projeto de renovação visou transformá-lo num Internet Data Center, com capacidades organizacionais, operacionais e procedimentais adequadas ao seu novo papel como ponto focal da Rede USP e de seus serviços de comunicação. Uma moderna central de operação foi instalada e um Centro para a gestão das atividades de resposta a incidentes em equipes de segurança foi criado. Moreira (2010) 
da menor visibilidade, outras comunidades estariam mais articuladas, e assim, com canais de reivindicação melhor consolidados, conforme a narrativa do professor Edson Moreira:

Então o que aconteceu, lá já estava tudo certinho, por exemplo, no Direitos Humanos, a Comunidade Judaica, toda articuladíssima, sabe, "porque a USP tem que fazer", aquele negócio assim, fortíssimo. Os japoneses da Poli já tinham convidado o imperador japonês pra vir ao Brasil, então já estava tudo certinho, os caras tinham um monte de dinheiro e tudo mais. Mas e os negros? Não tinha um negro no Conselho [de Cultura e Extensão], não tinha. Eu nem era presidente do... eu era suplente do presidente, então, é isso que eu tô dizendo, se você não tem a massa crítica nos lugares que definem estratégias, ela simplesmente não... não tem como passar, é isso.

A preocupação do professor Edson Moreira sobre a presença de docentes negros/as nos conselhos e outras instâncias decisórias na USP, aponta para uma questão central dessa pesquisa: a história da ausência e/ou pouca visibilidade dos/as docentes negros/as nesta universidade e quais as consequências acadêmicas e políticas dessa sub-representação, segundo indica na palestra que concedeu em 2002:

\begin{abstract}
A universidade é tímida no trato do aumento da presença do negro em seus quadros docente e discente porque tem muito pouca pressão em seus órgãos decisórios. Uma questão simples como a inserção de uma pergunta sobre a origem étnica no formulário da FUVEST não passa no Conselho de Graduação porque não temos lá representantes que entendam minimamente o assunto e o defenda. Nas grandes discussões que se travam na universidade os "confiáveis" são ouvidos. Mesmo a proposição, antes da discussão, só é aceita se vinda de "confiáveis". O conceito de "confiabilidade", na universidade, é intimamente ligado ao de "mérito". Tem mérito aqui docentes "de carreira" com currículo baseado em forte atuação em pesquisa. Estes são os formadores de opinião na universidade. Eles estão nos postos chaves e nos Conselhos; eles não são negros e a maioria não se questiona sobre a problemática racial no país.
\end{abstract}

É necessário ressaltar que o debate sobre a gestão acadêmica na USP suscita muitas críticas sobre a noção de representatividade. No dossiê intitulado "Democracia só para alguns",56, publicado pela Revista Adusp (Associação dos Docentes da USP) em 2005 para analisar como se organiza a estrutura de poder na USP, a jornalista Cristina Charão fala sobre a desproporcional distribuição de assentos dos docentes titulares no principal colegiado da universidade, que é o Conselho Universitário (CO), quando comparado ao número de conselheiros das demais categorias docentes, bem como o número de representantes dos funcionários e estudantes. $\mathrm{Na}$ ocasião a comunidade acadêmica era estimada em 95.000 pessoas, e os titulares que eram apenas 833, ou seja, 0,87\% desse universo,detinham 76 dos 108 assentos no Conselho Universitário, ou 70,4\%. Dados de 2014 do Anuário Estatístico da USP indicam que a população da universidade é 120.406 pessoas. Desse universo, 6009 são docentes e pesquisadores, dos quais, 1064 são Titulares (ou MS6), 1863 são Docentes Associados (ou MS5), 3038 são Docentes Doutor (ou 
MS3) além dos Auxiliares de Ensino e Pesquisadores. Atualmente, o Conselho Universitário tem 110 assentos, e a estimativa é de que 93 deles sejam ocupados por professores Titulares, dos quais nenhum negro/a ${ }^{57}$. Embora questionável, a super-representação dos Titulares no CO, está prevista no estatuto da universidade:

\begin{abstract}
A supremacia absoluta da "casta" dos professores titulares é mantida pela exigência, prevista no Estatuto da USP, de que só docentes com uma tal titulação podem postular os cargos de reitor, pró-reitor e diretor de unidade, que são os mais poderosos da universidade e com vaga reservada no CO. (Charão, 2005).
\end{abstract}

Desse modo a representação das categorias Associado e Doutor, servidores técnicos e administrativos e do corpo discente é meramente simbólica, com ínfima possibilidade real de intervenção. O que resulta na estrangulação da democracia na USP, conforme avalia o jornalista Antonio Biondi no referido dossiê. Além disso, tem-se ainda o agravante fato de que a pequena parcela negra da docência na USP está na categoria Doutor, como se verá no último capítulo. Assim, no ambiente acadêmico, a estrutura de poder tem "fisionomia" apreensível a partir de "uma série analítica de traços distintivos" como indica Bourdieu (2011, p. 28). Apesar de ainda não ter tido acesso a um assento no CO, a passagem do professor Edson Moreira pelo Conselho de Cultura e Extensão e pelo Conselho Curador da Fuvest permitiram páginas importantes para a história do acesso e democratização racial na USP. Do conjunto de dez docentes negros/as entrevistados/as para essa pesquisa, o professor Edson Moreira foi quem, dentro da USP, transitou por instâncias mais altas de representatividade e poder dentro da USP.

Assim, parte da atuação de docente negros/as como Kabengele Munanga e Milton Santos, ao longo dos anos 1990, seja no ano do tricentenário ou na CPPPN, foi fortalecida pela presença do professor Edson Moreira no COCEX e no Conselho Curador da FUVEST. Para melhor compreender o quarto momento do debate racial na USP e da atuação de docentes negros/as nessa agenda, é importante considerar que houve uma articulação de esforços e de possibilidades de trânsito. Enquanto os professores Kabengele Munanga e Milton Santos figuram como grandes nomes no segmento que investiga relações raciais, a presença do o professor Edson Moreira no COCEX e na FUVEST foi importante para a consolidação das tímidas, porém importantes propostas para a democratização da USP. Além, vale lembrar, da decisiva pressão feita pelos coletivos de estudantes negros/as da USP desde os anos 1990, conforme relata Conceição (2001).

Necessário destacar que o quarto momento do debate racial na USP é ainda corrente e

57Esta retrato estimado sobre a composição do Conselho Universitário me foi concedida pelo estudante de pósgraduação em Química na USP, Phelipe Pessoa, que também é Representante Discente da Pós-Graduação no Conselho Universitário na Gestão 2014-2015. 
envolve a participação de outros nomes de docentes negros/as, que se veem às voltas com a grande resistência que a USP oferece em termos de adoção de políticas de ações afirmativas, além de participarem da construção de conhecimento sobre o campo das relações raciais na USP. O conjunto de docentes apresentado a seguir atua em maior ou menor medida investigando as desigualdades raciais na sociedade brasileira, ou acolhendo discentes envolvidos com o debate. Importante ressaltar que há na USP atualmente um número maior de docentes negros/as, bem como docentes brancos/as que pesquisam a temática, mas que não são focalizados como sujeitos para esse trabalho. Assim, as sete trajetórias consideradas a seguir oferecem a possibilidade de entender como atua o/a docente negro/a na USP, considerando o quarto momento do debate dentro da instituição, mas não esgotam o conjunto de sujeitos comprometidos com o debate. Dentre os/as docentes negros/as que poderiam ter sido entrevistados e que trabalham com a questão estariam, por exemplo: Wilson do Nascimento Barbosa da História, Márcia Regina Lima da Sociologia, Gislene Aparecida dos Santos da EACH, Alexandro de Oliveira Santos da Psicologia, Ricardo Alexino da ECA. Em função do limite de fôlego de pesquisa, estas trajetórias que trariam importantes contribuições a esta pesquisa, infelizmente não puderam enriquecer este trabalho. Assim, considerase a seguir sete trajetórias de docentes negros/as que oferecem a possibilidade de entender alguns significados de ser docente negro/a na USP e construir parte da história de interpelar a exclusão racial perpetrada na USP por décadas, impedindo a integração da população negra neste universo. 


\section{Capítulo V - Gênero e raça do corpo docente da USP: horizontes que se ampliam, outras vozes em cena.}

No segundo capítulo desta tese discutiram-se as (re)definições dos mentores e clientelas da universidade, fatores que possibilitaram o acesso de mulheres e descendentes de imigrantes europeus à USP e à carreira acadêmica na própria universidade. Neste tópico a proposta é retomar este debate a partir da aproximação entre raça e gênero na docência da USP, tendo como ponto de partida análises que já fizeram a articulação entre gênero e docência na USP. ${ }^{58}$ Esta tese tem procurado, desde o primeiro capítulo, reter e destacar alguns aspectos e fatos da história da universidade que favoreçam a compreensão sobre a configuração do seu corpo docente, e a subrepresentação da população negra nesse espaço de construção do conhecimento. Tenho seguindo as trilhas sugeridas por Gilroy (2001) no sentido de rastrear os sinais raciais mais ou menos implícitos nas obras publicadas em importantes momentos comemorativos da universidade, para empreender uma leitura etno-histórica da instituição (Gilroy, 2001, p. 24). Muitas destas obras, apesar de comemorativas, não são necessariamente de celebração, como é o caso da leitura crítica sobre a história da universidade que pode ser verificada na obra publicada em 2004, de autoria das professoras Eva Blay e Beatriz Lang, fruto de pesquisa realizada em 1984 e intitulada Mulheres na USP: horizontes que se abre, trata- se de um esforço primoroso de encarar o acesso ao ensino superior e a ascensão das mulheres à carreira acadêmica. A obra se insere no contexto de comemoração dos setenta anos da fundação da Faculdade de Filosofia, Letras e Ciências Humanas e da Universidade de São Paulo.

Embora o acesso das mulheres ao ensino superior no Brasil tenha sido permitido em 1879 a partir da Lei Saraiva, o número de mulheres que efetivamente puderam ingressar foi bastante pequeno. Dentre os fatores, estava a prevalência feminina no acesso às Escolas Normais, que não habilitavam a continuidade dos estudos em nível superior. Dessa forma, até "o início da década de 30, foram muito poucas as mulheres que frequentaram as faculdades então existentes" (Blay \& Lang, 2008, p.4).

Considerando por uma perspectiva de gênero, a história da criação da Universidade de São Paulo e do seu núcleo central, a FFCL, deve ser compreendida, em pelo menos três planos:

De um lado, nos campos político, nacional e regional. De outro, num processo de avanço do ensino superior que vinha sendo gestado há várias décadas. Finalmente, da perspectiva do movimento de mulheres, pelas possibilidades que se abriam (Blay \& Lang, 2004, p.35)

58 Ver, por exemplo: PAULA (2002); BLAY (1984), (1991); PONTES (1998); TRIGO (1997); CERDEIRA (2001); SPIRANDELI (2008). 
Somente em 1984, por ocasião dos cinquenta anos da universidade, é que foi problematizada a importância das mulheres neste processo. A pesquisa desde então iniciada e publicada em 2004 foi pioneira na conciliação entre as especificidades em torno da educação feminina verificada no país e em São Paulo nas três primeiras décadas do século XX e na história da universidade. Desse modo, eventos até então desarticulados são por fim reconciliados, tais como a Semana de Arte Moderna de 1922, a fundação da USP e os movimentos feministas de então:

Ao analisar os pouco divulgados movimentos de mulheres da década de 20, observa-se que se formara uma camada de militantes muito conscientes dos obstáculos sociais, políticos e econômicos, o que as relegava a uma posição hierarquicamente inferior a dos homens. Raras já eram universitárias, outras eram escritoras, poetisas, trabalhadoras, vindas de meios sociais distintos. Este era o cenário quando foi criada a Universidade de São Paulo e a Faculdade de Filosofia, Ciências e Letras. (Blay \& Lang, 2004, p.32)

Assim como Miceli (2001) e Limongi (2001), as autoras também trazem dados referentes ao número de matrículas em 1934 e 1935 na Faculdade de Filosofia, que indicam o surpreendente aumento no número de mulheres e uma sensível diminuição nas matrículas masculinas. De igual modo, apontam o baixo número de alunos que frequentavam a nova universidade, somado à necessidade do estado de formação de professores para o ensino médio que se expandia, como explicação para a política de comissionamento instituída pelo governo estadual. Esta foi a primeira política pública implementada na USP, através da qual foram reservadas vagas para professores primários formados na Escola Normal, sem a necessidade de prestarem o exame de vestibular, aproveitando assim a capacidade instalada na Faculdade.

Conforme discutido no segundo capítulo desta pesquisa, a partir do regime de comissionamento verificou-se uma diferenciação no perfil do alunado da universidade, possibilitando a inclusão de alunos de diferentes condições socioeconômicas. O corpo discente passou a contar com pessoas vindas do interior do estado, oriundas de famílias ligadas ao magistério, famílias tradicionais empobrecidas, descendentes de imigrantes europeus e mulheres. Sendo assim,

\footnotetext{
Embora essa política tivesse como principal objetivo a formação de profissionais para a educação primária e secundária, essa ação teve uma outra consequiência, não previamente planejada: o regime de comissionamento permitiu uma presença significativa de mulheres na FFCL, já que estas representavam a maioria das egressas das escolas normais do Estado. Uma nova realidade para a época, quando era pouco comum a presença das mulheres no ensino superior do Brasil (Blay \& Lang, 2004, p.53)
}

Por outro lado, considerando as escolas tradicionais fundadas no século XIX e começo do XX, que foram incorporadas à USP em 1934, o número de matrículas femininas foi ínfimo. Segundo Blay \& Conceição (1991) na Faculdade de Direito, a primeira acadêmica formou-se em 1902 e somente em 1911 a Faculdade do Largo São Francisco formaria a segunda bacharel em 
Direito. Na Faculdade de Medicina a primeira turma a registrar mulheres é a de 1918, seis anos após a fundação da escola; e na Politécnica a primeira engenheira formou-se em 1928.

\begin{abstract}
Estas carreiras "tradicionais", excetuando-se a engenharia, só começam a mudar o perfil nos anos 40 ou mais tarde ainda. Das três escolas, a que mais se aproxima hoje de uma composição igualitária por sexo é a Faculdade de Direito, mas nem aí a presença feminina alcança a proporção de 50\%. Na Faculdade de Medicina, só nos anos 80, um pouco mais de $1 / 3$ dos formandos são mulheres. Na Escola Politécnica a proporção atinge, no máximo, $15 \%$ em alguns cursos como Engenharia Civil, Eletrônica, Produção e Química. (Blay \& Conceição, 1991, p. 52)
\end{abstract}

Assim, Faculdade de Filosofia significou para as mulheres a possibilidade de ingresso na Universidade de São Paulo, sendo a unidade onde mais se verificaram matrículas femininas. Nesta Faculdade, o número de matrículas de mulheres continuou a exceder o número de matrículas de homens, constituindo-se numa tendência nos anos seguintes. Desse modo, no momento em que "se abre às mulheres a oportunidade concreta de frequentar o ensino superior da USP e da FFCL, elas literalmente agarram a oportunidade". (Blay \& Lang, 2004, p.56). O primeiro obstáculo fora vencido, porém uma vez dentro da universidade novos desafios sondavam aquelas que abraçaram a carreira acadêmica, tal como pode ser verificado nos depoimentos ${ }^{59}$ concedidos pelas "pioneiras nos caminhos da mudança" (Ibidem).

A história da Faculdade de Filosofia indica, sem dúvida, novos horizontes e possibilidades abertas ao acesso das mulheres ao ensino superior, mas não obstante, revela também reservas, resistências e hierarquias. A construção da Sociologia como disciplina no país e a importância assumida pela chamada "Escola Paulista de Sociologia" são um bom exemplo disso. A Escola Paulista de Sociologia já foi considerada no segundo capítulo deste trabalho em função da sua importância como divisora de águas na discussão racial na sociologia e na academia brasileira. Mas aqui, ressaltam-se ainda alguns aspectos da sua importância quando se considera a presença feminina na construção da universidade. O primeiro grupo de assistentes de Florestan Fernandes foi constituído por Fernando Henrique Cardoso, Octavio Ianni, Renato Moreira Jardim e Maria Sylvia de Carvalho Franco, que se dedicaram inicialmente, aos estudos sobre relações raciais. Este primeiro grupo contava ainda com Marialice $\mathrm{M}$. Foracchi, que pesquisava temas voltados à sociologia da educação. Este núcleo inicial foi constituído tão logo Florestan Fernandes assumiu a regência da Cadeira de Sociologia I, de modo que a "estratégia de formação seguiu critérios de

59Na obra publicada por Blay \& Lang (2004) estão os depoimentos das primeiras acadêmicas formadas na USP e que participaram do encontro promovido pelas duas autoras em 1984: a filósofa Gilda de Mello e Souza; a química Jandyra França Barzaghi; a historiadora Alice Piffer Canabrava; a historiadora Olga Pantaleão, (da UNESP); a geógrafa Maria Conceição Vicente de Carvalho; a médica Verônica Rapp de Eston. 
escolha pessoal, mas a implementação dependia das disposições dos escolhidos de aceitar vínculos precários" (Arruda, 1995, p. 193).

O processo de formação deste primeiro grupo acabou por fortalecer a posição institucional de Florestan Fernandes, que dividia seus assistentes em dois grupos: primeiro e segundo escalão. "Na verdade, havia nítida hierarquia entre os assistentes e as resoluções tomadas ocorriam em discussões do petit comitê." (Arruda, 1995, p. 194). No primeiro escalão estavam Fernando Henrique Cardoso e Octávio Ianni. Já o segundo contava no primeiro momento com Maria Sylvia de Carvalho e Franco e Marialice Foracchi e depois com os novatos: Luis Pereira, Leôncio Martins Rodrigues Neto e outros. Efetivamente o segundo escalão não participava da dinâmica da Cadeira de Sociologia I, atuando apenas como implementador das medidas estabelecidas. Como destaca a autora, "é digno de nota que as professoras assistentes fossem membros do segundo patamar e parecem ter permanecido nesse lugar mesmo quando dois jovens foram convidados." (Arruda, 1995, p. 194).

Neste sentido, um exemplo foi o concurso para o preenchimento da vaga aberta na cátedra de Política em 1968, em razão do falecimento do professor Lourival Gomes de Machado, que era seu titular. A professora Paula Beiguelman era "a candidata mais 'natural' ao cargo, pois trabalhava na área de Política como assistente de Lourival Gomes de Machado, de modo mais sistemático, desde 1954." (Spirandelli, 2008, p.101). No entanto, além de um contexto de hegemonia da cadeira de Sociologia I sob a batuta de Florestan Fernandes, que estabelecia a nova forma de se fazer ciências humanas na Faculdade de Filosofia, a torcida pela indicação de Fernando Henrique não se fez tímida, e nela se incluiu até o professor Sérgio Buarque de Holanda, integrante da banca do concurso. Sendo assim, a indicação de Fernando Henrique "poderia ser também um 'acordo de cavalheiros'" (Ibidem).

É necessário pontuar, porém, que a produção acadêmica sobre a mulher foi inaugurada nas dependências da Escola Paulista de Sociologia com um trabalho orientado por Florestan Fernandes e publicado em 1969, com o prefácio do professor Antonio Candido de Mello e Souza. Trata-se da tese de livre-docência defendida em 1967 por Heleith Saffioti e intitulada A mulher na sociedade de classes: mito e realidade. Pinto (2003) aponta este trabalho como "fundador e definitivo", "um marco" em função do "seu inegável mérito acadêmico, mas também por ter trazido o tema da opressão da mulher para o debate marxista, que até então não a admitia de forma alguma" (Pinto, 2003, p.86). Além disso, a autora indica que outro grande mérito do trabalho da Saffioti foi implicar publicamente Florestan Fernandes e Antonio Candido, dois grandes intelectuais brasileiros, com o tema.

Outro concurso para cátedra que se tornou célebre foi o da professora Alice Piffer Canabrava. Sua tese, O comércio português no Rio do Prata recebeu elogios da crítica nacional e 
estrangeira, o que a fez emergir como possível candidata para a Cadeira de História da América até mesmo ante os olhos dos colegas homens, com os quais mantinha até então, relação de respeito e tranquilidade. A partir daí, "o círculo de hostilidade subterrânea começou a se desenhar para [ela] mim com evidência, a se apontar anonimamente numa ou outra ocorrência da atividade universitária sem alterar a aparência da superficial cordialidade". (Canabrava apud Blay \& Lang, 2004, p.98). Em suas próprias palavras "ouvi conselhos e insinuações de que não devia desafiar a hostilidade já constituída: iria ser fatalmente reprovada. A minha resposta foi invariavelmente a mesma, sem qualquer argumento: 'eu faço o concurso, caberá à banca me reprovar'". (Canabrava apud Blay \& Lang, 2004, p.99).

E foi justamente o que a banca fez. Embora a professora Alice tivesse obtido a média mais alta no conjunto de provas, o critério decisivo para a indicação ao cargo de catedrático foi a votação da banca e apesar do empate na votação, o presidente da banca decidiu pelo concorrente do sexo masculino. Na análise da professora, essa resistência indicava um padrão de masculinidade que se naturalizava como o lugar da razão:

Naturalmente, a resistência masculina na Faculdade em aceitar as mulheres em cargos de
categoria refletia arraigada consciência de superioridade, a tradição do meio quanto à
predominância dos padrões masculinos. Racionalizava-se o comportamento com a
afirmação de que tornava necessário proteger o ensino superior do baixo nível das
professoras oriundas do magistério primário. 'A Faculdade não é uma Escola Normal!
'Outros elementos se mesclavam à autodefesa de cargos e funções. Constituíram-se em
grupo, cujos membros soldaram o compromisso de luta sob o signo de 'um por todos e
todos por um', com a exclusão de qualquer elemento de fora, os 'pára-quedistas', como eram
chamados e, implicitamente, as colegas do sexo feminino. Nenhuma hostilidade manifesta
às mulheres no exercício de algumas funções administrativas: 'revelam-se ótimas
datilógrafas'"'. (Canabrava apud Blay \& Lang, 2004, p.102).

Apesar dos percalços, o esforço da professora Alice não foi infrutífero, pois ela tornou-se a primeira professora catedrática da USP em 1951 na Faculdade de Ciências Econômicas e Administrativas (Faculdade de Economia e Administração, após a Reforma de 1968), chegando a ocupar alguns dos postos mais elevados da administração acadêmica ${ }^{60}$. A história da professora Alice Canabrava está bem situada nos chamados "momentos fundamentais da ritualização da universidade". Assim, dentre os "ritos e produtos" que marcaram a institucionalização das ciências sociais na USP, as defesas de tese e concursos são "verdadeiros ritos de iniciação e consagração" e dentre outras funções, apontam "os eleitos e as hierarquias" (Arruda, 1995, p.211). É já no início da década de 1940 que as defesas de tese começam a se tornar regulares nas então cinco disciplinas das

60 Durante sua carreira acadêmica a professora Alice Canabrava exerceu os cargos de "diretora da instituição [Faculdade de Ciências Econômicas e Administrativas] (1954/57) e, como tal, membro do Conselho Universitário, representante dos professores nesse colegiado (1967/74); chefe do Departamento de Ciências Culturais (1960/69); presidente do Conselho Curador da Fundação Instituto de Pesquisas Econômicas (FIPE); membro do Conselho deliberativo do Instituto de Pesquisas Econômicas (IPE - 1966/70) e do Conselho Curador da (FIPE - 1974/77 e 1980/81)." (Blay \& Lang, 2004, p.102). Foi eleita Professora Emérita da Universidade de São Paulo em 1985. 
ciências humanas (Sociologia, Antropologia, Política, História e Filosofia), pois o modelo francês adotado excluía o mestrado (a primeira dissertação, da Faculdade, de autoria de Fernando Henrique Cardoso, é defendida apenas em 1953). Desse modo, tem-se a seguinte síntese para a produção acadêmica por sexo, entre os anos 1939 e 1973:

Entre as Ciências Sociais, as diferenças manifestam-se claramente, no momento inicial. Os primeiros doutoramentos em Sociologia ocorrem entre mulheres (3 em 1945) e em 1951 aparece a tese de Gilda de Mello e Souza. Na Antropologia, o ponto de partida é comum, pois, em 1945, Egon Schaden e Lavínia Costa Vilella defendem suas teses. Nesse sentido, há semelhanças entre a dinâmica da Antropologia e da História. Na cadeira de Política, ocorre o inverso: a primeira tese produzida por uma mulher data de 1961. Por essa razão, acontecem semelhanças entre a Ciência Política e a Filosofia, uma vez que, somente em 1967, há um doutoramento feminino. É significativo perceber que as mulheres não chegam ao topo da carreira, em todos os domínios, antes de 1973, quando Myriam Ellis, filha do primeiro catedrático de História do Brasil, vira titular. Excetuando a Filosofia, o conjunto das titulações no período que atinge aproximadamente 50 anos, ou equilibrou-se (caso da Sociologia e da Política), ou as mulheres ultrapassaram os homens no número de trabalhos (Antropologia e História). Interessante notar que a participação das mulheres é contínua e mesmo dominante, após a introdução do sistema de pós-graduação, inclusive na Filosofia, indicando clara feminização da profissão. No período privilegiado por nós, 1939-1973, término do regime antigo, as mulheres ganhavam visibilidade crescente, mas não galgavam o nível mais alto da carreira. Dentre todas as disciplinas, as mais femininas são a Antropologia e a História, mediadas pela Sociologia e Política. A mais masculina é a Filosofia, mas indicando nítida tendência à feminização, a partir dos anos 1980." (Arruda, 1995, p. 218-219)

É interessante destacar que se trata da FFCL, a primeira unidade da USP a ser mais permeável à presença feminina na instituição. Spirandelli (2008) propõe uma análise no sentido de desvelar os motivos da consagração dos homens como docentes das ciências humanas da Faculdade de Filosofia no período compreendido entre 1939 a $1969^{61}$, apesar da relativa abertura às mulheres. Aponta que gênero é, sim, um componente que media a diferença nas carreiras masculinas e femininas, mas não é a única explicação. Fugindo de um "suposto machismo" (Spirandelli , 2008, p.12) para explicar todas as relações entre homens e mulheres estabelecidas à época, indica que as assimetrias em questão não seriam adequadamente compreendidas sem considerar noções como a de hábitus de classe e geração. Criticando a ideia de que a universidade deve ser "democrática, aberta a todas as minorias, orientações sexuais, religiosas, étnico-culturais, de gênero, políticas e etc" (Spirandelli , 2008, p.16), considera que o espaço acadêmico é antes de tudo, um espaço de

61Spirandelli (2008) analisa duas gerações de professoras da FFCL. "Na Primeira Geração (1934-1952) estão Gioconda Mussolini (da cadeira de Antropologia), Paula Beiguelman (da Cadeira de Política), Lavínia Costa Vilella, Lucila Herrmann e Gilda de Mello e Souza (todas da Cadeira de Sociologia I), Maria Isaura Pereira de Queiroz e Aparecida Joly Gouveia (da Cadeira de Sociologia II; mas ela entraria somente em 1966). No momento posterior, a Segunda Geração (entre 1952-1969), estão Ruth Correa Leite Cardoso, Eunice Ribeiro Durham, Thekla Olga Hartmann e Renate Brigitte Nutzler Viertler (todas na Cadeira de Antropologia); Célia Nunes Galvão Quirino dos Santos, Nely Pereira Pinto Curti, Maria do Carmo Campello de Souza, Cecy Martinho e Marly Martinez Ribeiro Spinola (na Cadeira de Política); Maria Alice Mencarine Foracchi, Maria Sylvia de Carvalho Franco e Lourdes Sola ( na cadeira de Sociologia I) Lia de Freitas Garcia Fukui, Eva Alterman Blay e Heloísa Helena Teixeira de Souza Martins (na Cadeira de Sociologia II)". (Spirandelli, 2008, p.30) 
conflito e disputas. Sendo os conflitos "perenes" e os "interesses contraditórios eternos" Spirandelli (2008, p. 16) aposta numa análise em que a construção da carreira das professoras analisadas está atrelada não apenas à condição de gênero, mas ao modo como se moveram no âmbito das relações de poder, as redes estabelecidas, as margens de manobras e negociações por elas realizadas, dentro das regras do campo acadêmico-científico. Não obstante, o autor reconhece que, pelo menos no sistema de cátedras, as condições objetivas de ascensão não eram as mesmas para as mulheres. A situação tornou-se mais favorável a elas a partir das reformas estruturais pós-1970. (Spirandelli, 2008, p.86).

As trajetórias dessas professoras oferecem a possibilidade de ampliar a compreensão sobre a complexidade de tramas e enredos que tecem a história da produção do conhecimento no país e na USP. Apesar dos avanços no conhecimento, muitas lacunas ainda permanecem, muitas pesquisas necessitam ser feitas. Um hiato diz respeito à presença de docentes negras nos primórdios da universidade, pois raros são os trabalhos nesse sentido. Estudos recentes têm apontado a importância de uma docente negra na institucionalização dos "chamados saberes Psi” no país e na USP. Analisando a trajetória da professora Virgínia Leone Bicudo (1910-2003), Damasceno (2010, 2013) indica que Virgínia foi a primeira mulher negra no país a receber um título de pós-graduação em Sociologia, em 1945. O mestrado e o doutorado de Virgínia, ambos realizados na Escola Livre de Sociologia e Política (ELSP), foram também os primeiros trabalhos de pós-graduação defendidos no país que tematizaram as relações raciais brasileiras. A dissertação defendida por Virginia Leone Bicudo também foi pioneira por trazer para o foco as atitudes de pretos e mulatos para aferir a existência de preconceito racial em São Paulo e não atitudes de brancos, que era o que havia sido feito em trabalhos como o de Oracy Nogueira (Damaceno, 2013).

A trajetória pessoal e acadêmica de Virgínia, além de indicar pioneirismo na história de mulheres negras no ensino superior, aponta também novidades fundamentais nas teses concernentes às relações raciais brasileiras:

\footnotetext{
Virgínia defende a primeira tese sobre relações raciais no Brasil e torna-se, em maio de 1945, há exatamente 65 anos, a primeira mulher negra a receber um título de pós-graduação em Sociologia no país. A primeira tese sobre relações raciais no Brasil foi escrita por uma socióloga negra, crescida no Brás, fruto de uma família mestiça negra e italiana e que acreditava, a despeito da orientação teórica daquele momento, na existência de preconceito racial no Brasil, o que só foi tido como evidente apenas 10 anos depois da publicação de seu trabalho, em outra empreitada da qual fez parte: a publicação do relatório do Projeto Unesco, coordenado em São Paulo por Roger Bastide e Florestan Fernandes, em 1955. (Damasceno, 2010, p.8)
}

Virgínia Leone Bicudo foi contratada como professora na ELSP em 1940 e no seu documento de trabalho, admitiram-na como branca, o que revela o modo de operação da ideologia do branqueamento no Brasil. Virgínia é filha de descendentes de escravos e de imigrantes 
italianos $^{62}$. Seus pais se conheceram trabalhando numa lavoura cafeeira na cidade de Campinas. Seu pai, Teófilo Bicudo, além de descendente de escravo, foi afilhado de Bento Augusto de Almeida Bicudo, senador pelo Partido Republicano Paulista (PRP) e um dos fundadores do jornal $O$ Estado de São Paulo. Assim, contou com apoio financeiro do Coronel Bicudo quando veio para São Paulo realizar sua formação escolar, trazendo consigo a esposa e os filhos. A mobilidade social de Virgínia se deu mediante a escolarização, tendo ela também passado pela tradicional Escola Normal Caetano de Campos, vindo a ser "educadora sanitária, visitadora psiquiátrica, cientista social, professora universitária, psicanalista, divulgadora científica, protagonista de diversas iniciativas no plano da institucionalização da psicanálise no Brasil ${ }^{63}$.” (Maio, 2010:311)

No que diz respeito à sua passagem pela USP, em 1945 Virgínia conheceu o psicólogo social canadense Otto Klineberg, que viera dos Estados Unidos com o propósito de trazer a experiência norte-americana em Psicologia Social para o Brasil, além da missão de criar o Departamento de Psicologia da USP. Virgínia fez o curso "Seminário de Psicologia Social" que Otto Klineberg ministrou na Faculdade de Filosofia, Ciências e Letras da USP. Ainda em 1945, ela começou a lecionar como professora-assistente da Cadeira de Higiene Mental da Faculdade de Higiene e Saúde Pública da USP e em 1946 passa a ministrar o curso de Higiene Mental na Faculdade de Enfermagem, que era anexa à Faculdade de Medicina da USP. Em 1954 Virgínia Bicudo foi contratada pelo Departamento de Psicologia da Faculdade de Filosofia, Ciências e Letras, como membro de uma comissão designada a expandir a psicanálise no Departamento de Psicologia da USP (Maio, 2010).

Apesar de ter lecionado na Universidade de São Paulo, sua trajetória docente ficou associada à Escola Livre de Sociologia e Política, onde fez a graduação, mestrado e doutorado. Questionada pelas razões de não ter feito a formação na USP, alegou que não correspondia ao perfil de aluno da universidade, o que pode ser verificado no trecho da entrevista concedida a Marcos Chor Maio:

62Damaceno (2013) propõe uma análise interessante sobre as origens e os significados que o nome Virginia Leone Bicudo carrega, pois herda da avó paterna, uma escrava fugida e nunca conhecida por ela, o nome de Virginia. Da mãe italiana herda o sobrenome Leone. E por fim, herda do dono das terras em que se pai trabalhou, o nome Bicudo: "Virgínia Leone Bicudo recebeu o prenome da avó e os sobrenomes da mãe e do padrinho do pai. De certo modo, eles estão dispostos dentro de uma cadeia "evolutiva": da escrava Virgínia ao cidadão Bicudo, tendo como elo aquele imigrante ainda estranho ao Brasil: o estranho Leone. Seu nome em casa sempre seria a referência à avó nunca conhecida. O último sobrenome, a um lugar social aspirado...e, de certo modo, alcançado. Se a intenção do pai era também a de se modernizar e participar ativamente da vida da cidade que acabara de adotar, foi na figura da filha que este ideal acabou por se concretizar". (Damaceno, 2013:48)

63Dois intelectuais negros escreveram os primeiros capítulos da Psicanálise no Brasil: Virgínia Leone Bicudo que foi primeira mulher e segunda pessoa psicanalisada na América do Sul, e Juliano Moreira (1873-1933), pioneiro nos estudos sobre Freud no Brasil. Juliano Moreira que apresentou a Psicanálise á sociedade carioca, dedicou-se também a rebater as teorias raciais de Nina Rodrigues. "Tal era a discordância de Moreira com o racialismo rodrigueano, aseado num higienismo racial, que ele acabou desenvolvendo seus pressupostos científicos acerca da tese da degenerescência a partir da ideia de um higienismo mental, disciplina a qual Virgínia Leone Bicudo carregou por grande parte de sua vida profissional. Moreira deslocou a questão, ao propor que a mestiçagem não era fator de degeneração mental entre os brasileiros." (Damaceno, 2013:55) 
Marcos: Porque a senhora não foi fazer o curso na Faculdade de Filosofia, Ciências e Letras da USP?

Virgínia: Ah, porque lá eram os grã-finos e eu não era grã-fina. Pensa que eu era boba? [risos] Eu sabia escolher. Eu vi lá, tudo era filho de papai, Almeida Prado e eu não. A Escola de Sociologia é gente operária, é lá que eu vou. É isso. Sabe, a gente tinha esse feeling.

Marcos: Quer dizer que na Escola de Sociologia e Política havia uma diferença...

Virgínia: Mais operários, operariado da ciência. Na Filosofia... como é que era o nome?

Marcos: Faculdade de Filosofia, Ciências e Letras?

Virgínia: Eu disse: “Lá não era o meu lugar”. (In: Maio, 2010, p. 344)

Na trajetória de Virgínia há um episódio que talvez ajude a explicar a sensação de não pertencimento à Universidade de São Paulo, relatado na referida entrevista. Seu pai, Teófilo Bicudo, acreditava que a educação era a via possível de ascensão do negro no Brasil. Tal pensamento o norteou na sua vinda para São Paulo, onde procurou educar-se. Cursando o Ginásio do Estado, prérequisito para acesso ao curso superior, foi barrado pelo professor de Física, tão logo manifestou seu desejo de fazer Medicina. Teófilo Bicudo chegou a ouvir no seu último ano de ginásio que "negro não podia ser médico". Embora tivesse insistido por dez anos seguidos, foi reprovado nas dez tentativas e assim, acabou não cursando Medicina. Outro fato intrigante na trajetória de Virgínia, apontado por Jackson (2007) e Damasceno (2010), diz respeito à sua participação no projeto UNESCO. Nos seus trabalhos de mestrado e doutorado, formulou interpretações sobre as relações raciais no Brasil, de modo que "Virgínia antecipou as conclusões de Florestan Fernandes com quem iria trabalhar anos mais tarde no Projeto UNESCO em São Paulo.” (Damasceno, 2010, p. 1).

Neste projeto, Virgínia pesquisou atitudes de rejeição e aceitação de alunos negros por parte de alunos brancos e a influência da família na constituição dessas atitudes, constatando preconceito por parte dos alunos brancos em atitudes disfarçadas e justificadas por outros marcadores não explicitamente raciais. Jackson (2007) e Damasceno (2010) apontam para um fato interessante: a primeira publicação do relatório do projeto UNESCO, em 1955, com o título Relações raciais entre negros e brancos em São Paulo: ensaio sociológico sobre as origens, as manifestações e os efeitos do preconceito de cor no município de São Paulo, trouxe o conjunto completo das pesquisas produzidas pela equipe, formada por Roger Bastide, Florestan Fernandes, Virgínia Bicudo, Oracy Nogueira e Aniela Ginsberg. Na reedição do relatório, publicado em 1958, intitulada Brancos $e$ Negros em São Paulo: ensaio sociológico sobre aspectos da formação, manifestações atuais $e$ efeitos do preconceito de cor na sociedade paulistana, os trabalhos de Virgínia Bicudo, Oracy Nogueira e Aniela Ginsberg são excluídos, restando apenas os de Roger Bastide e Florestan Fernandes.

Conforme ressalta Jackson (2007), a pesquisa de Oracy sobre preconceito de marca e preconceito de origem, tinha como referência apenas o município de Itapetininga e as análises de 
Virgínia e Aniela eram referentes ao universo escolar e possuíam viés psicológico. Além disso, as três pesquisas foram feitas por pessoas que se formaram na Escola Livre de Sociologia Política. A conjunção desses elementos indica que

O jogo intrincado que se revela no caso em análise não se detém na assimetria das disciplinas (sociologia e psicologia) ou dos temas (urbano e rural). Manifesta a clivagem de gênero e a disputa acirrada entre as duas instituições, que se sobrepõem a possíveis afinidades biográficas e teóricas. (Jackson, 2007, p. 122)

Para o autor, se havia por um lado, a disputa entre a USP e a ELSP pela hegemonia na institucionalização da sociologia no país, houve também, por outro, a preterição das mulheres no jogo acadêmico. Dessa forma, as trajetórias de Virginia Bicudo e Aniela Ginsberg na ELSP se aproximam das trajetórias das docentes pioneiras na USP. A trajetória de Virgínia se torna excepcional por sua condição racial e de classe, mas destoa mesmo das professoras de origem mais humilde, cujas trajetórias foram analisadas por Spirandelli (2008). Talvez o grande traço em comum com essas trajetórias, é que Virgínia Leone Bicudo também é fruto dos processos históricos, conhecidos no Brasil, de profissionalização feminina pelo magistério, que nos anos 1930 e 1940 possibilitaram o ingresso das mulheres normalistas no ensino superior. Porém, a trajetória de Virgínia Leone Bicudo parece estar mais próxima daquelas de um conjunto de mulheres negras norte-americanas $^{64}$ nas Ciências Sociais que lhe foram contemporâneas, conforme aponta Damaceno (2013), considerando que muitas dessas intelectuais norte-americanas também pesquisaram relações raciais no Brasil. Em sua tese, Damaceno (2013) constata que tal como Virgínia Leone Bicudo, as trajetórias dessas intelectuais negras norte-americanas também desaparecem dos mapas de prestígio e legitimação acadêmicos.

Aventa-se aqui a hipótese de que a trajetória da professora e psicanalista Virgínia Bicudo possibilitaria um interessante caminho de análise das articulações e passagens possíveis entre as teorias e práticas higienistas no estado de São Paulo no início do século passado, os trabalhos de pesquisa da UNESCO e a Escola Paulista de Sociologia, pois sua atuação como educadora sanitária e visitadora psiquiátrica, pesquisadora da equipe da UNESCO, assim como a sua proximidade com Florestan Fernandes oferecem indícios de que sua trajetória aponta para capítulos importantes desse debate. A pesquisa de Damaceno (2013) apresenta esses elementos, mas se detém na questão dos estudos de atitudes na trajetória de Virgínia Bicudo.

Oferecendo um termômetro do ambiente acadêmico para as intelectuais negras que se

64Damaceno (2013) propõe em sua tese “Os segredos de Virgínia” comparar a trajetória de Virginia Leone Bicudo à de algumas intelectuais negras norte-americanas como Anna Julia Cooper - primeira americana a se graduar e obter um doutorado em Sociologia,as antropólogas Katherine Dunham (que foi também coreógrafa e orientanda de Herskovitz na Universidade de Chicago), Ellen Irene Diggs (que foi última assistente de W.E.B. Dubois) e Zora Neale Hurston, que foi orientanda de Franz Boas, o primeiro catedrático em Antropologia pela Universidade de Columbia. 
aventuraram no universo acadêmico nos anos 1940-1950, Damaceno (2013) traz também interessantes aspectos da trajetória da antropóloga negra e baiana Josidelth Consorte, que foi aluna de Thales de Azevedo e Anísio Teixeira. A partir de sua experiência como pesquisadora ainda na graduação, no Programa de Pesquisas Sociais do Estado da Bahia e Universidade de Columbia, Josidelth Consorte consegue uma bolsa para fazer sua pós-graduação em Nova Iorque. Um fato curioso dessa história é que Thales de Azevedo e Anísio Teixeira, conscientes do fato de que a passagem de uma pesquisadora negra brasileira numa universidade norte-americana não seria fácil, recomendaram a Josidelth Consorte que passasse uma temporada em São Paulo desenvolvendo estudos na Escola Paulista de Sociologia e Política, para que ela se habituasse com o racismo que possivelmente sofreria nos Estados Unidos:

São Paulo foi uma experiência nova e ampliada de vivência urbana e vivência de relações raciais. Eu saí da Bahia para São Paulo, a caminho dos Estados Unidos (onde a segregação racial era total, absoluta), e então era importante que eu fosse me preparando pra qualquer eventualidade, pra ser discriminada, etc. E foi assim que eu vim pra São Paulo pra completar os meus estudos, já que eu precisava de quatro anos pra ir pra Columbia. Mas também para viver uma outra experiência: urbana, de grande cidade e de outras relações raciais. Este contexto de outras relações raciais não era falado, não era mencionado, mas era um subtexto mais ou menos perceptível. (Consorte apud Damaceno et.al, 2009: 210)

Aproximar as trajetórias de Josidelth Consorte e Virgínia Bicudo é importante, pois ajuda a delinear qual era o clima racial em São Paulo para acadêmicas negras na primeira metade do século XX. Se a história da Cadeira de Sociologia I na USP em São Paulo, foi uma porta aberta para mulheres e filhos de imigrantes europeus, a ELSP foi a opção que se tornou mais acessível para Virgínia Bicudo e Josidelth Consorte, duas mulheres negras que transitaram pelas Ciências Sociais em São Paulo nas décadas de 1940 e 1950. As pesquisas de Virginia Bicudo já haviam constatado que a ascensão social via escolarização não blindava a população negra contra o preconceito:

O acesso ocupacional não lhe confere status social igual ao branco do mesmo nível profissional, econômico e intelectual. O preto sentindo que dele eram exigidos maiores esforços para cursar escolas superiores ou obter um "bom" emprego, novamente se traumatiza com as restrições que sofre na esfera social do branco. Sente-se considerado apenas como "profissional" e não como "pessoa". A conquista de um diploma de escola superior ou de um cargo de responsabilidade não garantem ao preto a satisfação do desejo de ser aceito socialmente sem restrições [...] (Bicudo, 1947, p.203 apud Damaceno 2013, p.106)

Cabe ressaltar que apesar do silêncio sobre a categoria raça, os estudos sobre gênero e docência na USP possibilitaram um conjunto denso de análises sobre as hostilidades que cercavam a vida das mulheres na carreira acadêmica, regida por concepções do fazer científico e perspectivas predominantemente masculinas. Desse modo, a necessária introdução da categoria raça faz a trajetória da professora Virgínia ser singular no seio das gerações pioneiras de docentes na USP e na 
ELSP. A professora Virgínia Leone Bicudo aparece como a única docente negra neste momento da história da universidade. Mesmo assim, com a ressalva de que não fez toda a sua carreira docente na USP, estando sua trajetória acadêmica mais associada à Escola Livre de Sociologia Política.

Porém um fato aproxima as trajetórias dessas gerações pioneiras: ter desafiado a estabilidade da produção do conhecimento científico, historicamente considerado como um domínio reservado aos homens; pois essa produção, apesar de não ser completamente impermeável à ainda inquietante presença feminina, lhe ofereceu muitas resistências. Situação que atualmente só não é mais grave, porque "pressupõe-se que a existência de um sujeito universal já não é mais plausível, e isso vale tanto para o eu masculino como para a tardia individualidade feminina." (Bandeira, 2008, p. 208). Do mesmo modo que não há produção de conhecimento sem ponto de vista. Ou como indica Bourdieu (2001) "não há objeto que não envolva um ponto de vista, mesmo se tratando do objeto produzido com a intenção de abolir o ponto de vista" (Bourdieu, 2011, p. 27). Embora as feministas não tenham sido nem as primeiras, nem as únicas a construírem um conjunto de críticas à ciência moderna, pois foram antecedidas por exemplo, pelos anti-colonialistas, ecologistas, antimilitaristas, etc, as novidades trazidas pelas críticas feministas estão em problematizar a “organização do mundo social e natural materializado nas relações sociais, cognitivas, éticas e políticas entre homens e mulheres, assim como nas suas expressões e significados no mundo simbólico". (Bandeira, 2008, p. 209). Se a ausência das mulheres na história do pensamento científico revela o caráter androcêntrico ${ }^{65}$ dessa atividade, a ausência da presença negra reafirma sua face eurocêntrica.

A crítica feminista, partindo da consciência histórica reconstruída, tornou evidente um sistema de dominação masculino de tal modo arraigado, que coloca(va) as mulheres como substrato da produção científica. As mulheres como sujeito individual ou coletivo na produção do conhecimento não estão sozinhas nesse processo de exclusões e incertezas nos caminhos da construção científica, pois essa condição é comum a outros grupos sociais, tais como certos grupos étnico-raciais (Bandeira, 2008). Tal fato aproxima as trajetórias das gerações pioneiras de mulheres docentes na USP, brancas e negras, apesar das especificidades históricas dos processos de exclusão

\footnotetext{
65Oliveira (2014) considera, a partir de sua leitura de Simone de Beauvoir, que uma grande força da noção de androcêntrismo é questionar a noção de humanidade como sinônima de homem: "Uma outra leitura possível do pensamento beauvoiriano consiste em reler a premissa de que se trata de um pensamento que visa alargar os horizontes de possibilidade de pensamento sobre «mulheres». Antes, podemos olhar para o modo como também alarga os limites estritos da compreensão do humano, permitindo uma maior abertura deste conceito, que nunca é um dado, mas antes uma categoria de inclusão ou de exclusão. Ao estabelecer e lançar a sua crítica ao androcentrismo, sinédoque de um humano confundido com o masculino, Beauvoir (1975) está a criticar um humano estrito e, ao mesmo tempo, a reclamar uma abertura do horizonte de possibilidade do humano enquanto categoria. É fundamental não confundir tal proposta com o humanismo que trata o humano como um dado, algo fixo. A proposta de Beauvoir é bastante mais radical do que essa, implica ver no humano uma categoria e não uma fundação, pois não fosse a instabilidade do seu significado, não teria sentido estabelecer esta crítica à equação humano-homem” (Oliveira, 2014, p. 73-74).
} 
vividos dentro da universidade. São páginas da história do fazer acadêmico que precisam ter mais investigações, que precisam ser mais amplamente divulgadas, para que se assente o consenso sobre a gravidade de uma perspectiva androcêntrica e eurocêntrica do fazer científico. No que concerne à produção encontrada e aqui considerada, observa-se que a bibliografia tradicional que se ocupa do gênero e docência na USP indica análises referentes ao período situado entre os anos 1930 e 1970, e contempla as chamadas "gerações pioneiras". Considerando o quão recente é a história da USP e a institucionalização das disciplinas acadêmicas, o legado dessas gerações fundamenta ainda hoje o nosso fazer acadêmico. Há muito a ser pesquisado sobre o trabalho dessas gerações cuja herança ainda não foi totalmente apreendida. Obviamente novas gerações têm dado continuidade ao trabalho inicial, ampliando a necessidade de compreensão sobre o legado que se acumula.

Essa pesquisa encontrou bibliografias voltadas para a compreensão das gerações pioneiras na USP, cuja atuação está no campo das ciências sociais e humanas. Tem sido difícil encontrar análises sobre a trajetória de docentes que fizeram suas carreiras mais recentemente, construindo a história da universidade. Neste sentido, um exemplo é a obra USP 70 Anos: Imagens de uma História Vivida, já considerada neste trabalho, que traz muitas narrativas sobre as gerações pioneiras e os trabalhos de gerações sucessoras em vários campos do saber e da administração acadêmica. A obra, de caráter enciclopédico, traz além da história da universidade, os feitos de gerações de docentes reconhecidos pela produção intelectual, bem como daqueles que também foram reitores, vice-reitores e pró-reitores. Porém, a preocupação maior é trazer a memória dos processos históricos que construíram a universidade e menos a trajetória docente que permeia esses processos. Esta tese tem chegado à compreensão de que as gerações pioneiras possuem vasta, porém não exaustiva, bibliografia sobre a trajetória de docentes que marcaram os primórdios da universidade. Por sua vez, as gerações mais recentes ainda não têm sido devidamente contempladas com uma produção bibliográfica que as considere enquanto agentes que apontam caminhos na construção da história da universidade. No que diz respeito à articulação entre ensino superior, trajetória docente e as categorias gênero e raça, a bibliografia encontrada também foi bastante rara, quase inexistente. Apesar disso, o que este trabalho propõe no próximo tópico, é considerar a importância das categorias gênero e raça nas trajetórias da atual geração de docentes negros/as da USP. 


\section{V.1- Sobre gênero, raça e docência na USP: outras vozes em cena}

bell hooks (1995) conta que quando começou seu trabalho como professora integral na Universidade de Yale, ela era uma das duas afro-americanas na universidade. Nas ocasiões em que questionava a ausência de acadêmicas negras na universidade, ouvia que "se as negras não estão aqui, não é porque a Yale é racista, é que as negras não são suficientemente capazes”. (hooks, 1995, p.77). No caso do homem negro, a autora indica que embora eles sofram racismo, gozam a condição de homem, que os legitima como membros de uma tradição intelectual estabelecida. O trabalho intelectual do homem negro tornar-se-ia então menos suspeito e melhor avaliado do que o da mulher negra. A autora conta ainda que nas suas aulas costuma fazer um exercício de solicitar à classe que dê nomes de intelectuais negros. De imediato aparece um panteão de homens negros intelectuais. Quando bell hooks solicita exemplos de intelectuais negras, os nomes pronunciados tornam-se mais raros e custosos. No percurso de busca dos sujeitos desta pesquisa, verificou-se fato semelhante, uma vez que foram indicados vinte nomes de docentes negros e sete de docentes negras; além de o nome do professor Kabengele Munanga ter sido lembrado muito frequentemente. Faz-se necessária uma ressalva aqui: se a menção à figura deste professor foi recorrente, é possível que se deva mais à sua vasta contribuição à construção do debate racial dentro e fora da academia e secundariamente às lógicas machistas que fundamentam a vida acadêmica.

Interpelar essas lógicas é um exercício necessário para a sua efetiva superação; neste sentido, um interessante ponto de partida é o conceito de gênero oferecido por Scott (1995), cuja definição parte de dois pressupostos: primeiro, gênero é "um elemento constitutivo de relações sociais fundadas sobre as diferenças percebidas entre os sexos"; segundo, gênero como "um primeiro modo de dar significado às relações de poder” (Scott, 2005, p.86). Por essa via, o conceito de gênero revela-se "uma categoria explicativa muito fértil para a análise dos aspectos da docência. Muito mais pródiga de razões que a pura e simples composição sexual poderia sugerir." (Vianna, 2001, p. 90). Propor análises de gênero no campo da docência não se revela tarefa fácil. Vianna (2001) nos alerta sobre os cuidados a serem tomados de modo a evitar incorrer em equívocos sobre tradicionais significados de masculino e feminino que permeiam a prática docente. Pois esta dicotomia tende a engessar concepções sobre o que deve ser atribuição de um professor e de uma professora, perpetuando assimetrias de gênero, aqui reconfiguradas em termos étnico-raciais. Tendo isso em vista, esta pesquisa, que ouviu cinco docentes negras e cinco docentes negros, procura estar atenta ao modo como as noções de gênero, as concepções sobre masculino e feminino aparecem nas narrativas docentes e informam suas práticas acadêmicas. 
Para o início da conversa, conciliada à história do feminismo brasileiro, está a trajetória da professora Eunice Aparecida Prudente, considerada no final do primeiro capítulo, mas que também terá destaque aqui em função da crônica que oferece de uma cena da articulação entre movimento feminista em São Paulo e a Faculdade de Filosofia da USP, na figura de algumas docentes. Tendo ingressado na graduação em Direito na Faculdade do Largo São Francisco em 1968, dentre os/as docentes negros/as entrevistados/as, a professora Eunice Prudente é quem possui vínculo mais antigo com a universidade. Conforme indica seu Lattes ${ }^{66}$, na sua trajetória como pesquisadora, ela tem se dedicado a um conjunto de debates:

(...) diferenças e desigualdades sociais, relações étnico-raciais, o negro na ordem jurídica brasileira, direitos coletivos - difusos e individuais homogêneos, advocacia pelos direitos humanos fundamentais, feminismo, (grifo meu) participação popular e planejamento. (Texto informado pela autora)

A trajetória da professora Eunice Prudente está marcada por alguns pioneirismos: ela é a primeira e única professora negra na história da Faculdade de Direito, foi a primeira mulher negra na Diretoria Executiva do Programa de Orientação e Proteção ao Consumidor (Procon); e ao assumir a Secretaria da Justiça e Defesa da Cidadania do Estado de São Paulo "passa à história como a primeira mulher a ocupar o cargo de secretária da Justiça, cargo nunca antes ocupado por nenhuma mulher negra ou branca." (Cruz, 2009, p. 66).

A discussão de gênero atravessa não apenas a carreira acadêmica da professora Eunice Prudente, mas a acompanha em outros espaços como no seu órgão de classe, a OAB (Ordem dos Advogados Brasileiros), onde também empunha bandeiras de gênero. Antes disso, porém, sua trajetória já indicava conciliações com um interessante capítulo da história do feminismo brasileiro, quando teve a oportunidade de acessar espaços de debates feministas como a Frente de Mulheres Feministas na década de 1980:

Tive a felicidade, deve ter sido em $1981 \ldots$ não sei... houve uma reunião da SBPC, da Sociedade Brasileira para a Ciência, aí eu fui e eu tive a felicidade de integrar a Frente das Mulheres Feministas. Foi um momento em que o PSDB estava chegando aqui ao governo de São Paulo, etc. Então a professora Ruth Cardoso, a Eva Blay e outras aí que são chamadas de "dinossauros" de nossa [época], do feminismo né, Eva Blay, a Cecília Prada que era diplomata, a Marta Suplicy, que não integrava diretamente assim a política, mas já era do PT, acho que só ela era do PT, era o que eles chamavam lá de "Sorbonne do PSDB", uma série de professoras vinculadas à política do PSDB. Mas enfim, criou-se a Frente das Mulheres Feministas, era supra-partidária, [...] E as reuniões eram aí no Pacaembu, na casa da atriz Ruth Escobar. Então a Ruth Escobar também integrava, algumas outras atrizes também, Regina Duarte, enfim. As reuniões eram lá. Ali foi um laboratório, uma riqueza eu vi e ouvi muita coisa. Aí eu comecei a dar entrevistas, comecei a ler e a dar entrevistas e a

66Currículo do Sistema de Currículos Lattes (Eunice Aparecida de Jesus Prudente). Disponível em: http://buscatextual.cnpq.br/buscatextual/visualizacv.do?metodo=apresentar\&id=K476...>Acesso em 18/12/2011 
escrever sobre as questões de gênero. Assisti também a Teresa Santos, a Sueli Carneiro, praticamente instituindo o feminismo negro aqui no Brasil. Então tive alguma participação. Aí depois veio Franco Montoro, ganhou as eleições e tivemos a instituição do Conselho da Condição Feminina. [...] Desfez-se a Frente das Mulheres Feministas, elas foram para os seus respectivos partidos e eu continuei na OAB. Então foi aí mais nas discussões da OAB que eu pude entender mais sobre as questões de gênero e saber o quanto ela é grave e vi, como todos os brasileiros, que a instituição da lei Maria da Penha é conquista. Mas ainda tem muito que construir.

A narrativa da professora Eunice transcrita acima oferece uma breve crônica, um instante da vivência de um feminismo brasileiro situado nos anos 1980 na cidade de São Paulo, descortinando um horizonte histórico e analítico. Embora na trajetória da professora Eunice Prudente seu protagonismo se evidencie em outras searas, a professora também testemunhou parte da história da construção acadêmica, bem como a político-partidária, de uma agenda de gênero e feminismo no Brasil.

Considerando a história da institucionalização dos estudos de gênero no país, Heilborn \& Sorj (1999) indicam que a relação entre o movimento feminista e a academia, apesar da flagrante inspiração norte-americana e europeia, guarda as suas especificidades. A primeira é que o movimento feminista brasileiro não teve a mesma coloração radical, mas uma orientação mais moderada concernente ao confronto entre os sexos, bem como afiliação ao discurso dominante das esquerdas nos diálogos com os movimentos sociais. A segunda, é que o feminismo brasileiro desde o princípio esteve articulado com a academia, "a tal ponto que algumas versões de sua história consideram que o feminismo apareceu primeiro na academia e, só mais tarde, teria disseminado entre mulheres com outras inserções sociais”. (Heilborn \& Sorj, 1999, p.186). Sendo assim, quando o movimento feminista passa a ter visibilidade no Brasil, sobretudo nos anos pós-1975, muitas de suas militantes e simpatizantes já eram docentes universitárias; mulheres que estavam em posição privilegiada de acesso, elaboração e disseminação das ideias feministas que circulavam internacionalmente nos países capitalistas avançados desde a década de 1960. (Heilborn \& Sorj, 1999).

Nos anos de 1970 no Brasil, grupos feministas de orientação marxista tiveram maior espaço de representatividade nos encontros dentro do movimento. Ao final da década acontece a criação de entidades, como o Coletivo de Mulheres que entendia o feminismo como um movimento libertário no qual não deveria caber a distinção entre lutas gerais ou de classe versus lutas tidas como específicas, como a das mulheres, muitas vezes subestimadas. Além disso, dentro do feminismo caberia refletir sobre o lugar ocupado pelas reivindicações das mulheres negras, camponesas, idosas, lésbicas e homossexuais (Pedro, 2006). É sabido que historicamente existem divergências sobre o espaço dentro do feminismo para as reivindicações de grupos interseccionalmente subalternizados. Houve parcialidade e seletividade nas inspirações do feminismo brasileiro, 
sobretudo no intercâmbio com o norte-americano, importante referência da teoria e prática construídas no Brasil,

O que quero chamar atenção aqui é que essa inspiração para os núcleos no Brasil é extremamente parcial: em nenhum momento as críticas ao racismo que estavam sendo feitas nos Estados Unidos ao feminismo ocidental desde pelo menos 1981 nos serviram de inspiração. Isto fica claro no desconhecimento entre nós das produções de mulheres de cor nos Estados Unidos - não existem traduções entre nós destas produções. Mas a parcialidade da inspiração aparece, sobretudo, na ausência desta discussão entre nós mesmas (Azeredo, 1994, p. 215-216).

Correa (2001) também aponta para essa questão indicando o problema da grande lacuna bibliográfica na relação entre gênero e raça. Nas suas palavras: "é claro que em relação à questão racial havia uma cegueira estrutural na sociedade brasileira, e a relação raça e gênero só começa a se tornar teoricamente relevante, a partir da leitura dos textos de autoras norte- americanas, elas sim questionadas pelo feminismo das mulheres negras" (Correa, 2001, p. 26). Assim, a autora endossa a opinião de que aqui a questão racial só se torna teoricamente relevante quando as feministas brasileiras não poderiam mais se esquivar da discussão, pois suas referências teóricas (brancas) haviam sido interpeladas pelo feminismo de mulheres negras, a exemplo de Lélia Gonzalez cuja trajetória com ampla circulação internacional a possibilitou entrar em contato com a bibliografia produzida por feministas negras mundo afora. Com amplo trânsito na universidade e na militância, Lélia Gonzalez não se furtava de apontar a miopia do feminismo brasileiro para as desigualdades de raça, e denunciava ainda o fato o feminismo branco brasileiro se valer da opressão da mulher negra. (Gonzalez, 1981).

Assim, do mesmo modo que teóricas feministas relatam a resistência de alguns movimentos de esquerda com relação à discussão de gênero, nunca é demais destacar também, que as teóricas do movimento feminista negro norte americano criticaram as contradições e limites de diálogo com o movimento e a teoria feminista, o movimento negro e movimentos de esquerda (hooks, 2004). Desse modo, um interessante quadro de referência para ajudar a compreender o movimento feminista brasileiro seria:

(...) é um movimento que luta por autonomia em um espaço profundamente marcado pelo político; defende a especificidade da condição de dominada da mulher, numa sociedade em que a dominação é comum a grandes parcelas da população; no qual há diferentes mulheres enfrentando uma gama de problemas diferenciados. (Pinto, 2003, p. 46)

Não é tarefa fácil traçar um perfil das feministas desta época, pois eram grupos bastante heterogêneos compostos por atrizes, jornalistas, professoras universitárias, estudantes, sindicalistas e militantes de diversos movimentos populares. Apesar da diversidade, havia algumas tendências, sobretudo no eixo Rio/São Paulo: "eram mulheres de esquerda e eram mulheres profissionais ou em 
vias de se tornarem profissionais." (Correa, 2001, p. 15). Apesar disso, eram de fato grupos de muitas orientações:

(...) com lealdades muito diversificadas - em relação à Igreja, ao Partido Comunista, ou à Universidade. Assim, uma das questões que reiteradamente aparecia nas nossas discussões era a clivagem entre militantes e pesquisadoras, clivagem que se tornou importante à medida que a pesquisa sobre a situação da mulher no país ganhou preeminência sobre os movimentos de mulheres. (Correa, 2001, p. 17).

De um modo geral, a década de 1980 é marcada pelo processo de reconstrução da democracia liberal brasileira. Conforme indica Soares (1998) a agenda feminista esteve em sintonia com os demais movimentos sociais na luta pelo reconhecimento de suas reivindicações junto ao Estado. Dessa forma,

\begin{abstract}
(...) o movimento feminista, a partir de 1981, ficou mais complexo em sua organização e mais diverso ideologicamente. Com a reorganização partidária, foi polarizado pelas diversas propostas que surgiram no âmbito das questões gerais da reconstrução da democracia liberal. Muitas mulheres privilegiaram a atuação nos partidos. A partir de então, apareceu uma nova militante nos partidos políticos, a feminista, e nestes espaços o tema 'mulher' tornou-se alvo de debate, item obrigatório dos programas e plataformas eleitorais dos partidos progressistas, como resultado da visibilidade que as questões das mulheres ganharam, trazidas pelos seus movimentos. (Soares, 1998, p. 43)
\end{abstract}

Assim, a década de 1980 trouxe novos temas como a partidarização e a institucionalização do movimento feminista no cenário nacional. Como consequência da reforma partidária que dividiu a oposição ao regime militar em pelo menos duas grandes tendências, uma acolhida pelo PMDB e a outra pelo PT, nas eleições estaduais de 1982 as militantes de São Paulo se posicionaram em referência a esses dois partidos. Com a eleição de Franco Montoro, as feministas de orientação mais peemedebista começam a ocupar cargos estaduais. A criação do Conselho Estadual da Condição Feminina, citada pela professora Eunice Prudente, ocorreu em 1983 e foi proposta ao governador recém-eleito por militantes peemedebistas. $O$ fato de ter sido o primeiro órgão desse tipo a ser criado no Brasil atesta o quanto o movimento feminista em São Paulo era organizado "e tinha algumas figuras de projeção nacional nas áreas de cultura, da política e da academia”. (Pinto, 2003, p.70).

As pesquisas sobre a mulher também estavam em pleno processo de consolidação como tema pertinente à academia brasileira. Conforme já mencionado, a primeira tese sobre o assunto foi defendida em 1967, por Heleith Saffioti, sob orientação de Florestan Fernandes na Universidade de São Paulo. E a partir de 1975, as feministas durante dez anos organizaram encontros nacionais nas reuniões anuais da SBPC (Sociedade Brasileira para o Progresso da Ciência). Nesse contexto, a “mais importante iniciativa na área do estudo de mulheres e das relações de gênero no Brasil foi, 
sem dúvida, o conjunto de concursos e dotações de recursos promovidos pela Fundação Carlos Chagas e financiados pela Fundação Ford, de 1978 a 1998.” (Pinto, 2003, p. 86). E foi na Fundação Carlos Chagas que começou a ser publicado o mais importante periódico feminista dessa década, o jornal Mulherio, que circulou entre os anos 1981 e 1988. Enfim, outros espaços importantes de produção e difusão sobre a mulher começaram a surgir nas associações nacionais de pesquisa nas diversas áreas do conhecimento como ANPOCS (Associação Nacional de Pós-Graduação e Pesquisa em Ciências Sociais), ANPED Associação Nacional de Pós-Graduação e Pesquisa em Educação, ANPOLL (Associação Nacional de Pós-Graduação e Pesquisa em Letras e Linguística), etc.

Desse modo, o depoimento da professora Eunice Prudente endossa a bibliografia a respeito da dinâmica histórica do movimento feminista em São Paulo nas suas interfaces com as institucionalizações política e acadêmica, exemplificando-a. Sobre a Frente de Mulheres Feministas, grupo citado pela professora e do qual participava, Santos (2006) destaca a participação das feministas afiliadas ao PMDB e PT no processo eleitoral de 1982, que resultou também na criação do Conselho Estadual da Condição Feminina de São Paulo, já mencionado, cuja primeira presidente foi a professora Eva Blay. Nome importante do NEMGE - Núcleo de Estudos da Mulher e Relações Sociais de Gênero criado na USP em 1985, Eva Blay veio a ser figura ativa no PMDB Mulher (Santos, 2006, p. 417), e construiu parte importante de sua carreira política no PSDB, chegando a ser suplente de Fernando Henrique Cardoso no senado e assumindo a cadeira quando ele foi eleito Presidente da República. Havia ainda uma não rara coincidência de nomes de militantes feministas em espaços como a Frente de Mulheres Feminista e o Conselho Estadual da Condição Feminina de São Paulo. A recorrência de nomes chega também aos conselhos editoriais de publicações da época ${ }^{67}$, dentre eles o Mulherio. Importante destacar que o Mulherio foi o único jornal feminista da década de 1980 que contava em seu corpo editorial com a presença de uma autora feminista negra, Lélia Gonzalez, nome fundamental no debate entre gênero e raça.

A professora Eunice Prudente esteve presente na interface de discursos, interesses e tensões que caracterizaram a história do feminismo brasileiro. Esteve na fronteira entre a versão acadêmica do feminismo representado pelas professoras da Faculdade de Filosofia Letras e Ciências Humanas (FFLCH) da USP; tinha contato com as ideologias feministas de esquerda e ainda, com posicionamentos partidários; assistiu a instituição do movimento de mulheres negras, suas reivindicações e denúncias, inclusive contra aspectos hegemônicos do movimento feminista brasileiro e o movimento negro. E nessa intersecção de discursos a professora Eunice acumulou capitais sociais que lhe possibilitaram ser a primeira mulher e mulher negra na Secretaria de Justiça 
de São Paulo. A relevância desse fato aumenta na medida em que o cargo de Secretário de Justiça e Defesa da Cidadania do Estado de São Paulo existe desde 1892 e num conjunto de 74 titulares (alguns por mais de um período) constam nomes de importantes figuras, como Miguel Reale, docente da Faculdade de Direito que por duas vezes foi reitor da USP, além de membro da Academia Brasileira de Letras; um ex-presidente da República, Washington Luiz, e ministros do Supremo Tribunal Federal, como Francisco Cardoso Ribeiro e Uladislau Herculano de Freitas ${ }^{68}$.

A trajetória da professora Eunice Prudente, guardadas as devidas proporções, aproxima-se da trajetória de outros alunos e docentes da Faculdade de Direito, instituição cuja vocação tem sido preencher os quadros burocráticos da política nacional e paulista, sendo assim tradicional celeiro de verdadeiros aprendizes e artífices do poder, conforme indica Adorno (1988). Se a trajetória da professora Eunice Prudente concilia-se em certa medida com as trajetórias de outros alunos e docentes da Faculdade, na possibilidade de exercício do poder; diferencia-se na medida em que a professora está na condição de exceção. Se da Faculdade de Direito saíram grandes políticos e figuras importantes, a função desses esteve na maioria das vezes relacionada à manutenção da ordem de privilégios de segmentos da sociedade brasileira, o que não foi o caso da professora Eunice Prudente, cuja atuação se dá no sentido de ampliar o acesso à justiça de mulheres, negros e pobres. Além disso, os bacharéis da Faculdade de Direito da USP que integraram os quadros do Estado viveram um processo de fortalecerem a trajetória acadêmica com essas experiências políticas fora da USP. O mesmo não aconteceu com a professora Eunice Prudente, que há mais de duas décadas como docente na Faculdade de Direito, ainda permanece no primeiro degrau da carreira docente, como Professor Doutor ${ }^{69}$.

Se a comparação entre a trajetória da professora Eunice Prudente com as trajetórias de seus colegas da Faculdade de Direito pode oferecer o conjunto de semelhanças e diferenças apontadas no parágrafo acima, por sua vez o perfil do grupo feminista destacado pela professora Eunice Prudente em sua fala e a sua possibilidade de acesso e trânsito instiga a algumas considerações. É interessante verificar que tipo de feminismo estava sendo endossado por esse grupo de mulheres para tentar entender como elas estavam situadas institucionalmente e as suas escolhas de tradução de um feminismo ocidental em São Paulo. O conjunto de investigações sobre a mulher no contexto da USP está historicamente ligado ao NEMGE (Núcleo de Estudos da Mulher e Relações Sociais de

68Informações retiradas da página eletrônica da Secretaria. In: http://www.justica.sp.gov.br/novo_site/ > Acesso em $08 / 03 / 2013$

69Talvez fosse o caso de questionar se as discussões sobre tokenismo propostas por Cashmore (2000) fariam sentido aqui, para avaliar as muitas dimensões da presença da professora Eunice Prudente na Secretaria de Justiça e na Faculdade de Direito da USP: "O que o tokenismo sugere é que a presença de indivíduos negros proeminentes ou que ocupam posições de evidência em meios institucionais brancos não indica necessariamente que: a) tais indivíduos tenham um desempenho significativo ou papéis influentes no progresso dos negros como grupo; $b$ ) que a presença de tais indivíduos reflete a paridade social entre os negros como grupo e os brancos na sociedade (...)" (Cashmore, 2000, p. 535). 
Gênero) onde se "refletia sobre as discussões que aconteciam na França, principalmente nas Ciências Sociais, em torno das terminologias relações sociais de gênero e relações sociais de sexo" (Zirbel, 2007, p. 141) e num certo sentido, assim se conciliava com a orientação francesa da Faculdade de Filosofia da USP. Apesar das contribuições que trouxeram aos estudos sobre mulheres, feministas e de gênero, e em consonância com a própria história do feminismo no ocidente e suas reinvenções nas universidades dos países periféricos, em São Paulo e na USP observam-se nesse momento as faces de um feminismo liberal, que abrigado na academia, diz muito das experiências de raça e classe dessas feministas. Considerando a juventude da USP e sua proposta imponente do fazer científico, informado desde sempre pela noção de meritocracia tão cara à universidade, a face liberal dos primeiros estudos feministas e de gênero na universidade se abrigou nas dependências da Escola Paulista de Sociologia, na adoção de métodos tradicionais de pesquisa como forma de proteção contra estereótipos, sexismos e diversas formas de discriminações a que estavam sujeitas as gerações pioneiras na USP. Uma estratégia que parece paradoxalmente ter sido necessária. Assim, apesar das dificuldades vividas, a Sorbonne do PSDB, foi o grupo que prevaleceu na USP, apontando para uma tendência geral na história do feminismo ocidental:

A meu ver, o que observamos é o triunfo do feminismo liberal sobre outras formas de feminismos, como sejam o feminismo negro e o feminismo socialista, sendo que esta corrente liberal do feminismo se coaduna de forma muito mais evidente com o regime capitalista neoliberal. É preciso então não só olhar para os sucessos, mas sobretudo para as contradições. (Oliveira, 2014, p. 72).

Essa pode ter sido a primeira face possível dos estudos feministas e de gênero na USP em seus primórdios, que devem sim, ser interpelados. As contradições também importam no desafiante processo de pensar a representatividade de determinados grupos marginalizados dentro da universidade pública. Muito oportuna para compreensão das trajetórias consideradas aqui são as considerações que Halberstam (2011) propõe a respeito do que ele chama de feminismos da sombra, que seriam os fantasmas que assombram as teorias feministas e que aparecem nos instantâneos de sucesso político e de conquistas que ecoam alguma vitória do feminismo liberal. Seriam as perturbações de ordem conceitual que eclipsam os supostos avanços num registro de que o regime capitalista liberal tem também sua face igualitária. As fragilidades conceituais referentes aos feminismos haviam sido consideradas por Joan Scott quando apontou o inevitável paradoxo:

O feminismo foi um protesto contra a exclusão das mulheres da política; seu objetivo foi o de eliminar a diferença sexual na política. Mas a sua campanha foi voltada às mulheres. Pelo fato de agir em favor das mulheres, o feminismo produziu a diferença sexual que buscava eliminar - chamando a atenção exatamente para a questão que pretendia eliminar. (Scott, 2005, p. 21) 
Das alianças (in)esperadas entre o feminismo e o liberalismo emergiram alguns avanços, e algumas reivindicações foram progressivamente contempladas, de modo a produzirem mudanças culturais, como o questionamento das desigualdades de escolaridade e salariais entre homens e mulheres, o combate à violência de gênero, ao tráfico e exploração de mulheres. Mas conforme aponta Nancy Fraser (2013) estes fenômenos não desapareceram ainda, o que aponta também para as insuficências dessa via. No que concerne à USP, a versão liberal do feminismo encampado pelas docentes da FFLCH apontadas pela professora Eunice Prudente também não deixou de mostrar limites e contradições. Em termos das carreiras políticas que estas docentes da Faculdade de Filosofia da USP construíram, apesar das trajetórias de lutas, a lógica liberal revelou também sua face perversa: a professora e antropóloga Ruth Vilaça Correia Leite Cardoso, por exemplo, repousa sob uma versão da história eclipsada por um nome importante da Escola Paulista de Sociologia: o ex-presidente Fernando Henrique Cardoso, que foi também seu marido. Para além disso, apesar da importância do NEMGE na construção do conhecimento sobre feminismo e gênero na academia brasileira, esse talvez seja um importante campo de pesquisa em que a USP acompanha outras universidades que possuem núcleos de estudos e pesquisa mais consolidados e que têm desenvolvido a discussão em nível nacional, a exemplo da Universidade Federal de Santa Catarina com a Revista Estudos Feministas e que sedia o Fazendo Gênero, maior evento acadêmico da área na America Latina, e a UNICAMP, com o Núcleo Pagu responsável pela revista Cadernos Pagu. Estes dois periódicos têm sido porta de entrada fundamental dos debates internacionais e das diversas regiões brasileiras sobre feminismo, gênero, orientação sexual, masculinidades, transexualidades, etc, atualizando a comunidade brasileira acadêmica interessada nesses campos de estudo.

E uma questão que permanece é: o que teria contribuído para que a professora Eunice Prudente destacasse sua relação com este grupo feminista mais do que com o grupo de feministas negras? Em primeiro lugar, ressalta-se que tal questão advém apenas da narrativa da docente transcrita acima, sem considerar outros fóruns onde talvez seja possível averiguar de fato qual o caráter da relação estabelecida entre a docente e as feministas negras em São Paulo ${ }^{70}$. Sem dúvida a Faculdade de Direito foi a principal via de acesso a grupos acadêmicos e políticos de São Paulo em sua trajetória. Conforme a narrativa concedida para este trabalho, a partir de uma reunião da SBPC,

\footnotetext{
70Em conversas com a pesquisadora Flávia Mateus Rios, cuja tese de doutorado intitulada Elite Política Negra no Brasil analisa a relação entre movimento negro, partidos políticos e Estado, entre os anos de 1978 a 2002 , ela me disse que em suas pesquisas sobre o feminismo dos 80 e 90, observou que a professora Eunice Prudente era convidada a falar e a dar palestras sobre a temática racial e direitos e depois sobre os direitos das mulheres. No entender da pesquisadora, é possível dizer que a professora Eunice Prudente "nunca foi uma militante de frente, mas aparece nas redes dos movimentos sociais e do feminismo das mulheres negras. Nunca foi uma voz decisiva nesses movimentos, mas sua posição acadêmica era sim reivindicada para dar legitimidade à atuação política". Gostaria de registrar aqui meus agradecimentos à Flavia Rios pela leitura do meu trabalho e comentários sempre pertinentes.
} 
a Sociedade Brasileira para o Progresso da Ciência foi que a professora Eunice Prudente construiu a ponte de acesso à Frente de Mulheres Feministas. Foi neste contexto que estabeleceu relações com as feministas de destacada importância política no estado, a exemplo de Marta Suplicy ${ }^{71}$, Ruth Cardoso, Cecília Prada e Eva Blay, citadas na sua fala. E ainda, assistiu à assunção do feminismo negro em São Paulo, onde teve 'alguma participação', conforme relata. A continuação de sua trajetória no debate feminista se deu no âmbito da OAB, a Ordem dos Advogados Brasileiros, seu órgão de classe. Vale lembrar que a professora Eunice Prudente foi também Superintendente do Instituto da Previdência Municipal, onde conheceu o professor Cláudio Lembo, que era então Secretário dos Negócios Jurídicos e que também foi vice-governador de Geraldo Alckmim. Da relação estabelecida com o professor Lembo veio o convite para ser a Secretária da Justiça, por quase um ano, período em que Claúdio Lembo assumiu o governo do estado para que Geraldo Alckmim disputasse a presidência da república. Na entrevista que concedeu para esta pesquisa a professora Eunice Prudente destacou o fato de sempre ter se considerado suprapartidária e independente politicamente, soube se equilibrar entre os pólos de diferentes espectros políticos e assim chegou à Secretaria de Justiça pelas mãos de um importante nome da história de alianças entre PFL e PSDB ${ }^{72}$.

Traçando elos possíveis entre as trajetórias das docentes na USP desde as gerações pioneiras, a história das mulheres na USP começou a ser contada a partir do esforço de feministas consideradas na fala da professora Eunice Prudente. As gerações pioneiras entraram na USP na condição de grupo, numa brecha possível na história da Faculdade de Filosofia, enquanto as mulheres negras têm entrado a conta gotas na carreira docente da USP. Além disso, conforme indicam Blay \& Lang (2004):

Uma vez na carreira universitária, concluíram os cursos, algumas se mantiveram nas primeiras turmas de docentes, doutoraram e ascenderam aos postos mais altos da carreira, superando montanhas de obstáculos. A semente germinou e algumas colaboraram na construção de novas faculdades pelo interior do Estado de São Paulo. (Blay \& Lang, 2004, p. 132)

71Difícil furtar à lembrança do fato de que a exemplo da professora Eunice Prudente, a professora e psicanalista Virgínia Leone Bicudo também teve acesso a certos segmentos da elite política paulistana, a exemplo da família Suplicy, da qual chegou a ser psicanalista de alguns membros.

72Curiosamente, o advogado e professor Claudio Lembo, que a convidou para a Secretaria de Justiça, em 2006 cunhou a célebre expressão "elite branca" no contexto dos ataques do Primeiro Comando da Capital, PCC, à cidade de São Paulo, mas que ainda tem causado bastante celeuma no cenário nacional. Com um passado ligado ás elites políticas tradicionais, questionado sobre o que seria a tal "elite branca", apresentou algumas definições em entrevista que concedeu ao Jornal Terra no dia 26 de julho de 2006: Jornal do Terra: O que o senhor quis dizer quando criticou a elite branca? Cláudio Lembo -Isso foi uma resposta incisiva a uma jornalista que perguntou incisivamente. Acho que temos no Brasil um grupo de pessoas que não se deram conta de que vivem em um país de terceiro mundo, e têm uma história muito amarga de cerceamento. O Brasil nunca conheceu a liberdade pessoal. Alguns tinham tudo e grande maioria vivia nas senzalas e colônias. Sou italianinho de São Paulo, daqueles que sofreram isso na pele. Temos que abrir as mentes e integrar a sociedade brasileira. 
Ou seja, estas mulheres entraram coletivamente na FFCL já na primeira década de fundação da faculdade, como "jovens burguesas [que] saíam das aulas de chapéu e luva" (Blay \& Lang, 2004, p. 131), formaram-se, fizeram carreira acadêmica na USP e ajudaram a construir a universidade, fortalecendo o modelo acadêmico adotado. Enquanto isso, a professora Virgínia Bicudo, filha de lavradores, passou pela USP nas décadas de 1940 e 1950 e não permaneceu na USP, embora tenha participado do processo de construção dos saberes "Psi" na universidade.; Por sua vez, a entrada da professora Eunice Prudente, também filha de lavradores do interior do estado que tornam-se metalúrgicos quando vêm para a capital, aconteceu muito posteriormente, na década de 1980, e sua trajetória docente ainda está sendo construída, a despeito das importantes conquistas na carreira política que construiu paralelamente. Mas, considerando o modo como se configurou a história da USP, com destaque para sua orientação francesa e a nevrálgica relação com determinados grupos políticos do estado de São Paulo, de um modo geral as articulações políticas e acadêmicas na construção do debate feminista, nas trajetórias dessas docentes aqui consideradas, apesar das diferenças de geração, de classe e raciais, estiveram conciliadas com o curso tradicional da história desta instituição, alinhadas às concepções gerais de universidade reinventadas na USP.

$* * * * * * * * * * * * * * * * * * * * * * * * * *$

Uma vez consideradas as trajetórias das intelectuais negras Virgínia Leone Bicudo e Eunice Prudente, buscando comparações com as primeiras gerações de docentes da USP, em função dos pioneirismos que marcam as trajetórias dessas duas intelectuais, esse capítulo prossegue considerando como as experiências de gênero marcam as trajetórias dos/as demais docentes negros/as entrevistados/as para esta pesquisa. Começando com o professor Kabengele Munanga, do Departamento de Antropologia na USP, que em sua narrativa aponta que na Universidade de São Paulo as relações de poder na docência são mais marcadas por assimetrias raciais do que de gênero:

\footnotetext{
Se você entrar no salão nobre da Faculdade de Filosofia, tem retrato de todos os diretores e não tem nenhum diretor e diretora negros. Uma vez eu convidei um professor da África do Sul, fizemos um seminário aqui sobre direitos humanos, nós fizemos na Faculdade de Direito, no Largo São Francisco. Quando entramos na sala do diretor da Faculdade, tinha retrato de todos os diretores e olhamos, vimos uma mulher, mas não tinha nenhum negro. Ele percebeu e disse "tem uma mulher, mas nenhum negro".
}

A O professor Kabengele Munanga observa que na academia as regras do jogo possuem algumas sutilezas perversas de modo que docentes negros/as não são explicitamente hostilizados em função da sua condição racial, ou de gênero, mas o não-dito indica que no jogo acadêmico, as regras são políticas e não apenas meritocráticas: 
Eu acho que homem negro, ou mulher negra numa universidade como essa aqui, não sei se haveria diferença de tratamento. Como falei, os colegas são pessoas inteligentes, eles sabem que a mulher negra ou homem negro passaram pelos mesmos concursos. Talvez esse problema possa ser colocado num outro nível: se o homem negro ou a mulher negra se apresentar como um candidato a reitor da universidade, se tiver título de professor titular, se apresentar para reitor da universidade aí há uma questão política, é muito importante, se não for eleito, você pode fazer falsas acusações (...).

Ser docente numa universidade pública na condição de funcionário público do estado, a princípio poderia oferecer alguma proteção, de modo que manifestações de racismo ou machismo não aconteceriam à queima-roupa. Esta é a percepção da professora de Geografia Vanderli Custódio, do Instituto de Estudos Brasileiros (IEB):

\begin{abstract}
Assim, que eu tenha percebido, nesses anos todos, tanto fora quanto dentro, tanto faz ser professora, ser professor, assim, há uma igualdade dentro do serviço público, pelo menos nesse sentido, mulher não ganha menos que homem, você tem diretora, tem diretores, professoras titulares, professores. Não tem, não tem essa relação não, pelo menos assim, dentro do serviço público, que eu vivi, porque às vezes, a minha experiência, não tem essa questão de gênero, ser homem, ou ser mulher, nada... Aqui a gente tem diretora, então... acho que a época que deu maior polarização nesse sentido, foi quando a gente teve a reitora, que eu ouvi muita piadinha. "Porque a reitora deve estar fazendo a unha, por isso que ela chegou atrasada no compromisso". A reitora Suely, "ah ela deve estar fazendo compra no shopping, por isso que...". Então saíram muitas piadinhas pela universidade afora, porque era uma reitora.
\end{abstract}

Vale lembrar que a professora Suely Vilela foi a única reitora que a USP teve em toda a sua história. A Revista ADUSP (Revista da Associação dos Docentes da USP) publicou um número especial em outubro de 2009 no intuito de fazer um balanço do mandato da reitora ocorrido entre os anos de 2006 a 2009. Basicamente, os adjetivos que sintetizaram as críticas feitas à sua gestão foram "perseguições e produtivismo exacerbados". Em nenhuma linha o periódico esboçou alguma reflexão sobre qual foi o significado da USP ter estado pela primeira vez, sob a gestão de uma reitora. Não se trata obviamente, de sacrificar a análise da gestão da reitora para focar exclusivamente na gestora. Mas a revista, tão atenta às relações de poder dentro da USP, perdeu sem dúvida uma grande oportunidade de debater as desigualdades de gênero nas instâncias de poder da instituição.

Analisando os significados de ser mulher no século XXI, Rago (2004) indica que a expressão “'mulher pública' é reveladora de uma longa história de constantes exclusões e humilhações ostensivas para as mulheres, mas também de profundos deslocamentos, conquistas e inovações realizadas pelas mulheres”. (Rago, 2004, p.31). Embora as mudanças culturais e mentais sejam difíceis e custosas, as mulheres têm redefinido seu lugar na sociedade:

(...) até mesmo intelectuais pouco atentos às questões de gênero não podem deixar de reconhecer que a única revolução que realmente vingou, no século $\mathrm{XX}$, foi a feminista, provocando não apenas o acesso das mulheres à cidadania, mas acentuando um fenômeno igualmente profundo, embora menos perceptível, pelo menos até recentemente: $a$ 
Sendo assim, as mulheres adentraram o mundo da cultura e da política, porém não sem acirrados conflitos, dificuldades e tensões. À medida que se refinam as conquistas, parece haver reações cada vez mais apuradas, numa espécie de “"revanche' machista” (Rago, 2004:39), que se traduz em recuo e distanciamento, bem como intensificação da violência perpetrada contra as mulheres, que assim se veem às voltas com novas preocupações, acúmulos de atribuições, solidão e ônus. "Nesse sentido, as mulheres continuam a reclamar do machismo, expresso em inúmeras formas de humilhação social, assédio sexual, violência doméstica, estupro e discriminação no trabalho, da fábrica à universidade". (Rago, 2004p, 40).

Mas sobre a discussão a respeito do acesso da mulher à vida pública é importante fazer uma ressalva, sobre a qual está assentada parte importante da história do feminismo negro norteamericano. O projeto de feminismo negro tal qual proposto por bell hooks (2004) entende a importância do feminismo como crítica ao sexismo, mas denuncia o racismo dentro do feminismo branco, quando este desliza numa pretensa universalidade que define como padrão a experiência feminina branca e de classe média. Exemplo dessa universalização é o que Betty Friedan definiu como "o problema que não tem nome", do qual padeciam as mulheres brancas, de classe média e com educação universitária, mas que não poderiam acessar a vida pública, construir carreira, restando-lhes apenas o confinamento da vida doméstica. O suposto de que as mulheres não trabalhavam na década de 1950 nos Estados Unidos escamoteava a realidade das mulheres negras e as brancas pobres, refletindo uma miopia de raça e classe, ainda que compartilhassem a experiência do jugo sexista. Ou nas palavras de bell hooks (2004):

La famosa frase de Friedan, «el problema que no tiene nombre», citada a menudo para
describir la condición de las mujeres en esta sociedad, se refería de hecho a la situación de
un grupo selecto de mujeres blancas, casadas, de clase media o alta y con educación
universitaria: amas de casa aburridas, hartas del tiempo libre, del hogar, de los hijos, del
consumismo, que quieren sacarle más a la vida. Friedan concluye su primer capítulo
afirmando: «No podemos seguir ignorando esa voz que, desde el interior de las mujeres,
dice: "Quiero algo más que un marido, unos hijos y una casa"». A ese «más» ella lo definió
como una carrera. En su libro no decía quién tendría entonces que encargarse del cuidado
de los hijos y del mantenimiento del hogar si cada vez más mujeres, como ella, eran
liberadas de sus trabajos domésticos y obtenían un acceso a las profesiones similar al de los
varones blancos. No hablaba de las necesidades de las mujeres sin hombre, ni hijos, ni
hogar. Ignoraba la existencia de mujeres que no fueran blancas, así como de las mujeres
blancas pobres. No decía a sus lectoras si, para su realización, era mejor ser sirvienta,
niñera, obrera, dependienta o prostituta que una ociosa ama de casa. (bell hooks, 2004, p.
33-34).

No contexto brasileiro esta questão foi tematizada por importantes nomes do feminismo negro brasileiro, a exemplo de Gonzalez (1983) que traz análises a respeito das noções de mulata, doméstica e mãe-preta para desvelar como a sociedade brasileira compreende a mulher negra nos 
espaços públicos e domésticos, bem como revelar como a academia brasileira também colabora para a manutenção de estereótipos sobre a população negra brasileira.

Sobre o desenvolvimento dos estudos de gênero no país, Heilborn \& Sorj (1999) propõem um esquema que vai dos caminhos da institucionalização destes estudos, passando pelas contribuições do conceito para melhor compreensão da organização social, chegando à avaliação das inovações cognitivas que o conceito de gênero trouxe para a crítica de paradigmas da produção de conhecimento aqui realizada. Neste trajeto, as autoras dão especial destaque a algumas áreas temáticas: trabalho, violência, sexualidade e família. No que diz respeito à violência como área de investigação, indicam a emergência de um campo de pesquisas preocupadas com a violência doméstica, bem como com a chamada violência institucional, em especial a verificada no sistema de saúde, onde se percebem diferenças de atendimento conforme o sexo da clientela e o atravessamento de ideologias de gênero na relação médico-paciente.

Interessa destacar para os propósitos deste texto, que a prática docente, se por um lado deve atentar para possíveis delimitações das formas como operam as relações de gênero nas diversas instituições, por outro, precisa perceber quando é inevitável atuar nas zonas de fronteira. É o que se passa com a professora do curso de Obstetrícia na EACH, Roselane Gonçalves, uma vez que seu cotidiano acadêmico implica na intersecção de gênero com pelos menos duas instituições: a universidade e o sistema de saúde,

Então, na verdade agora nós temos uma disciplina que vai discutir gênero, saúde e direitos reprodutivos. Mas nunca teve, isso sempre entrou como um tema transversal nas disciplinas e aí fica à mercê do quanto aquele docente traz essa discussão pra sua questão na sala de aula. Então depende muito, eu levo essa questão, porque estou envolvida com o movimento que discute essa questão da violência, que discute o cuidado, a humanização do cuidado, a integração do pai na relação com a mulher na assistência pré-natal, por exemplo, porque isso é coisa de mulher? Por que, por exemplo, método contraceptivo é só mulher que tem que usar? Então quando você discute planejamento familiar, a gente discute porque que é a mulher que se submete aos procedimentos mais invasivos, mais de risco pra sua saúde. Isso faz parte da minha discussão, porque eu sou eu, das outras colegas também, mas eu não duvido que existam temáticas abordadas, que não passem perto da questão de gênero, porque tem a ver com a formação do próprio profissional. Então a gente tem problemas, por exemplo, de ouvir, num estágio de parto, de pré-natal, em que a mulher vai fazer coleta de Papanicolau e que o técnico, especialista fala "põe a perninha aqui que nem frango assado", “ah, como você não sabe? Não é comum pra você abrir as pernas?". O que é interessante, trágico, mas também alunos que se deparam com essas cenas, mas falo "ué, mas não pode falar assim com ela, mas não pode achar, e nem pode questionar se ela está no sétimo filho, pode? Não pode, se ela quis. E nem pode questionar se ela não quer ter filho nunca, porque a mulher não foi feita pra reproduzir somente." Então tem as contradições, a gente flagra isso no dia-a-dia da prática, da assistência, da teoria em sala de aula, nos discursos provocados. Por exemplo, você está atendendo alguém que não quer aquela gravidez, o que se faz? Aí entra a questão do aborto, por exemplo: “ah, não quero saber a sua religião, nem o que você acredita, nem o seu credo político, eu quero saber que, enquanto profissional de saúde, atendendo uma mulher, o que você faz?" "Ah, porque eu não vou participar disso". Vai, você vai dar um encaminhamento, você vai dar um endereço de alguém que trabalha com isso, de uma clínica que atende a mulher integralmente, ué. "Não, eu vou convencê-la a ter esse filho.” Por que? Aí começa toda uma discussão, então é... eu ainda acho que a gente está engatinhando nisso, ter incluído a disciplina específica que discutirá isso, pra todos os alunos do curso, foi fundamental, pra gente ter essa perspectiva que futuramente 
isso vai ter que fazer parte de todas as discussões na formação.

Sendo uma instituição pública, a USP não foge a essa dinâmica de avanços e retrocessos cada vez mais refinados no quesito relações de gênero, o que pode ser verificado ainda na análise da professora Vanderli Custódio:

\begin{abstract}
A USP é uma universidade branca e elitista. Não vou dizer pra você que ela é masculina, eu acho que o maior número de docentes são homens, não sei, não tenho certeza disso. Mas independente disso, da quantidade, de mais mulheres ou homens, acho que o perfil ainda é masculino. Não vejo diferença entre homem e mulher, como falei pra você, aqui na pesquisa e tal, mas percebi essa diferença com a reitora, quando a reitora entrou, nossa, a quantidade de piadinhas que foram feitas pelo fato dela ser mulher, ela tá mais loira, tá menos loira, essa mulher, não sei o que, foi muita piadinha nesse sentido, que me fez pensar que essa universidade é elitista sim, ela é branca e ela é masculina, ela é machista. Isso é o perfil de USP, a USP é assim, não tenho a menor dúvida (...).
\end{abstract}

De fato, conforme indicado no último capítulo deste trabalho, na USP o número de professores é maior que o de professoras em qualquer segmento de cor/raça que se considere, com predomínio dos professores brancos. Sendo assim, a professora Vanderli tem razão, o perfil da universidade realmente é branco e masculino; mesmo tendo em conta que há uma diferença entre ter um corpo docente majoritariamente do sexo masculino e ser uma instituição masculina, pois a USP opera com valores e formas de trabalho que a sociedade considera masculinos. Assim, a diferença entre sexo e gênero no ambiente acadêmica por vezes se revela praticamente nula.

Apesar disso, mudanças significativas vêm sendo percebidas neste perfil. É o que indica a professora Maria Letícia, cujo vínculo com a Faculdade de Educação remonta ao seu ingresso na graduação em Pedagogia, no ano de 1976:

Essa coisa do gênero é complicada. Acho que é tão delicada quanto [a questão de raça]. Agora não acho, assim, que haja muita diferença, do ponto de vista do concurso, do ponto de vista dos relacionamentos, não acho que haja aí uma diferença significativa. Mas acho que politicamente é complicado ser professora e não professor. Os homens ainda são notadamente os escolhidos, de modo geral, para os cargos mais importantes. Pra darem conta de tarefas mais importantes. Mas isso é bem geral mesmo. Aqui eu não sei. É a terceira eleição para diretor que eu vejo e que as mulheres são predominantes e que a gente tem um espaço melhor. Mas agora acho que é difícil ser mulher negra, acho que essa é uma condição bastante complicada. Se não na vida acadêmica, na vida real ela é complicada, se agrava a situação. Eu fico imaginando. Eu fico pensando nas categorias da sociologia, a etnia, a classe social e o gênero, quem sobrevive é um vitorioso, certo? Eu nem tô falando da questão geracional (...). Mas eu não sei dizer sobre essa questão do gênero... Eu acho que o gênero discrimina sim. Aqui, na Faculdade de Educação não necessariamente, porque eu vejo que aqui é quase que um matriarcado. Os homens tentam a direção, mas eles são sempre expelidos. Acho que isso é bacana, acho que a gente é forte aqui. Nós mulhere,s acho que a gente é forte aqui. É só olhar pra carreira. Quando eu vim pra cá era um diretor, era o Roque Spencer Maciel de Barros, marido da Gilda. E era na época que predominavam os masculinos. Então você tinha um conjunto de professores, rígidos, de direita, vindos da Filosofia, então tinha o Roque, o Brejon, tinha o Heládio, o Villa-Lobos. Era um conjunto de homens que andava de terno e que eram predominantes. As mulheres eram um mero adereço. Há trinta anos atrás. Você vê que as coisas mudaram. Você contava nos dedos da 
mão a quantidade de professoras que havia na época. O grosso da Faculdade de Educação era os homens. E homens tinham muito poder. Eles publicavam, eles compunham o Conselho Estadual de Educação, eles eram chamados pelo governo, eles eram muito poderosos. As mulheres eram muito oprimidas quase. Hoje em dia mudou, inverteu. Não que os homens sejam oprimidos, mas acho que o clima seja um pouco menos pesado. Quando eu entrei era assim, quando eu saí era assim. Quando eu voltei pro mestrado [1994] já não era mais. Aí o equilíbrio, já é a segunda ou terceira diretora aqui. Então eu acho que deu uma modificada.

Conforme pondera a professora Maria Letícia, as considerações sobre ser professora na USP não permitem análises unívocas, apesar dos inegáveis avanços. Todavia, sua fala dá indícios de que a situação da professora negra na universidade está em certo descompasso se comparada à situação da professora branca. Esta constatação foi feita por outros professores nas entrevistas, como é o caso do professor da Escola de Comunicação e Arte, Dennis Oliveira:

\begin{abstract}
Sempre trago na consciência, tem uma pirâmide no Brasil que é assim, homem branco, mulher branca, homem negro, mulher negra, sem dúvida. Como eu falei, por exemplo, esses estereótipos de subalternidade mais intensa é em relação à mulher negra, que você vai pegar, por exemplo, você tem essa coisa que eu comentei, a mulher negra é tolerada desde que seja faxineira, doméstica, tal e essa questão da sexualização da mulher negra, como objeto sexual, isso é muito claro, você percebe os comentários, você percebe a forma que se olha. Chega assim até o desrespeito, desrespeitosa, percebo isso. Eu conheço só duas professoras negras aqui na universidade, que é a professora Eunice, ali do Direito e a professora Gislene lá da USP Leste. E você percebe que são professoras extremamente assim, que elas têm um espírito bastante armado contra isso, mas eu entendo mesmo isso, que elas sofrem de fato o racismo e o machismo juntos. Por exemplo, elas chegam, vamos imaginar, chamam um debate com qualquer professora negra pra cá, "tal professora", "quem é a professora do debate?", todo mundo não acha que ela é, acha que é outra pessoa, acha que ela é uma, sei lá, uma funcionária e tal, isso é muito comum. Numa banca, você percebe que a pessoa não se toca, por exemplo, que ela pode ser uma professora e isso é muito claro. Entre alunas negras às vezes também, elas vivem a mesma coisa, elas vivem isso também, elas vivem a mesma coisa, você percebe a estigmatização que é muito intensa, com as alunas negras, as poucas que eu conheço, que eu tenho contato aqui.
\end{abstract}

As observações do professor Dennis dão importante testemunho sobre o imaginário brasileiro a respeito da mulher negra, historicamente associada a funções subalternas e raramente imaginada como intelectual. E vão na mesma direção, por exemplo, do depoimento da professora Adriana Alves, da Geologia, que relatou ser frequente a suposição de que ela seja funcionária e não estudante ou professora.

Apesar do incipiente reconhecimento como agente da ciência, a mulher negra tem figurado como tema de pesquisas no Brasil. As análises sobre a mulher negra no pensamento social brasileiro foram fundamentadas na ideia de um corpo servil e erotizado, conforma analisa Gonzalez (1979). Para a autora, o processo acadêmico de sedimentação desse imaginário vem desde os trabalhos de Nina Rodrigues e contou com a colaboração decisiva da obra de Gilberto Freyre.

Embora o próprio Freyre tenha atualizado sua discussão sobre o corpo da mulher negra brasileira em análises sobre moda e comportamento feminino, conforme indica Goldenberg (2005), esse corpo ainda é compreendido nas funções descritas em 1933, na obra Casa Grande e Senzala, 
que seria mulata para fornicar e preta para trabalhar, tal como conclui Pacheco (2008). Críticas a estas percepções e a construção de novas referências discursivas sobre a mulher negra têm sido possíveis a partir dos estudos de importantes intelectuais negras, como atesta o legado de Beatriz Nascimento, Lélia Gonzalez, Sueli Carneiro, Matilde Ribeiro, Luiza Bairros, só para citar algumas das intelectuais negras pioneiras. A ausência de pesquisas sobre a mulher negra na atividade acadêmica parece indicar que "ainda se configura como sonho ver a academia brasileira constituirse também como espaço feminino negro" (Ratts, 2006, p.29).

Como sugere Haraway (1995), o corpo (e aqui especificamente o corpo negro feminino) é importante posição de conhecimento, de saberes localizados, a partir dos quais novos projetos de ciência se tornam possíveis. Apesar das agruras e desafios à espreita das mulheres negras no universo acadêmico, tal como indica o professor Dennis, estas mulheres têm se posicionado firmemente, fato também observado pelo professor de Literatura, Émerson Inácio, quando relata sua experiência como docente no ensino superior privado:

\begin{abstract}
Professores e professoras sabiam da dificuldade de ser uma negra que ensina numa universidade, ainda que fosse de segunda, mas numa universidade e das dificuldades que isso às vezes engendrava (...). Principalmente as mulheres, em situações como universidade particular, sofrem muito mais do que os homens, porque é a fragilidade feminina que se potencializa, quer dizer a suposta fragilidade, elucubrada pelas cabeças machistas, que se associa à situação subalterna, a uma dupla subalternidade da mulher negra também. Aí é que eles vão pra cima das professoras com tudo o que tem direito, iam, porque nenhuma dessas colegas de forma alguma nunca deixou, muito pelo contrário, eles que tiveram sempre que engoli-las inteira porque se colocavam sempre a partir dessas duas perspectivas e muito, de maneira muito bem colocada, nem que para isso tivessem que lembrar sempre que eles estavam tratando com uma professora negra e que deveria compor esse conjunto, mas que muitas vezes era esquecida por essas pessoas. Aqui espero que não aconteça isso, esse tipo de enfrentamento que eu vi, justamente sendo o quesito gênero e raça como um desqualificador do indivíduo.
\end{abstract}

Um dos aspectos do racismo e do machismo na sociedade brasileira é a tendência de responsabilizar a mulher negra pela ofensa que viveu, como se a ofensa não existisse e fosse intolerância ou fantasia de quem estaria o tempo todo na defensiva, vendo ameaça e preconceito em tudo. É o que indica a fala da professora de Geologia, Adriana Alves:

(...) eu me incomodo um pouco com as colocações, eu sou famosa por ser extremamente intolerante com o racismo e com o machismo, eu estouro. Então uma vez, numa viagem de campo um colega falou 'ah, é mal comida', eu falei 'não, você pode falar o que você quiser, isso não. Porque fulano, sicrano, beltrano são todos solteiros, você fala que eles não fazem sexo, que é por isso que eles são estourados? Não fala. Então eu não admito'. E foi feio porque foi na frente de todo mundo, inclusive na frente de uma professora visitante, mas eu não consigo me conter (...). É outro traço da personalidade que incomoda as pessoas. (...) Nas exatas, ao contrário do que acontece no exterior em que tem o núcleo básico para discutir questões humanas, a gente na USP não tem; o povo das exatas é extremamente tapado para estas questões, extremamente. As pessoas não vêm racismo, não vêm machismo, não vêm nada disso, elas preferem fechar os olhos e achar que são traços de personalidade. 
Em novembro de 2013 o Portal Fórum publicou uma notícia referente à professora Adriana Alves, que foi vítima de racismo e machismo quando estava com colegas da USP no Bar Dueto, que se localiza próximo da universidade. O dono do estabelecimento, um holandês desfechou uma sequência de impropérios:

\begin{abstract}
Adriana relatou que Peter tentou se aproximar:. "Ele começou perguntando se meus dentes eram verdadeiros, por serem muito brancos, eu dei uma risada e respondi que sim. Tentamos mudar o assunto da conversa, quando ele me perguntou se eu gostaria de tomar café da manhã com ele no dia seguinte". Peter, no entanto, é casado e quando a professora o questionou sobre sua esposa, ele respondeu "que ela não tinha nada com aquilo". Para se afastar dele, Adriana foi ao banheiro, mas, quando voltou, foi questionada novamente, dessa vez sobre sua depilação. Para dar um fim no constrangimento, a aniversariante falou que não tinha pelos. Então o proprietário do bar disse: "Aposto que tem e os de lá de baixo devem ser duros como os da sua cabeça". Os colegas de Adriana presentes no restaurante não se deram conta do assédio, então Peter ainda perguntou "qual era a última vez que ela tinha gozado gostoso" antes da professora ir embora. "Cheguei em casa e desatei a chorar. Pensei, sim, que a motivação dele foi racial. Há várias reclamações no site do restaurante, mas todas por grosseria. Então ele se achou no direito de falar daquela forma comigo, é porque sou e negra e sabemos muito bem como a mulher negra figura no imaginário brasileiro", desabafou Adriana ao Mundo Negro. Após o episódio, a geóloga entrou em contato com a Delegacia de Defesa da Mulher.73
\end{abstract}

Já bastante calejada nesta discussão, Beatriz do Nascimento, em meados dos anos 1970 apontava que se por um lado as relações interraciais no Brasil se revestem de amenidades, por outro, a "tolerância conosco camufla um profundo preconceito racial, que aflora nas mínimas manifestações, inclusive naquelas que aparentam ter um cunho afetivo. A todo o momento o preconceito racial é demonstrado diante de nós, é sentido". (Nascimento, 1974 apud Ratts, 2006:94). Assim, apesar da constância das manifestações, “"pensamos duas vezes’ antes de reagir, pois, como expus acima, no nosso "ego histórico" as mistificações agiram a contento." (Ibidem).

Em reflexões sobre as mulheres negras, às quais designou "esse mix de raça/gênero", Pierucci (2008) considera que nas mulheres negras raça e gênero estão inevitavelmente juntos. Desse modo, desde a década de 1980, com a afirmação do movimento de mulheres negras, não existe mulher negra sem raça (des-racializada), ou sem gênero, "(un-gendered). Nas mulheres negras, raça e gênero são traços salientes, imediatamente visíveis, marcas de identificação indeléveis - indeléveis!”. (Pierucci, 2008, p.136). Cabe ressaltar que tais traços marcam qualquer experiência, e portanto, não seriam exclusividade das mulheres negras. Mas na universidade o gênero costuma ser desconsiderado para os homens e a raça para homens e mulheres brancos/as. Tal como proposto por Pierucci (2008), configurar-se-ia um uso descritivo do gênero e da raça, como sinônimo de mulher e de negro. Porém, estudos sobre masculinidades mostram que o gênero é um

73 Professora da USP denuncia dono de restaurante por racismo e machismo. Portal Fórum, 26 de novembro de 2013. Disponível em : http://www.revistaforum.com.br/blog/2013/11/professora-da-usp-denuncia-dono-de-restaurante-por-

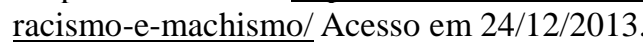


instrumento para pensar como masculindades e feminilidades são socialmente elaborados, do mesmo modo que raça é usada para entender identidades raciais e privilégios raciais, como a branquidade.

$\mathrm{Na}$ atividade docente cotidiana, questões referentes ao "mix raça/gênero" batem à porta frequentemente, vindas por diversas vias, implicando na decisão de permitir ou não que entrem, como relata a professora Vanderli Custódio:

E às vezes os alunos perguntam "oh Vanderli, você como negra... assim, assim e assado.". Vou vendo a história do negro e coloco, afinal, sou uma professora negra e isso é inalienável (...). O ser negra pra mim é uma coisa que eu vou vivendo situações de dois tipos: ou isso me liberta, ou me aprisiona, porque é inalienável, ninguém tira de mim o fato de ser uma mulher negra, também não tira o fato de ser mulher, mas isso pra mim é mais complicadinho. Então eu sou uma mulher negra, eu sou uma professora negra. E toda vez que falam da questão negra eu me coloco como negra, me coloco.

Vivenciar cotidianamente o desafio de sustentar a intersecção entre raça e gênero, não se revela tarefa fácil, tal como indica a professora Maria Letícia:

Já tive dificuldades do ponto de vista dessa coisa de, em alguns momentos de, me sentir deprimida de dizer: "ai meu deus do céu, negra, mulher, pobre!". Sabe aquelas coisas que você fala assim "Ai, o que eu tô fazendo? eu só brigo na vida!".

Apesar do cenário muitas vezes desalentador no segmento da população negra, as mulheres brancas e negras têm apresentado melhores indicadores em todos os níveis da educação, quando comparadas aos homens de seus segmentos raciais. Não obstante, proporcionalmente há mais docentes negros no ensino superior, e as mulheres negras continuam prevalecendo no magistério da educação básica. Neste sentido, as narrativas docentes estiveram atentas à complexa articulação entre os processos de discriminação contra a mulher negra e o notório êxito escolar das mesmas. É o que pode ser verificado na seguinte fala do professor Dennis de Oliveira:

Eu tive contato na pós, acho que só com alunas negras, não conheci nenhum aluno negro, ah não, conheci um, quando eu fui de uma banca. Acho que tive assim seis, sete alunas negras na pós, que eu fui em banca, que eu ajudei em pesquisa, que me procuraram e tal. De aluno negro eu lembro só de um na Poli, que eu fui da banca dele, no resto... no NEINB mesmo, a maior parte são mulheres negras que participam (...)Nesse sentido, tem puxado muito mais, tem avançado, tem avanços maiores mesmo tendo uma discriminação mais intensa. E aí, o incômodo é muito maior, o incômodo é muito maior. Mas acho interessante, é uma questão pra perguntar às mulheres negras, eu não posso falar em nome delas, eu acho que pro homem negro, essa questão da não inserção num grupo, ele pesa mais, a mulher negra trabalha melhor isso, porque como você fica na solidão, fica sozinho nesse meio, o jovem negro, particularmente assim, essa coisa de ser ' $O$ ' cara, ele passa muito mais dificuldade nessa situação, do que a mulher. Por isso que muitos desistem, não fazem, ficam mal e tal.

As observações do professor Dennis seguem a mesma direção das análises de Marrero (2008) quando propõe explicações alternativas às perspectivas tradicionais de que a educação 
desempenha apenas funções de reprodução das desigualdades de gênero. Ao contrário, Marrero (2008) aponta que a escola como espaço onde as mulheres podem suplantar a subordinação nas relações de gênero a partir de um melhor desempenho escolar. Dessa forma, o sistema escolar tende a favorecer estratégias mais comumente desenvolvidas por mulheres, que estariam mais afinadas com mecanismos próprios do sistema escolar. Sendo assim, "como consecuencia paradójica, la valoración que reciben las mujeres dependerá, entonces, de lo que se «hace» — se aprende, se sabe, se escribe, se recita, se exhibe-, y no de lo que se «es», se piensa, se imagina, se considera o se opina." (Marrero, 2008, p. 207). Numa cultura que exalta masculinidades, a associação do feminino ao sucesso escolar pode abrir precedente para o seu reverso, que é a oposição entre sistema escolar e o masculino.

Analisando o processo de escolarização de homens negros, bell hooks (2004) já indicava como o sistema escolar tem dificuldades de conceber um estudante negro que seja bom aluno, e a tendência de enquadrá-lo sempre na categoria dos alunos problemáticos:

\begin{abstract}
Quando era permitido a um garoto negro "especial" fazer parte de uma turma de alunos talentosos, isto ocorria apenas depois dele ter provado a si mesmo que poderia ser apropriadamente subordinado. Constantemente, ele foi o único garoto inteligente que obteve o êxito, aprendeu a ser obediente, a manter sua boca fechada. Garotos negros inteligentes que buscaram ser ouvidos, antes e agora, foram frequentemente expulsos, considerados encrenqueiros e colocados em classes de baixo rendimento ou em classes especiais que são meros espaços de confinamento para aqueles garotos considerados delinquentes. (bell, hooks, 2004, p. 6)
\end{abstract}

Assim, masculinidades negras (gênero e raça) são forjadas diante do racismo e do sexismo e devem ser investigadas também na sua complexidade fora da chave do privilégio sexista que o homem negro recebe. Existem problemas cotidianos na sala de aula que estão na ordem do não-dito e que devem ser enfrentados por homens negros que precisam corresponder a diferentes exigências para "ser homem negro" em espaços educacionais, pois "garotos negros que são intelectuais, que querem ler e que querem amar os livros correram o risco de ser ridicularizados como não masculinos" (Ibidem).

Tais questões interpelam a prática docente e como constatou Vianna (2001), as concepções de gênero vivenciadas pelos/as docentes informam sua prática profissional, e geram tensão entre os tradicionais significados de masculinos e femininos, bem como tentativas de transformação dos mesmos. É o que se pode verificar na fala do professor de Literatura Émerson Inácio,

A questão toda na época do meu concurso, que eu acho que deve ter causado alguma saia justa à banca, foi o fato de que eu trabalhava com literatura e homoerotismo, diversidade sexual, homossexualidade, essas coisas, e a banca muito preocupada porque, aspas, não há esse fenômeno em África, não há esse fenômeno em Literatura Africana (...). Como é que você vai trabalhar com literatura, com gays em África? É, eu tive claro que, naquela altura, criar toda uma forma de explicar que, por exemplo, alguns fatos ainda que não representados, não significam que eles não tenham uma existência e particularmente porque 
a gente sabe que há eleições, aquilo que a gente acha que é o cânone não representa o todo de uma literatura, todas as expressões. As expressões são obliteradas, não há, mas pode haver, foi o que eu respondi e a gente está aqui pra isso, pra pesquisar, pra procurar e identificar determinadas distorções que passam a ser identificadas, que passam a ser estudadas também.

Partindo de uma definição de masculinidade que seria "uma configuração prática em torno da posição dos homens na estrutura das relações de gênero.” (Connell, 1995, p.188), a masculinidade é tomada recorrentemente como uma narrativa convencional, gerando uma pressão para conformar as atitudes e sentimentos de homens sob normas que os distanciem de noções reiteradas de feminino. Essa narrativa é pelo menos muito incompleta, havendo necessidade de ser pelo menos corrigida. Uma dessas correções é considerar que as masculinidades hegemônicas são (re) construídas concomitantes a outras masculinidades, assim, a narrativa convencional deveria estar atenta também ao fato de que a construção da masculinidade é um projeto pra vida toda, sempre em processo de (des)encontro dialético com instituições e discursos. A construção da masculinidade deve ainda ser entendida como um projeto coletivo e não individual. Dentro da dinâmica histórica da política da masculinidade há a luta pela hegemonia da definição dominante na ordem do gênero, em função das vantagens advindas, mas as condições que sustentam a hegemonia estão sempre mudando. (Connell, 1995).

Todas as formas de política de masculinidade estão relacionadas ao feminismo. A pouca adesão dos homens às perspectivas feministas indica não apenas o fato de o feminismo ameaçar determinadas vantagens, como também considerar de forma insuficiente os custos que a posição dominante na ordem de gênero gera aos homens. Connell chama àquelas vantagens de "dividendos patriarcais" (1995, p.197), que de um modo geral indicam certa constância da assimetria nas relações de gênero numa balança que pende desfavoravelmente às mulheres. Mas "embora os homens, em geral, se beneficiem do dividendo patriarcal, grupos específicos de homens ganham muito pouco com ele." (Ibidem). Alguns desses grupos específicos pagam o preço juntamente com as mulheres, como é o caso dos negros e gays, alvos constantes de violência e preconceito.

Pensando mais especificamente a masculinidade negra, Pinho (2006) indica que ela incorpora as contradições e ambivalências próprias das estruturas de dominação do binômio raça e gênero, que a um só tempo se associam e se auto-contradizem. A masculinidade negra é, na base, incorporada como corpo negro, sempre flagrante, nunca desapercebido. Considerando que masculinidade não é um conceito fixo e uno, o autor propõe desdobramentos que evidenciam relações de poder:

(...) as próprias masculinidades e posições de sujeito masculinas são racializadas, de modo que não há apenas um homem, mas um homem negro ou branco ou um homem gay ou subsumido pela heterossexualidade compulsória. Homens e mulheres negros construídos pelos discursos de sexo e raça interagem articuladamente às regras do jogo e em um contexto onde mais poder significa mais masculinidade, e sua ausência, feminilização, na 
medida em que masculinidade é uma metáfora para o poder e vice-versa. (Pinho, 2006, p. 362)

Pensando a realidade norte-americana, West (1994) aponta que haveria certos acordos entre grupos masculinos em função da cor: homens brancos teriam maior propensão para manifestações de machismo, homofobia e racismo crônicos. Entre os homens negros o conservadorismo cultural assumiria a forma de "xenofobia incipiente (por exemplo, contra brancos, judeus e asiáticos), machismo sistemático e homofobia". (West, 1994, p. 44). E há discursos impostos aos corpos negros (de homens, mulheres, heterossexuais ou homossexuais) que os concebem como fetichizados, mitificados em imagens que ressaltam um erotismo bestial, anencéfalo, ao mesmo tempo em que tornam essa uma imagem tabu, pois a sexualidade que circunda os corpos negros é perigosa, não devendo ser evocada, pois se foge do controle, ameaça a segurança de uma moralidade branca. Os homens negros acossados por esses discursos tenderiam a constituir uma forma de auto-identificação e resistência afiliada a uma identidade machista, pronta para embates violentos. No entanto, para os negros homossexuais a situação seria "ainda mais desoladora" (West, 1994, p.107) pois,

(...) rejeitam a "opção dominante do estilo machista, mas são, por isso mesmo, marginalizados na sociedade dos brancos e penalizados na comunidade negra. Em seus esforços para serem eles próprios, acabam acusados de não serem realmente 'homens negros', de não identificarem com o machismo. (West, 1994, p. 107)

A recusa de aceitar as opções de vida propostas por negros homossexuais aproximaria em certa medida homens negros e brancos, sobretudo se os negros homossexuais se fundamentam no "letal esforço de rejeitar identidades machistas negras" (West, 1994, p.108). O caso das mulheres negras já seria bem diferente, porque o machismo branco e o machismo negro as afetam de modos diversos. Além disso, a possibilidade de ser mulher negra e lésbica seria mais fluida e menos policiada. Isso não indica que as lésbicas negras sofram menos que homossexuais negros, elas sofreriam mais em função da situação econômica inferior e pelo fato de terem a sexualidade geralmente mais desvalorizada, ocupando o lugar mais marginal na sociedade norte-americana.

Apesar do cenário desalentador, haveria saídas possíveis para o homem negro e para a mulher negra, embora sejam saídas específicas para cada segmento. Assim, as saídas disponíveis aos homens negros diferem das saídas disponíveis às mulheres negras. "Mas nem homens nem mulheres negras serão bem sucedidos sem que ambos os lados sejam, pois as degradações que sofrem são inseparáveis, ainda que não idênticas." (West, 1994, p.106). Embora esteja considerando a sociedade brasileira, o professor Émerson faz observações que possuem grande afinidade com estas análises de West (1994): 
Da mesma maneira renuncio essa questão de um papel tradicional do homem negro, porque vejo muitas das vezes no âmbito do gênero e da diversidade eu tenho sempre um problema quando eu associo essas discussões raciais. Mulheres lésbicas e negras até vai, agora dificilmente eu tenho um posicionamento que relacione identidade homossexual a identidade do homem negro também, porque eu preciso de certa maneira reafirmar os lugares do fetiche, os lugares comuns sobre esse fetiche, os lugares comuns do homem negro que só reforçam uma visão que não foi criada pelo negro sobre ele mesmo, mas por outras pessoas que resolveram fazer aí atribuições nesse sentido, sem perguntar para o negão se ele queria ser fetiche de loira ou de loiro ou não. Ou seja, não é que a questão da diversidade, homossexualidade pode alterar e vai alterar. Estamos aí, os Estados Unidos, por exemplo, tem gente que está pensando nisso agora. Se eu estou numa condição de border agora, fronteiriça, marginal e coisa e tal como homem negro, estou na linha de tiro literalmente, como diz a música da Erika Badhu, ou de uma outra que eu não lembro exatamente. Eu pioro essa situação quando me declaro também homossexual. O movimento negro, por exemplo, o pensamento negro brasileiro não se deu conta disso. A questão foi congelada numa determinada identidade que não corresponde à contemporaneidade. Politicamente não dá para pensar identidade de maneira fragmentária e pensar essa coisa de o homem negro, a mulher negra, tudo no singular, tudo como se fosse uma grande forma, não dá mais. Mas eu deixo a tarefa pra quem está querendo sistematizar essas coisas todas, ainda que eu ache que a fratura desse pensamento, às vezes muito monológico em relação ao negro brasileiro, esteja a ponto de se fraturar completamente, não se sustenta, dada a diversidade de papeis e de situações sociais, políticas, econômicas da atualidade. Pena que, por exemplo, isso vai um processo distópico muito sério, eu penso em termos literários, particularmente. Quando eu leio muita coisa dos Cadernos Negros e de gente que passou a escrever motivada por esses cadernos, vai causar uma distopia muito grande, porque algumas figuras estão muito cristalizadas, mesmo no imaginário do negro. Essa ênfase no patriarcado, essa coisa do homem negro, o grande pai de família, o grande avô, o grande bisavô, o grande, que é quase utópico, se desaba diante, por exemplo, de uma experiência homossexual. Que lugar então compensar esse novo homem, essa nova perspectiva? Complicado.

Além de situar criticamente o negro homossexual em face de discursos heterossexuais totalizantes, seja branco, seja negro, o professor Emerson também analisa criticamente qual é a posição do negro homossexual frente a uma homossexualidade masculina supostamente hegemônica,

Por exemplo, as formulações sobre identidades gays elas estão muito oxigenadas, acho, às vezes até excessivamente oxigenadas, porque a gente não fala mais em identidade homossexual, mas em identidades, tudo isso sendo sempre pensado no plural. Isso, por exemplo, favorece não diretamente ao que eu tenho pensado, porque eu ainda não encontrei um autor à exceção apenas de Durval DuMotta, que se coloca como homem negro e homossexual. Isso, porém tem favorecido a quê? Pensar que talvez nós não tenhamos só uma identidade do negro e da negra como muitas das vezes nós somos levados a pensar por certos setores do pensamento (...). Sem contar que essa constante renúncia que a homossexualidade faz à identidade majoritária, eu faço essa renúncia direto, a uma identidade gay majoritária, classe média, bonita, forte, tal, tal, rica, até porque eu não sou nada disso. Talvez classe média um dia, quando eu conseguir não ter dívidas e juntar dinheiro. Talvez a gente faça alguma coisa para além de apenas sobreviver.

\section{A fala do professor Emerson Inácio toca em pontos nevrálgicos da história do feminismo e} no pós-colonialismo que, conforme relembra Bahri (2013), está ligada a um projeto de póscolonialidade literária, que propõe um letramento crítico geral como nova forma de ler o mundo e as relações de gênero:

As ligações etimológicas entre "literário" e "letramento", que vêm do latim littera, "letra", 
reforçam a ideia de que a comunicação abrange não apenas o ato da "fala", como também o da recepção, da audição e da interpretação. Pode-se dizer, com efeito, que quase todos os debates centrais ao feminismo pós-colonial estão preocupados com os diferentes modos de ler o gênero: no mundo, na palavra e no texto. (Bahri, 2013, p. 660)

A busca pelo eu no sentido de busca de um novo mundo de relações de gênero promove a invenção de uma identidade e uma coerência que são também ficcionais. Disso decorre que gênero pode ser paródia. Negro, negra, mulher, homem, branco, branca, corpo, heterossexual, homossexual, gay, lésbica, travesti, transexual, desejo, etc, constituem ingredientes para múltiplas reescritas e/ou reinscrições de si a serem interpretadas, reinventando diferenças continuamente. Se gênero é historicamente marcado por insígnias como raça e cor, sustentando modos institucionalizados de controle, uma via de escape possível é multiplicar as paródias, as possibilidades de escrita e interpretação de si (Butler, 1990).

$* * * * * * * * * * * * * * * * * * * * * * * * * * * * *$

Partindo das trajetórias das gerações de docentes pioneiras na USP, foi proposto neste tópico compreender aspectos das trajetórias de docentes negros/as na USP diante dos desafios impostos pela noção de gênero. As análises das trajetórias das chamadas gerações pioneiras ofereceram a possibilidade de interpelar uma narrativa masculina na convencional historiografia da universidade. Mais do que apontar a presença das mulheres nesta universidade, as obras aqui consideradas permitem deslindar os meandros da configuração e institucionalização dos processos acadêmicocientíficos nesta universidade. Apesar de se mostrar uma via profícua, deparou-se com uma lacuna nos estudos de trajetórias de docentes, quando se considera a articulação entre gênero e as gerações posteriores às evocadas, uma vez que as pesquisas encontradas basicamente referem-se aos anos de 1930-1970. Assim, a compreensão da intersecção de gênero e raça na trajetória de docentes da USP revelou-se um grande desafio, em função da escassez de bibliografia. O que este capítulo propôs foi pensar os modos como a noção de gênero informa a trajetória e a prática da atual geração de docentes negros/as na USP. Não pretendeu oferecer uma análise exaustiva mas apenas uma aproximação com o problema, que merece maiores investigações.

Ressalta-se que gênero e docência na USP enseja uma história de (des)encontros. Se, por um lado, o acesso das mulheres foi possível como consequência não prevista do comissionamento, política pública que sinalizou a possibilidade da carreira acadêmica às mulheres, por outro, o cotidiano revela disputas e tensões em que a categoria gênero não pode ser desconsiderada. Por sua vez, a tríade gênero, docência e raça na USP revela outra história de (des)conciliações. A carreira acadêmica da atual geração de docentes negros/as não foi consequência, nem mesmo imprevista, de 
qualquer política pública. Trata-se de casos isolados que evidenciam o quão desigual é a distribuição por cor/raça no corpo docente da Universidade de São Paulo. Conforme evidenciado no primeiro capítulo, o projeto de fundação da USP não contemplava imigrantes, mulheres ou setores médios da sociedade. No entanto, para a própria sobrevivência do referido projeto, houve flexibilização que contemplou esses grupos, ainda que a contragosto. Embora à margem, a presença negra na docência amplia horizontes e possibilita outras vozes em cena; porém, também torna mais estridente a necessidade de debates e políticas específicas.

No conjunto das desigualdades que marcam as experiências docentes consideradas aqui, os dados levantados a partir das narrativas apontam no sentido de que na prática docente haveria maiores assimetrias de raça do que de gênero, ainda que ser docente na USP implique compor o funcionalismo público, o que protegeria contra manifestações explícitas de racismo e machismo. Apesar dos avanços verificados no acesso e carreira das mulheres na educação, há necessidade de cautela na consideração das conquistas. Além disso, foi possível verificar que permanece um descompasso entre as trajetórias das docentes brancas e negras, o que também limitaria maiores comemorações. Por fim, a partir das narrativas, foi possível perceber ainda que noções de gênero e raça informam a prática docente, gerando tensão entre os tradicionais significados de masculinos e femininos, bem como tentativas de transformação dos mesmos. 


\section{Capítulo VI- Configuração racial do corpo docente da USP: uma tentativa de dar cor aos pares}

Este capítulo apresenta os dados quantitativos referentes à configuração racial do corpo docente da USP. Conforme indicado na Introdução desta tese, trata-se de dados primários obtidos junto ao Departamento de Recursos Humanos da USP. Na primeira parte do capítulo é apresentada uma breve discussão sociológica sobre o sistema de classificação racial brasileiro, considerando as ideologias subjacentes ao mesmo, bem como um rápido debate sobre o acesso da população negra ao ensino superior. Nos tópicos subsequentes são apresentados os dados quantitativos sobre a configuração racial do corpo docente da USP e as análises que ensejaram.

\section{VI-1. Sobre o processo de classificação racial no Brasil e na academia: algumas considerações}

As análises sociológicas da realidade racial brasileira no pós-1930 vão, num primeiro momento, das pesquisas de Pierson na Bahia, em 1939, até o final dos estudos da UNESCO. Nesse período, formam-se duas interpretações: a primeira, proposta por Pierson, que indicava a sociedade brasileira como uma sociedade multirracial e de classes, na qual "raças" seriam constituídas por grupos abertos, de modo que raça não seria um princípio classificatório nativo, ou seja, "ninguém teria raça nativamente, mas sim cor" (Guimarães, 2003, p.101). Dessa forma, a primeira interpretação sociológica das relações raciais esteve colada à ideologia nacional. A segunda interpretação, possível a partir dos estudos da UNESCO, que documentam cientificamente a situação do negro no sudeste brasileiro, propõe uma releitura do uso das noções de cor e raça:

\footnotetext{
Pensava-se comumente que "a cor era apenas um acidente", éramos todos brasileiros. Esse pensamento era atribuído ao povo, ou seja, não apenas os ideólogos, mas as pessoas comuns, do povo, brancos e negros, pensariam assim. Os estudos de Bastide e Florestan (1955) e Costa Pinto (1953) rompem radicalmente com essa forma de pensar. A grande discussão que eles estabelecem é uma discussão já colocada pelo movimento negro nos anos 1930: a existência do preconceito racial no Brasil, apesar do ideal de democracia racial. (Guimarães, 2003, p.101)
}

A chamada Escola Paulista de Sociologia problematizou a existência do mito da democracia racial na sociedade brasileira, considerando-o um discurso de dominação, que desmobilizava a comunidade negra, escamoteando sob um ideal político de convivência igualitária entre brancos e negros, a realidade de preconceito racial e discriminação sistemática do negro. $\mathrm{O}$ Movimento Negro Unificado ao final da década de 70 também contesta esse mito e reintroduz a noção de raça, para que se efetive a construção da cidadania do negro. 
Os trabalhos de Carlos Hasenbalg e Nelson do Valle apoiados em dados estatísticos do IBGE, acabaram reforçando o discurso do movimento negro, pois agregaram os dados referentes a pretos e pardos sob a categoria negro ${ }^{74}$. Desse modo, o termo negro como sinônimo de afrodescendente passou a ter credibilidade nas ciências sociais, assim como a noção de desigualdade racial, que também contagiou o discurso político. Em termos sociológicos, estes movimentos implicaram em consequências conceituais, de modo que:

(...) 'cor' não é uma categoria objetiva, cor é uma categoria racial, pois quando se classificam as pessoas como negros, mulatos ou pardos é a ideia de raça que orienta essa forma de classificação. Se pensarmos em "raça" como uma categoria que expressa um modo de classificação baseado na ideia de raça, podemos afirmar que estamos tratando de um conceito sociológico, certamente não realista, no sentido ontológico, pois não reflete algo existente no mundo real, mas um conceito analítico nominalista, no sentido de que se refere a algo que orienta e ordena o discurso sobre a vida social. (Guimarães, 2003, p.103).

As reinterpretações das relações raciais propostas pelo MNU e pela Sociologia encontraram e encontram ainda hoje resistências. Na academia houve uma tentativa de evitar a "demonização de Gilberto Freyre" (Guimarães, 2003, p.104), e assim assegurar o legado interpretativo da democracia racial. Os sociólogos foram acusados de não compreenderem o conceito de mito no sentido de "um discurso sobre a origem das coisas, um discurso sobre o dia-adia, que não precisa ser real, ao contrário, é efetivo apenas na medida em que orienta a ação das pessoas, em que dá sentido às relações sociais do dia-a-dia" (Guimarães, 2003, p.104). Dessa forma, o mito da democracia racial permanece importante para a noção de nação brasileira. Esse argumento tem a sua força e enfrenta diretamente a reivindicação do movimento negro de ressaltar a condição de desigualdade social da população negra brasileira.

Se esse argumento é bom no sentido de ajudar a pensar como as relações raciais acontecem no cotidiano, cerceando uma politização extrema do tema, por outro lado, apresenta a inconsistência de um discurso que evidencia um apego a argumentos a-históricos,

(...) a ideia de estrutura, de longa duração, torna-se quase que um discurso a - histórico, como se estivéssemos tratando com uma matriz que não teve inicio e não terá fim. Se os que usam tal argumento são pouco críticos a respeito da historicidade dessa matriz, então eu os fustigo, perguntando: como nasceu a democracia racial? Quando se transformou num compromisso político? Será que esse discurso não pode acabar? Será que não está acabando? (Guimarães, 2003:104)

\footnotetext{
74Conforme lembra Osório (2003), agregar pardos e pretos sob a categoria negro se justifica duplamente, em termos teóricos e estatísticos: "Portanto, a agregação de pretos e pardos e sua designação como negros justificam-se duplamente. Estatisticamente, pela uniformidade de características socioeconômicas dos dois grupos. Teoricamente, pelo fato de as discriminações, potenciais ou efetivas, sofridas por ambos os grupos, serem da mesma natureza. Ou seja, é pela sua parcela preta que os pardos são discriminados. A justificava teórica é obviamente mais importante, pois ao fornecer uma explicação para a origem comum das desigualdades dos pretos e dos pardos em relação aos brancos, coloca os dois grupos como beneficiários legítimos de quaisquer ações que venham a ser tomadas no sentido de reverter o quadro histórico e vigente dessas desigualdades".(Osório, 2003, p.24)
} 
Diante do desafio metodológico de saber como uma pessoa se classifica racialmente no Brasil, o autor sugere que a melhor maneira de perguntar seria: "'qual é a sua cor?' ou 'como o sr(a). se classificaria em termos de cor?' ou variações em torno da pergunta sobre cor." (Guimarães, 2003, p.105). Trata-se de uma pergunta sem solução fácil. O autor lembra-nos das considerações de Marvin Harris, que na década de noventa apontou que o IBGE violentava a identidade dos brasileiros ao utilizar a categoria "parda", que não existiria na vida cotidiana. Dessa forma, Harris teria forçado a retomada dos estudos sobre classificação racial no país. Guimarães (2010) indica que talvez tenha sido Harris quem melhor sintetizou a singularidade da classificação por cor no Brasil, pois indicou que, ao contrário do que se verifica nos Estados Unidos, no Brasil não há regras de descendência racial, de modo que os filhos podem não herdar o mesmo status racial dos pais. Nos Estados Unidos, mesmo que a criança seja fruto de um relacionamento inter-racial, herdará o status racial do seu progenitor que tenha o menor prestígio social de status racial, fenômeno denominado por Harris como hipodescendência. No Brasil, a cor de cada pessoa pode ser socialmente definida independente dos pais, pois o principal critério de classificação racial são os marcadores fisionômicos e socioculturais.

Apesar das pesquisas que atestaram a consistência das categorias censitárias, segundo Guimarães (2010) o fato é que antropólogos e sociólogos voltaram a refletir sobre a classificação racial no Brasil. Harris (1993) critica a opção do IBGE pelo uso da categoria parda em detrimento da categoria morena. Para o autor a decisão do IBGE de adotar o termo pardo, (que seria pouco corrente entre a população, ao contrário do termo moreno) deveu-se às interpretações dos dados de um estudo que integrava a PNAD (Pesquisa Nacional por Amostra de Domicílios) de meados da década de 70. A partir deste estudo teria se entendido equivocadamente os termos moreno e pardo como sinônimos. O autor contesta a consideração de Nelson do Valle (1988) que apontava para a ambiguidade do termo moreno, que poderia se referir tanto à cor da pele como à do cabelo, gerando dúvida sobre o que de fato estava em questão. Para Nelson do Valle a opção pelo termo pardo reduziria as dúvidas, gerando respostas mais confiáveis. Embora Harris (1993) reconheça que o termo moreno seja mais ambíguo que o termo pardo, acredita que essa ambiguidade do sistema classificatório de cor no Brasil não possa ser retirada sem comprometer a sua integridade êmica. Assim, restringir a possibilidade de escolha dos entrevistados às opções do IBGE seria uma violação do direito à auto-identificação. Extirpar a categoria moreno seria levar ao extremo o descaso com o sistema de classificação corrente na sociedade brasileira, a partir do seu próprio senso de identidade. Assim, embora o Brasil não esteja mais perto do que outros países da chamada democracia racial, seu sistema de estabelecimento de identidade racial poderia ensinar muito ao resto do mundo (Harris, 1993). 
A classificação de cor ou raça empregada pelo IBGE é centenária. Ainda no século XIX o vocabulário étnico e racial era mais diversificado e elaborado do que o atual. Os termos usados eram relacionados à posição ocupada pelo sujeito no sistema escravocrata, poderiam dizer respeito à origem étnica e por fim, havia aqueles relacionados às variações da cor da pele. Apesar da grande variedade de termos, "três se destacavam de forma inequívoca como os mais usados: preto, pardo e branco" (Osório, 2003, p.18). Sendo assim, o primeiro censo oficial realizado no Brasil em 1872 fez a opção por esses três vocábulos raciais que já possuíam grande fluência social, o que aponta para o acerto da escolha desses termos:

Ressalva-se que tal escolha foi muito apropriada, pois em um levantamento dessa natureza é importante que os termos empregados tenham uso corrente e o mais disseminado possível para proporcionar maior uniformidade e confiabilidade aos dados obtidos. Além dessas três categorias, no Censo de 1872, havia a categoria "caboclo", que definia o grupo dos indígenas. As categorias preta e parda eram as únicas aplicáveis à parcela escrava da população, embora pudessem também enquadrar pessoas livres, assim nascidas ou alforriadas. (Osório, 2003, p.18)

Assim, o censo de 1872 não criou nenhuma terminologia racial nova, apenas esteve atento ao que já era corrente na sociedade brasileira. O segundo censo brasileiro, feito em 1890 trocou o termo pardo por mestiço e nos censos subsequentes até 1940 o quesito cor foi ignorado. A partir de 1940 e nos censos de 1950 e 1960 além do retorno da categoria pardo, acrescentou-se outra categoria, "amarela" destinada a sondar o percentual de asiáticos no país. O censo de 1970 ignorou novamente o quesito cor. Até o censo de 1980 ainda não havia sido introduzida a categoria "indígena", que era incluída na categoria parda. Nos censos de 1991, 2000 e 2010 são adotadas as cinco categorias: branca, preta, parda, amarela e indígena. Entre os censos de 1940 a 1980 a pergunta referia-se apenas à cor. A partir do censo de 1991 a classificação passou a ser cor ou raça.

Favorável à opção do IBGE pelo uso da categoria parda, Osório (2003) argumenta que o termo possui uma história que remete à preocupação referente à composição racial da população desde o final do século XVIII:

O termo pardo tem uma história e já era empregado em levantamentos e projeções sobre a composição racial da população ao menos desde 1798. Obviamente, pardo já tinha uma carga extremamente negativa. Mas, como dito, isso se devia ao fato de que o pardo, além de não ser branco, era a lembrança constante do "problema" de ter o Brasil recebido, parafraseando Nina Rodrigues, quantidades excessivas de sangue negro que se misturou ao branco, o que lhe teria subtraído a "pureza" e trazido uma série extensa de consequências negativas. (Osório, 2003, p.31)

É importante observar que no período anterior à emergência do mito da democracia racial e a subsequente invenção da morenidade, a cor morena não era um valor. É só a partir das primeiras décadas do século XX que o moreno surge como o tipo ideal brasileiro. Osório (2003) concorda com Pierson, que nos anos 1940 já apontava para o caráter ambíguo do termo moreno, que embora indicasse mestiçagem, não remetia necessariamente a uma herança negra. Reivindicar o 
termo moreno seria um sintoma do racismo e da persistência do ideal do embranquecimento, de modo que "a rejeição do negro e a morenidade andam juntas" (Osório, 2003, p.32). Assim, a principal razão pela qual a categoria morena não deveria substituir a parda no sistema de classificação racial vai além de motivos técnicos ou teóricos, pois "tal mudança, seria na verdade, uma concessão inadmissível ao racismo" (Osório, 2003, p.33). O retorno da pergunta sobre a cor no censo de 1980 foi uma conquista de ativistas negros e pesquisadores, contra a posição defendida por Gilberto Freyre de que o povo brasileiro constituía uma meta raça definida como morena. Em suma, além dos propósitos históricos e políticos, o uso terminológico da categoria "pardo" possui também importância analítica, pois assegura a comparabilidade entre as diversas fontes de dados. Assim, faz-se necessário "manter a forma de classificar do IBGE, sempre fraseada com a palavra cor" (Guimarães, 2003, p.105).

Segundo o levantamento do Censo 2010, São Paulo é a cidade com maior número de negros em todo o país (4,2 milhões de pretos e pardos), capital do estado mais populoso, que concentra 41 milhões de habitantes, dos quais, 20 milhões são homens e 21 milhões são mulheres. A distribuição da população do Estado de São Paulo por cor é 64,4\% de brancos; 5,8\% de pretos; 28,3 de pardos e $1,4 \%$ de amarelos e indígenas 75

No que concerne ao acesso da população negra ao ensino superior no Brasil, houve um crescimento entre os anos de 1988 a 2008, conforme indicam Paixão et.al (2011) que oferecem algumas constatações: o crescimento da proporção de alunos do ensino superior é um fato razoavelmente recente, concentrado basicamente entre os anos de 1998 a 2008; e apesar do ritmo mais acelerado de crescimento na proporção de brasileiros que frequentam o ensino superior, o conjunto da população que chega a este nível de ensino é pouco significativo. No que se refere à evolução proporcional do acesso de negros e brancos, indicam que:

\begin{abstract}
Entre 1988 e 2008, a evolução da taxa líquida de escolaridade dos pretos \& pardos $(321,6 \%)$ se deu em um ritmo mais intensivo do que os brancos $(165,9 \%)$. Porém, deve-se salientar que aquele incremento deve ser precisado à luz dos indicadores verificados no ponto de partida da série, cujo indicador era especialmente ínfimo no caso dos pretos \& pardos. Talvez o melhor exemplo nesse sentido seja que, em 2008, a taxa líquida de escolaridade no ensino superior dos pretos \& pardos ainda fosse igual à taxa observada entre os jovens brancos de vinte anos antes (grifo meu). (Paixão et.al, 2011, p.230)
\end{abstract}

Apesar da velocidade de acesso dentro do grupo negro ter sido maior que a verificada internamente ao grupo branco, percebe-se que houve manutenção da linha de cor que marca a distância historicamente verificada entre brancos e negros no ensino superior. Ambos os grupos tiveram incrementos no acesso, mas não houve diminuição da distância entre os indicadores de um e

75Dados do Síntese de Educadores Sociais: Uma análise das Condições de Vida da População Brasileira 2010. O documento agregou as categorias amarela e indígena nos resultados percentuais. 
de outro grupo:

(...) no ano de 1988, 92,7\% dos jovens brancos em idade para frequentar o ensino superior (18 a 24 anos) não o faziam. Entre os pretos \& pardos, este mesmo indicador chegava perto de $100 \%$. Vinte anos depois, o indicador passou por um incremento, mas o peso de jovens entre 18 e 24 anos que não estavam em alguma instituição de ensino superior ainda era de $86,3 \%$ na população como um todo, de $79,5 \%$ entre os brancos e de $92,3 \%$ entre os pretos $\&$ pardos. Sem ironia, tais indicadores reforçam o senso comum, existente na sociedade brasileira, de que a universidade não é para todos. (Paixão et.al, 2011, p.230)

O crescimento da população negra no ensino superior verificado na última década pode ser parcialmente explicado pela adoção de políticas de ações afirmativas pelas universidades públicas e pelos incentivos do governo federal à promoção do acesso ao ensino superior privado a partir de políticas como o Programa Universidade para Todos (PROUNI) e o Programa de Financiamento Estudantil (FIES) (Paixão et.al, 2011). Além disso, considerando o desempenho de mulheres e homens, negros e brancos, na educação brasileira no período 2003-2009, Rosemberg \& Madsen (2011) argumentam que no plano da justiça redistributiva ocorreram melhorias dos indicadores educacionais das mulheres. Contudo, tais indicadores devem ser analisados a partir de um olhar tridimensional que considere simultaneamente as perspectivas econômica (políticas de redistribuição), cultural-simbólica (políticas de reconhecimento) e política (políticas de representação). Só assim é possível uma compreensão mais ampla sobre como se entrecruzam as desigualdades socioeconômicas, geracionais, de gênero e raça na estruturação de um sistema que sustenta e produz desigualdades estruturais e simbólicas.

Não obstante o avanço, permanece a convivência entre intensas desigualdades de acesso e progressos etários, étnico-raciais, regionais e socioeconômicas tanto de mulheres como de homens, de modo que "algumas mulheres progrediram muito na educação; outras, nem tanto" (Rosemberg \& Madsen, 2011, p. 49). No que diz respeito ao acesso à pós-graduação, é recente e escassa a produção acadêmica que articule gênero e raça. Porém estudos já apontam que os diferenciais de raça/cor se acentuam no acesso à pós-graduação, de modo que em 2009, 76,4\% dos/as pósgraduandos/as eram brancos/as. As autoras indicaram melhorias no acesso e progressão das mulheres na educação, e também que há muito a ser feito em função das assimetrias. Um exemplo disso, é que embora o país titule mais doutoras ${ }^{76}$, o percentual de mulheres na docência do ensino superior ainda é menor que o de homens. Comparando os sexos, verifica-se acentuada diferença de acesso a favor das mulheres brancas, diferenças mais sutis quando comparados homens e mulheres negros/as e, entre os homens, sensível incremento para homens negros e discreto decréscimo para homens brancos, conforme a tabela:

76 As autoras trazem dados que indicam que houve "reversão do hiato de gênero" na formação de doutoras desde 2004. Ou seja, desde então o Brasil tem formado mais doutoras que doutores. (Rosemberg \& Madsen, 2011, p.45) 
Tabela I: Distribuição de estudantes de mestrado e doutorado por sexo e raça/cor. Brasil 2003 e 2009.

\begin{tabular}{|c|c|c|c|c|c|c|}
\hline & 2003 & $\%$ & 2009 & $\%$ & Variação & $\%$ \\
\hline Total & 310.593 & 100,0 & 330.351 & 100,0 & 6,4 & \\
\hline Homens brancos & 106.736 & 34,4 & 103.235 & 31,3 & $-3,4$ & \\
\hline Mulheres brancas & 141.543 & 45,6 & 148.958 & 45,1 & 5,2 & \\
\hline Homens negros & 23.659 & 7,6 & 30.977 & 9,4 & 30,9 & \\
\hline Mulheres negras & 33.564 & 10,8 & 41.360 & 12,5 & 23,2 & \\
\hline Outros & 5.091 & 1,6 & 5.821 & 3,5 & 14,3 & \\
\hline
\end{tabular}

Fonte: Tabulações especiais de microdados das PNADs 2003 e 2009, apud Rosemberg \& Madsen (2011, p.425)

Em função da crescente demanda por dados sobre o quesito raça/cor no ensino superior brasileiro, o CNPq incluiu em 2013 o quesito raça/a na como opção a ser preenchida no momento de atualização do Currículo Lattes; assim a população acadêmica cadastrada na Plataforma Lattes plataforma, seja estudantes, bolsistas e pesquisadores/as tem a opção de informar sua raça/a cor conforme as categorias do IBGE. Dados preliminares compilados por Tavares; Braga; Lima, analistas do CNPQ e publicados em março de 2015 na página77 da instituição trazem algumas informações importantes. As autoras apresentaram o estudo em três secções: 1) Dados gerais sobre a participação de negras e negros nas ciências brasileiras; 2) Os negros e negras nas bolsas de formação e de pesquisa; e 3) Os negros e negras nas áreas do conhecimento e faixa etária. Constatou-se que o número pretos/as e pardos/as diminui à medida que se eleve a formação de bolsistas homens e mulheres. Onde verifica-se maior participação do segmento negro é nas bolsas de iniciação científica e a menor parcela entre bolsistas de Produtividade em Pesquisa (PQ). Considerando a importância da PQ que premia os/as pesquisadores conforme a produtividade e relevância, esta é uma bolsa que torna-se um importante critério de reconhecimento de um seleto grupo de docentes das universidades públicas. Tendo isso em vista, assim se configura a distribuição de bolsas produtividade por sexo e raça/cor:

\footnotetext{
$\mathrm{Na}$ bolsa de Produtividade em Pesquisa, a participação dos negros (as) é muito pequena, principalmente entre as pretas que não atinge $1 \%$. Entre os homens, $1,2 \%$ apenas. A participação das brancas é superior a 70\%: 75,5\% em 2015. No total, são $7 \%$ de pesquisadoras negras com bolsa PQ e 9,5\% de pesquisadores negros com bolsa PQ. (...) As bolsas PQ são as que apresentam, de forma mais nítida, a exclusão de pretas e de indígenas no sistema de C\&T, assim como apresentam a maior desigualdade de gênero. De um total de 14.040 bolsas PQ, em janeiro de 2015, 35,6\% são mulheres e 64,4\% homens, ou seja: 4.993 e 9.047 , respectivamente.
}

Embora ainda não tenha sido disponibilizados dados que aponte para a configuração racial do corpo docente do ensino superior brasileiro, o interesse em destacar esses dados reside na tentativa de oferecer um pouco mais de informação sobre o universo acadêmico brasileiro no qual

77Análise sobre a participação de negras e negros no sistema científico Disponívelin: http://www.cnpq.br/web/guest/noticiaspopularizacao/-/journal_content/56_INSTANCE_a6MO/10157/2481034. Acesso em 20/03/2015 
se insere o corpo docente da USP. Este esforço se faz necessário em função da escassa e recente produção acadêmica sobre as especificidades do magistério no ensino superior.

\section{VI-2. Trilhas abertas no processo de sondagem da configuração racial do corpo docente na Universidade de São Paulo}

A reflexão sobre a composição racial da docência no ensino público superior no Brasil e na USP especificamente, depara-se com os debates sobre o processo de classificação por cor e raça no país. Onde estão e quem são os/as docentes negros/as na USP, é uma pergunta que esse trabalho faz. Na busca por algumas respostas, recorreu-se às informações disponibilizadas pelo Censo da Educação Superior de 2009, publicado pelo INEP (Instituto Nacional de Estudos e Pesquisas Educacionais Anísio Teixeira). O censo considerou "docente" o indivíduo vinculado a uma instituição de ensino superior (IES), que na ocasião da coleta dos dados, estivesse "pelo menos 16 dias durante o ano de 2009 atuando em uma ou mais das seguintes atividades: ensino, pesquisa,

extensão, gestão, planejamento e avaliação" ${ }^{78}$. O censo considerou função docente o vínculo com a IES, de modo que um docente pode ter mais de uma função docente e estar vinculado a mais de uma IES. Sendo assim, os 307.815 docentes correspondem a 359.089 funções docentes (vínculo com a IES), das quais 340.817 estão em exercício e 18.272 correspondem a docentes afastados.

Com relação à titulação, no cenário nacional permanece o predomínio de docentes que possuem mestrado (36\%), em seguida os especialistas (29\%) e por fim os doutores (27\%). A distribuição destes docentes nas instituições públicas e privadas indica que mestres e doutores são mais frequentes nas IES públicas (75\% do total de docentes) enquanto que nas IES privadas o percentual é de $55 \%$. No que diz respeito ao regime de trabalho, nas instituições públicas predomina o regime de dedicação integral $(78,9 \%)$, com destaque para as instituições federais (87,5\%). Nas instituições privadas prevalece a função docente "horista" (53,0\%), e os docentes em regime de tempo integral correspondem apenas a 21,5\%.(p.17) Os docentes das IES públicas seriam em média mais velhos que os das IES privadas. O censo traçou o perfil "típico" (p.19) dos docentes das IES públicas e privadas, que seria:

(...) o 'típico' docente vinculado às IES públicas é do sexo masculino, possui 44 anos, nacionalidade brasileira, doutorado e atua em regime de tempo integral. Já o 'típico' docente vinculado às IES privadas é do sexo masculino, possui 34 anos, nacionalidade brasileira, mestrado e atua em regime de trabalho horista. (Resumo Técnico Censo da Educação Superior de 2009, p.18) 
Basicamente, o resumo técnico do censo de 2009 trouxe informações do perfil da função docente em exercício nas IES públicas e privadas referentes à distribuição por titulação e regime de trabalho. O relatório não trouxe maiores detalhes sobre a distribuição dos docentes por sexo, porém deu indicações no perfil "típico" de que há prevalência dos homens na docência no ensino superior. No que diz respeito aos indicadores de cor ou raça dos docentes no ensino superior brasileiro, não foi possível encontrar qualquer informação.

No caso da Universidade de São Paulo especificamente, o Anuário Estatístico reúne estatísticas demográficas e acadêmicas sobre a universidade com o intuito de subsidiar o gerenciamento e o planejamento das atividades de ensino, pesquisa e prestação de serviço. $\mathrm{O}$ Anuário oferece informações demográficas referentes a quadro de docentes efetivos; distribuição do corpo docente por departamento, regime de trabalho e categoria; evolução do quadro de docentes por regime de trabalho, evolução da disponibilidade de docentes equivalentes em RDIDP (Regime de Dedicação Integral à Docência e à Pesquisa) e evolução do quadro de docentes por categoria. Considerando que a evolução do corpo docente historicamente foi relativamente pequena, por exemplo, dados de 2014 do Anuário Estatístico da USP, indicam que em 25 anos, enquanto o corpo discente cresceu $96 \%$, no mesmo período o crescimento do corpo docente foi apenas de 6,8\%; assim, toma-se aqui por exemplo o ano de 2011, momento em que em números absolutos a USP apresentava 5943 docentes.

Comparando a realidade do corpo docente da USP com os dados do censo do ensino superior de 2009, é possível perceber algumas concordâncias, porém a docência da USP possui indicadores sensivelmente acima da média nacional, referentes ao percentual de docentes em regime de dedicação em tempo integral: $84,98 \%$, enquanto nas IES públicas o percentual é de $78,9 \%$. O mesmo se verifica para a titulação, pois a média nacional indica que nas IES públicas $27 \%$ dos docentes são doutores e na USP o percentual é muito maior: 98, 65\% dos docentes tem titulação de doutor, ou acima (pós-doutor e livre-docência), embora o censo nacional não indique a porcentagem de docentes pós-doutores ou livres-docentes. No que diz respeito à distribuição por sexo, na USP, como no conjunto das IES, há prevalência de docentes homens, que significam 62,92\%, enquanto as mulheres são 37,08\%. O conjunto de publicações do Anuário Estatístico publicado pela USP até o ano de 2015 não trouxe informações referentes à distribuição de docentes por cor ou raça.

Diante da ausência de um censo que indique a composição racial do corpo docente das instituições de ensino superior no país, foi proposto no início da década "um censo racial informal, com a ajuda de colegas e estudantes negros" (Carvalho, 2006, p.91). Foi um levantamento impressionístico, a partir de contagens diretas realizadas por professores e alunos negros em diversas universidades públicas do país, chegando ao seguinte resultado: 
Mesmo admitindo uma margem de erro nas amostragens por eles reunidas (e na verdade colocamos um percentual de $20 \%$ acima do número encontrado), deparamo-nos com situações chocantes, como as da USP, Unicamp, UFRJ e UFRGS, instituições em que a proporção de professores negros não passa de 0,2\%; a da UFSCAR, de 0,5\% e a da UFMG, de $0,7 \%$. Dito de outro modo, em nenhuma universidade considerada como referência nacional na pesquisa esse número parece não passar de 1\% (Carvalho, 2006, p.92)

Nesse sentido, outro trabalho foi realizado por Ribeiro (2001), considerando apenas as universidades públicas do estado de São Paulo. A autora empreendeu uma sondagem sobre o número de professores negros na USP, na Universidade de Campinas (UNICAMP), na Universidade do Estado de São Paulo (UNESP) e na Universidade Federal de São Carlos, (UFSCAR). Para tanto, ela encaminhou cartas aos departamentos de recursos humanos dessas instituições solicitando alguma informação a respeito do número de professores negros em seus quadros. Como não obteve qualquer resposta, tentou encontrar alguma pista em publicações da Fundação Carlos Chagas e junto a setores do movimento negro, chegando aos nomes de três professores na USP e na UFSCAR. Desses, um estava nos Estados Unidos na ocasião da sua pesquisa. Tentou mais informações junto ao Núcleo de Pesquisas e Estudos Interdisciplinares do Negro Brasileiro (NEINB) existente na USP. Através de um docente, que na época lecionava na USP São Carlos, obteve a indicação de outros nomes. Assim, Ribeiro (2001) conseguiu chegar a um total de 17 docentes negros distribuídos em todas as universidades públicas de São Paulo.

Outras pesquisas indicam processos semelhantes na busca de docentes negros em outras instituições de ensino superior: Praxedes e Teixeira (2009) em pesquisa realizada na UFMG, entrevistaram 16 docentes negros/as, dentre os quais o ex-reitor da universidade, professor Tomaz Haroldo Mota Santos e a então diretora da Faculdade de Educação Antônia Vitória Soares Aranha, que também chegou a pró-reitora de graduação daquelas universidade. Ainda nesta instituição, Laborne (2008) diante da inexistência de um censo racial do corpo docente, realizou uma coleta de dados quantitativos que lhe possibilitasse sondar o número de professores e estabelecer contatos. Para tanto, aplicou 224 questionários, nos quais 181 professores se declararam brancos, 29 se declararam pardos e um se declarou preto.

Na Universidade Federal do Pará (UFPA), um levantamento foi feito por Coelho (2000) que aplicou questionários em três unidades, no Centro de Educação, no Instituto de Filosofia e Ciências Humanas e no Instituto de Letras, Artes e Comunicação. Dos docentes que responderam ao questionário, $13 \%$ declararam-se negros. Ainda na UFPA, outra pesquisa foi realizada na qual foram entrevistados cinco docentes negros/as de um conjunto de 18 professores encontrados em toda a universidade. Na Universidade Federal do Mato Grosso do Sul (UFMT), Garcia (2010), coletou dados com apoio do INEP, configurando um censo nesta universidade, e apontando num 
total de 3.557 docentes a existência de 58 docentes negros e 208 docentes pardos. Também na UFMT, Santos (2007) analisou as trajetórias de dez docentes negras/as da instituição.

Este conjunto de trabalhos indica alguns desafios no sentido de estabelecer a configuração racial do corpo docente das universidades públicas no país. No caso específico da USP, esta pesquisa atravessou percalços semelhantes. Para que fossem encontrados os/as docentes negras desta universidade, alguns procedimentos foram adotados: num primeiro momento foram feitas sondagens num tom informal junto a professores e alunos aleatoriamente. Digno de nota é o fato de que muitos docentes e alunos se espantavam com a pergunta, para eles inusitada. Muitos alunos indicaram que nunca tiveram aulas com docentes negros. Dentre os professores indicados, o primeiro nome e o mais recorrente, foi o do professor Kabengele Munanga, único professor negro no departamento de Antropologia há quase trinta anos e muito conhecido nacionalmente. Aos poucos foram aparecendo nomes e departamentos, porém, as indicações estavam concentradas em poucas unidades, basicamente onde estão os cursos mais orientados para as Ciências Humanas. Na primeira tentativa, obtive a indicação de quinze docentes efetivos: quatro na Faculdade de Educação; quatro na Faculdade de Filosofia e Ciências Humanas; dois professores na Escola de Artes e Comunicação; um na psicologia; um na EACH, um no Direito, um na Geologia e um no Instituto de Ciências Matemáticas e de Computação de São Carlos. No percurso da pesquisa o número de indicações foi crescendo.

Apesar deste primeiro conjunto de nomes levantados ter se mostrado interessante para estabelecer contatos para as entrevistas, não apresentava uma dimensão significativa do quadro de docentes da USP. Numa tentativa de configurar melhor meu universo de pesquisa, foram resolvi enviar e-mails para cada Assistente Acadêmico da universidade. Esta iniciativa me foi sugerida por minha orientadora, uma vez que em função das suas atribuições, os/as assistentes acadêmicos/as conhecem todos os docentes da sua unidade ${ }^{79}$. Ao todo foram enviados quarenta e dois e-mails e obtive sete respostas, com indicações de mais cinco nomes: um docente na Faculdade de Zootecnia e Engenharia de Alimentos (FZEA); mais três nomes na Escola de Artes, Ciências e Humanidades $(\mathrm{EACH})$. Assim, com as indicações dos assistentes acadêmicos, cheguei a vinte docentes. Considerando o quão complexo é o processo de classificação racial no país, o texto do e-mail enviado aos assistentes acadêmicos utilizou a pergunta que o IBGE faz sobre cor ou raça, conforme

\footnotetext{
79Segundo consta em página eletrônica da universidade é responsabilidade da Assistência Acadêmica: a organização e supervisão administrativa das Seções de Graduação, de Pós-Graduação e de Apoio aos Colegiados; assessorar o Diretor e Vice-Diretor, os Presidentes das Comissões Estatutárias - assim como outras comissões acadêmicas - e os Chefes de Departamento, sobre a legislação pertinente ao setor, para que quaisquer decisões institucionais sejam fundamentadas técnica e legalmente; organizar, convocar e secretariar as reuniões dos órgãos colegiados (Congregação e Conselho Técnico Administrativo); e organizar e estabelecer os procedimentos administrativos dos concursos da carreira docente, assim como prestar assistência às respectivas Comissões Julgadoras sobre a legislação concernente à matéria. Airton Ferreira Gonçalves Assistente Técnico de Direção IV - Acadêmico: http://www2.iq.usp.br/assistencia/academica/ Acesso em 18/11/2011
} 
transcrito abaixo:

(...) Como parte dos desafios dessa pesquisa, está a tarefa de localizar em quais unidades e departamentos estão os/as professoras pardos/as e pretos/as da USP. Considerando que a condição de Assistente Acadêmico possibilita grande proximidade e conhecimento do quadro docente da universidade, solicitamos que nos indique quais professores e professoras da sua unidade e/ou departamento que você, caro/a Assistente Acadêmico, classificaria como PARDO OU PRETO, conforme as categorias do IBGE. Agradecemos a sua colaboração em atender essa solicitação e nos enviar os nomes e emails dos professores pardos e pretos e das professoras pardas e pretas da sua unidade. Sem dúvida, seu gesto é uma valiosa contribuição para a localização desses/as docentes nesta instituição. Esclarecemos que as informações dadas somente serão utilizadas para fins acadêmicos.

Solicitar a alguém a opinião sobre cor ou raça de outrem implica na consideração do que seja um método de identificação racial. Um "método de identificação racial é um procedimento estabelecido para a decisão do enquadramento dos indivíduos em grupos definidos pelas categorias de uma classificação, sejam estas manifestas ou latentes" (Osório, 2003, p.7). Existem três métodos de classificação racial: a autoatribuição, em que é o próprio sujeito que escolhe o grupo racial de pertença; a heteroatribuição, em que outra pessoa aponta qual é o grupo de pertença racial de determinado sujeito; e, em terceiro lugar, a identificação biológica, que supostamente indicaria a partir de análise de DNA, " quais seriam os grandes grupos "raciais" a que teriam pertencido os ancestrais de uma pessoa" (Osório, 2003, p.8). Há uma série de inadequações referentes às técnicas de identificação biológica e um dos principais aspectos da sua ineficiência, consiste no fato de "não haver correspondência entre as "raças" que a genética pode oferecer e o que as sociedades entendem por raça" no sentido sociocultural. (Osório, 2003, p.11)

A opção pela autoatribuição ou heteroatribuição, no fundo é sempre a "uma escolha entre subjetividades" (Osório, 2003, p.13), a do próprio sujeito ou a do observador externo. Para a realidade brasileira, no uso de qualquer um dos dois métodos existe a tendência de branqueamento do sujeito, que pode ser explicada pela existência do ideal de brancura como valor prezado na sociedade e pela etiqueta das relações raciais no Brasil, apontada por Oracy Nogueira, que sinaliza como falta de polidez mencionar a cor das pessoas. Na heteroatribuição haveria assim, a possibilidade do observador fazer uma "concessão" ao observado: "quanto mais preto pior, ver o preto como pardo e o pardo como branco torna-se uma "gentileza" à luz da ideologia racial". (Osório, 2003, p.17). A autoatribuição oferece uma distribuição de cor mais acurada que a heteroatribuição, apesar dos resultados desta não desautorizarem seu uso (Osório, 2003).

Esta pesquisa fez usos de ambos os métodos: tanto a autoclassificação, quanto a heteroclassificação. No primeiro momento recorreu à heteroatribuição, pois de outra forma, não teria a indicação dos nomes dos docentes negros. As respostas obtidas em alguns emails enviados aos assistentes acadêmicos são indicativas da complexidade da questão no país, uma vez que a pergunta sobre quem é negro no Brasil suscita algumas hesitações. Em um dos email fizeram-me o 
seguinte questionamento:

Gostaria de saber se a sua pesquisa tem aprovação do Comitê de Ética e Pesquisa.

Em outro, a seguinte consideração:

(...) não tenho conhecimento da definição de PARDO OU PRETO, conforme as categorias do IBGE, mas eu não reconheço características geralmente associadas a pardos ou pretos nos docentes da FEA-RP [Faculdade de Economia e Administração de Ribeirão Preto]. Caso você tenha a definição do IBGE, favor enviar-me para responder com maior segurança.

Esta foi minha resposta:

O IBGE, em função da grande abrangência das suas pesquisas em todo território nacional, possibilita o conhecimento de indicadores sócio demográficos, que embora não sejam conclusivos, acabam constituindo um importante acervo de referências. Considerando a diversidade étnico-racial do país, o IBGE adota cinco classificações: branco, preto, pardo, amarelo e indígena. Estas classificações variaram historicamente a ainda geram muitas controvérsias. No entanto, foi adotada no último censo nacional realizado em 2010. De um modo geral, a maioria dos pesquisadores sobre relações étnico-raciais usam os termos preto e pardo para definir a população negra. Esse é o critério que tenho utilizado. Espero ter colaborado com algum esclarecimento. Reforço minha solicitação de auxílio pois cada professor negro (preto ou pardo), encontrado amplia os horizontes dessa pesquisa.

A partir da qual obtive a seguinte consideração:

Ok, mantenho minha informação anterior: eu não reconheço características geralmente associadas a pardos ou pretos nos docentes da FEA-RP.

O esforço de trazer essas transcrições de e-mails tem o propósito de oferecer alguma possibilidade de etnografia do ethos racial acadêmico, que conforme aponta Carvalho (2003), apesar de necessária é ainda muito escassa. Solicitar a atribuição de uma cor ou raça para os assistentes acadêmicos deu ensejo à verificação do que disse Oracy Nogueira sobre o o quão complexos são os processos de classificar alguém em termos de cor/raça e falar da cor do outro.

Uma vez indicados os nomes dos professores, foi enviado um e-mail para dez docentes com uma carta de apresentação da pesquisa, solicitando uma entrevista. Em função do limite de tempo para a realização do trabalho, foi estabelecido um número de dez entrevistas. Todos os professores responderam e concordaram em participar. Assim, quanto aos professores entrevistados, a autoatribuição aconteceu a partir da heteroatribuição. Porém, essa pesquisa utilizou também dados da reitoria em que todos os professores da USP declararam sua cor, conforme será discutido mais adiante.

O processo de heteroatribuição teve continuidade no momento em que eram realizadas as entrevistas, pois uma das perguntas feitas ao docente, era se conhecia algum colega preto ou pardo. Muitos diziam que tinham colegas que poderiam ser considerados pardos, mas não 
sabiam nomes. Ainda assim, consegui mais seis indicações, uma na Geologia, uma na Escola de Comunicação e Artes, outra na Escola de Enfermagem e três no Instituto de Ciências Matemáticas e de Computação. Assim, cheguei a 27 nomes de docentes da USP que seriam negros/as por heteroatribuição, num universo que em 2011 era de 5943 (cinco mil novecentos e quarenta e três) docentes distribuídos nos sete campus da universidade, conforme dados do Censo do Funcionalismo Público de 2011. Na ocasião em que estive solicitando aos docentes negros indicações de nomes de outros colegas negros, fiz também alguns comentários sobre a quantidade de nomes indicados e um dos docentes entrevistados, o professor Edson Moreira fez uma observação que apontou possibilidades muito férteis ao meu trabalho, conforme pode ser verificado a seguir:

\begin{abstract}
Acredito que, se forem questionados, tem mais um ou dois que se declarariam negros. Eu acho que temos aqui no ICMC um perfil que não é típico na USP (quatro negros em 120 professores: $3.3 \%$ ). Se fosse assim, teríamos cerca de 200 professores negros na USP. Mas a estimativa de duas dezenas do prof. José Jorge, que eu conheço, está claramente muito baixa. Minha estimativa é que somos uns cento e poucos (2\%) (...) Eu conheço alguns poucos professores negros na USP talvez uns 10. No meu instituto, somos quatro. Apesar de poucos, imagino que somos da ordem de várias dezenas, talvez chegando na casa das centenas. Eu sugiro a você que, através de sua orientadora (e, eventualmente com a intermediação da direção de sua Faculdade), solicite ao DRH (Departamento de Recursos Humanos) ou ao DI (Departamento de Informática), ambos da CODAGE, uma lista dos professores que se declararam negros em suas fichas cadastrais. De outra forma, acredito que seu trabalho vá ser bastante complicado, podendo chegar a resultados não conclusivos. Outra sugestão seria buscar o apoio da própria Comissão Permanente [de Políticas Para a População Negra na USP], que deve ter algum dado relacionado ao tema. Fico a disposição para ajudar no que for possível (Professor Edson).
\end{abstract}

A partir dessa dica, e com o apoio da minha orientadora, fomos à procura desses dados junto à Reitoria. De fato, foi possível um levantamento quantitativo a partir das informações referentes ao Recadastramento Anual que todo servidor público do Estado de São Paulo deve fazer na ocasião do seu aniversário, conforme o decreto de No. 52.691, de $1^{\circ}$. Fevereiro de 2008. Dentre outras questões, cada servidor público do estado de São Paulo responde sobre seu pertencimento racial, conforme o método de autoatribuição. O recadastramento anual é obrigatório para efetivação do pagamento de cada servidor. No tópico seguinte são apresentados os dados referentes à configuração racial do corpo docente da USP, conforme os dados deste recadastramento

VI-3. Retrato em preto e branco: raça/cor na docência da USP: 


\section{VI-3.1. Descrições Preliminares Sobre os Dados}

O Departamento de Recursos Humanos da USP disponibilizou para esta pesquisa informações de docentes aposentados e ativos referentes aos anos de 2008 a 2015. Os dados incluem professores colaboradores, assistentes, auxiliares de ensino e temporários aqui agregados na categoria Outros; além de professores doutores, associados e titulares, em diferentes regimes de trabalho. Considerando o conjunto de docentes aposentados tem a seguinte distribuição percentual: 37, 1\% de Doutores; 21,7 de Associados; 36,2\% de Titulares e 5\% de Ativos. No conjunto de docentes ativos a distribuição é: 50,4\% de Doutores; 31,3\% de Associados; 17,4\% de Titulares e $0,9 \%$ de Outros.

As informações congregam as categorias docente, sexo e raça/cor por unidade de ensino e pesquisa. Em relação ao tamanho da população, entre docentes aposentados variou entre 2448, em 2008, para 2889, em 2015; entre os docentes ativos a população variou de 5515, em 2008, para 6151, em 2015.

Uma vez que a declaração de raça/cor é facultada ao docente, uma parcela significativa não informou sua raça/cor. O percentual de docentes na categoria 'não-informado' variou, entre os docentes aposentados, de 13,5\%, em 2008, a 9,8\%, em 2015; e, entre os docentes ativos, cerca de $2,1 \%$ ao longo da série histórica.

Em termos absolutos, em 2015, no quadro de aposentados, 1 docente se declara indígena, 2 declaram-se pretos e 25 pardos. No quadro de servidores docentes ativos, no mesmo ano, 2 docentes declaram-se indígenas, 21 declaram-se pretos e 106 declaram-se pardos.

Os dados do quadro de ativos e de aposentados foram avaliados separadamente e comparativamente. Embora menos numeroso e com menor frequência de declaração de cor/raça, os dados do quadro de inativos da universidade trazem informações bastante valiosas, pois não há informações raciais para a categoria antes de 2008 na USP. Sendo assim, a análise destes dados pode ser um recurso para inferirmos sobre o quadro de ativos num período anterior, ou seja, considera-se que os docentes inativos do presente correspondem a uma amostra do quadro ativo no passado. Nesse sentido desenharemos algumas formulações que apontam para um quadro geral possível, porém não conclusivo, pois necessitaria de informações adicionais ainda não disponibilizadas pelo DRH. Se considerarmos a idade média dos docentes inativos 80 anos, entre 2008 e 2015, e a idade média dos docentes ativos, entre 1965 e 1985, 40 anos, é plausível assumir que o quadro de aposentados reflete o quadro de docentes ativos entre 1965 e 1985. Tem-se em tela também, o fato de que a probabilidade de um docente aposentar independe de sua cor/raça, uma vez que observando a estabilidade da carreira docente, na condição de servidor público, essa é uma hipótese razoável. Embora estas condições adicionem alguma incerteza à análise, esse esforço é 
feito para trazer reflexões analíticas sobre a dinâmica histórica do quadro docente da USP referente à categoria raça/cor.

A distribuição de docentes entre as unidades de ensino e pesquisa da USP, em função da cor/raça, apresenta informações interessantes. Uma vez que o número absoluto de docentes pretos e indígenas na universidade é muito pouco expressivo frente ao total de docentes, avaliar a distribuição de frequência destes nas mais de 40 unidades de ensino e pesquisa da USP é pouco aconselhável. Soma-se a isso o fato do tamanho das unidades ser também bastante heterogêneo. Como exemplo, um único docente preto em uma unidade pequena, com poucas dezenas de docentes, levaria a uma interpretação otimista quando o quadro geral é bastante dramático. Sendo assim, em relação a docentes negros/as, não se observa uma forte correlação entre unidades de ensino e pesquisa e a cor/raça dos docentes. Além disso, quando nos referirmos à categoria negro/a trata-se da junção entre as categorias preto/a e pardo/a. 


\section{VI-3.2. Configuração racial corpo docente da USP dos/as Aposentados/as:}

São apresentados na seguinte tabela dados referentes à distribuição por raça/cor do quadro de docentes aposentados/as entre os anos de 2008 a 2015.

Tabela II: Percentual de Aposentados/as 2008-2015.

\begin{tabular}{|r|r|r|r|r|r|}
\hline Aposentadd & Brancos/as & Pardos/as & Pretos/as & Negros/as & Amaralos/a \\
\hline 2008 & 92,3 & 1,0 & 0,03 & 1,0 & 6,5 \\
\hline 2009 & 92,4 & 1,0 & 0,03 & 1,0 & 6,4 \\
\hline 2010 & 92,0 & 1,8 & 0,03 & 1,8 & 6,0 \\
\hline 2011 & 92,6 & 1,5 & 0,00 & 1,5 & 5,7 \\
\hline 2012 & 92,9 & 1,3 & 0,00 & 1,4 & 5,6 \\
\hline 2013 & 93,5 & 1,2 & 0,01 & 1,2 & 5,1 \\
\hline 2014 & 92,5 & 1,1 & 0,01 & 1,1 & 6,2 \\
\hline 2015 & 92,3 & 1,0 & 0,01 & 1,0 & 6,5 \\
\hline
\end{tabular}

Fonte: Departamento de Recursos Humanos da USP, 2015.

Acompanhando a evolução do conjunto de docentes aposentados/as desde 2008, tem-se que o conjunto de brancos é de quase $94 \%$ e o de não-brancos/as gira em torno de 6,5\%. Dentre os não-brancos, o grupo de docentes autoclassificados/as como amarelos/as é o maior nessa faixa. Destaque para o fato de que o conjunto de pretos/as ao longo desses anos esteve próximo de $0 \%$ e desse modo a representação do conjunto de negros/as se confunde com a de pardos/as, conforme pode ser visualizado no gráfico a seguir: 


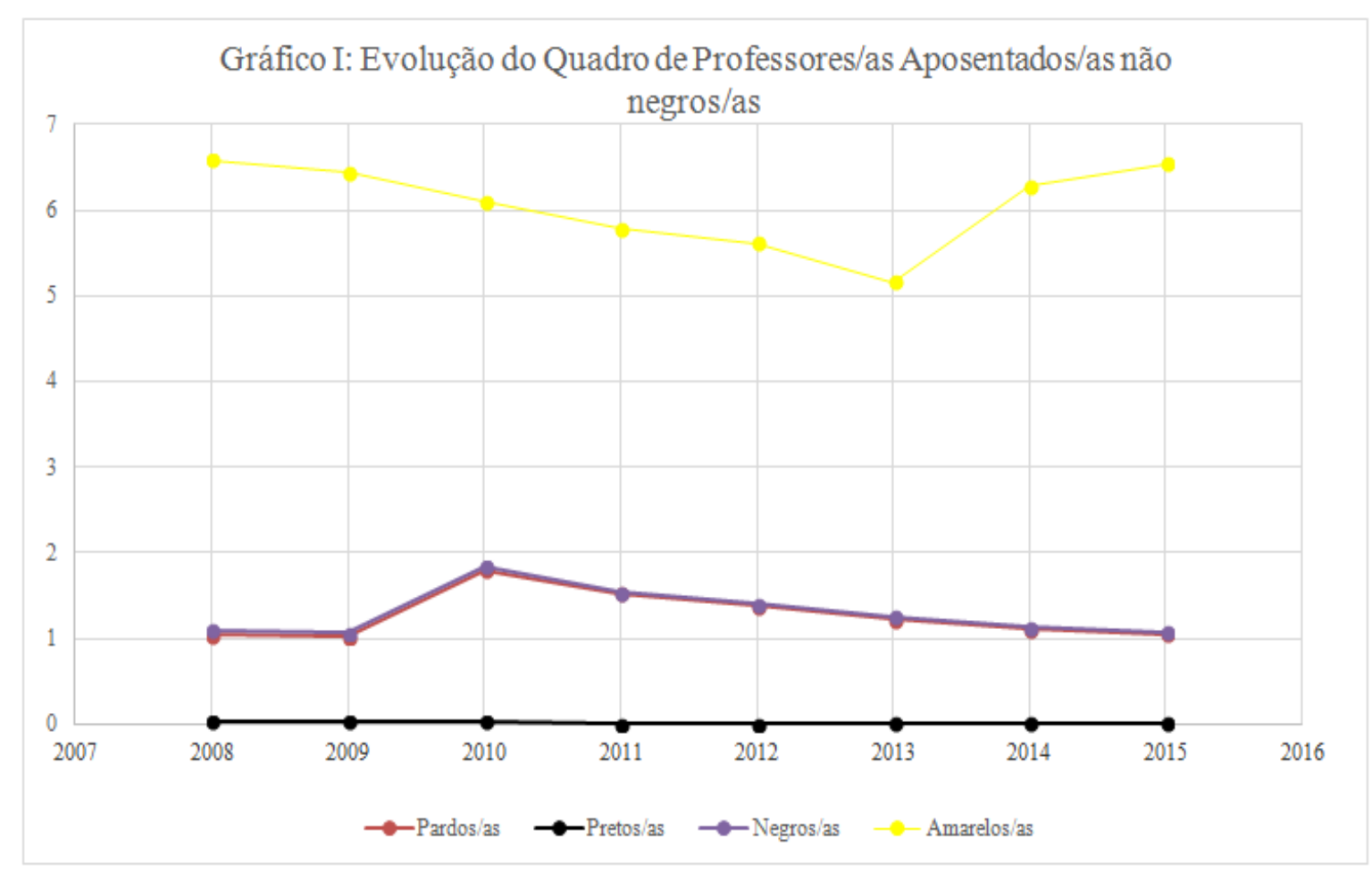

Fonte: Departamento de Recursos Humanos da USP, 2015.

Interessante destacar que as desigualdades na distribuição racial tornam-se mais evidentes quando articuladas à distribuição por sexo:

Tabela III: Distribuição Docentes Aposentados/as por Raça e Sexo de Docentes USP 2008-2015:

\begin{tabular}{|c|c|c|c|c|c|c|c|c|}
\hline Aposentado & 2008 & 2009 & 2010 & 2011 & 2012 & 2013 & 2014 & 2015 Ativos/as \\
\hline Brancos & 1317 & 1351 & 1388 & 1423 & 1488 & 1527 & 1577 & 1590 Brancos \\
\hline Pardos & 16 & 18 & 18 & 18 & 19 & 19 & 18 & 18 Pardos \\
\hline Pretos & 0 & 0 & 0 & 1 & 1 & 2 & 2 & 2 Pretos \\
\hline Negros & 16 & 18 & 18 & 19 & 20 & 21 & 20 & 20 Negros \\
\hline Amarelos & 54 & 59 & 59 & 62 & 64 & 66 & 72 & 76 Amarelos \\
\hline Brancas & 673 & 695 & 717 & 745 & 769 & 809 & 833 & 854 Brancas \\
\hline Pardas & 4 & 4 & 6 & 6 & 6 & 6 & 7 & 7 Pardas \\
\hline Pretas & 1 & 1 & 1 & 0 & 0 & 0 & 0 & 0 Pretas \\
\hline Negras & 5 & 5 & 7 & 6 & 6 & 6 & 7 & 7 Negras \\
\hline Amarelas & 52 & 53 & 52 & 54 & 56 & 56 & 57 & 58 Amarelas \\
\hline \multicolumn{9}{|l|}{$\%$} \\
\hline$\%$ Brancas & 33,8 & 34,0 & 34,1 & 34,4 & 34,1 & 34,6 & 34,6 & $34,9 \%$ Branca \\
\hline$\%$ Pardas & $20,0^{\prime}$ & $18,2^{\top}$ & $25,0^{\prime}$ & $25,0^{\mathbf{V}}$ & $24,0^{\prime}$ & $24,0^{\top}$ & $28,0^{\prime}$ & $28,0 \%$ Pardas \\
\hline$\%$ Pretas & 100,0 & 100,0 & 100,0 & 0,0 & 0,0 & 0,0 & 0,0 & $0,0 \%$ Pretas \\
\hline$\%$ Negras & $23,8^{\top}$ & $21,7^{\mathbf{V}}$ & $28,0^{\top}$ & $24,0^{\top}$ & $23,1^{\prime}$ & $22,2^{7}$ & $25,9^{\prime}$ & $25,9 \%$ Negras \\
\hline$\%$ Amarela: & 49,1 & 47,3 & 46,8 & 46,6 & 46,7 & 45,9 & 44,2 & $43,3 \%$ Amarel \\
\hline
\end{tabular}

Fonte: Departamento de Recursos Humanos da USP, 2015.

Quando se considera a distribuição de docentes por sexo, ao longo de sete anos, para cada 
grupo racial que se considere, a proporção de aposentados homens sempre é maior que a proporção de mulheres, exceto entre os/as pretos/as, entre os quais foi possível contabilizar apenas uma docente negra e nenhum docente negro. O grupo racial mais numeroso é o grupo racial branco sendo que as mulheres brancas correspondem a quase $35 \%$ deste segmento, proporção que tendeu a manter-se estável, com pequeno crescimento ao longo dos anos, conforme mostra o gráfico a seguir, construído de modo a evidenciar dentro de cada grupo racial a porcentagem referente ao conjunto de mulheres:

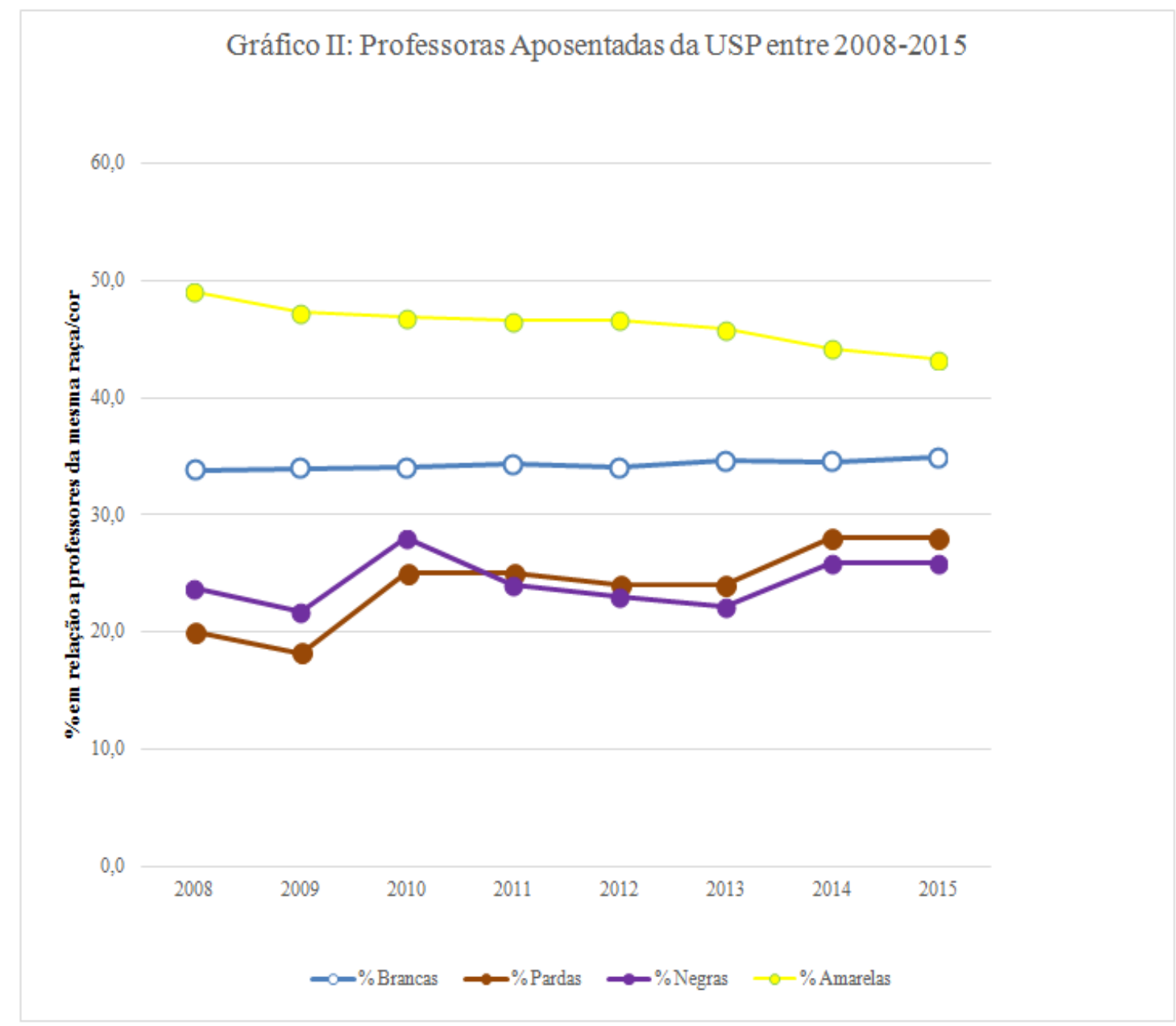

Fonte: Departamento de Recursos Humanos da USP, 2015.

A partir deste gráfico tem-se que o grupo racial amarelo embora não configure o conjunto mais numeroso de docentes, é o grupo mais equitativo; pois mesmo que a proporção de homens amarelos seja maior que a de professoras mulheres autoclassificadas como amarelas, ainda assim, permaneceu bem próxima de $50 \%$. Nota-se, no entanto, uma tendência à diminuição na proporção de docentes amarelas ao longo dos anos, o que fica mais evidente quando se considera o conjunto de docentes ativos/as apontados no tópico a seguir. E em função da ausência de docentes homens no 
grupo racial preto, no conjunto de docentes aposentados, é mais interessante observar a evolução da categoria pardo/a, que revelou a maior diferença entre os grupos raciais representados: além de ser o menor conjunto em termos absolutos ao longo dos anos considerados, as docentes pardas representaram entre aproximadamente $18 \%$ a $28 \%$ deste grupo racial, de modo que apesar de numericamente ínfimo, no conjunto de docentes aposentados/as pardos/as, o grupo docentes homens é pelo menos três vezes maior que o de docentes mulheres.

\section{VI-3.3. Configuração racial dos/as docentes ativos/as:}

TabelaVI: Distribuição docentes ativos/as por raça 2008-2015:

\begin{tabular}{|r|r|r|r|r|r|r||}
\hline Ativo/as & Brancos/a & Pretos/as & Pardos/as & Negros/as & Amarelos/as \\
\hline 2008 & 94,4 & 0,14 & 1,24 & 1,38 & 4,14 \\
\hline 2009 & 94,7 & 0,15 & 1,18 & 1,33 & 3,88 \\
\hline 2010 & 94,2 & 0,18 & 1,24 & 1,42 & 4,3 \\
\hline 2011 & 94,3 & 0,31 & 1,24 & 1,55 & 4,12 \\
\hline 2012 & 94,5 & 0,29 & 1,2 & 1,49 & 3,98 \\
\hline 2013 & 94,4 & 0,29 & 1,29 & 1,58 & 3,98 \\
\hline 2014 & 94,4 & 0,29 & 1,55 & 1,84 & 3,69 \\
\hline 2015 & 94,6 & 0,3 & 1,53 & 1,83 & 3,46 \\
\hline
\end{tabular}

Fonte: Departamento de Recursos Humanos da USP, 2015.

O grupo de docentes brancos/as é o mais numeroso e representa quase $95 \%$ do corpo docente da USP. Nos cerca de 5\% restantes há prevalência da categoria amarelo/a que gira em torno de $4 \%$. O conjunto de pretos/as evolui de $0,15 \%$ a $0,30 \%$ e pardos/as de $1,19 \%$ a $1,56 \%$. Desse modo, agregando pretos/as e pardos/as na categoria negro/a, tem-se que menos de $2 \%$ do corpo docente da USP encontra-se nesse grupo racial. Além disso, dentro desse universo de quase 5\% de docentes não-brancos da USP, observa-se a seguinte tendência: pequena redução do grupo de amarelos/as e algum crescimento dos grupos pardos/as e pretos/as, que pode ser visualizado no gráfico abaixo: 


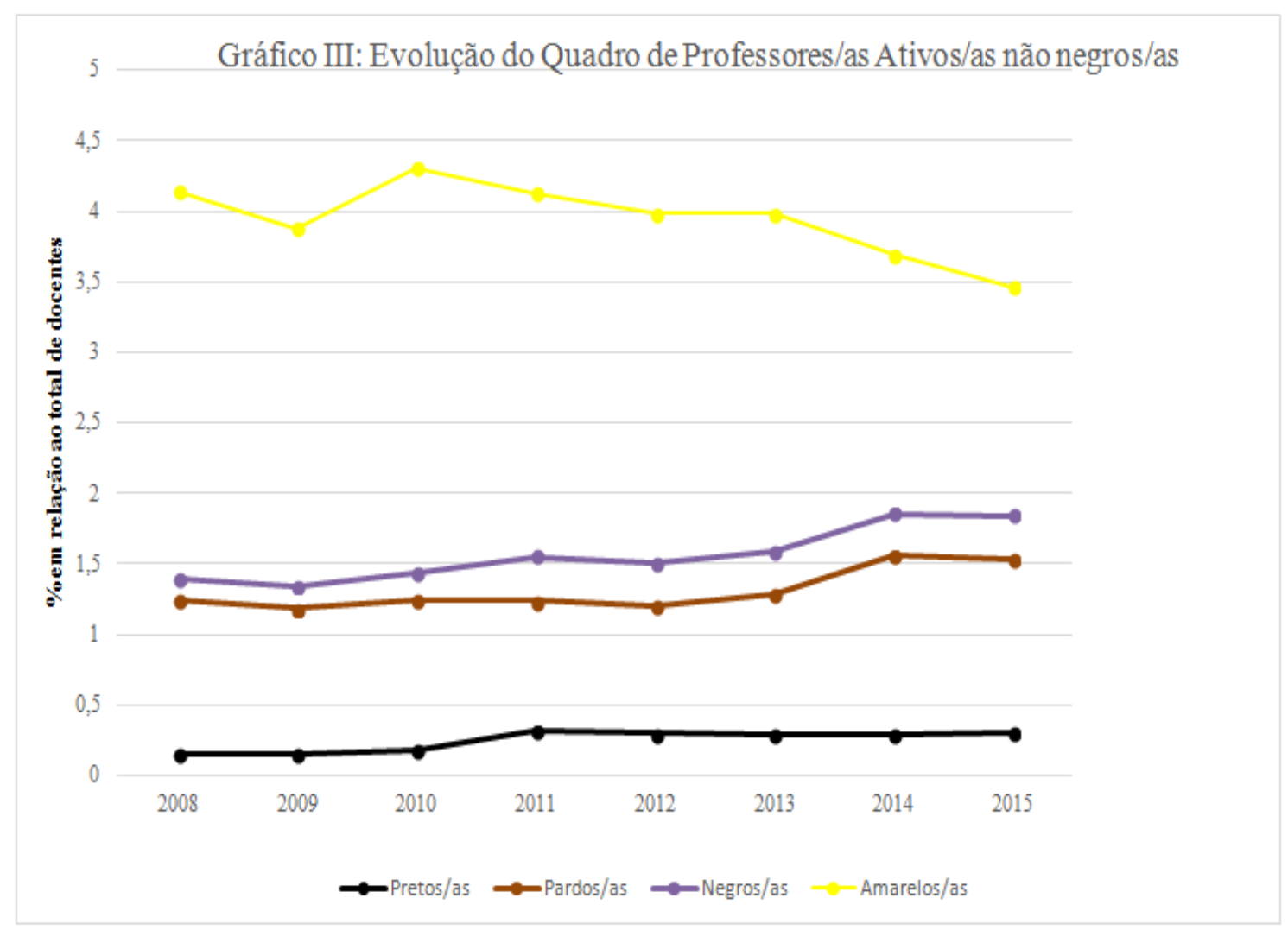

Fonte: Departamento de Recursos Humanos da USP, 2015.

Quando se articula com a categoria sexo, tem-se que as professoras brancas são pouco menos de $40 \%$ do grupo racial branco. Isso confirma um fato apontado pelo Anuário Estatístico da USP 2015, que indica que os professores homens são cerca de $60 \%$ do corpo docente da universidade. Se no conjunto de aposentados/as, a representação se revelava um pouco mais equitativa, mais próxima de 50\%; entre os/as ativos/as nesse grupo racial, observa-se a tendência de crescimento do número de docentes homens entre 2008 e 2015 e o grupo de docentes do grupo passa a ser 37,8\% em relação aos homens auto-declarados amarelos. No grupo de pardos/as as mulheres estão entre $35 \%$ a $40 \%$, e no conjunto dos pretos/as as mulheres são quase $1 / 3$ da categoria, conforme indica a tabela a seguir:

Tabela V: Distribuição Docentes Ativos/as por Raça e Sexo de Docentes USP 2008-2015:

\begin{tabular}{|l|r|r|r|r|r|r|r|r|r|}
\hline Ativos/as & 2008 & 2009 & 2010 & 2011 & 2012 & 2013 & 2014 & 2015 \\
\hline Brancos & 3240 & 3362 & 3392 & 3459 & 3440 & 3420 & 3504 & 3486 \\
\hline Pardos & 51 & 51 & 55 & 57 & 58 & 63 & 70 & 69 \\
\hline Pretos & 11 & 12 & 12 & 13 & 13 & 12 & 13 & 14 \\
\hline Negros & 62 & 63 & 67 & 70 & 71 & 75 & 83 & 83 \\
\hline Amarelos & 145 & 150 & 154 & 155 & 157 & 157 & 162 & 155 \\
\hline Brancas & 1824 & 1923 & 1976 & 2052 & 2081 & 2092 & 2172 & 2156 \\
\hline Pardas & 32 & 30 & 31 & 33 & 33 & 34 & 38 & 37 \\
\hline Pretas & 3 & 3 & 4 & 6 & 6 & 6 & 7 & 7 \\
\hline Negras & 35 & 33 & 35 & 39 & 39 & 40 & 45 & 44 \\
\hline Amarelas & 89 & 92 & 95 & 94 & 94 & 95 & 95 & 94 \\
\hline
\end{tabular}


Fonte: Departamento de Recursos Humanos da USP, 2015.

O gráfico a seguir possibilita visualizar quais têm sido as tendências de crescimento do universo de professoras em relação aos professores do mesmo grupo:

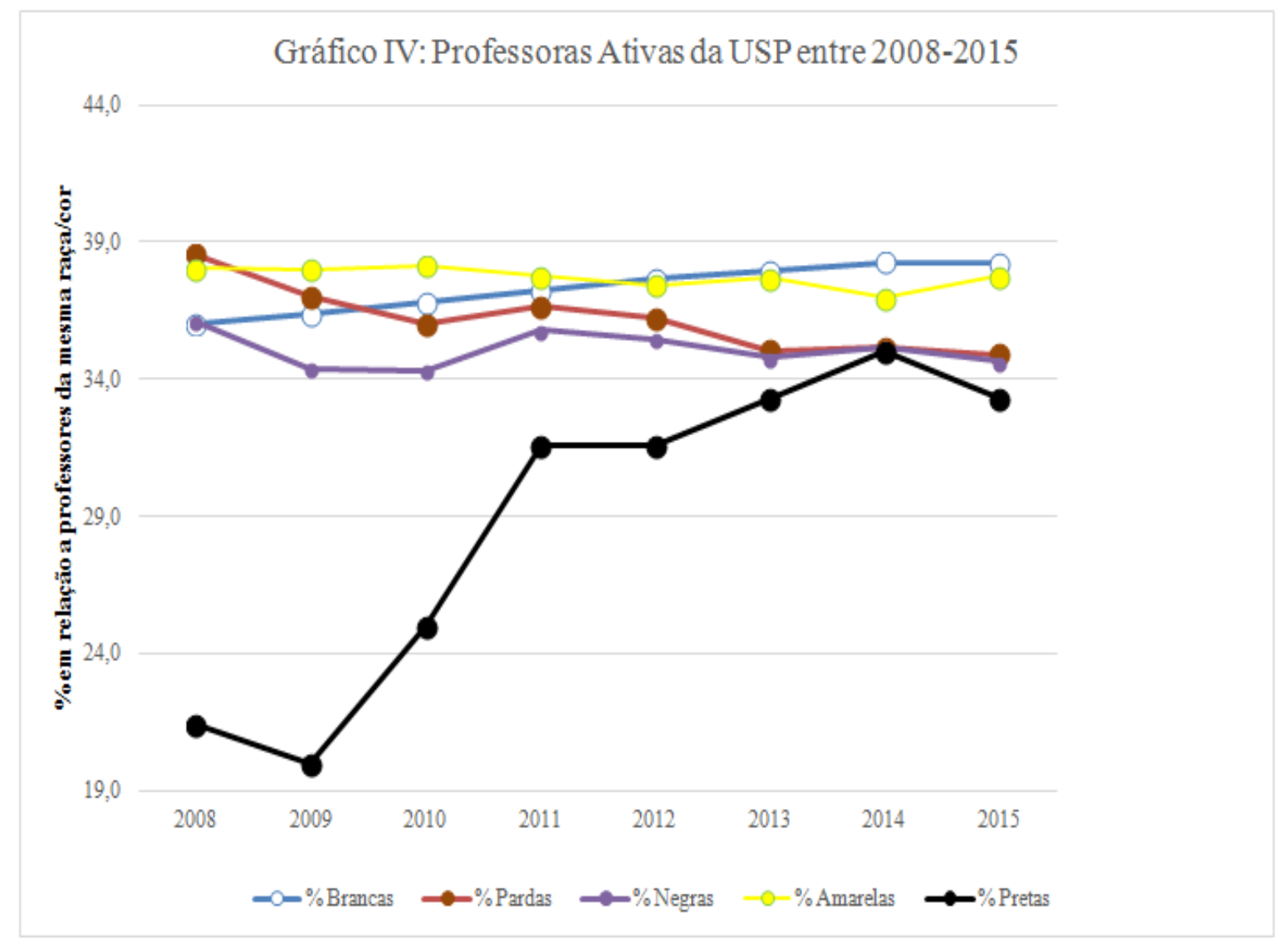

Fonte: Departamento de Recursos Humanos da USP, 2015.

De um modo geral, apresenta-se uma tendência de crescimento do número de professoras, embora longe da possibilidade de igualar ou ultrapassar o número de professores em cada grupo racial respectivamente. Comparando com a evolução do quadro de aposentado/as a ser apresentado em tópico adiante, as professoras do grupo amarelo foram as únicas que diminuíram proporcionalmente. Dentro do menor universo racial de docentes, representado pela categoria preto/a, o crescimento das professoras pretas foi proporcionalmente o maior. 


\section{VI-4. Algumas considerações sobre raça/cor, sexo \& categoria docente}

O Estatuto da Universidade de São Paulo ${ }^{80}$ indica que o desempenho das atividades docentes obedece ao princípio de integração de atividades de ensino, pesquisa e extensão universitária, a partir das seguintes categorias: I - Professor Doutor; II - Professor Associado; III Professor Titular. A categoria inicial, Professor Doutor e a categoria final, de Professor Titular, constituem cargos. A categoria Doutor possui dois níveis: Professor Doutor 1 e Professor Doutor 2. Por sua vez, a categoria Professor Associado está dividida em três níveis: Professor Associado 1, Professor Associado 2 e Professor Associado 3.

Pelo artigo 81 do Estatuto, tem-se que a USP "manterá a instituição da Livre-Docência, independentemente de vinculação à atividade acadêmica na Universidade", porém os candidatos a Livre Docência devem ser doutores, e caso já seja Professor Doutor da universidade, passará ao nível de Professor Associado 1. O título de Livre-Docente outorgado pela USP ou por ela reconhecido é também pré-requisito para concurso de provimento do cargo de Professor Titular. Assim, Professor Doutor constitui o primeiro degrau da carreira docente da USP, Professor Titular o nível mais elevado e o concurso de Livre Docência permite a progressão de Doutor para Associado, que é o nível médio.

Considerada a legislação referente às categorias docentes da USP, apresentam-se a seguir alguns gráficos referentes aos anos de 2008 para a categoria Aposentados/as e 2015, referente à categoria Ativos, para que se possa comparar como evoluiu a distribuição racial para cada nível da carreira docente da USP. Assim, para o nível de Professor Doutor observa-se a seguinte distribuição racial entre esses anos: 


\section{Gráfico VII: Professores/as Doutores/as}

Aposentados/as da USP em 2008

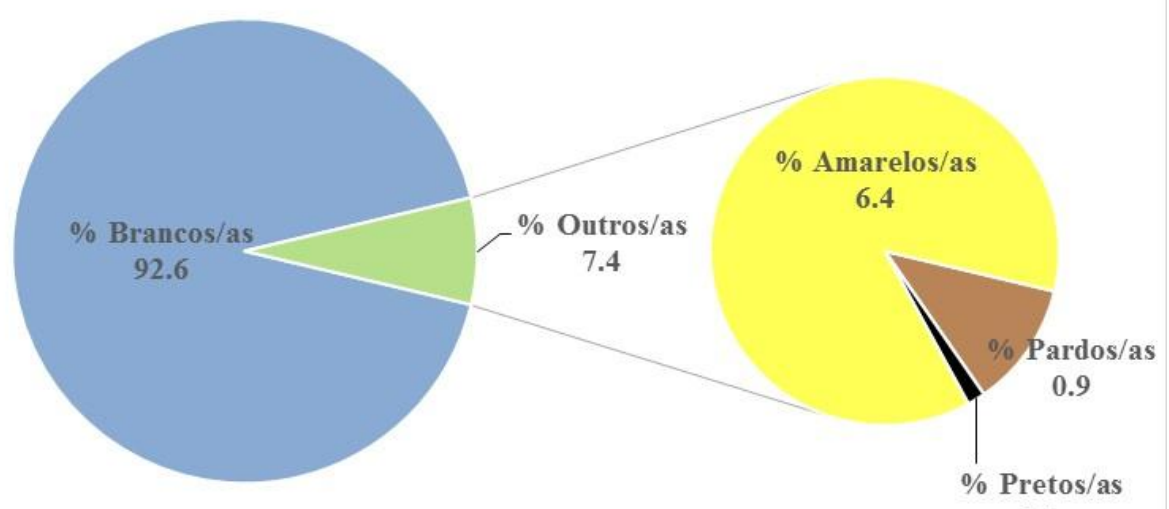

0.1

\section{Gráfico VIII: Professores/as Doutores/as \\ Ativos/as da USP por raça/cor em 2015}

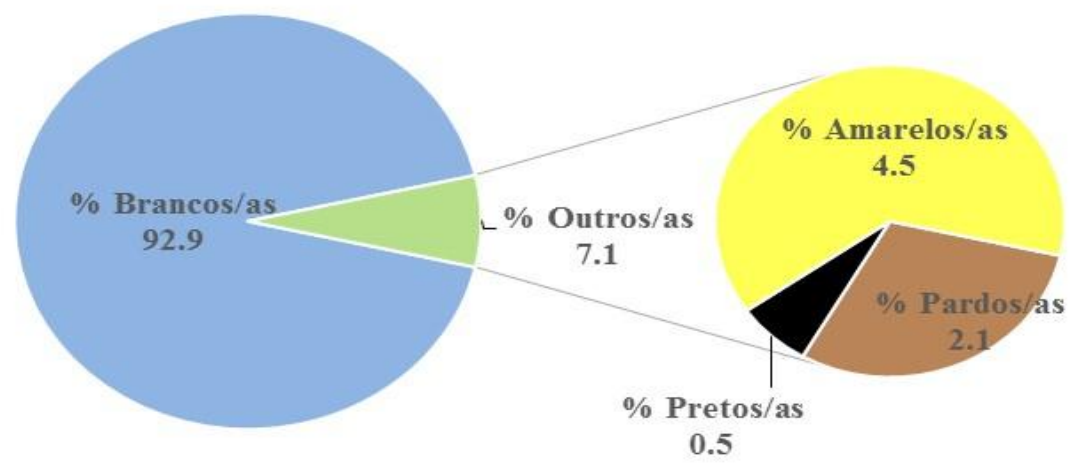

Entre aposentados/as e ativos/as do grupo racial branco, há um ligeiro crescimento de modo que atualmente quase $93 \%$ da categoria de Professor Doutor da USP é constituída por brancos. O segundo grupo de maior representação, os amarelos, era 6,4\% entre os Aposentados de 2008, caindo para 4,5\% entre os/as Ativos de 2015. Entre os/as negros/as, pretos/as vão de 0,0\% para $0,5 \%$ e pardos/as de $0,9 \%$ para $2,1 \%$.

Na categoria Professor Associado, verifica-se a seguinte evolução: 


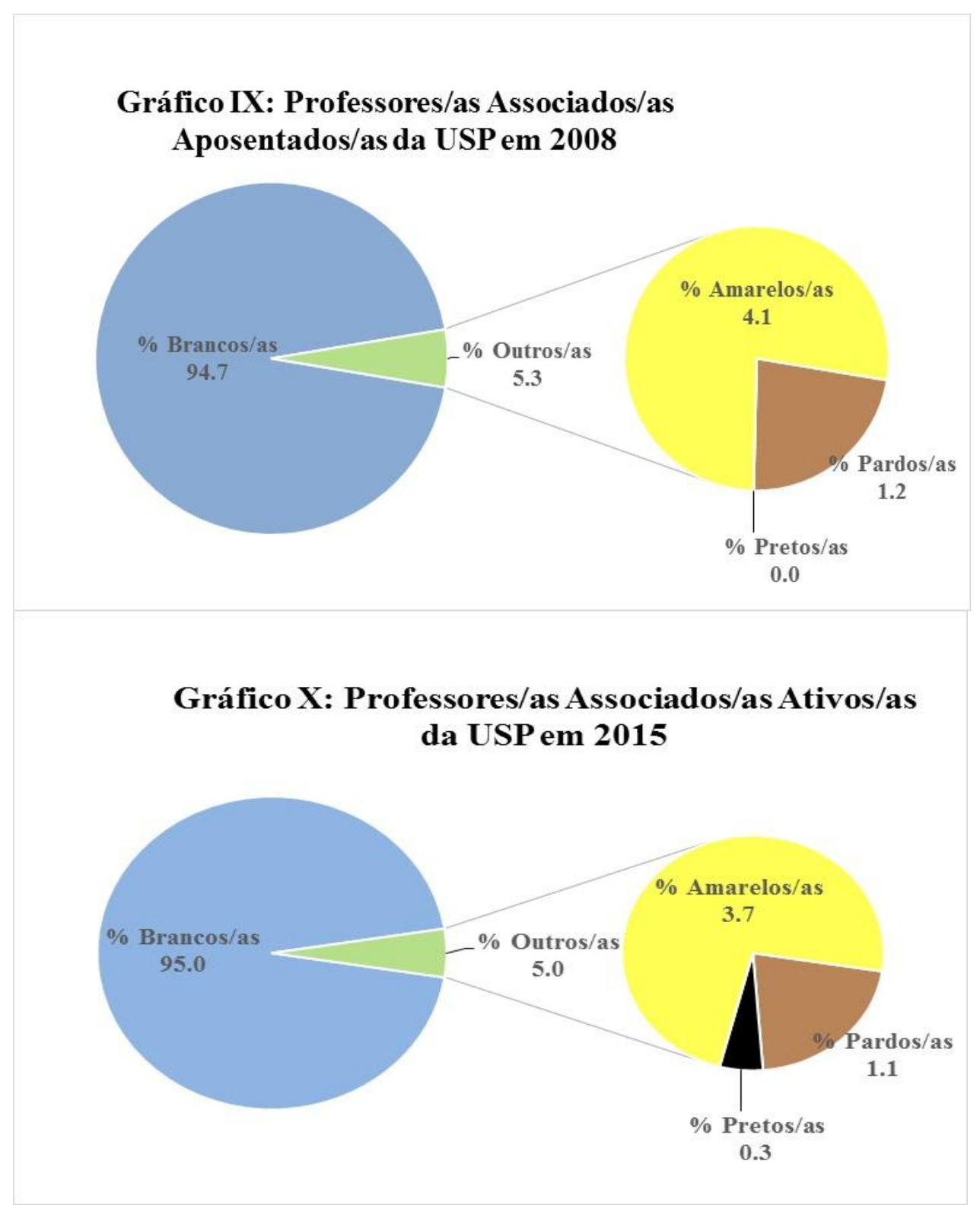

Na categoria Professor Associado verifica-se a mesma tendência observada na categoria Doutor : crescimento do grupo de brancos/as e diminuição do grupo de amarelos/as. Entre os aposentados de 2008 não se verifica docentes pretos/as e nos Ativos o percentual é de 0,3\%. E entre os/as pardos não há alteração significativa (1,2\% em 2008 e 1,1\% em 2015).

E no topo na carreira docente, na categoria Professor Titular tem-se a seguinte distribuição: 


\section{Gráfico XI: Professores/as Titulares Aposentados/as da USP em 2008}

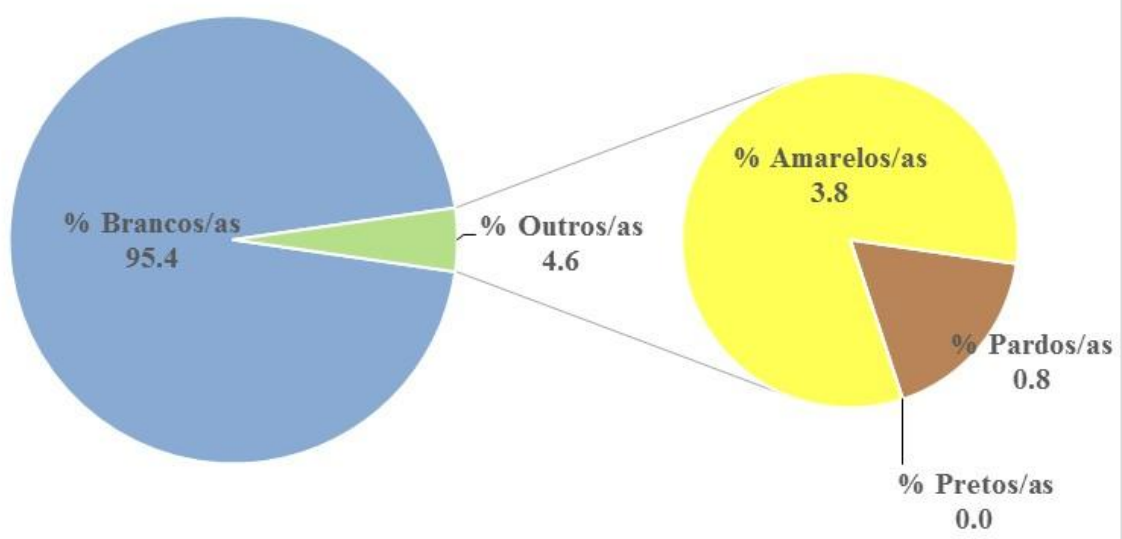

\section{Gráficos XII: Professores/as Titulares Ativos/as da USP em 2015}

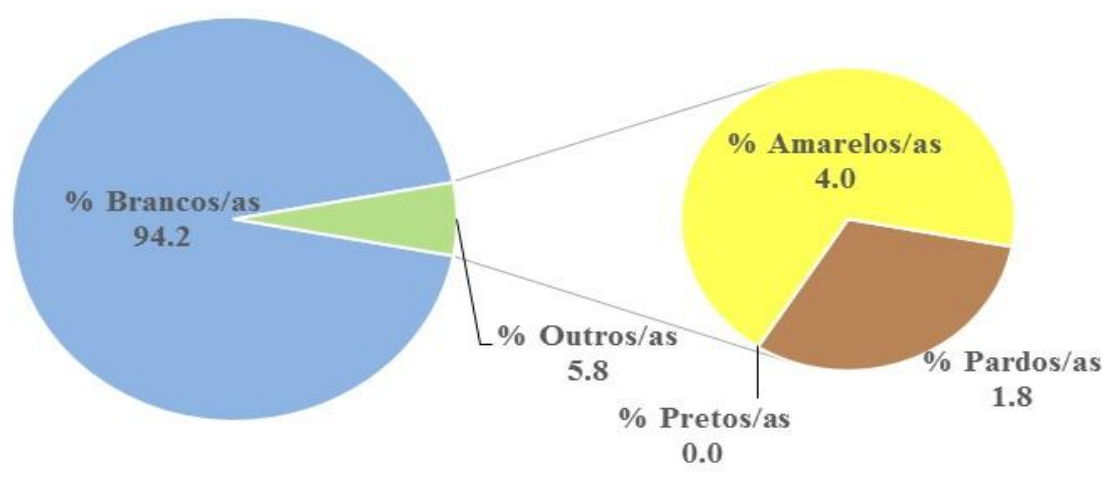

Enquanto a o grupo de docentes brancos/as titulares permanece em torno dos $95 \%$ e dos/as amarelos em torno dos $4 \%$, os/as pardos/as saltaram de $0,8 \%$ para $1,8 \%$. Por sua vez a proporção de pretos/as titulares é estaticamente nula.

Vale ressaltar que na estrutura de poder da universidade o estatuto prevê nos Títulos IV e V, a prevalência da categoria Professor Titular na administração da universidade a partir dos seus órgãos centrais (conselho universitário, conselhos centrais, reitoria, pró-reitorias e conselho consultivo); bem como dos órgãos de administração de cada unidade (congregação, diretoria, conselho técnico-administrativo, comissão de graduação, comissão de pós-graduação, demais comissões e departamentos). Os artigos 46 e 55 do Estatuto possibilitam algumas interferências pontuais nesta estrutura de poder, uma vez que permitem ao Professor Associado 3 dirigir unidades e departamentos e ao Professor Associado 2 dirigir departamentos.

Estas três categorias, como docentes na graduação e na pós-graduação, assumem as 
nevrálgicas funções de ensino, pesquisa e extensão. Dentre as três, a menos numerosa delas é a categoria de Professor Titular, que detém a hegemonia do poder administrativo e decisório. Sendo assim, o topo da carreira docente da USP é representado quase exclusivamente por docentes brancos/as e amarelos.

Conforme indicado, a carreira docente na USP é representada pelos níveis de Doutor, Associado e Titular. No entanto, há ainda outras categorias que pertencem ao conjunto técnicoadministrativo da universidade, que representa 5\% do conjunto de Aposentados em 2015 e 0,9\% do total de docentes ativos na USP em 2015. : Professor Assistente, Professor Auxiliar de Ensino, Professor Auxiliar Instrutor e Professor Colaborador. Interessante observar como se configura a distribuição racial nestas categorias consideradas menores hierarquicamente dentro da USP:

\section{Gráfico V: Professores/as Aposentados/as de outras categorias da USP em 2008}

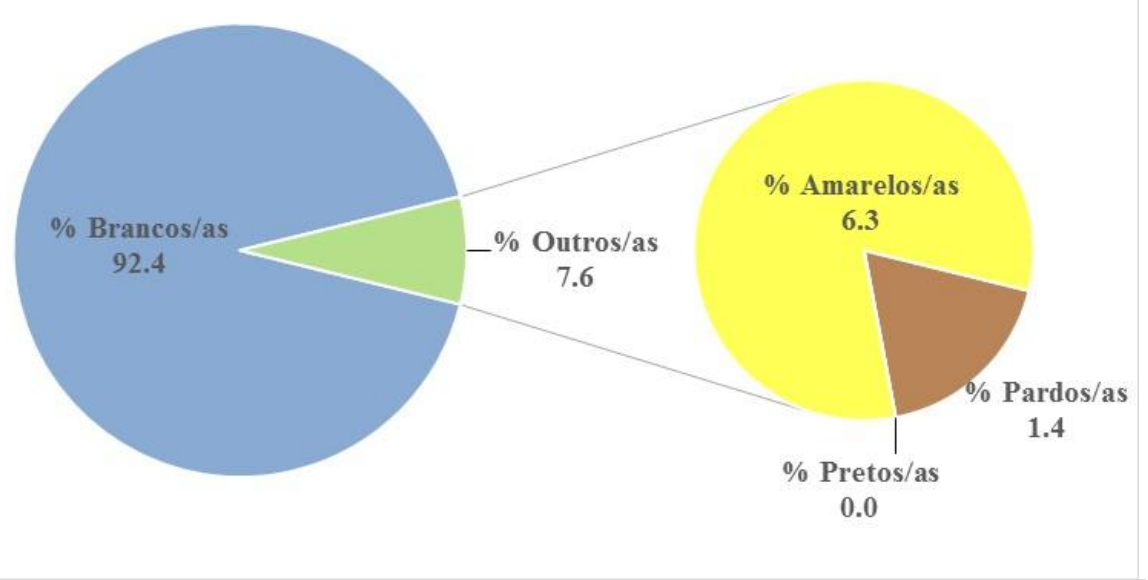

Gráfico VI: Professores/as Ativos/as de outras categorias da USP em 2015

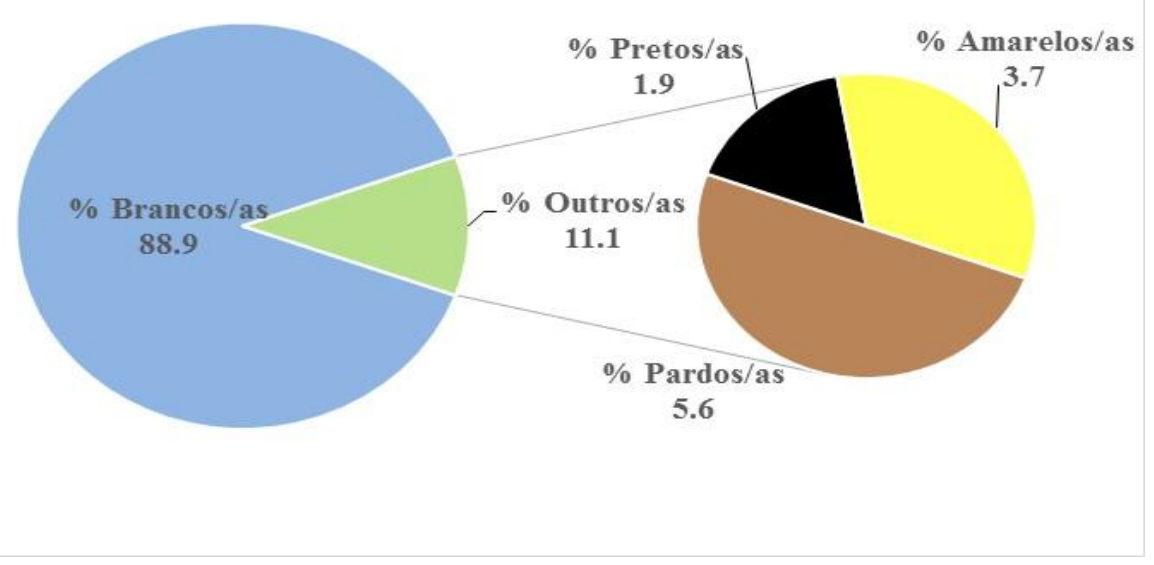


Observa-se que nestas categorias tidas como menores, aqui agregadas como Outras, tem-se a única ocasião em que se verifica sensível diminuição do grupo de brancos/as no período estudado. No grupo de amarelos também há diminuição, passando de 6,3\% entre Aposentados/as de 2008 a 3,7\% dos/as Ativos/as de 2015. Interessante o que acontece no grupo de negros/as: se em 2008 não há pretos/as, em 2015 eles/as representam 1,9\% e os/as pardos saltam de 1,4\% para 5,6\%. Desse modo tem-se que o aumento mais sensível do grupo de docentes negros/as aconteceu na categoria "Outros", ainda que permaneça uma distância muito significativa até o grupo branco. Assim, de um modo geral, quando negros/as entram na docência da USP, entram como servidor TécnicoAdministrativo e não na condição de Docente, carreira que só tem início na categoria de Doutor, tal qual o Estatuto da universidade distingue hierarquicamente. Considerando que no conjunto de docentes aposentados seguinte distribuição percentual seja de: 37, 1\% de Doutores; 21,7 de Associados; 36,2\% de Titulares e 5\% de Ativos. E que no conjunto de docentes ativos a distribuição seja : 50,4\% de Doutores; 31,3\% de Associados; 17,4\% de Titulares e 0,9\% de Outros. Destaca-se que entre os aposentados a distribuição de Titulares e de Outros é muito maior que entre os Ativos; além disso, se no conjunto de ativos a proporção de negros/as é pequena em todas as categorias, inclusive na Outros, onde a presença negra seria maior.

Assim, a sub-representação de negros/as no corpo docente da universidade tende a permanecer historicamente, indicando uma clara racialização na (im)possibilidade de ascensão de negros/as na carreira docente da USP, uma vez que esse grupo, conforme indicado, tendeu a diminuir proporcionalmente à medida que se avança os degraus das categorias docentes.

E por fim, vale ainda registrar que, considerando a gigantesca estrutura da USP, que é composta por 42 unidades de ensino e pesquisa, seis institutos especializados, quatro museus e quatro hospitais, espalhadas em sete campi situados em sete cidades diferentes, uma análise interessante a ser feita ainda, poderia ser o modo como se configura a distribuição racial do corpo docente da USP em função das unidades. Diante dos dados, a primeira constatação foi que a quantidade de docentes pretos/as e pardos/as por unidades era irrelevante em termos absolutos. Conforme indicado acima, menos de $2 \%$ do corpo docente da USP pode ser agregado na categoria negro/a. Distribuir esse valor inferior a $2 \%$ em 42 unidades, seis institutos, quatro museus e quatro hospitais em sete campi e cidades revela um esforço estatisticamente estéril. De um modo geral, considerando a distribuição por unidades e docentes Aposentados/as, é possível ver que 75\% das unidades não tinha registro de qualquer docente do grupo racial preto e $50 \%$ das unidades não tinham docentes negros/as. No que concerne ao conjunto de docentes Ativos/as, houve uma pequena evolução, considerando que se reduz para 50\% o percentual de unidades sem docentes pretos/as e a $25 \%$ as unidades com completa ausência de docentes negros/as. E de um modo geral, a distribuição de pardos/as é mais regular que a de pretos/as. Considerando que o maior desafio foi 
encontrar docentes pretos/as, as unidades que chegaram a apresentar um registropequeno, mas ainda assim fora da curva, foram, em ordem crescente: IME, FEA, ICMC, FEUSP, ECA, FFLCH, IP, IFSC, FZEA, IAU, IGC.

A partir desses dados, percebe-se um descompasso entre, de um lado, a configuração racial da população nacional e do Estado de São Paulo, e por outro, a configuração racial do corpo docente na USP. Enquanto a proporção de brancos no estado paulista é de 64,4\%, na USP esta porcentagem é em torno de $94 \%$. A população negra do estado é de $34,1 \%$ (considerando pardos e pretos) e, no entanto, menos de 2,0\% do corpo docente da USP é auto-declarada como negra. Tendência diferente verifica-se no grupo dos declarados amarelos, pois, se no estado o percentual é tão pequeno a ponto de ser agregado juntamente com a categoria indígena, somando 1,4\%, na universidade o percentual de docentes que se declararam amarelos gira em torno de 5,0\%. Além disso, em qualquer raça/cor que se considere, o número de docentes homens é sempre maior que o de docentes mulheres. 


\title{
Capítulo VII- Docente Negro/a na USP hoje: Outras Trajetórias e Significados
}

Eu fiquei muito feliz, sabia? Inclusive eu ia falar, gostei pra caramba. Eu gostei assim, porque são coisas que a gente não tem com quem conversar, achei legal isso. Acho bacana assim a sua preocupação como intelectual de ver isso, acho legal pra caramba (...) até gostaria de saber o resultado da sua pesquisa, o quê que deu. Achei muito legal, fiquei feliz mesmo, fiquei muito feliz, muito entusiasmado, entusiasmado, aí que foi um espaço que você abriu para que eu pudesse falar sobre isso, que é um assunto assim, que eu tenho na minha cabeça, eu assim, verbalizo pontualmente com algumas pessoas, mas eu nunca tive espaço pra falar isso de forma articulada, como discurso, como você propôs, proporcionou, pra mim foi ótimo. (Professor Dennis de Oliveira)

\begin{abstract}
Agradeço a oportunidade de falar dessas coisas, a gente sente falta também, de falar um pouco da própria trajetória e é uma coisa curiosa ser objeto de estudo, até brinquei com meu irmão "nossa, eu já sou objeto de estudo, gente, tão cedo, já virei objeto de estudo" e na medida do possível, no que eu puder ajudar você, você entra em contato e a gente vai auxiliando. (Professora Vanderli Custódio)
\end{abstract}

O propósito deste capítulo é analisar como as marcas da origem social e da condição racial que as narrativas de docentes negros/as da USP revelaram, conformaram ou não suas carreiras acadêmicas e uspiana. Assim, as trajetórias acadêmicas e percepções sobre esse universo são postas em diálogo para fazer conhecidas as articulações entre docência no ensino superior e raça. Adota-se aqui o sentido proposto por Bourdieu (1996b) segundo o qual trajetória social,

\begin{abstract}
define-se como a serie das posições sucessivamente ocupadas por um mesmo agente ou por um mesmo grupo de agentes em espaços sucessivos (a mesma coisa valeria para uma instituição; da qual ha apenas historia estrutural: a ilusão da constância do nominal ,consiste em ignorar que 0 valor social de posições nominalmente inalteradas pode diferir nos diferentes momentos da historia própria do campo). E com relação aos estados correspondentes da estrutura do campo que se determinam em cada momento o sentido e o valor social dos acontecimentos biográficos, entendidos como colocações e deslocamentos nesse espaço ou, mais precisamente, nos estados sucessivos da estrutura da distribuição das diferentes espécies de capital que estão em jogo no campo, capital econômico e capital simbólico como capital especifico de consagração. (Bourdieu, 1996a, p. 292
\end{abstract}

Assim, as trajetórias seriam o resultado construído a partir de um sistema dos traços pertinentes de uma biografia individual ou de um conjunto de biografias (Bourdieu, 1998); explicitando o modo como as relações são objetivadas e revelando as forças presentes no campo intelectual e científico. A partir do conjunto das narrativas concedidas pelos/as docentes pretendese perseguir em cada trajetória os processos históricos do grupo social negro no que concerne ao acesso ao ensino superior e a construção de legitimidade dentro do campo acadêmico. Para tanto apresenta-se neste capítulo, a origem socioeconômica, o modo como percebem sua pertença racial e elementos destacados das carreiras docentes aqui consideradas a partir de dados obtidos primeiramente a partir das entrevistas que concederam para essa pesquisa. Também foram utilizadas 
informações levantadas de fontes secundárias, como o currículo Lattes, memoriais para concursos, e colhidas na mídia acadêmica como a TV USP, nas redes sociais e espaços de debates virtuais onde também foi possível acompanhar a atuação desses/as professores/as universitários/as.

Do conjunto de dez docentes negros/as da Universidade de São Paulo entrevistados/as (cinco mulheres e cinco homens), três docentes entraram na carreira acadêmica na USP antes dos anos 2000 e sete após essa data. As trajetórias pessoais e acadêmicas do primeiro grupo, a saber: Eunice Prudente, Kabengele Munanga, e Edson Moreira Santos - foram consideradas mais pormenorizadamente ao longo dos capítulos anteriores, em função da importância que tiveram nos anos 1980 e 1990 para o fortalecimento da pesquisa e do debate racial dentro da Universidade, no sentido de ampliação da presença da população negra no corpo discente da USP. Apesar da grande resistência que enfrentaram e ainda enfrentam ao longo do processo, pequenas, porém significativas vitórias foram possíveis, numa história marcada por avanços e retrocessos, num contínuo valsar, conforme metáfora do professor Kabengele Munanga. Neste capítulo, considera-se analiticamente o conjunto das sete trajetórias de docentes negros/as cuja entrada aconteceu ao longo dos anos 2000.

Este segundo grupo mantém diversas semelhanças de percurso com o primeiro grupo e de modo geral, engrossou o coro de pesquisadores/as negros/as desta universidade e que estão atentos/as à pauta antirracista e trouxe também elementos novos que serão melhor considerados a seguir. Compõem esse segundo grupo os seguintes nomes, por ordem de ingresso na docência da USP: Roberto da Silva (2002, Faculdade de Educação); Vanderli Custódio (2003, Instituto de Estudos Brasileiros), Denis de Oliveira (2003, Escola de Comunicação e Artes), Roselane Gonçalves (2006, Escola de Artes, Ciências e Humanidades), Emerson Inácio (2006, Faculdade de Filosofia, Letras e Ciências Humanas), Maria Letícia Nascimento (2007, Faculdade de Educação) e Adriana Alves (2010, Instituto de Geociências). No primeiro tópico desse capítulo dois quadros são apresentados para ajudar a entender a localização institucional dos dois conjuntos de docentes negros/as entrevistados/as. Após as considerações sobre os quadros, o capítulo prossegue considerando as entrevistas a partir das origens sócio-econômicas, processos de auto-declaração racial, trajetória de escolarização na educação básica, escola do curso superior e entrada na universidade; passagem pela graduação e pós-graduação; concurso para docente na USP, vivência acadêmica cotidiana na USP e os significados de ser docente negro/as nesta universidade. 
VII. 1 Perfil dos/as docentes ingressantes a partir dos anos 2000:

Os quadros a seguir trazem informações sobre a formação acadêmica, ano de ingresso como docente na USP, categoria docente e unidade de todos os/as dez entrevistados/as.

Quadro 1: sexo, ano de ingresso, categoria docente, formação e unidade de vinculação:

\begin{tabular}{|c|c|c|c|c|c|c|}
\hline Grupo & Nome & Sexo & $\begin{array}{ll}\text { Ano } & \text { de } \\
\text { Ingresso } & \text { na } \\
\text { Docência } & \\
\end{array}$ & $\begin{array}{l}\text { Categoria } \\
\text { Docente }\end{array}$ & $\begin{array}{l}\text { Formação } \\
\text { Acadêmica }\end{array}$ & $\begin{array}{l}\text { Unidade } \\
\text { Acadêmica }\end{array}$ \\
\hline \multirow{3}{*}{ I } & Kabengele Munanga & Masculino & 1981 & Titular & Livre Docência & FFCLH \\
\hline & Edson Moreira & Masculino & 1984 & Titular & Livre Docência & ICMC \\
\hline & Eunice Prudente & Feminino & 1985 & $\begin{array}{l}\text { Professor } \\
\text { Doutor }\end{array}$ & Doutorado & Direito \\
\hline \multirow{7}{*}{ II } & Roberto da Silva & Masculino & 2002 & $\begin{array}{l}\text { Professor } \\
\text { Associado }\end{array}$ & Livre Docência & FEUSP \\
\hline & Vanderli Custódio & Feminino & 2003 & $\begin{array}{l}\text { Professor } \\
\text { Doutor }\end{array}$ & Doutorado & IEB \\
\hline & Dennis de Oliveira & Masculino & 2003 & $\begin{array}{l}\text { Professor } \\
\text { Associado }\end{array}$ & Livre Docência & ECA \\
\hline & Roselane Gonçalves & Feminino & 2006 & $\begin{array}{l}\text { Professor } \\
\text { Doutor }\end{array}$ & Doutorado & $\mathrm{EACH}$ \\
\hline & Émerson Inácio & Masculino & 2006 & $\begin{array}{l}\text { Professor } \\
\text { Doutor }\end{array}$ & Doutorado & FFCLH \\
\hline & M. Letícia Nascimento & Feminino & 2007 & $\begin{array}{l}\text { Professor } \\
\text { Doutor }\end{array}$ & Doutorado & FEUSP \\
\hline & Adriana Alves & Feminino & 2010 & $\begin{array}{l}\text { Professor } \\
\text { Doutor }\end{array}$ & Pós-Doutorado & IGC \\
\hline
\end{tabular}

Fonte: Dados extraídos dos currículos Lattes de cada docente.

Para melhor compreender o modo como as categorias docentes apontadas no quadro indicam o processo de ascensão na carreira, é preciso ter em mente que conforme Regimento81 da USP, a categoria Professor Doutor é o nível inicial da carreira docente nesta universidade, seguido pela categoria Professor Associado e no topo da carreira a categoria Professor Titular. Dentre os dez docentes entrevistados/as para esta pesquisa, seis estão na categoria Professor Doutor, sendo cinco professoras e um professor. Assim, todas as professoras entrevistadas estão no primeiro nível da carreira; dois professores estão na categoria de Professor Associado e os dois homens restantes estão na categoria de Professor Titular. Os dois professores que lecionam desde a década de 1980 e são professores titulares. A única professora que também leciona na universidade desde os anos

81Conforme o Título VI, Capítulo I e primeira Seção do Regimento Geral da Universidade de São Paulo, disponível on-line: http://citrus.uspnet.usp.br/leginf/rg/rg.html >Acesso 21/02/2015. 
1980 está na categoria de Professor Doutor.

Na década de 1990 não houve contratação de nenhum/a professor/a negro/a entrevistado/a, mas foi a década de formação de alguns/as deles/as conforme o Quadro 2. Sete contratações aconteceram ao longo dos anos 2000. O docente entrevistado que está há mais tempo na carreira docente da Universidade de São Paulo é o professor Kabengele Munanga, que há mais de 30 anos leciona no Departamento de Antropologia da USP. A mais recente docente negra entrevistada é a professora Adriana Alves, do Instituto de Geociências. A idade dos/as docentes em 2011, ano de realização das entrevistas, variava entre 31 a 69 anos, sendo a professora Adriana Alves a mais nova e o professor Kabengele Munanga o mais velho. O quadro apresentado a seguir indica o ano de formação de cada docente na ocasião das entrevistas.

Quadro 2: ano e área de cada diplomação obtida:

\begin{tabular}{|c|c|c|c|c|c|c|c|}
\hline Grupo & Nome & Graduação & Especialização & Mestrado & Doutorado & $\begin{array}{l}\text { Pós- } \\
\text { Doutorado }\end{array}$ & $\begin{array}{l}\text { Livre- } \\
\text { Docência }\end{array}$ \\
\hline \multirow{3}{*}{ I } & $\begin{array}{l}\text { Kabengele } \\
\text { Munanga }\end{array}$ & $\begin{array}{l}\text { Antropologia } \\
1964-1969\end{array}$ & --------------- & |----------- & $\begin{array}{l}\text { Antropologia } \\
1975-1977\end{array}$ & ----------- & $\begin{array}{l}\text { Antropologia } \\
1997\end{array}$ \\
\hline & Edson Moreira & $\begin{array}{l}\text { Engenharia } \\
\text { Elétrica } \\
1977-1982\end{array}$ & -------------- & $\begin{array}{l}\text { Física } \\
1982-1984\end{array}$ & $\begin{array}{l}\text { Ciência da } \\
\text { Computação } \\
1985-1989\end{array}$ & $\begin{array}{l}\text { Ciência da } \\
\text { Computação } \\
1993-1993 \text { e } \\
2006-2007\end{array}$ & $\begin{array}{l}\text { Ciência da } \\
\text { Computação } \\
1996\end{array}$ \\
\hline & Eunice Prudente & $\begin{array}{l}\text { Direito } \\
1968-1972\end{array}$ & $\begin{array}{l}\text { Direito: 1973- } \\
1975\end{array}$ & $\begin{array}{l}\text { Direito } \\
1975-1980\end{array}$ & $\begin{array}{l}\text { Direito } \\
1993-1996\end{array}$ & ----------- & ---- \\
\hline \multirow{7}{*}{ II } & $\begin{array}{ll}\text { Roberto da } \\
\text { Silva }\end{array}$ & $\begin{array}{l}\text { Pedagogia } \\
1990-1993 \\
\end{array}$ & $\begin{array}{l}\text { Criminologia } \\
\text { (Direito) } 1994\end{array}$ & $\begin{array}{l}\text { Educação } \\
1994-1997\end{array}$ & $\begin{array}{l}\text { Educação } \\
1998-2001\end{array}$ & ------------- & $\begin{array}{l}\text { Educação } \\
2009\end{array}$ \\
\hline & $\begin{array}{l}\text { Vanderli } \\
\text { Custódio }\end{array}$ & $\begin{array}{l}\text { Geografia } \\
1981-1986\end{array}$ & --------------- & $\begin{array}{l}\text { Geografia } \\
1987-1994\end{array}$ & $\begin{array}{l}\text { Geografia } \\
1996-2002\end{array}$ & ---------- & ----------- \\
\hline & $\begin{array}{l}\text { Dennis de } \\
\text { Oliveira }\end{array}$ & $\begin{array}{l}\text { Jornalismo } \\
1982-1986\end{array}$ & --------------- & $\begin{array}{l}\text { Ciências da } \\
\text { Comunicação } \\
1987-1992\end{array}$ & $\begin{array}{l}\text { Ciências da } \\
\text { Comunicação } \\
1992-1998\end{array}$ & ------------ & $\begin{array}{l}\text { Jornalismo } \\
2014\end{array}$ \\
\hline & $\begin{array}{l}\text { Roselane } \\
\text { Gonçalves }\end{array}$ & $\begin{array}{l}\text { Enfermagem } \\
\text { *Não Consta no } \\
\text { Lattes }\end{array}$ & $\begin{array}{l}\text { *Não Consta no } \\
\text { Lattes }\end{array}$ & $\begin{array}{l}\text { Enfermagem } \\
\text { *Não Consta no } \\
\text { Lattes }\end{array}$ & $\begin{array}{l}\text { Enfermagem } \\
\text { *Não Consta no } \\
\text { Lattes }\end{array}$ & $\begin{array}{l}\text { Enfermagem } \\
2001-2005\end{array}$ & ------------ \\
\hline & Émerson Inácio & $\begin{array}{l}\text { Letras } \\
1992-1996\end{array}$ & $\begin{array}{l}\text { Literatura } \\
1996-1997\end{array}$ & $\begin{array}{l}\text { Letras } \\
1998-2000\end{array}$ & $\begin{array}{l}\text { Letras } \\
2002-2006\end{array}$ & $\begin{array}{l}\text { Linguística/ } \\
\text { Letras } \\
\text { 2013- }\end{array}$ & ------------- \\
\hline & Maria Letícia & $\begin{array}{l}\text { Pedagogia } \\
1976-1981 \\
\end{array}$ & -------------- & $\begin{array}{l}\text { Educação } \\
1994-1997 \\
\end{array}$ & $\begin{array}{l}\text { Educação } \\
199-2003 \\
\end{array}$ & $\begin{array}{l}\text { Sociologia } \\
2014\end{array}$ & ------------ \\
\hline & Adriana Alves & $\begin{array}{l}\text { Geologia } \\
1999-2003\end{array}$ & --------------- & ----------- & $\begin{array}{l}\text { Geociências } \\
\text { 2004-2009 }\end{array}$ & $\begin{array}{l}\text { Geociências } \\
\text { 2009- }\end{array}$ & $\begin{array}{l}--- \\
--1\end{array}$ \\
\hline
\end{tabular}

Fonte: Dados extraídos dos currículos Lattes de cada docente.

Considerando a formação desde a graduação, a professora Eunice Prudente é quem possui vínculo mais antigo com a Universidade de São Paulo, tendo iniciado sua formação superior em 1968. O professor Kabengele Munanga fez a sua graduação na Université Officielle Du Congo à Lubumbashi, entre os anos de 1964 a 1969, vindo a realizar o doutorado na USP em 1977. Conforme indicam as entrevistas realizadas e o Lattes, além do professor Kabengele, mais três docentes não fizeram a graduação na USP: Roberto da Silva, que fez a graduação na Universidade Federal do Mato Grosso; e a Roselane Gonçalves que fez a graduação numa instituição particular 
em São Paulo, porém o mestrado e o doutorado na USP, na Escola de Enfermagem. Somente o Émerson Inácio não realizou qualquer etapa da sua formação na USP, pois cursou a graduação, especialização e o mestrado na Universidade Federal Fluminense e o doutorado na Universidade Federal do Rio de Janeiro e desse modo, a maioria dos docentes entrevistados passou pela USP durante sua formação. A USP é desde os seus primórdios uma universidade empenhada num padrão de formação de excelência internacional. Nesse sentido, a formação no exterior é também muito valorizada. Dentre os docentes que fizeram parte da formação acadêmica fora do Brasil, está o professor Kabengele que fez a graduação na Université Officielle Du Congo à Lubumbashi e formação complementar no Museu Real da África Central, Tervuren; o professor Edson Moreira, que fez o doutorado na University of Manchester, na Inglaterra, o primeiro pós-doutorado em 1993 na Strathclyde University e o segundo pós-doutorado na University of Cambridge; e a professora Adriana Alves que fez o doutorado-sanduíche na University of Alberta. O professor Roberto da Silva, por sua vez, coordena o Grupo de Estudos e Pesquisas em Educação da Universidade Lueji A'Nkonde, de Angola. O professor Émerson Inácio começou seu pós-doutorado em 2013 na Universidade do Porto em Portugal e a professora Maria Letícia iniciou seu pós-doutorado em 2014 na Universidade de Sussex, Inglaterra.

Os cursos de Antropologia, Letras, Educação, Direito e Jornalismo concentram seis docentes. Além das Ciências Humanas, nas outras áreas estão: uma professora na área da Saúde, um docente nas Exatas e as outras duas docentes nas Geociências. Interessante observar também que contando os anos de formação desde a entrada na graduação até a conclusão do doutorado, no conjunto dos cinco homens professores, a média de formação é de 13 anos, sendo que o menor tempo de formação foi onze anos e o maior foi 16 anos. Dentre as professoras, foi possível verificar os anos de formação de quatro docentes, o que resultou numa média de 21,5 anos, desde a graduação até o final do doutorado. Entre as mulheres, o menor tempo de formação foi 10 anos e o maior foi 28 anos. Além disso, os três livre-docentes entrevistados são homens.

Em linhas gerais, assim se configura a formação acadêmica e a localização institucional dos/as docentes negros/as da USP que constituem os sujeitos desta pesquisa. Conforme o percurso metodológico traçado pelos temas a seguir, busca-se tornar conhecida uma realidade ainda pouco explorada em pesquisas sobre a temática, que é trazer analiticamente os significados do que é fazer parte de um universo de grande prestígio na comunidade acadêmica brasileira: pertencer ao corpo docente da Universidade de São Paulo. Quais são os bônus e ônus dessa condição? Quem são esses/as docentes? Quais caminhos trilharam até aqui? Quais desafios enfrentam cotidianamente na Universidade? O que significa ser docente negro/a da USP? Em linhas gerais, essas são as questões que persegui no conjunto das narrativas, nas mais de trezentas páginas de áudio transcrito. Embora houvesse um esforço de fugir de um olhar de celebração dessas trajetórias, as análises caminham no 
sentido de ampliar a visibilidade da presença negra na docência da USP, bem como reconhecer a importância das mesmas, pois apesar de serem ainda em número pequeno, aplainam os caminhos para gerações de pesquisadores/as negros/as em formação e que também almejam chegar à docência não apenas da USP, como das demais universidades públicas brasileiras.

\section{2- Origens Sócio-Econômicas e Auto-Classificação Étnico-Racial:}

Nas pesquisas qualitativas nas quais são utilizados métodos biográficos, a origem social é um aspecto imprescindível para uma compreensão mais ampla das trajetórias, pois "o hábitus primário, devido ao ambiente familiar, é uma primeira e profunda impressão social sobre o indivíduo, que sofrerá outras sedimentações ao longo da vida”. (Montagner, 2007, p. 257). Tendo isso em vista, as considerações sobre a origem sócio-econômica dos/as entrevistados/as que possibilitam delinear a noção de classe social á qual pertenciam suas famílias de origem, estão assentadas nas informações e indicadores narrados pelos/as docentes, tais como: profissão dos pais, grau de escolaridade dos pais e irmãos, trajetória escolar do/a entrevistado/a e sua família, e tipo de escola que frequentaram nos ensinos fundamental e médio. Não foi feita nenhuma questão sobre renda familiar ou individual. Além disso, neste tópico serão apresentadas as reflexões de cada docente sobre o processo de se auto-classificarem em termos étnico-raciais.

\section{Professor Roberto Silva:}

Nascido em agosto de 1957, o professor Roberto da Silva82 viveu dos três aos 17 anos em abrigos, dos 17 aos 19 morou nas ruas de São Paulo, até ser condenado a 36 anos de reclusão. Cumpriu pena no extinto Complexo Penitenciário do Carandiru até os 28 anos de idade. Roberto da Silva fez parte da primeira geração de crianças ditas órfãs e abandonadas, entregues à custódia do regime militar; entrou no sistema de abrigos em 1963, um ano antes do golpe. Conforme relata, até o ano de 1963 os sistemas de abrigos eram geridos pela igreja católica e não pelo estado brasileiro. Em dezembro de 1964 foi criado o sistema FUNABEM, uma espécie de FEBEM no âmbito estadual. Assim, os abrigos foram estatizados e passados à custódia dos militares, sob a vigência do

82 As considerações feitas neste tópico estão baseadas na entrevista que o professor Roberto da Silva concedeu para esta pesquisa e no programa Trajetórias da TV USP. Apresentado pelo professor Ricardo Alexino, o programa foi ao ar em no dia 07 de março de 2012. https://www.youtube.com/watch?v=wp1d1hHd5Zo Acesso em 11/02/2014 
Código Penal de 1927. Por esse código, os juízes tinham plenos direitos de intervir nas chamadas famílias desestruturadas, determinando quando uma criança estaria em estado de abandono e a sentença de internação, até completar a maioridade. Tendo vivido a infância e adolescência dentro desse sistema, parte importante do que o professor Roberto da Silva sabe sobre sua trajetória é o que ele chama de "história oficial", ou seja, as informações que constam em processos e prontuários das instituições por onde passou. Nesses registros consta que sua família é de São José dos Campos, composta de mãe, pai e quatro filhos, sendo ele o segundo filho. Após a família ter sido abandonada pelo pai, a mãe vem para a capital paulista com os filhos em busca de ajuda de algum programa oficial no juizado de menores. O atendimento à recém-chegada família a São Paulo não se deu imediatamente, de modo que tiveram que viver por um tempo na rua. E dessa forma, os técnicos avaliaram que a mãe deveria ser internada num hospital psiquiátrico, onde permaneceu até a sua morte e as crianças foram internadas em abrigos. Em função das diferenças de sexo e idade, os filhos foram para abrigos em cidades diferentes, impossibilitando a visita da mãe aos quatro filhos e acarretando com isso o estado de abandono. A família ficou separada durante os anos de vivência nos abrigos e sem saberem da existência um do outro. Localizar os irmãos foi um dos objetivos da dissertação de mestrado do professor Roberto Silva. O reencontro aconteceu no momento da defesa, embora tenha revisto de fato apenas dois irmãos, pois sua mãe já havia falecido e o irmão mais velho fora adotado por uma família italiana e mudou-se para a Europa. Em entrevista concedida para esta pesquisa, assim o professor Roberto relata o reencontro com seus irmãos:

Até o mestrado eu não conhecia família. O meu mestrado teve como título exatamente a reconstituição da trajetória de institucionalização de uma geração de ex-menores, que foi a primeira geração de crianças ditas órfãs ou abandonadas, tuteladas pelo Estado, entregues pra FEBEM pra criação no regime militar. Então no âmbito desse mestrado eu fui tentar entender a minha própria trajetória de vida sob a tutela do regime militar e a trajetória dessa geração também. E foi no âmbito da pesquisa do mestrado que eu localizei os meus irmãos, que eu não conhecia e eles também não me conheciam e não sabiam da minha existência. Então eles não tiveram condições de um ganho de escolaridade significativo. Eles não são analfabetos exatamente, mas não puderam prosseguir nos estudos e se limitaram ao ensino do primeiro grau.

Desse modo, em seu mestrado o professor Roberto utilizou sua própria história de vida para analisar um conjunto de políticas brasileiras de abrigos e reclusão a partir dos anos 1960 . Assim, o professor Roberto se fez adulto privado da noção de família consanguínea, tendo que reinventar esses laços com colegas de reclusão e com os trabalhadores dessas instituições. Repensando sua trajetória, o professor Roberto avalia o desvio de curso em sua vida a partir do momento em que foi confiscado de sua família pelo poder público, o que revela a falsidade e inconsistência da noção de abandono familiar, que foi cunhado pelo poder público brasileiro e lançado porta adentro de muitas famílias pobres e negras.

Autoditada, Roberto da Silva, iniciou seus estudos dentro da prisão com o propósito de 
melhor compreender seus direitos legais e de outros detentos. Sua trajetória escolar foi bastante irregular e atípica. Cursou até a quarta série sob a vigência da LDB de 1971, dentro de um abrigo em Sorocaba, mas foi transferido para São Paulo antes de concluir o ensino primário e fícou um ano sem estudar. Tentou exames de admissão à quinta série, mas não tendo sido aprovado, parou de estudar aos 16 anos. Viveu uma década e meia em abrigos, nas ruas, até ser encarcerado, e retomou os estudos formais aos 33 anos. Fez supletivo para concluir o ensino fundamental e o médio em apenas quatro meses. Prestou vestibular na Federal do Mato Grosso e ingressou em Pedagogia. Formou-se em 1998, defendeu o mestrado em Educação pela FEUSP em 1998, o doutorado em 2001 e a tese de Livre-Docência em 2009.

Então eu fiz na verdade o que chamava ensino de primeiro grau, segundo grau, graduação, especialização, mestrado e doutorado, eu fiz tudo em onze anos, quando numa trajetória normal se leva vinte e quatro anos pra fazer isso.

O esforço de tentar compreender-se nas experiências de encarceramento possibilitou-lhe considerável refinamento político, de modo que o professor Roberto Silva se tornou uma voz conhecida e atuante Brasil afora mesmo antes de entrar na universidade83. Assim, cursar Pedagogia foi uma estratégia de profissionalização para dar continuidade aos trabalhos que já realizava:

Não pra mim foi uma necessidade, porque aos 33 anos eu já tinha viajado bastante por esse Brasil afora e já havia acumulado bastante experiência na área de trabalho social, trabalho comunitário. Pra mim a opção entrar na universidade era uma questão de profissionalização dos trabalhos que eu já fazia. E além da dificuldade natural de interlocução com órgãos de governo, órgãos da própria sociedade civil, que tem dificuldade de entender a natureza de um projeto, ou conceder um financiamento, se o projeto não é respaldado em uma formação acadêmica. Então essas foram as razões que tornaram inevitável eu ter que ir pra universidade.

A escolha do curso de Pedagogia foi uma aposta no sentido de construir, a partir da educação, caminhos e instrumentos para a transformação social.

Eu conheço suficientemente áreas como o Direito, por exemplo. Meus amigos me cobram porque eu não enveredei pela área do Direito. Mas eu não entendo que o Direito forneça os instrumentos necessários pra gente fazer o que eu acho que tem que ser feito. Eu acho que por meio da Educação, por meio das ferramentas da Educação, o trabalho de transformação

83No programa Trajetórias da TV USP apresentado pelo professor Ricardo Alexino aparece um trecho em que o jovem Roberto da Silva em 1984 vai à TV Cultura no Programa RTC Debate na condição de ex - detento e militante que protestava contra os limites no acesso ao sistema de justiça que a população carcerária enfrentava. Em publicação do jornal Folha de São Paulo (que enviou equipe para acompanhar a defesa de doutorado do professor Roberto da Silva) do dia 23 de setembro de 2001, foi pontuada essa experiência militante do jovem Roberto da Silva: "Na cadeia, começou a estudar Direito por conta própria e tornou-se um autodidata para advogar em causa própria. Teve bons resultados: conseguiu reduzir a pena a um quinto da condenação. Em liberdade, em 1984, ajudou a organizar os que ficaram presos para defender seus direitos. Mas, diante da oposição do Poder Judiciário, resolveu tentar a vida em outra praia". 
social ele é mais impactante, é mais significativo, é mais duradouro do que se poderia fazer no âmbito do Direito, da Psicologia, da História, da Geografia. Então é uma aposta que eu fiz e eu tive que encontrar na área de Educação os caminhos pelos quais trabalhar essa dimensão mais ampla da sociedade que não seja só a sala de aula e a escola. Por isso, meu foco de trabalho, minha vinculação a esse departamento, o estudo de políticas públicas e políticas sociais e as linhas de pesquisa que eu tenho, a educação social e a pedagogia social.

É necessário destacar que além da complexidade da experiência de reclusões em abrigos e prisões, o professor Roberto da Silva é também negro. E na entrevista concedida para essa pesquisa, ele se auto-classificou como pardo. E como se verá ao longo desse capítulo as marcas de raça e origem social têm sido fatores imprescindíveis na atividade docente e construção de sua carreira acadêmica na USP.

\section{Professora Vanderli Custódio:}

A professora Vanderli Custódio nasceu em fevereiro de 1963 no estado do Paraná, sendo filha de trabalhadores agrícolas e negros. Seu pai é de Minas Gerais, mas foi colher café no Paraná, onde conheceu a então futura esposa e mãe da professora Vanderli Custódio. O casal vem para São Paulo na década de 1960, no início do processo de expansão da periferia da cidade, para trabalharem como zeladores de prédios, e instalam-se nas cercanias da rodovia Raposo Tavares. Sua mãe, filha mais velha de uma família de quatro irmãos, ficou órfã muito jovem, não pôde estudar e assim não aprendeu a ler; porém o pai chegou a cursar o ensino primário. A professora Vanderli tem um irmão mais velho, formado em Ciências Contábeis em universidade particular e que atualmente é funcionário do setor administrativo da USP. Por sua vez, a professora Vanderli Custódio fez toda a sua formação escolar em escola pública de ensino municipal e estadual de São Paulo. Considerando que no contexto de sua história familiar, entrar no ensino superior era algo inimaginável, ela declara:

\footnotetext{
Mas a minha mãe foi completamente analfabeta, ela era a mais velha de uma família de quatro irmãos, perdeu a mãe com cinco anos, ela como mais velha, ficou em casa cuidando de todos os outros, foi a única que não estudou. Então ela achava que devia deixar pra nós o mais importante era o estudo. Ela queria que a gente se formasse na oitava série, que era o sonho dela, nem imaginou que a gente fosse continuar.
}

Porque precisava trabalhar, a professora Vanderli Custódio cursou o colegial noturno no colégio Fernão Dias, no bairro Pinheiros. Ainda nos tempos de colégio, surgiu a ideia de fazer Geografia. Essa decisão foi fruto da consideração de alguns fatores, conforme relata: 
opção, porque assim, ou eu entraria na universidade pública ou eu não conseguiria entrar em lugar nenhum, sabia que eu gostava da área de humanas e de ciências sociais. Eu tinha facilidade pra história, pra literatura e pra geografia. Entrar em geografia era mais fácil naquela época do que é hoje e também possibilitava uma diversificação interna que me agradava (...) Aí eu escolhi geografia como minha primeira opção mesmo e escolhi o período noturno e foi um susto, porque eu não esperava entrar. Eu não fiz cursinho, eu fui estudando em casa, pegando apostila de amigos, na medida do possível estudando em casa, aí prestei entrei. Entrei cedinho, tinha 17 anos ainda, no meu primeiro ano que eu fiz 18 e segui.

Interessante observar que entrando na graduação na década de 1980, o relato da professora Vanderli Custódio traz alguns elementos semelhantes ao estudo clássico de trajetórias de docentes e discentes negros/as da UFRJ de Teixeira (2003). Fazendo uma exaustiva pesquisa de fichas de alunos/as matriculados/as nos anos de 1992, 1994 e 1995, e de docentes a partir de indicações de funcionários técnico-administrativos da universidade, a autora constatou que nas áreas de Humanas se concentravam os/as negros/as que ingressavam na universidade pública, e que, dentre os cursos em que havia maior proporção de os/as negros/as, está o de Geografia. O processo de escolha do curso analisado a partir das 70 entrevistas concedidas por docentes e discentes negros/as a Teixeira (2003) traz também e de modo marcante esse fato: qual carreira é possível a partir da história pregressa de escolarização.

Depois de passar no vestibular, a professora Vanderli Custódio narra que no ato da matrícula viveu uma situação interessante: as pessoas na fila apostariam que ela seria ou da Geografia ou da História e o mais interessante é que o comentário ou a aposta veio do fato de ela ser "flagrantemente negra"84, interrompendo a paisagem normalmente branca que costuma configurar o universo de calouros/as. Conforme indica hooks (1999), as pessoas brancas nem sempre estariam atentas à sua pertença racial ou às dimensões de sua branquitude. Uma consequência disso é que em determinadas posições sociais a presença branca é ou passa como a normalidade. Sendo assim, a simples presença de uma aluna negra numa fila de matrícula teria o poder de suspender a tranquilidade de um cotidiano acadêmico, que cria como resposta imediata alguma "alcunha", algum preconceito, admitido ou não:

Agora tem uma coisa, que do ponto de vista de uma pesquisa negra interessa, que é a tal da alcunha. Quando eu entrei, eu tinha feito... eu fazia teatro alternativo com o pessoal de Pinheiros, então eu estava lendo muito Augusto Boal, Teatro do Oprimido, Teatro Alternativo, que é uma coisa toda... Aí arrumei na verdade uma desculpa pra fazer arte, então, se eu passar no vestibular eu vou raspar a cabeça e até a minha madrasta foi comigo e tal, aí eu estava careca quando entrei na Geografia e eu fazia uns brincos e tal, ainda peguei um remanescente daquela coisa meio hippie, então eu fazia minhas roupas com barbante, usava uns vinte colares, umas vinte pulseiras, usava pulseira até aqui, fazia uns turbantes assim deste tamanho e tal, então eu entrei, no primeiro dia que eu vim fazer a inscrição disseram "nossa, é da Geografia ou da História? Fui pra fila da Geografia fazer a

84Esta foi uma definição usada por outra docente entrevistada, a professora Adriana Alves, da Geologia, quando se referia ao fato de que no contexto das relações raciais brasileiras algumas pessoas negras são mais facilmente identificadas como negras do que outras. 
Muito mais do que uma questão de cor da pele, a branquitude e a negritudes ainda que não sejam conceitos análogos, são úteis para compreender os processos de tornar-se branco ou tornar-se negro, e revelam a existência de hierarquias, privilégios e normalidades. Enquanto negritude é uma construção identitária, que envolve agência individual ou coletiva, a branquitude diz de uma estrutura social que envolve os indivíduos não negros, os quais podem se valer com consciência ou não das suas posições de privilégio e de poder. Obviamente, são também conceitos atravessados por outras categorias como classe, nacionalidade, geração, gênero, orientação sexual, em movimentos interseccionalizados. Ser branco e ser negro não são categorias estabelecidas a priori e num país que se proclama mestiço, ser branco funciona "como uma espécie de senha visual e silenciosa para entrar em lugares de acesso restrito" (Sovik, 2005, p. 171). Assim, um insólito corpo negro numa fila de matrícula de ingresso na USP revela a normalidade dos estudantes brancos como corpos raciais que normatizam o perfil racial da Geografia.

\title{
Professor Dennis de Oliveira:
}

O professor Dennis de Oliveira nasceu em outubro de 1963, na cidade de São Paulo, no ano anterior ao golpe militar, e o fato de crescer sob o regime da ditadura certamente configurou sua visão de mundo. Esta informação torna-se relevante em função da militância do professor Dennis de Oliveira na UNEGRO85, entidade do movimento negro, na qual figura como fundador, assim como sua filiação ao Partido Comunista Brasileiro. Sua mãe cursou o primário e seu pai fez o supletivo, o antigo Madureza. A escolha pela carreira de jornalista está diretamente ligada à atuação do pai, que trabalhava como protográfico em grandes jornais como O Estado de São Paulo e a Folha de São Paulo:

\begin{abstract}
Meu pai era protográfico, meu pai. Ele trabalhou no jornal "O Estado de São Paulo", na "Folha de São Paulo" e tal. Ele não era jornalista porque naquela época não tinha o diploma, não tinha exigência. Então ele tinha só o primeiro grau completo, mas aí ele trabalhava com jornalismo. Só que a produção dele era mais na área gráfica, na produção de diagramação, paginação. Eventualmente ele escreveu algum texto, mas não era muito a praia dele não. E devido ao fato de meu pai trabalhar em casa, meu pai trabalhava muito, meu pai trabalhava de noite no jornal e durante o dia ele fazia alguns bicos para manter a família. Ele trabalhava muito em casa, ele fazia isso. Então olhar para o meu pai me
\end{abstract}

85 Segundo Calderano (2002) a UNEGRO (União dos Negros pela Igualdade) do Estado de São Paulo é uma sociedade civil sem fins lucrativos fundada em 1991. Suas origens remonta à cidade de Salvador, ano de 1988, quando um grupo de militantes do Movimento Negro Unificado (MNU) discordavam de alguns encaminhamentos dados por esta entidade. Baseando-se na narrativa do professor Dennis de Oliveira, a autora aponta que o principal ponto de desacordo com o MNU que motivou os militantes a fundarem a UNEGRO foi o fato de o MNU ter se tornado ao longo de sua história um movimento sectário, cuja atuação se assemelhava a um partido político. 
incentivou. E sempre tive uma ilusão que jornalismo era uma forma de mudar o mundo. (risos). Eu tinha um pouco essa ilusão quando eu era jovem, de jornalismo ser uma forma de poder denunciar as desigualdades, de poder fazer isso, tal.

Cursou toda a educação básica em escola pública e entende que era uma escola de qualidade. Não fez cursinho, mas junto com alguns amigos do ginásio organizou um grupo de estudos para prestar vestibular. Desse grupo resultaram três aprovações, sendo ele o único a ingressar numa universidade pública. $\mathrm{Na}$ sua família, uma irmã conseguiu fazer faculdade particular, quando o pai trabalhou na gráfica de uma instituição de ensino superior privado e conseguiu uma bolsa pra ela. A segunda irmã a fazer ensino superior o fez muitos anos depois de completar o segundo grau, mas a maioria de seus familiares não cursou ensino superior:

Então a gente foi muito criado nesse universo de leitura e meu pai era muito exigente, ele era assim, era quase que uma obrigação nossa ir bem na escola, ele era muito rígido nisso. Então é por isso que todo mundo lá em casa foi bem, conseguiu, teve um bom desempenho escolar. Aí de acordo com a situação de cada um, uns foram para a faculdade, outros não foram, a maioria não foi. Na verdade quem foi para a faculdade direto, depois do ensino médio foi eu e minha irmã mais velha. Minha irmã mais velha ela foi, ela fez a faculdade Objetivo, que hoje é UNIP, mas fez também... meu pai trabalhava nessa época na gráfica, fazia as apostilas do Objetivo, conseguiu bolsa pra ela e eu entrei na USP depois (...)

Uma questão levantada por Teixeira (2003) refere-se ao porque de alguns/mas negros/as em condições sociais semelhantes entrarem no ensino superior e outros não. O que permitiria que alguns passassem pelo estreito gargalo, sobretudo do ensino superior público e a maioria não? Não são questões de resposta fácil, porém a autora oferece uma ideia da importância das redes de solidariedade e apoio, que na trajetória do professor Dennis, pode ser uma explicação possível. Tem-se aqui a importância da figura do pai, cuja profissão de protográfico tornou possível desde o acesso a livros à escolha do curso de Jornalismo; bem como a rede de amigos que com o propósito de ingresso no ensino superior se apoiaram na preparação do vestibular. Mas, conforme ressalta Teixeira (2003), as redes são caracterizadas também por fragilidades como a dependência das relações construídas ao longo da vida. Assim, a possibilidade de ingresso no ensino superior e ascensão social e econômica da população negra fica comprometida enquanto projeto coletivo.

Tendo estudado em escola pública e de bairro durante toda a vida até a entrada no ensino superior, o professor Dennis de Oliveira conta que não vivera os desafios de ser negro na escola pública, o que só veio acontecer quando ingressou na USP: “O que acontecia é na verdade eu me senti negro na universidade. Como a minha pele é mais clara, eu achava que não tinha nada a ver." 


\section{Professora Roselane Gonçalves:}

A professora Roselane Gonçalves nasceu em maio de 1965, em Barra Mansa. Sua mãe cursou o ensino fundamental no sistema denominado Mobral e seu pai fez o equivalente ao Ginásio. O Mobral foi a sigla utilizada para designar o Movimento Brasileiro de Alfabetização, instituído em 1971 durante o regime militar, com intuito de alfabetizar jovens e adultos.

Do conjunto de docentes entrevistados/as, a professora Roselane Gonçalves foi a única que fez graduação em instituição de ensino superior privado. Na sua família, uma irmã cursou até o ensino médio e a outra também fez graduação paga, com a mesma rotina de dupla jornada de trabalho e faculdade. A professora Roselane Gonçalves, graduada em Enfermagem, narra que o processo de escolha do curso dependeu menos das dúvidas quanto à sua vocação profissional, e mais das opções de faculdades particulares que ofereciam formação na área além de de suas possibilidades de pagar pela formação:

\footnotetext{
Tive que trabalhar. Inclusive eu esperei mesmo esses dois anos pra eu decidir aonde eu iria prestar, porque de fato na época nem passava pelas nossas cabeças tentar o ensino público no vestibular, porque era muito mais difícil do que é hoje. Então eu teria que pagar os estudos. Então eu fiquei pensando, será que eu vou dar conta, que escola que vai dar pra que eu concilie trabalho e estudo, enfim. Eu tive que trabalhar e pagar os estudos e até uma certa data, ano de graduação que eu
}

A escolha do curso de Enfermagem se deve em boa parte à experiência de trabalhos com a Pastoral da Juventude da Igreja Católica onde a professora Roselane Gonçalves teve envolvimento com obras sociais e contato com a área de cuidados e de assistência:

Eu sempre gostei dessa área de cuidado, de cuidar das outras pessoas, trabalhava paralelamente em pastoral, pastoral da juventude, na igreja católica e a gente tinha algumas obras sociais. Então me identificava um pouco com isso e fiquei dois anos para decidir mesmo que área que eu queria e defini que era Enfermagem e acho que acertei.

A escolha pelo curso de Enfermagem está historicamente associada a alguns traços de raça e de gênero no ensino superior brasileiro. Segundo Teixeira (2003), considerando alguns padrões de distribuição dos grupos de cor nas carreiras universitárias, na área da saúde o curso Enfermagem aparece como carreira viável para um maior número de estudantes negros, em função da combinação de fatores como status e nível de concorrência no vestibular. A carreira de Enfermagem tem menor concorrência dentro da área da saúde, comparada a outras carreiras, como Medicina, Odontologia, Psicologia, etc.

As questões de raça e gênero na escolha do curso de Enfermagem na trajetória da professora Roselane Gonçalves pavimentaram uma via já delimitada por questões de classe. Ela relata qual foi a importância de cada uma dessas categorias no modo como pensa a si mesma e 
como tem construído a sua carreira acadêmica. A compreensão de sua condição de classe configurou a escolha do curso numa faculdade particular e a obrigatoriedade de trabalhar durante a graduação; ainda que um pouco mais, os debates sobre gênero têm sido fundamentais na sua carreira de enfermeira e pesquisadora em Obstetrícia, como será melhor considerado mais adiante nesse capítulo. E o processo de se pensar em termos raciais construído ao longo da vida, revela também algumas dinâmicas das relações raciais brasileiras nas últimas décadas:

\begin{abstract}
Negra, agora, talvez depois de tantas mudanças nos discursos e tal, mas eu sempre preenchia como parda, embora minha certidão de nascimento esteja como branca (risos). Mas eu sempre me auto identifiquei como parda e hoje se eu tivesse que responder, se eu tivesse essa alternativa, né, em algum formulário e tal, seria negra, preta, não sei como definir. Então, na verdade tem a ver com a forma como você também vai prestando atenção nas histórias dos outros e a sua e se colocando nesse contexto. (...) Mas pra mim, eu sou filha de um homem branco com uma mulher negra e na minha casa sou a mais branca (risos) entre aspas e eu tenho uma irmã do meio que é bem negra e uma outra intermediária. Então a gente sempre conversava mesmo na nossa casa, "mas o que você é, na verdade?". Lá em casa eles me chamavam de branca azeda, porque além de ser a mais nova, mais xexelenta, então eu carreguei muito tempo essa coisa, tanto que uma época, quando eu era criança, minha mãe dizia que eu falava "será que eu fui adotada, por que só eu que sou a mais branquinha?". Mas o tempo foi passando, o cabelo sempre foi crespo e a minha filha já nasceu mais branca, porque eu casei com um homem branco. Então a gente ficava nessa conversa, num contexto mais familiar, mais privado. Publicamente, eu acho que eu fui acompanhando as discussões a respeito dessa denominação, o que você é, como você se declara, a questão da inclusão mesmo, das, das cotas. Eu acho que é muito recente essas coisas na cabeça começaram a tomar uma forma e um sentido diferente, porque de fato, eu nunca, talvez por não ter vivido nenhuma situação de constrangimento e de exclusão explícita por conta da minha raça, talvez isso não tenha tido um peso tão grande assim pra mim.
\end{abstract}

Filha de um casamento inter-racial, com pai branco e mãe negra, a herança racial da mãe foi mais marcante na vida das irmãs e muitas vezes foi uma questão indefinida na vida da professora Roselane, que chegou a ser registrada em sua certidão de nascimento como branca. Tal fato se coaduna com o sistema de classificação racial brasileiro em sua complexidade, ambiguidade e fluidez; decorrente da sofisticada combinação de traços de aparência como cor da pele, formato de nariz, lábios, tipo e cor de cabelo, origem regional e social, grau de instrução, renda, considerando assim a aparência num sentido amplo e geral, conforme indicam Rocha \& Rosemberg (2007).

Considerando que as relações raciais brasileiras são também marcadas por hierarquias, declarar se negro/a caracteriza-se como um ato político que contraria a tendência ao branqueamento nas relações raciais brasileiras. Assim, assumir a negritude pode passar por um processo de reflexão e afirmação dos significados de ser negro na sociedade brasileira, mas pode estar associado também ao fato de que, conforme indicam os últimos censos demográficos brasileiros, está em curso no Brasil um sensível aumento no conjunto da população que se auto classifica parda, migrando da categoria branco. 


\section{Professor Emerson Inácio:}

O professor Emerson Inácio nasceu em fevereiro de 1973. Tendo feito todo o ensino fundamental em escola pública, recorda bem como foi sua educação básica no estado do Rio de Janeiros dos anos 1980:

Sempre estudei em escola pública. Só entrei na escola particular pra trabalhar, já formado, já quase me formando na graduação. Sou resultado da política dos anos 80 no Rio de Janeiro, que embora não houvesse professor, que muitas vezes não havia e ... muita greve, mas era uma espécie de... quer dizer, hoje em dia já não vejo assim, mas me deu muita impressão de um pouco pão e circo, porque nos levavam... Darcy Ribeiro era o secretário de educação, enchia os ônibus da companhia pública de transporte e levava para o Maracanã, Teatro Municipal, quer dizer, dando uma outra oportunidade de acesso cultural às escolas de áreas mais carentes e na segunda-feira, como não tinha professor, enchiam a gente de merenda. Levavam a gente pra, mandavam a gente pra casa com dois, três litros de leite, mais não sei quantos de comida dentro da bolsa.

A decisão de tentar entrar na universidade foi uma tentativa de não seguir um curso profissional de muito trabalho e pouca remuneração bastante comum em sua família. Foi o primeiro e até a ocasião dessa entrevista em 2011, o único da família a ingressar na universidade, fazer graduação, especialização, mestrado e doutorado. O curso de Letras não foi a primeira opção pensada pelo professor Emerson Inácio, que tentou alguns concursos de vestibular considerando também as possibilidades de acesso e permanência na graduação:

Primeiro fiz opção por Direito, prestei vestibular pra Direito três vezes, não passei. Eu acho que numa das vezes eu até passei, mas eu já estava tão de saco cheio de vestibular, que eu não fui nem lá conferir a lista. Concomitante sempre havia segundas opções, passei uma vez pra Filosofia, só que não era perto de casa, não dava pra ir, eu morava em São Gonçalo, região metropolitana, tinha que atravessar a ponte Rio - Niterói, pra estudar na UERJ, não dava. E fui fazer Letras justamente porque, pela questão da proximidade e porque eu achava, eu tive professores interessantíssimos de português e de literatura. Eram tão interessantes que me fizeram pensar: pô deve ser uma coisa bem, bem legal.

O fato de ter ingressado na universidade pública fez dele um referencial para a família, como estímulo e como cobrança para que o desempenho dos/as sobrinhos/as possa ser melhor, pois a universidade se abre como possibilidade no horizonte da formação escolar familiar, embora alguns processos acadêmicos ainda possam soar pouco compreensíveis ou assustadores:

Acredito que em breve a gente vai ter mais uns dois ou três fazendo faculdade, ainda que eles já suassem muito, essa figura de alguém que fica ausente durante muito tempo porque está escrevendo dissertação de mestrado, tese de doutorado, isso meio que assusta, particularmente os meus sobrinhos e alguns primos, de quem eu sou muito próximo.

O impacto de ser o primeiro da família a entrar na universidade, soma-se a outros importantes deslocamentos e novas provocações: o professor Émerson Inácio trouxe da universidade, bem como de sua militância em cursinho populares, mais especificamente o 
EDUCAFRO, a discussão sobre os significados de ser negro/a em outros termos que provocaram reconsiderações no modo como se pensa o pertencimento racial na cultura familiar. Assim, ele tornou-se uma referência também nesse sentido, de trazer outro olhar para a questão, com um posicionamento marcadamente antirracista. Decorreram desse processo questionamentos e incômodos no ambiente famíliar, conforme transcrito a seguir:

\begin{abstract}
Na minha formação o fato de ser negro foi mais resolvido e primeiro resolvido, porque eu venho de uma família com uma nuance, digamos assim, étnica muito vasta. Meu avô negro, filho de escravos, minha avó, filha de branco português com indígena e havia uma certa distinção na família assim, os netos mais pretos eram pior tratados do que os netos mais brancos. Toda a política do esticamento do cabelo, do embranquecimento. Minha avó dizia pra mim "não, você não vai namorar menina preta não, porque você tem que melhorar a família". Coisas do tipo. Então eu cresci com essa consciência muito, digamos assim, aguçada, de que o fato de ser negro era um espaço, configurava um certo espaço de diferença que no meu caso eu aprendi a usar a meu favor, até porque a coisa de ter experimentado o movimento eclesial de base, em que essas identidades, essas expectativas eram muito vivenciadas também me ajudou nesse processo. (...) Porque na minha família há um problema, por exemplo, se eu me referir a determinados tios ou tias como negros... (...) eu na melhor das intenções dei uma boneca negra pro filho do meu primo e digo pra ele todo feliz da vida, cumprindo a minha tarefa cidadã que eu estava dando para a filha dele uma boneca com a qual ela pudesse se identificar, que não era magra, nem loira e nem peituda, nem cumprida toda vida, mas uma boneca com a cara dela e ele responde pra mim "mas minha filha não é preta!". O que a gente faz? Eu não vou absolutamente estabelecer a política draconiana de pegar no colarinho e repete comigo 'sua filha é preta sim!' Não vou fazer isso, é uma criação de consciência que talvez a própria vida vá criar nessas pessoas, ou determinadas situações que as obriguem a ter.
\end{abstract}

A presença de estudantes negros/as no ensino superior e, sobretudo, na universidade pública traz mudanças não apenas no cotidiano da instituição acadêmica, quanto na vida familiar desses/as estudantes. A fala transcrita acima sugere que nas trajetórias de acadêmicos/as negros/as que tiveram participação em grupos de debates sobre relações raciais nas universidades públicas, têm trazido à tona experiências de mudanças, deslocamentos e às vezes distanciamentos entre acadêmicos/as negros/as e seus familiares em função dos modos como o debate racial é colocado. Esse parece ser um aspecto das trajetórias de acadêmicos/as negros/as ainda pouco estudado, visto que as pesquisas têm trazido com mais frequência debates sobre a importância do apoio familiar no processo de ingresso e permanência sobretudo de estudantes pobres e negros/as na universidade pública nos últimos anos. Porém, os efeitos no seio familiar da adesão desses/as discentes e docentes a um debate político acadêmico antirracista devem ser melhor investigados, pois nem sempre essa adesão é acompanhada de compreensão e/ou cumplicidade familiar. Faz-se necessário um conjunto maior de investigações no sentido de compreender como ocorre a mudança geracional na classificação racial e uma melhor verificação do processo de politização racial vivida pelo/a discente na universidade pública, e de que modo essa experiência dialoga com a socialização racial nas famílias negras brasileiras. 


\section{Professora Maria Letícia Nascimento:}

A professora Maria Letícia Barros Pedroso Nascimento nasceu em 1956 em Campinas. Ela vem de uma casa de professores que migraram para o funcionalismo público. Sua mãe exercera o magistério em Minas Gerais e seu pai no Espírito Santo:

Ela era de Minas e ele do Espírito Santo e eles acabaram ingressando no serviço público, quando eu nasci eles já eram do serviço público. Mas era uma casa de professores, então todo mundo lia muito, lia jornal, era uma coisa constante, se escrevia muito.

Filha única de um casamento inter-racial, o magistério aparece na vida de seus pais com implicações de raça e gênero: de um lado como possibilidade de ascensão para o pai que era negro, como tentativa de se firmar intelectualmente e para sua mãe que era branca, o magistério era uma das poucas possibilidades de formação profissional para muitas mulheres brasileiras na primeira metade do século passado. No caso da relação entre população negra e o exercício do magistério é possível pensar, conforme indica Dávila (2006) num processo histórico de afastamento da população negra desse ofício na primeira metade do século passado. No caso das mulheres brancas, o magistério foi uma importante porta de entrada para a vida pública; ainda que o objetivo não fosse a emancipação intelectual, econômica e social feminina, mas manter a mulher vinculada à vida e cultura domésticas, conforme indica Besse (1999). Embora se tratasse de uma situação contraditória, em que se diz que não haverá ruptura, mas sempre há alguma (salário, independência, circular pela cidade etc).

Assim, a experiência no magistério para o pai e a mãe da professora Maria Letícia dizem um pouco da história dos significados dessa profissão para as populações negra e feminina nesse momento da história da educação brasileira:

\footnotetext{
O que aconteceu, os ministérios abriram concurso e o papai se engajou no Ministério da Fazenda, naquela época né. Então ele deixou de lado o magistério. Ficou no magistério enquanto ele morava em Vitória, depois que ele mudou pro Rio de Janeiro e aí ele não exercia mais o magistério. Mas naquela época o magistério pros homens ainda era prestigioso. Acho que o papai foi por esse caminho por que era prestigioso. A família da mamãe era o contrário. A família da mamãe era uma família que não tinha problemas financeiros. Meu avô era dono de terra no sul de Minas, tinham fazenda, minha mãe cresceu na fazenda, eram 11 irmãos, mas tudo bem. Família tradicionalmente das professoras. Muitas professoras, quase todas as mulheres são professoras, os homens, todos advogados, engenheiros, sabe assim. Meu avô não tinha muito estudo não, meu avô era viajante, ele tinha as terras dele, era sujeito empreendedor. E todo mundo pode estudar, só não estudou quem não quis. (...) Uns tios que viraram militar, Tive um tio que foi pra um convento estudar Direito, porque minha tia não tinha dinheiro, enfim. Então era uma outra história. Então ser professor pra minha mãe era quase que uma decorrência natural. Não tinha como não ser professora. Mas ela odiava ser professora. Aí ela fez um acordo lá com o meu avô e ela foi pro serviço público. E aí foi quando ela e meu pai se conheceram. Mas pro papai era uma época em que era prestigioso ser professor né. Era quase como ter faculdade naquela época, 1930 e alguma coisa, imagina. Provavelmente tinha acabado de surgir tudo isso. Então era uma coisa que dava prestígio.
} 
Crescer numa família inter-racial possibilitou à professora Maria Letícia viver o contraste rico/pobre e branco/negro. De um lado, pela família materna a experiência de ser branco de classe média; por outro, o pai da professora Maria Letícia, negro das camadas populares, apresentou claramente um projeto de ascensão social, dentro de suas possibilidades: magistério, o funcionalismo público e o casamento. Mas a efetivação desse projeto não foi suficiente para apagar as marcas de sua origem racial:

\begin{abstract}
Papai teve muitas dificuldades por ser negro e ocupar altos cargos, ele acabou ocupando uns cargos, lá na Fazenda... Eu com metade do que ele passou, eu já teria desistido... Porque ele era homem, se fosse mulher seria mais provável assim. Mas ele era muito envolvido, muito metido também, competente, nossa... Mas passar metade da vida dele no Ministério da Fazenda... Nossa que horrível... Assim, de discriminação total, colocarem coisas na mesa dele, sabe, um horror, ele sofreu muito por ser negro. Mas, enfim, ele enfrentou tudo né, ele achava que tinha mais é que dar conta... Mas toda essa preparação foi interessante. Todo mundo achava que o papai tinha feito Direito, porque ele trabalhava com legislação tributária, enfim, ele pôs os irmãos todos fazendo faculdade né, nem todos... Mas eu tenho tio advogado, tio contabilista, que fez Ciências Contábeis, essas coisas, mas ninguém tão prestigioso. A família da minha mãe era diferente da família do papai. Minha mãe era de uma família de classe média alta. Meu pai era de uma família de classe popular. Aí, na verdade é o papai, é aquela história do trabalho e vai, vai fazendo as coisas. E aqui a família da minha mãe tinha umas formações em ensino superior, digamos assim, mais prestigiadas. A família do papai não foi tão prestigiada assim né, carreiras tão prestigiadas, mas, era o que ele tinha pra fazer né. Ele achava que ele tinha mais é que ter um emprego que fosse bacana. Por isso que ele fez o magistério. Era uma maneira de lidar intelectualmente com as coisas.
\end{abstract}

Um grande desafio diante da população negra e pobre que empreende algum projeto de ascensão econômica e social é que a família nem sempre consegue acompanhar o processo. Costuma-se criar uma lacuna entre a família e o sujeito em ascensão, ameaçando assim a consistência desse projeto. Diante da relativa ausência de pesquisas sobre classe média negra Figueiredo (2004) aventa a hipótese de que a pequena parcela da população negra neste estrato social seria composto majoritariamente por indivíduos da primeira geração de ascendentes e que não herdaram patrimônios e nem foram socializados em ambiente de classe média, ou construíram esse habitus de classe ${ }^{86}$. Seria essa uma fração da classe média composta por "um grupo subalternizado, instável, incipiente e que encontra muitas dificuldades em manter-se na posição de classe" (Figueiredo, 2004, p.203). No processo de tentar ascender à classe média, o pai da professora Maria Letícia empreendeu o múltiplo esforço de trazer consigo toda a família para o projeto de ascensão, possibilitando a todos a formação superior, embora ele mesmo não a tenha feito. Assim, considerando a formação superior como via possível de ascensão econômica e social, a universidade na trajetória da professora Maria Letícia não foi um elemento completamente

86 A autora define classe média a partir de alguns critérios objetivos tais como, escolaridade, ocupação e renda. Em texto anterior ela problematiza o uso da noção de classe média quando aplicada aos negros e da expressão classe média negra Ver: FIGUEIREDO, A. Novas elites de cor: estudo sobre os profissionais liberais negros de Salvador. São Paulo, Annablume/UCAM, 2002. (Figueiredo, 2004, p. 203-204) 
inesperado, como apresentado na maioria das trajetórias de docentes aqui considerados/as

De certo modo, toda a formação escolar da professora Maria Letícia esteve voltada para a entrada no ensino superior, e foi dividida em escolas privadas e públicas. Ela viveu parte da sua infância em São Paulo e começou sua vida escolar numa escola de freiras, que era uma espécie de semi-internato no bairro Santa Cecília, em Higienópolis. Mudou-se de cidade, para o interior do estado onde fez o resto do primário e parte do ginásio. Retorna para São Paulo e termina o ginásio em escola particular. Conta que era uma escola de freiras "semi pública" e cuja mensalidade era de baixo custo:

Essa escola de freiras era semi- pública, eu lembro que ela era super baratinha, devia ser conveniada, hoje em dia eu suponho que fosse. E aí eu vim fazer em uma escola particular. Meu pai ficou muito bravo com minha mãe, "porque que eu fui pra escola particular", escola pública era boa na época. Mas enfim, e gente voltou do interior muito em cima da hora, enfim, não sei, aí eu fiz, o ginásio numa escola particular. E quando eu terminei o ginásio, claro eu fui pra uma escola pública, porque não tinha sentido não fazer.

Assim, fez o colegial em escola pública e em período noturno para poder dedicar-se a outras atividades durante o dia, como inglês, computação e teatro. No último ano de colegial, em 1973, começou também a fazer cursinho, mas interrompeu o inglês. Prestou vestibular para Jornalismo na ECA, pois conforme relata, relutou um pouco até decidir-se por Pedagogia. Mas não foi aprovada nesse vestibular. Passou os dois anos seguintes em processo de escolha do curso e de negociações nesse sentido com seu pai, que tinha como meta a entrada da filha no ensino superior:

\begin{abstract}
Aí foi aquela situação, meu pai ficou chateado, desesperado, porque ele achava que eu tinha que entrar pra faculdade. Eu queria fazer teatro, em paralelo, a essa história toda eu fazia teatro, teatro infantil. E o meu pai não queria que eu fizesse teatro porque filha dele não podia dançar, não podia cantar, não podia nada. Meu pai era super fechado pra essas coisas, muito rigoroso. Aí eu fiquei um ano, o ano de 74, eu fiquei ao léu, fazendo teatro. Aí em Agosto de 74 eu voltei pro cursinho. Aí eu fiz um combinado com meu pai, porque o papai queria que eu fizesse ou medicina ou direito, era o que ele achava que eu devia fazer, embora ele achasse que eu podia ser professora também, porque ele achava que as pessoas não ficavam sem emprego nestas três carreiras. Medicina eu nunca quis fazer, Direito eu nunca me interessei também. Aí eu fiz um combinado com ele: "olha, seguinte: você me deixa fazer teatro e eu presto pedagogia". "Tá bom". Mas eu dei uma enrolada no pai, porque eu não tava a fim de fazer pedagogia, de ser professora. Mas aí nesse meu tempo eu comecei a fazer teatro infantil e me engajei, voltei pro cursinho, foi em 75 que eu voltei pro cursinho. 74 eu passei o ano fazendo nada assim, só teatro né, que pra mim era muito, mas pra minha família era nada. Em 75, entrei no cursinho em Agosto, fiz cursinho e ingressei na Pedagogia, mas porque eu já fazia teatro infantil, aí eu falei “Ah bacana né, porque aí eu vou entender melhor as crianças”. Escrevi peças de teatro infantil, sabe, era uma coisa que me interessava, a dramaturgia infantil.
\end{abstract}

Apesar de ter começado o curso de Pedagogia na USP, a professora Maria Letícia cogitou a possibilidade de fazer Jornalismo na Cásper Líbero, mas um acidente que culminou com o falecimento de sua mãe a fez retomar o curso de Pedagogia, onde tem construído toda a sua carreira acadêmica. A professora Maria Letícia foi quem mais trouxe o processo de escolha do curso como a 
tentativa de privilegiar a vocação, algo que estivesse além de uma simples escolha profissional, mas que levasse em conta seus desejos e a sensação de conforto dentro de uma carreira. Considero interessante destacar esse aspecto da trajetória da professora Maria Letícia, pois foi a única docente negra que relatou a experiência de ter feito cursinho pré-vestibular. Porém, ter nascido numa família de classe média e ter vivido mais confortavelmente uma vida de setores médios desde a infância não blindou a professora Maria Letícia de conhecer alguns dilemas sociais e econômicos bem semelhantes aos de outros/as docentes negros/as entrevistados/as, como se verá mais adiante.

A trajetória da professora Maria Letícia é marcada por processos de dualidades e de pertencimento a dois universos paralelos. De um lado, significados sobre ser negro/a introduzidos pelo pai negro e seu esforço de ascensão social, um percurso que lhe exigiu oferecer respostas ao racismo cotidiano; e de outro, as condições de vida da sua família materna, plena dos significados de ser branca e de classe média.

\begin{abstract}
Eu sempre pertenci a dois mundos, o mundo da família da minha mãe e o mundo da família do meu pai, que eram mundos que se entrecruzavam. Então eu sempre transitei nos dois. Então eu tenho um pertencimento étnico, eu sou negra, eu não tenho a menor dúvida disso, mas eu não tenho a menor dificuldade de lidar com o branco de igual para igual, porque eu nunca tive esse tipo de enfrentamento com a família da minha mãe, por exemplo, eu nunca tive. Eu sempre brinquei com as minhas primas brancas quando eu era pequena. Eu vim me dar conta que eu não era branca aos 10 anos de idade. Ou que o mundo era branco e preto, amarelo e vermelho, mas que era basicamente branco e preto aos dez anos de idade. Então eu sempre convivi, viajava para um canto, viajava para outro, ia pra casa de um, ia pra casa de outro, sabe, nunca houve assim, uma tia que discriminasse o meu pai, talvez tenha até tido assim, mas do ponto de vista do meu cotidiano de infância, eu nunca deixei de brincar com ninguém por conta da cor da minha pele quando eu era pequena. (...) Eu nunca fui uma criança negra, por esse contexto. Eu nunca me senti uma criança negra. Eu era uma criança que brincava com outras crianças, que tinha primos. Eu me tornei negra a partir das questões que eu fui enfrentando na adolescência. $E$ hoje em dia eu sou negra, não só eu, mas eu e meu filho, sabe? Faço parte disso, brigo por isso, abro espaço pra isso, mas de alguma maneira não vejo sentido em fechar meu estudo em relação a isso, maluco isso né? Mas acho que é trajetória mesmo. E acho que essa coisa da família mista que dá esse tipo de possibilidade, não sei. A minha família me deu, né. Mas eu acho que sou muito atípica nesse ponto de vista. Eu não tenho digamos assim, uma infância, papai teve, difícil. Não, imagina... Tinha um quarto só pra mim, vivi numa classe média muito boa. Nunca fui uma pessoa... Tive sim, tive épocas difíceis sem dúvida, tive que ter um trabalho muito puxado pra sobreviver, mas minha infância foi muito tranquila. Comia fora, em restaurante, viajava. Eu nunca tive restrição desse ponto de vista... Sempre fui classe média. Então acho que isso dá uma diferença, família mista de classe média talvez dá uma diferença... Não sei, Viviane, são coisa que estão postas aí. Mas eu gosto de ser negra, eu acho que é bacana. [grifos meus]
\end{abstract}

A percepção do eu racial da professora Maria Letícia é contígua à sua percepção de classe, pois ela se percebe classe média antes de se entender como negra. Desse modo o processo de perceber-se negra relatado pela professora aponta na direção do tornar-se negro analisado por Souza (1983). Na concepção da autora, no processo de ascensão social o negro era compelido a embranquecer-se anulando sua negritude. Assim, tornar-se negro seria o processo de suplantar a tendência ao embranquecimento, afirmando sua consciência de raça. Trabalhando com a noção de 
“identidade étnica tardia”, Figueiredo (2004) também indica que no processo de ascensão social, a população negra desenvolveria e assumiria sua identidade étnica, contrariando a suposta tendência de embraquecimento, como propõem interpretações clássicas sobre a ascensão negra, a exemplo de Thales de Azevedo. Tal "identidade étnica tardia” é também uma resposta ás discriminações vividas por negros/as em ascensão e que tenderia a ser maior, quanto mais alto for o estrato social.

De modo geral, na trajetória da professora Maria Letícia, essa experiência de hibridismo de classe e raça configurou as experiências escolares, de gênero e classe. A professora Maria Letícia pôde transitar entre a possibilidade de não ser negra, numa infância protegida das intempéries da discriminação racial; e ser negra a partir da adolescência, tomando conhecimento também dos desafios de ser mulher:

$\mathrm{Na}$ verdade durante a adolescência, pra mim, a partir dos 10 anos, eu tive algumas dificuldades de discriminação mesmo, como eu digo a você. Principalmente por parte do porteiro de prédio, motorista de ônibus. Aquela história de ir visitar uma amiga e o sujeito mandar entrar por trás, né, pela entrada de serviço do prédio. E que isso me incomodava um bocado. Afinal de contas eu não sabia por que eu tinha que entrar por trás e achava que ninguém tinha que entrar por trás. Uma vez eu estava no ônibus, eu assumia muito a questão da negritude, essa coisa de deixar o cabelo, quando eu era estudante eu tinha os cabelos enormes assim. E uma vez um sujeito, um cobrador de ônibus queria por fogo no meu cabelo no ônibus, imagina! Ele pegou um isqueiro pra queimar o meu cabelo! (...) Então eu sempre tive discriminações desse ponto de vista, onde as pessoas achando que podem mandar na sua vida porque você é negra. E eu comecei a pensar mesmo nesta questão foi a partir da adolescência. Por conta dessas dificuldades do cotidiano que eu achava que era muito complicado. Mas quando eu fui fazer teatro, isso era uma questão que me pegava, porque quais os papéis que eu podia fazer ou não. (...) Então eu sempre transitei muito né. Já tive dificuldades do ponto de vista dessa coisa de, em alguns momentos de, me sentir deprimida de dizer: "ai meu Deus do céu, negra, mulher, pobre!". Sabe aquelas coisas que você fala assim "Ai, que eu to fazendo, e só brigo na vida".

Mesmo com a experiência de classe média, a professora Maria Letícia não foi poupada de experiências raciais comuns a negro/as de estratos sociais mais baixos; pois "ao que parece, pertencer à classe média, longe de ser um antídoto contra a discriminação e o preconceito racial, expõe as pessoas negras a situações de maior vulnerabilidade, uma vez os espaços sociais que convivem são majoritariamente freqüentados por brancos" (Figueiredo, 2004, p. 208-7). 


\section{Professora Adriana Alves:}

Nascida em Diadema/SP em agosto de 1980 a professora Adriana é a mais jovem do conjunto de docentes entrevistados/as. Na ocasião da entrevista, em 2011, ela estava no primeiro ano de contratação docente. Seus pais cursaram até a quarta série do ensino primário e sua mãe tentou voltar a estudar depois de aposentada, mas não deu sequência. Dos irmãos por parte de pai, um tem o primeiro grau completo e o outro quase finalizou o ensino médio, porém interrompeu a formação no segundo ano. Desse modo, a professora Adriana Alves foi a primeira da sua família a ingressar na universidade. Sua irmã gêmea tem graduação e mestrado em Educação pela USP, porém seu ingresso como estudante foi um pouco mais tardio. Desse modo, ambas tornaram-se referência na família quando o assunto é formação escolar:

\footnotetext{
É, então, a gente é usada como exemplo só para as crianças, na verdade. O povo fala quando tem alguém que não gosta de estudar, olha lá a Adriana e a [irmã] estudaram, por isso que elas têm o que elas têm hoje, então se você não estudar você não vai ser ninguém, este tipo de coisa. Mas... de novo, é um misto de admiração com ressalva, porque é inevitável, quem disser que não se distancia das pessoas da família quando passa a estudar mais e passa a entender um pouquinho mais do mundo, está mentindo, porque as discussões, por exemplo, a [irmã] que estuda raça e eu discuto muito isso com ela, até pra dividir as vivências e tal, esses assuntos em casa são tratados como tabu, a gente já é vista como chata, de ser intolerante porque vê as coisas já de um modo um pouquinho mais intelectualizado do que o restante da família. Mas em termos de criação dos pequenos, a gente tem influência direta na criação só de uma das sobrinhas, que é a que mora com a minha mãe, que morava comigo e com minha irmã enquanto eu estava junto com elas, que agora eu não moro mais lá. Mas essa tem desde pequena embutida a ideia de que se ela não estudar ela não tem chance de ser alguém. O meu irmão tem muitos filhos, ele tem seis filhos no total, e essa é a única que realmente vai levar adiante o que a gente acha, que ela está com quatorze anos ainda, que vai levar adiante os estudos. Que a mais velha dele, por exemplo, acabou o segundo grau e acha que terminou os estudos, essa é a fala dela. Então, apesar do impacto ser grande, eu acho que ele não é tão decisivo na vida da nova geração dos meus sobrinhos.
}

A professora Adriana Alves, assim como o professor Émerson Inácio levantam a questão do distanciamento da família que a vida acadêmica exige. Tal distanciamento não é exclusivo às trajetórias de acadêmicos negros/as, mas é parte constitutiva da atividade intelectual. A novidade, creio, deve se ao fato de que nas famílias negras, os ritos da vida acadêmica costumam ser parte de um universo distante, passível de consideração apenas quando um integrante da família desbrava tais desconhecidas terras. Historicamente, conforme indica Paixão et. al (2011) percebeu-se um quadro de baixo ingresso da população negra nas universidades públicas, e dessa forma as famílias negras têm estado alijadas desse universo e de seus ritos, até que um membro se arrisque, mesmo sem compreender completamente do que se trata, de modo que a universidade torna-se uma descoberta direta para quem entrou na universidade e indireta para quem vai acompanhando, mesmo que à distância, esses elementos não óbvios da vida acadêmica. Para quase totalidade do 
caso do universo dos sujeitos de pesquisa considerados aqui, desde Kabengele Munanga que ingressou na universidade nos anos 1960 `a Adriana Alves que ingressou no início dos anos 2000, a vida da universidade se revelou como grande novidade no conjunto dessas famílias. Nesse conjunto de entrevistados/as, se um ou outro pai ou mãe dos/as entrevistados/as chegaram a desejar o ensino superior como melhor educação para os/as filhos/as, como relatam a professora Maria Letícia e o professor Dennis de Oliveira; isso não implica que de fato tivessem grande familiaridade com a vida acadêmica, porque nenhum deles chegou a cursar uma graduação e aqueles/as cujos/as irmãos/as possuem formação superior o ingresso se deu no sistema privado, à exceção da professora Adriana Alves, cuja irmã gêmea também entrou na USP.

A professora Adriana Alves fez toda a sua formação em escola pública, até a oitava série em colégio estadual. Ao final da oitava série, prestou seleção para na Escola Técnica Industrial Lauro Gomes, antes ETI e agora ETEC ou Escola Técnica Estadual, integrando o grande conjunto de ETEC's do estado de São Paulo. Fez curso técnico noturno, mas a formação técnica só era assegurada ao final do quarto ano e em três completava-se o ensino médio. Foi o caso da professora Adriana Alves, que ao final do terceiro ano tentou vestibular para Geologia na USP e foi aprovada. A escolha da carreira também seguiu a regra dos/as demais entrevistados/as de combinação entre qual curso seria possível passar numa universidade pública, considerando a história pregressa de formação na escola pública, embora as escolas técnicas sejam consideradas de qualidade superior ao conjunto das escolas públicas. De modo que a nota de corte da Geologia foi também um fator atraente para a então candidata Adriana Alves:

\footnotetext{
$\mathrm{Na}$ verdade, no último ano do colégio a gente tinha um projeto pra fazer, como era processamento de dados, a gente mexia com computação, a gente tinha que simular um jogo que a gente gostasse. E como eu não jogava vídeo-game, nunca foi do meu cotidiano, eu pedi a um amigo pra me emprestar um CD. E na época era um jogo que chamava "a escavação", que era o protótipo daquele filme "Armagedom" do Spielberg. E era uma equipe de geólogos, que era mandada para um meteoro, pra resolver um probleminha, que ele estava se dirigindo pra Terra, e eles tinham que explodir. E eu gostei do papel do geólogo no jogo e resolvi saber mais. Comprei o guia do estudante e aí algumas palavrinhas mágicas me chamaram atenção, tipo emprego garantido, nota de corte não muito alta, e aí eu falei ah, vou ver o que é. Ao contrário dos meus amigos, que grande parte deles já sabiam o que queriam desde pequenos, eu não tinha certeza. Tanto que no primeiro ano inteiro eu queria pedir transferência, eu queria ir pra engenharia. Desisti por conta de uma matéria que eu fiz no segundo semestre do primeiro ano, com o professor que depois virou meu orientador, e é até hoje.
}

Interessante observar que a professora Adriana Alves começou a graduação em 1999. No ano seguinte Guimarães et.al (2000) publicaram um relatório com análise dos dados sobre o perfil segundo a cor dos candidatos e dos aprovados no Vestibular Fuvest Ano 2000, pois esse foi o primeiro ano de adoção do quesito cor nos questionários respondidos por candidatos/as e ingressantes da FUVEST. Este relatório diz respeito aos/as candidatos/as que tentaram o concurso 
no final de 1999 para ingressarem no ano seguinte e pode nos oferecer elementos que permitem melhor compreender como a professora Adriana está situada no contingente de candidatos/as e ingressantes da USP. Dentre as conclusões do relatório, tem-se que é possível agrupar candidatos/as e ingressantes da FUVEST dos quatro grupos raciais em dois subgrupos raciais com características semelhantes. De um lado, teriam muito mais semelhanças o subgrupo compostos por brancos e amarelos, que apresentavam uma série de características que combinadas os deixavam em situação de concorrência muito melhor, quando comparados ao outro subgrupo, composto de pretos e pardos. No conjunto de fatores que alavanca a competitividade estão: maior escolaridade dos pais, ter estudado em escola particular, nível de renda, familiaridade com os processos do vestibular. Estudo realizado por Sampaio, Limongi e Torres (2000) chegou a conclusões semelhantes: as chances de um/a jovem concluir o ensino médio eram afetadas pela renda, cor e escolaridade dos pais de modo conjunto; pois mesmo que os pais estivessem na mesma faixa de escolaridade e renda, a proporção de jovens brancos/as que concluía o ensino médio era maior do que a de jovens negros/as. O que se refletia no acesso ao ensino superior: em 1997 nas famílias com renda até dois salários e mãe com até três anos de estudos, apenas 2,9\% de jovens afrodescendentes entre 18 a 24 anos entravam no ensino superior.

$\mathrm{O}$ que de fato contou favoravelmente à aprovação da professora Adriana Alves em seu primeiro vestibular foi ter feito ensino médio numa escola técnica, pois conforme outro relatório publicado por Guimarães et.al em 2007 sobre o perfil dos candidatos e dos aprovados dos vestibulares FUVEST entre os anos 2001 a 2007, considerando os/as aprovados/as negros/as, aqueles que estudaram em escola pública tiveram maiores chances de aprovação no vestibular por ter cursado ensino técnico.

Estudos87 têm apontado que estudantes negros/as nas universidades públicas estão concentrados nas áreas de Ciências Humanas. A professora Adriana Alves está numa carreira em que negros/as são minoria e isto se revela no fato como colegas de curso a perceberam na sala de aula:

$\mathrm{Na}$ Geo[logia], agora melhorou um pouco, mas entra um negro por ano, de cinquenta alunos, sempre é um flagrantemente negro, digamos assim, eu não posso dizer que eu sou moreninha, eu não passo por moreninha. Então, que é negro mesmo a olhos vistos entra um por ano. E a primeira manifestação que eu na época não notava como preconceito mas que hoje se me perguntarem eu acho que é, é o apelido. Todo mundo aqui tem apelido, você entra você é batizado, que eles falam, e o meu é Bisteca, por exemplo. E aí quando... você entra você faz uma entrevista, preenche um formulário e em geral o seu apelido é baseado nas suas respostas, exceto se você for negro. Então se você é negro você faz parte da feijoada, então você é Bisteca, tinha o Feijoada, tinha o Torresmo, tem a Costelinha, então todos os negros já de cara, independente do que eles responderem no formulário eles ganham o apelido baseado na raça. Mas assim o é com os japoneses e com os 
homossexuais, assim, declarados ou a olhos vistos, então se você não é a norma, que não é branco ou heterossexual você ganha um apelido baseado na sua pertença ou racial ou na sua pertença de gênero. E a [irmã] foi a primeira que me chamou atenção pra isso, porque até então eu achava Bisteca um apelido divertido, que pra mim não tinha conotação nenhuma. Tinha apelidos muito piores, que tem palavrão no meio e tal, e aí quando ela perguntou pra mim porque e eu respondi, e ela falou "então você entende que independente das suas respostas o seu apelido seria esse?”. E aí que eu comecei a pensar: é verdade.

O ensino superior é marcado por tradições e rituais. Este trabalho tem discutido como a USP foi construída originalmente a partir do projeto de formar uma elite intelectual, sobretudo paulistana. Boa parte da resistência da USP com relação ao debate de implantação das cotas e a adoção do INCLUSP tem, segundo os docentes entrevistados/as para essa pesquisa, o intuito de preservar aspectos da tradição uspiana, como se verá mais adiante neste capítulo. A fala da professora Adriana Alves revela ainda algo do que é a tradição em seus elementos cotidianos, como o processo de recepção de calouros ou "bixos", nome que se usa tradicionalmente na USP e em todo o estado de SP a cada leva de novos ingressantes por ano em todos os cursos. Cada curso traduz essa tradição com particularidades e no caso da Geologia, os "bixos" passam por essa espécie de sabatina, que lhe garante um rótulo que o acompanha graduação afora. A professora Adriana, assim como os/as poucos/as alunos/as negros/as da Geologia, fez parte da tradicional "feijoada", a única forma de se conceber o/a negro/a na Geologia da USP, independentemente de sua história de vida.

Em suma, nesta primeira parte do capítulo foi proposto apresentar cada docente, com detalhes de sua trajetória anterior à universidade, no sentido de desvelar a face docente negra da USP, suas origens sócio-econômicas familiares, os percursos escolares, as vias que esses/as docentes abriram pioneiramente sem referências anteriores; a escolha da carreira, e o processo de se perceberem e auto-classificarem como negros/as. O próximo tópico desse capítulo propõe construir um panorama que indique como foi cursar o ensino superior, se viveram ou não experiências de racismo como estudantes na graduação e pós-graduação. 


\section{3- Estrada para a Docência: Vivências Acadêmicas na Graduação e Pós-Graduação, e o Concurso de Entrada na USP}

Nesta seção do capítulo pretende-se discutir como foi a passagem desses/as sete docentes pela vida universitária desde a graduação até o momento do concurso de entrada na docência da USP. Pretende-se destacar aspectos das trajetórias que apontem para as experiências de raça, gênero e classe que marcaram a passagem desse/as docentes pela vida acadêmica anterior à docência.

No conjunto de docentes aqui considerado, um fato comum é que uma vez aprovados no vestibular emerge de pronto o primeiro desafio de desbravar a vida universitária sem muitas referências anteriores, pois ninguém no núcleo familiar imediato chegou a fazer graduação anteriormente. Um exercício narrado foi o de tentar encontrar os pares, aquelas pessoas que de alguma maneira teriam vivido experiências de raça ou classe semelhantes. Nesse sentido, entre 80 ingressantes no noturno e 80 no diurno em Geografia em 1981, a professora Vanderli Custódio relata que encontrou na sua turma, no noturno, outros dois colegas negros, um rapaz que desistiu do curso e uma outra aluna que conseguiu concluir, com a qual ainda mantém contato. Nas turmas do diurno, se lembra de ter conhecido outros dois alunos negros. A professora Vanderli Custódio conseguiu se situar confortavelmente dentro do curso, mesmo com a baixa representatividade negra e do modo como os colegas de curso leram sua negritude:

\footnotetext{
"Nossa, temos uma pérola negra agora na geografia, olha a pérola negra". E isso, tem gente que me chama de pérola até hoje. Isso virou uma alcunha por causa da música do Luis Melodia - "pérola negra, te amo, te amo".E aquilo ficou e isso me acompanhou o curso inteiro. E eu não, não, não gostava disso, mas o tratamento das pessoas era carinhoso, mas é uma coisa muito difícil, tanto que eu falo, Vanderli é meu nome profissional, porque eu tenho um monte de apelido, tem Vanda, me chamam de Líli, de Lili e aí então o pessoal mais antigo, ainda no tempo do curso, que depois não acompanhou a minha vida, me chama de Pérola. Mas eu não, não, não gostava, mas não consegui tirar das pessoas essa alcunha da "pérola negra da geografia". Era pior ainda (risos). Mas a minha graduação foi muito boa, foi muito legal, foi muito afetuosa. Muito, muito, muito namorico com os colegas, parceiros, tem pessoas com quem eu trabalho até hoje. Você faz a graduação e não imagina que você vai ter uma rede e que você faz parte dessa rede e que você vai, por mais que as pessoas se movimentem, cada uma seguindo um caminho, a gente foi se esbarrando pela vida afora. Então faz dez, vinte, trinta anos, numa instituição trabalhei com fulano, na outra trabalhei com cicrano, a outra foi minha chefe, uma menina foi minha chefe, depois eu fui chefe dela em outra instituição. Ah, "vamos escrever um artigo?" Então vamos escrever um artigo. "Vamos escrever um livro didático?" Então vamos escrever um livro didático. "Participa dessa banca?". A gente foi se esbarrando harmoniosamente pela vida afora. Então assim, se fosse para caracterizar a minha graduação entre conflitos e harmonia, foi super harmônico, foi muito legal, foi muito especial. E eu acho que foi especial até dentro da geografia, porque tem professor que lembra "aquela turma de vocês, aquela turma de vocês". E daquela turma, saíram muitos autores de livros didáticos de geografia e saíram professores que estão no departamento hoje. Então foi uma safra, uma safra um tanto diferenciada. Formou uma turma que foi muito legal, muito interessada. Então a minha graduação foi muito boa, não tenho queixa. (...)Tirando essa coisa da alcunha, que era um incômodo, então tinha a coisa do exótico, que é uma pecha horrorosa, porque quando não conseguem enquadrar você de jeito nenhum, te enquadram como exótico. E... com relação á religião também, tinha uma "ah você é filha de santo, você é não sei o quê, você é de candomblé, você é de umbanda?". Porque se, era todo mundo muito marxista na década de
} 
80, então não combina com religião, mas eu como negra, poderia ser de candomblé, poderia ser de umbanda. Se eu falasse católica ou kardecista, não, “já virou classe média, já virou burguesa". Tinha um policiamento todo complicado, que na verdade a nossa esquerda sempre foi complicada e continua sendo complicada. Então tinha essa coisa da alcunha, essa coisa do exótico, que eu não gostava, mas as relações pessoais, afetivas assim, foram muito legais.

Essa experiência de enquadramentos raciais por parte de colegas de curso, que liam sob o viés de estereótipos a negritude de estudantes negros/as na USP, também foi relatada pelo professor Dennis Oliveira durante sua graduação em Jornalismo. Porém, ser minoria dentro da sala de aula foi marcado muito mais por conflitos e isolamentos, distante de experiências de afeto ou solidariedade:

Então, foi meio complicada assim, eu tive um problema... tive muito problema sério de relacionamento. Eu nunca tive problema de relacionamento na escola, assim, não tive muitos problemas de relacionamento na escola, porque era o pessoal aqui do meu bairro, conhecia, então não tinha muito... no colegial um pouquinho mais. $\mathrm{O}$ meu colégio era público, mas era um colégio um pouco mais de classe média, que é na região da Praça da Árvore. Agora aqui [na USP] na verdade foi muito difícil, eu tive problema sério, assim de entrosamento no começo, eu era estigmatizado. Por exemplo, tinha disciplina aqui que chamava História da Cultura e Comunicação, quem dava era o professor Virgílio, que já faleceu. Mas na disciplina a gente fazia um seminário sobre os vários movimentos culturais, Modernismo, Tropicália, era bem legal. E a gente fazia os seminários sempre em forma de teatro, fazia alguns esquetes teatrais para fazer esses seminários. Então sempre os papeis nessas montagens que a gente fazia de subalternos eram reservados a mim, sempre eu era faxineiro, era o vendedor. Quando teve a peça Tropicália eu fiz o papel de Gilberto Gil, era muito isso, tinha esse perfil, então isso era um pouco. O meu gosto musical era bastante, não vou dizer ridicularizado, mas era bastante criticado por meus colegas. Eu não gostava... o pessoal gostava de rock, eu gostava de samba, de funk, sempre gostei muito de funk. Os lugares que eu frequentava na minha juventude, não eram os lugares que meus colegas da universidade frequentavam. Eu frequentei os bailes da Chic Show, nessa época toda eu frequentava o [inaudível]. Então eu tive problema de relacionamento sim, tive, tanto é que eu saí daqui da universidade quase sem amizade. Me respeitavam, mas amizade mesmo, não namorei ninguém na universidade, minhas namoradas eram todas de fora da universidade. Então eu passei por aqui, estudei, mas não tive uma relação, assim, forte aqui na graduação...

Assim como a professora Vanderli Custódio, o professor Dennis Oliveira também fez a graduação ao longo dos anos 1980, década de intenso debate sobre o processo de redemocratização política da sociedade brasileira, na reta final do período da ditadura. Embora em São Paulo na década de 1980 algumas iniciativas governamentais anunciassem também novas possibilidades de enfrentamento do racismo, pois em 1984 no governo de Franco Montoro é criado o CPDCN, o primeiro Conselho de Proteção e Desenvolvimento da Comunidade Negra, dentro da USP predominava um debate marxista que ou endossava um processo de estigmatização da população negra, conforme relato da professora Vanderli Custódio, ou fechava as portas para o debate, priorizando a luta de classe em detrimento da luta antirracista, conforme indica o professor Dennis de Oliveira: 
Quando eu entrei aqui na universidade, assim, a gente tinha uma questão que era mais, que era muito premente, que era a luta contra o regime militar, nos anos 80 . Então assim, todo movimento social, a discussão que permeava a maior parte da universidade era assim a luta pela democracia, liberdade, então era muito isso. Então essas temáticas [raciais] acabavam meio no segundo plano, todas elas, então, o regime militar, derrubá-lo, a ditadura, democracia, isso era quase que meio a palavra de ordem unificada, única quase, naquele período lá, então esse debate não aparecia. Já na... agora eu acho que houve um avanço, embora a gente tenha ainda muito o que fazer, acho que teve um avanço, um avanço, pelo menos no seguinte, a gente desmontou esse mito da democracia racial, tá? Isso eu acho que, embora muita gente ainda acredita nisso, mas o fato, por exemplo, do estado brasileiro, ele assumir que há racismo no Brasil, tanto é que tem políticas de ações afirmativas, já é um grande avanço. Então no Brasil tem racismo, então acho que isso é uma coisa que tem crescido, essa ideia, não a de um país que não é racista, como acreditava-se muito fortemente tempos atrás, na democracia racial, tudo isso.

Não significa no entanto, que a população negra universitária esteve à parte dos debates e das lutas pela redemocratização. Durante a graduação o professor Dennis Oliveira começa a construir uma importante carreira militante tanto dentro do Partido Comunista, como na fundação da UNEGRO. Segundo Calderano (2002) a UNEGRO (União dos Negros pela Igualdade) do Estado de São Paulo é uma sociedade civil sem fins lucrativos fundada em 1991 em São Paulo como dissidência do Movimento Negro Unificado (MNU), sendo herdeira da UNEGRO fundada em Salvador em 1988, ano do centenário da abolição da escravidão. A autora apresenta resumidamente a trajetória militante do professor Dennis de Oliveira da seguinte maneira:

\begin{abstract}
"Dennis de Oliveira, 38 anos, com doutorado em Comunicação (USP), graduação e mestrado em Jornalismo (ECA-USP), é professor universitário (Universidade Metodista de Piracicaba) e Anhembi Morumbi) e jornalista (assessor de imprensa no Sindicato dos Químicos). Aos 16 anos, já manifestando interesse de participar de organizações coletivas, fez parte de um grêmio em sua escola. No entanto, ele coloca como marco inicial de sua militância a sua vinculação ao Movimento Estudantil no ano de 1982, quando tinha 18 anos. Foi diretor do Centro Acadêmico e membro da UEE (União Estadual dos Estudantes). Sua militância no Movimento Negro se deu a partir da fundação da UNEGRO, em 1991, tendo sido um dos seus fundadores. É nesse espaço que dedica mais tempo e empenho, sendo notória a opção privilegiada dada à sua atuação nessa área. Também participa, segundo ele, "meio a distância", do Movimento Sindical, no Sindicato dos Professores de Campinas, ao qual é filiado e suplente em sua diretoria. Na UNEGRO, Dennis de Oliveira é membro da Coordenação Estadual e da Executiva Nacional. [grifos da autora] (Calderano, 2002, p. 17).
\end{abstract}

Depois de algumas décadas de militância na UNEGRO e no PC do B, em janeiro de 2014 o professor Dennis de Oliveira publicou uma nota na sua página de facebook na qual dizia não ser mais militante nem da entidade, nem do partido e reitera sua maior dedicação ao NEINB (Núcleo de Estudos Interdisciplinar sobre o Negro Brasileiro) da USP:

Gostaria de tornar público e "escurecer" o seguinte: 1 - NÃO SOU MILITANTE E MUITO MENOS DIRIGENTE DE UMA ENTIDADE CHAMADA UNEGRO (UNIÃO DE NEGROS PELA IGUALDADE). Fui um dos fundadores da Unegro em São Paulo e participei das primeiras direções nacionais da entidade nos anos 1990, tive papel destacado na organização dos primeiros encontros nacionais da entidade, junto com companheiros (...) Tenho alguns amigos que militam na Unegro, muitos dos que estão nas fileiras dela foram filiados por mim, mas não respondo por esta organização e tampouco concordo com várias das avaliações e estratégias que tem 
adotado nos últimos anos. Sou um militante anti-racista mas não estou em nenhuma entidade, tenho participado mais organicamente do Neinb (Núcleo de Estudos Interdisciplinares sobre o Negro Brasileiro), do qual sou atualmente coordenador-geral. 2 - TAMBÉM NÃO SOU MAIS MILITANTE DO PC DO B. Atuei neste partido desde 1982, no movimento estudantil, movimento popular e movimento negro. Também tenho alguns amigos do PC do B, mas atualmente não tenho vínculo partidário nenhum, embora continue no campo da esquerda e continuo defensor do socialismo. Tenho participado de algumas atividades do PT, do PSOL e um pouco mais do Consulta Popular. Assim, por favor, dúvidas e questionamentos sobre posições destas organizações NÃO FAÇAM A MIM e sim as respectivas direções destas entidades. Por fim, informo que a minha saída destas organizações, em especial a Unegro, deu-se por divergências políticas e ideológicas. (Nota publicada pelo professor Dennis de Oliveira publicada em sua página pessoal no Facebook. [Grifos do autor])

De modo semelhante, a professora Maria Letícia Nascimento, que também fez sua graduação durante o regime militar no final da década de 1970, também narra sua experiência de militância no movimento estudantil. Mas, ao contrário da professora Vanderli Custódio e do professor Dennis de Oliveira, a narrativa da professora Maria Letícia indica ausência de experiências de estigmatização racial, o que também pode sugerir o quanto o movimento estudantil de então estava distante das questões raciais, pois o fato dela ser negra nem entrou em questão:

\begin{abstract}
$\mathrm{Na}$ verdade nunca fui alijada de alguma coisa na universidade porque eu fosse negra. Ao contrário, eu sempre fui muito participante, muito ativa. E tinha essa coisa de fazer teatro, então eu vivia nos bares conversando com as pessoas, a gente tinha várias atividades extra né, aqui. Depois a gente remontou o CA[ Centro Acadêmico], que na época não existia isso, era a ditadura , 77, tinha aquelas corridas aí, colocavam os cachorros atrás da gente. Ia fazer assembleias na História, vinha aqui... Eu quase apanhei de aluno, mas muito mais porque a gente propunha greve do que porque eu fosse negra.
\end{abstract}

A passagem pela graduação tal qual narrada pela professora Vanderli Custódio, o professor Dennis Oliveira e a professora Maria Letícia, revela diferentes faces do mesmo racismo brasileiro: a face cordial, da estigmatização e da negação ou invizibilização. E como indicam Pinho \& Figueiredo (2002) "não fosse trágico, seria até mesmo irônico perceber como mesmo aqueles setores mais progressistas ou esquerdizantes sucumbiram ante a certeza de que uma nação moderna seria culturalmente homogênea e eurocentrada". (p. 200-201)

Em tempos de regime democrático, os docente negros aqui entrevistados também tiveram atuação política acadêmica, assim, a experiência de militância marcou igualmente a graduação do professor Roberto da Silva, no início dos anos 1990 e que já vinha de uma trajetória de luta pela ampliação de direitos da população jovem, negra e encarcerada:

Eu fiz na Federal do Mato Grosso, num campus afastado, em Rondonópolis, onde a cultura universitária praticamente inexiste. Mas eu tive uma participação muito ativa, porque desde o primeiro ano eu assumi a direção do centro acadêmico, depois no restante do curso 
assumi a direção do Diretório Central de Estudantes, então eu participava dos colegiados, participava, discutia política universitária, que era minha forma de fazer o aprendizado da cultura universitária. Não se faz esse aprendizado na sala de aula, é preciso estar nesses espaços coletivos, participar das discussões, tomar conhecimento, tomar conhecimento dos conflitos, entender como se encaminha as soluções dos problemas, toda a negociação político-acadêmica que se faz dentro dessas instâncias. Então esse foi um aprendizado, foi a minha forma de eu participar da vida universitária, quer dizer da vida acadêmica, ainda que o campus do interior não tenha necessariamente uma vida universitária de integração de estudantes, essas coisas assim.

As experiências de militância narradas pelos docentes foram também informadas pelos parâmetros de atuação instituídos pelo movimento estudantil das décadas de 1960 e 1970. Conforme indicam Venturi \& Bokany (2005) historicamente a militância política juvenil é frequentemente comparada à vanguarda jovem universitária dos anos de resistência ao regime militar brasileiro. Mas tal comparação muitas vezes desconsidera que tais estudantes correspondiam a parcela ínfima da população brasileira. Em trabalho pioneiro Foracchi (1965) analisa um conjunto de 377 estudantes da USP (o que em 1960 correspondia a 5\% da população estudantil da Universidade), chegando à articulação entre as categorias estudante universitário e classe média para entender o comportamento e a atuação estudantil:

\begin{abstract}
$\mathrm{Na}$ sociedade brasileira, a mobilização de recursos educacionais de nível superior é definitivamente marcada pela estrutura de classes. Não é sem razão que o estudante universitário se considera a si um privilegiado, usufruidor exclusivo de oportunidades inexistentes para a maioria dos jovens. Tais representações o incitam, no entanto, a desenvolver uma modalidade de atuação social que busca ultrapassar os fatôres responsáveis pela natureza privilegiada do ensino superior. (Foracchi, 1965: 6-7)
\end{abstract}

$\mathrm{O}$ engajamento estudantil converteria assim o estudante num agente da praxis (embora pequeno - burguesa) que intentaria implantar uma nova ordem social que superasse o status quo. A autora considera a condição pequeno burguesa dos estudantes universitários e da USP em particular como unidade de interpretação dominante, embora isso não destituísse a atuação desse segmento de suas virtudes inovadoras, nem "neutraliza sua intenção 'revolucionária', mas permite particularizálas em suas proporções reais”. (Foracchi, 1965, p.7). A transformação de jovem a estudante possibilitaria ressignificar suas origens e pertença social, conferindo-lhe autonomia política. Passadas quatro décadas, no perfil dos estudantes da USP ainda predominava o pertencimento às classes sociais mais favorecidas, segundo pesquisa de Pimenta (2001) que compara os perfis de estudantes que ingressam na USP e em duas grandes universidades particulares em São Paulo, a Universidade Paulista ou UNIP e UnicSul ou Universidade Cruzeiro do Sul.

Apesar das dinâmicas históricas de construções dos movimentos estudantis no Brasil ao longo desses anos todos, no processo de ruptura entre passado e presente e de luta por um futuro de 
menores distâncias entre classes sociais, um aspecto da luta estudantil desde anos 1960 foi a adesão às lutas das classes proletárias. E nesse sentido, como indica Mortada (2009) efetiva-se o "curioso destino" da camada estudantil:

(...) esse pitoresco agente histórico, não tão promissor como o operário do século XIX ou o camponês da revolução maoísta, parece percorrer o caminho traçado por Lenin: vai do espontaneísmo à consciência revolucionária, descobrindo $O$ que fazer a partir das condições que lhe são imanentes. (Mortada, 2009: 375).

As experiências de militância na graduação dos professores Dennis Oliveira, Roberto da Silva, mesmo que a partir de outra inserção social, os colocam no seleto e reduzido segmento da população negra brasileira que pôde ingressar o ensino superior público. Porém permaneceram bem distantes socialmente do perfil de jovens que historicamente compuseram a população estudantil da USP. Além disso, a narrativa dos docentes Dennis de Oliveira e Roberto da Silva apontam ainda para o fato de que viveram também uma diferença no processo de autonomia e consciência política na passagem entre o ser jovem e ser estudante como categoria social analisado por Foracchi (1965): além de ser jovem ou estudante, esses sujeitos também eram negros e pobres. Dessa maneira, a atuação política desses/as professores/as durante a graduação difere sensivelmente em termos de ponto de partida de raça e classe social, dos estudantes considerados pela autora. Destaca-se ainda a atuação do professor Dennis de Oliveira na fundação da UNEGRO em trajetória paralela à graduação e a militância do professor Émerson Inácio na EDUCAFRO no Rio de Janeiro dos anos 1990, período inicial de construção dessa rede de cursinhos pré-vestibular voltada para a população negra; indicando uma atuação política para além dos muros da universidade e em diálogo com a mesma.

No processo do jovem transformar-se em estudante, Foracchi (1965) indica que deve haver mudanças nos vínculos de dependência à família para assim redefinir a condição de manutenção. Conclui que o caráter da dependência com a família era necessariamente financeiro, pois o jovem não seria obrigado a trabalhar durante a formação. Assim, a realização do ensino superior não seria uma aposta para o processo de ascensão social. Enquanto dependente economicamente esse jovem teria diante da família a responsabilidade de assegurar seu próprio destino e o de pelo menos preservar o patrimônio familiar acumulado. No entanto, o desafio da autonomia prossegue e só se efetiva na situação de trabalho, "quando o estudante se firma como unidade autônoma de manutenção" (Foracchi, 1965:58), alterando profundamente as relações com a família. No primeiro momento, a vinculação do jovem ao sistema se dá pela família, unidade ativa de manutenção e, no segundo momento, pela emancipação relativa, advinda das condições de trabalho. 
Foracchi (1965) analisa um segundo segmento do corpo discente da USP constituído por uma parcela minoritária e bem diferente do primeiro perfil estudantil, considerado padrão. Este outro segmento sempre teria sido obrigado a trabalhar, pois além da família não ter condições de sustenta-los, muitas vezes o estudante precisaria contribuir com as despesas em casa. A noção de autonomia e emancipação pode aqui não se efetivar, pois a necessidade de trabalhar sustenta o vínculo com a família, que depende da renda do aluno e ainda, poderia obrigar o estudante a trabalhos cujo sentido seria sobretudo a possibilidade de manter-se na graduação. Apesar do conjunto de docentes aqui analisado estar mais próximo desse outro universo de estudantes considerados pela autora, percebe-se diferenças importantes. Por exemplo, a trajetória da então aluna Vanderli Custódio é bem interessante para considerar o trabalho como possibilidade de emancipação, a despeito do caráter de obrigatoriedade:

\begin{abstract}
E assim, eu fui aluna daqui, eu fui funcionária também, uma coisa que eu esqueci, que eu entrei na geografia em 81 , em 82 , meu irmão já trabalhava na reitoria, eu prestei um concursozinho interno na reitoria e entrei, trabalhei como funcionária administrativa aqui da reitoria durante cinco anos e foi muito legal. Eu trabalhava das nove às seis e pouco, saía, subia o morro e ia pra geografia, porque eu fazia geografia à noite. Aí saí de casa, fui morar, fui viver com uma menina, uma colega de trabalho que depois foi namorada do meu irmão, então assim, eu consegui a minha independência, na hora do almoço ia na biblioteca e pegava livro, datilografava os trabalhos no serviço. Então, a universidade me proporcionou uma porção de coisas e eu vivi intensamente o que pude da universidade, tanto que eu falo aos alunos "aproveita, aproveita tudo da universidade, aproveita o máximo que você puder, porque isso é recurso público que está sendo colocado aqui pra ser aproveitado. Aproveita e garanta sem blá, blá, blá nenhum sustentável, mas garante pros que venham depois, para as novas gerações, que esses serviços continuem com qualidade e que sejam ampliados."
\end{abstract}

O fato de trabalhar na universidade durante a graduação ampliou a possibilidade da professora Vanderli Custódio viver e explorar outros meandros da vida acadêmica. Neste sentido, seria interessante resgatar aqui a trajetória da professora Eunice Prudente considerada em capítulo anterior deste trabalho. Ambas aprenderam a se situar na instituição USP não apenas como alunas, mas também como funcionárias técnico-administrativas. No caso da professora Eunice Prudente, ela fez quase toda a carreira no Departamento de Direito do Estado: foi técnica-administrativa e chegou a secretária do departamento. Se a professora Eunice Prudente tivesse a Livre Docência bem como a Titulação, poderia tentar a coordenação do Departamento. Talvez fosse o caso de tentar compreender porque uma carreira tão promissora no interior de um importante departamento da Faculdade de Direito estacionou no primeiro nível da carreira docente, a despeito da brilhante carreira da professora em cargos públicos fora da Faculdade de Direto. Em Adorno (1988) verificase que na Faculdade de Direito na USP uma carreira de sucesso na vida política dos bacharéis do Largo de São Francisco não inviabiliza o progresso na carreira docente, pelo contrário, se retroalimentam, o que não foi o caso da professora Eunice Prudente. Mas voltando à trajetória da 
professora Vanderli Custódio, transitar pela carreira administrativa da USP ampliou sua noção de universidade e de funcionalismo público dentro da USP, conforme se verá mais adiante nesse capítulo.

Considerando a trajetória na graduação da professora Roselana Gonçalves, apesar de não ter sido na USP, percebe-se um esforço de conciliação entre a graduação em Enfermagem em instituição particular, e os trabalhos remunerados para conseguir pagar e concluir a formação, de modo a não se consumir pelo trabalho e deixar a condição de estudante assim suplantada, como o caso de parcela do conjunto de estudantes-trabalhadores analisado por Foracchi (1965). Nesse sentido, a dificuldade de conseguir atividades de trabalho que favorecessem seu aprendizado no curso, só foi superada com o acesso a políticas de financiamento do curso, como o crédito educativo:

\footnotetext{
Então eu tive que trabalhar e pagar os estudos e até uma certa data, ano de graduação que eu tive que fazer uma opção, porque os estágios aconteciam em período integral e aí eu tinha que pensar num outro tipo de trabalho pra manter e aí eu consegui crédito educativo que hoje se chama de FIES. Foi difícil, foi uma luta, porque meu pai já falou na época do colegial que "olha, até aqui eu ajudei, custear material, uniforme e tudo mais, porque o estado pagava a escola. Daqui pra frente faculdade eu não pago pra ninguém porque eu não posso". Então eu e minha irmã fizemos o esforço por conta própria. Começamos a trabalhar cedo e fizemos essa trajetória mesmo por empenho.
}

Do conjunto de docentes considerados/as nessa pesquisa e que fizeram graduação no Brasil, à exceção das professoras Roselane Gonçalves e Maria Letícia, todos/as relataram a escolha da universidade pública como primeira opção em função da gratuidade do ensino, seguida da qualidade. Isso não implica que não estivessem cientes e perseguissem também o conceito de qualidade e excelência que caracteriza a universidade pública brasileira. A professora Maria Letícia em seu relato, apesar de ter cursado Pedagogia na USP, indica que seria possível fazer outro curso e numa instituição particular, sem grandes dilemas para o custeio, em função da situação econômica de sua família de origem. No caso da professora Roselane Gonçalves, no acesso à graduação prevaleceu a noção corrente nas escolas públicas de ensino médio de que a USP não é para todos/as, sobretudo os oriundos desse segmento escolar, conforme relata: "de fato na época nem passava pelas nossas cabeças tentar o ensino público no vestibular, porque era muito mais difícil do que é hoje. Então eu teria que pagar os estudos”.

As trajetórias docentes aqui consideradas são unânimes no sentido de terem logrado sucesso e longevidade escolar. De um modo geral, há uma grande semelhança no conjunto de sujeitos dessa pesquisa, em termos de algumas variáveis objetivas como níveis de renda e escolaridade dos pais. É necessário, portanto, considerar além dos dados macrossociológicos gerais, que nesse caso são muito semelhantes, e tentar compreender as “diferenças secundárias" entre essas 
famílias, que além de pertencerem às camadas populares, são negras também. Seguindo a trilha de Lahire (1997), atentar para as configurações singulares a partir de combinações específicas de traços gerais ajuda a entender porque nestas famílias com traços semelhantes de "disposições econômicas" foi possível tanto a formação em universidade pública de prestígio, quanto em faculdade particular. Tenho em tela três diferenças sutis, porém significativas, nos traços dos "modos familiares de investimento pedagógico" e "formas de autoridade familiar", nos termos de Lahire (1997) para algumas falas referentes à figura paterna relatadas pelos/as docentes entrevistados/as:

\begin{abstract}
Meu pai dizia o seguinte, você tem que ser bom e acabou, meu pai tinha muito essa idéia, você tem que ser o melhor na sua carreira, o melhor que você faz, para ninguém falar nada de você. (Professor Dennis de Oliveira)

Como eu falei, nem tentei uma escola pública na minha época, porque o número era menor eu achava mesmo que não conseguia, não tinha essa coisa do... meu pai quando ele falou, não posso pagar, ele não falou mais "presta o vestibular na escola pública". Nem passava pela cabeça. Então hoje os pais precisam voltar a acreditar que seus filhos um dia vão ingressar e que a gente tem que ter mais vagas, mais cursos, mais unidades pra facilitar. (Professora Roselane Gonçalves)

Aí eu fiz um combinado com meu pai, porque o papai queria que eu fizesse ou medicina ou direito, era o que ele achava que eu devia fazer, embora, ele achasse que eu podia ser professora também, porque ele achava que as pessoas não ficavam sem emprego nestas três carreiras. Medicina eu nunca quis fazer, Direito eu nunca me interessei também. Aí eu fiz um combinado com ele: "olha, seguinte você, me deixa fazer teatro e eu presto pedagogia". (Professora Maria Letícia)
\end{abstract}

Estes/as foram os/as docentes que trouxeram a opinião paterna sobre seus processos de escolarização. Nessas três narrativas têm-se três diferentes possibilidades de posicionamento diante do modo de escolha das carreiras profissionais e da instituição: no primeiro caso, "ser bom" ou "o melhor" num ambiente familiar que orientava para a carreira jornalística, (o pai do professor Dennis de Oliveira, conforme dito anteriormente, era protográfico e essa condição informou a escolha do curso) pode ser facilmente traduzido em cursar Jornalismo na USP e este é um fato considerado pelo professor Dennis de Oliveira quando avalia sua turma de graduação em conversa informal após a entrevista ocorrida em 2011. Ele relatou que sua turma foi célebre e que ainda realizava encontros ocasionais e o do ano seguinte seria especial, pois era a comemoração de 30 anos de ingresso. A festa que teve o nome de TrintEca, contou com colegas de turma do professor Dennis de Oliveira e dentre eles, o jornalista William Bonner, âncora e apresentador do Jornal Nacional da emissora Globo.

Concernente às professoras Roselane Gonçalves e Maria Letícia temos duas diferentes condições paternas referentes à possibilidade de fazer formação em nível superior: no primeiro caso, diante da possibilidade da filha entrar numa faculdade, o pai esclarece que não poderia pagar e que a professora Roselane Gonçalves deveria assumir esse compromisso por sua conta e risco 
financeiro e coincidentemente ou não, essa foi a única docente que fez graduação em instituição particular; no segundo caso, a questão paterna não era onde fazer o curso, mas sim, a obrigatoriedade de cursar uma graduação. Nesse sentido, a grande questão para a professora Maria Letícia foi conciliar desejos ou vocações profissionais, as dinâmicas e exigências dos vestibulares e as concepções de carreira que seu pai tinha, marcadas por concepções de classe e também de gênero. Assim, ela teve que fazer negociações entre a carreira de teatro, que era sua vontade, com a carreira de pedagoga, que veio a ser abraçada posteriormente, uma vez que ela não foi aprovada no vestibular para Jornalismo da ECA e não pôde seguir com a ideia de fazer Jornalismo numa instituição particular, em função do repentino falecimento de sua mãe. Cabe destacar que não se trata aqui de fazer um balanço dos traços familiares em positivos ou negativos, simplesmente. Lahire (1997) chama a atenção para a ingenuidade de tal exercício nesses termos, apontando para a ambiguidade desses traços, que podem ao mesmo tempo ter efeitos positivos, negativos, facilitadores ou não nas trajetórias de sucesso e longevidade escolar.

Outro exercício para o qual somos convocados na obra de Lahire (1997) é a consideração da multiplicidade de fatores explicativos da longevidade escolar. Não a escolha e absolutização de certos traços sociais, mas antes, a busca das interdependências possíveis. Além da importância dos fatores familiares, é necessário ressaltar os elementos da passagem pela graduação que foram importantes para que esse conjunto de docentes continuassem a apostar na vida acadêmica. Destacaria aqui alguns fatores: a existência de professores/as negros/as que apontaram a possibilidade de acesso e avanço do/a negro/a para além da graduação, como também para a pesquisa e ensino na universidade pública; a existência de docentes não - negros/as porém com olhar sensível e postura de incentivo; a transição para o mercado de trabalho, sobretudo a experiência docente na educação básica e/ou em instituições particulares de ensino superior, que conduziu à pós-graduação como melhoria ou re-orientação na carreira e, por fim, a aposta nos concursos para docência nas universidades públicas, na USP especificamente.

A existência de docentes negros durante a graduação foi destacada apenas pelos professores Emerson Inácio e Vanderli Custódio. A graduação do professor Émerson Inácio foi na Universidade Federal Fluminense, nos anos 1990, uma década antes do pioneirismo da Universidade Estadual do Rio de Janeiro na implantação das cotas raciais, em 2002. Segundo narra o professor Émerson Inácio -cuja entrada na graduação acontece em 1992 e a defesa de doutorado em 2006 - comparando com o que constata ainda hoje, as universidade públicas do estado do Rio de Janeiro estavam já nos anos 1990 e meados dos anos 2000 relativamente mais democrática no acesso de negros/as nas carreiras docentes: 
uma figura muito positiva e muito contraditória também, que era a professora Laura Padilha, uma das primeiras pesquisadoras em Literaturas Africanas, uma mulher negra, super de classe média negra alta, mas que nunca, mas que nunca perdeu essa coisa da referencialidade do negro, de ter nascido na periferia e ter ascendido socialmente, inclusive pela questão da universidade, que meio que colocou durante muito tempo para os alunos negros da faculdade, se colocou como referencial, ainda que ela não fosse tão próxima assim. As pessoas olhavam pra ela e viam assim "nossa, diretora do Instituto de Letras, a coordenadora da pós-graduação, a chefe de departamento", porque ela teve todos esses cargos, é uma mulher negra e coisa e tal e que se assumia como tal, que dou, por exemplo, um certo, não digo respaldo, mas cria um referencial. E ela sempre muita à frente de situações como de discriminações, que se não aconteceu na Letras, aconteceu em outros espaços da universidade, se colocando muito politicamente, digamos assim, considerando até a influência e a penetrabilidade que ela tem na universidade a favor de algumas questões. Na faculdade eu tive, de um conjunto aí de uns vinte professores, três professores negros. Na UFRJ onde eu fui aluno e também fui professor, porque fui boa parte do doutorado contratado na graduação de lá, existiu também Joel Rufino, professor que era da Letras, mas que eu acho que está agora na Comunicação e outros colegas dos quais eu não me lembro o nome. Eu achava até mais expressivo, considerando a áurea da UFRJ, uma áurea muito próxima da áurea uspiana o número de professores negros que havia lá. Muitas mulheres, particularmente, pegando as de Língua Portuguesa, Lingüística, muitos colegas na Educação também, que acho que até hoje é o lugar onde eu mais vi professores negros, nos cursos de Educação, Serviço Social, mais de longe, muito mais que na Letras. Por exemplo, a figura do Joel Rufino, agora mais recentemente, Denílson Lopez, coordenador do Fórum Ciência e Cultura da UFRJ, e na prática ele é o grande articulador cultural da universidade. Professora Maria Vitória que é ligada à Faculdade de Psicologia da UFF. Uma outra professora, genial, da Educação, não me lembro o nome dela. Na UFRJ, uma figura muitíssimo conhecida, Francisca Nóbrega, na UFRJ uma das primeiras, senão a primeira professora negra, daquelas bem grandona, muito arrumada, cabelo super bem penteado e que embora não falasse muito, tinha percepção da sua condição dentro daquele espaço. (...) Tive, professores muito interessantes todos eles. Quer dizer, considerando o Rio de Janeiro onde o contingente populacional negro é bem maior que São Paulo, quer dizer, proporcionalmente maior, acho até que tive poucos. Mas professores de atuação muito significativa na minha história.

Em 2003 o professor e Antropólogo José Jorge de Carvalho da Universidade de Brasília publicou um texto no qual fez um levantamento de nomes de docentes negros/as em universidades públicas a partir de indicação de professores/as que conheciam docentes negros/as nessas instituições. Apesar de ter sido um ensaio censitário longe de ser conclusivo, teve o mesmo princípio da contagem do professor Émerson Inácio: a memória de docentes negros/as cuja presença no espaço acadêmico se fez notável. A despeito dos silêncios das fontes oficiais diante da omissão na produção de dados sobre o quesito cor da docência do ensino superior, o que esse censo qualitativo indica é que há mais de uma década pelo menos, pesquisadores/as antirracistas procuram com olhar atento a presença negra docente; mas nesse momento só puderam constatar aqueles/as cuja presença na instituição se fez notável de alguma maneira. Desse modo, se havia mais docentes negros/as na instituição, acabaram por serem invizibilizados. É o que nos ajuda a compreender a surpresa da professora Maria Letícia quando se dá conta da ausência de docentes negros em sua formação: "Nossa que louco, eu nunca tinha pensado nisso. Gente eu nunca tive professor negro!"

A experiência de ter um docente negro durante a graduação acaba sendo um privilégio restrito a poucos/as discentes negros/as. Infelizmente, a chance de ser aluna de um docente do quilate do professor Milton Santos, como foi o caso da professora Vanderli Custódio, é quase nula 
na academia brasileira.

Em cinco anos eu tinha praticamente terminado, mas o professor Milton Santos anunciou que ia dar uma disciplina pra graduação, ele trabalhava só com a pós, que ia dar uma disciplina pra graduação no próximo semestre. Eu pensei "eu vou ficar mais um pouquinho pra pelo menos ter possibilidade de fazer uma disciplina com ele". Então eu fiquei mais um semestre e fiz uma disciplina com ele "Introdução aos Estudos da Urbanização do Terceiro Mundo". E o mundo dá quinhentas mil voltas, quando eu entrei aqui no IEB, eu precisava cumprir minha carga horária, que você tem que cumprir uma carga horária de aulas dadas, tal e eu fui bater na porta do departamento, porque até criar disciplina aqui e tal, "tem uma optativa aqui, Urbanização dos Países do Terceiro Mundo". Eu estava ministrando a danada da disciplina que eu tinha feito com ele! Nem, nunca ia imaginar isso e acho que ele muito menos.

Apesar de ter herdado do professor Milton Santos uma disciplina, criando entre ambos um elo acadêmico - institucional, a professora Vanderli Custódio não se percebe santosiana, pois sua carreira na Geografia foi orientada por outros debates teóricos. No entanto, teve na figura de um dos maiores nomes da Geografia brasileira, um ponto de afeto, de alguma cumplicidade de raça dentro da USP:

\begin{abstract}
A gente se via assim nos corredores e eu já tinha feito uma disciplina com ele. A gente brigava um pouquinho, eu e o Milton, a gente brigava um tiquinho. E aí perguntaram pra ele“ e os geógrafos, tem geógrafo tratando da questão negra?". Ele falou assim, "não, pelo que se saiba não, mas você não precisa ser negro pra tratar da questão negra no território, se a colega ali quiser participar, fazer um trabalho" 88 . Ele adorava me expor, então eu ficava possessa da vida com ele, me provocando. (...) Depois nós organizamos, aqui na PUC e eu e o Luis Antonio, um jornalista que trabalha no Museu Afro no Ibirapuera, tem um jornalista negro que fez Ciências Sociais aqui, se eu não me engano. Eu, ele e mais um outra moça da PUC que eu não me lembro mais, faz tanto tempo. Roseli! Roseli. Nós organizamos na PUC um dia de discussão sobre a especificidade... especificidade do negro na universidade, alguma coisa assim. E nós realizamos algumas mesas, uma mesa a tarde, uma mesa de manhã e uma mesa na tarde. Na mesa da tarde convidamos o professor Milton Santos. Ele não dirigia, a gente também não tinha carro, a gente também com pouco patrocinador, "como é que a gente vai trazer o professor Milton?". Ele disse "pode deixar que eu vou sozinho, eu pego táxi, vou, não tem esse problema não". E a gente ficou preocupado com ele, quem que vai levar, quem vai dar carona? Mas ele falou "não, fique sossegado". Assim, as condições que ele encontrava, ele se adaptava. "professor, não tem café agora, tem café só daqui meia hora"; "não, mas tudo bem. Tem água?" "tem água só gelada"; "então tudo bem". Ele assim, ia, participava de graça, discutia tranquilamente. E nos últimos tempos, depois que a gente, depois de uns dois anos de briguinha, nós ficamos às boas.
\end{abstract}

Surge a questão se o professor Milton Santos, com a tremenda carreira e o renome que construiu, aceitaria condições tão modestas de participação em eventos acadêmicos, se os/as organizadores/as fossem discente não negros/as. Na universidade pública é senso comum a deferência que se deve ter com a figura docente, todo cuidado e respeito como parte da vida acadêmica cotidiana e principalmente quando é necessário construir alguma parceria, algum diálogo. Essa preocupação que revela sempre aspectos das hierarquias nas relações docente -

88A professora Vanderli Custódio narrava a respeito do Encontro Estadual de Pesquisadores e Pós-Graduandos Negros das Universidades Paulistas, que aconteceu em 1989, na cidade de Marília, São Paulo. 
discente, costuma ser diretamente proporcional ao renome, pouca simpatia ou "estrelismo" do/da docente. Considerando a passagem não muito fácil do professor Milton Santos pelo Departamento de Geografia da USP, dos anos 1980 até sua morte em 2001; é possível que essa cumplicidade racial tenha sido importante não apenas para a jovem Vanderli Custódio, ainda em processo de aprender a transitar pela universidade na condição de negra; como também para o próprio Milton Santos, pois conforme discutido anteriormente nesse trabalho, sofreu muita incompreensão, isolamento e subestima por parte de colegas de Departamento.

$\mathrm{Na}$ ausência de docentes negros/as nas universidades públicas, discentes negros/as relatam a esperança e as portas que se abrem a partir do momento em que encontram na trajetória algum/a docente branco/a na universidade, que ajudam a fortalecer o projeto de longevidade escolar, conforme relata a professora Adriana Alves:

\begin{abstract}
Ao contrario dos meus amigos, de grande parte deles já sabiam o que queriam desde pequenos eu não tinha certeza. Tanto que no primeiro ano inteiro eu queria pedir transferência, eu queria ir pra engenharia. Não desisti por conta de uma matéria que eu fiz no segundo semestre do primeiro ano, com o professor que depois virou meu orientador, e é até hoje, com quem eu estudei durante a graduação toda, depois no doutorado e depois no pós-doc também, e aí resolvi ficar, dar mais um ano, mais um ano, e quando eu vi eu já estava envolvida, já estava gostando do que fazia, fiquei. (...) Olha, ele é um excelente professor e foi o primeiro que notou, nas palavras dele, que eu tinha um diferencial. E aí então ele, quando a gente conversou no final do meu primeiro ano, que eu precisava de dinheiro desesperadamente, eu tinha uma bolsa trabalho para o primeiro ano e no segundo ano eu queria pedir uma iniciação cientifica, e aí é natural aqui que a gente procure os professores que mais agradaram a gente durante os cursos de graduação. E como eu tinha gostado muito das aulas dele, eu procurei por ele, ele apostou as fichas, logo de cara eu pedi uma bolsa de iniciação e isso foi em 99 , final de 99 , e eu trabalhei com ele até passar no concurso aqui. Ele que foi meu orientador supervisor e amigo. Na verdade... ele meio que se surpreendeu, eu brinco com ele hoje, é tradição para ele quando ele ministra esta disciplina na primeira prova ele pega a prova na mão e te entrega na sua mão, entendeu? [Chama] seu nome e você vai pegar, e meu nome é Adriana Alves, então eu fui a primeira a ser chamada e ele entregou, olhou a prova, olhou pra mim e aí eu vi naquela hora que ele tinha ficado surpreso, aquele "não assumo". E naquele hora ele desenvolveu acho que aquela admiração que... inicio de admiração e surpresa que os brancos desenvolvem quando vêm negros bem sucedidos intelectualmente. E aí a gente se conectou de pronto. Esse era o diferencial que ele via, alguém que precisava de grana e que estava disposta a trabalhar duro pra conseguir, se manter na universidade. E ele apostou as fichas dele, que não é comum um professor pedir bolsa de iniciação no... [começo], eles deixam mais pra frente. É, foi isso. Também foi uma das pessoas decisivas pra eu me manter no curso, que eu não estava feliz no primeiro ano com o curso, eu queria sair.
\end{abstract}

Conforme indica Figueiredo (2004), quando negros/as brasileiros/as acessam bens sociais e simbólicos associados à setores de poder aquisitivo mais elevado; além do desconforto gerado, despertam um misto de curiosidade e espanto por parte de observadores/as surpreendidos pela presença negra em lugares e posições sociais menos usuais na sociedade brasileira, como a sala de aula da maior universidade brasileira. A autora aponta três razões para explicar a desconfiança diante da insólita, ainda que crescente presença negra na classe média brasileira: 
1) do baixo percentual de negros em posições sociais mais elevadas; 2) da construção social sobre o negro que o coloca sempre em uma posição econômica e simbólica inferior à dos brancos; e 3) da construção sócio-antropológica da categoria negro que tem construído uma incompatibilidade entre ser negro e poder desfrutar dos bens associados à modernidade. Isto significa que há uma ressonância ou uma interpenetração das construções sociais originalmente formuladas em diferentes lugares e por diferentes agentes, ou seja, as ciências sociais e o senso comum estão em perfeita consonância no que se refere ao entendimento sobre o "lugar dos negros" na sociedade brasileira. (Figueiredo, 2004, p. 202)

Interessante destacar que em estudos clássicos de trajetórias de sucesso de camadas populares na universidade pública, como Portes (2000); Nogueira, Romanelli \& Rago (2000); Viana (2001); Souza \& Silva (2003); Teixeira (2003), dentre outros; é comum o/a discente destacar o fato de que em algum momento de sua formação tenha sido reconhecido/a como alguém que trazia certo diferencial, como ter excelentes notas e grande comprometimento com as atividades próprias do processo de escolarização, a ponto de despertar a atenção de algum/a docente mais atento ou sensível. Embora nenhum/a docente entrevistado/a nessa pesquisa tenha mencionado aspectos de sua trajetória escolar que indicassem ótimo desempenho escolar, o que sem dúvida ajuda a compreender a trajetória de sucesso e longevidade escolar; no caso da professora Adriana Alves, o fato de ter passado por um prévio vestibular para acesso à escola técnica e ter ingressado numa carreira com nota de corte alta, oferece indícios de que o diferencial que o professor viu nela, foi a soma de bom desempenho acadêmico e o fato de ser negra, traduzido na admiração e surpresa que os brancos desenvolvem quando vêm negros bem sucedidos intelectualmente. A percepção e apoio desse docente veio em um momento fundamental da trajetória da professora Adriana Alves, pois do contrário ela poderia ter desistido da carreira na Geologia.

Um apoio ou conselho docente em momentos cruciais ajudou também a definir a sequência da trajetória acadêmica na pós-graduação, de outros/as docentes negros/as dessa pesquisa, como relatado pelo professor Dennis de Oliveira, que viveu uma difícil passagem da graduação para o mercado de trabalho, que quase o fez abandonar a área de Jornalismo:

E aí assim, o que aconteceu, comecei a fazer alguns estágios de forma gratuita ou mal remunerada, ainda hoje é assim. Só que aconteceu o seguinte, eu tive trabalhar para sustentar a minha família, ajudar a minha família em casa, eu trabalhava e aí eu não podia abrir mão de, por exemplo, de um emprego que eu ganhasse um pouquinho mais, registrar a carteira e... ganhar 200 ou 300 contos e ficar sem emprego, não tinha como, eu tinha que me manter. Fora isso, eu fui pai muito cedo, eu fui pai com vinte e três anos. Minha namorada era uma menina negra, fazia matemática na Oswaldo Cruz e aí não tinha jeito, tinha que manter a menina, a nossa filha, tal, então um emprego era necessário também. Aí nos últimos anos eu não pude fazer os estágios, aí eu terminei a faculdade quase sem nenhuma experiência. A minha experiência era basicamente a produção e desenvolvimento social, que eu atuava, militava, movimento negro, movimento sindical, tudo isso. Então foi muito complicado assim. E é muito interessante que, quando eu estava... um dia eu estava aqui na universidade, aqui na Faculdade, vim para pegar o meu certificado, eu acho, alguma documentação, 86, nessa época eu trabalhava no Tribunal do Trabalho, TRT, estava trabalhando como escriturário lá, fiz concurso e estava lá, minha filha estava nascendo e tal, e aí eu encontrei uma professora, que deu aula pra mim na graduação, que chamava... 
chama, ela está viva, a professora Maria Aparecida Bascelia, ela está aposentada também. Aí ela me encontrou, e abraçou, tal, que eu cheguei a fazer uma monitoria pra ela na graduação, uma época aí e ela me perguntou o que eu estava fazendo, eu disse, oh, estou fora, no mercado, trabalhando, estou com minhas coisas, tal. E ela me incentivou a fazer pós "acho que você tem que ir, você é uma pessoa que estuda bastante, gosta de estudar, gosta de ler, vem pra cá, o mercado... já que você não... vem pra cá e tal. E aí a próxima descoberta, que fui interessante, porque eu pude fazer... pelo menos foi uma opção de emprego, estar na área e tal, e segundo que me permitiu discutir coisas, aprofundar questões que eu vivia, então a minha vivência, ela foi possível ser compreendida, entendida melhor a partir dessa minha vivência na pós-graduação. E eu tive uma orientadora muito legal, que foi importante pra mim, que foi a professora Maria Nazaré Ferreira, ela me orientou no mestrado e no doutorado. Que é uma pessoa que tem um vínculo muito grande com essa discussão do movimento social, movimento anti-discriminatório. E aí eu consegui fazer meu mestrado e doutorado um pouco nessa área, discutindo esses temas assim, então foi bem interessante. É... agora já na pós, na pós foi mais tranqüilo.

A pós-graduação também apareceu como uma alternativa dentro da falta de alternativas ou de um espectro reduzido de possibilidades de escolha, como indica a professora Vanderli Custódio: Olha, não sei se eu escolhi fazer carreira acadêmica. Chega uma hora que você tem que continuar, fazer o que? Tem que continuar. No entanto, as narrativas dos/as docentes dessa pesquisa descrevem o processo de transição da graduação para a pós-graduação como mais tranquilo, e como uma possibilidade de enriquecer a passagem pelo mercado de trabalho89:

Primeiro fui trabalhar com pré-vestibular popular Educafro, um projeto que havia lá no Rio de Janeiro, ligado à igreja católica, Frei Davi e coisa e tal e num segundo momento aí eu fui para a escola particular, já digamos assim, regular, isso antes ainda de me formar. E como por exemplo, as coisas vão vindo meio que como contingências da vida, eu fiz a especialização, falei, ah, vou fazer mestrado, porque pelo menos eu posso, isso eu já estava na rede pública, que pagava muito mal. Posso fazer mestrado, porque eu posso fazer concurso pra universidade federal, pra faculdade federal, pra instituição federal, pagam melhor, tal. Aí quando vi, estava no doutorado. Mas por exemplo, no mestrado a questão já foi um tanto quanto mais consciente, não dava mais pra ir meio inercial, como foi a entrada, inercialmente como foi a entrada na faculdade. Aí eu já tinha clara a percepção de uma série de questões políticas e sociais muito sérias, com relação, por exemplo, ao espaço universitário, que era um espaço onde eu não vivia, que na época não tinha... havia muito poucos negros, muito pouca gente pobre, muita pouca gente que morava longe. Então você não dá pra lidar com o espaço de determinadas características e passar por ele como se estivesse passeando. (Professor Émerson Inácio)

\section{Assim como o professor Dennis de Oliveira, para o professor Émerson Inácio a pós-} graduação foi um espaço de problematizar as desigualdades raciais e sociais vividas na graduação a

\footnotetext{
89 Nos casos aqui considerados, à exceção da professora Adriana Alves, docentes narraram a experiência do magistério em universidades particulares e/ou escolas do ensino básico, informação que também pode ser verificada no currículo lattes de cada um/a. As professoras Vanderli Custódio e Maria Letícia e o professor Émerson Inácio narram também a experiência de docência na educação básica. No caso da professora Vanderli Custódio, essa experiência a ajudou também no campo de produção de livro didático de Geografia, conforme relato para essa pesquisa. Se por um lado o mestrado de modo geral era exigido nas faculdades particulares, de outro, a obtenção do título de doutor para continuar nas instituições de ensino superior privado, não parecia uma alternativa atraente, pois como disse o professor Roberto da Silva em entrevista para essa pesquisa "para uma universidade particular não interessava doutores, porque doutor custa caro". Assim, essa confluência de fatores: a obtenção o título doutorado sem a equivalente ascensão de carreira nas faculdades privadas, acabou por orientar esses/as docentes para concursos em universidades públicas.
} 
partir da pesquisa. Com maior consciência da possibilidade de apropriar-se dos instrumentos acadêmicos - institucionais da universidade pública. Apesar da carreira acadêmica aparecer como alternativa no horizonte nem sempre é um percurso fácil ou linear. No caso da professora Maria Letícia a pós-graduação na universidade pública não aconteceu nem na primeira tentativa e nem como sequência à graduação:

\begin{abstract}
Eu sou Pedagoga, fiz minha graduação aqui na FEUSP, ingressei em 76, e, fiz a Pedagogia, terminei em 80. Aí eu fiquei, eu tentei fazer o mestrado, eu tive meu filho em 82, começou em 82, eu tentei fazer o mestrado, porque eu fui trabalhar com a rede pública quando eu saí pedagoga daqui. (...) Tentei aqui, mas não, não entrei. Tentei na PUC, meu filho tinha três anos de idade. Entrei na PUC, mas não dei conta de fazer o mestrado, cuidar do filho, cuidar da casa e tudo isso aí. Eu voltei pra cá, comecei como aluna especial em 94, é, enfim. Eu terminei o mestrado em 97. Não sei se foi em 93 ou 94 que eu voltei como aluna especial. Já não me lembro mais. Aí eu aqui em 97 e aí eu tentei engatilhar, foi setembro de 97, tentei engatilhar o doutorado pro ano seguinte porque em setembro já não dava mais pra eu me inscrever pra seleção do doutorado no mesmo ano. Então eu me engajei no doutorado em 98, nas provas de 98, e ingressei no doutorado em 99 e terminei em 2003. Então minha formação acadêmica é aqui.
\end{abstract}

Interessante ressaltar que nesse conjunto de docentes considerado aqui, das quatro mulheres entrevistadas, três narraram algum tipo de dificuldade no acesso à pós-graduação na USP. Nenhum docente narrou algum tipo de impedimento no ingresso no mestrado e nem no doutorado. No caso da professora Maria Letícia, a maternidade apareceu como fator fundamental que a fez ingressar no mestrado treze anos após a conclusão da graduação e doze anos após o nascimento da filho. Além da professora Maria Letícia, as professoras Roselane Gonçalves e Vanderli Custódio também relataram que o ingresso na pós não foi um processo automático, como se verá a seguir.

$\mathrm{Na}$ trajetória da professora Roselane Gonçalves, o processo de se apropriar da USP como espaço do conhecimento pra si, aconteceu a partir da pós-graduação, no mestrado, num processo de comprovar que aluno/a vindo de instituição particular de ensino tem mérito e qualidade. No doutorado a passagem foi mais tranquila, uma vez que já era aluna da instituição com competência comprovada no mestrado. Mesmo assim, permanecia o desafio de conciliar pós-graduação e trabalho:

O tempo todo fui conciliando, fiz o mestrado e o doutorado trabalhando, que era também uma grande dificuldade, porque se você colocasse toda a sua pouca disponibilidade pra estudar, em função do trabalho você nem era selecionado nos programas de pós-graduação. Teve uma época que isso era um pouco de... era um critério, você tinha que ter dedicação quase que exclusiva pra fazer a formação e pra mim foi difícil. Eu sinto que... então, aí pensando um pouco, eu sinto que nessa fase eu me senti um pouco discriminada sim, não pela raça, mas pela procedência. Então também fiz... então aí inverteu a história, quando você faz ensino médio, por exemplo, na rede privada, você tem um status diferenciado, você... apostam em você, porque você vai passar no vestibular mais concorrido, porque o nível de formação é melhor. Na graduação, tendo feito uma graduação numa escola privada, isso não era mérito, pelo contrário, significava que você não entrou numa escola pública, porque você não tinha tido capacidade de entrar numa universidade pública. Então eu sinto que o meu ingresso no mestrado, que foi na própria USP, as primeiras tentativas, foi uma 
tentativa só e na segunda eu já entrei, eu sinto que fiquei um pouco pra trás, comparando os outros candidatos e uma das coisas que pra mim ficou muito claro, era alguém que trabalhava e que teria que continuar trabalhando e conciliar o curso, a pós-graduação com o trabalho. Diferente das outras pessoas que às vezes vinham de escola, de... já estavam vinculadas a uma universidade, trabalhando, que seriam liberados para estudar, ou outros que não tinham vínculo, ou que poderiam abrir mão do vínculo empregatício, só pro mestrado. Mestrado, no doutorado já foi diferente. No doutorado já tinha um vínculo grande com a orientadora, uma identidade, uma identificação boa com a área de estudo dela, que eu engatei um pouco os dois processos, então terminei o mestrado e já fui tentando construir um outro projeto na mesma linha de pesquisa dela. Aí me submeti à seleção e entrei. Mas o mestrado eu sinto que teve sim, uma certa dificuldade pra quebrar essa barreira.

Um fato corriqueiro na vida acadêmica refere-se ao modo como os processos de seleção para a pós-graduação frequentemente não são imparciais. Apesar de alguns editais exigirem a supressão do nome do/a candidato/a da capa do projeto; em função dos interesses, das linhas teóricas e de pesquisa, experiências de iniciação científica, das redes, das relações de grupos de pesquisas e orientações, dentre outros fatores, não seria muito difícil identificar um/a candidato/a dentro de um departamento. Além disso, pode acontecer o chamado "corredor" durante os processos seletivos para a pós-graduação, tal qual narrado pela professora Vanderli Custódio:

\begin{abstract}
Uma coisa que eu nunca fiz na universidade, por exemplo, é fazer corredor, que é uma coisa que eu não fiz e hoje como orientadora procuro não fazer e às vezes isso me causa um problema, que é ficar com projeto debaixo do braço, andando pelo corredor pra baixo e pra cima "você quer me orientar", ficar puxando saco do professor e essa coisa toda. No mestrado eu fiz o projeto e entreguei, junto com os outros projetos. Professor Seabra [orientador do mestrado] "nossa nem vi que você tinha se inscrito e tal". No doutorado fiz a mesma coisa, fui lá quem tinha vagas em Políticas Públicas e Territoriais serve pra mim, tem uma vaga. Fiz o projeto, encaminhei, na entrevista não conhecia esse professor Antonio Carlos, conhecia de literatura, porque ele escreve muito, um dos grandes autores de Geografia do Brasil. Mas eu não o conhecia e ele "nossa eu não conhecia você, você só escreveu, eu não tenho vaga". Falei "paciência, tento ano que vem", mas ele "não, mas eu empresto uma vaga". Então uma coisa que eu nunca fiz foi corredor e até hoje também não gosto de fazer isso, porque você abre uma vaga para o mestrado se já está tudo acertado com alguém que vai entrar naquela vaga, então pra que você abre, pra que o outro vai fazer um projeto? Então eu abro vaga e espero que quem venha faça avaliação dos projetos, faça entrevista.
\end{abstract}

Apesar de terem transposto com sucesso os obstáculos no acesso à pós-graduação na USP, as narrativas das docentes Roselane Gonçalves e Vanderli Custódio revelam os modos como a academia elege alguns sujeitos enquanto outros são alijados do processo de disputa de alguns recursos dentro da universidade pública. Enquanto a professora Roselane Gonçalves teve que construir um elo com a USP sem ter uma história anterior com a universidade, a professora Vanderli Custódio mesmo tendo feito a graduação na Universidade e ter feito um trabalho de conclusão de curso com o mesmo professor que a orientou no mestrado, entrou na fila da ampla concorrência, depois daqueles que já tinham articulações prévias com possíveis orientadores e depois daqueles 
que na ausência dessas redes, fazem o chamado "corredor". Este é um aspecto importante e preocupante da vida acadêmica, na qual é comum ouvir que orientadores/as por vezes dão prioridade a candidatos com os quais já tenha trabalhado anteriormente ou que foi indicado por alguém, para evitar futuros problemas na relação de orientação. Essa lógica não é porém muito diferente do que acontece nas bancas de seleção para docentes dentro dos departamentos, conforme narram os/as docentes dessa pesquisa.

Segundo Bourdieu (2011) o poder sobre os mecanismos de reprodução do corpo universitário repousa sobre o controle, cooptação e acesso ao corpo universitário, a partir das relações de proteção e dependências entre orientadores e orientandos e sobre o controle de posições institucionais de poder, como as bancas de concursos de admissão. (Bourdieu, 2011, p. 142-3). De um modo geral, a universidade pública parece operar confortavelmente nessas lógicas , embora cada vez mais frequentemente haja reivindicações políticas que buscam confrontar o curso "natural" da vida acadêmica como as discussões sobre cotas raciais para a graduação, pósgraduação e docência. Esse não era o panorama político quando o professor Roberto da Silva apresentou seu projeto para a seleção do mestrado na FEUSP na primeira metade da década de 1990. De modo estratégico trouxe uma proposta de pesquisa que de certo modo constrangeu a Faculdade a encarar o fato de que não se dedicava de modo satisfatório a investigar questões de desigualdades sociais na sociedade brasileira:

É... eu entrei... no mestrado aqui eu vim, retornando do Mato Grosso depois de dez anos fora de São Paulo, não conhecia nada da USP e também era um absolutamente desconhecido aqui. Mas eu apresentei um projeto de pesquisa exatamente pra retomar as discussões que eu fazia dez anos atrás quando eu tive que me afastar de São Paulo. O que era essa vivência de abrigo, vivência de rua, vivência de prisão e tudo mais, que pra mim não eram bem resolvidas. Então o projeto causou estranhamento aqui nas pessoas porque o meio acadêmico não estava acostumado, hoje talvez já pense diferente, em que o pesquisador seja o próprio objeto da investigação. Isso contraria várias regras do método científico, pelo menos as regras que eram vigentes na época aqui. Mas acharam a banca de entrevista, que me entrevistou, achou uma ousadia fazer aquilo, mas não tinha ninguém nos quadros da universidade, da faculdade aqui que fosse capaz de me orientar. Então eu fiquei o primeiro ano basicamente sem orientador. Mas a rigor, eu precisava do orientador para as questões formais da vida acadêmica, porque eu tinha clareza sobre o trabalho que eu tinha pra fazer, eu tinha acesso às fontes de dados, eu conhecia melhor do que ninguém esse meio, essas fontes de pesquisa. Então eu tinha plena autonomia pra fazer o meu trabalho. E finalmente depois de pouco mais de um ano, foi nomeada uma orientadora aqui, que não era... era uma socióloga... e o fato... acho que entenderam o fato de ela ter morado em favela permitia entender melhor a minha situação e não era exatamente isso, porque ela era uma socióloga de elite. Ela também achou que não dava conta de ter uma compreensão quanto ao significado do trabalho que eu estava fazendo e ela pediu ajuda de um coorientador, que foi o Sérgio Adorno, do núcleo de estudos da violência, que tinha um pouco mais de trânsito, um pouco mais de conhecimento nesses universos que faziam parte da minha pesquisa, como abrigos, FEBEM, prisões. É... mas a participação dos dois enquanto orientadores no trabalho, na construção do trabalho foi mínima. No caso... não que eles não quisessem, ou que não pudessem, é que eu tinha uma idéia muito consistente em relação ao trabalho que eu estava fazendo. Algumas coisas, a maioria das coisas com que eu estava trabalhando eram novidade nessa área, portanto não se tinha conhecimento acumulado a respeito, não se tinha reflexões mais sistematizadas a respeito disso. O que dava mostra de 
que era um fato que sociedade não se preocupava de forma adequada com o problema e a academia havia passado completamente ao largo dessas questões. Então em todos os sentidos, o tema aqui na universidade se constituía uma novidade. E com os orientadores a gente se limitava a se discutir mais as questões formais de pesquisa, de aplicação do método científico e não das questões de fundo da pesquisa, propriamente dita.

No relato do professor Roberto da Silva não foi o ingresso na pós-graduação que esteve em questão, mas o que sua trajetória e sua proposta de pesquisa representavam para a instituição. Não ficaria bem para a Faculdade de Educação da USP rejeitar um projeto de pesquisa cuja importância política era manifesta. De certo modo, o professor Roberto da Silva trazia à superfície com dois ou três anos de antecedência, questões sobre democratização que eclodiram na mídia internacional com o Comitê Pró-Cotas para Negros da USP90. A passagem do professor Roberto da Silva pelo mestrado foi memorável para a FEUSP, pois sua defesa de dissertação tornou se um evento público: Bom... tinham 120 pessoas assistindo, foi capa da Folha de São Paulo, comentários em todos os telejornais. Recebi nota dez com louvor e fui promovido para o doutorado. E sua defesa de tese de doutorado também foi noticiada, conforme indica essa matéria do Jornal Folha de S. Paulo de 23/09/2001: Ex - interno da Febem agora é doutor pela USP. É possível que além da qualidade do seu trabalho e da sua competência como pesquisador; toda essa visibilidade em torno da pesquisa e da trajetória do professor Roberto da Silva possa ter aplainado o terreno para sua aprovação no concurso para docente na FEUSP, quebrando possíveis correntes de favoritismo em torno de outros nomes:

\begin{abstract}
Então não tive dúvida em me inscrever aqui. Foi um concurso concorrido, que tinha inclusive... claro, concurso dessa natureza, assim para professor aqui, vários deles são oriundos daqui mesmo, fizeram mestrado e doutorado aqui ou tem relações pessoais com orientadores, são parentes de professores, que também prestaram concurso. Mas eu inaugurei uma boa estratégia e me saí muito bem.
\end{abstract}

Vale destacar que a USP é uma instituição de consolidada história e tradição de excelência, com orgulho de seu passado de bandeirantismo científico, tendo formado boa parte da academia

900 Comitê Pró-Cotas para Negros da USP foi um movimento de reivindicações pró-cotas que agitou a USP na década de 1990. Segundo um de seus membros, o então estudante de Jornalismo na ECA, Fernando da Conceição, em texto publicado no jornal Folha de São Paulo de 16 de junho de 1997; o comitê foi pioneiro no debate pró-cotas no Brasil. Além de alunos, o comitê contou com a participação e apoio de docentes como Kabengele Munanga, Milton Santos, Jair Borin, Solange Couceiro, Thomas Skidmore, o então diretor da Faculdade de Direto da USP, Antonio Junqueira de Azevedo, o professor Paulo Sérgio Pinheiro, presidente da Comissão Nacional da Verdade, e que pagou a fiança de Fernando da Conceição quando este foi detido no domingo de páscoa de 1996 por pichações na USP com reivindicações. O então reitor da época, o professor Flávio Fava de Moraes foi radicalmente contrário ao conjunto de reivindicações do Comitê. Apesar das cotas não terem sido implantadas na USP até o presente momento, o Comitê atraiu a atenção da mídia nacional, com grande cobertura sobretudo do Jornal Folha de S. Paulo e da mídia internacional também, pois o "Wall Street Journal" chegou a enviar seu correspondente na América Latina para entrevistar os integrantes do comitê pró-cotas na USP e alguns docentes. 
brasileira e que se mantém anos a fio na posição de melhor universidade brasileira nos rankings de avaliação internacional. Desse modo, não seria plausível acreditar que uma trajetória excepcional como a do professor Roberto da Silva fosse suficiente para assegurar uma vaga no corpo docente da maior universidade brasileira, pois mais do isso, seria necessário comprovar mérito:

(...) eu acho que depois que a gente avança em certas trajetórias em termos de estudo, conhecimento, titulação, fica difícil a discriminação. Tá... num concurso aqui pra Doutor, para Professor Doutor, todos são iguais, porque todos são doutores, seja titulado aqui, fora, em qualquer outro lugar mas em termos de propriedade, de conhecimento, titulação acadêmica, alcançaram o mesmo grau. Então o diferencial aí é desempenho, competência, que... Eu posso até ter ganho de pessoas mais competentes do que eu, mas que pra este concurso não tiveram o desempenho que precisava ter. Então nessas circunstâncias eu acho que... eu já conheci situações aqui na USP em que o fator étnico-racial foi decisivo, mas no meu caso não. Ali prevaleceu a questão do desempenho.

De fato, discriminado negativamente no concurso docente em função de seu pertencimento de raça, classe e de sua trajetória, o professor Roberto da Silva não foi; pois do contrário, dificilmente ele teria sido aprovado. Mas é também possível considerar que sendo ele um doutor bem qualificado pela própria FEUSP, em condições de competir pela vaga de docente em pé de igualdade com outros candidatos; o fato de sua história de vida ser bem conhecida dentro da Faculdade e em vários meios de comunicação, pode ter gerado alguma pressão no sentido da Faculdade de Educação da USP ter que revelar sua face mais democrática e progressista não apenas em termos de produção teórica, mas na prática efetivamente.

Considerando os processos de concurso dos/as sete docentes aqui considerados, três passaram na primeira tentativa e os/as outros/as quatro lograram êxito na segunda investida. E no conjunto de docentes que tiveram sucesso na primeira tentativa, os motivos do sucesso apresentam diferenças que merecem ser destacadas. E em função disso, serão considerados primeiramente. Assim, além do professor Roberto da Silva, cujo concurso acaba de ser considerado, tem-se ainda as experiências das professoras Vanderli Custódio e Roselane Gonçalves. A narrativa da professora Vanderli Custódio é uma rara oportunidade de conhecer com detalhes um processo de preparação para um concurso, e mais do que isso, corajosamente, ela nos revela dilemas e inseguranças que raramente são admitidos na vida acadêmica na posição de docente. Por isso, a transcrição a seguir merece a leitura de cada caracter com atenção, respeito e admiração:

O concurso... eu tive uma sorte, que foi o seguinte, quando eu estava, eu tinha terminado, tinha terminado o doutorado, terminei em 2001, eu estava trabalhando só na Fiel de Osasco e estava com duas disciplinas só. Então eu ia numa noite trabalhava 4 horas, ia noutra noite e trabalhava 4 horas. (...) Então nós morávamos no Taboão da Serra e mudamos aqui pra Pinheiros em 2001, nós mudamos em 2000, nós mudamos no ano de 2000. Então a gente estava sem dívida nenhuma, que a gente conseguiu acertar tudo, quitar tudo, estava trabalhando na Fiel 2 noites, então eu estava com um tempo muito legal pra estudar, então eu me inscrevi nesse concurso, imaginei "ah o IEB é um lugar pequeno". Eu não queria fazer um concurso no Departamento de Geografia, você conhece um pouco dos bastidores, "não sei se eu vou querer trabalhar aqui, não sei"... Aí apareceu essa vaga aqui, eu não 
conhecia o IEB, o IEB é muito conhecido na História, na Letras, mesmo na Arquitetura, mas para Geografia é um instituto desconhecido, essa vaga na área de Geografia "vamos ver, sem nenhum compromisso", porque de qualquer maneira, conta pra currículo aprovação em concurso que você faz, mesmo que você não entra, se você for aprovado, consta lá, uma indicação boa e tal. Eu peguei os 12 pontos do concurso e fui estudando, fui fazendo apostila, preparando aulas, tanto que ficou um calhamaço assim, eu tive tempo pra estudar com bastante calma. E como eu não estava naquele desespero pra entrar, preciso entrar, qualquer coisa, foi um concurso muito tranqüilo. Nós éramos em 9, depois no dia, vieram 7 candidatos, alguns conhecidos colegas. É super esquisito você encontrar colegas em concursos, alguns amigos mesmo, mais do que colegas, fez parte, caminhando mesmo com a gente. E aí foi um susto. Eu eu fui bem no concurso, quando você sabe que você faz, vai bem. Sortearam o texto, o tema da prova escrita, um tema fácil que é Região, na Geografia, achei fácil e essa coisa de dar aula no ensino fundamental, eu nunca dei aula pra colegial, mas trabalhei muito com vestibular, eu trabalhei muito com vestibular na UNIP, trabalhei com vestibular na UNICAMP, uns 4 ou 5 anos, elaborando questões, corrigindo questões, aí você vai aprendendo com as pessoas, aí tem toda a coisa, como é que você dá uma aula tecnicamente, como é que dá uma aula. A gente nunca dá uma aula como deveria dar, você elabora uma questão, você desenvolve, no final você recupera a questão que você colocou lá na frente e discute com a bibliografia e envolve a comunidade que está assistindo a sua aula, então há técnica. Então eu fiz uma prova, uma prova escrita nos moldes de uma aula. Eu levantei uma questão, desenvolvi, fechei o tema na Geografia. Então, depois na aula prática, a mesma coisa. Saiu outro tema, um tema que eu não gosto muito que é Paisagem na Geografia, mas que me acompanha, esse tema vai me acompanhando a vida toda, eu vou fugindo dele, ele vai a vida afora atrás de mim. Eu fiz a mesma coisa, dei uma aula técnica, correta, certinha, dentro do tempo. Então assim, eu sabia que tinha feito um bom concurso, que eu não seria reprovada, por que o vexame, o medo era tirar 5, abaixo de 7, eu sabia que eu ia ser realmente aprovada. E no sábado, o concurso foi sei lá, terça, quarta e quinta ou sexta, alguma coisa assim e excepcionalmente no sábado, no meio dia, que eles iriam anunciar quem ganhou, eu estava na feira comendo pastel com meus amigos de uma turma que a gente se encontra há uns 15 anos numa feira livre, numa esquina e conversa e conversa, aí eu estava lá, roupinha de verão, toda simples, tomando sol, à vontade e comentei com um colega negro, Marcão "ah, prestei um concurso, o resultado deve estar saindo hoje meio-dia, daqui a pouco"; "vai lá?"; "depois eu vou lá e vejo"; "como você não vai?"; "não vou"; "ah não, você vai". Me enfiou pra dentro do carro e me largou aqui na porta, eu com roupinha de verão, que você vai na feira encontrar os amigos, de modo algum era uma roupa de docente... estava super à vontade. E daí esperava que eu ia passar, mas vi sexto lugar, quinto lugar, quarto lugar, terceiro lugar, segundo lugar, e fiquei "porque ainda não me citaram, já é segundo lugar e...?" Daí, gente, eu quase tive uma coisa, quase mesmo, porque eu não, eu não imaginava, entrei em desespero e agora? Porque eu tive uma insegurança muito grande, por uma porção de motivos, sabe. Acho que eu nunca falei sobre isso, assim, eu era uma boa professora, fazia uma pesquisa na média, nada de excepcional, porque você sabe o que é uma boa pesquisa, um bom trabalho, quem tem um bom tino teórico. Eu faço ali na mediana, eu não tenho nada de excepcional no que eu faço. Então eu fiquei pensando: "até que ponto a academia foi paternalista comigo?". Porque acho que as duas coisas fazem mal: faz mal ser rechaçado mesmo, categoricamente e ao mesmo tempo faz mal o paternalismo, porque você não sabe até onde aquilo foi mérito. E ao mesmo tempo, tinha uma outra coisa, parecia, eu entrei, com o nível que eu tenho, que é um nível mediano, não é um nível, eu fiquei em dúvida com a Universidade de São Paulo mesmo. Eu falei assim, "se eu entrei, o nível da universidade caiu muito (risos); o nível da universidade caiu muito, porque eu tô na mediana". E eu tive professores excelentes, eu sei o que é uma professora, um pesquisador excelente, que é a excelência que a USP diz que tem. Então eu fiquei muito confusa, fiquei extremamente insegura com relação a isso. Depois falei, como é que eu vou fazer jus agora à essa excelência, dentro do Instituto, que é interdisciplinar, que tem professores titulares de muito tempo, que faz uma pesquisa em Ciências Humanas, basicamente erudita, como é que eu vou criar uma área de Geografia, ninguém sabe o que é geografia pra começar. Todo imagina que Geografia é ah é só pegar um mapa, qualquer coisa de mapa chama Vanderli que ela é da Geografia. Todo mundo acha que sabe o que é Geografia, mas ninguém sabe. Então eu fiquei, eu saí daqui eu chorava, eu sentava, chorava de alegria, eu sentava, eu ria, fiquei em delírio uma semana. Precisaram falar "professora, você precisa vir aqui, porque tem uns papéis pra assinar, umas coisas pra providenciar". (...) Foi um susto, eu passei uma semana sem vir aqui, tiveram que me chamar lá em casa. Eu não sabia se eu chorava ou ria, se eu ria ou chorava, levei um 
susto imenso. (...) mas entrei muito insegura na universidade como docente, muito, muito, muito insegura.

É necessário destacar alguns elementos narrados: a professora Vanderli Custódio já tinha uma carreira docente no ensino básico e em algumas faculdades particulares e gozava de certa estabilidade financeira, com casa própria e estava sem dívidas. Ela possuía condições de tempo e calma para estudar e estudou bem. Prestar um concurso na USP seria uma opção interessante, mas sua vida e sua carreira não dependiam de uma aprovação. Ela foi estratégica: tentou o concurso num instituto onde a área de Geografia estava sendo instituída e não no seu Departamento de origem, onde conhecia os bastidores e os eventuais problemas. A professora concorreu com antigos colegas de curso, que tiveram portanto, formação semelhante a dela. Sabia que havia feito um bom concurso e que seria pelo menos aprovada. Diante de todo esse conjunto de condições favoráveis, o que ajudaria a compreender o misto de alegria e de insegurança decorrentes de sua nomeação?

Adentrar os portões da USP é encarar involuntariamente uma narrativa épica, de celebração da universidade. O discurso de excelência que alimenta a áurea uspiana é injetado nas mentes e corações da comunidade acadêmica sistematicamente de diversas formas. Todo calouro é mergulhado nesse discurso já na primeira semana de recepção. A título de ilustração, o Manual dos Calouros, edição 2015 dá as boas vindas à USP com a seguinte mensagem do reitor Marco Antonio Zago:

O ingresso em uma universidade de excelência como a USP representa uma nova etapa de vida, em que se abre um amplo espectro de oportunidades de conhecimento e descobertas no ambiente universitário. (...) Neste momento é importante que você tenha consciência de sua importância para a construção do processo universitário.

A mensagem de boas vindas à vida acadêmica varia conforme o reitor, certamente. Mas mesmo no caso do professor Marco Antonio Zago, cuja gestão já entrou para a história da universidade como a co-responsável pela maior crise vivida pela USP em oitenta anos de existência; ainda assim na mensagem prevalece a noção de excelência. De modo geral, o tom não varia muito ao longo do documento; na seção do Manual intitulada Conheça a USP a mensagem é: O talento e dedicação dos docentes, alunos e funcionários têm sido reconhecidos por diferentes rankings mundiais, criados para medir a qualidade das universidades a partir de diversos critérios, principalmente relacionados à produtividade científica. Assim, o corpo discente já ingressa na USP informado do privilégio de ser parte de um universo de prestígio, sendo sua responsabilidade cuidar desse legado e seu dever trabalhar para perpetuá-lo. Se estudantes já entram com essa missão, quem ingressa no corpo docente não teria tarefa menor. Este trabalho tem 
defendido a ideia de que toda a história da USP é configurada por um debate étnico-racial latente de valorização do legado branco e europeu. Antes da USP ser USP, desde 1827 com a Faculdade de Direito e em 1912 com a Faculdade de Medicina o debate já se fazia presente, conforme discutido nos primeiros capítulos. Não coincidentemente a marca da fundação na USP em 1934 é ainda a contratação da missão européia, conforme destaca a seção A Trajetória da USP no referido Manual de Calouros:

Hoje com 42 unidades de ensino espalhadas em sete campi, ela iniciou suas atividades em 1934, reunindo tradicionais escolas já existentes e a lendária Faculdade de Filosofia, Ciências e Letras, o "coração da USP". Os primeiros professores - entre eles, o francês Claude Lévi Strauss - foram contratados na Europa.

E foi no "coração da USP" que a professora Vanderli Custódio fez toda a sua formação ao longo das décadas de 1980 e 1990. A história do curso de Geografia da USP, na então FFCL é narrada a partir da presença fundamental de seus dois primeiros mestres franceses: Primeiramente, Pierre Deffontaines que ficou em São Paulo somente um ano. Porém suas iniciativas foram consolidadas pelo seu sucessor Pierre Monbeing que ocupou a cátedra de Geografia por 11 anos (1935 - 1946). A Associação de Geógrafos no Brasil foi criada em 1934, ano de fundação da USP, o que indica que o país já conhecia a profissão e contava em seus quadros com nomes brasileiros como Delgado de Carvalho, com formação na França. E como destaca o professor Pasquale de Petrone em entrevista publicada na edição especial da Revista Estudos Avançados de 1994 na ocasião dos 60 anos da USP, “ a Faculdade de Filosofia não foi tão somente instrumento de processos de mudança, mas também decorrência desse processo". (p.141). O professor credita ao francês Pierre Monbeing a configuração e ampliação do Departamento de Geografia durante sua estadia na USP em termos que teriam transformado a história da Geografia brasileira.

Sem subestimar a importância do mestre francês, seria interessante lembrar, que essa missão europeia contratada foi composta de jovens docentes em início de carreira. Pierre Monbeing por exemplo, realizou seu doutorado após sua incursão no campo brasileiro. Assim, a excelência desses primeiros mestres, deve-se sobretudo ao fato de serem europeus e à possibilidade de trazer para São Paulo concepções europeias de universidade, conforme discutido no primeiro capítulo desse trabalho. E ainda, segundo relato do então reitor Flávio Fava de Moraes na referida publicação comemorativa dos 60 anos da USP: (...) a Ciência moderna inicia-se no país com a criação da USP e quando para ela veio um grupo de professores estrangeiros, dedicados integralmente à missão de formar pesquisadores, trazendo como bagagem, em várias áreas, a experiência universitária européia. (p.21)

A professora Vanderli Custódio foi aluna de discípulos e herdeiros diretos da missão francesa, como o professor Aziz Ab`Sáber, por exemplo. O legado europeu esteve presente em toda 
a sua formação acadêmica, numa universidade que convoca seu corpo docente a perpetuar sua tradição de excelência. Dificilmente seria de outro modo. Considerando a comunidade acadêmica uspiana e a brasileira de um modo geral, tem-se que na história intelectual brasileira o cânone do pensamento científico estabeleceu-se a partir de parâmetros estrangeiros, conforme indicam Pinho \& Figueiredo (2002). Os autores exploram a noção de colonialidade do poder/saber91 na discussão da relação centro-periferia e o modo como a reflexão crítica latino-americana se posiciona em relativa subordinação.

Se a função da missão europeia na fundação da USP era introduzir a universidade na linguagem universal da ciência, cabe questionar "como poderia o conhecimento pretender a universalidade se na sua base se encontra a pressuposição da introdução no pertencimento, na tradição ou na autoridade, que sempre é particular e contextual?” (Pinho \& Figueiredo, 2002: 195). Assim, a modernidade científica instituída pela USP reforçaria sua condição de periferia que mira o centro, como culturas de imitação ou de um realismo fantástico, com a vitória do simulacro sobre a realidade acadêmica anterior. E desse caráter inautêntico resulta que brasileiros instruídos padeçam de um mal estar crônico, um permanente sentimento de inadequação. O problema nem seria tanto a imitação, pois a mesma estaria presente em toda e qualquer formação sócio-cultural, mas o fato de a imitação deliberadamente ou não, desconsiderar a realidade e estrutura social do país, em cujas bases estão o colonialismo e o trabalho escravo (Pinho \& Figueiredo, 2002).

Não seria absurdo dizer que na narrativa oficial da história da USP não há lugar para problematizar o modo como as injustiças raciais informaram o transplante das concepções européias e posteriormente norte-americanas de universidade. Passados oitenta anos, prevalece na narrativa o tom bandeirante em que coube á elite intelectual uspiana carregar o fardo do homem branco de ocidentalizar e esclarecer o país. É pois o que sugere esse trecho da publicação da revista Pesquisa FAPESP, edição especial de comemoração dos 80 anos da USP: “A USP faz o Brasil ser um país melhor. Não é pouco. Além disso, no âmbito do ensino superior é certamente a instituição que mais contribui para esse objetivo nacional". 92

Diante desse peso histórico, parece bastante compreensível o sentimento de insegurança da professora Vanderli Custódio quando assume a condição de docente da USP e consequentemente a missão de perpetuar o legado de tradição. Assim, além dos sentimentos de inadequação, desterro e inferioridade vivido pela intelectualidade brasileira em função da sua inserção colonial no sistema

91Os autores partem da noção de colonialidade do poder proposta por Aníbal Quijano, que seria em linhas gerais o modo como a ordem simbólica colonial engendra a máquina das hierarquias culturais políticas e econômicas modernas; para desenvolverem a noção de colonialidade do saber. Ver: QUIJANO, Aníbal (2001). Coloniality of Power and Democracy in Latin America.

92Texto A USP faz o Brasil ser um país melhor escrito pelo professor e diretor científico da FAPESP, Carlos Henrique de Brito Cruz para a edição comemorativa da Revista FAPESP, edição especial dos 80 anos da USP e publicada em dezembro de 2014. 
acadêmico mundial, de orientação masculina e branca, a posição da intelectualidade negra não seria menos desconfortável, pois:

(...) periferalizada no conjunto hegemônico das nações capitalistas, a consciência intelectual nacional periferaliza seus próprios sujeitos coloniais repondo o negro como uma categoria, vamos dizer, alegórica dentro do campo das Ciências Sociais. (...) As elites brancas, dentre estas os intelectuais brancos, mesmerizados pela cultura central da Europa, alternativamente oprimiram, desbarataram e ocultaram a manifestação da vida social afrodescendente e, do mesmo modo, representaram, alegorizaram e objetificaram o negro como alteridade interna, passível de representação como um objeto sociológico plenamente constituído, mas impossibilitado de se colocar como sujeito do discurso, como artífice de uma crítica social em primeira pessoa. Talvez pudéssemos descrever essa situação como aquela na qual a colonialidade do poder se transfere como colonialidade do saber. (Pinho \& Figueiredo, 2002, p. 204)

A concepção de universidade traduzida na criação da antiga Faculdade de Filosofia Ciências e Letras da USP ainda é um desafio perseguido pela instituição, como mostra a recente história da Escola de Artes e Ciências Humanas (EACH), também conhecida como USP Leste, inaugurada em 2005. Na ocasião dos 70 anos da universidade em 2004, a professora Myriam Krasilchik, que dentre outras atribuições foi vice-reitora da universidade, diretora da FEUSP, e presidente da comissão do projeto USP/Zona Leste, admite em entrevista93 que a proposta da EACH foi também informada pelo que significou a FFCL: Fizemos um relatório, sugerimos que houvesse novos cursos inseridos em uma única unidade; pretendíamos, dessa maneira, reaver aquele espírito da antiga Faculdade de Filosofia, Ciências e Letras, para possibilitar maior integração entre os alunos e os professores. Apesar do desejo de perpetuar um legado, a história da EACH tem se revelado uma complicada e complexa subversão desse espírito USP. A USP Leste é fruto em grande medida de reivindicações de movimentos sociais pela democratização da Universidade, na região de maior densidade populacional da cidade de São Paulo e historicamente marginalizada pelo poder público:

Uma região com mais de 4 milhões de habitantes que conta com uma única escola pública de nível superior. (...). Um movimento de quase 20 anos de luta por uma universidade pública. Nesse contexto, e mediante uma crescente pressão da sociedade ${ }^{94}$ por mais vagas nas universidades públicas paulistas é que a Zona Leste, finalmente, vê uma possibilidade concreta de ver sua reivindicação atendida - ou melhor, seu direito assegurado. (Biondi, 2003).

Por décadas as reivindicações de expansão das universidades estaduais paulistas foram sonegadas, ganhando novo impulso somente em 2001, quando o Conselho de Reitores das

93Entrevista concedida pela professora Myriam Krasilchik em 30 de março de 2004 e publicada na obra MOTOYAMA, Shozo (org.). USP 70 anos: Imagens de uma história vivida. São Paulo: EDUSP, 2006

94Destaque para o Fórum de Educação da Zona Leste, criado em 1991, e assessorado pela ONG Ação Educativa. 
Universidades Estaduais de São Paulo (CRUESP) foi instado a apresentar projetos de ampliação. Conforme destaca Biondi (2003), essa repentina retomada esteve vinculada ás eleições de 2004 e ao aniversário de 70 anos da USP. Muitas polêmicas cercam a USP Leste desde o seu projeto de fundação, como o cerceamento da participação da comunidade local no projeto do campi e na vida acadêmica desde então, a escolha dos cursos implantados, a contratação dos professores, as irregularidades ambientais e constantes ameaças de fechamento do campus, etc. Essas questões serão retomadas no próximo tópico desse capítulo. Por hora, interessa destacar mais detidamente, como aconteceu o processo de contratação dos/as docentes, para melhor compreender o contexto em que acontece o concurso da professora Roselane Gonçalves, que assim como o professor Roberto da Silva e a professora Vanderli Custódio, também foi aprovada em seu primeiro concurso para docente da USP. Porém, diferentemente de ambos, ingressou numa nova USP, a USP Leste.

Em 2006, ano em que a professora Roselane Gonçalves inicia sua carreira docente na USP a universidade vivia ás voltas com o debate sobre a precarização dos contratos de professores. Em linha gerais, era esse o quadro:

\begin{abstract}
Mais de 1.000 dos cerca de 5.000 professores da USP em atividade foram contratados em processos seletivos, sem as garantias de estabilidade oferecidas pelos concursos públicos por isso são chamados de "precários". Embora o próprio Conselho Universitário tenha determinado em 2004 que novas contratações devem ocorrer exclusivamente por concurso público, a USP não abandonou os processos seletivos: em cada 10 docentes da novíssima USP Leste (Escola de Artes, Ciências e Humanidades, ou EACH, nove são "precários". Os docentes nessa situação estão sujeitos a arbitrariedades e perseguições. O mesmo problema afeta os funcionários técnico-administrativos (Hora, 2006)95
\end{abstract}

Em agosto de 2006, um ano após o início das atividades acadêmicas na EACH, o clima era de insegurança na unidade. Muitos docentes entenderam tardiamente que não haviam ingressado no quadro permanente da USP. Só lhes ficou clara sua verdadeira condição quando começaram a freqüentar a unidade e conversaram com os colegas. A confusão aconteceu porque os rituais de um processo seletivo são praticamente idênticos aos de um concurso público. (Hora, 2006, p. 22). Além da apreensão quanto à possibilidade de efetivação a médio prazo, esta só ocorria mediante novo concurso, aberto não apenas para os docentes precários, mas também para uma nova e ampla concorrência. Embora a professora Roselane Gonçalves tenha entrado na USP na condição de docente precário, seu concurso é apresentado como um processo tranquilo:

Eu acho que foi um processo tranqüilo, porque até hoje a gente ainda tem, nós temos vários doutores na área de Enfermagem, porque assim, nós não temos ainda, nosso curso de Obstetrícia, nós não temos obstetrizes graduados e pós-graduados pra ingressarem como docente de curso desse. Então quem ingressou na área específica de assistência obstétrica, foram as enfermeiras obstétricas e eu sou enfermeira obstétrica e com mestrado e doutorado. Então não são tantas que já tinham esse pré-requisito. E foi tranqüilo porque

95Texto do jornalista Daniel Garcia Hora intitulado Precários na USP, Drama sem fim? Publicado na Revista Adusp em Agosto de 2006. 
existiu uma necessidade grande de contratação, porque o curso era novo, tinha... começou com pouquíssimos docentes pra dar conta de toda uma grade e nós chegamos num momento assim muito... dos dois lados, uma necessidade grande. O processo de seleção acho que foi normal, porque logo em seguida a gente teve que fazer um outro, exatamente igual, pra conseguir um vínculo diferenciado, porque nós fizemos primeiro um contrato precário, como eles diziam, em seguida, todos os docentes da escola, não só da Obstetrícia, tiveram que fazer um novo concurso pra garantir um vínculo mais estável. Então fizemos tudo de novo, abriram as inscrições, outros candidatos se inscreveram e nos submetemos às provas. Eu entrei em 2006... acho que logo em 2007 ou 2008, uma coisa assim, a gente já estava tendo que fazer um novo concurso. E eu acho que... não sei se porque também a pósgraduação, o mestrado e doutorado, um pouco já te prepara pra essas... pra se submeter a este tipo de processo, então uma banca de concurso, não é muito diferente de uma banca de defesa de uma tese ou dissertação, é lógico que é diferente, porque te contratam ou não te contratam e uma banca de doutorado não é tanto assim, mas é... você se acostuma a se submeter a avaliações desse gênero, dar aula pra alguém que vai te avaliar, enfim. Então sinto que esse processo foi exaustivo, mas sem maiores problemas.

De fato, a questão da precarização dos contratos docentes era uma questão que a USP enfrentava desde o final da década de 1980 em função de uma brecha do Estatuto da universidade que previa contratações especiais em caráter de urgência para o recrutamento de profissionais com título de doutor. A luta de oposição contra essas irregularidades nos concursos de ingresso se intensificou ao longo da década de 1990 e contou com grandes juristas como Amaury Mascaro Nascimento e Dalmo de Abreu Dallari. A proporção de professores em regime de precariedade em 1998 equivalia a 40\% do corpo docente da USP, e na ocasião do ingresso da professora Roselane Gonçalves essa proporção já havia reduzido à metade, cerca de $20 \%$ do universo docente da universidade. A questão é que a criação da $\mathrm{EACH}$ de fato usou e abusou da possibilidade de contratações irregulares, de modo que em 2006, em seu segundo ano de atividade, 90\% das vagas preenchidas para docente estavam na condição de precários (Hora, 2006).

Apesar de ser mais um tópico na história de constantes crises vividas pela USP, na primeira metade da década passada a EACH assomou como uma grande possibilidade de ingresso na USP como docente, ainda que em condições precárias. Quando a professora Roselane Gonçalves terminou seu doutorado a USP estava contratando um grande contingente de profissionais com título de doutor. Em seus dois primeiros anos de funcionamento, a EACH contratou mais de uma centena de docentes. Esse é um fato memorável, considerando que a expansão do corpo docente da USP acontece em ritmo muito aquém da demanda. Dados de 2014 do Anuário Estatístico da USP, indicam que em 25 anos, enquanto o corpo discente cresceu 96\%, saltando de 44.811 em 1989 estudantes para 87.751 em 2014; no mesmo período o crescimento do corpo docente foi apenas de 6,8\%, passando de 5.626 para 6.008 docentes, indicando que em 25 anos não houve nem 400 contratações, o número de novos docentes que a criação do campi EACH demandou foi um fator atípico na história da USP. Desse modo, o concurso da professora Roselane Gonçalves aconteceu num momento excepcional na história da universidade e foi sem dúvida, uma grande oportunidade para uma recém-doutora. 
Por sua vez, os processos dos concursos dos/as professores/as Dennis de Oliveira, Émerson Inácio, Maria Letícia e Adriana Alves têm como ponto comum o sucesso na segunda tentativa. Digno de nota também é o fato de três docentes terem relatado que ficaram na segunda colocação quando tentaram pela primeira vez. Cada processo apresentou alguma especificidade que de modo geral aproxima ou afasta a importância do pertencimento étnico-racial de cada candidato/a durante a disputa. Neste sentido, considera-se não apenas o fenótipo do/a candidato/a dentro das dinâmicas do racismo à brasileira; como também o modo como a carreira de pesquisa de cada um/a é ou não marcada pelo debate racial.

Apesar de ter sido a última a ingressar na USP como docente em 2010, no Departamento de Geologia; no relato dos concursos que prestou a professora Adriana Alves, trouxe questões que estão no cerne do debate sobre o preconceito de marca no Brasil:

É, essa questão é meio polêmica, eu prestei duas vezes concurso, o primeiro eu fiquei muito chateada porque como... se eu disser para você que concurso é mérito é a mesma coisa que eu dizer para você que o vestibular é mérito, e eu não acredito nisso. Então, existe sim o tráfego de influências, existe sim a percepção que as pessoas têm de mundo que, da banca, elas levam para mesa, elas levam para a [arguição]. As etapas são uma aula, uma prova que você tem que ler em público e uma entrevista. E a primeira coisa que um dos participantes, o primeiro participante da banca na minha arguição falou foi a sua erudição me surpreendeu para alguém como você, reticências, que foi o concurso que eu não passei. Então... e o intervalo entre um concurso e outro era de uma semana, então aquilo me deixou extremamente mal porque o quê que eu pensava que eu tinha me preparado a vida inteira, que eu tinha estudado, que eu tinha feito a minha parte e que por um detalhe técnico que eu não podia mudar, que é a cor da minha pele, ou minha aparência, talvez eu nunca tivesse um lugar na universidade, pirações de quem... não estou dizendo que o cara que passou não tem o seu mérito, estou dizendo que naquele momento eu acho que fala dele, se não foi intencionalmente para ferir, com o intuito de me desestruturar psicologicamente, ele fez um belíssimo trabalho neste aspecto porque na hora eu desmoronei e eu não conseguia mais pensar, não conseguia mais responder, tudo o que eu conseguia pensar era eu não vou passar porque eu sou negra. E é obvio que tem uma carga de paranoia, obvio que tem, e tinha mesmo. O meu desempenho no segundo concurso foi muito melhor do que no primeiro, é o primeiro, eu estava nervosa. Mas na hora me fez mal, aquilo me fez mal, acho que era desnecessário, porque se eu fosse gorda eu pensaria que é porque eu era gorda, se eu fosse mulher, se eu fosse baixinha, entende? Então a frase dele, para quem tem uma vivência como a minha só poderia ser absorvida dessa forma. Então ninguém mais viu isso na sala, porque ninguém mais teve o tipo de vivência que eu tive. Então se alguém tem, e eu vejo assim né, se fosse alguém que tivesse problema com beleza, que nem eu tenho uma amiga minha que fala que o maior problema dela é ser bonita e que as pessoas não a respeitam por isso, ela levaria essa frase para o lado de que nossa ele acha que eu sou bonita demais, que eu devia estar desfilando, entende? Então, naquela hora a minha vivência, a minha experiência também contou para a interpretação do que ele falou. Mas se você me perguntar friamente se eu achei que ele foi racista eu vou te falar que sim. Chega.

Tendo feito toda a sua formação na Geologia, o simples acesso ao currículo lattes da professora Adriana Alves indica que suas preocupações de pesquisa estão bem longe do debate racial. Seu universo de investigação gira em torno da mineralogia e petrologia, datação u-pb, granitos crustais, geoquímica elemental, geocronologia e microssonda eletrônica. Nesse sentido a 
negritude que a professora Adriana Alves apresentou à banca, foi um detalhe técnico que ela não poderia mudar, a sua cor de pele. Em outro momento da sua narrativa, a professora revela que $n a$ Geo[logia], agora melhorou um pouco, mas entra um negro por ano, de cinqüenta alunos, sempre é um flagrantemente negro [grifos meus]. E deste modo, ela nos indica que nos parâmetros do alunado da Geologia, ela seria flagrantemente negra, como afirma: digamos assim, eu não posso dizer que eu sou moreninha, eu não passo por moreninha. Considerando que outra característica do racismo à brasileira é a sutileza, o refinamento para contornar o politicamente correto, o comentário da banca apontando para a erudição de alguém como a professora Adriana Alves, não passa por uma simples e inocente observação. Se a USP reiteradamente aponta para a sua excelência, para seu papel de formadora da elite intelectual brasileira, é importante destacar, que elite intelectual não é apenas uma entidade discursiva, mas de fato, possui lattes, departamento e corpo. E na Geologia, pela frequência que entra estudantes negros/as, a professora Adriana Alves não seria uma típica representante da elite intelectual do Departamento. Encarar esse fato numa banca de concurso, não parece favorecer o desempenho de nenhum/a candidato/a. A emergência do sentimento de inadequação de intelectuais negros/as na academia brasileira, discutido anteriormente a partir de Pinho e Figueiredo (2002), passa a ser uma ameaça constante em suas carreiras. Desse modo, ser docente negro/a na USP passa a ser também um exercício cotidiano de implodir essas concepções de sujeito periférico da academia brasileira. E isto inclui o esforço de voltar, tentar um novo concurso e conquistar a aprovação que pode exigir mais do que a "simples" qualificação acadêmica.

Há de se considerar também que a universidade não está hermeticamente fechada para debates sobre as desigualdades sociais, de raça, gênero ou orientação sexual, como se verá nos processos dos professores Dennis de Oliveira e Émerson Inácio. Assim, ocasionalmente os departamentos abrem vaga para pesquisadores de temas marginais dentro da academia:

Então, foi o seguinte, eu fiz dois concursos aqui, o primeiro concurso que eu fiz, foi para uma disciplina aqui no Departamento de Comunicação e Artes, CCA. Eu não passei nesse concurso (...) Depois eu fiz o segundo concurso, foi para essa disciplina que eu estou fazendo, que é do Jornal São Remo. Foi... tinha um professor aqui na casa, que era muito amigo da minha ex-orientadora (...) Ele falou pra Nazaré, tal, desse concurso, era uma disciplina que eu achei interessante, que, é uma disciplina para trabalhar com um jornal, que feito para a favela São Remo que é atrás da USP, um jornal comunitário. E aí eu achei interessante, eu fiz, assim, foi bem complicado, tinha quinze candidatos, parece e no final a prova foi bem disputada, afinal, estava concorrendo com um professor, dois doutores, um da UNESP e outro da São Caetano, então foi bem complicada, bem difícil. E tive dificuldade depois, no início da minha carreira aqui na universidade, alguns problemas assim, desde incompreensão de alguns alunos aqui, tive problemas com isso. (...) O que acontece assim, o que eu sinto assim, efetivamente, Viviane... Viviane, né? É assim, a gente quando entra num espaço como esse a gente fica, parece que a gente é intruso, a impressão "o que esse cara está fazendo aqui”. Então vira e mexe eu vejo que o pessoal tem, não falam isso abertamente, mas pelo olhar, pela forma de perceber, tem um pouco isso. Como eu tenho me defendido disso? Eu defendo com isso a partir do momento que eu vou discutir, eu vou 
assumindo essa questão da negritude e vou assumindo esse discurso no campo acadêmico. Porque você mostra assim: não é uma rebeldia sem causa, não é uma vitimização, mas é uma situação que é colocada, explicada teoricamente, conceitualmente e tal. Então, com esse tipo de situação eu consigo me defender. Mas é assim, muito nítido isso, o mal estar, o incômodo, você percebe. Imagino inclusive, isso tenho noção, que as pessoas que têm a pele mais escura que a minha, mais ainda, eu percebo isso. Os alunos, os pouquíssimos alunos negros que entram aqui, você percebe o mal estar que eles sentem. Ainda não é um ambiente assim, convidativo, isso é muito nítido, isso daí. (Professor Dennis de Oliveira)

Interessante observar que o mestrado e doutorado do professor Dennis de Oliveira versaram sobre questões como imprensa sindical, imprensa alternativa, greve, consciência de classe, globalização, neoliberalismo e era sobre esses temas que concentrava a maior parte de suas publicações até seu concurso de ingresso em 2003. O debate racial foi progressivamente sendo assumido depois do seu ingresso na USP como docente, aprofundando sua inserção nos temas pouco palatáveis para a academia. Abraçar o debate racial não tornou sua vida mais fácil desde a sua entrada, mas o permite delimitar um espaço de legitimidade, que cumpre também a função de defesa.

O concurso de ingresso do professor Émerson Inácio em 2006 se assemelha muito ao do professor Dennis de Oliveira. Em ambos os casos, o sucesso da segunda tentativa aconteceu quando tentaram concursos que foram a cara dos candidatos, pois as vagas que foram abertas exigiam qualificação e experiência de pesquisa eram bem na linha das trajetórias acadêmicas de ambos. No caso do professor Dennis de Oliveira trata-se obviamente do segundo concurso; e no caso do professor Emerson Inácio, pode se dizer que os dois concursos teriam sido concebido sob medida pra ele. Apesar do professor Émerson Inácio ter tido o dobro de chance de passar no concurso, considerando essa questão de perfil para a vaga, uma outra questão importante que emerge também, é o fato de que o professor Émerson Inácio não foi um uspiano de formação, o que geraria outros e novos desafios de competição à vaga. O processo dos concursos do professor Émerson Inácio traz detalhes interessantes sobre o fato de que mesmo sendo o perfil da vaga, isso não é garantia de aprovação:

Eu entrei no segundo concurso que eu fiz pra cá. Eu fiz concurso em 2003, fui aprovado em segundo lugar, mas só tinha uma vaga e um outro concurso em 2006, que havia duas vagas. Eu voltei, na minha síndrome de segundo lugar, enfim. (...) Em 2003, um amigo meu que estava fazendo pós-doutorado aqui disse "olha, abriu um concurso pra USP, muito interessante, sua cara". Falei: por quê? "Porque é trabalhar com portuguesa, brasileira e africana ao mesmo tempo". Vim aqui, me inscrevi e coisa e tal. Fui o segundo colocado, voltei para o Rio de Janeiro, fui trabalhar no Colégio Pedro II (...) Em 2006 reabre concurso. (...) Olha, meu concurso foi um concurso bem concorrido, principalmente porque tinha duas figuras no concurso, o [nome do candidato] que foi aprovado comigo e um outro colega de Coimbra, que tinha interesse de vir para o Brasil na época, que meio que assustava os demais. Então se o colega de Coimbra tivesse vindo, certamente eu não estaria aqui e não eu... porque havia dois perfis muito claro no concurso, os dos colegas que já tinham uma carreira e nós e de todos nós outros que estávamos iniciando. Muito tranqüilo até certo ponto, como eu já te falei, porque eu vinha de uma trajetória de trabalho com Literatura Comparada, em termos teóricos e em termos de experiência mais prática 
também. A questão toda na época do meu concurso, que eu acho que deve ter causado alguma saia justa à banca foi o fato de que eu trabalhava com literatura e homo-erotismo, diversidade sexual, homossexualidade, essas coisas e a banca muito preocupada porque, aspas, não há esse fenômeno em África, não há esse fenômeno em Literatura Africana. (...) Como é que você vai trabalhar com literatura, com gays em África. É tive claro que, naquela altura eu criar toda uma forma de explicar que, por exemplo, alguns fatos ainda que não representados, não significam que eles não tenham uma existência e particularmente porque a gente sabe que há eleições, aquilo que a gente acha que é o cânone não representa o todo de uma literatura, todas as expressões. As expressões são obliteradas, não há, mas pode haver, foi o que eu respondi e a gente está aqui pra isso, pra pesquisar, pra procurar e identificar determinadas distorções que passam a ser identificadas, que passam a ser estudadas também. Mas por exemplo em termos étnico-raciais, eu era o único no conjunto de todos os candidatos, fui o único candidato negro. E na semana seguinte teve o concurso de Africanas, aí sim, dois meninos que estavam inscritos no meu concurso não vieram a fazer, mas também estavam inscritos no concurso de Africanas, aí mesmo assim, no concurso da semana seguinte, havia, num universo de treze ou quatorze pessoas, duas candidatas negras só, que também não foram aprovadas. Mas a estranheza toda que há sempre no trabalho com determinados temas. Eu brinco sempre, quer dizer, eu não brinco nada porque isso é sério pra chuchu, que ainda mais a questão uspiana que pensa paradigma histórico-sociológico como ponto de partida, ponto de chegada, quando se pensa a questão de estudo literário, priorizou classe, nacionalidade e esqueceu de sexualidade ou gênero e raça e etnia. Então a gente só vivencia os paradigmas que interessam, aqueles que vão causar algum incômodo, ou vão deixar as pessoas numa certa saia justa, faz que nem o ministro, fatura, e o que é bomba, esconde, o que não é tão bom assim. Acho que foi um concurso bem interessante, acho até hoje, que eu estava no lugar certo, na hora certa, com um perfil adequado e claro, acho que de todas as minhas melhores capacidades é sala de aula. Dei uma aula muito boa, que eu acho que não vou dar nunca mais na minha vida. (risos).

Apesar de ser a cara, ou o perfil dos dois concursos que tentou, a aprovação do professor Émerson Inácio só aconteceu na segunda tentativa. E mesmo assim em função do que pode ter sido decisivo: a ausência do candidato português que era o favorito para a vaga. E não foi um detalhe banal o fato de o professor Émerson trazer em sua trajetória e para o processo seletivo um conjunto de preocupações de pesquisas e de temas que o chamado cânone literário não encara normalmente. Colocar as omissões de sexualidade, gênero, raça e etnia sobre a mesa foi uma jogada perigosa, mas que constrangeu a banca a encarar algumas omissões na vida acadêmica.

Por fim, é interessante considerar ainda, o concurso da professora Maria Letícia que apesar de se inserir na lógica do sucesso na segunda tentativa e da segunda colocação na primeira, apresenta diferenças fundamentais. Ao contrário do que foi narrado pelos/as três docentes logo acima, na experiência da professora Maria Letícia, seu pertencimento racial parece não ter tido nenhuma relevância:

Olha... Eu prestei um concurso em 2003, logo depois da minha defesa. (...) A banca foi muito simpática, a banca foi uma gracinha (...) Mas eu fiquei em segundo lugar, fiquei muito brava. Eu tinha certeza que eu ia entrar, fiquei muito brava. (...) Eu fiquei muito brava, eu fui atrás disso, mas aí foi uma bobagem. (...) mas o mérito foi todo dela porque de fato a prova, a aula que eu dei era pra fazer em tanto tempo eu fiz mais curta, aí eu emendei com umas bobagens, certo, aí eu não me saí bem mesmo no concurso. Eu fíco até muito contente em ter ficado em segundo lugar, acho que eles foram muitos generosos comigo porque eu fiz bobagem mesmo. (...) E eu tinha passado aqui num concurso pra auxiliar de ensino em didática, em 99 (...) mas era aquela história que você trabalha doze horas, você é contratado por 12 horas e na época o salário era assim, tipo, 200 reais, uma 
coisa irrisória e era uma época em que eu estava comprando apartamento, estava fazendo um monte de coisa, não dava pra... (...) Depois eu me arrependi muito de não ter entrado na época porque aí eu não teria passado por essas situações posteriores de concurso né. Já estaria aqui e faria o concurso com outra propriedade né. Então foram esses dois concursos que eu fiz.(...) Um concurso é sempre um espaço complicado. Porque você conversa com os teus pares que estão prestando concurso vocês se conhecem, eu conhecia meus pares. (...) E foi interessante porque com as meninas com quem eu prestava o concurso a gente tinha aquela questão da disputa né, mas a gente tinha uma boa relação e com a banca eu não tinha assim, eu fiquei um pouco atemorizada (...) Mas de alguma maneira eu era mais da educação infantil, porque eu lido com políticas públicas, e pra minha sorte, os pontos, que não fui eu quem sorteou, foi a primeira, da lista, todos os pontos caíram pelas políticas públicas. Era meu esse concurso. Aí eu fiz a dissertação, tive uma excelente nota, na dissertação. Aí fiz a prova pública, que era a aula né que você tem que dar, que também caíram políticas públicas. Eu sei que eu fiz uma comparação entre o referencial e as diretrizes curriculares nacionais da educação infantil e depois a entrevista. Não tive nenhuma dificuldade. E era só eu negra, se é isso que você quer saber, a banca era branca e as minhas colegas de concurso também eram brancas. Mas eu passei assim, se somasse os 9.5 e 10 que eu tive eu passei com média 9.8, eu passei muito bem nesse concurso. E to aqui!

Apesar de mencionar o fato de que era a única candidata negra no concurso no qual foi aprovada; em outros aspectos seu pertencimento racial parece não ter feito alguma diferença no processo. Mas o mais interessante é que desse conjunto de docentes, a professora Maria Letícia foi a única que enfatizou o fato de a USP ser sua meta na construção da carreira acadêmica. Sendo assim, a noção de inadequação ou de sujeito periférico da academia parece não fazer sentido no seu projeto de vida acadêmica da USP, na qual sempre se sentiu em casa. Conforme considerado no próximo tópico, não significa no entanto, que a professora não tropece ocasionalmente em situações cotidianas de teor racista. Mas no que diz respeito a seu ingresso na carreira docente, em termos raciais, ela não encontrou nenhum obstáculo racial.

$\mathrm{Na}$ trajetória da professora Maria Letícia é possível suspender ainda que temporariamente o peso da raça, e deslocar o poder da noção de "lugar de negro" na percepção de si, narrada pela professora; que não vê sua vida sob o peso do racismo como elemento significativo. Gilroy (2002) na obra Atlântico Negro, cunha a noção de "eu racial pensante" para indicar "uma identidade 'enraizada' supostamente autentica, natural e estável” (p.84), que no caso da professora Maria Letícia se manifesta na sua consciência de raça, mas não é causal sobre seu eu, não entra como elemento fundamental que causa e explica os significados de suas experiências e vida; pois as vivências de classe média influenciam seu eu racial pensante. Assim, de modo geral, seria possível considerar que a pobreza econômica não revelaria as experiências raciais, mas as explicita. E no caso da professora Maria Letícia, isso faz uma grande diferença quando ela reconstrói sua trajetória de negra de camadas médias, comparada aos negros de camadas mais populares. Em outros termos, ela é membro de uma classe média e é negra. Embora essas categorias estejam articuladas em sua trajetória, no seu processo de entendimento de si, ser classe média antecedeu o ser negra. 
De modo sucinto, o propósito desse tópico foi discutir a vida acadêmica desde o ingresso na graduação à aprovação no concurso para docente da USP do conjunto das sete trajetórias dos/as acadêmicos/as negros/as que dão ensejo a esse capítulo. Destaca-se dentre outras questões, o reduzido número de colegas negros/as que tiveram na graduação, conforme relatos; o modo como viveram a experiência de serem minorias no curso; as experiências de militância, que apontam uma complexa relação entre os movimentos de esquerda e antirracistas; o modo como estudantes negros/as se inserem nos movimentos estudantis, de modo que a raça por vezes pode simplesmente desaparecer, tornando-se uma categoria para a qual movimentos estudantis ainda não estão suficientemente atentos; este tópico procurou apresentar também elementos que ajudam a compreender porque este específico conjunto de sujeitos lograram êxito e longevidade escolar, e dentre os fatores destaca-se a cultura familiar, o apoio de algum docente sensível à escassa presença negra na universidade e a presença mais rara ainda, porém de extrema importância de docentes negros/as durante a formação; procurou-se destacar também a importância do trabalho durante a formação acadêmica, delineando a experiência estudantil desses/as sujeitos; procurou-se atentar para o modo como se deu a passagem da graduação para a pós-graduação, sublinhando o fato de as professoras terem encontrado mais dificuldades nesse processo de transição; por fim, considerou-se os processos de concurso para docente na USP, procurando compreender porque alguns/mas docentes lograram êxito na primeira tentativa e outros/as na segunda empreitada. Uma vez aprovado/a no concurso, o próximo tópico procura compreender as experiências de ser docente negro/a na USP. 


\section{4- Ser Docente Negro/a na USP: Faces (In)Visíveis}

Neste tópico do capítulo pretende-se trazer a experiência dos sujeitos entrevistados considerando dois aspectos: ser docente da USP e ser docente negro/a da USP. Essa comparação se faz necessária para demarcar quais são as especificidades de ser docente negro/a na maior universidade do país. De um modo geral, considera-se que no atual contexto acadêmico nacional, algumas questões perpassam a atividade docente em qualquer universidade pública brasileira, seja de caráter federal ou estadual. Alguns elementos são comuns à atividade de ensino, pesquisa e extensão em função da legislação do ensino superior vigente e dos processos de captação de recursos, produção e divulgação científica. Como qualquer docente de universidade pública brasileira, os/as docentes aqui considerados também vivem essa rotina acadêmica. Têm, no entanto, vantagens que os/as favorecem no cenário nacional: antes de tudo, o prestígio de fazerem parte do corpo docente da maior universidade pública brasileira, a melhor representada nos rankings nacionais e internacionais, favorecendo a disputa por verbas para pesquisa, sobretudo quando se leva em conta a histórica desvantagem do Norte e Nordeste. Mesmo com a crise que a USP atravessa hoje, e a despeito do suposto de que a USP está bem coberta pelas verbas da Fapesp (o que nem sempre verdadeiro), ainda permanece envolta nessa tradição, o que a faz ser uma meta na carreira de grandes profissionais acadêmicos/as. Diante disso, quais são as especificidades de ser docente negro/a na USP? No intuito de responder essa questão, esse tópico destaca elementos narrados que nos ajudam a dimensionar os sentidos da negritude na docência.

O conjunto de docentes negros/as aqui considerado não se sentiu intimidado pela dimensão do nome USP e a possibilidade de ser professor/a nesta instituição aparece como objetivo ou como horizonte possível na sua carreira, conforme relata a professora Maria Letícia:

\footnotetext{
A USP era meu objetivo na vida? Era, era. Quando eu resolvi ir pro ensino superior era meu objetivo vir pra USP sim, vir pra Faculdade de Educação sim porque era o meu lugar. Trabalhar em escola privada não me interessava, a não ser se enquanto eu não tivesse conseguido um cargo público aqui, eu achava que aqui valia a pena trabalhar.(...) Ah, significa ter atingido um bom nível na carreira. Na verdade essa era a minha meta. Essa era a minha meta a partir do momento em que eu acabei enveredando pra carreira universitária. Além do que foi a grande alegria do meu pai, além do que nesta história toda, pra ele foi muito importante, que eu tivesse passado em um concurso e pra mim também, eu sempre achei que a FEUSP era a minha casa e eu queria voltar pra cá! E tem essa coisa do prestígio profissional, você ser professor da USP é diferente de você ser professor de outra universidade em termos de Brasil, não só em termos de São Paulo, porque você tem um prestígio profissional diferenciado. Eu acho que era uma meta minha de ingressar, voltar pra USP como professora em algum momento, depois que eu enveredei pela carreira universitária. (...) lá. E eu só via aqui como opção.
}

A entrada na docência da USP é um processo fundamentalmente de comprovação de mérito e excelência, discurso assentado no imaginário da universidade, inclusive dos/as docentes 
dessa pesquisa:

Primeiro acho que eu fui acolhido na universidade, na Faculdade, no Departamento porque eu sempre demonstrei competência. Se eu não tivesse a competência que se exige nesses ciclos, não tivesse o desempenho que tive quando fui aprovado, não importaria minha cor e minha história de vida. Isso eu acho que é a primeira coisa. (Professor Roberto)

O contato com a docência da USP é também por a prova expectativa e realidade por parte desses/as docentes ainda que já tivessem uma carreira discente ou docente no ensino superior antes da USP. É de fato situar-se na universidade sob outra perspectiva:

Conhecer os bastidores da universidade também é bastante interessante, porque também você começa a perceber que a imagem que se tem lá fora é diferente da imagem de quem está aqui dentro, porque a gente percebe os percalços, as dificuldades para estar aqui, particularmente neste nosso curso [Obstetrícia], a gente tem trabalhado numa carga horária bastante grande, comparado aos outros cursos, por carência de docentes mesmo. Então quando se recomenda que a gente tenha oito horas aula só e o resto todo dedicado à pesquisa e extensão, no nosso curso hoje, nós temos feito vinte, vinte quatro, trinta horas aulas em sala de aula, por semana, por semana! E sobra o que, pra você apresentar a cada dois anos na sua avaliação periódica? Então nós temos sofrido um pouco, tem saído trabalhos, pesquisas, alguma coisa assim, mas com muito sacrifício. Então esse lado é ruim, porque me parece que é um preço muito alto que você paga e que a instituição também paga de alguma forma pra se manter nesse patamar de ser uma escola conceituada, enfim. (Professora Roselane Gonçalves)

Se a USP aparece como a conquista de um patamar elevado na carreira acadêmica brasileira, revela-se problemática em vários sentidos:

\begin{abstract}
Antes eu pensava que fosse muita coisa, por isso eu desejei entrar aqui (risos), num é? É... hoje eu estou já há 9 anos aqui, como professor (...) Do ponto de vista da vida acadêmica há tempos eu percebi, eu não sou professor da USP, eu não sou professor da Faculdade de Educação, eu sou professor de um departamento. Não se tem mobilidade docente aqui, como não se tem mobilidade discente, mobilidade funcional. Se tem um estado que tem três grandes universidades, mas as três universidade não compõem um sistema de ensino superior no estado que permitiria esta mobilidade docente, discente e funcional. Se tem uma universidade com 42 unidades aqui e você não pode sequer migrar de um departamento a outro. Então o professor é escravo de um Departamento e de um conjunto de disciplinas. Pra mim são limites muito estreitos. (Professor Roberto da Silva).
\end{abstract}

A fala do professor Roberto da Silva revela limites institucionais que desfavorecem uma missão fundamental da universidade: a circulação de ideias e o diálogo. O trânsito discente pelas unidades da USP pode ser muito mais interessante do que o de docentes. A licenciatura possibilita, por exemplo, que alunos/as de diversos cursos tenham que passar pela FEUSP. A possibilidade de circulação docente dentro da USP acaba não sendo tão maior do que a de transitar por outras universidades públicas brasileiras, como por exemplo nas ocasiões de exames de qualificação e defesa na pós-graduação, e eventos como seminários, congressos, simpósios, etc. Raramente os/as docentes podem pertencer a dois organismos, a exemplo dos professores Dennis Oliveira, e Kabengele Munanga, que além de seus departamentos de origem, estão credenciados também no Programa de Pós-Graduação em Direitos Humanos da Faculdade de Direito. A professora Vanderli Custódio também está credenciada em dois programas de pós-graduação, no Instituto de Estudos 
Brasileiros e na Geografia. Porém, ao invés desse trânsito significar a possibilidade de diálogos e trocas, a professora avalia que este foi um aspecto problemático e constrangedor na carreira quando ingressou:

E aqui (no IEB) também, quando eu entrei, eu precisei dar aula no Departamento de Geografia, porque até a disciplina aqui ficar pronta e tal, demorou e eu precisava cumprir a carga horária, fui bater lá no Departamento, ficou uma coisa super desagradável, porque parecia que eu tinha entrado na Geografia pelas portas dos fundos. "Como é que vem alguém de outro instituto, do IEB e vem dar aula aqui no nosso departamento, o que é isso? Não fomos nós quem escolhemos." então teve um problema institucional que já ficou complicado. E depois, dar aula lá, então, assim, passei por uma situação no primeiro ano, de gente que me encontrava no corredor da geografia, professores, que antes diziam oi, bom dia e que viravam a cara. Uma coisa muito hostil mesmo, uma coisa muito pesada, principalmente porque foi feito um acordo entre os diretores, o diretor daqui da época e o representante da geografia na congregação na filosofia, que seriam contratados docentes do IEB, mas pra ajudar a dar aula na Faculdade de Filosofia, na Geografia, na História, porque estava com falta de professores. [...] Mas ele não comunicou seus pares. Aí chego eu lá na distribuição de aulas, os alguns constam "quem é Vanderli que vai dar aula aqui, que é que escolheu, de onde veio?". Era como se eu não tivesse feito graduação, mestrado e doutorado lá, eu entrei pelo IEB. (Professora Vanderli Custódio)

A experiência de ter sido tratado como intruso na USP também foi relatada pelo professor Dennis de Oliveira, cuja entrada na ECA provocou alguns estranhamentos:

É assim, a gente quando entra num espaço como esse a gente fica, parece que a gente é intruso, a impressão “o que esse cara está fazendo aqui?". Então vira e mexe eu vejo que o pessoal tem, não falam isso abertamente, mas pelo olhar, pela forma de perceber, tem um pouco isso. Como eu tenho me defendido disso. Eu defendo com isso a partir do momento que eu vou discutir, eu vou assumindo essa questão da negritude e vou assumindo esse discurso no campo acadêmico. Porque você mostra assim: não é uma rebeldia sem causa, não é uma vitimização, mas é uma situação colocada, explicada teoricamente, conceitualmente e tal. Então, com esse tipo de situação eu consigo me defender. Mas é assim, muito nítido isso, o mal estar, o incômodo, você percebe. Imagino inclusive, isso tenho noção, que as pessoas que têm a pele mais escura que a minha, mais ainda, eu percebo isso. Os alunos, os pouquíssimos alunos negros que entram aqui, você percebe o mal estar que eles sentem. Ainda não é um ambiente assim, convidativo, isso é muito nítido, isso daí. (Professor Dennis de Oliveira)

Interessante observar que docentes negros/as que estão na USP desde a graduação, tendo

feito também mestrado e doutorado, mesmo assim, não são automaticamente reconhecidos/as como parte da comunidade acadêmica, havendo a possibilidade da emergência da tentativa de afastar o/a negro/a acadêmico/a de seu pertencimento à universidade:

Assim, são diversas pequenas coisas. No primeiro ano [como estudante], eu passava no corredor, um professor estava incomodado com o lixo dele, ele simplesmente abriu a porta e perguntou a que horas o lixo dele seria tirado da sala dele, sem se dar conta que eu podia ser uma aluna. A Geologia é deste tamanho, então eu conheço todo mundo... é engraçado porque como o mundo dá volta, esse mesmo professor que eu falei para você do lixo, ele era do meu Departamento então a gente convive como colegas de igual para igual. Tem um outro professor de um outro Departamento que... a gente teve um problema com uma sindicância de livro, eu estava presente quando o rapaz passou com o livro e na primeira reunião ele me disse "ah, o seu tipo quando não caga na entrada caga na saída", e ele não 
sabia porque que eu estava lá, eu ia depor para esclarecer alguns fatos, e ele logo assumiu que eu tinha há ver com a subtração do livro da biblioteca. Só que ele é famosamente racista. Na hora, eu podia ter até ameaçado processá-lo, podia, só que a gente sempre pensa "não vale a pena, ele já é um idiota, tanto faz". E esse é um dos que eu tenho mais prazer em torturar... eu ocupo agora a sala que é de um amigo dele, então ele entrou intempestivamente na minha sala e ele falou 'nossa, você que está aqui?", e eu falei 'é, para você ver como o mundo dá volta'. E é bom, é bom, desculpa o clichê, mas você quebra um pouco os paradigmas quando você chega lá. As pessoas passam a te ver com mais respeito e passam a ter que acreditar que a inteligência não é um privilégio dos brancos ou dos japoneses, que é de todo mundo. (Professora Adriana Alves)

Em suas análises sobre as experiências de professores/as negros/as numa universidade pública do Rio de Janeiro, Teixeira (2003) destaca a importância da ideia do crachá para que esses/as docentes fossem aceitos/as socialmente ou como justificativa para poder circular com naturalidade no meio acadêmico; mas conforme a narrativa da professora Adriana Alves transcrita acima, às vezes, o crachá de um/a acadêmico/a negro/a dentro da USP não é reconhecido como suficientemente legítimo.

E quando o docente não teve história de formação na USP, no processo de não reconhecimento de sua posição docente, é possível até a experiência de "infantilização" na carreira e ser tratado como aluno e não como docente, como relata o professor Émerson Inácio:

É claro, eu acho no meu caso eu tenho três estranhezas bem recorrentes, o fato de ser carioca, o fato de ser homossexual e o fato de ser negro. E como as três identidades, ou melhor, os três aspectos da minha identidade eles sempre andam muito juntos, eu acho que em algum momento isto tenha criado algum tipo de estranheza, particularmente porque durante muito, muito tempo, eu entrei com 32 anos na faculdade, eu tinha cara de garoto, eu fui tratado como aluno. Então era muito interessante, eu me identifiquei, era preciso que eu me identificasse em algumas situações, para que inclusive o tom de voz mudasse, uma certa grosseria, por exemplo, de alguns funcionários que não estão mais aí, coisa de "o que você quer?", eu sou o professor Emerson, "ah, professor, não diga!", e coisa e tal. Uma segurança, por exemplo, com os colegas hoje, a coisa muda de figura porque embora a gente saiba que haja, que as formas de preconceito são silenciosas e coisa e tal, nunca tive grandes problemas, talvez eu ache que na maioria dos casos tem incomodado muito mais o fato de ser um homossexual e assumido, não ter nenhum tipo de problema com a expressão da minha sexualidade no trabalho, na sala de aula e coisa e tal, do que necessariamente a questão étnico-racial. Até porque a velha e boa política do abrandamento "moreninho, ah, aquele professor moreno que veio do Rio de Janeiro..." essa economia de tinta, que no final das contas não faz bem pra identidade de ninguém.

Embora o professor Émerson Inácio não credite apenas ao racismo algumas experiências vividas no momento de seu ingresso na docência da USP, agregando questões como a homossexualidade e sua idade, é importante trazer aqui considerações sobre um artigo publicado em setembro de 2010 pela Revista ADUSP a respeito da nova face da docência da USP. O texto, de autoria dos/as jornalistas Tadeu Breda e Tatiana Klein, colheu depoimentos de 14 docentes, homens e mulheres, que ingressaram na carreira docente ao longo dos anos 2000. A grande queixa relatada por esse conjunto de docentes diz respeito à problemática produtividade compulsória da qual a academia brasileira se vê refém. Essa é uma questão que também atravessa a carreira dos docentes 
negros/as aqui considerados/as; mas uma questão merece ser assinalada: há relatos de docente que foi contratado com a mesma idade do professor Émerson Inácio, como também há relatos de pessoas que dizem ter sido muito bem recebidas pela USP no ingresso à carreira docente e ninguém fez qualquer queixa referente à classe, gênero, orientação sexual ou pertencimento racial. Conforme indicou uma docente entrevistada para a reportagem da ADUSP, o principal critério que definiria essa nova geração docente, seria o currículo Lattes. Considerando os relatos do conjunto de dez docentes negros/as levantados para a presente pesquisa, é possível que para além do currículo de excelência que devem construir, eles sejam cobrados por outros critérios que não a atual política de produtividade, mas também por outros fatores como a origem de raça e classe ou orientação sexual.

O atual modo de produção de conhecimento está organizado institucionalmente de modo a favorecer a produção quantitativa, daí cunhando o jargão conhecido como produtividade. Conforme destaca Luz (2005), além dos danos causados à saúde de quem está sob esse regime ou ordem de produção, pois seres humanos não seriam produtivos como as máquinas, a longo prazo verifica-se que a produtividade é uma séria ameaça ao coração ou à fonte seminal da produção de conhecimento: a criatividade. Assim a produtividade pode ser definida:

\begin{abstract}
A categoria é geralmente entendida como quantum de produção intelectual, sobretudo bibliográfica, desenvolvida num espaço de tempo específico, crescente de acordo com a qualificação acadêmica ("titulação") do professor/pesquisador. Esse quantum básico é necessário para conservar os pesquisadores na sua posição estatutária em seu campo científico. A categoria analítica campo, aqui empregada, é assimilada das análises sobre trabalhadores da ciência e sua produção, feitas pelo sociólogo Pierre Bourdieu (1989, 1998)96. O quantum de produção é estipulado atualmente, em quase todos os campos disciplinares, em termos de papers editados em periódicos de circulação nacional ou internacional, cuja qualidade de divulgação (base Qualis) é estabelecida por cada área de conhecimento (Luz, 2005: 43)
\end{abstract}

Historicamente, no contexto acadêmico brasileiro, um importante marco para essa discussão é a implantação das mudanças advindas da Reforma de 1968. Ao longo da década de 1970, sob o regime militar a pós-graduação passa a ser o lócus privilegiado de pesquisa no país:

\begin{abstract}
Situamos na década de 70 o marco inicial dessa concepção e política da pós-graduação como nicho institucional legitimado e privilegiado da pesquisa no país, gerando com isto um trágico equívoco pedagógico para a nação. Esta concepção está na raiz da escolha da concentração da atividade de pesquisa no cume do sistema educacional e da hierarquização dos "produtores". As políticas públicas de ciência e tecnologia começaram a se estruturar como tal na década de 50 do século XX, fundamentalmente através das grandes agências de fomento à pesquisa, ainda hoje as mesmas (CNPq e CAPES). (Luz, 2005: 45)
\end{abstract}

Disso resultou a dualidade ensino-pesquisa, num processo irreversível de elitização da

96Ver: BOURDIEU, Pierre. O poder simbólico. Rio de Janeiro: Bertrand Brasil, 1989 \& BOURDIEU, Pierre. Contrafogos: táticas para enfrentar a invasão neoliberal. Rio de Janeiro: Zahar, 1998. 
pesquisa, com efeitos desagregadores para a atividade científica, intensificados durante os anos 1990 no governo de Fernando Henrique Cardoso (Ibidem). Conforme relatado pela professora Vanderli Custódio,

Mas a ideia é que você entre com o projeto e consiga bolsa e dinheiro da FAPESP e do CNPQ, da CAPES, da PETROBRÁS e sei lá eu de quem, SANTANDER. Então agora a universidade, docente é bom se ele consegue trazer dinheiro de fora da universidade, se ele não precisar de dinheiro da universidade para fazer as coisas...

Desse modo, como os programas de pós-graduação das universidades públicas concentram as atividades de pesquisa e sendo o/a docente a principal peça da engrenagem, assumem papéis distantes da função de professor e, além de agentes produtores de ciência, precisam ter habilidades de disputa,captação e administração de verba. Quanto melhor o cumprimento dessas tarefas, maior quantidade de produtos ou derivados de pesquisa pode ser gerado, portanto maior é a produtividade docente. Como as agências de fomento são do Estado, a partir de editais o poder público anuncia a oferta de subsídios à atividade de pesquisa que se torna cara, porque é tecnologicamente muito sofisticada. Os recursos são bem disputados, e devem seguir algumas lógicas ditadas pelo poder público no processo da oferta e esse processo, de um modo geral:

Conduz (ou induz, para empregar o termo institucional), de acordo com os variáveis interesses da política governamental, não apenas os eixos temáticos de investigação (o que pesquisar), como também o roteiro metodológico a ser seguido pelos pesquisadores (como pesquisar), e a lista de "produtos" que devem resultar do processo da pesquisa (os resultados). (Luz, 2005: 44 [grifos do autor])

O conjunto de docentes negros/as aqui considerado, precisa entrar nesta disputa seguindo as mesmas regras do jogo, das quais todos/as relataram plena consciência. No entanto, foi destacado que nesse processo de condução ou indução presente nos editais de recursos, algumas linhas de pesquisa acabam tendo prioridade sobre outras:

Os convênios da universidade de São Paulo, a maior parte deles são com universidades europeias, a grande maioria, europeias, vão pra França, pra Bélgica, pra Inglaterra. Não que não deva ir, mas aí assim, acaba formando um pensamento colonizador, um pensamento assim, anti-nacional, um pensamento que pensa a população brasileira de uma forma preconceituosa. Então ela reproduz isso, a universidade. E o prestígio acadêmico aqui, se dá, quando você tem o perfil de pesquisas e produções científicas que utilizem essas referências eurocêntricas, europeias, , quando você trabalha com essas referências eurocêntricas e você responde a problemas dados por essas referências, a tendência é você ter uma produção que seja mais valorizada. As produções que inovam, que vão pegar outras referências mais próximas da América Latina, da África, e por diversas razões, se atendem mais expectativas e demandas sociais do Brasil, acabam não tendo tanto prestígio. (...) Então, ser professor, eu acho que é o enfrentamento concreto de tudo isso, é o enfrentamento dessa situação na universidade, que implica em você primeiro colocar essas questões, você mobilizar pessoas, você despertar no corpo discente o papel que ele tem que desempenhar, enquanto profissional, então são coisas assim bem difíceis de enfrentar, mas eu acho que é prazeroso (risos) fica prazeroso. Acho que é isso que tem que fazer.(Professor Dennis de Oliveira) 
Apesar do esforço de positivar a atividade docente sob essas condições de disputa, o exercício cotidiano de viver sob a pressão da produtividade acaba por não se revelar fácil para ninguém, independente do pertencimento racial; embora, defende-se aqui, que no caso de docentes negros/as raça seja um elemento que agudiza os desconfortos da atividade docente. Na vida acadêmica, parte do desafio é fazer emergir de um cotidiano comum de tarefas, o extraordinário de uma pesquisa, de uma análise. Desse esforço resulta que a universidade pública brasileira é também celeiro de importantes pensadores de várias áreas do saber. Mas como uma publicação nem sempre evidencia suficientemente seus bastidores, as disputas nos atuais termos das políticas de financiamento de pesquisa e produção do conhecimento podem fazer emergir versões violentas dos atores acadêmicos, por mais brilhante que seja a sua produção. Conforme relatado pela professora Vanderli Custódio, nesse ambiente de acirrada competição e vaidade, a luta é para manter a dignidade diante dos absurdos que a atividade acadêmica pode encerrar:

E um problema sério que tem na universidade é o ego. Um professor, um amigo meu, disse que o docente é um artista frustrado, gosta de palco. Eu, eu não quero nem saber disso. Eu se eu quiser aparecer, ponho um brinco no nariz, corto o cabelo, não tenho esse tipo de preocupação, mas o ego é muito forte. E tem uma cultura muito complicada, difícil de explicar, seu patrão é o Estado, então ninguém vai ser mandado embora, deveria ser mais tranquilo. Se o outro lançou um livro, que legal que ele lançou um livro, que legal, mas não é bem assim. O outro lançou um livro, "nossa lançou um livro, que coisa". É uma... tem um processo de desqualificação do trabalho do outro dentro da universidade, que é um negócio incrível, é uma destruição do outro, porque o outro apareceu um pouquinho mais. Eu não vivi isso na iniciativa privada, que com toda a precariedade que tinha, não vivi isso durante vinte anos da minha vida, aí vim viver dentro da universidade. Eu pensava que, imagina, todo mundo é estudado. Aqui que eu vim ver professor gritando em reunião, tratando mal o outro. E assim, eu sou muito chata com a questão de... eu sou muito briguenta, tenho um gênio do cão, mas eu sou muito educada, que eu acho que é o meu freio. Então, bom dia, boa tarde, por favor, seria possível e falo baixo. E aqui assim, eu ficava completamente desarmada porque, eu estou num instituto de cultura brasileira, ou de geografia, geografia do Brasil e a geografia é tão crítica com as questões sociais, entre dominantes e dominados, e aí, de mentir em reunião, de falar alto, de interromper a fala do outro, de apontar o dedo, de gritar. Eu ficava assim... ah... destruída. Eu falava "gente, não imaginava, eu imaginava algumas coisas diferentes da intelectualidade, da esquerda na universidade, eu imaginava outra coisa." Então foi muito decepcionante, sabe? Com toda a formação que eu tinha, que eu tive, eu acreditava naquilo, entendeu? Aí quando você vê colocar em prática, gente, que coisa horrorosa, de um chamar o outro de vagabundo, que o outro não produz, de ouvir cada coisa, e isso me fez muito mal, me fez muito mal. Ouvi muita besteira, muita grosseria, e falei o seguinte: não estou ouvindo seu silêncio, agora quem está falando sou eu; "ah mas que agressividade"; você não ouviu minha agressividade, ninguém viu minha agressividade, ninguém viu, se é pra ser agressivo...". e a luta aqui dentro, acho que foi minhas grandes crises, era pra não virar bicho, num vou... vivi até agora tentando ser gente, vou entrar na universidade, inclusive vou formar gente, não vou virar bicho na universidade, não vou virar bicho. Aí entendi porque é que as pessoas falavam "ah espero que seu ingresso seja tranquilo, viu...". E eu ficava "o que pode ser tão terrível, imagina..." Você vira bicho. Eu conheci vários colegas que viram bicho na universidade, porque é uma forma de sobreviver, vira monstro, é uma coisa impressionante. Citar texto do outro sem colocar o nome, o sujeito é uma referência na área, tanto quanto você, mas você faz 500 mil trabalhos mas não coloca o nome do outro porque você não vai com a cara do outro, é uma competição, é uma coisa, é um negócio assim, muito podre. Então isso me fez muito mal, mas encontrei meu caminho aqui dentro, e assim, eu quero continuar com a minha retidão, 
porque eu acho que dá, dá pra não virar bicho. (...) Como é que eu encontro esse caminho? Acho que hoje eu encontrei, hoje o IEB está numa fase muito boa, no último um ano e meio, teve mudanças internas, o pessoal novo que chegou, tá todo mundo muito mais tranquilo, eu to mais sossegada também, então vamos indo.

Nesse processo de disputa qualquer trunfo é posto sobre a mesa; qualquer quinhão intelectual é ostentado; sobretudo na USP, que é uma universidade orgulhosa de suas tradições e de suas origens elitistas, por mais que o projeto, os mentores e as clientelas da instituição tenham se diversificado historicamente. Segundo Bourdieu (2011) o prestígio científico, por ser ligado ao portador é mais estável que o poder universitário, já que este é mais ligado à posição e segundo o autor "sabe-se todavia - e essa é uma das características mais reveladoras desse campo que proclama reconhecer unicamente os valores da ciência - que não existe, ou existe pouco, um verdadeiro critério institucional do valor científico" (Bourdieu, 2011, p. 109). Assim, entrar nas disputas acadêmicas como herdeiro/a do legado de determinados nomes importantes da história intelectual da USP favorece os processos de perpetuação da legitimação dos patrimônios intelectuais, conforme pode ser verificado nesse interessante trecho narrado pela professora Vanderli Custódio:

(...) mas você tem ainda na universidade, em algumas áreas uma coisa que é: "fulano é filho de quem mesmo?" Sabe, ainda tem uma coisa assim, "ah é Queiroz Filho, ah por que o tio...". Tem uma coisa de ver se a linhagem é da USP, "ah, Queiroz Filho, primo do Queiroz Júnior da FAU, que é primo do Queiroz Neto do Direito, que é filho do Queiroz Primo, que é da Faculdade de História". Então, às vezes tem isso, "fulana, a filha de fulana de tal". É... a nossa diretora agora, ela é uma Pereira Leite, tá bom, uma Pereira Leite. Ela não sai por aí falando "eu sou uma Pereira Leite, me respeita", imagina, nada disso, as pessoas é que falam, que outorgam o poder à Pereira Leite. Então ainda tem um pouco isso, das pessoas ficarem fazendo referência à linhagem, mas aqui ou ali, tem unidades que são mais apegadas a essa chamada tradição e essa tradição é uma tradição elitista. A Faculdade de Direito, por exemplo, é uma, tem muito essa coisa, de sei lá, o que é uma besteira. Nas ciências sociais e humanas tem um ranço, uma coisa que é uma erudição, lugar de ser erudito é na universidade, você pode ser erudito no escrever, não precisa ser erudito na relação coloquial, do dia a dia. Agora tem gente que é erudito 24 horas por dia e faz questão de ser erudito, então é um ranço, porque teve uma formação, fez não sei quantos pós-doc, que não sei o quê. Conheço colegas que falam "eu já conheci 50 países no mundo, então eu posso falar sobre isso, sobre aquilo". que eu acho que é desnecessário, uma chatice, uma besteira. Mas você tem menos hoje, a universidade é muito mais misturada, mas em toda unidade você tem alguém que tem um nome que remete a alguém, entendeu? Quando eu falo "ah... eu... minha mãe era da roça do Paraná e meu pai era da roça de Minas", as pessoas acham estranho, porque normalmente o que você mais conhece aqui, o pai, o primo, o irmão, é gente da universidade, gente que já está na universidade. Então tem gente que tem obrigação de estar aqui, e que a família esperava dele nada menos do que isso, esperava que ele entrasse na Universidade de São Paulo e que fosse docente da Universidade de São Paulo, entendeu? Então isso é muito marcado. Eu conheço gente que está na universidade, que é docente na universidade e que está aqui porque é um projeto da família, não era necessariamente um projeto dele, isso é muito marcado, carrega um nome da família. O tio era da Poli, o pai era da Arquitetura, o primo é da Matemática, o irmão entrou na Letras e ele tinha obrigação de entrar na USP e ser docente da universidade também, que é um fardo que a gente não carrega, eu pelo menos não carrego esse fardo, carrego outros, mas não carrego esse, é isto. 
Algumas vezes a existência de determinados grupos que se assemelham em termos de trajetórias e prestígio dentro da USP e nas suas imediações, é assumida em função da ampla visibilidade que possuem; como é o caso do conjunto de intelectuais formados pela FFLC e que constituíram a chamada Revista Clima, de crítica de arte, conforme analisado por Pontes (1998). Desse grupo, saíram verdadeiras dinastias acadêmicas uspianas, como o casamento intelectual e afetivo entre Gilda de Mello e Souza e Antonio Cândido. Difícil se furtar à consideração de que na USP enquanto alguns/mas docentes possuem nome e sobrenome que anunciam patrimônios acadêmicos, os/as docentes negros/as dessa pesquisa se veem às voltas com a questão das alcunhas e dos apelidos. É preciso ter vista que no campo universitário há de um lado um conjunto de "critérios" ou "propriedades" e a mais preciosa dela é o "nome próprio" que na prática cotidiana é usada para "identificar" e "classificar" os universitários; e, de outro lado, "uma série de características que a experiência prática do campo universitário instiga a considerar como pertinentes, constituindo assim propriedades classificatórias”. (Bourdieu, 2011, p. 29). E conforme indica o autor, as fronteiras entre as "propriedades institucionalizadas, recuperáveis portanto em documentos oficiais" e as "propriedades pouco ou nada objetiváveis" (p. 30), são relativamente tênues. Desse modo o nome próprio é uma "etiqueta suscetível de ser aplicada arbitrariamente em qualquer objeto, ele diz daquele que designa que ele é diferente sem enunciar em que ele difere; instrumento de reconhecimento, e não de conhecimento". [grifo do autor] (Bourdieu, 2011, p.45 ).

Três docentes negras entrevistadas trouxeram relatos sobre os epítetos usados na universidade para se referirem a elas:

E eu não, não, não gostava disso, mas o tratamento das pessoas era carinhoso, mas é uma coisa muito difícil, tanto que eu falo, Vanderli é meu nome profissional, porque eu tenho um monte de apelido, tem Vanda, me chamam de Líli, de Lili e aí então o pessoal mais antigo, ainda no tempo do curso, que depois não acompanhou a minha vida, me chama de Pérola. Mas eu não, não, não gostava, mas não consegui tirar das pessoas essa alcunha da “pérola negra da geografia". (Professora Vanderli Custódio).

Eu acho que eu vou começar a ter maior dimensão mesmo daqui três ou quatro anos, quando as turmas novas que vão me conhecer já como professora Adriana, vão ter maior vivência comigo, por hora ainda é uma mescla daqueles que me chamam de Bisteca com aqueles que me chamam de professora. Então eu não tenho a dimensão completa ainda. E ser professora é preparar melhor a aula possível em cima da hora, ir lá com a cara e coragem e tentar passar o conteúdo, pelo menos eu acredito, de forma simples, objetiva e sem mistificar o assunto. É o que eu tento fazer, nem sempre é possível. (Professora Adriana Alves)

Não é uma fala, exatamente, mas por exemplo, acho que as pessoas que veem com muita intimidade falar comigo, por exemplo, eu sou Maria Letícia, as pessoas me chamam de Letícia, e alguém vem me chamar de Lelê e eu não tenho a menor intimidade eu acho que essa pessoa no mínimo é racista. Ela tá achando, só porque eu sou negra ela pode me chamar do jeito que achar melhor, entendeu? É meio que esse esquema da estrutura aqui. Agora com as pessoas que eu tenho uma boa relação e se me chamarem de Lelê eu não vou 
sentir a menor diferença. Faz parte da relação porque ela deixa de ser só profissional e tem a pessoal também. (...) Não é uma fala discriminatória que alguém tenha dito "não, não faça isso" ou tenha dito "não, você não pode participar" ou qualquer coisa nesse sentido. Não é racista nesse ponto de vista ou de ofensa ou nada disso, mas é um jeito mais íntimo de se chegar quando a pessoa não tem espaço pra essa intimidade. A pessoa não tem uma relação mais afetiva, um vínculo pessoal. E às vezes as pessoas explicitam sua posição política, filosófica e a gente fica achando que por trás disso pode estar associado né, o racismo. (Professora Maria Letícia)

Se a USP possui no seu corpo docente um patrimônio histórico-cultural, os servidores técnico-administrativos podem por vezes, cumprir a função de guardiães desse legado, cobrando do corpo docente da universidade que faça jus à condição de professor/a da Universidade de São Paulo

Tem uma outra coisa também que fica no ar, a universidade tem funcionários técnicoadministrativos e alguns são de carreira, então estão aqui há muitos anos, têm orgulho de trabalhar na USP, a USP é como se fosse um patrimônio deles. Então, um docente tem que fazer jus à universidade, tem que ter porte para estar na universidade. Então tem um professor com o qual eu trabalho, que com a roupa que ele vai no CEPEUSP ele vai no Conselho Universitário, porque ele é professor titular daqui e veio de bermuda e chinelo participar de uma banca aqui: "quê isso, quem é aquele sujeito de cabelo grisalho?"; "professor de uma banca"; "ah, professor da universidade?". Funcionários técnicoadministrativos: "vestido desse jeito... gente que é isso... uma vergonha para a universidade". Então também tem essa coisa. Nos meus primeiros tempos, eu percebi que ficavam observando como é que eu vinha trabalhar, com que roupa eu vinha, em lançamento de revista ou então numa exposição, então ficavam me olhando pra ver se eu saberia me portar bem dentro da instituição da qual eles têm tanto orgulho. Então tem coisas que ficam no ar assim, essas coisas veladas, que são bastante curiosas mesmo. Enfim... e você acaba ouvindo numa situação ou noutra que não é você, você percebe o clima, mas você vê verbalizado isso na figura de outras pessoas, né: "nossa, como o professor vem vestido desse jeito?". Eu vi outro dia um professor que vinha muito fazer pesquisa aqui, "gente esse professor, titular, aposentado, com essa camisa puidinha, toda, toda costuradinha, tá limpinha, mas puidinha, que horror" e eu, a última coisa que eu ia reparar na vida é se ele estava com a camisa puída... (Professora Vanderli Custódio)

(...) o que você percebe é assim... é... a gente sair do estereótipo que eles pensam como professor. Então... tem um funcionário que falou assim "pôxa, uma vergonha você com esse carro velho" (risos), ele tem um carro novo, zero, eu tenho um gol aí velho, caindo aos pedaços e tal. Então aquela coisa assim, o pessoal estranha. Eu morar num apartamento de um dormitório alugado, na Bela Vista, porque pra eles, professor é aquele nível social diferente. Eu vivo com meu salário só e acabou, para o meu salário é eu, minha filha, mãe e tal, tenho que dar conta de tudo isso aí. (Professor Dennis de Oliveira).

A USP funciona estruturada em diversas hierarquias internas à categoria docente (Doutor, Associado e Titular) e em relação às categorias técnico-administrativas tem-se nível básico, técnico e superior. Segundo dados publicados em 2014 no Portal Transparência USP ${ }^{97}$, a maior parte dos servidores da universidade, (8.093) é de nível técnico, seguidos por 5.141 de nível básico e 4.203 de nível superior. Verificando a tabela de rendimentos dos funcionários, percebe-se que $15 \%$ dos servidores da USP podem ter salários que superam o de um Docente Doutor que acaba de ingressar na carreira. Considerando o fato de que a categoria de servidores técnico-administrativos é muito 
maior do que a de docentes, a relevância desse segmento na vida acadêmica do/a docente é inquestionável, apesar de no cotidiano estabelecer-se que hierarquicamente os servidores técnicoadministrativos estariam abaixo da categoria de servidores docentes. Conforme relato da professora Vanderli Custódio, existe uma cultura docente de reafirmar essa distância e hierarquia. Porém o fato de ser negro/a parece reinventar ou encurtar a distância institucional entre as categorias docente e técnico-administrativo:

E também tem, por sua vez, docentes que acham que são muito mais do que qualquer funcionário. Eu já ouvi uma coisa que eu fiquei estarrecida.Quando eu entrei aqui eu falei "vamos tomar café na copa?"; "não, quem toma café na copa são os funcionários, docentes tomam café que está ali no corredor, que é o café dos pesquisadores". Pensei, o que é isso, na área de ciências humanas, entendeu? Então tem docente que acha que funcionário tem que chamar ele de doutor mesmo, tem que chamar ele de professor. Então os funcionários daqui, por mais que, por mais legais que, por mais legal que seja a relação que eu tenho com eles, eu já falei pra mais de um "me chama só de Vanderli", "não, professora, é pra evitar problema, eu já passei, já tive problema numa unidade tal que eu trabalhei, porque eu não chamei de professor...". Então tem essas tensões, tem uma tensão muito marcada. Tanto que tem o sindicato dos docentes e tem o sindicato dos funcionários, tem ADUSP e tem SINTUSP e então tem dois sindicatos porque os interesses são diferentes, porque se veem como categorias diferentes, porque o pesquisador, ele é... E a briga é lembrar, lembrar que ele é servidor público, nossa, é como se fosse uma desonra, "sou professor doutor". (Professora Vanderli Custódio)

(...) tem umas coisas que são muito específicas, por exemplo, como é que eu vou dizer... todo mundo pode ser... um docente pode ser mal humorado, pode ser fresco, pode ser metido, mas uma docente negra não pode ser fresca, mal humorada e nem ser grossa. Os funcionários técnico-administrativos ficariam horrorizados "uma professora, nossa, negra, né, sabe o que é ser humilhada, sabe o que é ser mal tratada, não ser bem recebida, como é que vai tratar, a gente, funcionário, assim?" Então tem uma coisa no ar. Eu nunca passei por isso, mas uma conhecida sim, já passou por isso, que ela entrou mal humorada e não cumprimentou ninguém e isso deu um buchicho: "como ela, professora negra, não cumprimenta, trata mal assim, chegou batendo o pé, não disse bom dia, não cumprimentou, se fosse a fulana, a gente até compreenderia..." Dela é imperdoável, entendeu? Então é uma coisa assim, eu nunca passei por isso, mas essa é uma coisa que está no ar. (Professora Vanderli Custódio).

Contudo, a presença negra na docência da USP pode ser indicativa de uma custosa, porém inicial possibilidade de democratização desse espaço, no sentido de outras USP`s possíveis:

Agora o que significa em termos mais práticos é como é que eu posso, por exemplo, falar para os alunos na FUVEST, tornar esse espaço um espaço possível, porque as pessoas olham para essa universidade e não se veem, "isso não é pra mim". Mas eu estou aqui e eu de certa maneira tenho a cara do meu povo, eu sou negro, eu sou gay, eu tenho cara de pobre, eu venho de uma família pobre, eu sou flamenguista, espalhafatoso, carioca, tenho a cara do povo. Então esse lugar também é um espaço para as pessoas mais comuns, para as pessoas que, vai sempre deixando claro que é um espaço a que se admira, mas é um espaço para o qual se exige esforço. Estou aqui nesse espaço porque, claro, eu sou um homem negro, gay, mas que demonstrou capacidade intelectual, porque não adiantava outros aspectos se aquilo para o qual eu estaria sendo formado o tempo todinho não tivesse em questão. E claro, como eu não venho sozinho, e aquilo que eu sou vem antes de mim, não faço nunca questão de obliterar este fato, trabalhar este fato, trabalhar sempre a dimensão, a minha dimensão étnico-racial, associada a uma certa origem de classe, associada a uma certa história pessoal, também a vivência da minha sexualidade. Afinal de contas é essa a história que me compõe, ela não pode ficar fora da universidade tem que vir junto. (...) É 
contraditória essa política porque, torno a dizer, as situações em que encarecer a presença de um professor, de uma professora negra em determinados situações, em outras com a implementação de uma política de cotas por recorte étnico-racial, essa negritude se dilui, esse aspecto não é relevante, isso não nos contempla. Por outro lado, pensar de certa maneira se o modelo de universidade que nós temos pensou a chegada nesse espaço de todos os atores sociais que compõe esse estado, porque isso aqui não é feito só de imigrante vindo de países europeus, ou do Japão, Coréia, isto também é feito de homens e mulheres vindos do interior de Minas, que são negros que vieram do Brasil, que vieram do Brasil é péssimo, (risos) ou ótimo. Que vieram do Brasil tal qual a gente o conhece, que são negros e negras que cedo ou tarde terão seus filhos ou netos chegando aqui também. Não sei se é um espaço que por um lado tenta se democratizar, mas é claro, não pode democratizar tanto sob o risco de colocar alguns valores que são muito encarecidos aqui dentro em questão, esta certa imagem da USP é sempre muito pensada. Agora eu não acho que tenha sido, eu não fui mal recebido nos espaços, muito pelo contrário, eu acho que academicamente, intelectualmente eu chego num momento muito propício, a implantação de leis que favoreciam o ensino de, por exemplo, literatura afro-brasileira. Chego num momento político, digamos assim também interessante para essas discussões a tempo de eu, não digo interferir, mas pelo menos participar delas e de certa maneira demarcar determinados lugares, que é dessa associação da origem com sexualidade com classe. Eu faço sempre questão de deixar muito claro, de dizer para os meus alunos, por exemplo, que eu sou filho de uma empregada doméstica negra diarista e que não tem sobrenome, não tem nenhum tipo de vínculo a não ser com minha própria origem. (Professor Émerson Inácio).

Assim, os/as docentes dessa pesquisa estão cientes das implicações de serem negros/as numa universidade que não manifesta nenhuma intenção de modificar sua condição elitista, que em última instância favorece também sua aura de melhor universidade brasileira. Uma vez parte do corpo docente da USP, torna-se perene para esse conjunto de docentes como sua negritude perpassa a carreira acadêmica:

Pelo seguinte, olha: independente de qualquer coisa, quando você é... afro-descendente, você é negro, você vem de uma situação social, você vem de um lugar social que é bem diferente do que a maioria da universidade é, bem diferente. Então o primeiro problema que se coloca é isso. Então por mais que se fale assim, "não tem racismo", não tem oficialmente falando, não tem. Mas você vem de um lugar, que é um lugar estranho para a universidade, seja no corpo docente, seja na maioria do corpo discente também. Então isso é a primeira coisa. Segundo, que quando você vem de um lugar como esse, é evidente que você luta por mudança. Você pode lutar por mudança individual, coletivamente, ou por uma mudança revolucionária ou não, mas efetivamente você não pode nunca assumir um lugar desse e achar que está bem do jeito que está, porque sabe, vivenciou isto, vivenciou. E é por conta disso, por conta dessa situação que você vem e dessa preocupação fazer parte da sua própria trajetória, ser professor negro é mais complicado ainda, porque você vai ter que, primeiramente... isso é uma coisa que o... não lembro quem foi que falou, um militante falou que ser negro é matar um leão por dia (risos) porque você vai ter sempre que estar provando que você é capaz, que você está como intruso naquele lugar. Segundo, você tem que batalhar para que essas temáticas sociais sejam colocadas como importantes nas discussões na universidade. E terceiro, que você tem que, a partir disso contar que na universidade, que ela é já montada para não se ter essa posição, para que ela de fato tenha uma preocupação com essa questão. Então aí ser professor negro é muito, é uma tripla dificuldade, eu penso, uma tripla dificuldade, pela sua própria origem, pelas temáticas que te preocupam, que a maioria não preocupa. É difícil encontrar interlocução aqui e terceiro por fato de você ter que enfrentar uma universidade que na sua origem é elitista, então isso é o problema que a gente tem, então é diferente (risos). (Professor Dennis de Oliveira)

Para o conjunto de docentes negros/as desta pesquisa, compor o corpo docente da USP é 
uma questão de mérito, mas a vida da academia acaba sendo marcada também por questões raciais. De uma maneira geral, narraram ter sensibilidade e/ou atuação para as diferenças entre as demandas sociais, para discussões de raça e classe. Com exceção da professora Adriana Alves, cuja experiência de pesquisa acontece nas geociências, todos/as os/as outros docentes transitam em suas pesquisas por debates acadêmicos que interpelam desigualdades de classe, raça ou gênero. Assim, seis docentes desse conjunto, narraram a experiência de colocar em pauta na USP a necessidade de pesquisar e trazer para a sala de aula questões que a universidade não privilegia por não serem temas de prestígio acadêmico. Isso só é possível em grande parte, pela experiência de pobreza e negritude - anterior à USP - que marca a trajetória de todos/as esses/as docentes. Enfrentar temas que a universidade costuma invizibilizar,tem feito desses/as docentes pioneiros/as ou referência em determinados debates ou campos de pesquisa e atuação.

Nesse sentido, o professor Roberto da Silva, ao estudar gerações de jovens em situações de abrigo e o sistema carcerário brasileiro, propondo políticas nesses campos, cria na USP um nicho importante de pesquisa; além de sua atuação no sentido de tornar melhor difundida a Pedagogia Social como campo de uma educação comprometida com as transformações da sociedade brasileira:

É... hoje eu estou já há 9 anos aqui, como professor. No início tem pra mim, pelo menos teve, assim uma perspectiva revanchista, vamos dizer assim. O que eu sempre fiz é difundir os temas de pesquisa com que sempre me ocupei na USP. Hoje há uma cultura, há uma massa crítica que considera esses segmentos sociais, essa problemática social como um objeto de interesse científico, tanto que prosperam os estudos nessa área. Mas também a perspectiva de colocar toda a infra-estrutura de utilizar os recursos que a USP tem a serviço dessas questões. Eu fiz isso também, eu usei isso ao máximo, à exaustão. Mas hoje, à medida que a gente vai amadurecendo na vida acadêmica e fazendo algumas reflexões internas aqui, a gente vê que talvez não seja tão interessante, depois de dez anos na carreira, agredir a USP. (...) Eu transito muito, eu ampliei cada vez mais meu espaço de trabalho, da pedagogia institucional, da pedagogia social. Hoje eu atuo no plano internacional também (...) Então isso foi importante no sentido de tematizar essas linhas de pesquisa com que eu me ocupo, anunciar para as agências de que existe professores doutores interessados em aprofundar as investigações sobre isso. (Professor Roberto da Silva).

Esse sentimento de ambiguidade com relação à USP, gerado pelo desconforto de saber que a universidade é elitista, mas fazer desse espaço um campo de apoio para debates pouco reconhecidos, também esteve presente na narrativa do professor Dennis de Oliveira. Conforme dito anteriormente, ele possui vasta experiência na militância; foi fundador da UNEGRO, entidade do movimento negro, além de ter sido militante do PC do B e da imprensa sindicalista. Sua atuação como docente na USP é descrita como continuidade para um projeto de jornalismo comunitário desenvolvido no bairro Jardim São Remo, bairro originado de uma favela urbanizada, popularmente conhecida como São Remo e que faz fronteira com o Hospital Universitário da USP, 
próximo ao Portão III da universidade. No entanto, apesar de ter herdado um projeto existente, o professor Dennis de Oliveira reformula e amplia a proposta, criticando a partir do Jornal Notícias do Jardim São Remo, os processos de marginalização e afastamento que a USP perpetra contra o seu entorno, se enclausurando dentro de seus muros. Além disso, o professor Dennis de Oliveira tem grande atuação e é parceiro de luta do Núcleo de Consciência Negra da USP, compõe o corpo de docentes pesquisadores do NEINB (Núcleo de Estudos Interdisciplinar sobre o Negro Brasileiro). Além de ser figura de destacada relevância nas mídias sociais, conforme indica a popularidade de sua coluna no Portal Fórum, uma página de notícias na internet, que nasceu junto como Fórum Social Mundial em 2001, em Porto Alegre. O Portal, que aposta na multiplicidade de vozes e na força dos movimentos sociais no processo de construção de um mundo mais igualitário, tem na figura do professor Dennis de Oliveira um colunista para colocar em pauta a luta antirracista. Sendo assim, apesar dos desconfortos institucionais vividos na USP, conforme narrado, o professor tem ciência de que seu espaço de atuação na universidade já tem reconhecimento, advindo de um outro público, que não é o público tradicional da USP, mas um segmento que lutou por cada polegada de espaço de visibilidade e justiça na sociedade brasileira e na universidade:

\begin{abstract}
Então, o reconhecimento que eu tenho, o prestígio, a maior parte do prestígio que eu tenho, são das pessoas comprometidas com esse projeto de mudança, você mesmo me disse que me encontrou através de pessoas que discutem relações raciais. Então nesse meio, movimento social, eu sou muito reconhecido, eu sou muito agradecido por isso. Isso aí, acho que... o que eu tenho hoje de prestígio acadêmico na universidade, devo aos meus colegas, companheiros, as pessoas que estão juntos comigo, ou que me ajudaram depende muito disso. Agora o meu prestígio em termos de estrutura é muito pequeno, mas eu tenho consciência que é isso mesmo, não tenho nenhuma ilusão, que eu vou ter muito prestígio, não tenho nem esperança que eu vou ter algum prestígio da direção da universidade, nem espero isso, o que eu estou lutando muito mais é respeito, respeito pelo que eu faço, aí sim, que respeite, que saiba que o que eu estou fazendo tem importância, tem qualidade. Então minha briga é respeito, por isso. Agora eu não tenho nenhuma ilusão com essas pessoas que estão aí, que elas vão prestigiar, porque isso contraria a própria consciência dela do que é a universidade. Inclusive eu falo pra você assim, eu acho que a mudança da USP, ela vai se dar de fora pra dentro, porque infelizmente ainda, a população, a sociedade civil de São Paulo, Brasil, não tem noção que a USP é dela, que é ela que banca isso aqui, ela que banca.
\end{abstract}

Interessante observar que "posições marginais" dentro das lógicas de prestígio acadêmico tenderiam a ameaçar "o poder sobre os mecanismos de reprodução" de modo que quem ocupa posições marginais, mesmo "sem jamais romper com a ordem universitária" realizam "um desvio mais ou menos decisivo em relação às trajetórias 'normais"'. (Bourdieu, 2011, p. 145). Assim, enquanto para o professor Dennis de Oliveira a atuação acadêmica está sobretudo vinculada ao extra-muro da USP, para a professora Roselane Gonçalves, um importante desafio é construir a EACH como campus legítimo da USP. Conforme dito anteriormente neste capítulo, a EACH é em 
grande parte fruto da mobilização da sociedade pela ampliação e democratização da universidade. No entanto, desde o seu projeto de fundação a EACH ou, como também é conhecida, a USP Leste tem sido marcada por um conjunto de problemas e equívocos, como a escolha da localização, uma vez que segundo a comunidade organizada que participou da construção do projeto, o campus deveria estar dentro do coração da Zona Leste e não na entrada da região; e ao que parece, a USP deu prioridade à proximidade com o aeroporto de Guarulhos. Desse modo, o diálogo da USP com a comunidade do entorno se mostrou insuficiente. Além disso, a contratação docente, conforme considerado anteriormente, aconteceu em regime de total precariedade. Mesmo assim, em função do discurso de excelência, e resistindo ao espectro da democratização que sempre rondou a USP, na gestão do reitor Zago a EACH foi sacudida pela polêmica de reduzir o número de vagas da unidade para que se aumentasse o nível do alunado ${ }^{98}$. Um dos motivos levantados teria sido o fato de a EACH se revelar uma USP mais popular, e que estava ameaçando a tradição de uma universidade elitista, como comentou o professor Dennis de Oliveira:

\begin{abstract}
Não sei se você acompanhou lá na USP Leste, a proposta do reitor de reduzir o número de vagas para aumentar o nível do aluno. Como a USP Leste tem mais negros, por que está na Zona Leste, ali a região, a proposta era essa, a USP Leste é hoje vista como um patinho feio da USP, patinho feio. Então ali, qual a idéia, vamos reduzir o número de vagas, para aumentar a concorrência e aumentar o nível do aluno, quer dizer, o nível do aluno é baixo pra eles, porque tem muito aluno de escola pública. (Professor Dennis de Oliveira).
\end{abstract}

Enfim, no caso da trajetória da professora Roselane Gonçalves, a polêmica mais destacada e diretamente ligada à sua atuação na EACH diz respeito à escolha dos cursos, que foi outra questão muito complexa na história da unidade. O fato é que o estatuto da USP não permite a duplicação de um curso dentro de uma mesma cidade. Na ocasião da discussão do projeto EACH haveria possibilidade de mudanças no estatuto para permitir a oferta de cursos tradicionais na USP Oeste e Leste. No entanto, a universidade foi irredutível e não permitiu a oferta de cursos tradicionais. Desse modo, a EACH oferece cursos novos e desconhecidos da população, muitos dos quais pensados especialmente para a criação do campus e têm, portanto, caráter experimental. Como decorrência, tem-se a insatisfação da comunidade da Zona Leste, apesar da USP oficialmente dizer que pensou os cursos conforme demandas da população do entorno. Como o perfil do alunado da EACH não é da Zona Leste exclusivamente, aliás, a minoria do corpo discente é da região, a comunidade uspiana que ingressou nesses novos cursos, também se queixa da oferta e do caráter dos mesmos, pois conforme relata a professora Roselane Gonçalves, seu curso de atuação, Obstetrícia, vive a batalha pela obtenção do registro profissional dos egressos, assim como outros

980 campus teve que ser fechado ao longo de 2014 em função da contaminação do solo. Há suspeitas de que a terra contaminada usada no aterro do campus foi retirada da obra de construção do Templo de Salomão construído pela Igreja Universal do Reino de Deus na região do Brás em São Paulo. 
Nós temos aqui, dois, sei lá quantos, quantas frentes de luta. Primeira a própria escola, porque é uma escola que se pretende num modelo diferente, na sua constituição, de não ter departamento, de trabalhar com colegiados de cursos, de todos os cursos terem um ciclo básico único, que todos os alunos desta escola no primeiro ano, têm o ciclo básico, de disciplinas mais diversas. Nós participamos desse ciclo básico, então a gente é chamada também pra se envolver em disciplinas que não são usuais da sua área básica de formação, num projeto em que você trabalha com a problematização do aprendizado, baseado em problemas, que se pretende construir situações com os alunos e a partir daí começar a parte mesmo do conhecimento. E particularmente o curso de Obstetrícia que tem sido uma outra briga pra se consolidar dentro da escola, dentro da universidade, por enfrentar no mercado de trabalho uma briga política muito grande, por que o curso vem propor uma mudança de modelo na assistência, então a gente tenta formar parteiras diplomadas, pra melhorar a qualidade da assistência aí fora, que devem trabalhar integrados com médicos, com enfermeiros e tudo mais. Então esse grupo corporativo externo faz uma pressão muito grande e aí dentro da escola a gente tem tido que mostrar e pedir pra USP nos bancar, bancar nosso projeto, sabe. Então tem sido muito difícil. Essa questão acho que é uma das mais importantes da sua entrevista, porque, enquanto universidade você tem essa, a USP, e aí você tem as outras unidades todas que têm lá suas dificuldades, mas a EACH, ela tem se colocado, ela está num momento bastante crítico, com muita coisa boa, mostrando a cada dia que é possível mudar, mas não necessariamente sendo, tendo todo apoio dessa macroestrutura, na universidade como um todo. Então a EACH me parece, também pegou um pouco de "ah, lá tem esses cursos aí que ninguém sabe pra que serve, vai formar o cara pra fazer o que? O que um cara da licenciatura em Ciências da Natureza vai fazer?". Então muito assim, parece que tinham que por um negócio lá e puseram esses cursos. E é uma crítica também da rede, do movimento social, porque na verdade não eram essas profissões que os alunos de ensino médio interrogados na ocasião queriam. Todo mundo queria aqui engenharia, medicina, direito, física, química, não sei, psicologia, aqui, e não é isso que veio. Então muita gente fala "eu não quero fazer desse que está aí", até porque nem conhece que curso é esse, que possibilidade você abre, que mercado é esse, porque aí tem essa história do mercado mesmo, tem que ter. Nós da Obstetrícia estamos sofrendo muito por isso, de colocarem em questão se o curso deve ou não continuar porque existe um corporativismo médico e de enfermeiros no mercado dizendo que não nos querem. Então hoje nós temos integrado lutas com os egressos, lutas internas como garantia de grade curricular. (risos) Mas está sendo bom. Porque a gente percebe que existe sim é discriminação, em função da localização do campus, a função de como se pensou essa escola, por ser cursos de períodos vespertino, matutino e noturno e foi exatamente a ideia de facilitar a inclusão, pra que o aluno possa trabalhar e estudar em algum dos períodos. Tudo isso coloca um pouco da diferença, então tem pessoas, tem colegas que a gente já ouviu comentários de que isso aqui é uma USP mais ou menos, que não A USP, porque está na periferia da cidade, porque o que se propõe é integrar um pouco mais nesse outro contexto. Então eu acho que a gente tem muita dificuldade ainda de mostrar um pouco para os colegas das outras unidades quem somos, o que fazemos, porque de fato, enquanto política eu acho que a gente veio dividir o orçamento da universidade e isso não deve ter sido muito bom para as outras unidades. A gente sabe que o formato da EACH também não agrada a todos, a gente ouve um pouco isso, mas tudo assim, a gente ouve... nunca houve um momento em que se discutiu numa mesa, as várias unidades, talvez nos outros âmbitos de cada colegiado, mas é que a gente sente que nós estamos um pouco tendo que provar para os outros que nós também somos curso de excelência, que os professores podem ter produções tão boas quanto os outros, que podem publicar nas revistas de qualis tão bom quanto os outros. Eu acho que existe uma pressão um pouquinho grande interna, nossa e da própria instituição. Parece-me que a EACH é um projeto que as pessoas querem ver se vai dar certo, mesmo internamente, uma das grandes críticas do movimento social da zona leste é que esta escola, ela foi construída aqui, mas deveria ter sido construída mais no coração da Zona Leste, que o acesso aqui também não é fácil. Então você pega alguém que veio da cidade de Tiradentes pra chegar aqui, é difícil. Então já começa por aí, o local onde 
ela se colocou, não é de fácil acesso, é uma rodovia, agora temos o trem e tal, mas se você pensar na zona leste mesmo, ela está próxima, mas a zona leste tem 4 milhões e meio de habitantes. E hoje, não sei se é desse último ano, eu não sei, mas a gente, acho que teve um primeiro ano com $40 \%$ de alunos ingressantes procedentes do ensino médio público, depois esta taxa caiu, acho que nós temo hoje 30 ou 35\%, não sei. Então a gente está na zona leste recebendo alunos de todas as partes aí, de outros estados, do estado de São Paulo, do país. Então acho que o ingresso ainda está sendo... esta história da inclusão precisa ser revista.

Apesar das lutas pela construção da USP Leste enquanto campus legítimo da USP, a atuação da professora Roselane Gonçalves vai além dos limites da EACH. Conforme atesta seu Lattes e relato para essa pesquisa, ela também se propõe a trabalhar no tripé ensino-pesquisaextensão, a humanização do parto, considerando tantas violências às quais as parturientes ainda estão sujeitas. Nesse sentido, sua carreira acadêmica está também vinculada aos debates de gênero e acesso ao sistema de saúde pública, mais especificamente às demandas da assistência à saúde reprodutiva.

O professor Émerson Inácio por sua vez, propõe trazer para dentro do Departamento de Letras Clássicas e Vernáculas da FFLCH literaturas insólitas, porque são negra, periférica, africana, gay e lésbica:

\begin{abstract}
Por exemplo, aquilo a que eu tenho me detido, na questão dessa produção mais periférica, mais marginal, não nesse sentido mais lato que tem sido usado com relação a Literatura. É de dar, por exemplo, visibilidade a uma questão autoral eminentemente marcada por mãos negras, digamos assim. E mãos negras conscientes desse papel político, social e estético principalmente, que é o ato de escrever. É uma necessidade a que eu me imponho de entender esse procedimento. Daquela coisa da Carolina [Maria de Jesus], que precisa escrever porque ninguém mais escuta o que ela fala e ela precisa dizer. Será que é uma tônica que se repete? Portanto, o que eu quero dizer é dessa necessidade de investimento no objeto. (...) Não adianta continuar lendo um trabalho em sala de aula com textos com os quais não haja diálogo entre a vida, tal qual ela é e a ficcionalização sob o risco desses textos passarem. Daí a minha opção por também trazer esses outros aspectos. Machado [de Assis], há pessoas que ensinam. Clarice [Lispector], tem outras pessoas que ensinam. Durval do Mota, pouca gente ensina. Carolina Maria de Jesus, pouca gente ensina. Cadernos Negros, pouca gente ensina. Pouca gente pensa teoricamente, seriamente esses aspectos. É essa a minha preocupação de criar substrato teórico crítico pra tirar a literatura produzida por homens e mulheres negros, identificados com as questões da afrodescendência, da posição de janela, vidraça, onde todo mundo pode, justamente por falta de tutano, digamos assim, tutano crítico.
\end{abstract}

Ainda que não dedique sua carreira de pesquisa às questões raciais, a professora Maria Letícia também tem construído um campo de saber e que eventualmente é atravessado por questões raciais: a Sociologia da Infância. Seu nome começa a aparecer como uma referência na discussão que paulatinamente vai se fortalecendo no Brasil:

Meu projeto profissional é ver a sociologia da infância ser ampliada cada vez mais. Eu estou contente que várias publicações Qualis A estão trazendo textos que eu fiz a tradução, ou fiz a revisão técnica, ou fiz a tradução, enfim. De alguma maneira está difundindo e está ligando meu nome à Sociologia da Infância. Isso é estratégico, sem dúvida. Então eu quero 
ampliar mesmo esse campo.

Importante destacar que embora não pesquise diretamente a respeito de crianças negras, a professora Maria Letícia sempre é convidada e participa de fóruns sobre o tema, vide sua presença na ANPED (Associação Nacional de Pesquisa em Educação) no Grupo de Trabalho Educação e Relações Étnico-Raciais (GT 21). Além disso, orienta pesquisas sobre a temática. Aqui cabe fazer um importante parêntese. A professora Maria Letícia ao longo de sua narrativa trouxe um posicionamento racial que levou em consideração sua experiência de ser filha única de um casamento inter-racial, ponderando sua negritude a partir das dificuldades vividas pelo pai negro e o trânsito na sua família materna que é branca. Conforme indicado anteriormente, este trânsito em certo sentido facilitou a vida da professora Maria Letícia no acesso a modos de vida de classe média num momento de vida anterior ao experenciado pelos demais docentes aqui considerados e lhe possibilitou certa agilidade nas relações estabelecidas com brancos e negros ao longo da vida. Mesmo assim, o fato de circular com facilidade nos dois universos raciais não livrou a professora Maria Letícia de ter vivido situações de cunho racista dentro da USP, como indica o relato a seguir:

\begin{abstract}
Eu acabo participando de várias bancas, embora eu não trabalhe com pertencimento étnicoracial, eu já fiz parte de duas ou três bancas nessa linha, aqui também. Então eu sinto que as pessoas me chamam. Os estudantes negros, não só eles, mas eles me chamam pra participar do trabalho deles de uma maneira bastante prazerosa, sabe assim, é gostoso. E eu to muito contente porque eu tenho duas orientandas negras nesse momento. Logo que eu ingressei aqui, logo que eu comecei a orientar, uma colega da área dizia assim: "a Letícia e suas loirinhas". Porque tinham passado duas candidatas loiras no mestrado, e eram minhas orientandas, eu não escolhi por cor. E essa colega brincava: "a lá vem a Letícia e suas loirinhas". Ah, que bobagem. Isso pra mim é uma fala racista. Mas enfim... Pois é, mas agora eu tenho duas orientandas negras, certo, e eu to esperando falar "Letícia e suas negrinhas". Vamos ver se ela vai dizer, né? Provavelmente ela não vai... tem umas falas que saem das pessoas e elas nem se dão conta ou se não dão conta, que às vezes me incomoda um pouco né.
\end{abstract}

Por fim, a professora Vanderli Custódio também relata a experiência de ajudar a construir uma área de atuação dentro da USP. No seu caso especificamente, é menos um campo teórico e mais uma área institucional. Conforme relata, no IEB até sua entrada em 2003 não havia nenhum docente e nem pesquisas na área da Geografia:

É, sou docente aqui do IEB. O IEB é um instituto interdisciplinar, formado por áreas temáticas nas ciências sociais e humanas. Então nós temos aqui, as duas áreas mais fortes, mais tradicionais literatura e história, mas aí temos música, por exemplo, geografia, nós estamos em dois docentes, um entrou agora. Tem sociologia, antropologia, arquitetura, então é um instituto interdisciplinar com áreas temáticas e eu pertenço á área temática de geografia. Era só eu até agora, de 2003 até agora, 2010, praticamente a área era eu, agora que acabou de entrar um outro colega da geografia e somos em dois. Agora dá pra dizer que somos uma área mesmo 
Porém o processo de entrada e estabelecimento na docência não se revelou tão tranquilo conforme indica esse belo e doloroso relato:

As pessoas falavam assim "espero que seu debut seja fantástico". Pensava, mas porque as pessoas estão falando "espero que seu ingresso na universidade não seja traumático, espero que não". E eu estava praticamente há vinte anos na iniciativa privada. Curso de história e geografia nunca deu dinheiro para a iniciativa privada, a gente vivia com o risco de no final do ano ter o curso fechado e todo mundo ser mandado embora, você está com um número $\mathrm{X}$ de aula, mas corria o risco de no outro ano, no outro semestre estar com um número menor de aula, portanto seus rendimentos diminuírem, uma competitividade interna grande, mas eu sempre tive uma tranquilidade no ambiente profissional, eu sempre soube que trabalhei bem, nunca tive grandes problemas nem com colegas, nem com alunos, fui sempre muito tranquila e aí eu falava assim "mas o que pode ser mais complicado do que a iniciativa privada?". Mas é. Mas é muito complicado, uma coisa também que eu nunca falei pra ninguém desde 2003 pra cá, é que nos primeiros quatro anos eu cheguei a escrever 3 vezes uma carta de exoneração, pra sair da universidade, porque é muito, é uma cultura muito perniciosa, que é a cultura do serviço público, que é uma coisa muito complicada. E assim, eu fui aluna daqui, eu fui funcionária também, uma coisa que eu esqueci, que eu entrei na geografia em 81 , em 82 , meu irmão já trabalhava na reitoria, eu prestei um concursozinho interno na reitoria e entrei, trabalhei como funcionária administrativa aqui da reitoria durante cinco anos e foi muito legal. (...) Então aproveitei muito isso, é... ser funcionária da universidade foi uma coisa muito legal também, depois aluna da universidade, agora docente da universidade. $\mathbf{E}$ desses três papéis, dessas três vivências, a vivência como docente foi a mais complicada, psicologicamente mais... de uma porção de desilusões, de muitas desilusões, uma coisa muito complicada mesmo. [grifos meus]

Na sua entrada para o corpo docente da USP a professora Vanderli Custódio também precisou lecionar no Departamento de Geografia, onde também foi mal recebida, conforme considerado anteriormente neste capítulo. Concebida academicamente no coração da USP, a Faculdade de Filosofia, a professora Vanderli Custódio viveu intensamente toda a sua vida nesta universidade, o que significa cotidianamente a construção de um legado de excelência com direito aos bônus e ônus. Não passa despercebido o fato de que nem Milton Santos, mesmo com o Prêmio Vautrin Lud, considerado o Nobel da Geografia, teve passagem fácil pelo Departamento de Geografia ou conseguiu transformar, com suas propostas epistemológicas revolucionárias, as estruturas num espaço afeito a algumas tradições. Desse modo, ter sido santosiana, e ter abraçado o legado teórico de Milton Santos não a teria ajudado muito. E ainda, por mais que na Geografia ela tenha tido a preocupação de ministrar as disciplinas de Geografia Regional África do Sul e Geografia Regional África do Sul e Ásia, ela reconhece que enfrentar as relações raciais como tema de pesquisa teria sido uma dor a mais na sua carreira:

Eu trabalho com Geografia Urbana, não trabalho com a questão negra, mas qualquer temática vinculada ao negro, me chamam, é a coisa mais engraçada, me chamam pra banca e eu vou, né, eu vou, não vou deixar de ir pra banca por causa disso. Mas essa associação que o colega faz de que ela é negra, a temática é negra e me chamam, que eu acho muito, muito sintomático isso também que mais... Então tem, tem aparecido um monte de trabalho na geografia trabalhando com a questão negra, feita por alunos negros, mas docente, pesquisando a questão negra, na geografia, não tem, não é um forte na geografia. Tem na 
antropologia, sociologia, marcadamente, mas não na geografia não tem muito não. E eu não sei nem te dizer por que, não me deu vontade de lidar com a questão negra. Fui, fui me enveredando pela questão das cidades, do urbanismo e tal, da habitação urbana e depois pro saneamento e fui caminhando pra essa área. Hoje, hoje, fazendo uma avaliação, eu acho que eu fiz bem, apesar de todos os problemas que eu vivi na universidade, porque o quanto que eu fiquei fragilizada, e se eu lidasse com a questão negra ainda, eu teria desistido, seria uma dupla, uma dupla fragilidade. Seria mais complicado ainda se eu lidasse ainda do ponto de vista da pesquisa, com a questão negra. Eu acho que a política de desqualificação seria muito mais pesada, eu acho que eu me cobraria muito mais até. Acho que seria dolorido ficar lidando, seria como ficar tocando numa ferida 24 horas por dia. Mas não foi assim... quando eu comecei, que eu escolhi Geografia Urbana, não foi para... vou trabalhar com Geografia Urbana para não trabalhar com a questão negra, que é muito dolorida pra mim, não foi. Eu fui enveredando pela questão urbana por que foi, fui me apaixonando, porque eu gostei de cidades, fui me apaixonando por esta questão e por acaso eu fui me enveredando por aí.

Embora as narrativas docentes se aproximem, por exemplo, das denúncias feitas em espaços políticos acadêmicos de contestação e crítica, como as publicações da Revista ADUSP, por exemplo, que trazem para a ordem do dia os debates sobre as crises que a USP viveu e vive ao longo da história; os relatos apresentados conseguem também contemplar aspectos de uma vivência cotidiana na universidade que vai além das políticas macroestruturais da USP e contemplam aspectos da vida acadêmica que não são discutidos. Podem assim oferecer uma visão completamente não elitista da USP e a universidade emerge como um elevado patamar de conquista pessoal profissional, e nesse sentido, para os/as docentes negros/as aqui considerados, a carreira docente na USP é a expressão da ascensão social vivida por este segmento:

Olha, todo mundo critica a universidade, quem está dentro, quem está fora, acho que é uma mania de brasileiro de ficar reclamando mesmo. Mas no fundo, no fundo, no fundo, a gente reclama como docente, os funcionários técnico-administrativos reclamam nas suas áreas, mas todo mundo sabe que nós somos privilegiados na USP, nós estamos bem empregados. Se está ruim aqui, fora daqui muito pior. Todo mundo conhece alguém que saiu da USP e nunca mais conseguiu arrumar um emprego fixo, estável, com qualidade de vida razoável. A USP tem uma série de problemas, o serviço de saúde, por exemplo, da USP é um horror, pros alunos, pros funcionários técnico-administrativos, docentes, podia ser melhor. Já deu uma melhoradinha nos últimos anos, cartão para fazer compra no mercado, vale-refeição e isso a USP não tinha. A USP mesmo acho que tinha essa coisa de, ah como está bem empregado na USP, não tem do que reclamar. Mas aí acho que as pessoas reclamaram tanto "olha aí, até uma firma simplesinha aí fora tem V[ale] R[efeição] e tem um convêniozinho e a USP não tem um convênio, não tem um vale-refeição, não tem um vale-supermercado, não tem nada. Então nos últimos tempos a USP tem feito isso. O serviço médico ainda está muito ruim, eu acho que quem precisa de acompanhamento... tem funcionários com LER, com lesão por esforço repetitivo, porque não tem um atendimento na universidade, que tem um hospital que deveria... não é privilégio de quem é da USP, mas pelo menos dar uma olhada em quem é da própria casa. Então tem funcionário que tem problema de LER, que não tem um acompanhamento, por exemplo, com periodicidade, um mínimo. Você tem docente com problema de nódulo na garganta, por exemplo, porque falou demais a vida inteira, que podia ter acompanhamento especial dentro da universidade e não tem. Então tem esses problemas dentro da USP, mas a USP é um bom patrão, é um bom patrão. Por mais que todo mundo reclame, que todo mundo reclame, mas vamos falar sério, a gente está vivendo bem dentro da USP, imagina um cara que trabalha aí fora como é que está, no final das contas nós estamos bem. (Professora Vanderli Custódio) 
Apesar da USP aparecer como uma grande conquista na vida acadêmica desses docentes, pode também ser a razão de desencantos com a atividade acadêmica, de desapropriação e desinvestimento afetivo desse espaço:

E eu particularmente assim, tudo que eu tenho, eu devo à USP, eu não digo tudo que eu sou não, porque eu acho que eu já entrei aqui bem formada, com 18 anos eu tive uma mãe incrível, que quanto mais o tempo passa, daqui a pouco eu faço 50 anos, eu falo da educação primorosa que a minha mãe analfabeta me deu, primorosa. Eu acho que eu tenho, eu tenho uma educação rara. Eu fico olhando esse povo aí que teve toda a condição de estudar, eu tenho colegas que estudaram em colégios particulares e que falam não sei quantas línguas e que são colegas que são de uma grosseria, de uma estupidez, de uma mesquinharia, que a minha mãe seria incapaz, sabe? (...) Agora a formação acadêmica e a possibilidade de trabalhar e viver com dignidade, foi a USP que proporcionou, foi a Geografia que proporcionou, "ah. Vai viver de Geografia, como você vai ganhar dinheiro com isso?". Então assim, tudo que eu sou eu devo a minha mãe, e tudo que eu tenho, eu devo à USP. Devo a USP e que eu nunca me esqueço que é uma instituição pública, que é o Seu Zé lá que paga, que é a Dona Maria que paga e que eu tenho que fazer jus a isso, fazendo bem o meu trabalho, minimamente isso, fazendo bem o meu trabalho. Então essa é a concepção que eu tenho. (...) E quando eu entrei aqui, por exemplo, como eu falei pra você, encontrei um monte de mesquinharia, um monte de miséria, eu falei, como é que eu vou me maravilhar com isso né? Foi uma frustração muito grande, assim, o perfil das pessoas que eu encontrei aqui. Eu não imaginava que pós-graduados e intelectuais e lidos e não sei o quê, pudessem ser tão mesquinhos, tão... sabe... tão baixaria mesmo, não imaginava. Então não me maravilhou nesse sentido. Às vezes as pessoas falam "você nega a USP, porque você não fala que trabalha lá, que é professora da USP, o que tem você falar que é professora da USP, você conquistou isso". Eu sei, mas eu, eu... porque eu não me maravilhei com a USP, entendeu? (...) Eu fico deslumbrada com aluno que faz uma pergunta que eu não tinha nem imaginado que pudesse ser feita, que aí você fala "nossa to falando, tentando atingir esse objetivo e aí você atinge um outro que você nem imaginava, nossa, eu não tinha feito esse raciocínio". Então é muito legal como você percebe que o que você falou suscitou uma outra coisa na cabeça da pessoa que você não tinha nem passado pela sua cabeça, e assim eu dou aula há tantos anos, eu falo desse mesmo texto há tantos anos, já fizeram tanta pergunta, mas essa, nunca fizeram, olha só, como é que pode ser. Então isso me maravilha, isso me deslumbra. Mas a USP não me deslumbra, porque eu me decepcionei muito assim, em termos da relação com as pessoas, das mentes, das cabeças que eu encontrei, fiquei muito decepcionada, eu tive umas duas ou três decepções, muito grandes com a USP, então eu não consigo me deslumbrar muito com a USP não. (...) Mas essa coisa fica no ar, tem uma coisa no ar assim, pra ver se você faz jus ao nome USP. Tanto que é uma coisa que eu não falo pras pessoas assim: "você dá aula?"; "sim eu dou aula, sou funcionária pública, eu dou aula de Geografia"; "aonde?"; "lá no Butantã, sou professora da rede pública". Porque se você fala que é docente da USP, tudo muda, tudo muda, tudo muda. Nossa você leciona na universidade, que não sei o quê...porque meu filho vai fazer medicina, porque não sei o quê, porque como é o vestibular, porque, então professora". Já muda, o Vanderli some, a Vanda some, aparece a doutora. Isso pra mim é um porre, isso me enche a paciência, eu não gosto disso, entendeu? Então eu falo assim, "sou funcionária pública, professora de Geografia, do estado e tal, dou aula ali no Butantã, numa escola que tem ali no Butantã, numa escola que tem ali (risos). (Professora Vanderli Custódio)

Conforme indica Isaia (2001) a carreira do/a professor/a universitário seria permeada pela tensão entre centração na própria pessoa e a problemática dos alunos; inventividade e conformismo; aspirações, necessidades, valores pessoais e estruturas institucionais; sentimento e razão; cultural institucional e social; investimento afetivo e desinvestimento; fases da vida adulta e fases da carreira docente. (Isaia, 2001, p. 45). Sendo assim, certa dose de frustração e descontentamento já 
estaria prevista na carreira acadêmica universitária e conforme indica Morosini (2001) esta possibilidade foi intensificada pelo processo de precarização da atividade docente no Brasil verificada desde os anos 1990 em função do plano de expansão do ensino superior e reformulações nas legislações da educação brasileira. Nesse sentido, a professora Vanderli Custódio revela queixas que podem ser coletivas. Mas é interessante destacar que a bibliografia sobre sofrimento docente, sobretudo no ensino superior, além de escassa, é insuficiente na consideração da dimensão racial desse sofrimento. E conforme as narrativas dos/as docente dessa pesquisa, essa é uma dimensão presente na carreira e que complexifica os processos de competição e disputa próprios da vida acadêmica. Nesse sentido pode ser compreendido também o sentimento de isolamento e solidão narrado por docentes dessa pesquisa, por exemplo quando manifestam interesse por localizar outros/as docentes negros/as no intuito de se fortalecerem institucionalmente:

Mas os poucos professores negros que tem na universidade, quase que não há elos de ligação entre eles. Eu por exemplo conheço o Kabengele porque eu tomei a iniciativa de me aproximar, de conversar com ele. Mas quantos outros fazem isso? Então visitando pelas unidades, participando de reuniões por aí, você vê algum ou outro, mas isolados, sozinhos. (Professor Roberto da Silva)

Apesar de não constituírem um coletivo dentro da universidade e nem terem herdado diretamente nenhuma grande tradição dentro da USP, os/as docentes negros/as aqui considerados têm arriscado a construção de novas tradições sabendo o quanto custa cada tijolo assentado nesse processo. Mais ou menos ostensivamente, sob a capa da condição racial e de classe, tentam a partir de suas práticas acadêmicas construir uma USP mais democrática. Apesar de ainda jovens na carreira e de ainda estarem sentindo o solo sobre o qual estão assentados, posicionam-se e propõem mudanças no sentido de uma USP mais negra e periférica, ainda que tendo que enfrentar resistências:

Por exemplo, "ah, a USP tem que se posicionar com relação à questão das cotas, estão pedindo o posicionamento do IEB, mas é lógico que nós somos contra!" "Eu sou a favor." Um silêncio total. Um professor falou assim "então, pega uma bolsa de estudo e dá uma bolsa pra cada favelado e põe todo mundo aqui dentro". Eu falei "não to falando isso, eu disse que eu sou a favor, mas não do jeito que as coisas estão sendo feitas, mas eu sou a favor". E depois eu tive uma outra discussão, (...) aqui porque, eu tive um professor que estava recebendo do estado por conta de ter sido torturado, ele não escutava bem e tal, foi barbaramente torturado. Então ele dizia: "o Estado brasileiro me deve", e eu acho que deve mesmo, pra todo mundo que foi torturado pelo regime militar, o estado deve, mas que também deve pra todos aqueles que foram mortos pelos terroristas, para familiares daqueles que foram mortos pelos terroristas, também deve pra esses. Bom, aí eu ouvi dele todo esse discurso de que o Estado brasileiro devia pra ele. Falei, bom... mas ele é contra as cotas, falei "bom se o estado brasileiro deve, se você acha que ele lhe deve, deve pra mim também. Se a independência, desde 1822 se tem a independência do país, tem estado brasileiro, esse estado brasileiro até 1888 manteve a escravidão, certo? Então o estado brasileiro nos deve. Se for contar pelo menos esse período aí, nos deve, tem que pagar, tem que ressarcir cada negro". "Mas quem é negro aqui?" "Na hora de discriminar, todo mundo sabe quem é negro, na hora de inverter o discurso, fica lá fazendo exame de DNA pra dizer 
que fulano loiro, olha tem $80 \%$ de sangue negro, mas ele é branco, olha, tá vendo só que não dá pra saber quem é negro no Brasil?". Mas na hora de discriminar, todo mundo sabe exatamente quem é negro no Brasil, exatamente. (...) Agora entrou outro colega, meu de sala, da área de História, professor Alexandre, que também numa conversa ele falou assim "ah eu também sou a favor das cotas". Brinquei "você tá falando por sua conta e risco hein, não fui eu que te influenciei (risos). Você tá falando por sua conta e risco". Então assim, hoje me posicionar, falar isso aqui dentro, é tudo mais tranquilo, muito mais legal agora. Então depois de praticamente oito anos que eu estou vivendo uma fase boa na universidade, o respeito dos colegas, dos funcionários técnico-administrativos nunca tive falta de respeito. Então uma relação boa agora, tranqüila. (Professora Vanderli Custódio)

Apesar de não ser o foco deste trabalho, é importante ao menos mencionar a face problemática da relação entre movimentos de esquerda e movimentos antirracistas dentro das universidade públicas brasileiras. Ainda persistem entre acadêmicos/as negros/as decepções advindas de determinados debates com algumas vertentes da esquerda brasileira que apesar de se mobilizarem por uma sociedade mais justa, ainda não legitimam a luta antirracista. Além disso, outro aspecto da fala da professora Vanderli Custódio merece ser destacado: que tipo de política de acesso ao ensino superior deveria ser adotado na USP? A fala da professora transcrita acima e as de outras/os docentes negras/os concedidas para essa pesquisa indicam posicionamentos favoráveis às políticas de ações afirmativas ainda que com distinções importantes. No caso da professora Vanderli Custódio, tem-se que não basta apenas implantação das cotas, mas também se fazem necessárias políticas de permanência estudantil,posicionamento semelhante ao do professor Dennis de Oliveira e Émerson Inácio:

Eu particularmente sou a favor das cotas, mas não do jeito que as coisas estão sendo feitas, precisa discutir muito, precisa arranjar um jeito de implantar isso com toda uma infraestrutura antes, durante e depois, porque senão... psicologicamente é um massacre. Eu encontrei alguns alunos na geografia, hoje tem muito mais alunos negros na geografia do que no tempo que eu estudei. Mas muitos são muito, muito perdidos, muito fragilizados, se sentem muito deslocados mesmo. Muitos entram com bastante dificuldade teórica e aí não encontram um apoio. Então alguns desistem. Eu tinha uma aluna que ela tinha tanta dificuldade, que no dia de fazer prova ela tinha diarréia, ela tinha medo, ela não se sentia capaz, uma coisa assim, um trabalho quase que de psicólogo com ela "você precisa procurar um psicólogo, você precisa procurar uma ajuda especializada", que foi, que deu um up pra ela que fez com que ela conseguisse fazer um TGI, concluir a graduação e ficar mais em paz e trabalhar, porque ela, muito preocupada com questão negra e toda uma vida numa comunidade, de infância negra, tudo muito intenso. Chegou aqui e ficou completamente perdida, quase que perde a possibilidade da universidade, porque psicologicamente é um massacre. (Professora Vanderli Custódio)

Eu penso que a USP está muito atrasada nisso, se pensar assim, outras universidades, estão muito mais avançadas. Hoje, por exemplo, nas federais, o que se discute não é só acesso, é permanência. Então por exemplo, você garante cotas pra negros nas universidades públicas, legal, mas e a permanência desse aluno?(...) Você vai ter que pensar, por exemplo, bolsa, pensar tutoria, se você vai pensar, por exemplo, que se aluno, boa parte deles, vêm de escolas com problemas de deficitários por conta da escola pública nessa situação, tem que pensar no nivelamento, tem que pensar transporte público, assistência estudantil, enfim, tem uma série de elementos que têm que ser garantidos, para que esse aluno entre e continue, senão ele vai embora, desiste do curso. Agora na USP, nem sequer acesso, é uma resistência grande. Não é que não querem, não querem mesmo! É uma resistência, acham que vai cair 
o mérito, na USP é horrorosa essa discussão. (Professor Dennis de Oliveira)

Eu tento investir sempre na garantia de que haverá um público formado por homens e mulheres negros que queiram estar na Universidade de São Paulo e pra isso eu preciso ter políticas tanto de entrada quanto de permanência, quanto de investimento na carreira, na formação e qualificação desses indivíduos. (...) O negócio é esperar. Eu sou sempre muito esperançoso com relação a algumas coisas. Eu acho que elas já foram muito piores, elas já foram muito mais acintosas. (Professor Émerson Inácio).

A fala do professor Dennis de Oliveira define o que seriam políticas de permanência conforme bibliografia especializada. Em obra organizada pelo professor Jocélio Santos e publicada em 2013 a respeito do impacto das cotas raciais nas universidades federais e estaduais entre os anos de 2004 a 2012, percebe-se o mesmo que indica o professor Dennis de Oliveira: de fato a USP ainda está muito aquém na proposição e adoção de políticas nesse sentido ${ }^{99}$. Porém, como indica o organizador da referida obra, mesmo nas universidades federais e um grande conjunto de universidades estaduais, algumas questões ainda são muito problemáticas. Apesar da lei ser bem interessante e de já estar sendo aplicada com sucesso, sobretudo via ENEM, que se tornou a primeira e/ou principal porta de entrada para as universidades federais; Santos (2013) relata que a referida lei esbarra numa estrutura acadêmica que secularmente tem sido concebida como lócus de reprodução das elites brasileiras. Essa estrutura secular burocrática ainda apresenta pouca boa vontade com os/as pesquisadores/as negros/as que têm se dedicado a acompanhar e monitorar o cumprimento da lei e a conseqüente gradual mudança da face do ensino superior brasileira. Santos (2013) assim relata o processo de levantamento dos dados:

Processos de solicitação levando meses para serem respondidos, engavetados ou mesmo negados. Assim, a continuidade ou o início de pesquisas, na maioria das instituições, teve um contínuo de empecilhos na circulação de informações para a produção de dados. A demarcação do controle dos dados passou a ser reverberado ou silenciado pelos setores e órgãos responsáveis pela produção e veiculação das informações. E é provável que se tratasse do exercício de poder tão comum nas instituições burocráticas estatais. (Santos et. al, 2013:11)

Mesmo com avanços na adoção de políticas de ação afirmativas nas universidades federais, há muitas arestas a serem aparadas. Se esse é o melhor panorama que temos, na USP onde a discussão sobre cotas é sistematicamente abortada, o debate tem que ser ampliado. E os posicionamentos dos/as docentes negros/ transcritos acima estão de um modo geral bem alinhados com as reivindicações do movimento negro dentro e fora da universidade pública, de que a

99De um modo geral, grande parte das universidades federais e estaduais foram obrigadas a terem que adotar as cotas em função da Lei 12.711 que estabeleceu cotas de no mínimo $50 \%$ das vagas para estudantes que tenham cursado integralmente ensino médio em escolas públicas. Dentro desses 50\%, metade deve ser para estudantes cuja renda familiar per capita seja igual ou inferior a um salário mínimo e meio. Além disso, o segundo artigo da lei ainda define que o preenchimento das vagas para candidatos auto-declarados pretos, pardos e indígenas deve ser em proporção racial igual à distribuição no estado no qual se localiza a instituição federal de ensino superior. 
instituição não está preparada para o processo em curso de democratização da universidade pública. Mas outros/as docentes apresentaram posicionamentos um pouco distintos, ainda que também favoráveis à adoção de políticas de ações afirmativas e dentre elas, as cotas raciais:

Eu mudei de opinião... No começo, eu era contra as ações afirmativas. Por conta da minha história de vida, de certa maneira, e porque eu achava que o mérito superava qualquer dificuldade de classe, de etnia, de gênero, Mas eu fui amadurecendo essa ideia, e eu acho que as cotas são importantes sim. (...) Eu não gosto do termo reparação... Sabe assim, reparação parece que fica meio perto da filantropia. Mas eu acho que é importante. Hoje em dia eu acho que é importante. Eu acho que tem que abrir espaço para que o mérito possa aparecer, entendeu? Essa segunda-feira, a discussão lá da Fundação Ford, a Cristina Teodoro disse uma coisa que é muito legal. Eu não sei quantas pessoas pleiteando bolsa, e ela disse assim: "e eu estava disputando com os meus iguais". E isso ficou na minha cabeça, sonhei com isso, fiquei pensando. E acho que a ideia das cotas é exatamente isso. É mérito, e eu não sou meritocrata, mas acho que mérito é uma coisa que faz você se sentir bem. (...) E eu acho que as são importante pra isso, pra você dizer "puxa vida, eu sou competente, eu sou um estudante competente, estou na universidade, eu faço iniciação científica". Coisa que faz com que você se perceba como alguém que tem valor, que tem mérito. Antes eu achava que as cotas não permitiam isso, que as pessoas ingressavam antes pela condição social desfavorável, pela cor da pele, do que antes por que se sentiam bom para isso. Mas pra que as pessoas possam de fato se sentir boas nisso e se sentirem conhecidas, é importante que a gente tenha as cotas. Essa é a minha posição, eu sou favorável. (Professora Maria Letícia).

(...) eu sinceramente acho que precisa ter, mas tem que ser feito com muito cuidado porque senão você refaz preconceitos. Eu já ouvi os mais absurdos argumentos contra as cotas, desde vai cair a qualidade do ensino, até não, mas então todo mundo precisa porque todo mundo tem uma gota de sangue negro. Precisa definir bem que no Brasil não se trata de uma questão puramente biológica, se trata da percepção que as pessoas têm de você, e que varia, como diz um amigo meu, se você colocar a Rota, ou a polícia, PM, na condição de escolha, eles vão saber separar direitinho quem é branco de quem é negro, direitinho. Suspeito padrão, só perguntar para ele, quem é o suspeito padrão, pronto, esse merece cota. Agora, o meu medo é que... trajetórias como a minha, que nem devem ser tomadas como exemplo, não é nada disso, mas que elas sejam diminuídas ou que sejam, sei lá, as pessoas passem a ver como ah, você está lá porque tem cota. A gente já ouve isso sem ter cota, é porque [ ] só se for branco ou japonês, porque a gente ouve isso a vida inteira, e reforçar isso, legitimar isso eu acho complicado. Agora, eu estou falando isso do alto da minha posição de funcionária pública com o direito garantido para o resto da vida. Se você falar com minha sobrinha que tem 18 anos e talvez pudesse fazer bom uso de uma oportunidade como as cotas para ser alguém na vida, ela poderia te falar "eu sou absolutamente a favor, eu concordo". Então, é delicado o assunto, eu sou a favor, mas eu acho [ ], muito complicada. (...) Mas eu sou a favor. (Professora Adriana Alves).

Embora tenham tido trajetórias tão distintas e apesar do posicionamento crítico e informado, ambas as professoras tendem a concordar com uma face do debate sobre mérito e excelência amplamente difundido na USP. A principal diferença entre os posicionamentos é que, no primeiro grupo, a negação da meritocracia nem está em questão, alinhando-se a uma vertente dos debates acadêmicos e da militância a respeito da falácia e equívocos em torno do conceito. Já o segundo grupo está mais próximo do debate que considera o fato de que a meritocracia é um conceito do qual a universidade pública brasileira não irá abrir mão, mas que mesmo assim, a adoção cotas é possível, porque o sistema de cotas reinventaria a noção de mérito. Ou seja, tem mérito aquele/a que disputa em iguais condições dentro de cada sistema, o da ampla concorrência 
de um lado e do outro o de cotas para estudantes de escola pública, negros/as, pardos/as, indígenas e portadores/as de necessidades especiais.

Mas conforme indica o professor Dennis de Oliveira, esse debate não reverbera devidamente dentro da USP. Nesta universidade é possível ser pesquisador antirracista e ser signatário do manifesto contra as cotas, conforme visto anteriormente neste trabalho. As ações possíveis na USP atualmente são o INCLUSP e o PIMESP e de modo unânime todos/as os/as dez docentes negros/as entrevistados/as para essa pesquisa acham as propostas problemáticas e não as apoiam. De um modo geral, esses/as sete docentes aqui considerados apoiam os debates e pesquisas sobre a democratização da universidade pública brasileira. Porém a possibilidade de proposição e de pressão por mais e melhores políticas de inclusão e de promoção da população negra na USP também como docente é ainda limitada, pois com exceção dos professores Roberto da Silva e Dennis de Oliveira, o restante está na categoria Doutor.

No que diz respeito aos planos de ascensão na carreira, os/as entrevistados/as narraram que pretendem fazer o concurso de Livre Docência e assim, ascender à categoria de Associado; e além disso, mencionaram a possibilidade de fazer pós-doutorado. Os dois docente mais próximos da possibilidade de chegar à categoria Titular são os professores Roberto da Silva e Dennis de Oliveira, mas esta alternativa está ainda longe dos seus horizontes, não por falta de interesse, mas devido ao modo como funciona um concurso para Professor Titular na USP:

\footnotetext{
Em termos de carreira acadêmica é seguir pra frente. E seguir pra frente o próximo passo é prestar concurso para professor titular. Nesse sentido aqui o cenário não é muito favorável. Num universo em torno de cento e vinte de professores aqui [na FEUSP] tem poucos titulares, tem poucas vagas, a política de recursos humanos da reitoria é de não abrir novas vagas, o que tem a ver com a composição das relações de poder da universidade, porque só os titulares têm acesso aos cargos de direção. E depois tem... não é a disputa necessariamente, mas cada departamento tem as suas filas de prioridade. $\mathrm{O}$ tempo de serviço, o tempo de titulação, coisas assim. Então concurso de titular eu nem coloco isso no horizonte. Livre docência não, não há problema, porque a gente pode prestar o concurso de livre docência, independente de aprovação, então quer dizer, só a deliberação do professor. Mas chegar ao último degrau da carreira requer um consenso interno muito grande. $\mathrm{E}$ eu talvez não... nove anos de casa, não esteja nem em condições de pleitear esse cargo. Em termos de pesquisas a prioridade é essa aí que eu falei social, da pedagogia social, que esse é um campo em estruturação no Brasil. Eu assumi responsabilidades em relação a isso então é um desafio pela frente. Mas eu não preciso fazer isso a partir da USP, posso fazer isso a partir de qualquer outra instância. (Professor Roberto da Silva)
}

Além de tentarem se adequar, ainda que com críticas, às políticas de produtividade acadêmica, sobretudo visando as publicações Qualis A e maior circulação internacional, é interessante ressaltar aqui, que mesmo sendo docente da USP, e com planos para a carreira, os/as professores/as negros/as entrevistados/as para essa pesquisa revelaram certo desconforto diante do fato de terem que fazer o pós-doutorado fora do Brasil: 
Então isso é uma coisa e aí assim o que acontece, como homem negro, como mulher negra, então, o que acontece, por conta disso, muitas vezes, você, já coloca pra você uma limitação, tá bom até aqui, não dá pra ir mais além, vou até aqui acabou, beleza, é onde eu posso chegar e tal. Eu, por exemplo, assim, tenho uma coisa muito concreta, eu estou numa, situação, por causa do pós-doutorado. O pós-doutorado é super complicado, que exige você tenha uma estrutura de sustentação muito complicada. Lógico, a USP favorece essa questão do afastamento, cobre tudo isso, com investimento, tudo isso, mas implica em uma bolsa, implica numa situação em que você consiga manter a sua família aqui, estando lá fora, implica em você ter um bom domínio do idioma, que poucos de nós tivemos condições de fazer um curso legal fora, implica em você ter um desprendimento de estar lá fora, que é uma coisa complicada. Você vai para um lugar estranho, você vai ficar intimidado com isso, então você tem que enfrentar... tem pessoas que já têm uma, já tem uma experiência maior de viagem exterior, já está mais familiarizado com isso. Então tudo isso vai te colocando situações que você vai ficando meio amedrontado, com medo, será que eu vou ou não, aí você se recua e fica naquele lugar que você está e tá bom aquilo. A expectativa é muito motivada por isso, a expectativa... e outra coisa assim, quando você vai, por exemplo, para o seu lugar de origem, pra sua família, para as pessoas que você convive, você já é top, já tá lá. Pensam, pô tá legal, pô o cara tá lá na universidade, pô legal, tá bom, beleza. A minha mãe, por exemplo, no meu mestrado ela fez festa, quando falei vou fazer pós, ela, "pra quê, bobagem, já tá bom, você já é doutor”. (...) Então ali você já está bom, já, pra lá, pelo universo de ascensão que você tem, quando que pra cá você tem essas outras barreiras, você fica numa situação muito complicada (risos), que é meio, você e você mesmo, você e você mesmo. Vai, tá beleza, mas vai ter que pagar um preço, tem um custo e tal e aí você não vai ter interlocução, não vai ter suporte até mesmo emocional pra segurar isso, então você vai ter que enfrentar mesmo sozinho. (...) vou fazer a livre docência, vou fazer. Só não fiz ainda, porque eu estou... estou esperando... é... eu estou pouco tempo na pós, eu estou no Direitos Humanos e aí estou esperando meu primeiro orientando defender, até pra melhorar o currículo, porque isso conta bastante pra livre docência, então... a livre docência. O pós doc... eu tenho a possibilidade assim que é mais fácil, que é ir pra Portugal, pra Universidade do Minho, que é a... tem convênio com a daqui e uma outra mais difícil, mas que eu acho que é mais me seduz, pra mim é mais interessante, que é ir pra Inglaterra, por conta daquela discussão do multiculturalismo do Stuart Hall (...) É... mas aquela coisa, é mais pro futuro, minha filha está formando agora, pra poder fazer isso. (Professor Dennis de Oliveira)

Cabe aqui uma pequena observação: essa pesquisa foi realizada em 2011, e dentre os tópicos listados pelo professor Dennis de Oliveira no seu processo de ascensão na carreira docente, um já se efetivou, que foi a obtenção do título de Livre Docente em 2014, lhe assegurando progredir de Professor Doutor, para Professor Associado. O projeto de ascensão na carreira empreendido pelo professor esbarra em alguns obstáculos, tal qual relatado acima. Sendo assim, surge a questão: qual é a dimensão de fato, da ascensão social dos/as sujeitos dessa pesquisa? A efetividade da ascensão social desses/as docentes negros/as? Hasenbalg e Silva (2003), analisando o modelo de realização socioeconômica da população negra brasileira, indicam como se dá a transmissão das desigualdades sociais entre gerações ao longo dos ciclos de vida individual e familiares. Nas famílias negras observa-se um efeito cumulativo de desvantagens ao longo de cada etapa do ciclo da vida, desde a origem familiar até a realização de status na vida adulta conforme a inserção dos indivíduos na estrutura sócio ocupacional, com impacto intergeracional. Para o professor Dennis de Oliveira a família aparece como um elemento sempre presente na carreira 
acadêmica, que aponta para a instabilidade de sua ascensão social. Se de um lado, recebe todo apoio e carinho familiar, onde ele já alcançou o topo da carreira acadêmica; por outro lado, sua família aparece também como responsabilidade da qual ele não pode se esquivar, de modo que sempre será necessário conciliar carreira e sustento familiar. Interessante observar que nas trajetórias de professores/as negros/as de universidade pública analisadas por Teixeira (2003) um docente do curso de Arquitetura demonstrou uma visão marcadamente pessimista sobre a inserção da população negra num 'mercado globalizado', “como se esse processo acabasse por acentuar as desigualdades inerentes às classes sociais de origem" (Teixeira, 2003, p.224).

Além disso, o professor Dennis de Oliveira chama a atenção para algo que merece atenção e pesquisa: como tem acontecido a circulação internacional de acadêmicos/as negros/as? Xavier de Brito (2004), analisando os sentidos da internacionalização nas trajetórias de estudantes brasileiros no exterior, constrói dois modelos de trajetórias que dão lugar a diferentes tipos de hábitus: o itinerário de herdeiro, que pode ou não ser internacional e o itinerário escolar ao qual pode ou não associar-se um hábito de migrante. No caso do hábitus de herdeiro, a autora indica a proximidade entre a condição de herdeiros locais como aqueles que são também os brasileiros com maior possibilidade de circulação internacional. De um modo geral, são aqueles cujos pais pertencem a classes sociais de bom nível de renda e de escolaridade; para quem o apoio familiar se estende até o nível universitário; vivenciam a socialização precoce na profissão; e se beneficiam de uma sponsored mobility. (Xavier de Brito, 2004, p. 90-92). Caso o hábitus de herdeiro esteja associado ao habitus internacional, há ainda a possibilidade desse acadêmico em circulação descender de famílias mistas, em que um dos pais não seja brasileiro; possuir capital social internacional e possuir familiaridade com a cultura acadêmica internacional. (Xavier de Brito, 2004, p. 92-94).

No segundo modelo a autora analisa os casos de circulação acadêmica internacional em que os estudantes viveram o processo de ascensão social via escola, cunhando assim, os conceitos de habitus escolar local e habitus de migrante. Apesar de oriundos de camadas sociais modestas, esse segmento acadêmico aprendeu a aspirar a tornar-se professor universitário e a encontrar brechas de inserção no circuito acadêmico que é bastante elitista e fechado. No conjunto de indivíduos pesquisados pela autora e que se enquadravam nesse modelo, os níveis de renda e escolaridade familiar eram mais altos que a média nacional, ainda que bem menores do que aqueles estudantes do primeiro modelo; o capital cultural familiar teria sido substituído pela escola, ou seja, as famílias se mostraram prontas para sacrifícios de diversas ordens para garantir a educação dos filhos; as estratégias adotadas pelas famílias observavam critérios de gênero com significativa vantagem no investimento da escolarização dos filhos homens; além disso, o grau de dependência familiar é menor do que o verificado dentre os herdeiros do primeiro modelo, de modo que muitos 
universitários chegavam à pós-graduação a partir de seus próprios esforços; as influências universitárias vieram de círculos externos à família e a partida para o exterior delineou-se progressivamente, foi emergindo como possibilidade na carreira ao longo do percurso. O hábitus de migrante quando emerge, está bastante associado ao fato de o estudante descender de migrante, mas ter uma história familiar com novas raízes brasileiras, de modo que necessitam recriar uma familiaridade imaginária com o exterior.

Em função do pequeno universo de pesquisas sobre a circulação internacional e formação intelectual das elites acadêmicas brasileiras, o estudo de Xavier de Brito (2004) oferece algumas possibilidades para a comparação com o conjunto de docentes negros/as considerados nessa pesquisa. Além da experiência do professor Dennis de Oliveira transcrita acima, é interessante trazer os relatos das professoras Vanderli Custódio e Adriana Alves para ajudar a compreender como a experiência desses docentes difere daquelas analisadas por Xavier de Brito (2004):

\begin{abstract}
E também tem uma coisa que ser negro, é ser negro em qualquer lugar do mundo. Eu estive na Alemanha em 2002, tenho uma amiga que mora lá e foi uma coisa, 2004 outra coisa, estive no ano passado... não posso falar da Europa, porque eu só estive na Alemanha dessa vez, passei por Amsterdam também, que é cosmopolita, gente do mundo inteiro, mas, na Alemanha, principalmente o norte da Alemanha, eu senti uma diferença muito grande de 2004 pra 2009, quando estive lá, a xenofobia está no ar, estava uma coisa muito tensa. Em 2004 eu passava despercebida, em 2009 não. (...) "Ah não, Paris é tão linda, Paris não sei o que...". Pra branquinho de olho azul é fácil, você se vira bem, não vão nem notar, você some no contexto. Não é o nosso caso. "Ah, você está sendo pouco corajosa, está sendo um pouco não sei o quê". Mas é uma energia que você gasta diariamente, uma coisa que você gasta diariamente e aqui digamos que a gente sabe como lidar, ou como... (...) Então eu vou sair daqui pra ficar passando este tipo de apuro lá, com quase 50 anos? Eu não estou a fim disso não. Então, eu posso fazer um pós-doc aqui também, tenho possibilidade de fazer um pós-doc na FAU, só não comecei ainda a fazer pós-doc porque eu estou com muitos orientandos, eu preciso de dar um jeito de, como o pessoal diz grosseiramente de desovar, desovar essa molecada toda, dá uma descansada, para poder... (...) Digamos assim que eu estou confortável até demais na minha situação de professora doutora, é um conforto que eu estou começando a me cobrar, porque eu preciso me mexer já, né? Fiz doutorado em 2002, entrei aqui em 2003, faz 8 anos e está na hora de eu me mexer, preciso dar uma movimentada na minha carreira aí, fazer um pós-doc dentro de um ano, vou ver se eu volto a fazer Francês, porque o meu Francês está enferrujado. (Professora Vanderli Custódio).
\end{abstract}

Quando questionada sobre o estágio do doutorado sanduíche no Canadá, a professora Adriana Alves assim definiu a experiência:

Traumática. (risos). Não, mentira, eu faria de novo. Foi difícil porque eu sou muito ligada à minha irmã e ficava [ ] muito difícil, mas... eu não sei se todo mundo é assim, mas teve uma hora que eu me senti à vontade no lugar, e quando eu me sinto eu não quero mais sair, que é o caso da Geo[logia]. Então eu me sentia à vontade aqui, por mais que eu tenha citado alguns exemplos de episódios não tão felizes, a maior parte da minha vida, dos períodos de felicidade de vida adulta foram aqui. E aí quando eu me vi tendo que me [inaudível] do zero lá fora, tanto intelectualmente, quanto fisicamente, quanto tudo o que você imaginar, eu meio que me perdi, porque eram coisas que eu julgava terem ficado para trás, não ter mais que provar para os outros que eu era inteligente, apesar de ser negra, que eu era capaz, apesar de ser negra, então voltou tudo, foi muito difícil. Mas a boa notícia é 
que eu consegui, sobrevivi, e eu acho que para o meu crescimento pessoal foi essencial.

Algo já bem difundido na vida acadêmica e destacado por Xavier de Brito (2004) é o fato de que a experiência internacional é imprescindível na carreira acadêmica como estratégia de valorização do currículo, tanto em nível individual, quanto institucional, além de ser amplamente fomentada pela CAPES e CNPQ. Importante destacar o que aproxima, mas sobretudo o que afasta os conjuntos de acadêmicos/as pesquisados/as pela autora com o conjunto de docentes aqui considerado: em primeiro lugar, se há semelhança entre os sujeitos, seria com aqueles/as pertencentes ao segundo modelo analisado pela autora, cuja ascensão social aconteceu via escola. Essa também é uma regra para o conjunto de docentes aqui considerados, mas as semelhanças não são muitas. Além dos docentes aqui considerados pertencerem a um segmento social mais modesto, a pesquisa de Xavier de Brito indica que de um modo geral, a circulação internacional acadêmica é uma conquista mesmo para os classificados no segundo modelo, havendo a apropriação irrestrita da possibilidade de transitar internacionalmente. E isso não parece acontecer de modo definitivo com os docentes negros/as aqui considerados. Seja devido ao fato de que precisam conciliar a viagem e o suporte à família, seja em função da proficiência em outro idioma que ainda gera timidez, seja em função do racismo que acaba impondo limites de modo que toda viagem internacional ainda permanece um desafio, mesmo sendo docente da USP.

$* * * * * * * * * * * * * * * * * * *$

Considerando o conjunto de entrevistas analisadas, no que diz respeito à experiência de ser docente e negro/a na USP, as narrativas aqui apresentadas explicitam diferentes aspectos conforme a trajetória de cada docente. A professora Vanderli Custódio, docente da Geografia, foi quem mais destacou o cotidiano da atividade docente, marcando a distinção entre o prestígio de estar numa universidade de tamanha tradição e as exigências de um cotidiano acadêmico muitas vezes extenuante e nada prestigioso. Além disso, revela com grande sensibilidade algumas faces do sofrimento docente agudizados pela pertença racial negra. A narrativa do professor Dennis Oliveira, docente do curso de Jornalismo na ECA, foi a mais marcante ao trazer a relação da USP com seu entorno, com a comunidade extramuros, sobretudo a São Remo, favela que faz fronteira com o Portão III da USP. Tal perspectiva é em grande parte decorrente de sua experiência de militância em partidos de esquerda, como o PC do B, ou movimentos negros como a UNEGRO, entidade que ajudou a fundar. A narrativa da professora Adriana Alves, do curso de Geologia, traz a discussão sobre ser a nova geração de docentes da USP, a imagem da renovação do corpo docente da Universidade. Além disso, traz ainda detalhes sobre ser mulher negra num curso de exatas, 
predominantemente branco e masculino. O professor Emerson Inácio, da Literatura, trouxe a experiência de transitar por algumas fronteiras como ser negro, homossexual e pobre, e o modo como essas experiências definem sua produção acadêmica. Além disso, o professor Emerson, pelo fato de não ter feito a formação na USP, traz a discussão de uma universidade atenta aos profissionais formados em outras instituições, revelando uma USP menos endógena, além do desafio de propor, num departamento tradicional, o debate sobre literaturas insólitas, que são negras, africanas, periféricas e gay, confrontando alguns cânones estabelecidos. A professora Letícia Nascimento, da Faculdade de Educação, traz discussões relevantes sobre a importância de ser negra, e do "para além de ser negra", de modo que ser negra não é a única questão que estrutura sua visão de mundo e suas possibilidades de escolhas e interesses acadêmicos. A professora considera pertinente a preocupação com a temática racial para a pesquisa, mas se sente livre para pesquisar outros temas. A trajetória do professor Roberto da Silva, também da Faculdade de Educação, é bastante conhecida em alguns veículos midiáticos, por ser marcadamente uma trajetória de exceções. O professor Roberto da Silva passou por instituições de abrigo a menores, mais precisamente compôs a primeira geração de crianças reclusas da FEBEM, chegou a ser morador de rua e passou por sistemas prisionais, e assim, ao chegar à docência da maior universidade, configura um ponto fora da curva. Além disso, assume na sua carreira acadêmica a trajetória de marginalização e exclusão como estratégia de afirmação acadêmica e de contribuição para o debate sobre democratização da USP. Por fim, a professora Roselane Gonçalves da EACH, do curso de Obstetrícia, traz na narrativa sobre sua carreira como docente da USP a destacada preocupação de luta pela institucionalização do curso de Obstetrícia, uma profissão nova a ser reconhecida ainda, e de fortalecimento da $\mathrm{EACH}$, uma unidade da USP recém-criada e açoitada por crises e polêmicas de várias ordens, muito em função do fato de ameaçar uma concepção de USP elitista. 


\section{Considerações Finais}

A USP foi criada com apoio dos Mesquita, o pessoal do Estadão com o apoio dos Mesquita e aí você tinha a produção cafeeira no estado de São Paulo, a riqueza produzida por café, o início da atividade industrial, como derivado das riquezas do café aí você tem uma elite paulista, que quer mostrar para o Brasil a pujança do estado de São Paulo, a riqueza do estado de São Paulo. (...) A referencia era a França, era Paris, a Europa, um pouco os Estados Unidos, mas a França tinha lá o seu glamour. Então uma universidade para a elite paulistana. (...) e você tem essa elite que quer se legitimar do ponto de vista cultural. Então ela cria uma universidade trazendo pra cá a missão francesa. (...) Então você vem com professores franceses, pra mostrarem a pujança do conhecimento europeu, então ela nasce elitista, ela nasce com um viés europeu muito forte e quem é que vem participar dessa universidade, quem são os alunos? Os filhos da elite paulistana. Então ela nasce com um ranço já. Então começa com uma produção muito, muito intensa, já desde o início (...) Então a USP atrai, foi um imã nacional, você forma esse pessoal todo que volta, muitos voltam para os seus estados, para as suas cidades e lá vão acabar gerando outros núcleos de pesquisa. Então a USP foi ao longo do tempo adquirindo essa projeção nacional e projeção internacional. (Professora Vanderli Custódio)

Politicamente a USP sempre mexeu os seus pauzinhos pra ter um destaque. Acho que a USP sempre foi conivente, de alguma maneira, com o governo ou os intelectuais da USP se opuseram ao Governo, mas sempre de uma maneira a destacar a influência da USP na comunidade não acadêmica... mas política também. A escola de Direito da USP é secular, já formou os maiores juristas do Brasil e coisas nesse sentido. Eu diria sim, cada unidade têm pessoas que tiveram certo destaque né, na produção de conhecimento e no envolvimento político, acho que tem isso que torna a USP interessante, acho que USP tem... estou juntando essa coisa dos rankings (...) Eu não gosto muito de rankings, mas a USP costuma aparecer nos rankings internacionais né. Fora do Brasil também se você diz que é da USP, todo mundo diz: "Oh! Você é da USP". Ou então, "Há, USP, eu já ouvi falar". Ela tem talvez uma política de divulgação, por meio dos egressos, por meio da pesquisa, uma internacionalização talvez mais destacada. (Professora Maria Letícia)

Pra você ter uma idéia, a USP hoje tem o terceiro orçamento de São Paulo, os orçamentos de São Paulo é o seguinte, no estado de São Paulo, o segundo orçamento é a capital de São Paulo, o terceiro é Guarulhos, o quarto é a USP, ela perde pra capital e pra Guarulhos só. Então o orçamento da universidade de São Paulo é maior que o de Santos, de Campinas, do as cidades do interior de São Paulo, todas. Parece que ela é o décimo quinto do Brasil, supera capitais do Brasil. É muita grana que rola aqui. (Professor Dennis de Oliveira)

A Universidade de São Paulo chega à sua oitava década de fundação com uma sólida narrativa que a define como a mais relevante universidade brasileira, cumprindo assim, seu propósito de ser uma universidade bandeirante que amplia as fronteiras da produção científica nacional. Some-se ainda sua importância enquanto celeiro de quadros políticos para o estado de São Paulo e para o Brasil. Uma tarefa de tamanha envergadura teve início na primeira metade do século XIX com a criação da Faculdade de Direito, recrutando em um primeiro momento setores das elites política, econômica e intelectual do estado de São Paulo; configurando a primeira e fundamental safra de mentores e clientelas da instituição. No entanto, para assegurar a longevidade do projeto de universidade, reformulações foram necessárias e as portas da instituição tiveram que se abrir a novos setores da população paulista. Decorrência direta da política de comissionamento adotada pela Universidade na primeira década de existência, o ingresso de imigrantes e mulheres, ainda que 
como resultado não planejado, sobretudo na Faculdade de Filosofia, Ciências e Letras antes da primeira década de vida da nova Universidade de São Paulo foi fundamental para a revisão do projeto inicial de universidade, tornando a USP viável.

Desde os primórdios a população negra esteve alijada do processo, embora a universidade tenha se ocupado do "problema do negro" em diversos momentos de sua história, sob diversas perspectivas e diferentes unidades. Seja na Faculdade de Direito e Medicina, endossando teorias eugenistas correntes no século XIX e na primeira metade do século XX; seja através da Escola Paulista de Sociologia, no âmbito da Faculdade de Filosofia apesar da importante virada de perspectiva sobre as relações raciais brasileira; até que finalmente intelectuais negros ao ingressarem na docência, sobretudo a partir da década de 1980 trazem um conjunto de críticas e propõe novos olhares sobre as relações raciais no país; além de atuarem academicamente no sentido de ampliar o acesso da população negra na USP e no ensino superior brasileiro.

Vale destacar que apesar de ínfima, verifica-se registros da presença de negros/as no corpo docente da universidade ao longo de sua história. Mas a entrada na USP de docentes negros/as ao longo de toda a história da instituição não foi decorrência direta de nenhuma política pública específica no ensino superior, externa ou interna à Universidade. No caso de docentes negros/as, a entrada aconteceu de forma aleatória e completamente em sintonia com a história de exclusão e/ou invisibilidade dos/as negro/as no ensino superior brasileiro e paulista especificamente. Neste sentido, o estado de São Paulo possui elementos que merecem ser destacados: em São Paulo construíram-se importantes e tradicionais formas de mobilização das populações negras, configurando uma importante imprensa negra e um importante corpo de intelectuais negros/as militantes e/ou que haviam cursado ensino superior. A pesquisa de Florestan Fernandes (1964), por exemplo, foi possível em grande parte graça aos diálogos estabelecidos com esses intelectuais, que apesar de orbitarem ao redor da Universidade de São Paulo, permaneceram na condição de sujeitos de pesquisa, sem atravessar a fronteira acadêmico-institucional que conduz à discência ou à docência, no caso dos que chegaram a fazer formação superior.

Uma questão para a qual esse trabalho se debruçou foi como aferir quando e como a presença negra é possível no corpo docente da USP. Apesar de rara e aleatória, existe registro da presença de docentes negros/as nesta história, mais especificamente na Faculdade de Direito, desde antes da abolição da escravidão. No entanto, verifica-se também um grave processo de silenciamento de fontes. A controversa relação histórica do país com os itens de raça e/ou cor nos censos demográficos, tem também sua face conservadora dentro do sistema universitário brasileiro, como bem ilustrado pela recente polêmica sobre o quesito cor para a atualização do currículo Lattes. No primeiro semestre de 2013 foi introduzida na plataforma Lattes o quesito sobre raça/cor que todo/a pesquisador/a deveria preencher. Segundo a SEPPIR a medida foi adotada para que 
órgãos públicos possam monitorar e avaliar acões que promovam a igualdade racial, previstas desde a lei 12.288, que instituiu o Estatuto da Igualdade Racial. Em entrevista para a reportagem 100 de Sofia Moutinho e publicada pelo Jornal Ciência Hoje, o pesquisador Marcelo Paixão indica que:

"A variável cor/raça não é novidade, faz parte dos sistemas de produção de dados
estatísticos do país desde a década passada e constitui um importante mecanismo para
mensurar as desigualdades sociais em nosso país" (...) O mesmo ocorre no meio acadêmico
brasileiro, que veio se notabilizando pela sua escassa presença de pessoas de peles escuras."

E a medida mobilizou um conjunto de debates de pesquisadores/as contrários/as à adição da questão, como o geneticista Sérgio Danilo Pena que chegou a enviar um e-mail para o CNPQ, órgão que gerencia o Lattes, e na referida reportagem disse que o teor do e-mail era o seguinte:

\begin{abstract}
"Disse a eles que a história está crivada de lamentáveis episódios em que a ciência se curvou perante demandas irracionais da política, com consequências invariavelmente dramáticas", conta. "Ao contrário de colaborar imediatamente com essa imposição racialista e anticientífica, o $\mathrm{CNPq}$ deveria ter se recusado a obedecer a essa circular (que não está lastreada na Lei) e protestado fortemente através de sua Procuradoria Jurídica. Afinal, o CNPq deveria ser o primeiro a proteger a ciência, em vez de se curvar perante os burocratas do governo."
\end{abstract}

Outro importante pesquisador no campo das relações raciais contrários à medida está o antropólogo Roberto DaMatta, que "acredita que o preenchimento do novo campo acaba reforçando a discriminação racial”. Em outra reportagem101 para o mesmo jornal, duas professoras da USP, Lilia Schwarcz do Departamento de Antropologia e Maria Helena P. T. Machado do Departamento História defenderam a iniciativa, destacando as possibilidades de pesquisas que esses dados poderiam gerar: "Não se atropelam iniciativas que visam a melhor conscientização, estudo e compreensão de nossa sociedade antes que possam minimamente mostrar suas potencialidades".

Diante de uma comunidade acadêmica dividida quando interpelada sobre a sua raça/cor, o conhecimento sobre o perfil racial da universidade brasileira permanece sendo um desafio. E na USP mais especificamente, a pesquisa sobre presença de docentes negros/as ao longo de toda a história da USP dificilmente poderia ser conclusiva, e o que temos são algumas portas de arquivos

100Qual a sua raça/cor? Obrigatoriedade de responder a essa pergunta na Plataforma Lattes provoca indignação em parte da comunidade científica e renova a discussão sobre a ideia de raça e políticas afirmativas. Reportagem escrita por Sofia Moutinho para o Jornal Ciência Hoje do Portal UOL, publicado em 13/05/2013 e atualizado em 19/05/2013. Disponível em http://cienciahoje.uol.com.br/noticias/2013/05/qual-a-sua-raca-cor. Acesso em 18/05/2015.

101Raça/cor no Lattes: fomentando o debate. Pesquisadoras da USP defendem iniciativa do CNPq de incluir tal critério na definição do perfil do acadêmico brasileiro. Para elas, os dados colhidos podem contribuir para a conscientização, o estudo e a melhor compreensão de nossa sociedade. Publicado pelo Jornal Ciência Hoje do Portal UOL. Disponível em: http://cienciahoje.uol.com.br/blogues/bussola/2013/06/raca-cor-no-lattes-fomentando-o-debate/ Acesso em 18/05/2015. 
ou janelas bibliográficas abertas em um ou outro momento da história de algum instituto da Universidade, revelando algo sobre a passagem de algum/a docente negro/a. Um dos esforços desta pesquisa foi investigar qual é a configuração racial do quadro atual de docentes da USP, através dos dados do Recadastrameto Anual que todo servidor do estado de São Paulo deve efetuar existentes desde 2008. Diante da polêmica gerada pela implementação do quesito raça/cor na plataforma CNPQ, fica a questão: o conjunto de pesquisadores/as tenderiam a aceitar responder à pergunta na condição de servidor público e ofereceria resistências quando deve responder na condição de pesquisador/a?

Os dados referentes à configuração racial do corpo docente da USP revelaram um crônico monocratismo branco da instituição, que precisa ser interpelado. E conforme narrativa dos/as dez docentes entrevistados para esta pesquisa, a vida acadêmica é uma seara de grandes desafios e a USP em função de suas dimensões, parece potencializar as dificuldades inerentes à carreira acadêmica. O conjunto de docentes analisado aqui demonstrou ter consciência da narrativa oficial de concepção de universidade que a USP endossa, dos mitos de fundação que apontam para a origem elitista da universidade; bem como relembraram a história de fundação da USP ligada ao grupo Comunhão Paulista Ilustrada, o poder econômico da elite cafeeira do início do século, a importância da missão estrangeira, o compromisso de formar os quadros políticos do estado de São Paulo, a produtividade e a relevância internacional da instituição. A emergência desses elementos presentes nas narrativas docentes indica que essa concepção de universidade foi absorvida em maior ou menor medida por toda a comunidade uspiana, como um código compartilhado, ainda que apresentem críticas ao caráter elitista do projeto de universidade encampado pela USP.

Nesse sentido, os/as docentes negros/as aqui considerados também apontam como os discursos históricos oficialmente encampados pela instituição têm sido estrategicamente importantes para atrasar o processo de democratização da USP e ampliação do acesso da população negra a esse espaço. Ainda que os mentores e clientelas da USP historicamente tenham se diversificado em algum grau, o conjunto de docentes aqui considerado é ciente do fato de que são histórias de exceção que confirmam a regra de exclusão e marginalização de determinados segmentos dentro da universidade. Apesar disso, esse conjunto de docentes negros/as buscam construir espaço dentro da universidade a realização acadêmica. Mesmo que o discurso sobre excelência seja a tônica na universidade, as narrativas docentes aqui apresentadas possibilitam uma leitura que explicite as complexidades da vida acadêmica para além da USP oficial, com os dilemas da sub-representação da população negra na instituição e assim revelando uma outra face possível e necessária da universidade. 


\section{Referências Bibliográficas}

AZEVEDO, Thales de. As Elites de Cor numa cidade brasileira: um estudo sobre a ascensão sociale classes sociais e grupo de prestígio. Salvador, EDUFBA, 2a ed., 1996.

ALMEIDA, Sérgio Tenório de. Novas oportunidades de acesso ao ensino superior? Trajetórias escolares de alunos negros que se formaram na Faculdade de Medicina da Universidade de São Paulo (1935-1964). Dissertação, (Mestrado) Faculdade de Educação, Pontifícia Universidade Católica de São Paulo, São Paulo, 2009.

ANTUNHA, Heládio C. G. Universidade de São Paulo. "Fundação e Reforma". Estudos e Documentos. São Paulo: CRPE, (10), 1974, p. 7-264.

ARROYO, Miguel. (2009). Narrativas do sistema escolar desde a condição de negro. In: PRAXEDES, Vanda; TEIXEIRA, Inês Assunção de Castro; SOUZA, Anderson Xavier de; GONZAGA, Yone Maria (orgs). Memórias e percursos de professores negros e negras na UFMG. Belo Horizonte: Autêntica Editora, 2009. Coleção Cultura Negra e Identidades.

ARRUDA, Maria Arminda do Nascimento. A Sociologia Acadêmica no Brasil: Florestan Fernandes e a Escola Paulista. In: Sérgio Miceli. (Org.). História das Ciências Sociais no Brasil. 1a ed. São Paulo: Vértice, v. 2, 1995, p. 107-232.

A Trajetória da Pesquisa na Sociologia na USP.

Estudos Avançados, São Paulo, v. 8, n. 22, p. 315-324, 1994.

AZEREDO, Sandra. Teorizando sobre gênero e relações raciais. Rio de Janeiro, Revista Estudos Feministas. Número Especial. 1994, p. 203-216.

AZEVEDO, Célia Maria Marinho de. O abolicionismo transatlântico e a memória do paraíso racial brasileiro. Estudos Afro-Asiáticos, n. 30, dez., 1996.

BAHRI, Deepika. Feminismo e/no pós-colonialismo. Estudos Feministas, n. 21, p. 659-688, 2013.

BARBOSA, Irene Maria Ferreira. Enfrentando preconceitos: um estudo da escola como estratégia 
de superação de desigualdades. Campinas: Centro de Memória da UNICAMP, 1997.

BARCELOS, Luiz Cláudio \& CUNHA, Olívia Maria Gomes da \& ARAÚJO, Tereza. Escravidão e relações raciais no Brasil: cadastro da produção intelectual (1970-1990). Rio de Janeiro: Centro de Estudos Afro-asiáticos, 1991.

BASTIDE, Roger \& FERNANDES, Florestan. Brancos e Negros em São Paulo. São Paulo, Editora Nacional, 1959.

BEISIEGEL, Celso Rui. Educação e sociedade no Brasil após 1930. In: FAUSTO, Boris (Org.). História Geral da Civilização Brasileira. O Brasil Republicano. Economia e Cultura (1930-1964), 1984, p.381-416,

BENTO, M. A. S. (Org.) ; CARONE, I. (Org.). Psicologia Social do Racismo. $2^{\text {a }}$ Ed. São Paulo: Vozes, 2002.

BESSE, Susan. Modernizando a desigualdade: reestruturação da ideologia de gênero no Brasil (1914-1940). São Paulo, Edusp, 1999.

BLAY, Eva Alterman; LANG, Alice B. Mulheres na USP: horizontes que se abrem. São Paulo, EDUSP. 2004.

A mulher nos primeiros tempos da Universidade de São

Paulo, Ciência e Cultura/SBPC, v.36, n.12, 1984.

BLAY, Eva Alterman; CONCEIÇÃO, Rosana. A mulher como tema nas disciplinas da USP, Cadernos de Pesquisa, n.76, Fundação Carlos Chagas, 1991.

BORGES PEREIRA, João Baptista. Estudos Antropológicos das Populações Negras na Universidade de São Paulo. In: Revista de Antropologia, São Paulo, vol. 24, p.63-74, 1981.

BORGES PEREIRA, João Batista. Emilio Willens e Egon Shaden na história da Antropologia. Revista Estudos Avançados , n. 22, 1994.

BORGES PEREIRA, João Baptista. Entrevista com João Batista Feita por Stélio Marras, 2003. 
BOSI, Alfredo. Dialética da colonização. São Paulo: Companhia das Letras, 1992.

BRAH, Avtar. Cartographies of Diaspora. Contesting Identities. London, Routledge, 1996.

BROOKOVER, Wilbur B. Áreas da Sociologia da Educação In: Educação e sociedade: leituras de sociologia da educação. PEREIRA, Luis \& FORACCHI, M. (orgs). São Paulo, Ed. Nacional, 1977.

BUTLER, Judite. Problemas de Gênero: Feminismo e a subversão da identidade. Nova York, ed. Routledge, 1990.

BIONDI, Antonio. USP Zona Leste, Enfim a expansão? Revista ADUSP, Novembro, 2003.

BOURDIEU. Pierre. Homo academicus. (Trad. Ione Ribeiro Valle; Nilton Valle, Rev. Téc. Maria Tereza de Queiroz Piacentini. Florianópolis: Editora da UFSC, 2011.

BOURDIEU, Pierre. O Poder Simbólico. Rio de Janeiro: Bertrand Brasil, 1989.

BOURDIEU, Pierre. Contrafogos: táticas para enfrentar a invasão neoliberal. Rio de Janeiro: Zahar, 1998.

CALDERANO, Maria Letícia Cotta. Concepções e práticas do exercício do poder: a experiência vivida pela UNEGRO. Campinas, Unicamp, mimeo, 2002.

CAMPOS, Ernesto de Souza. História da Universidade de São Paulo. São Paulo: Edusp, Universidade de São Paulo, 2004.

CAMPOS, Maria José. “Cassiano Ricardo e o mito da Democracia racial”, REVISTA USP. São Paulo, n 68, p. 140-155. Dezembro/fevereiro 2005-2006

CARDOSO, Irene. A Universidade da Comunhão Paulista. São Paulo: Cortez.1982.

CARDOSO, Suzana Alice M. Milton Santos, meu professor. In: SOUZA, Maria Adélia A. de. O mundo do cidadão, um cidadão do mundo. São Paulo: Hucitec, 1996. p. 82-84

CARVALHO, José Jorge. O confinamento racial do mundo acadêmico brasileiro. REVISTA USP, São Paulo, n.68, p. 88-103, dezembro/fevereiro 2005-2006 
CARVALHO, José Jorge. Ações afirmativas para negros na pós-graduação, nas bolsas de pesquisas e nos concursos para professores universitários como resposta ao racismo acadêmico. In: GONÇALVES E SILVA, Petronilha B.; SILVÉRIO, Valter (orgs.) Ações Afirmativas: Entre a injustiça simbólica e a injustiça econômica. Brasília: Editora INEP, 2003, p.161-192.

CAUVILLA, Waldir. A ideia de Universidade e as Universidades Brasileiras surgidas nas décadas de 30 e 40 - e outros estudos. São Paulo: Mandruvá, 1999.

CERDEIRA, Cleide, M.B. O ensino Superior e a mulher: aspectos da presença feminina na Universidade de São Paulo. São Paulo. Tese (Doutorado), Universidade de São Paulo, São Paulo, 2001.

CHAUÍ, Marilena. USP 94: A terceira fundação. Revista Estudos Avançados, v. 8, n. 22, pp. 49-68, 1994.

CIRQUEIRA, Diogo Marçal. Entre o corpo e a teoria [manuscrito]: a questão étnico-racial na obra e trajetória socioespacial de Milton Santos, 159 folhas, 2010.

COELHO, Wilma. N. B. Docência e relações Étnico-raciais no Ensino Superior. Revista Olhar (UFSCar), São Carlos, v. 4, n. 7, p. 89-94, 2003.

CONNEL, R. W. Políticas da Masculinidade. Revista Educação e Realidade, Porto Alegre, v. 20, n. 2, Julho-Dezembro, 1995, pp. 185-206.

CONCEIÇÃO, Fernando Costa da. Milton Santos: ser intelectual e negro. In: SILVA, M. A. da; TOLEDO Jr., R. Encontro com o pensamento de Milton Santos: o homem e sua obra. Salvador: EDUFBA, p. 63-69, 2009.

CONCEIÇÃO, Fernando Costa da. Um café com Milton Santos. In: Jornal Folha de São Paulo. São Paulo, 08 de Jul., Cadernos Mais!, p. 10, 2001.

CORREA, Mariza: O mato \& o asfalto: campos da Antropologia no Brasil. Revista Sociologia \& Antropologia, V.I, pp. 209-229, 2011. 
CORREA, Mariza cadernos. Do feminismo aos estudos de gênero no Brasil: um exemplo pessoal. Pagu (n. 16) 2001, pp.13-30.

CORNELIA, Eckert. \& GODOI, Emilia Pietrafesa de. (Org.) Homenagens: Associação Brasileira de Antropologia: 50 anos. Blumenau: Nova Letra, 2006.

CRUZ, Ricardo Alexandre da: Negros e Educação: as trajetórias e estratégias de dois professores da Faculdade de Direito de São Paulo nos séculos XIX e XX. Programa de Pós - Graduação em Educação: História, Política, Sociedade pela Pontifícia Universidade Católica de São Paulo, 2009

CUNHA, Maria Amália de Almeida; VIANA, Maria José Braga; RESENDE, Tânia de Freitas. Entre memórias, percursos, identidades e diferenças: tecendo diálogos. In: PRAXEDES, Vanda; TEIXEIRA, Inês Assunção de Castro; SOUZA, Anderson Xavier de; GONZAGA, Yone Maria (orgs). Memórias e percursos de professores negros e negras na UFMG. Belo Horizonte: Autêntica Editora, Coleção Cultura Negra e Identidades, 2009.

DAMASCENO, Janaína. Estudo de atitudes e Preconceito Racial na obra de Virgínia Leone Bicudo. In: CONE: I Prêmio Construindo a Igualdade Racial. São Paulo: Prefeitura Municipal de São Paulo, maio de 2010.

DAMATTA, Roberto. "Digressão: a fábula das três raças, ou o problema do racismo à brasileira", In: Relativizando, uma introdução à antropologia social. Rio de Janeiro: Rocco, 1990, pp. 58-87.

DANTAS, Carolina Vianna. "O Brasil café com leite. Debates intelectuais sobre mestiçagem e preconceito de cor na primeira república", Revista Tempo, Dossiê A Nova "Velha" república. Vol. $13, n^{\circ} 26,2009$.

DÁVILA, Jerry. Diploma de brancura: política social e racial no Brasil (1917-1945). São Paulo: Editora Unesp, 2006.

DIWAN, Pietra: Raça Pura. Uma história da eugenia no Brasil e no mundo. São Paulo: Contexto, 2007.

DRÉZE, Jacques e DEBELLE Jean. Conceptions de I'Université. Paris, Universitaires, 1968.

DEGLER, Carl. Neither black nor white: slavery and race relations in Brazil and the United States. 
Nova York, Macmillan, 1971.

FORACCHI, M. M. O estudante e a transformação da sociedade brasileira. São Paulo, Companhia Editora Nacional, 1965.

FERNANDES, Florestan. Circuito fechado: quatro ensaios sobre o "poder institucional". São Paulo: HUCITEC, (Coleção Estudos Brasileiros), nº 6. 1976.

FERNANDES, Florestan. Ciências Sociais na ótica do intelectual militante. n. ${ }^{\circ}$ 8, (22): p. 123-38, 1994.

FIGUEIREDO, Angela; GROSFOGUEL, Ramón. Por que não Guerreiro Ramos? Novos desafios a serem enfrentados pelas universidades públicas brasileiras. Ciência Cultura, São Paulo, v. 59, n. 2, (Junho), 2007.

FIGUEIREDO, Angela. Fora do jogo: a experiência dos negros na classe média brasileira. Cadernos Pagu, no.23. 2004, pp. 199-228.

FRANKENBERG, Ruth. A miragem de uma branquidade não marcada. In. WARE, Vron. (org.) Branquidade: identidade branca e multiculturalismo. Rio de Janeiro: Garamond, 2004.

FRASER, Nancy, The fortunes of feminism: from state-managed capitalism to neoliberal crisis, Londres, Verso, 2013.

FREITAG, Barbara. Florestan Fernandes: revisitado. Estudos Avançados, São Paulo, v. 19, n. 55, (Dec.), 2005.

FRY, Peter. O que a Cinderela Negra tem a dizer sobre a 'Política Racial' no Brasil. Revista USP, $\mathrm{n}^{\circ}$ 28, p. 122-135, 1995.

GARCIA, Hagrayzs Rosa. O Docente Afro-brasileiro na Universidade Federal do Mato Grosso do Sul: memórias escolares, Dissertação (Mestrado), Faculdade de Educação, Universidade Federal do Mato Grosso do Sul, 2010.

GILROY, Paul. O Atlântico Negro: modernidade e dupla consciência, São Paulo, Editora 34, 2002. 
GOLDENBERG, Miriam. Gênero e Corpo na cultura brasileira. In: Psicologia Clínica, Rio de Janeiro, v. 17, n. 2. 2005.

GONZALEZ, Lélia. O Papel da Mulher Negra na Sociedade Brasileira: uma abordagem políticoeconômica, Los Angeles. Mimeo, 1979.

. "Mulher Negra”. Mulherio, São Paulo, ano 1, n.3, 1981, p. 8-9.

. Racismo e Sexismo na Cultura Brasileira. In: SILVA, L. A. Movimentos sociais urbanos, minorias étnicas e outros estudos. Brasília: ANPOCS, Cap. 3, (Ciências Sociais Hoje, n. 2), 1983.

GRIN, Mônica. Modernidade, identidade e suicídio: o "judeu” Stefan Zweig e o “mulato” Eduardo de Oliveira e Oliveira. Topoi, (Dez.) 2002, pp. 201-220.

GUIMARÃES, Antônio Sérgio A. Colour and Race in Brazil: from whitening to the search for Afrodescent. XVII ISA World Congress of Sociology, Gothenburg, July 2010.

. Racismo e Anti-racismo no Brasil. 2a . ed. São Paulo: Editora

34, 2009. v. 1.254 p.

Ingresso em universidades de prestígio e desempenho no vestibular de grupos privilegiados negativamente: negros na Universidade de São Paulo de 2001 a 2007.http://www.FFCLh.usp.br/sociologia/asag/

Como trabalhar com "raça" em sociologia. Educação e

Pesquisa. São Paulo, v. 29, n. 1, Jun. 2003.

HALBERSTAM, J. Jack. The queer art of failure, Londres, Duke University Press, 2011.

HASENBALG, Carlos. Discriminação e Desigualdades Raciais no Brasil. 2. ed. Belo Horizonte: Editora UFMG; Rio de Janeiro: IUPERJ, 2005, 316 p. 
Pesquisas, vol. 4. Racismo. Niterói: Eduff, pp. 9-41, 1998.

HARAWAY, Donna. Saberes Localizados: a questão da ciência para o feminismo e o privilegio da perspectiva parcial. Cadernos Pagu, 1995

HARRIS, Marvin et al. "Who are the whites? Imposed census categories and the racial demography of Brazil". In: Social Forces, Chapel Hill, v. 72, n. 2, p. 451-462, (Dez.), 1993.

HEILBORN Maria Luiza. \& SORJ Bila. Estudos de Gênero no Brasil. In: O que ler na Cciência Social brasileira (1970/1995) In: Sérgio Miceli (org) - São Paulo: Editora Sumaré: ANPOCS; Brasília, DF: CAPES, 1999.

hooks, bell. Intelectuais negras. In: Revista Estudos Feministas. IFCS/UFRJ \& PPCCIS/UERJ. Rio de Janeiro, v. 3 n.2, p. 464-478,1995.

. Talking Back: Thinking Feminist, Thinking Black. Boston: South End Press, 1989

Mujeres Negras: dar forma a la teoria feminista, In: hooks, bell, BRAH, Avtar, SANDOVAL, Chela \& ANZALDÚA, Gloria (Orgas.), Otras inapropriables: feminismos desde las fronteras, Madrid, Traficantes de Sueños, 1984/2004, pp. 33-50.

"Escolarizando Homens Negros." In: We Real Cool: black man and Masculinity. New York: Routledge, 2004, pp. 32-43. Tradução Alan Augusto Ribeiro e Keysha-Khan Perry (no prelo).

.Representing Whiteness in the Black Imagination”, in Ruth Frankenberg (org.), Displacing Witheness. Essays in Social and cultural Criticism. Durham: Duke University Press, 1999, pp. 164-179.

HASENBALG, Carlos Al. Discriminação e desigualdades raciais no Brasil. Rio de Janeiro, Graal, 1979.

HASENBALG, Carlos e SILVA, Nelson do Valle. Origens e Destinos: Desigualdades Sociais ao Longo da Vida. Rio de Janeiro, Iuperj/UCAM/Topbooks/Faperj, 2003.

ISAIA, Sílvia Maria de Aguiar. Professor universitário no contexto de suas trajetórias como pessoa 
e como profissional. In: Morosini, Marília Costa (et. al.) Professor do Ensino Superior. Identidade, Docência e Formação. Brasília: Plano Editora, 2001.

LAHIRE, B. Sucesso Escolar nos meios populares: as razões do improvável. SP: Ática, 1997.

JACKSON, Luiz Carlos. Gerações pioneiras na sociologia paulista (1934-1969). Tempo Social, revista de sociologia da USP, v. 19, n. 1, 2007.

KOBAYASHI, Elisabete; FARIA, Lina; COSTA, Maria Conceição da. Eugenia e Fundação Rockefeller no Brasil: a saúde como proposta de regeneração nacional.Sociologias, Porto Alegre, $\mathrm{n}$. 22, (Dez.) 2009 .

KERR, Clark. Os Usos da Universidade. Fortaleza: Universidade Federal do Ceará, 1982.

LABORNE, A. A. P. Trajetória de docentes do ensino superior: ações afirmativas e o contexto da Universidade Federal de Minas Gerais. In: VI Congresso de Pesquisadores (as) Negros (as), 2010, Rio de Janeiro. Anais COPENE 2010, 2010.

LANG, A.B.S.G.; BLAY, Eva A. Pioneiras na Universidade de São Paulo. Brasa, www.usp.br/nemge, 2008.

LIMONGI, Fernando. Mentores e Clientelas da Universidade de São Paulo. In: Histórias das Ciências Sociais no Brasil/ Sérgio Miceli (org) - São Paulo: Editora Sumaré: ANPOCS; Brasília, DF: CAPES, 2001.

MAIO, Marcos Chor. Educação sanitária, estudos de atitudes raciais e psicanálise na trajetória de Virgínia Leone Bicudo. Cadernos Pagu (35), (jul-dez.) pp. 309-355, 2010.

MAYORGA, Claudia. Universidade cindida; universidade em conexão: ensaios sobre democratização da universidade. Belo Horizonte: Editora UFMG, 2010.

MARINHO, Maria Gabriela. A presença norte-americana na educação superior brasileira: uma abordagem histórica da articulação entre a Fundação Rockefeller e estruturas acadêmicas de São Paulo. Revista Thesis. São Paulo: AJOMESP/Faculdade Cantareira, v. , p. 103-116, 2005. 
. Norte-americanos no Brasil: uma história da Fundação Rockefeller

na Universidade de São Paulo (1934-1952). Campinas: EDUSP - Autores Associados/Universidade São Francisco, 2001.

MARERO, S. La escuela transformadora. Evidencias sobre las relaciones entre educación y género. Una propuesta teórica de interpretación. Papers, nº 90, p. 191-211, 2008.

MARTINS, Tatiana Gomes. Florestan Fernandes e Guerreiro Ramos na construção de uma Ideia de Brasil Moderno. Temáticas (UNICAMP), v. 27/28, p. 157-185, 2006.

Florestan Fernandes e Guerreiro Ramos, para além de um debate,. Tese (Doutorado), Programa de Pós Graduação em Sociologia, Universidade de Campinas, 2008.

MASSI, Fernanda Peixoto. Estrangeiros no Brasil: a missão francesa na Universidade de São Paulo. Dissertação (Mestrado) Programa de Pós-Graduação em Antropologia Social, Universidade de Campinas, 1991.

MELLO E SOUZA, Laura de. Vícios, Virtudes e Sentimento Regional: São Paulo, da lenda negra à lenda áurea. Revista de História, São Paulo, n. 142-143, (Dez.) 2000 .

MICELI, Sérgio. Condicionantes do Desenvolvimento das Ciências Sociais. In: Histórias das Ciências Sociais no Brasil/Sérgio Miceli (org) - São Paulo: Editora Sumaré: ANPOCS; Brasília, DF: CAPES, 2001.

MONSMA, Karl. Vantagens de imigrantes e desvantagens de negros: emprego, propriedade, estrutura familiar e alfabetização depois da abolição no oeste paulista. Dados - Revista de Ciências Sociais, (Universidade Candido Mendes), vol. 53, núm. 3, pp. 509-543, 2010.

MONTAGNER, Miguel Ângelo. Trajetórias e biografias: notas para uma análise bourdieusiana. Sociologias, Porto Alegre, ano 9, no 17, (Jan./Jun.) p. 240-264, 2007.

MOROSINI, Marília Costa. Docência Universitária e os desafios da realidade nacional. In: In: Morosini, Marília Costa (et. al.) Professor do Ensino Superior. Identidade, Docência e Formação. Brasília Plano Editora, 2001. 163p. 
MORTADA, Samir Pérez. De Jovem a Estudante: apontamentos críticos. Psicologia Social, v. 21, n. 3, dez. 2009 .

MOTOYAMA, Shozo (org.). USP 70 anos: Imagens de uma história vivida. São Paulo: EDUSP, 2006.

CLÓVIS, Moura. Sociologia do negro brasileiro. São Paulo: Ática, 1988.

MUNANGA, Kabengele. 100 anos de produção bibliográfica sobre o negro. Brasília: Fundação Cultural Palmares, Vol. 01, 2000.

. O Anti-racismo no Brasil. In: MUNANGA, K. (org.). Estratégias e políticas de combate à discriminação racial. São Paulo: Edusp, p.79-111, 1996

NASCIMENTO, Alexandre do. Os Novos Manifestos sobre as cotas. Revista Lugar Comum: Estudos de Mídia, Cultura e Democracia, n. 25/26, Rio de Janeiro, 2008.

NASCIMENTO, Beatriz do. Por uma História do Homem Negro. Publicado originalmente em: Revista de Cultura Vozes. 68 (1), pp. 41-45, 1974.

NOGUEIRA, M.A.; ROMANELlI, G.; ZAGO, N. (orgs.). Família \& Escola: trajetórias de escolarização em camadas médias e populares. Petrópolis: Vozes, 2000.

OLIVEIRA, Lúcia Lippi. A sociologia do Guerreiro. Rio de Janeiro: Editora da UFRJ, 1995.

OLIVEIRA, Julvan Moreira de. Africanidades e Educação: ancestralidade, identidade e oralidade no pensamento de Kabengele Munanga., 2010. Faculdade de Educação, da Universidade Sao do Estado de São Paulo, . Ano de obtenção: 2010.

OSORIO, Rafael Guerreiro. O sistema de classificação de cor ou raça do IBGE. Brasília: IPEA, 2003 (Texto para Discussão).

PACHECO, A. C. L. Branca para Casar, Mulata para F.... e Negra para Trabalhar: escolhas afetivas e significados de solidão entre mulheres negras em Salvador, Bahia. Tese de Doutorado, UNICAMP, 2008. 
PAIXÃO, Marcelo; ROSSETO, Irene, MONTOVANELE, Fabiana e CARVANO, Luiz M. (orgs.). Relatório Anual das Desigualdades Raciais no Brasil; 2009-2010, 2011.

PALLARES-BURKE, Maria Lúcia. G. Gilberto Freyre, um vitoriano dos trópicos. São Paulo. Editora da UNESP, 2005.

PAULA, M. F. C. USP e UFRJ: a influência das concepções alemã e francesa em suas fundações. Tempo Social. Revista de Sociologia da USP, São Paulo, v. 14, n. 2, p. 147-161, 2002.

PAULA, M. F. C. . (2002) A modernização da Universidade e a transformação da intelligentzia universitária: casos USP e UFRJ. 1. ed. Florianópolis: Insular. v. 1. 320 p.

PEIRANO, Mariza G. S. : A Antropologia como ciência social no Brasil. Etnográfica, Vol. IV (2), pp. 219-232, 2000.

PEIRANO, Mariza G. S. : Antropologia no Brasil (Alteridade Contextualizada). In: O que ler na ciência social brasileira (1970-1995) (org) MICELI, S. São Paulo: Editora Sumaré: ANPOCS; Brasília, DF: CAPES, 1999.

PEDRO, J. M. Narrativas fundadoras do feminismo: poderes e conflitos (1970-1978). Revista Brasileira de História v. 26, n. 52, pp. 249-272. 2006.

PIERUCCI, Antonio Flávio. Ciladas da Diferença. São Paulo. Ed. 34, 1999.

PINHO Osmundo Araújo. Etnografias do Brau: corpo, masculinidade e raça na reafricanização em Salvador. In: Olhares Feministas/Hildete Pereira de Melo, Adriana Piscitelli, Sônia Weidner Maluf, Vera Lucia Puga (orgs) - Brasília: Ministério da Educação/UNESCO (Coleção Educação para Todos; v. 10), 2006.

PINHO, Osmundo de Araújo.; FIGUEIREDO, Ângela. Idéias Fora do Lugar e o Lugar do Negro nas Ciências Sociais Brasileiras. Revista Estudos Afro-Asiáticos, Ano 24, no 1, 2002, pp. 189-210.

PONTES, Heloisa. Destinos mistos: os críticos do Grupo Clima em São Paulo, 1940-68. São Paulo: Companhia das Letras, 1998. v. 1. 297p. 
PIMENTA, Melissa de Mattos. Jovens em transição: um estudo sobre a transição para a vida adulta entre estudantes universitários em São Paulo. Dissertação (Mestrado), Programa de Pós-Graduação de Sociologia, Faculdade de Filosofia, Letras e Ciências Humanas da Universidade de São Paulo, São Paulo, 2001.

PINTO, Regina Pahim. Educação do negro: uma revisão da bibliografia. Cadernos de Pesquisa. São Paulo, n.62. Agosto, pp.3-34, 1987.

PORTO-GONÇALVES, Carlos W. Milton Santos: ciência, ética e responsabilidade sociais. In: RIBEIRO, Wagner Costa (org.). O País distorcido. São Paulo: Publifolha, 2002. p. 172-185.

PULICI, Carolina. Entre Sociólogos: versões Conflitivas da "Condição de Sociólogo" na USP dos Anos 1950-1960. São Paulo. EDUSP. 2008.

QUIJANO, Aníbal. Coloniality of Power and Democracy in Latin America, Editora, 2001.

RAGO, Margareth. A mulher no século XXI ou Carta de Alforria. In: A mulher brasileira nos espaços públicos e privados/ VENTURI, Gustavo. RECAMAN, M. 2004.

RATTS, Alex. J. P. Eu sou Atlântica: Sobre a Trajetória de Vida de Beatriz Nascimento. São Paulo: Imprensa Oficial/Instituto Kuanza, 2006.

Revista ADUSP. Implacável Burocracia: perseguições e Produtivismo Exacerbado marcam a gestão de Suely Vilela na Reitoria da USP (2006-2009). Outubro de 2009.

RIBEIRO, Maria Solange Pereira. O romper do silêncio: história e memória na trajetória escolar e profissional dos docentes afrodescendentes das Universidades do Estado de São Paulo. Tese de Doutorado. Ano de Obtenção, 2001.

ROCHA, Edmar José da \& ROSEMBERG, Fúlvia. Autodeclaração de cor e/ou raça entre escolares paulistanos(as).Cadernos de Pesquisa. 2007, vol.37, n.132 [ pp. 759-799 .

RODRIGUES, Raymundo de Nina. Os Africanos no Brasil. Domínio Público. (2010) 
ROSEMBERG, F; MADSEN, N. Educação Formal, Mulheres e Gênero no Brasil Contemporâneo. In: BARSTED, L. L.; PITANGUY, J. (Org.). O Progresso das Mulheres no Brasil 2003-2010. 1 ed. Rio de Janeiro/Brasília: CEPIA/ONU Mulheres, 2011, v. , p. 390-434.

RUFINO DOS SANTOS, Joel. Milton Santos: o limite do intelectual de classe. In: BRADÃO, Maria A. (orga.). Milton Santos e o Brasil. São Paulo: Fundação Perseu Abramo, 2004.

SAHLINS, Marshall. Ilhas de história. Rio de Janeiro, Jorge Zahar, 1990.

SAMPAIO, Helena; LIMONGI, Fernando; TORRES, Haroldo. Equidade e heterogeneidade no ensino superior brasileiro. São Paulo: NUPES/USP, 2000. (Documento de Trabalho, 1).

SANTOS, Boaventura de Sousa. Para além do Pensamento Abissal: Das linhas globais a uma ecologia de saberes", Revista Crítica de Ciências Sociais, n. 78, pp. 3-46, 2007.

SANTOS, Tereza. Trajetórias de professores universitários negros: a voz e a vida dos que trilharam. Cuiabá: Ed. UFMT, 2007.

SANTOS, Jocélio Teles dos. (org.) O impacto das cotas nas universidades brasileiras (2004-2012). Salvador: CEAO, 2013.

SARDENBEG, C.B.. A mulher frente à cultura da juventude: Reflexões Teóricas e pessoais de uma feminista cinquentona. In: Imagens da mulher na cultura contemporânea FERREIRA, Sílvia Lúcia e Enilda Rosendo do NASCIMENTO. Salvador: NEIM/UFBA (Coleção Bahianas), 2000.

SCOTT, Joan Wallach. Gênero: uma categoria útil de análise histórica. Educação \& Realidade, Porto Alegre, vol. 16, nº 2, jul./dez. 1990,

. O Enigma da Igualdade. Estudos Feministas, 13(1): 11-30, 2005.

SCHWARCZ, Lilia K. Moritz. "Questão racial e etnicidade”. In: O que ler na ciência social brasileira (1970-1995). MICELI, Sergio. (Org) São Paulo: Editora Sumaré: ANPOCS; Brasília, DF: CAPES, 1999. 
Sociais, n. 29, 1995.

. O Espetáculo das Raças. São Paulo Cia das Letras, 1993.

Introdução ao artigo: "questão racial brasileira vista por três professores". Revista USP, São Paulo, v. 68, p. 168-180, 2006.

SERRA, Lia Novaes \& SCARCELLI, Ianni Régia. Por um sangue bandeirante: Pacheco e Silva, um entusiasta da teoria eugenista em São Paulo. Rev. latinoam. psicopatol. fundam.[online], vol.17, n.1, 2014.

SGUISSARDI, V. Universidade no Brasil: dos modelos clássicos aos modelos de ocasião? In: SGUISSARDI, Valdemar. (Org.). Universidade brasileira no século XXI - Desafios do presente. São Paulo: Cortez, v. 1, 2009, p. 285-309.

SOVIK, Liv. Por que tenho razão: branquitude, estudos culturais e a vontade da verdade acadêmica. Contemporânea Revista de Comunicação e Culture Journal of Comunication and culture. vol. 3, $\mathrm{n}^{\circ}$ 2, julh. Dez, 2005. p. 159-180

SOVIK, Liv. Aqui Ninguém é Branco: hegemonia branca e media no Brasil. In: Vron Ware. (Org.). Branquidade: identidade branca e multiculturalismo. Rio de Janeiro: Garamond, 2004, p. 363-386.

SOUSA E SILVA, J. Por que uns e não outros? Caminhada de Jovens Pobres para a universidade. Rio de Janeiro: Editora Sette Letras, 2003.

PORTES, E. A. O trabalho escolar das famílias populares. In: NOGUEIRA, M. A. et al. Família \& Escola: trajetórias de escolarização em camadas médias e populares. Petropólis: Vozes, 2000.

SOUZA, Neusa dos Santos. Tornar-se negro: ou as vicissicitudes do negro brasileiro em asecensão social. Rio de Janeiro: 2a edição, Graal, 1983.

SOVIK, Liv. Aqui ninguém é branco. Rio de Janeiro: Aeroplano, 2009.

SPIRANDELI, Claudinei C. Trajetórias intelectuais: professoras do curso de Ciências Sociais da FFCL - USP (1934-1969). São Paulo. Tese de Doutorado - Universidade de São Paulo, 2008. 
SPOSITO, Marilia Pontes. O povo vai à escola. A luta popular pela expansão do ensino público em São Paulo. São Paulo: Loyola, 1992.

STEPAN, Nancy. 'Eugenesia, genética y salud pública: el movimiento eugenésico brasileño y mundial'. Quipu, 2 (3): 351-384, 1985.

SILVA, Cristiano Pinto da. Educação Brasileira e Identidade Negra em Kabengele Munanga. Faculdade de Educação, da Universaidade Federal do Pará. Ano de obtenção:, 2009.

SILVA, Maria A.; TOLEDO Jr., Rubens de. Encontro com o pensamento de Milton Santos: a interdisciplinaridade na sua obra. Salvador: EDUFBA, 2006.

SILVA, Maria Auxiliadora da. "Milton Santos: a trajetória de um mestre". In: El ciudadano, la globalización y la geografía. Homenagem a Milton Santos. Scripta Nova. Revista electrónica de geografía y ciencias sociales, Universidad de Barcelona, vol. VI, núm. 124, 30 de septiembre de 2002.http://www.ub.es/geocrit/sn/sn-124.htm

Milton Santos: o homem, o seu tempo e o seu espaço. In:

SOUZA, Maria Adélia A. de. O mundo do cidadão, um cidadão do mundo. São Paulo: hucitec, 1996. p. 68-73.

TEIXEIRA, Moema de Poli. Negros e Universidade: Identidade e Trajetória de Ascensão Social no Rio de Janeiro. Tese de doutorado. Rio de Janeiro. PPGAS/Museu Nacional/UFRJ, 1998

TRIGO, Maria Helena B. Espaços e tempos vividos: estudos sobre os códigos de sociabilidade e relações de gênero na Faculdade de Filosofia da USP (1934-1970). São Paulo. Tese de Doutorado Universidade de São Paulo, 1997.

VENTURA, Roberto. Estilo Tropical: história cultural e polêmicas literárias no Brasil. 1870-1914. São Paulo: Companhia das letras, 1991.

VIANNA, Cláudia Pereira. O sexo e o gênero da docência. Cadernos Pagu, n. 02, pp. 81-103. 2001.

WEST Cornell. Questão de Raça. São Paulo: Companhia das Letras. 1994. 
WITTER, José Sebastião. USP 50 anos: Registros de um Debate. $2^{\text {a }}$. ed. São Paulo: EDUSP, 2006. WOLFF, Robert Paul. O ideal da universidade. São Paulo: Editora da UNESP, 1993.

SANTOS, Yumi Garcia dos : A implementação dos órgãos governamentais de gênero no Brasil e o papel do movimento feminista: o caso do Conselho Estadual da Condição Feminina de São Paulo, cadernos Pagu (27), julho-dezembro de 2006: pp.401-426.

SOARES, Vera: Muitas faces do feminismo no Brasil. In: Mulher e política: Gênero e feminismo no Partido dos Trabalhadores/Ângela Borba, Nalu Faria, Tatau Godinho (organizadoras). São Paulo: Editora Fundação Perseu Abramo, 1998.

ANGELA, Xavier de Brito. "Habitus de herdeiro, habitus escolar: os sentidos da internacionalização nas trajetórias dos estudantes brasileiros". In Almeida A. M. F., Canedo L., Garcia A., Bittencourt A. Circulação internacional e formação intelectual das elites brasileiras. Campinas: Editora Unicamp: 2004, 85-104.

VENTURI, Gustavo \& BOKANY, Vilma. Maiorias adaptadas, minorias progressistas. In H. W. Abramo \& P. P. M. Branco (Orgs.), Retratos da juventude brasileira: análises de uma pesquisa nacional, São Paulo: Fundação Perseu Abramo 2005, pp. 351-368.

VIANA, Maria José Braga. Longevidade escolar em famílias de camadas populares: algumas condições de possibilidade. In: NOGUEIRA, Maria Alice. et al. Família \& Escola: trajetórias de escolarização em camadas médias e populares. Petropólis: Vozes, 2001.

WIEVIORKA. Michel. O racismo, uma introdução. SP: Perspectiva 2007.

\section{ENDEREÇOS ELETRÔNICOS VISITADOS:}

Academia de Medicina de São Paulo. Disponível em: <http://www.academiamedicinasaopaulo.org.br/?pg=home\&idioma=1> Acesso em: 1 jun. 2011.

Prefeitura Municipal de Araçatuba: Disponível em: <http://www.aracatuba.sp.gov.br/Conhe\%C3\%A7aata/aracatuba.html > Acesso em: 1 jun. 2011.

Jornal "O Estadão" Disponível em: http://www.estadao.com.br/noticias/nacional,julio-de-mesquita- 
filho-um-liberal-movido-pelo-amor-ao-pais,401286,0.htm Acesso em: 02 nov. 2012

Universidade de São Paulo:http://www.prpg.usp.br/100mil/ >Acesso em: 03 nov, 2011;

Currículo do Sistema de Currículos Lattes (Eunice Aparecida de Jesus Prudente). Disponível em: http://buscatextual.cnpq.br/buscatextual/visualizacv.do?metodo=apresentar\&id=K476...> Acesso em 18/12/2013.

Carta Aberta do Professor Kabengele Munanga. Disponível em: http://www.geledes.org.br/areas-deatuacao/questao-racial/afrobrasileiros-e-suas-lutas/23302-racismo-as-altas-esferas-quem-tem-medode-um-negro-que-sabe-professor-kabengele-munanga-quebra-o-silencio-academico>. Acesso em: 14/02/ fev. 2014.

Beneficiado fui eu, mas a vitória é coletiva, diz Kabengele Munanga http://www.afropress.com/post.asp?id=17402\#.U_Xxrdf_ajc.facebook: Acesso em 09/09/2014.

IBGE: http://www.ibge.gov.br/ibgeteen/datas/discriminacao/cenferenciadedurban.html.

http://www1.folha.uol.com.br/opiniao/2013/03/1244586-tendenciasdebates-cotas-em-dialogo.shtml. Acesso em 14/07/2013.

página eletrônica da Pró-reitoria de Graduação da USP. http://www.prg.usp.br/?page_id=365.

Página eletrônica mantida pela família de Milton Santos: $\underline{\text { http://miltonsantos.com.br/site }}$

http://www.adusp.org.br/index.php/revista-adusp/113-revista-n-35-outubro-de-2005

página eletrônica da Secretaria. In: http://www.justica.sp.gov.br/novo_site

Professora da USP denuncia dono de restaurante por racismo e machismo. Portal Fórum, 26 de novembro de 2013.

Regimento Geral da Universidade de São Paulo, disponível on-line: http://citrus.uspnet.usp.br/leginf/rg/rg.html 
http://www.transparencia.usp.br/ Portal Transparência USP 